MÁRCIA REGINA PEREIRA LIMA

USO DE ESTUFA AGRÍCOLA PARA SECAGEM E HIGIENIZAÇÃO DE LODO DE ESGOTO 
MÁRCIA REGINA PEREIRA LIMA

\title{
USO DE ESTUFA AGRÍCOLA PARA SECAGEM E HIGIENIZAÇÃO DE LODO DE ESGOTO
}

\author{
Tese apresentada à Escola Politécnica da \\ Universidade de São Paulo para obtenção \\ do título de Doutor em Engenharia
}




\section{USO DE ESTUFA AGRÍCOLA PARA SECAGEM E HIGIENIZAÇÃO DE LODO DE ESGOTO}

Tese apresentada à Escola Politécnica da Universidade de São Paulo para obtenção do título de Doutor em Engenharia

Área de concentração:

Engenharia Hidráulica

Orientador: Prof. Titular

Pedro Alem Sobrinho

São Paulo 
Este exemplar foi revisado e alterado em relação à versão original, sob responsabilidade única do autor e com a anuência de seu orientador.

São Paulo, 23 de março de 2010.

Assinatura do autor

Assinatura do orientador

\section{FICHA CATALOGRÁFICA}

Lima, Márcia Regina Pereira

Uso de estufa agrícola para secagem e higienização de lodo de esgoto / M.R.P. Lima. -- São Paulo, 2009.

284 p.

Tese (Doutorado) - Escola Politécnica da Universidade de São Paulo. Departamento de Engenharia Hidráulica e Sanitária.

1. Lodo de esgoto I. Universidade de São Paulo. Escola Politécnica. Departamento de Engenharia Hidráulica e Sanitária II. t. 
DEDICATÓRIA

Aos

Meus familiares.

Em especial:

Meus pais - José Elton e Vanira;

Meu esposo - Marcelo e;

Meus filhos - Laís e Marcel.

Razão de tudo! 


\section{AGRADECIMENTOS}

Meus eternos agradecimentos a todos que contribuíram para o preenchimento de mais esta página da minha vida, em especial:

a Deus por tudo;

aos meus irmãos e familiares pelo apoio incondicional;

ao Programa de Pós-Graduação da EPUSP, área de concentração Engenharia Civil;

ao IFES pelas contribuições,

ao professor Pedro Alem Sobrinho por possibilitar acontecimentos inéditos na minha vida, cercado de tanto aprendizado e, principalmente, pela orientação, confiança e amizade;

à Cesan pelo apoio para a realização da pesquisa, em especial à Elza, Nadja, Fernando e Dalton;

à Construtora Norberto Odebrecht, representada pelo engenheiro Eduardo Kalle e pela engenheira Magnólia, pela montagem da estufa e assistência, e aos funcionários da ETE Araçás pela ajuda e apoio durante a pesquisa;

à Capes, Facitec e Fapes pelo apoio financeiro;

aos meus alunos Bruno, Edvânia, Karla, Leonardo e Mayara, que compartilharam alguns preciosos momentos nesse caminho;

ao Facitec e ao Funcefetes pelas bolsas de inciciação científica concedidas aos alunos que participaram da pesquisa;

aos professores Dione Mari Morita e Roque Passos Piveli pelas contribuições;

à professora Eliana Zandonate pelo valioso auxílio na análise estatística dos resultados;

à Silvana pelas análises de ovos de helmintos;

à Sara e Marluce, amigas de todos os momentos; 
à amiga Fernanda Gualberto, irmã paulistana, pelo carinho e companheirismo;

ao amigo Nilton pelas caronas à estação de metrô mais próxima da USP durante o curso;

aos amigos Humberto, Rodrigo, Diego, Mailer e Luciano por terem estado sempre por perto;

à Ana Elisa, Stela, Ana Carolina, Denise, Fátima, Geise, Marcela, Ana Cristina, ...companheiras do alojamento (Crusp), que sempre serão lembradas como pessoas especiais;

à amiga Carol pela acolhida e amizade;

à amiga Lucia Garcia pelas palavras de incentivo e ajuda;

a todas as amigas e companheiras do basquete e ao amigo (treinador) Saudino pelos momentos de descontração, fundamentais ao equilíbrio da mente;

aos professores, funcionários, colegas e amigos do Programa de Pós-Graduação;

aos motoristas e pilotos que me possibilitaram tantas idas e vindas. 
FRASE

"Antes do compromisso, há hesitação, a oportunidade de recuar, a ineficácia permanente.

Em todo ato de iniciativa (e de criação), há uma verdade elementar cujo desconhecido destrói muitas idéias e planos esplêndidos: no momento em que nos comprometemos de fato, a Providência também age.

Ocorre toda espécie de coisas para nos ajudar, coisas que de outro modo nunca ocorreriam.

Toda uma cadeia de eventos emana da decisão, fazendo vir em nosso favor todo tipo de encontros, de incidentes e de apoio material imprevisto que ninguém poderia sonhar que surgiria em seu caminho.

Começa tudo o que possas fazer, ou que sonhas poder fazer. A ousadia traz em si o gênio, o poder e a magia."

GOETHE

(RITTO; MACHADO FILHO, 1995, p. 5) 


\section{RESUMO}

LIMA, M. R. P. Uso de estufa agrícola para secagem e higienização de lodo de esgoto. 2009. 288 f. Tese (Doutorado) - Escola Politécnica, Universidade de São Paulo, São Paulo, 2009.

Esta pesquisa buscou avaliar a secagem e higienização em estufa agrícola de excesso de lodo ativado gerado em Estações de Tratamento de Esgoto que tratam esgoto doméstico, localizadas na Região Metropolitana da Grande Vitória, Espírito Santo e, à partir dos resultados, estimar a área e o custo de investimento necessários para a instalação da estufa. A intenção foi atingir os padrões para lodo Classe A (Resolução n ${ }^{0}$ 375/2006 do Conama), que possibilita o uso do material na agricultura. A estufa possuía cobertura e revestimento lateral em lona plástica translúcida para impedir a penetração de água e possibilitar a penetração da radiação solar. O estudo foi dividido em duas etapas, ou seja, num primeiro momento, houve a avaliação do lodo digerido aerobiamente, com e sem cal, e, num segundo, a do lodo não encaminhado ao digestor, com e sem cal. Cada etapa era composta de três ciclos (repetições) com procedimentos metodológicos diferenciados e tempo de duração aproximado de 70 dias. Com o monitoramento temporal dos parâmetros estudados em cada ciclo, foi possível avaliar e definir a melhor configuração para a otimização da técnica estudada. As concentrações de substâncias inorgânicas no lodo usado na pesquisa já se apresentavam com valores bem inferiores aos padrões do Conama. Os parâmetros de interesse agronômico monitorados apresentaram valores atraentes sob o aspecto agronômico. Com relação aos vírus, os resultados apresentados foram inconclusivos e, em face disso, os resultados não foram usados nas considerações finais acerca do processo utilizado. Diante dos resultados obtidos, é razoável afirmar que entre as condições metodológicas testadas, a melhor configuração para o uso da estufa agrícola na secagem e higienização do lodo, atendendo aos padrões para lodo Classe A (exceto vírus), foi: tempo de secagem aproximado de 36 dias; forma de disposição do lodo com altura igual a $10 \mathrm{~cm}$; período de revolvimento de três vezes por semana; lodo sem adição de cal. Essa configuração possibilita obter um biossolido com umidade final de, aproximadamente, $25 \%$, resultando numa diminuição do volume bastante expressiva, de cerca de $76 \%$. As estimativas de dimensão e custo, também foram realizadas.

Palavras-chave: lodo de esgoto, estufa agrícola, secagem, higienização, lodo Classe A, custo. 


\begin{abstract}
LIMA, M. R. P. Use of greenhouse to dry and hygienization of the sewage sludge. 2009. 288 f. Thesis - Escola Politécnica, Universidade de São Paulo, São Paulo, 2009.

This research aimed at assessing the dry and hygienization in a greenhouse excess of the activated sludge generated in Wastewater Treatment Plants that treats domestic sewage, located in the Metropolitan Region of the Great Vitória, Espírito Santo, and from the results, estimate the area and the cost of investment required for installation from the greenhouse. The intention was to meet the standards defined for sludge Class A (375/2006 Resolution of Conama) which enable the use of the material in the agriculture. The greenhouse had coverage and coating side canvas translucent plastic to prevent the ingress of water and allow the penetration of solar radiation. The study was divided into two stages, i.e. first, there was an assessment of the aerobically digested sludge behavior and, with and without lime, and second, the sludge which was not sent to the digester, with and without lime. Each part was composed by three cycles (repetitions) with differentiated methodological procedures and time of duration approximately of 70 days in order to evaluate the best configuration for the optimization of the studied technique. The concentrations of inorganic substances in the utilized sludge in the research were already presented with much lower values in relation to the standards of Conama. The parameters of monitored agricultural interest show interesting values under an agricultural aspect. In relation to virus, the presented results were inconclusive. Therefore, they were not used in the final considerations in relation to the utilized process. In face of the obtained results, it is reasonable to state that among the tested methodological conditions, the best configuration for the use of agricultural greenhouse in the dry and hygienization of the sludge, meeting the standards for the sludge Class A (except virus) was: the time of dry approximately 36 days; form of sludge disposition with $10 \mathrm{~cm}$ height; revolving period of 3 times a week; sludge without the addition of lime. With this configuration, it is possible to obtain a biosolid with moisture of approximately $25 \%$ resulting in a very expressive decreasing of volume, around $76 \%$. Estimates of the size and cost were also performed.
\end{abstract}

Key word - sewage sludge, greenhouse, dry, hygienization, sludge Class A, cost. 


\section{LISTA DE FIGURAS}

Figura 3.1 - Transformações do material orgânico presente no afluente em sistema de tratamento aeróbio e anaeróbio do esgoto ...................................................... 32

Figura 3.2 - Etapas de tratamento do lodo até a disposição final ..............................................38

Figura 3.3 - Esquema das sequências metabólicas e dos grupos microbianos envolvidos na

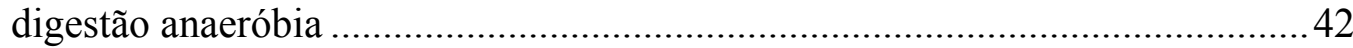

Figura 3.4 - Esquema da sequência metabólica ocorrida durante a digestão aeróbia .............44

Figura 4.1 - Localização aproximada das quatro ETE nos respectivos municípios ...............115

Figura 4.2 - Vista panorâmica das quatro ETE implantadas na RMGV que geram o lodo

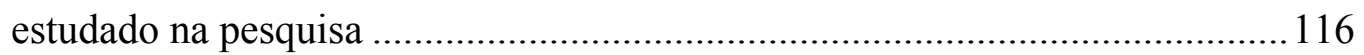

Figura 4.3 - Esquema simplificado, em vista superior, do fluxo da fase líquida e da fase sólida nas ETE

Figura 4.4 - Fluxograma das condições operacionais adotadas para o desenvolvimento da pesquisa

Figura 4.5 - Vista externa e interna da estufa agrícola usada na pesquisa

Figura 4.6 - Disposição das células de lodo dentro da estufa para o desenvolvimento da pesquisa

Figura 4.7 - Disposição do lodo nas células e período de revolvimento durante o Ciclo 1 .. 127 Figura 4.8 - Disposição do lodo nas células e período de revolvimento durante o Ciclo 2 .. 128 Figura 4.9 - Disposição do lodo nas células e período de revolvimento durante o Ciclo 3 .. 128 Figura 5.1 - Característica visual do lodo nas células durante os três ciclos em diferentes dias e as umidades correspondentes 


\section{LISTA DE QUADROS}

Quadro 3.1- Descrição das etapas de tratamento do lodo até a disposição final e respectivos processos.

Quadro 3.2 - Vantagens e desvantagens dos processos de digestão aeróbia e anaeróbia do lodo

Quadro 3.3 - Principais organismos encontrados no lodo de esgoto sanitário e as respectivas doenças/sintomas

Quadro 3.4 - Legislações específicas e os aspectos relacionados ao gerenciamento do lodo em alguns países da América Latina

Quadro 4.1 - Condições metodológicas adotadas e período de monitoramento de todos os ciclos das duas etapas

Quadro 4.2 - Parâmetros monitorados na pesquisa, frequência, métodos e laboratórios responsáveis

Quadro 7.1 - Condições definidas para a estimativa da área da estufa, considerando dados de projeto e fatores analisados na pesquisa 


\section{LISTA DE GRÁFICOS}

Gráfico 5.1 - Valores de pH considerando diferentes porcentagem de cal, para o lodo da Etapa 1

Gráfico 5.2 - Variação das temperaturas média das médias horárias, máximas horárias e mínimas horárias dentro e fora da estufa, durante a Etapa 1 - Ciclo 1/1 (5.2a), Ciclo 2/1 (5.2b) e Ciclo 3/1 (5.2c).

Gráfico 5.3 - Variação da umidade do lodo sem cal (L1 e L2) e com cal (LC1 e LC2) durante os ciclos da Etapa 1 - Ciclos 1/1 (5.3a), 2/1 (5.3b) e 3/1 (5.3c)

Gráfico 5.4 - Variação do pH do lodo sem cal (L1 e L2) e com cal (LC1 e LC2) durante os ciclos da Etapa 1 - Ciclos 1/1 (5.4a), 2/1 (5.4b) e 3/1 (5.4c)

Gráfico 5.5 - Variação da densidade de coliformes termotolerantes e umidade no lodo digerido sem cal (L1 e L2) e com cal (LC1 e LC2) durante os ciclos da Etapa $1-$ Ciclos $1 / 1$ (5.5a), 2/1 (5.5b) e 3/1 (5.5c)

Gráfico 5.6 - Variação da quantidade de ovos viáveis de helmintos e umidade no lodo digerido sem cal (L1 e L2) e com cal (LC1 e LC2) durante os ciclos da Etapa 1 - Ciclos $1 / 1$ (5.6a), 2/1 (5.6b) e 3/1 (5.6c)

Gráfico 5.7 - Variação da densidade do lodo em relação ao teor de sólidos totais (ST), com base nos valores obtidos nos Ciclos 1/1, 2/1 e 3/1 de lodo digerido sem cal (L1 e L2) e com cal (LC1 e LC2) durante a Etapa 1 160

Gráfico 5.8 - Valores de $\mathrm{pH}$ considerando diferentes porcentagem de cal, para o lodo da Etapa 2

Gráfico 5.9 - Variação das temperaturas média das médias horárias, máximas horárias e mínimas horárias, dentro e fora da estufa, durante a Etapa 2 - Ciclo 1/2 (5.9a), Ciclo 2/2 (5.9b) e Ciclo 3/2 (5.9c). 164

Gráfico 5.10 - Variação da umidade do lodo sem cal (L1 e L2) e com cal (LC1 e LC2) durante os ciclos da Etapa 2 - Ciclos 1/2 (5.10a), 2/2 (5.10b) e 3/2 (5.10c) .... 166

Gráfico 5.11 - Variação do pH do lodo sem cal (L1 e L2) e com cal (LC1 e LC2) durante os ciclos da Etapa 2 - Ciclos 1/2 (5.11a), 2/2 (5.11b) e 3/2 (5.11c) ..... 168

Gráfico 5.12 - Variação da densidade de coliforme termotolerante e umidade do lodo não encaminhado ao digestor sem cal (L1 e L2) e com cal (LC1 e LC2) durante os ciclos da Etapa 2 - Ciclos 1/2 (5.12a), 2/2 (5.12b) e 3/2 (5.12c). 
Gráfico 5.13 - Variação da quantidade de ovos viáveis de helmintos e umidade no lodo não encaminhado ao digestor sem cal (L1 e L2) e com cal (LC1 e LC2) durante os ciclos da Etapa 2 - Ciclos 1/2 (5.13a), 2/2 (5.13b) e 3/2 (5.13c) .... 172

Gráfico 5.14 - Variação da densidade do lodo em relação ao teor de sólidos totais (ST), com base nos valores obtidos nos Ciclos $1 / 2,2 / 2$ e 3/2 de lodo não encaminhado ao digestor sem cal (L1 e L2) e com cal (LC1 e LC2) durante a Etapa 2

Gráfico 6.1 - Perfil temporal das médias de umidade e respectivos intervalos de confiança de $95 \%$, considerando todos os resultados obtidos nas Etapas 1 e 2 de acordo com o fator tipo de lodo

Gráfico 6.2 - Perfil temporal das médias de umidade e respectivos intervalos de confiança de $95 \%$ para os resultados obtidos no teste de Tukey

Gráfico 6.3 - Perfil temporal das médias de umidade e respectivos intervalos de confiança de $95 \%$, considerando todos os resultados obtidos nas Etapas 1 e 2 de acordo com o fator cal

Gráfico 6.4 - Perfil temporal das médias de umidade e respectivos intervalos de confiança de $95 \%$, considerando todos os resultados obtidos nas Etapas 1 e 2 de acordo com o fator disposição/revolvimento

Gráfico 6.5 - Perfil temporal das médias de SV/ST e respectivos intervalos de confiança de 95\% , considerando todos os resultados obtidos nas Etapas 1 e 2 de acordo com o fator tipo de lodo 187

Gráfico 6.6 - Perfil temporal das médias de SV/ST e respectivos intervalos de confiança de 95\%, considerando todos os resultados obtidos nas Etapas 1 e 2 de acordo com o fator cal 188

Gráfico 6.7 - Perfil temporal das médias de SV/ST e respectivos intervalos de confiança de 95\%, considerando todos os resultados obtidos nas Etapas 1 e 2 de acordo com o fator disposição/revolvimento

Gráfico 6.8 - Perfil temporal das médias de $\mathrm{pH}$ e respectivos intervalos de confiança de 95\%, considerando todos os resultados obtidos nas Etapas 1 e 2 de acordo com o fator tipo de lodo

Gráfico 6.9 - Perfil temporal das médias de $\mathrm{pH}$ e respectivos intervalos de confiança de 95\%, considerando todos os resultados obtidos nas Etapas 1 e 2 de acordo com o fator cal 
Gráfico 6.10 - Perfil temporal das médias de $\mathrm{pH}$ e respectivos intervalos de confiança de 95\%, considerando todos os resultados obtidos nas Etapas 1 e 2 de acordo com o fator disposição/revolvimento

Gráfico 6.11 - Perfil temporal das médias de CTt e respectivos intervalos de confiança de 95\%, considerando todos os resultados obtidos nas Etapas 1 e 2 de acordo com o fator tipo de lodo.

Gráfico 6.12 - Perfil temporal das médias de CTt e respectivos intervalos de confiança de $95 \%$, considerando todos os resultados obtidos nas Etapas 1 e 2 de acordo com o fator cal.

Gráfico 6.13 - Perfil temporal das médias de CTt e respectivos intervalos de confiança de 95\%, considerando todos os resultados obtidos nas Etapas 1 e 2 de acordo com o fator disposição/revolvimento 200

Gráfico 6.14 - Perfil temporal das médias de OVH e respectivos intervalos de confiança de $95 \%$, considerando todos os resultados obtidos nas Etapas 1 e 2 de acordo com o fator tipo de lodo .202

Gráfico 6.15 - Perfil temporal das médias de OVH e respectivos intervalos de confiança de $95 \%$, considerando todos os resultados obtidos nas Etapas 1 e 2 de acordo com o fator cal 203

Gráfico 6.16 - Perfil temporal das médias de OVH e respectivos intervalos de confiança de 95\%, considerando todos os resultados obtidos nas Etapas 1 e 2 de acordo com o fator disposição/revolvimento

Gráfico 6.17 - Concentrações médias e desvios padrões dos parâmetros de interesse agronômico no início e final dos Ciclos das Etapas 1 e 2 - Lodo sem cal (6.17a), Lodo com cal (6.17b)

Gráfico 6.18 - Concentrações médias e desvios padrões das substâncias inorgânicas (íons metálicos) no início e final dos Ciclos das Etapas 1 e 2, comparadas com o padrão estabelecido pela Resolução n ${ }^{0}$ 375/2006 do Conama - Lodo sem cal (6.18a e 6.18b), Lodo com cal (6.18c e 6.18d)

Gráfico 6.19 - Curvas ajustadas na regressão linear das densidades do lodo em relação ao teor de sólidos totais (ST), do lodo digerido sem cal (L1 e L2) e com cal (LC1 e LC2) durante as Etapas 1 e 2 


\section{LISTA DE TABELAS}

Tabela 3.1 - Faixas de densidade e massa específica para diferentes tipos de lodo 37

Tabela 3.2 - Efeito do tratamento do lodo de esgoto sobre os patógenos (redução em log) .. 41

Tabela 3.3 - Temperatura e tempo de manutenção para a destruição de alguns organismos ..47

Tabela 3.4 - Concentrações de helmintos e protozoários em diferente períodos do ano na utilização de cal virgem e cal hidratada para a higienização do lodo de esgoto sanitário

Tabela 3.5 - Características médias (5 a 16 amostras) em porcentagem de base seca de lodo aeróbio (ETE Belém) e anaeróbio (reator tipo RALF), bruto e tratado com $50 \%$ de cal em base seca, ao longo dos anos de 1994 e 1995 .

Tabela 3.6 - Variação de nutrientes em lodo com cal e sem cal presentes em lodo de esgotos da Alemanha durante os anos de 1985 e 1991.

Tabela 3.7 - Características do lodo gerado em ETE no Brasil - teores de nutrientes e carbono

Tabela 3.8 - Características do lodo gerado em ETE no Brasil - teores de micronutrientes.. 60

Tabela 3.9 - Nível de nutrientes de fertilizantes químicos convencionais, lodo de esgoto e resíduos orgânicos

Tabela 3.10 - Concentrações de metais pesados em urina, fezes mais papel sanitário e águas cinza.

Tabela 3.11 - Metais pesados presentes em diferentes produtos usados no comércio e nas residências

Tabela 3.12 - Quantidade de patógenos e indicadores presentes em lodo de esgoto...............73

Tabela 3.13 - Tempo de sobrevivência de agentes patogênicos no solo. ...............................79

Tabela 3.14 - Parâmetros a serem monitorados para a utilização do lodo na agricultura e as respectivas concentrações máximas de acordo com a Resolução nº 375/2006 do Conama

Tabela 3.15 - Concentrações máximas permitidas de metais pesados e indicadores bacteriológicos de acordo com a Resolução n ${ }^{0}$ 375/2006 do Conama, os estados de São Paulo e Paraná e o Distrito Federal

Tabela 3.16 - Concentrações máximas permitidas de substâncias inorgânicas para o uso de biossólidos na agricultura no Brasil e em diversos países.

Tabela 3.17 - Concentrações máximas permitidas de indicadores bacteriológicos e agentes patogênicos para lodo Classe A no Brasil e em diversos países 
Tabela 3.18 - Temperaturas médias ocorridas durante a secagem do biossólido em estufa agrícola

Tabela 3.19 - Teores finais de S-sulfato, $\mathrm{Na}, \mathrm{Ca}, \mathrm{Mg}, \mathrm{Fe}, \mathrm{Mn}$ e B em amostras de biossólido submetido à secagem em estufa agrícola

Tabela 3.20 - Concentrações máximas e médias de metais pesados em amostras do biossólido submetido à secagem em estufa agrícola 108

Tabela 3.21 - Densidade de coliformes totais, E. coli e a contagem de ovos de helmintos no lodo durante as três repetições e o teor de umidade correspondente

Tabela 4.1 - Valores de vazão e quantidade de lodo produzido nas ETE de acordo com o projeto

Tabela 4.2 - Principais características das unidades (reatores/tanques) componentes do tratamento da fase líquida da ETE Araçás

Tabela 4.3 - Principais características das unidades (reatores/tanques) componentes do tratamento da fase sólida da ETE Araçás

Tabela 4.4 - Características médias do esgoto afluente e da vazão de operação da ETE Araçás durante o período do desenvolvimento experimental

Tabela 4.5 - Características médias do lodo digerido desaguado em centrífuga da ETE Araçás durante o período do desenvolvimento experimental

Tabela 4.6 -Número de eventos planejados e realizados no tempo para os diversos parâmetros em função dos diferentes fatores de variação e categorias utilizados na avaliação estatística dos resultados

Tabela 4.7 -Número de medidas planejadas, imputadas, não imputadas e respectivos percentuais para os parâmetros avaliados estatisticamente

Tabela 5.1 - Teores de cal testados e respectivos valores de $\mathrm{pH}$ para a determinação da quantidade de cal a ser adicionada ao lodo da Etapa 1 nos diferentes tempos definidos pela Resolução 375/2006 do Conama.

Tabela 5.2 - Temperaturas médias das médias horárias, máximas horárias e mínimas horárias dentro e fora da estufa durante a Etapa 1.

Tabela 5.3 - Valores de umidade, SV/ST e pH do lodo sem cal (L1 e L2) e com cal (LC1 e LC2) durante os Ciclos 1/1, 2/1 e 3/1.

Tabela 5.4 - Ocorrência de coliformes termotolerantes, ovos viáveis de helmintos e Salmonella sp. do lodo digerido com e sem cal, durante os Ciclos 1/1, 2/1 e $3 / 1$ 
Tabela 5.5 - Concentrações médias, máximas e desvio padrão dos parâmetros de interesse agronômico no material das células de lodo digerido sem cal (L1 e L2) e com cal (LC1 e LC2), no início e no final dos ciclos da Etapa 1

Tabela 5.6 - Concentrações médias, máximas e desvio padrão de íons metálicos no material das células de lodo digerido sem cal (L1 e L2) e com cal (LC1 e LC2), no início e no final dos ciclos da Etapa 1

Tabela 5.7 - Teores de cal testados e respectivos valores de pH para a determinação da quantidade de cal a ser adicionada ao lodo da Etapa 2 nos diferentes tempos definidos pela Resolução 375/2006 do Conama....

Tabela 5.8 - Temperaturas médias das médias horárias, máximas horárias e mínimas horárias dentro e fora da estufa durante a Etapa 2.

Tabela 5.9 - Valores de umidade, SV/ST e pH do lodo sem cal (L1 e L2) e com cal (LC1 e LC2) durante os Ciclos 1/2, 2/2 e $3 / 2$. 165

Tabela 5.10 - Ocorrência de coliformes termotolerantes, ovos viáveis de helmintos e Salmonella sp. do lodo não encaminhado ao digestor com e sem cal, durante os Ciclos $1 / 2,2 / 2$ e $3 / 2$.

Tabela 5.11 - Concentrações médias, máximas e desvio padrão dos parâmetros de interesse agronômico no material das células de lodo não encaminhado ao digestor sem cal (L1 e L2) e com cal (LC1 e LC2), no início e no final dos ciclos da Etapa 2 .

Tabela 5.12 - Concentrações médias, máximas e desvio padrão de íons metálicos no material das células de lodo não encaminhado ao digestor sem cal (L1 e L2) e com cal (LC1 e LC2), no início e no final dos ciclos da Etapa 2

Tabela 6.1 - Resultados dos testes ANOVA para medida repetida, com fator dependente o tempo e fator independente o tipo de lodo, a presença de cal e o modo de disposição/revolvimento para os parâmetros umidade, SV/ST e pH . 180

Tabela 6.2 - Resultados do teste de Tukey (p-valores) para os modos de disposição/revolvimento do lodo refrerentes ao parâmetro umidade. 185

Tabela 6.3 - Médias e desvios padrões da umidade ao logo do tempo considerando todos os resultados obtidos nas Etapas 1 e 2 de acordo com o tipo de lodo e a condição de adicionar ou não cal ao lodo.

Tabela 6.4 - Médias e desvios padrões da umidade ao logo do tempo considerando todos os resultados obtidos nas Etapas 1 e 2 de acordo com a forma de disposição do lodo na célula e o período de revolvimento 
Tabela 6.5 - Médias e desvios padrões de SV/ST ao logo do tempo considerando todos os resultados obtidos nas Etapas 1 e 2 de acordo com o tipo de lodo e a condição de adicionar ou não cal ao lodo

Tabela 6.6 - Médias e desvios padrões de SV/ST ao logo do tempo considerando todos os resultados obtidos nas Etapas 1 e 2 de acordo com a forma de disposição do lodo na célula e o período de revolvimento.

Tabela 6.7 - Médias e desvios padrões de $\mathrm{pH}$ ao logo do tempo considerando todos os resultados obtidos nas Etapas 1 e 2 de acordo com o tipo de lodo e a condição de adicionar ou não cal ao lodo

Tabela 6.8 - Médias e desvios padrões de $\mathrm{pH}$ ao logo do tempo considerando todos os resultados obtidos nas Etapas 1 e 2 de acordo com a forma de disposição do lodo na célula e o período de revolvimento

Tabela 6.9 - Resultados dos testes ANOVA para medida repetida, com fator dependente o tempo e fator independente o tipo de lodo, a presença de cal e o modo de disposição/revolvimento para os parâmetros coliforme termotolerante e ovos viáveis de helmintos

Tabela 6.10 - Médias e desvios padrões da densidade de CTt ao logo do tempo considerando todos os resultados obtidos nas Etapas 1 e 2 de acordo com o tipo de lodo e a condição de adicionar ou não cal ao lodo

Tabela 6.11 - Médias e desvios padrões da densidade de CTt ao logo do tempo, considerando todos os resultados obtidos nas Etapas 1 e 2 de acordo com a forma de disposição do lodo na célula e o período de revolvimento 201

Tabela 6.12 - Médias e desvios padrões do número de OVH ao logo do tempo considerando todos os resultados obtidos nas Etapas 1 e 2 de acordo com o tipo de lodo e a condição de adicionar ou não cal ao lodo

Tabela 6.13 - Médias e desvios padrões do número de OVH ao logo do tempo considerando todos os resultados obtidos nas Etapas 1 e 2 de acordo com a forma de disposição do lodo na célula e o período de revolvimento

Tabela 6.14 -Resultados de p-valores dos testes a posteriori de Tukey para os parâmetros de interesse agronômico dos lodos usados nas Etapas 1 e 2

Tabela 7.1 - Resultados obtidos na avaliação estatística das variáveis coliformes termotolerantes e ovos viáveis de helmintos de acordo com os fatores analisados 
Tabela 7.2- Condições usadas para estimar a área de estufa necessária para o tratamento do lodo gerado na ETE Araçás (Vila Velha).

Tabela 7.3-Condições usadas para estimar a área de estufa necessária para o tratamento do lodo gerado na ETE Aeroporto (Guarapari)

Tabela 7.4- Condições usadas para estimar a área de estufa necessária para o tratamento do lodo gerado na ETE Bandeirantes (Cariacica)

Tabela 7.5-Condições usadas para estimar a área de estufa necessária para o tratamento do lodo gerado na ETE Mulembá (Vitória).

Tabela 7.6- Características gerais da estufa, do lodo e do biossólido gerado nas ETE Araçás, Aeroporto, Bandeirantes, Mulembá

Tabela 7.7- Custo de investimento estimado da estufa, considerando a configuração definida para cada ETE para alcance de projeto de 2023

Tabela 7.8- Custo de investimento estimado da estufa, relativo às dimensões físicas da estufa, à população atendida e à quantidade de lodo a ser tratado, para cada ETE.

Tabela 7.9- Custo de investimento estimado de secador térmico para tratamento do lodo gerado na ETE Bandeirantes 


\section{LISTA DE ABREVIATURAS E SIGLAS}

Abes - Associação Brasileira de Engenharia Sanitária e Ambiental

ANOVA - Analise of variance (Análise de variância)

Cesan - Companhia Espírito Santense de Saneamento

Cetesb - Companhia de Tecnologia de Saneamento Ambiental

Conama - Conselho Nacional do Meio Ambiente

Crusp - Conjunto Residencial da Universidade de São Paulo

CTt - Coliforme termotolerante

DBO - Demanda Bioquímica de Oxigênio

DQO - Demanda Química de Oxigênio

Embrapa - Empresa Brasileira de Pesquisa Agropecuária

EPUSP - Escola Politécnica da Universidade de São Paulo

ETE - Estação de Tratamento de Esgoto

Facitec - Funde de Apoio à Ciência e Tecnologia

Fapes - Fundação de Apoio à Ciência e Tecnologia do Espírito Santo

Ifes - Instituto Federal do Espírito Santo

IN - Instrução Normativa

L1 - Célula 1 - lodo sem cal

L2 - Célula 2 - lodo sem cal

LC1 - Célula 1 - lodo com cal

LC2 - Célula 2 - lodo com cal

M.O. - Matéria Orgânica

OVH - Ovos viáveis de helmintos

PAC - Programa de Aceleração Econômica

PCBs - Bifenilas Policloradas

pH - potencial Hidrogeniônico

Prosab - Programa de Pesquisa em Saneamento Básico

RMGV - Região Metropolitana da Grande Vitória

Sabesp - Companhia de Saneamento Básico do Estado de São Paulo

Sanepar - Companhia de Saneamento do Paraná

SES - Sistema de Esgotamento Sanitário

SF - Sólidos Fixos

SS - Sólidos Sedimentáveis

ST - Sólidos Totais

SV - Sólidos Voláteis 
UASB - Upflow Anaerobic Sludge Blanket Reactor (Reator Anaeróbio de Fluxo Ascendente e Manta de Lodo)

UGL - Unidade de Gerenciamento de Lodo 
1 INTRODUÇÃO .......................................................................................................................25

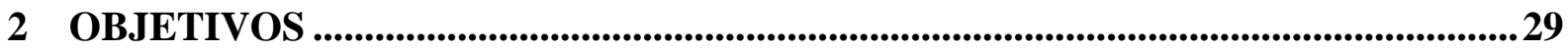

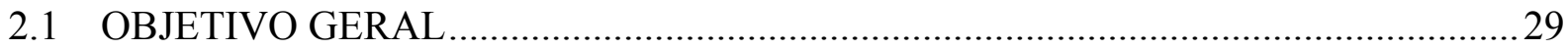

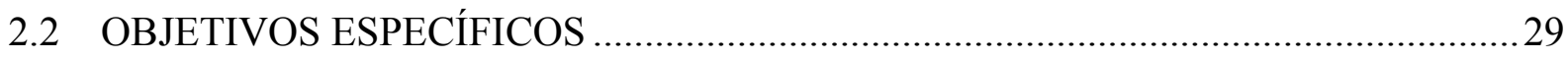

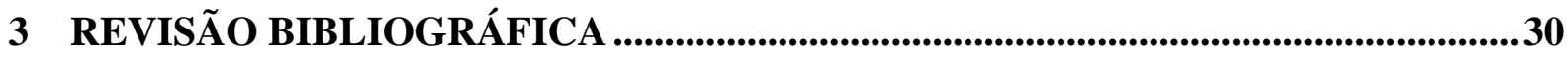

3.1 RESÍDUOS GERADOS NO TRATAMENTO DE ESGOTO DOMÉSTICO E SUAS

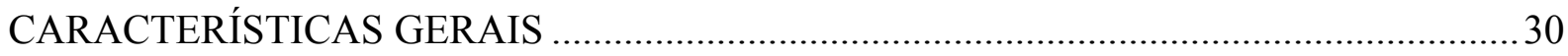

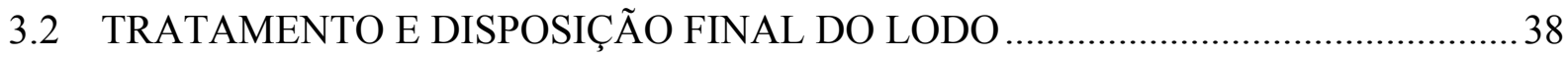

3.2.1 Tratamento do lodo - Estabilização e higienização........................................41

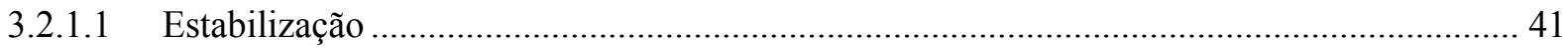

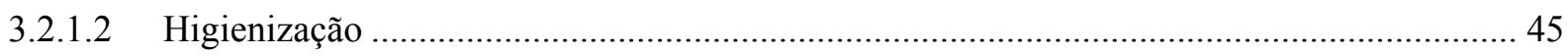

3.2.2 Alternativas de disposição final do lodo ......................................................54

3.3 UTILIZAÇÃO DO LODO (BIOSSÓLIDO) NA AGRICULTURA ..............................57

3.3.1 Aspectos positivos relacionados à utilização do lodo na agricultura ................59

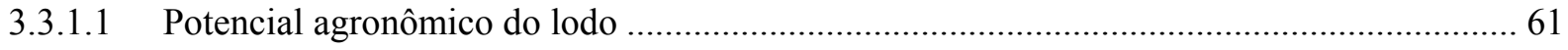

3.3.2 RISCOS relacionados à utilização do lodo na agricultura .............................65

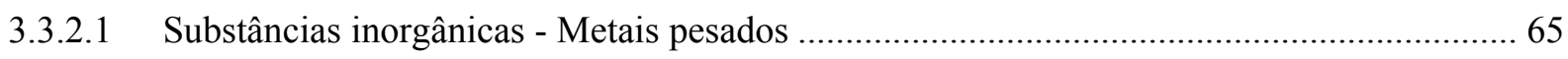

3.3.2.2 Organismos patogênicos e indicadores bacteriológicos.................................................. 71

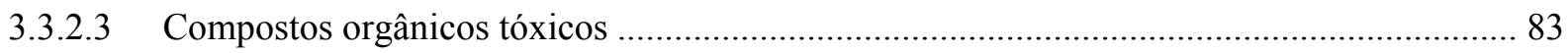

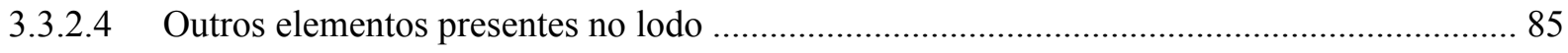

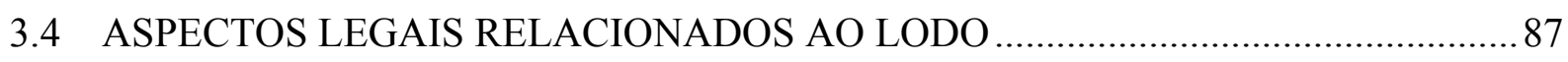

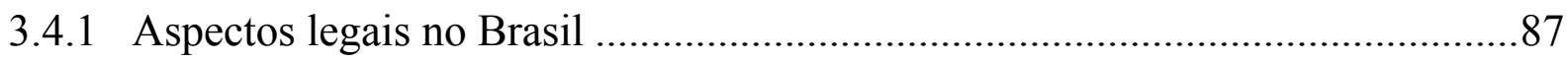

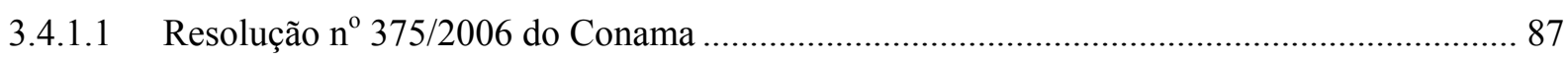

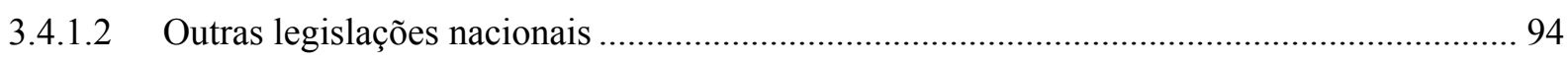

3.4.2 Limites restritivos no Brasil e em outros países............................................96

3.5 HIGIENIZAÇÃO/SECAGEM DO LODO EM ESTUFA AGRÍCOLA ...................... 100

3.5.1 Pesquisa que usa estufa agrícola na secagem e higienização do lodo..............103 
3.5.1.1 Caracterização do lodo utilizado no experimento ............................................................ 104

3.5.1.2 Resultados obtidos com a higienização do lodo em estufa agrícola .................................... 105

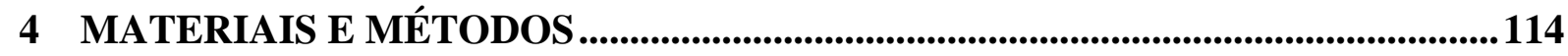

4.1 CARACTERIZAÇÃO DA ÁREA DE ESTUDO ...................................................... 114

4.1.1 Descrição das ETE ..............................................................................116

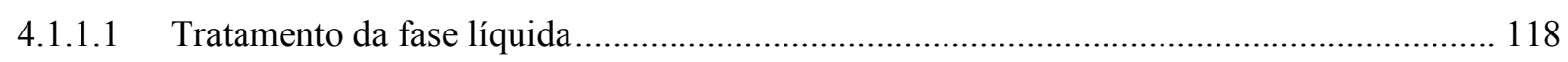

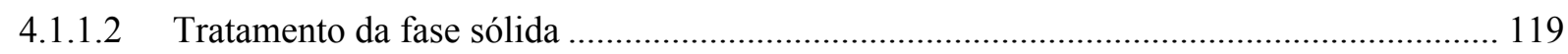

4.1.2 ETE Araçás - Características gerais da ETE, do esgoto afluente e do lodo

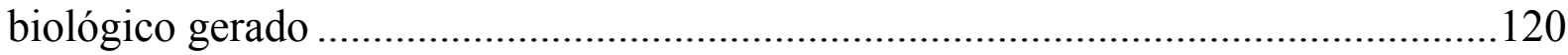

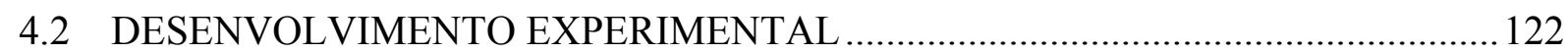

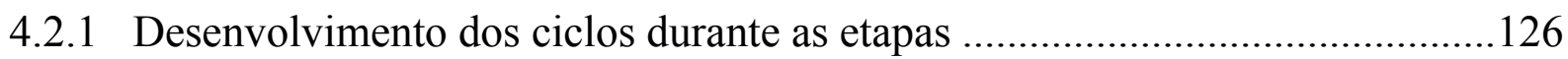

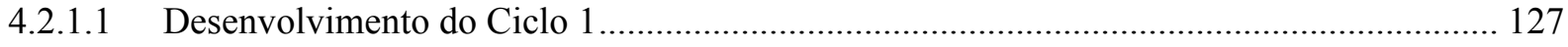

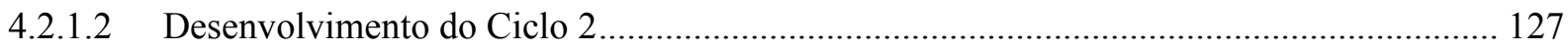

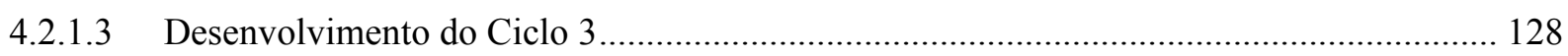

4.2.2 Determinação da quantidade de cal utilizada em cada etapa da pesquisa........130

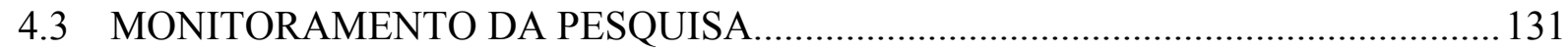

4.3.1 Parâmetros monitorados e metodologias analíticas usadas............................131

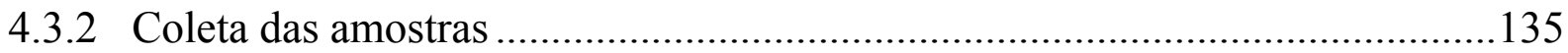

4.4 AVALIAÇÃO ESTATÍSTICA DOS RESULTADOS OBTIDOS .............................. 136

4.5 ESTIMATIVA DA ÁREA E DO CUSTO DE INVESTIMENTO DA ESTUFA........ 139

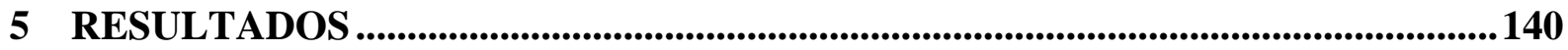

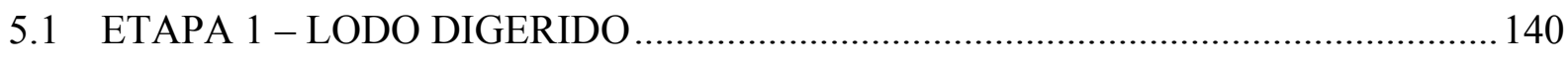

5.1.1 Determinação da quantidade de cal a ser usada na etapa 1 ...........................141

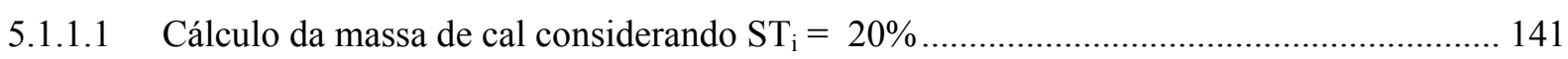

5.1.1.2 Cálculo do teor de sólidos totais real .......................................................................... 141

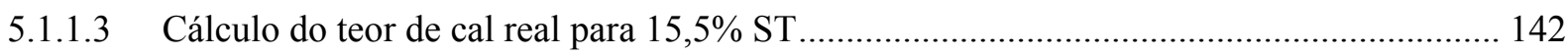

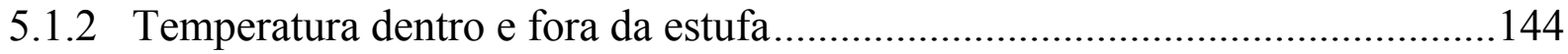

5.1.3 Parâmetros: umidade, sólidos e potencial Hidrogeniônico ............................146

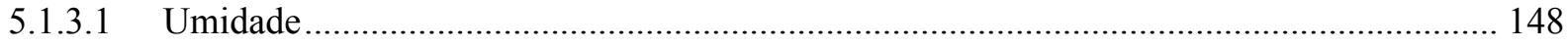

5.1.3.2 Relação entre sólidos voláteis e sólidos totais ………….................................................. 150 


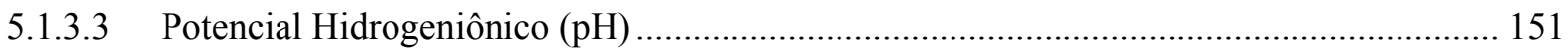

5.1.4 Indicadores bacteriológicos e agentes patogênicos ..................................152

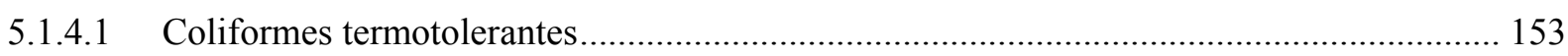

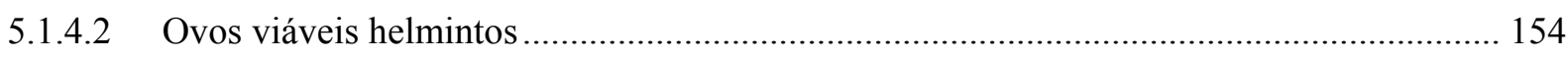

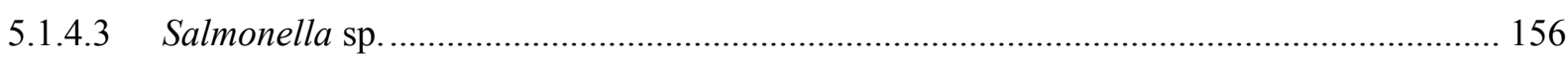

5.1.5 Parâmetros de interesse agronômico .......................................................156

5.1.6 Substâncias inorgânicas (íons metálicos) .............................................. 157

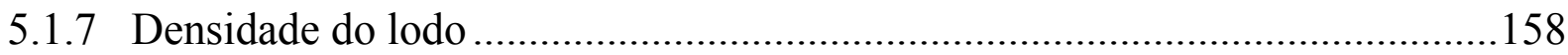

5.2 ETAPA 2 - LODO NÃO ENCAMINHADO AO DIGESTOR .................................... 160

5.2.1 Determinação da quantidade de cal a ser utilizada na etapa 2 .......................161

5.2.2 Temperaturas dentro e fora da estufa ....................................................163

5.2.3 Parâmetros - umidade, sólidos e potencial hidrogeniônico............................ 165

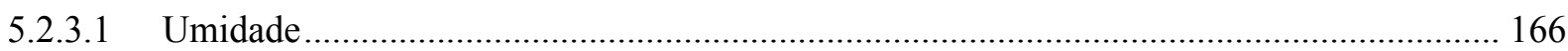

5.2.3.2 Relação entre Sólidos Voláteis e Sólidos Totais (SV/ST) ............................................... 167

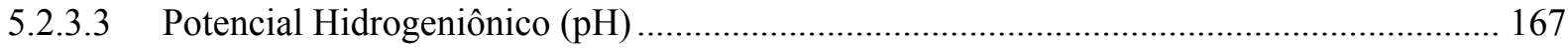

5.2.4 Indicadores bacteriológicos e agentes patogênicos ...................................169

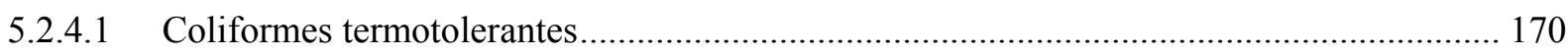

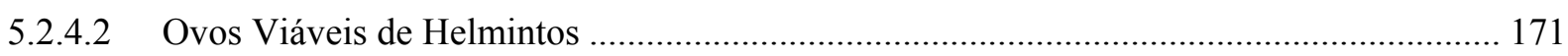

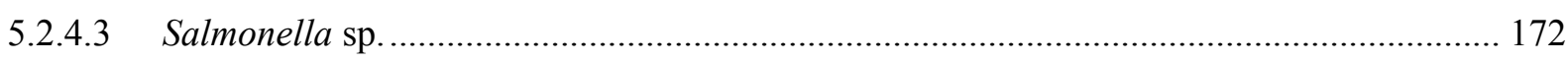

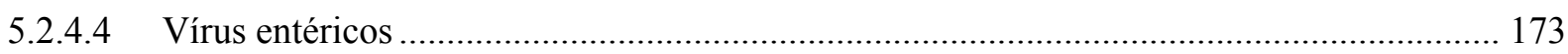

5.2.5 Parâmetros de interesse agronômico ........................................................176

5.2.6 substâncias inorgânicas (íons metálicos) .................................................... 176

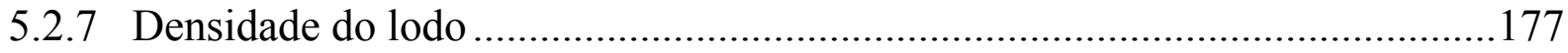

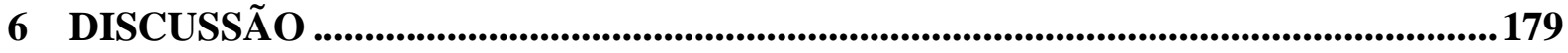

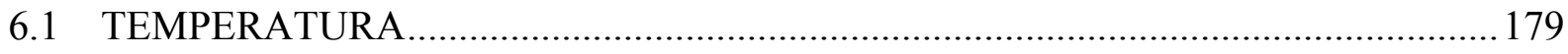

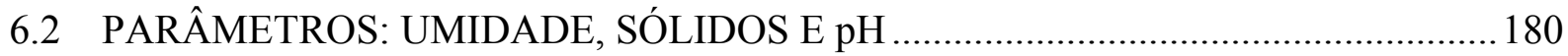

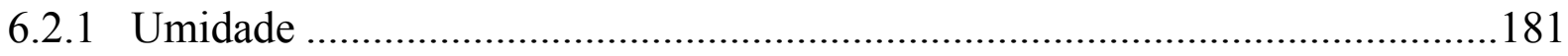

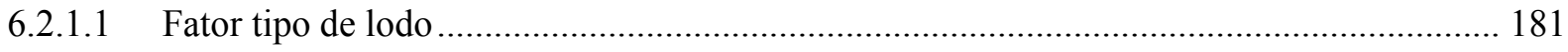

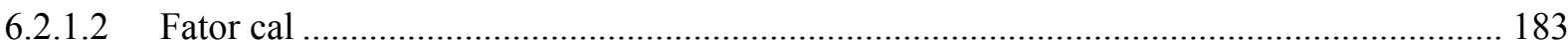

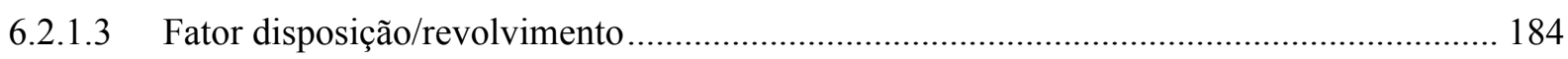

6.2.2 Relação entre sólidos voláteis e sólidos totais (SV/ST) ................................187

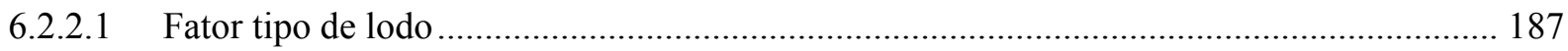




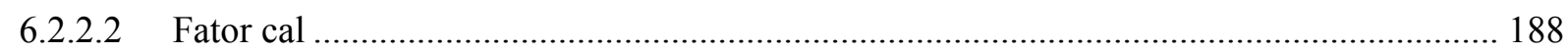

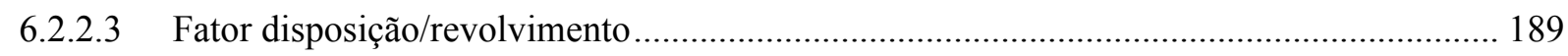

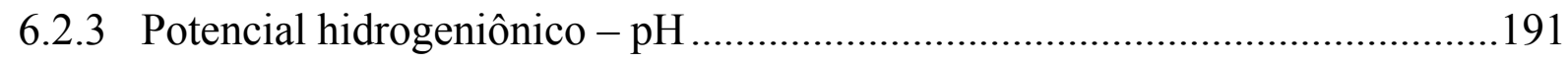

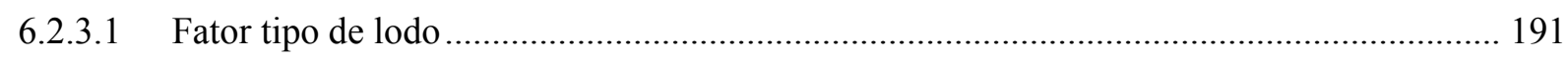

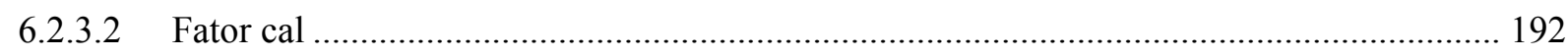

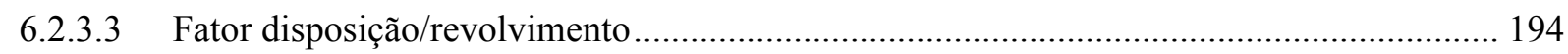

6.3 INDICADORES BACTERIOLÓGICOS E AGENTES PATOGÊNICOS ................... 196

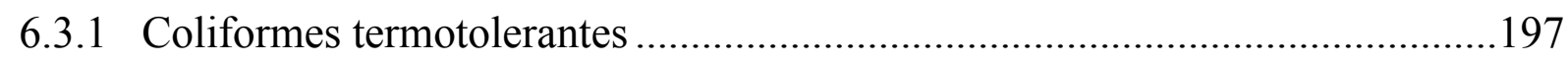

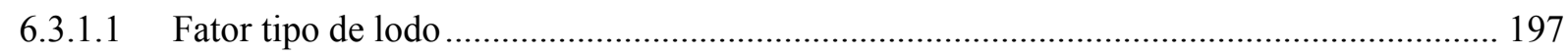

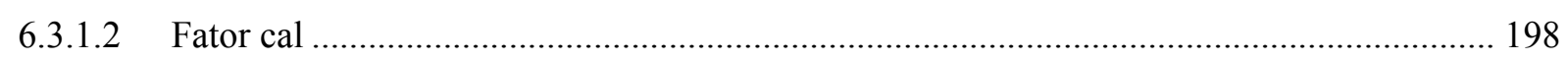

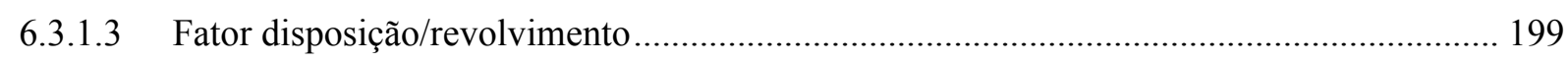

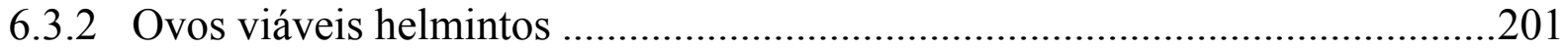

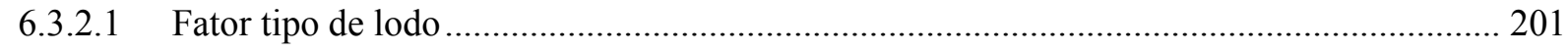

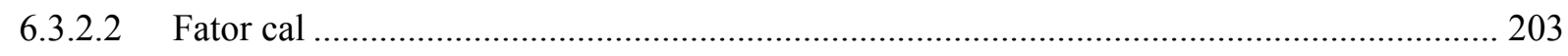

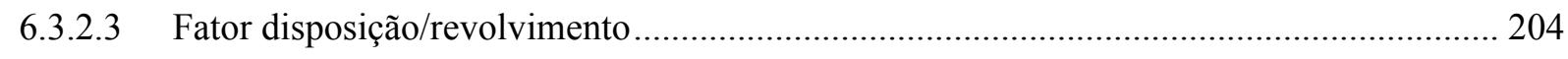

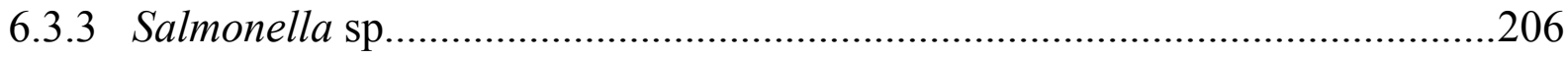

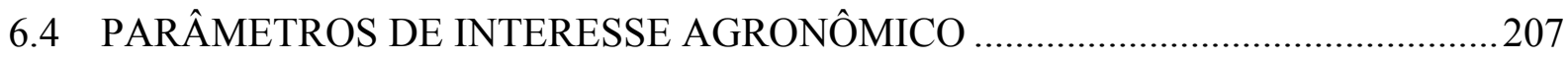

6.5 SUBSTÂNCIAS INORGÂNICAS (ÍONS METÁLICOS) .....................................212

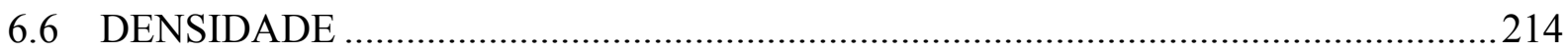

7 ESTIMATIVA DE ÁREA E DE CUSTO PARA A INSTALAÇÃO DA ESTUFA . 215

7.1 CONDIÇÕES PARA A ESTIMATIVA DE ÁREA DA ESTUFA ..............................215

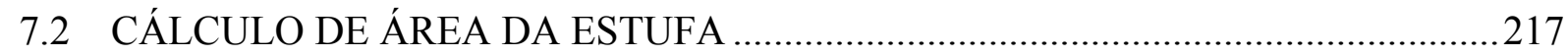

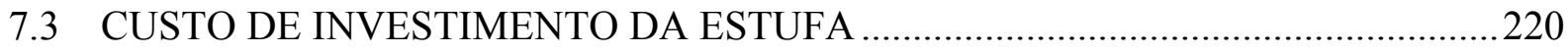

CONCLUSÕES E RECOMENDAÇÕES ....................................................................223

REFERÊNCIA

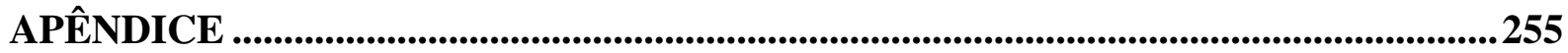

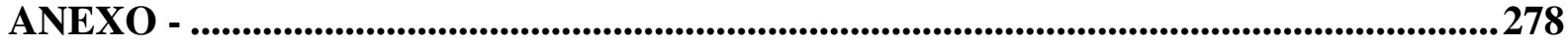




\section{INTRODUÇÃO}

Quando se processa o tratamento do esgoto, resolve-se apenas parte de um problema ambiental, porque, com o tratamento, são gerados produtos finais, como o efluente tratado, que é o objetivo principal do tratamento, o lodo, que agrega grande parte da carga orgânica do esgoto bruto original e os gases. O efluente tratado deve atender a padrões legais de qualidade para ser lançado ao meio ambiente e, dependendo do processo utilizado, os gases gerados são reaproveitados ou tratados e lançados à atmosfera. Já a destinação do lodo ainda é um grande desafio para as empresas de saneamento, públicas ou privadas. Assim, é fundamental que a implantação dos Sistemas de Esgotamento Sanitários (SES) deva ser pensada amplamente, com o envolvimento de todas as questões pertinentes ao sistema, para que os problemas relacionados com a poluição ambiental sejam realmente minimizados.

O lodo se apresenta em quantidade e qualidade bastante específicas. A presença de componentes indesejáveis é inevitável, como os microrganismos patogênicos. Em alguns casos, ele pode apresentar metais pesados e poluentes orgânicos (nos esgotos de origem predominantemente doméstica se apresentam em pequenas quantidades), e fármacos (principalmente antibióticos). Esses componentes podem provocar impactos ambientais negativos, tanto para o ser humano, quanto para o meio ambiente, que, possivelmente, anulariam os benefícios gerados com a coleta e o tratamento do esgoto.

Por sua vez, o lodo é apontado como um excelente adubo orgânico e passa a representar um insumo de grande valor para a agricultura, por apresentar na sua composição elementos fundamentais para o crescimento das plantas, como macronutrientes e micronutrientes, atuando como condicionador de solo e fertilizante agrícola. Assim, entre as principais opções de disposição do lodo no ambiente, é indicada, sempre que possível, a sua reciclagem na agricultura, quando este apresentar características adequadas em atendimento aos padrões estabelecidos pela legislação vigente (Resolução n ${ }^{0}$ 375/06 do Conama) (BRASIL, 2006c). Então, antes apontado como um problema, o lodo agora passa a ser um insumo que contribui para uma agricultura sustentável.

Na maioria das vezes, o gerenciamento do lodo é compreendido de atividades com elevado grau de complexidade e também de alto custo. Apesar de o lodo corresponder a apenas de 1\% a $2 \%$ do volume de esgoto tratado, pode chegar a atingir cerca de $60 \%$ do total gasto com a 
operação de sistemas de tratamento de esgoto. Kroiss e Zessner (2007) revelam que, na Áustria, o tratamento e a disposição do lodo gerado em ETE atingem, aproximadamente, 50\% dos custos do tratamento das águas residuárias, o que corresponde a $10 \%$ das tarifas pagas pelo serviço de saneamento. O mesmo percentual de 50\% também é apresentado por Leblanc, Matthews e Richard (2008) ${ }^{1}$ como o ocorrido nas cidades de Ontário e Greater Moncton, no Canadá.

Em todo o mundo, a geração de lodo vem crescendo rapidamente e tomando proporções alarmantes. Nos Estado Unidos, por exemplo, no ano de 2004, o país gerava mais de 7 milhões de toneladas em massa seca de lodo (LEBLANC; MATTHEWS; RICHARD, 2008). $\mathrm{Na}$ Europa, a implantação de várias estações de tratamento de esgoto resultou na produção de uma enorme quantidade de lodo, quando, em 2005, 9 milhões de toneladas de matéria seca de lodo foram gerados, e a expectativa é que, em 2015, esse valor tenha um incremento de $50 \%$ (MULLER et al., 2007).

Para o Brasil, von Sperling e Andreoli (2001) estimaram a produção de lodo em razão da população beneficiada com serviços de coleta e tratamento de esgoto, divulgada pela revista $\mathrm{Bio}^{2}$, e dos valores médios de produção per capita de lodo, chegando a valores da ordem de 90.000 a 350.000 toneladas/dia de lodo líquido a ser tratado (produção per capita volumétrica de cerca de 1 a 4 L/hab.dia) e 9.000 a 13.000 t/dia de lodo desaguado a ser disposto (produção per capita volumétrica de cerca de 0,1 a $0,15 \mathrm{~L} / \mathrm{hab}$.dia).

Cabe ressaltar que os valores apresentados para o Brasil são apenas estimativos, podendo os valores reais ser surpreendentes em virtude das políticas implantadas pelo governo federal, tais como a de Recursos Hídricos (Lei 9.433/1997)³ , o Marco Regulatório (Lei Federal $11.455 / 2007)^{4}$ e o Programa de Aceleração Econômica (PAC), que prevê um investimento de R\$ 40 bilhões em Saneamento Ambiental até 2010 (MOURIM, 2007). Outro aspecto importante que vale destaque é a conscientização por parte da população sobre as consequências advindas dos problemas de poluição ambiental, que exige das autoridades providências e comprometimento no trato das questões relacionadas ao saneamento básico.

\footnotetext{
${ }^{1}$ http://esa.un.org/iys/docs/san_lib_docs/habitat2008.pdf

${ }^{2}$ BIO. Caderno especial. O saneamento em números. Revista Bio: Rio de Janeiro. Abes, jan/mar 2001, p. 17-36.

${ }^{3}$ Lei 9.433/1997 - Institui a Política Nacional de Recursos Hídricos e cria o Sistema Nacional de Gerenciamento de Recursos Hídricos.

${ }^{4}$ Lei $11.445 / 2007$ - Define as Diretrizes Nacionais para o Saneamento Ambiental.
} 
No caso específico do estado do Espírito Santo, a situação não é diferente, pois a Região Metropolitana da Grande Vitória (RMGV), especificamente o município da Serra, era a região com maior cobertura quanto à coleta e ao tratamento de esgotos sanitário. Porém, nos últimos anos, várias estações foram implantadas em diversos municípios do estado. $\mathrm{Na}$ RMGV, especificamente nos municípios de Vitória, Vila Velha, Guarapari e Cariacica, já se encontram em operação quatro grandes estações que utilizam o processo de lodos ativados. A previsão inicial era que, em 2002, essas estações produzissem diariamente $73 \mathrm{~m}^{3}$ de lodo e que, em 2023, chegassem a atingir $235 \mathrm{~m}^{3}$ (desaguado com 25\% de sólidos totais) (ANDREOLI et al., 2002). Essa situação aponta uma preocupação bastante eminente na busca por técnicas de tratamento e alternativas de disposição final do lodo que tornem seu gerenciamento viável, considerando aspectos técnicos, ambientais e econômicos.

Atualmente, o lodo gerado nessas ETE é encaminhado a um aterro sanitário particular, localizado no município de Cariacica. Pouco se sabe sobre as suas características, e nenhuma técnica, nenhum processo foi testado para promover a sua secagem e higienização, possibilitando, assim, o seu uso na agricultura. Além disso, a digestão do lodo é realizada por processo aeróbio, com uma demanda bastante expressiva de energia.

Diante dessas considerações, fica evidente a necessidade de se estudar técnicas e processos que visem a diminuir o volume e melhorar a qualidade do lodo gerado nas ETE. Para isso, pensou-se em avaliar um processo de tratamento de baixo custo que operasse utilizando-se, apenas, das condições favoráveis de clima e temperatura da região, minimizando, assim, a complexidade e o custo do seu gerenciamento. Surgiu, então, a ideia de usar a estufa agrícola por apresentar como grande vantagem a capacidade de maximizar a energia solar no aquecimento do lodo, retendo o calor e, com isso, acelerando o processo de secagem do material. Com a diminuição da umidade, reduzem-se as concentrações de microrganismos patogênicos e o volume de lodo a ser disposto.

A estufa foi montada na área da ETE Araçás, localizada no município de Vila Velha, por apresentar melhores condições para o desenvolvimento da pesquisa. Parâmetros relevantes ao gerenciamento do lodo foram investigados, quando o foco principal é sua utilização na agricultura, respeitando as condições impostas pela legislação em vigor (BRASIL, 2006c). Com a intenção de minimizar os custos com energia, foi investigado, além das características do lodo de excesso digerido aerobiamente, gerado rotineiramente nas ETE, o lodo de excesso 
não encaminhado ao digestor, e sim, encaminhado diretamente para a centrífuga após adensamento.

Esta investigação se propõe, então, a dar suporte ao gerenciamento do lodo gerado nas ETE, estudando uma técnica simplificada para a melhoria de suas características. Esta poderá não ser a única alternativa, mas provavelmente trará contribuições importantes sob os aspectos ambiental, social e econômico para o Estado. No espectro mais amplo, espera-se que contribua no favorecimento de adoção de formas de tratamento e disposição final de lodos gerados em outras ETE. Além disso, poderá disponibilizar informações que ajudarão outros pesquisadores na constante busca por conhecimentos e novas tecnologias. 


\section{OBJETIVOS}

\subsection{OBJETIVO GERAL}

Avaliar as alterações das características físicas, químicas e biológicas de excesso de lodo ativado digerido ou não aerobiamente gerado em Estações de Tratamento de Esgoto, localizadas na Região Metropolitana da Grande Vitória (ES), quando submetido à secagem e higienização em estufa agrícola, tendo como alternativa de disposição final a agricultura.

\subsection{OBJETIVOS ESPECÍFICOS}

- Identificar as condições de secagem e higienização em estufa agrícola de lodo digerido aerobiamente: sem e com adição de cal.

- Identificar as condições de secagem e higienização em estufa agrícola de lodo não encaminhado ao digestor aeróbio: sem e com adição de cal.

- Verificar, entre as variáveis e os fatores estudados, qual a configuração ideal para o dimensionamento da estufa, considerando o tempo de secagem necessário para o atendimento aos padrões legais para lodo Classe A, segundo a Resolução n 375/2006 do Conama.

- Estimar a área e o custo de investimento necessários para a secagem e higienização do lodo gerado nas ETE da RMGV, considerando os resultados obtidos na pesquisa. 


\section{REVISÃO BIBLIOGRÁFICA}

Entre os diferentes tipos de esgotos existentes, estão: esgoto doméstico, esgoto industrial e esgoto pluvial. Cada um desses apresenta características específicas, relacionadas aos processos de consumo de água que a eles deram origem ou de águas de escoamento superficial que geraram as vazões de esgoto. Apesar da necessidade iminente de tratamento do esgoto, boa parte é lançada in natura nos corpos d'água, gerando sérios problemas ambientais. Porém, somente com o tratamento do esgoto (fase líquida), o problema não está finalizado e sim, apenas minimizado, porque os resíduos gerados durante o seu tratamento necessitam de gerenciamento adequado. Sabe-se que, durante muito tempo, nos estudos de concepção dos projetos de tratamento de esgotos sanitário, o foco principal estava, normalmente, relacionado ao tratamento/eficiência da fase líquida, não havendo estudos detalhados sobre o gerenciamento adequado dos subprodutos gerados. Assim, atualmente, pensar apenas no tratamento da fase líquida isoladamente já é condição ultrapassada.

\subsection{RESÍDUOS GERADOS NO TRATAMENTO DE ESGOTO DOMÉSTICO E SUAS CARACTERÍSTICAS GERAIS}

Os subprodutos ou resíduos sólidos são gerados nas operações físico-químicas e nos processos biológicos dos sistemas de tratamento, podendo-se destacar:

- os sólidos grosseiros e a areia, removidos na etapa definida como preliminar, que são comuns a todos os sistemas de tratamento;

- a escuma, que pode ocorrer durante o tratamento e é caracterizada por materiais flutuantes (graxa, óleos, gorduras) que aparecem na superfície do líquido em diversos reatores;

- o lodo primário, constituído de sólidos sedimentáveis (SS) orgânicos e inorgânicos que se sedimentam em decantadores primários. Esse lodo é gerado no tratamento primário da fase líquida, em que são removidos até $50 \%$ dos sólidos em suspensão, $20 \%$ da demanda bioquímica de oxigênio (DBO) e 50\% dos coliformes fecais (WRIGHT, 2001); 
- o lodo químico, produzido em algumas estações de tratamento que utilizam a etapa físico-química, normalmente com o intuito de remover poluentes específicos (US EPA, 1995);

- o lodo biológico, proveniente dos tanques de aeração e separados nos decantadores secundários, por isso chamado também de lodo secundário, é composto essencialmente de células bacterianas (biomassa) que se desenvolvem no interior do reator, no tratamento biológico, em virtude das condições ambientais favoráveis, especialmente o alimento (matéria orgânica) que é fornecido pelo esgoto afluente (TCHOBANOGLOUS; BURTON; STENSEL, 2002; US EPA, 1995). É normalmente gerado no tratamento secundário da fase líquida, em que pode ser removido mais de $85 \%$ de DBO e sólidos em suspensão (QASIM, 1999).

A geração do lodo nos sistemas de tratamento do esgoto ocorre, essencialmente, por causa da remoção da matéria orgânica (M.O.) presente. Segundo van Haandel e Alem Sobrinho (2006), essa remoção/transformação acontece de diferentes formas nos sistemas aeróbios e nos anaeróbios de tratamento. No primeiro caso, sistemas aeróbios, parte da M.O. afluente se transforma em lodo (anabolismo ${ }^{5}$ ), parte é oxidada (catabolismo ${ }^{6}$ ) e outra parcela, não removida, se mantém no efluente final. No segundo caso, sistemas anaeróbios, a M.O. também se subdivide em três parcelas, sendo parte transformada em lodo, parte é digerida e transformada em metano e uma parcela, não removida, permanece no efluente. A FIGURA 3.1 apresenta, de forma simplificada, a divisão da M.O. do afluente nos sistemas aeróbios e anaeróbios de tratamento do esgoto.

Em sistemas aeróbios, existe uma particularidade que é o fato de o lodo produzido ser altamente putrescível, necessitando passar por um processo de estabilização (FIGURA 3.1).

Em princípio, considerando o tamanho das partículas e a biodegradabilidade, o material orgânico pode ser dividido em quatro frações, a saber: (1) biorrefratário e solúvel; (2) biorrefratário e particulada; (3) biodegradável e solúvel; (4) biodegradável e particulada. No caso das frações biorrefratárias, independentemente de o sistema ser aeróbio ou anaeróbio,

\footnotetext{
${ }^{5}$ Anabolismo - Processo em que as bactérias usam o material orgânico como fonte de material transformando-o em massa celular. Processo de assimilação ou síntese de nova massa celular (VAN HAANDEL; MARAIS, 1999).

${ }^{6}$ Catabolismo - Processo em que as bactérias usam o material orgânico como fonte de energia. Transformação química do material orgânico (VAN HAANDEL; MARAIS, 1999).
} 
essas não são metabolizadas. Porém, a fração particulada é floculada, passando a fazer parte do lodo (fração inerte) e a solúvel, é descartada junto com o efluente (VAN HAANDEL; ALEM SOBRINHO, 2006).

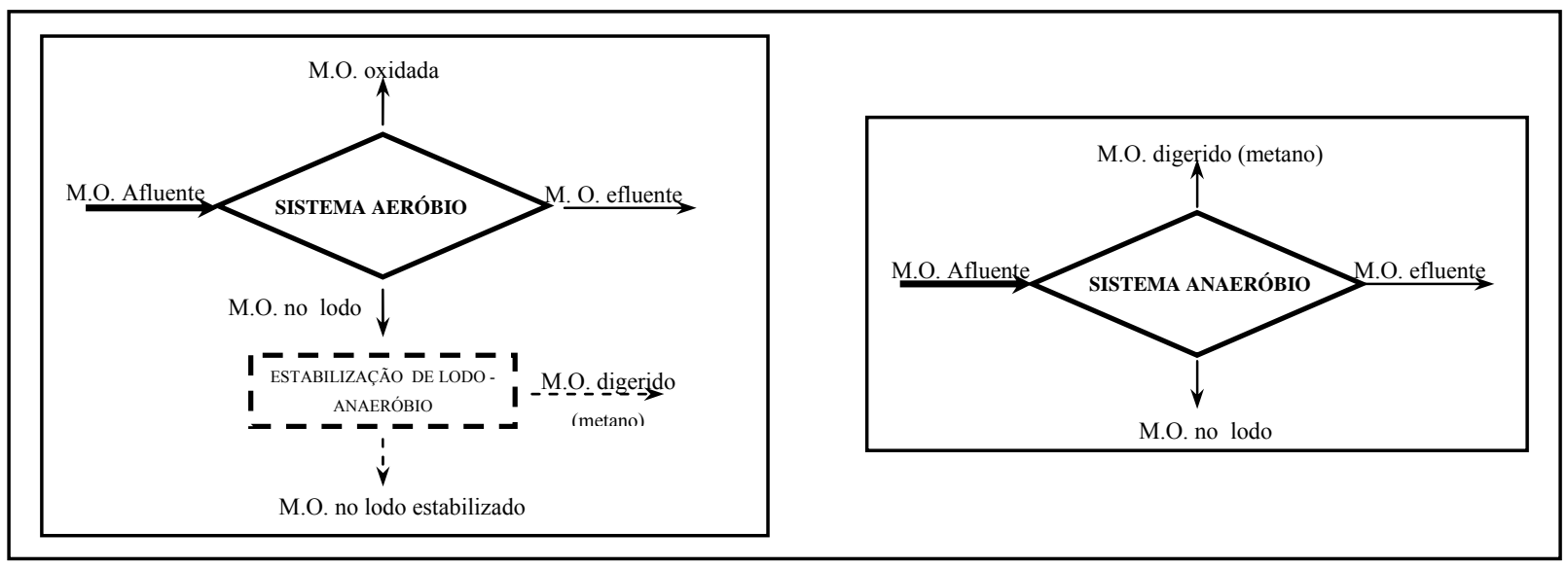

Figura 3.1 - Transformações do material orgânico presente no afluente em sistema de tratamento aeróbio e anaeróbio do esgoto

Fonte: Adaptado de VAN HAANDEL; ALEM SOBRINHO, 2006.

A parcela da M.O. que se transforma em lodo, formando assim o lodo biológico, apresenta-se como vários tipos, dependendo do tipo de tratamento utilizado (TCHOBANOGLOUS; BURTON; STENSEL, 2002):

- lodo biológico aeróbio não estabilizado - constituído de biomassa bacteriana que cresce e se multiplica dentro do reator. É também chamado de lodo biológico excedente, pois é removido continuamente para manutenção do equilíbrio do sistema. Esses sólidos biológicos não se encontram estabilizados, ou seja, digeridos, devido à quantidade elevada de alimento disponível no meio e ao seu baixo tempo de permanência no sistema. Nesse caso, os sólidos biológicos terão maiores teores de matéria orgânica em sua composição celular, necessitando, então, de tratamento adequado para sua digestão. Esse tipo de lodo é gerado em processos de lodos ativados convencional ou em reatores aeróbios com biofilme de alta carga. Estes últimos podem ser os filtros biológicos de alta carga, os biofiltros aerados submersos e os biodiscos;

- lodo biológico aeróbio estabilizado - constituído, também, de microorganismos aeróbios que se desenvolvem à custa da matéria orgânica contida no afluente. São provenientes de sistemas de baixa carga e, sendo assim, a disponibilidade de alimento é menor. A biomassa fica mais tempo retida no reator, ocorrendo, então, a respiração 
endógena, que consiste na utilização, pelos microrganismos, das próprias reservas de matéria orgânica contidas no protoplasma celular. Dessa forma, o lodo apresenta-se digerido com menor teor de matéria orgânica e maior teor de sólidos inorgânicos, não necessitando de uma etapa posterior de digestão. Esse tipo de lodo é gerado em processos de lodos ativados de aeração prolongada e reatores aeróbios com biofilme de baixa carga (filtro biológico de baixa carga, biofiltro aerado submerso e o biodisco);

- lodo biológico anaeróbio estabilizado - este lodo é constituído de biomassa anaeróbia que cresce e se multiplica, também, em função da matéria orgânica presente no esgoto afluente. A diferença em relação aos outros dois tipos apresentados é a falta de oxigênio no meio, caracterizando um ambiente anaeróbio. Fica retido dentro do reator por longos períodos de tempo, possibilitando a digestão anaeróbia do próprio material celular. Nesse caso, o material não requer uma etapa posterior de digestão. É oriundo das lagoas de estabilização, como as lagoas facultativas, as lagoas anaeróbias seguidas de uma facultativa, as lagoas aeradas facultativas, as lagoas aeradas de mistura completa seguidas de lagoas de decantação e, também, de reatores anaeróbios como os reatores $\mathrm{UASB}^{7}$ e os filtros anaeróbios.

Durante muito tempo o gerenciamento desses subprodutos, especialmente os lodos, foi negligenciado no Brasil, podendo-se referir que por necessidades emergenciais, durante a década de 70, o foco era voltado apenas para o tratamento da fase líquida e, a partir da década de 90, percebeu-se a necessidade de promover, também, um gerenciamento adequado dos resíduos gerados durante esse tratamento. Outro fator que pode ser referenciado são os altos custos associados ao tratamento e disposição final da fase sólida (lodo), embora, segundo von Sperling e Andreoli (2001), esses representem apenas 1\% a 2\% do volume de esgoto tratado. Nos dias atuais, maior atenção tem sido dada ao gerenciamento desses subprodutos, em especial aos lodos, sobretudo em virtude das exigências legais.

No entanto, o tratamento e a disposição final adequada dos lodos não devem ser desprezados durante os estudos de concepção de uma estação de tratamento de efluentes. Além disso, é constante a busca por alternativas viáveis para o aproveitamento do lodo, em face da

\footnotetext{
${ }^{7}$ A sigla UASB advém de Upflow Anaerobic Sludge Blanket. No Brasil são também conhecidos como DAFA (Digestor Anaeróbio de Fluxo Ascendente), RAFA (Reator Anaeróbio de Fluxo Ascendente), RALF (Reator Anaeróbio de Leito Fluidizado), RAFAALL (Reator Anaeróbio de Fluxo Ascendente através de Leito de Lodo) (CHERNICHARO, 1997).
} 
possibilidade de minimização tanto dos custos relativos ao seu gerenciamento, quanto dos problemas socioambientais ocasionados por uma disposição inadequada do material.

Como destacado anteriormente, os subprodutos sólidos são gerados nas diferentes etapas do tratamento a que o esgoto é submetido na ETE. Dependendo do afluente e do processo de tratamento utilizado, os subprodutos apresentam características e quantidades diferentes, sendo os lodos (primário e secundário) os principais deles, devido ao grande volume e massa gerados. Além disso, as características químicas, físicas e microbiológicas dos lodos dependem dos processos adotados no seu tratamento. Diferentes processos de tratamento do esgoto e dos subprodutos geram diferentes tipos e volumes de lodos. Assim, suas características podem variar anualmente, sazonalmente, ou até mesmo diariamente, devido à variação do esgoto afluente e à variação no desempenho do processo de tratamento.

Tratando-se de sistemas de esgotos municipais, grandes variações são mais observadas naqueles que recebem quantidades elevadas de efluentes industriais (MALINA, 1993a; PECKENHAM, 2005) ${ }^{8}$, na maioria das vezes, sem tratamento prévio ou inadequado que, do ponto de vista ambiental e da saúde da população, é uma prática bastante condenável. Nesse caso, é importante ressaltar que os órgãos ambientais já trabalham com a perspectiva de prevenção da descarga de efluentes industriais nos SES por serem uma fonte potencialmente poluidora, assim evitam a necessidade de implantação de tratamento complementar específico para a remoção desses elementos. Inclusive, a NBR 9800 da ABNT (1987) já estabelece critérios para o lançamento de efluentes líquidos industriais no sistema coletor público de esgoto sanitário.

Em termos gerais, apesar das diferentes condições de geração dos lodos, após o tratamento das águas residuárias, alguns componentes são, então, incorporados aos lodos, proporcionando a eles uma característica específica. O conhecimento dessas características é muito importante para o manejo e gerenciamento do material, pois estabelece condições e possibilidades adequadas para o seu tratamento e disposição final e o seu reuso ou reciclagem.

O lodo é caracterizado por uma parcela de água, definida pela umidade, e outra de sólidos. Os sólidos encontram-se nas formas dissolvida e em suspensão, constituindo os sólidos totais (ST), que se subdividem em inorgânicos ou fixos (SF) e orgânicos ou voláteis (SV). A

\footnotetext{
${ }^{8} \mathrm{http}: / /$ www.umaine.edu/waterresearch/outreach/biosolids_white_paper.htm
} 
maioria dos sólidos do lodo é representada pelos sólidos em suspensão (SS) e, ainda, a grande fração de sólidos orgânicos é putrescível e facilmente biodegradável (MALINA, 1993a; VON SPERLING, GONÇALVES, 2001).

As informações sobre as propriedades mecânicas do lodo, a produção de lodo expressa em massa ou volume e a densidade do lodo são também necessárias para o seu gerenciamento e estão ligadas diretamente aos teores de sólidos e umidade do material.

A água contida no lodo é apresentada em várias publicações com diferentes nomes, porém com definições bastante semelhantes. Van Haandel e Lettinga (1994, apud VON SPERLING; GONÇALVES, 2001) afirmam que, em razão da facilidade de separação dos sólidos, a água é dividida em quatro classes distintas: água livre, a que pode ser removida por gravidade (adensamento ou flotação); água adsorvida, a que pode ser removida por força mecânica ou uso de floculante; água capilar, a que se encontra adsorvida ao sólido por força capilar, diferenciando-se da adsorvida por necessitar de maior força para sua separação; água celular, a que pode ser removida apenas com uma mudança no estado de agregação da água, ou seja, por congelamento ou evaporação.

Já Vesilind (1995) considera que a água contida nos lodos pode ser classificada operacionalmente em quatro categorias: água livre, que pode ser removida facilmente por gravidade, não estando associada às partículas sólidas em suspensão nem sofrendo influências delas; água intersticial, que está presente aos capilares ou espaços intersticiais dos flocos e organismos, e parte dessa água está aderida ao interior da estrutura do floco, podendo virar água livre se o floco for destruído; água vicinal, que representa parte da parcela de água molecular não removível e que está presa na superfície das partículas sólidas por adsorção e adesão; água de hidratação, que é também a água não removível e se encontra quimicamente ligada às partículas sólidas. Exemplificando, de acordo com o autor, a água de hidratação é liberada no processo de conversão termal da cal hidratada $\left[\mathrm{Ca}(\mathrm{OH})_{2}\right]$ para cal virgem $(\mathrm{CaO})$.

Colin e Gazbar (1995) apresentam a classificação da água no lodo segundo relatos de diversos pesquisadores, e é a que mais se diferencia daquelas dos outros autores citados. Nesse caso, são apresentadas três definições: água operacional, água energética e água estrutural. Segundo os autores, a definição operacional é a mais usada e estabelece a separação em duas categorias, ou seja, água livre e água confinada. A água livre representa a maior parte contida no lodo e, relativamente à termodinâmica, se comporta como água pura. Essa água pode ser 
eliminada com a aplicação de força mecânica leve. Em contrapartida, a água confinada representa a menor parcela da água contida no lodo, sendo distinguidos três tipos, ou seja: água confinada quimicamente, que é fixada ao sólido por forte ligação química e pode ser eliminada por desaguamento térmico com temperaturas acima de $105^{\circ} \mathrm{C}$; água confinada fisicamente, que pode ser retirada também por desaguamento térmico e está fixada na partícula sólida por adsorção e absorção; água confinada mecanicamente, que é encontrada tanto em microporos como em macroporos capilares e, de acordo com Laubenberger e Hartmann (1971), está fixada nos poros devido à aglomeração das partículas.

Como descrita, a maior ou menor dificuldade em remover e/ou diminuir a umidade do lodo está relacionada diretamente à condição em que a água se apresenta no material. As técnicas disponíveis para essa operação são bastante variadas, possibilitando a remoção da quantidade desejada de umidade para obtenção de menor volume final de lodo, permitindo, assim, um melhor manejo, de acordo com a forma de disposição final adotada.

Os lodos brutos (sem tratamento) contêm, normalmente, de $88 \%$ a 99,75\% de umidade, que correspondem a um percentual de $12 \%$ a $0,25 \%$ ST e se encontram na forma líquida ou semisólida, dependendo da operação e do processo adotado no tratamento da fase líquida (TCHOBANOGLOUS; BURTON; STENSEL, 2002). Os valores elevados de sólidos totais no lodo ocorrem, em geral, em lagoas de estabilização ou de decantação após lagoas aeradas. Entretanto, dependendo do tratamento adotado na fase sólida, esse percentual, de acordo com US EPA (1995), eleva-se consideravelmente, podendo atingir de 12\% a 40\% ST.

Tendo em vista que o lodo bruto possui uma parcela significativa de água e baixos teores de sólidos totais, a densidade do lodo é aproximadamente à da água. Entretanto, segundo Crites e Tchobanoglous (2000), a densidade de sólidos fixos situa-se em torno de 2,5 e a de sólidos voláteis é próxima a 1,0, como a da água. Nesse caso, a densidade do lodo, que é uma mistura de água e sólidos, depende da distribuição relativa entre esses constituintes, tendendo a ser sempre superior à da água. Na TABELA 3.1, são apresentadas faixas de densidade e de massa específica de diferentes tipos de lodo. 
Tabela 3.1 - Faixas de densidade e massa específica para diferentes tipos de lodo

\begin{tabular}{ccc}
\hline Tipo de lodo & Densidade & Massa específica $\left(\mathbf{k g} / \mathbf{m}^{\mathbf{3}}\right)$ \\
\hline Lodo primário & $1,02-1,03$ & $1020-1030$ \\
Lodo secundário anaeróbio & $1,02-1,03$ & $1020-1030$ \\
Lodo secundário aeróbio & $1,005-1,025$ & $1005-1025$ \\
Lodo adensado & $1,02-1,03$ & $1020-1030$ \\
Lodo digerido & 1,03 & 1030 \\
Lodo desaguado & $1,05-1,08$ & $1050-1080$ \\
\hline
\end{tabular}

Fonte: TCHOBANOGLOUS; BURTON; STENSEL, 2002; VON SPERLING; GONÇALVES, 2001.

$\mathrm{Na}$ parcela de sólidos estão presentes constituintes específicos que, particularmente, são fundamentais na avaliação das diferentes opções de uso e/ou de disposição final do lodo, como carbono orgânico, nutrientes, patógenos, metais e compostos orgânicos tóxicos (MALINA, 1993a; TCHOBANOGLOUS; BURTON; STENSEL, 2002). Dependendo da forma de disposição final a ser adotada, alguns constituintes são considerados benéficos, enquanto outros são indesejáveis em razão dos riscos potenciais que podem representar à saúde e ao meio ambiente.

O carbono orgânico é normalmente expressa em porcentagem de sólidos voláteis (SV), sendo esse parâmetro, utilizado no controle de odor e de atração de vetores. No lodo bruto, a relação entre SV e ST (relação em base seca) apresenta-se entre 75\% e 85\%, enquanto em lodo estabilizado (digerido) pode atingir até 50\% (MALINA, 1993a; US EPA, 1995).

Os lodos provenientes do tratamento de esgoto doméstico contêm nutrientes importantes caso o uso agrícola seja uma das formas possíveis de destinação final. Podem conter quantidades significativas de vários elementos essenciais às plantas, como carbono e os nutrientes nitrogênio, fósforo, potássio, cálcio, magnésio, enxofre (macronutrientes) e cobre, ferro, manganês, zinco, boro, molibdênio (micronutrientes). Alguns desses elementos apresentam concentrações maiores que as encontradas em diversos adubos orgânicos de uso tradicional na agricultura (MALINA, 1993a; MELO; MARQUES, 2000).

Com relação aos organismos presentes no lodo, US EPA (1995) afirma que as características da população servida com o SES e o processo de tratamento a que foi submetido o lodo estão diretamente associados à presença, à diversidade das espécies de organismos e ao número de agentes patogênicos que conferem riscos à saúde da população e, por isso, demandam uma atenção especial. Dumontet et al. (2001), focando mais o problema, acrescentam que a presença dos patogênicos está associada diretamente com a saúde da comunidade local. 
Além dos organismos patogênicos, os metais pesados e os compostos orgânicos tóxicos merecem uma avaliação mais detalhada. A presença desses elementos está relacionada à descarga de efluentes industriais e também a diversos produtos de uso doméstico ou comercial que contêm essas substâncias em sua composição (CHANG et al., 2002; KUCHAR et al., 2006; MATTHEWS, 1984).

\subsection{TRATAMENTO E DISPOSIÇÃO FINAL DO LODO}

Dependendo das características e da destinação final do lodo, este deve passar por etapas específicas de tratamento. O adensamento, a digestão, o desaguamento e a higienização são algumas etapas pelas quais pode passar o material.

No QUADRO 3.1, é apresentada a descrição das etapas explicitadas na FIGURA 3.2, bem como os processos que poderão ser usados em cada uma.

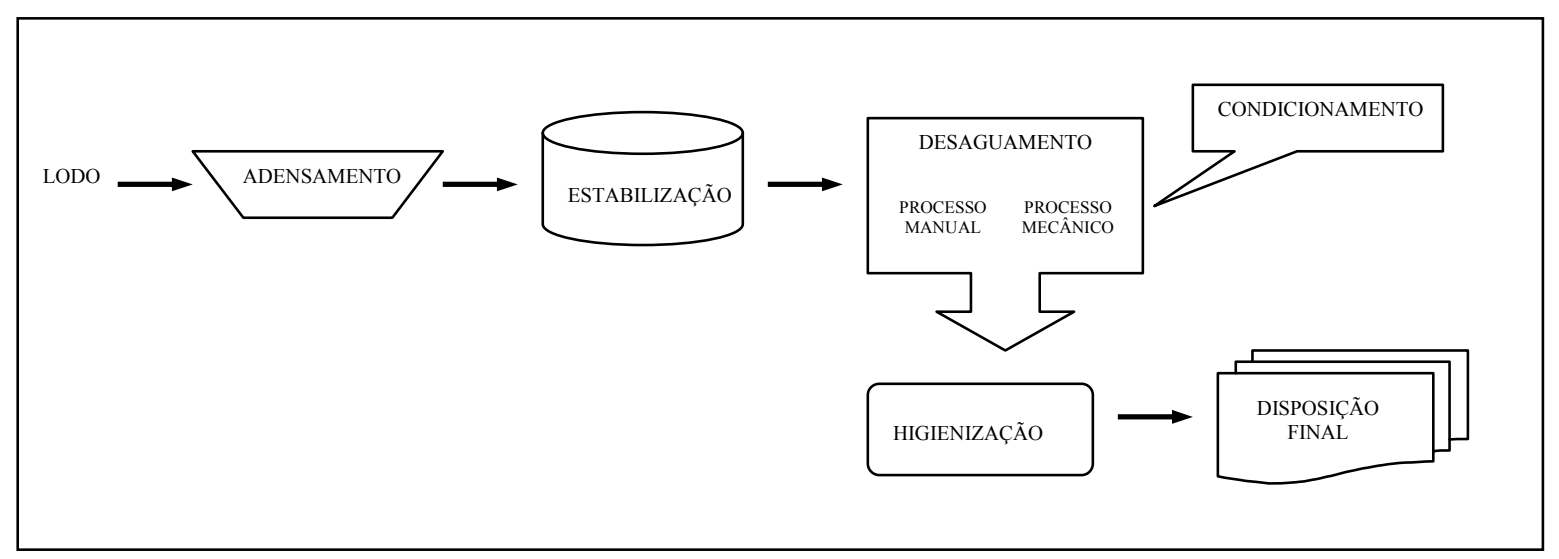

Figura 3.2 - Etapas de tratamento do lodo até a disposição final

Cada etapa do tratamento do lodo possui objetivo bastante específico que promove uma alteração ou melhoria das características físicas, químicas e biológicas do lodo. De acordo com a forma de destinação final adotada, o material deve passar por várias etapas do tratamento, para atender aos preceitos instituídos para a forma adotada, que pode estar ligada a questões técnicas, econômicas, ambientais e de saúde pública. Assim, definir a forma de destinação final é fundamental para o gerenciamento do lodo no planejamento das etapas, dos processos e dos equipamentos que serão usados. 
Caso a alternativa final escolhida seja o uso na agricultura, dependendo do tipo de lodo, o material deve passar por praticamente todas as etapas apresentadas no QUADRO 3.1, sendo fundamentais as de estabilização e higienização (THOMAZ-SOCCOL, 1998; WRIGHT, 2001). Essas etapas de tratamento vão garantir, entre outras coisas, a redução de patógenos, a estabilidade do lodo e a redução de vetores, como moscas, roedores e mosquitos, transmissores de doenças. Trata-se de procedimento fundamental para que o material atenda aos quesitos legais para essa forma de disposição final (BRASIL, 2006c) ${ }^{9}$, em razão das características potencialmente perigosas que possui.

O tratamento do lodo possibilitará também a redução do teor de água e, consequentemente, um material sólido em menor volume e estável, não constituindo perigo para a saúde das comunidades, mas podendo ser manipulado e transportado com facilidade e a baixo custo.

Cabe acrescentar que, em 2008, foi publicado um importante documento, o Global atlas of excreta, wastewater sludge, and biosolids management: moving forward the sustainable and welcome uses of a global resource, pela United Nations Human Settlements Programme (UNHABITAT). Nele, são encontradas informações sobre a situação atual do gerenciamento do lodo em mais de 30 países e regiões do mundo, com relevantes informações sobre tratamento, disposição final, aspectos legais, custo (LEBLANC; MATTHEWS; RICHARD, 2008). Os trabalhos apresentados na Conference Wastewater Biosolids Sustainability: Technical, Managerial, and Public Synergy, da IWA, realizada em junho de 2007 no Canadá, serviram de base para a compilação das informações apresentadas no atlas.

\footnotetext{
${ }^{9}$ http://www.mma.gov.br/port/conama.
} 
Quadro 3.1- Descrição das etapas de tratamento do lodo até a disposição final e respectivos processos

\begin{tabular}{|c|c|c|}
\hline Etapa & Descrição & Processo \\
\hline Adensamento & $\begin{array}{l}\text { Processo físico que visa reduzir o teor de umidade do lodo, consequentemente, seu volume, } \\
\text { facilitando as etapas seguintes. }\end{array}$ & $\begin{array}{l}\text {-Adensamento por gravidade } \\
\text {-Flotação } \\
\text {-Centrífuga } \\
\text {-Filtro prensa de esteira }\end{array}$ \\
\hline Estabilização & $\begin{array}{c}\text { Remoção da matéria orgânica biodegradável (redução de sólidos voláteis). Visa atenuar os maus } \\
\text { odores no tratamento e no manuseio do lodo. }\end{array}$ & $\begin{array}{l}\text {-Digestão anaeróbia } \\
\text {-Digestão aeróbia } \\
\text {-Tratamento térmico } \\
\text {-Estabilização química } \\
\text {-Compostagem }\end{array}$ \\
\hline Condicionamento & $\begin{array}{l}\text { Preparação do lodo para a etapa de desaguamento (normalmente para processos mecânicos). } \\
\text { Utilizam-se produtos químicos (coagulante, polieletrólitos) para melhorar a captura de sólidos e } \\
\text { facilitar o desaguamento. }\end{array}$ & $\begin{array}{l}\text {-Condicionamento químico } \\
\text {-Condicionamento térmico }\end{array}$ \\
\hline Desaguamento & $\begin{array}{l}\text { Pode ser por processo natural ou mecânico. Objetiva reduzir ainda mais o volume com a remoção } \\
\text { de água livre, produzindo lodo com comportamento próximo ao dos sólidos, facilitando o manuseio } \\
\text { e diminuindo custos com transporte e destinação final. }\end{array}$ & $\begin{array}{c}\text {-Leito de secagem } \\
\text {-Lagoa de lodo } \\
\text {-Filtro prensa } \\
\text {-Centrífuga } \\
\text {-Filtro prensa de esteira } \\
\text {-Filtro a vácuo } \\
\text {-Secagem térmica }\end{array}$ \\
\hline Higienização & O seu principal objetivo é reduzir o nível de patógenos a valores aceitáveis. & $\begin{array}{c}\text {-Adição de cal (caleação) } \\
\text {-Tratamento térmico } \\
\text {-Compostagem } \\
\text {-Oxidação úmida } \\
\text {-Outros (radiação gama, solarização, etc) }\end{array}$ \\
\hline Disposição final & $\begin{array}{c}\text { Etapa final do tratamento. Dependendo da alternativa escolhida para destinação final, algumas das } \\
\text { etapas anteriores poderão ser suprimidas. }\end{array}$ & $\begin{array}{c}\text {-Reciclagem agrícola } \\
\text {-Recuperação de áreas degradadas } \\
\text {-Uso não agrícola (fabricação de lajotas, combustível, etc.) } \\
\text {-Aterro Sanitário }\end{array}$ \\
\hline
\end{tabular}

Fonte: TCHOBANOGLOUS; BURTON; STENSEL, 2002; US EPA, 1999. 


\subsubsection{TRATAMENTO DO LODO - ESTABILIZAÇÃO E HIGIENIZAÇÃO}

\subsubsection{Estabilização}

O lodo bruto (antes de passar por etapas de tratamento) gera, rapidamente, odores ofensivos, por ser rico em organismos patogênicos facilmente putrescíveis. Com o intuito de minimizarem esse efeito, os lodos são submetidos a processos de estabilização que visam a controlar a decomposição da fração biodegradável da M.O. presente, reduzindo a parcela de $\mathrm{SV}$ e, consequentemente, diminuindo a concentração de patógenos e, com isso, o risco de putrefação (BOROWSKI; SZOPA, 2007; LAKE, 1987).

Os processos de estabilização podem ser divididos em: estabilização biológica, em que são utilizadas bactérias específicas na estabilização da fração biodegradável da matéria orgânica; estabilização química, caso em que é adicionado produto químico para promover a oxidação química da matéria orgânica; e, por fim, a estabilização térmica, que é obtida com a ação do calor sobre a fração volátil do lodo (US EPA, 2003).

Dentre esses procedimentos, o mais comum é o de estabilização biológica, que pode ocorrer por processos biológicos de digestão anaeróbia e/ou digestão aeróbia, em condições ambientais favoráveis (BOROWSKI; SZOPA, 2007).

A digestão reduz consideravelmente o número de patógenos no lodo, incluindo bactérias, protozoários, helmintos e vírus (US EPA, 2003). Isso faz que as concentrações de organismos sejam bastante variadas em virtude do nível de tratamento a que o material for submetido. A TABELA 3.2 apresenta a redução nas quantidades de microrganismos contidos no lodo após ser submetido à digestão anaeróbia.

Tabela 3.2 - Efeito do tratamento do lodo de esgoto sobre os patógenos (redução em log)

\begin{tabular}{cccc}
\hline Tratamento & Bactéria & Vírus & $\begin{array}{c}\text { Parasitas } \\
\text { (protozoários e helmintos) }\end{array}$ \\
\hline Digestão anaeróbia & $0,5-4,0$ & $0,5-2,0$ & 0,5 \\
Digestão aeróbia & $0,5-4,0$ & $0,5-2,0$ & 0,5 \\
Compostagem & $2,0-4,0$ & $2,0-4,0$ & $2,0-4,0$ \\
Secagem ao ar & $0,5-4,0$ & $0,5-4,0$ & $0,5-4,0$ \\
Estabilização com cal & $0,5-4,0$ & 4,0 & 0,5 \\
\hline
\end{tabular}

Fonte: US EPA, 2003.

Nota: A redução de $1 \log$ corresponde a cerca de $90 \%$ de remoção. 


\section{Digestão anaeróbia}

Em ambiente anaeróbio, são desenvolvidas bactérias anaeróbias que utilizam a M.O. contida no lodo para a realização dos seus processos metabólicos fermentativos, resultando em produtos gasosos estáveis como o metano e o dióxido de carbono (TCHOBANOGLOUS; BURTON; STENSEL, 2002).

A FIGURA 3.3 apresenta, de forma resumida, as fases microbiológicas da digestão anaeróbia com as devidas seqüências metabólicas e os grupos microbianos envolvidos na digestão.

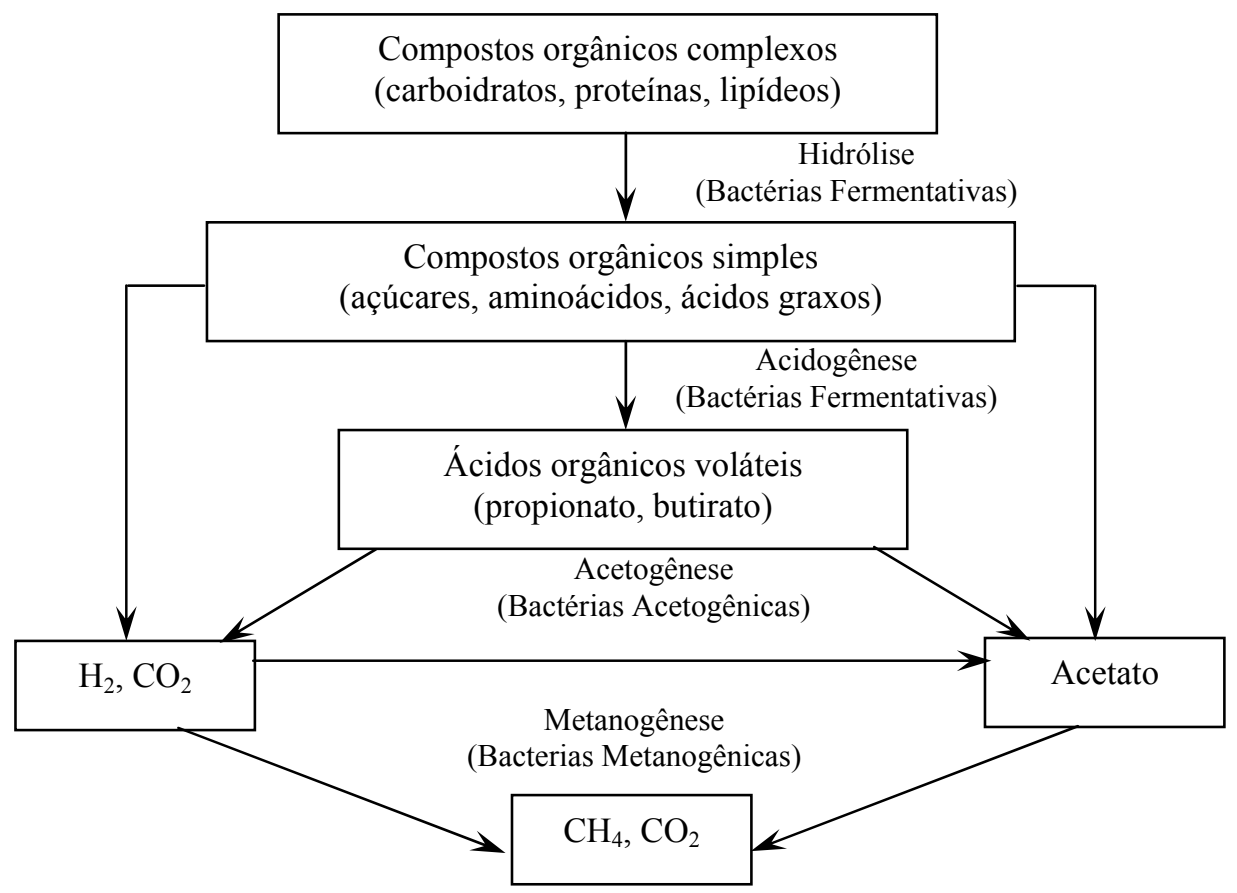

Figura 3.3 - Esquema das sequências metabólicas e dos grupos microbianos envolvidos na digestão anaeróbia

Fonte: Adaptado de GERARD, 2003; JOLLY et al., $2004^{10}$.

Como mostrado na FIGURA 3.3, o processo de conversão dos compostos orgânicos ocorre em quatro fases: hidrólise, acidogênese, acetogênese e metanogênese. Essas fases são interdependentes e podem se desenvolver simultaneamente. A digestão anaeróbia ocorre em temperaturas específicas, sendo a digestão mesófila aquela que acontece com faixa ótima de temperatura de 30 a $38^{\circ} \mathrm{C}$, e a termófila, a que se situa entre 49 e $57^{\circ} \mathrm{C}$. Em termos práticos, as vantagens conseguidas com a digestão termófila, como o aumento na taxa de digestão e a maior redução de patógenos, não são compensatórias, em virtude das dificuldades

\footnotetext{
${ }^{10} \mathrm{http}: / /$ www.earthtech.com/documents/Advanced_in_BioSolids_Stabilization.pdf
} 
operacionais para a manutenção de temperaturas elevadas (JOLLY et al., 2004; TCHOBANOGLOUS; BURTON; STENSEL, 2002).

\section{Digestão aeróbia}

Na digestão aeróbia, o lodo bioquimicamente oxidado pelos microrganismos é convertido em dióxido de carbono, água e nitrogênio na forma de nitrato, sob condições apropriadas de operação, principalmente o fornecimento e a manutenção do oxigênio dissolvido no reator. $\mathrm{O}$ oxigênio pode ser introduzido por intermédio de agitação do lodo por misturadores ou pela injeção forçada de ar (QASIM, 1999). Por isso, em razão dos custos elevados de operação e manutenção, esse processo tem sido tradicionalmente usado em pequenas comunidades (ROS; ZUPANCIC, 2002).

A digestão aeróbia de lodo biológico pode ser considerada como uma continuação do processo de lodos ativados sob condições endógenas. Quando uma cultura de microrganismos heterotróficos aeróbios está presente em um ambiente que contém uma fonte de matéria orgânica, os microrganismos preferem remover e utilizar a maioria desse material. Uma fração da matéria orgânica removida é usada na síntese de novos microrganismos, resultando em um aumento da biomassa (ROS; ZUPANCIC, 2002). O material celular remanescente será, então, oxidado, resultando em dióxido de carbono, água e material inerte solúvel, provido, ainda, de energia para a promoção das funções de síntese e a manutenção da vida do sistema (TCHOBANOGLOUS; BURTON; STENSEL, 2002).

O processo de digestão aeróbia consiste basicamente em duas fases: a oxidação direta da matéria biodegradável, e a respiração endógena, em que o material celular é oxidado. Esse processo encontra-se ilustrado na FIGURA 3.4 (ROS; ZUPANCIC, 2002).

Existem opiniões diferentes entre alguns pesquisadores quanto à capacidade de desaguamento do lodo aeróbio. No entanto, experiências práticas mostram que o lodo aeróbio é mais difícil de ser desaguado que o lodo anaeróbio, em razão da destruição da estrutura do floco durante o processo de respiração endógena (LUDUVICE, 2001). 


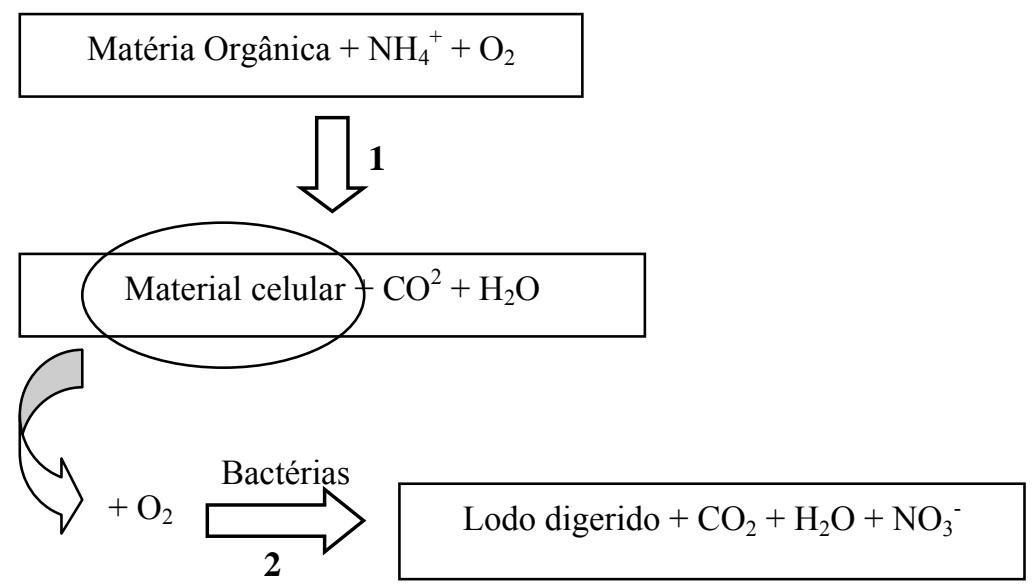

Nota: 1- Oxidação da matéria orgânica obtendo-se material celular; 2- Oxidação do material celular, obtendo-se lodo digerido.

Figura 3.4 - Esquema da sequência metabólica ocorrida durante a digestão aeróbia

Os processos de digestão anaeróbia e aeróbia apresentam vantagens e desvantagens que devem ser avaliadas quando há a adoção de uma das alternativas no tratamento do lodo. No QUADRO 3.2, são apresentadas as principais vantagens e as desvantagens desses processos.

Quadro 3.2 - Vantagens e desvantagens dos processos de digestão aeróbia e anaeróbia do lodo

\begin{tabular}{|c|c|c|}
\hline Processo & Vantagem & Desvantagem \\
\hline $\begin{array}{l}\text { Digestão } \\
\text { anaeróbia }\end{array}$ & $\begin{array}{l}\text { - boa destruição de sólidos voláteis ( } 40 \% \text { a } 60 \%) ; \\
\text { - custo operacional pequeno se usado o gás metano } \\
\text { gerado no tratamento da fase líquida; } \\
\text { - boa inativação de patógenos; } \\
\text { - baixa demanda de energia; } \\
\text { - reduz a massa total de lodo. }\end{array}$ & $\begin{array}{l}\text { - pode ocorrer formação de espuma; } \\
\text { - sobrenadante rico em DQO, DBO, sólidos em } \\
\text { suspensão e amônia; } \\
\text { - dificuldade de limpeza; } \\
\text { - pode gerar maus odores resultantes do próprio } \\
\text { processo anaeróbia; } \\
\text { - alto custo inicial; } \\
\text { - possibilidade de aproveitamento do gás metano } \\
\text { gerado no processo; } \\
\text { - medidas de segurança devem ser tomadas com o } \\
\text { gás gerado no processo. }\end{array}$ \\
\hline $\begin{array}{l}\text { Digestão } \\
\text { aeróbia }\end{array}$ & $\begin{array}{l}\text { - boa destruição de sólidos voláteis ( } 50 \% \text { a } 60 \%) \\
\text { - baixa concentração de DBO no sobrenadante se } \\
\text { comparado com lodo anaeróbio; } \\
\text { - operação é relativamente fácil; } \\
\text { - baixo custo de capital; } \\
\text { - baixa geração de odor indesejável; }\end{array}$ & $\begin{array}{l}\text { - alto custo de energia em função da demanda de } \\
\text { oxigênio; } \\
\text { - não é possível a recuperação dos subprodutos } \\
\text { gerados, como o metano no processo anaeróbio; } \\
\text { - o lodo produzido apresenta dificuldade para } \\
\text { desaguamento mecânico; } \\
\text { - o processo é afetado diretamente por temperatura, } \\
\text { condição local e tipo de material utilizado na } \\
\text { fabricação do reator. }\end{array}$ \\
\hline
\end{tabular}

Fonte: BITTON, 2005; MAIER; PEPPER; GERBA, 2009; QASIM, 1999; TASK FORCE ON SLUDGE STABILIZATION, 1985; TCHOBANOGLOUS; BURTON; STENSEL, 2002. 
Alguns pesquisadores, citados por Borowski e Szopa (2007), têm investigado a associação dos dois processos, ou seja, pré-tratamento com digestão aeróbia termofílica seguida de digestão anaeróbia, obtendo resultados bastante interessantes, principalmente na inativação de patógenos.

Além dos aspectos apresentados, a digestão do lodo desempenha um papel importante no controle da mobilidade e dispersão ambiental de metais como cobre, chumbo e cádmio, na seguinte ordem: cobre > chumbo > cádmio (LAKE; KIRK; LESTER, 1989).

\subsubsection{Higienização}

Tanto a digestão anaeróbia como a aeróbia podem reduzir os níveis de organismos patogênicos contidos no lodo, porém muitos parasitos intestinais e, principalmente, seus ovos não são destruídos por processos de digestão convencional, necessitando, então, da etapa de higienização. Essa etapa busca reduzir a concentração de microrganismos patogênicos para não causar riscos à saúde da população, aos trabalhadores que vão manusear o material, bem como impedir impactos ambientais negativos (PINTO, 2001).

A compostagem, a caleação e o tratamento térmico são processos comumente usados na higienização do lodo em razão, principalmente, dos baixos custos requeridos (ANDREOLI; PEGORINI; FERNANDES, 2001). Além desses, tecnologias avançadas para a estabilização de biossólido, que incluem melhorias nos processos de digestão aeróbia e anaeróbia, são apresentadas por Jolly et al. (2004). Destacam-se, nesse caso, a hidrólise térmica e a digestão termofílica.

No processo de compostagem, a inativação dos microrganismos patogênicos ocorre pela elevação da temperatura, normalmente em torno de 55 a $60^{\circ} \mathrm{C}$, decorrente da decomposição da matéria orgânica em condições ambientais favoráveis e do tempo de contato. A umidade e o oxigênio são controlados para impedir a geração de odores. Materiais como resíduos de podas de árvores, folhas, cavacos de madeira, palha de arroz, serragem são, normalmente, misturados ao lodo para desempenhar o papel de agente estruturante, retendo melhor a umidade, aumentando a porosidade e controlando a relação entre carbono e nitrogênio (PINTO, 2001; US EPA, 1999). 
O tratamento térmico consiste na aplicação de calor ao lodo, provocando a remoção da umidade e, consequentemente, alcançando a inativação térmica dos microrganismos. Antes de o lodo ser tratado termicamente, é importante que ele esteja estabilizado e desaguado até concentração de sólidos em torno de $20 \%$ a $35 \%$, visando a minimizar os custos referentes ao tratamento (PINTO, 2001).

No caso dos tratamentos avançados, esses são caracterizados por melhorar a destruição de sólidos voláteis, aumentar a produção de biogás, melhorar a estabilidade operacional, melhorar o desaguamento do lodo, aumentar a redução de patógenos e diminuir a capacidade (tamanho) dos processos requeridos (JOLLY et al., 2004). Akerlund ${ }^{11}$ (2008) revela que, no processo de hidrólise térmica são utilizadas temperaturas elevadas, em torno de $160^{\circ}$ e $180^{\circ} \mathrm{C}$, que destroem a parede celular e liberam substâncias intracelulares, tornando-as, assim, facilmente acessíveis para biodegradação. Países como Dinamarca, Noruega e Reino Unido já realizaram estudos desse processo em grande escala (KEPP; SOLHEIM, 2001; WEISZ et al., 2000)

No entanto, o processo de digestão anaeróbia termofílica é normalmente caracterizado por reações bioquímicas aceleradas, índices de crescimento mais elevados de microrganismos e acelerada transferência de hidrogênio, resultando em um aumento do potencial metanogênico para baixos tempos de retenção hidráulica (GAVALA et al., 2003).

Sendo a caleação o processo utilizado nesta pesquisa para melhorar as características do lodo quanto à concentração de patógenos, maior atenção será dada a esse processo.

\section{$\underline{\text { Tratamento químico - Higienização alcalina }}$}

A caleação, também conhecida como estabilização química, implica adicionar ao lodo uma quantidade suficiente de material alcalino (cal) para elevar o $\mathrm{pH}$, reduzindo, assim, os microrganismos patogênicos e a emanação de odores. A adição de material alcalino ao lodo possibilita a desintegração de compostos orgânicos e a solubilização de células microbiológicas (AKERLUND, 2008).

\footnotetext{
${ }^{11} \mathrm{http}: / /$ www.stockholmvatten.se/Stockholmvatten/commondata/rapporter/avlopp/Processer/ R03_2008_Anna_Akerlund_examensarbete.pdf
} 
Historicamente, a cal virgem $(\mathrm{CaO})$ e a cal hidratada $\left(\mathrm{Ca}[\mathrm{OH}]_{2}\right)$ são os produtos mais usados. Tratam tanto lodos primários quanto secundários ou digeridos com teores elevados de umidade ou não (ANDREASEN, 2001; US EPA, 1999).

Com a aplicação da cal virgem ao lodo, além do aumento do $\mathrm{pH}$, ocorre também a elevação da temperatura em virtude do calor provocado durante a reação química entre o óxido de cálcio e a água contida no lodo, no processo definido como extinção da cal virgem. O calor obtido é suficiente para elevar a temperatura a valores acima de $50^{\circ} \mathrm{C}$ (TCHOBANOGLOUS; BURTON; STENSEL, 2002), que, de acordo com Ilhenfeld, Andreoli e Lara (1999), é uma faixa de temperatura suficiente para a completa destruição de alguns microrganismos, dependendo do tempo a que ficarem expostos (TABELA 3.3).

Tabela 3.3 - Temperatura e tempo de manutenção para a destruição de alguns organismos

\begin{tabular}{ccc}
\hline Microrganismo & Tempo (min) & Temperatura $\left({ }^{\circ} \mathbf{C}\right)$ \\
\hline Salmonella typhosa & Instantâneo / 30 & 55 a $60 / 46$ \\
Salmonella sp. & 15 a $30 / 60$ & $60 / 55$ \\
Shigella sp. & 60 & 55 \\
Escherichia coli & $5 / 15$ a $20 / 60$ & $70 / 60 / 55$ \\
Entamoeba histolytica (cistos) & Instantâneo & 68 \\
Taenia saginata & 5 & 71 \\
Trichinella spiralis (larvas) & Instantâneo / 60 & 62 a $72 / 50$ \\
Necator americanus & 50 & 45 \\
Brucella abortus & 50 & 45 \\
Estreptococos fecais & 60 & 70 \\
Coliformes fecais & 60 & 70 \\
Ascaris sp. (ovos) & $60 / 7$ & $55 / 60$ \\
\hline
\end{tabular}

Fonte: ILHENFELD; ANDREOLI; LARA (1999)

Apesar de o aumento da temperatura promover a destruição de microrganismos, a elevação do pH pode ser considerada como uma condição suficiente para higienização do lodo. Isso porque, citando Pinto (2001), a elevação do $\mathrm{pH}$, além de alterar o protoplasma celular dos microrganismos patogênicos de forma letal, produz um ambiente impróprio para sua sobrevivência. 
Essa condição já foi relatada há décadas, quando Malta (2002) cita que Wattie e Chambers (1943) relatam que a exposição do lodo por 2 horas a $\mathrm{pH}$ variando de 11 a 11,5, ou por 4 horas de 10,5 a 11, é condição necessária para eliminar 100\% de vários organismos, como: Pseudomonas pyocyaneus, Aerobacter aerogenes, Eschierichia coli, Eberthella typhosa e Shigella dysenteriae. Com o mesmo enfoque, Ramirez e Malina (1980) destacam que pH de 11,5 é o bastante para obter efetiva remoção de bactérias e que, para o $\mathrm{pH}$ de 12, é possível a remoção efetiva de coliformes totais, com um tempo de contato de 48 horas e, para coliformes fecais e estreptococos fecais, será necessário um tempo de exposição de 24 a 48 horas.

Efetiva remoção de coliformes com a adição da cal foi percebido, também, por Malta (2002), que avaliou o uso de diferentes dosagens de cal virgem na otimização da estabilização cálcica do biossólido, visando ao seu uso na agricultura. Dosagens de 3, 4, 5, 10, 20, 35, 50, 65 e 80\% de cal em base seca foram investigadas, sendo constatado que quantidades de até $50 \%$ não foram suficientes para promover a elevação da temperatura até valores próximos a $50^{\circ} \mathrm{C}$. Apenas as dosagens de $65 \%$ e $80 \%$ possibilitaram valores de temperatura superiores a $50^{\circ} \mathrm{C}$. Entretanto, a dosagem de 5\% foi suficiente para atingir uma redução de 99,99\% de coliformes fecais com pH de 12,45 até 2 horas após a mistura e de 11,89, 24 horas depois.

A redução de patógenos para diferentes dosagens de cal foi verificada por Fernandes et al. (1996), os quais obtiveram reduções próximas a 100\% para quase todos os microrganismos estudados com dosagens de 30\%, 40\% e 50\% de cal em base seca, exceto para ovos de helmintos (totais), que atingiram redução de cerca de 80\%. Em Fernandes (2000), o autor revela que os resultados obtidos com a utilização tanto da cal virgem quanto da cal hidratada são bastante similares, porém, a vantagem na utilização da cal virgem está relacionada apenas ao seu custo, que é inferior ao da cal hidratada.

Outwater (1994), apresentando resultados de pesquisa realizada por Ritter (1990), relata que o autor observou uma redução significativa de coliformes fecais com o aumento da dosagem de cal ao lodo. No estudo, o lodo bruto que se apresentava com densidade desse microrganismo de $23 \times 10^{6} \mathrm{NMP} / 100 \mathrm{ml}$ atingiu $430 \mathrm{NMP} / 100 \mathrm{ml}$ após a adição de $25 \%$ de cal em base seca. O valor obtido quando se adicionaram $50 \%$ de cal, foi o mesmo verificado com a utilização de $25 \%$.

Para avaliar a capacidade de sobrevivência de parasitas entéricos em lodo, Gaspard e Schwartzbrod (2001) observaram o seu comportamento em onze diferentes processos de 
tratamento de lodo, entre eles a higienização com cal virgem e hidratada. A cal hidratada foi testada em lodo proveniente de processo de tratamento de esgoto por aeração prolongada, com percentual de cal de $26 \%$ e lodo desaguado de processo físico-químico com $62 \%$ de cal. Já a cal virgem foi usada em lodo proveniente de pós-tratamento de processo físico-químico com percentual de cal de $25 \%$. O estudo foi realizado durante três estações do ano: outono, inverno e primavera, sendo os valores apresentados na TABELA 3.4, inclusive as média para o período estudado.

Tabela 3.4 - Concentrações de helmintos e protozoários em diferente períodos do ano na utilização de cal virgem e cal hidratada para a higienização do lodo de esgoto sanitário

\begin{tabular}{|c|c|c|c|c|c|c|c|}
\hline \multirow{2}{*}{$\begin{array}{l}\text { Parasita } \\
\text { entérico }\end{array}$} & \multirow{2}{*}{ Período } & \multicolumn{2}{|c|}{ Cal hidratada (26\%) } & \multicolumn{2}{|c|}{ Cal hidratada (62\%) } & \multicolumn{2}{|c|}{ Cal virgem $(25 \%)$} \\
\hline & & Entrada & Saída & Entrada & Saída & Entrada & Saída \\
\hline \multirow{4}{*}{ 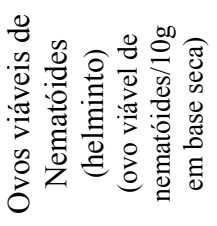 } & Outono & 4 & 5 & 7 & 4 & 12 & 30 \\
\hline & Inverno & 2 & 2 & 12 & 4 & 8 & 12 \\
\hline & Primavera & 1 & 3 & 3 & 2 & 45 & $\mathrm{ND}$ \\
\hline & Valor médio & 2,3 & 3,3 & 7,3 & 3 & 21,6 & 14 \\
\hline \multirow{4}{*}{ 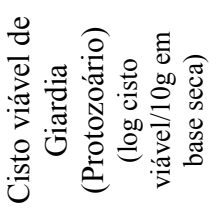 } & Outono & ND & ND & ND & ND & ND & ND \\
\hline & Inverno & 2,12 & ND & ND & ND & 2,23 & $\mathrm{ND}$ \\
\hline & Primavera & 2,72 & ND & ND & ND & 1,88 & ND \\
\hline & Valor médio & 1,61 & ND & ND & ND & 1,37 & ND \\
\hline
\end{tabular}

Fonte: Gaspard; Schwartzbrod, 2001.

Nota: ND - não detectado.

Os resultados da TABELA 3.4, sugerem que, provavelmente, a elevação do $\mathrm{pH}$ com a adição de cal tenha sido o fator preponderante na eliminação dos cistos viáveis de giardia, porém o mesmo não aconteceu com os ovos viáveis de nematóides, que, nas circunstâncias testadas, não apresentaram resultados satisfatórios, mostrando-se mais resistentes.

De acorodo com US EPA (2003), a higienização com cal tem pequeno efeito em espécies resistentes, como ovos de helmintos. Entretanto, no Brasil, experimentos mostraram que o processo de calagem apresentou eficácia na redução da viabilidade de ovos de helmintos. . Passamani (2001) mostrou que 24 horas de contato entre lodo de UASB e cal hidratada é suficiente para inviabilizar $100 \%$ de ovos de helmintos. Thomaz-Soccol, Paulino e Castro (1998) relataram que a partir de 30 dias, foi possível perceber a inviabiliação de ovos de helmintos, com uma dosagem de 50\% de cal em lodo gerado em valo de oxidação aeróbio. 
Essas diferenças podem ter ligação com o tempo de contato, o tipo de lodo e o tipo de cal usada.

No México, em estudo realizado com lodo proveniente de indústria têxtil misturado ao de residências, Franco-Hernandez et al. (2001), mesmo não relatando o tempo a que ficou exposto o material, declaram que a quantidade de cal hidratada adicionada à mistura para elevar o pH a 12 mostrou-se eficiente na destruição de Salmonella sp.. Inicialmente, o lodo bruto (sem tratamento) apresentava concentração de $250 \mathrm{UFC} / \mathrm{gST}$ não sendo detectada a sua presença após as condições testadas. Para coliformes totais, coliformes fecais e ovos de helmintos, a condição testada foi suficiente para o enquadramento do lodo como Classe B, segundo a legislação americana (US EPA, 2003).

Na pesquisa desenvolvida com lodo bruto primário, gerado em uma estação de tratamento biológico de esgoto municipal na República da Eslováquia foi constada a eficácia da cal hidratada na eliminação de Salmonella typhimurium. O lodo foi submetido a testes de estabilização mesofílica aeróbia e estabilização química com cal hidratada para avaliar o comportamento da sobrevivência da Salmonella typhimurium. Adicionou-se única dosagem de cal de $100 \mathrm{mg} / \mathrm{gST}\left(10 \mathrm{Kg} / \mathrm{m}^{3}\right)$ em amostras de lodo com elevado teor de umidade $(5 \%$ ST). Em seguida, a presença do microrganismo no material foi monitorada durante um período de 120 horas. Até a primeira hora detectou-se a presença de Salmonella typhimurium e, daí em diante, não se constatou a presença do microrganismo. A temperatura média durante o período do experimento manteve-se na faixa de $22^{\circ} \mathrm{C}$ e o $\mathrm{pH}$ sempre acima de 12 . Na análise estatística dos resultados, a correlação entre $\mathrm{pH}$ e a sobrevivência da Salmonella foi satisfatória (PLANCHÁ et al., 2008)

Todavia, vale destacar que, com a variação do pH conseguida com a adição da cal ao lodo, atenção especial deve ser dada às bactérias, pois algumas são capazes de crescer novamente mesmo depois de sua inativação, principalmente em temperaturas amenas (DUMONTET et al., 2001; STRAUB; PEPPER; GERBA, 1993; US EPA, 2003). Em pesquisa realizada por Ramirez e Malina (1980), conseguiu-se a efetiva remoção de bactérias com pH de 11,5; no entanto, os pesquisadores revelam que, caso o $\mathrm{pH}$ atinja valores inferiores a 11,5, poderá ocorrer a recolonização delas.

Além disso, é importante salientar que, de acordo com US EPA (2003), a adição de material alcalino ao lodo não reduz SV e, caso o $\mathrm{pH}$ atinja valores abaixo de 11, bactérias patogênicas 
remanescentes podem crescer rapidamente para densidades elevadas, dada a rica disponibilidade de alimento no meio. A redução de SV é conseguida com tratamento adicional com cal para manter $\mathrm{pH}$ elevado, desaguamento do lodo ou tratamento que promova a redução de sólidos voláteis, como compostagem. Ainda citando informações relatadas pela US EPA, na higienização com cal, $99 \%$ ou mais de bactérias e vírus patogênicos podem ser reduzidos.

Apesar de a maioria das publicações apresentar resultados apenas da porcentagem de cal adicionada ao lodo e, às vezes, o tempo de contato, na verdade, tem-se percebido que a quantidade de cal utilizada, independentemente de ser virgem ou hidratada, não é informação suficiente para caracterizar a eficiência na higienização do material. Pesquisas realizadas por Pegorini et al. (2006a) e Pegorini et al. (2006b) mostraram que o fator mais importante na estabilização alcalina do lodo é a quantidade de oxido de cálcio $(\mathrm{CaO})$ aplicada. De acordo com os autores, devido à elevada quantidade de $\mathrm{CaO}$ contida nas cales calcíticas $(\mathrm{CaO}$ entre 90 e $100 \%$ da massa total), a reatividade é bem mais rápida quando comparada com as magnesianas $(\mathrm{CaO}$ entre 65 e $90 \%$ da massa total) e as dolomíticas $(\mathrm{CaO}$ entre 58 e $65 \%$ da massa total). Isso ocorre em razão de os compostos químicos neutralizantes da acidez presentes nas cales possuírem diferentes capacidades de neutralização de ácidos, sendo o hidróxido de cálcio $\left(\mathrm{Ca}[\mathrm{OH}]_{2}\right)$, proveniente da reação entre o $\mathrm{CaO}$ e a água, o melhor deles. Nesse sentido, as cales calcíticas podem promover a higienização do lodo com uma quantidade menor que as das magnesianas e dolomíticas.

Essas questões foram pesquisadas com base em informações divulgadas por Christy (1990) ${ }^{12}$ e Mineropar (2005) ${ }^{13}$.

Os pesquisadores apontaram outros aspectos importantes na caleação, tais como: a influência da granulometria, ou seja, quanto menores as partículas de cal, a reação é mais fácil, rápida e eficiente, sendo fundamental em cales com baixa concentração de $\mathrm{CaO}$ para assegurar a solubilização dos óxidos; a influência do tempo e homogeneidade da mistura (lodo + cal), possibilitando a alcalinização de toda a massa de lodo, sendo necessário um tempo de mistura acima de um minuto que, consequentemente, acarreta uma melhor homogeneidade entre os materiais; a influência do teor de sólidos do lodo, ressaltando-se que os lodos mais secos (49\% e 60\% ST) demandam menores doses de $\mathrm{CaO}$ relativas aos teores de $\mathrm{ST}$ que os mais

\footnotetext{
${ }^{12} \mathrm{http}: / / \mathrm{www} \cdot$ rdptech.com/tch1wet.htm

${ }^{13} \mathrm{http}: / / \mathrm{www} . \mathrm{pr}$.gov.br/mineropar/htm/rocha/carctcorretivo.html
} 
úmidos $(29 \%$ e $17 \%$ ST), para alcalinização e manutenção do pH. A questão da umidade foi citada também por Qasim (2000), ressaltando que com o incremento da concentração de sólidos a dosagem de cal diminui.

Alguns autores têm destacado que a higienização do lodo com cal pode causar diversas alterações ao material. Com relação aos aspectos físicos, destacam-se a formação de uma camada mais dura e branca quando o lodo é exposto ao ar livre e o aumento do volume a ser disposto. Quanto aos aspectos químicos, a cal reage com muitos constituintes orgânicos do lodo, alterando a composição química do material, como: a imobilização dos metais pesados por causa da precipitação; a redução de fósforo solúvel por causa da precipitação; a redução dos valores de nitrogênio com a volatização da amônia (stripping) decorrente da elevação do pH; a redução da concentração de sólidos voláteis em relação a totais de $10 \%$ a $30 \%$, causada exclusivamente pelo incremento no teor de sólidos totais e efeito de diluição, porém a matéria orgânica não é destruída (LUE-HING; ZENZ; KUCHENRITHER, 1992; QASIM, 2000). Entre as alterações apresentadas, as que mais chamam a atenção são: o aumento do volume a ser disposto, que implica a elevação dos custos do gerenciamento do lodo, e a redução dos valores de nitrogênio, caso a alternativa de disposição final adotada seja a agricultura, haja vista tratar-se de um nutriente essencial para o desenvolvimento das plantas. Além disso, dependendo da origem e da composição da cal, um aspecto negativo é a possível existência de impurezas no material que serão incorporadas ao lodo quando ocorre a mistura.

A higienização do lodo com material alcalino contribui ainda com outros aspectos favoráveis, como a possibilidade de o material ser usado como corretivo do solo em regiões que apresentam solos ácidos (AKRIVOS et al, 2000; PLANCHÁ et al., 2008). Nesse caso, além de elevar o $\mathrm{pH}$, promove a redução dos níveis de alguns elementos tóxicos, fornece cálcio e magnésio ao meio, melhora a absorção de nutrientes pelas plantas e estimula a atividade microbiana do solo. Entretanto, deve-se ter cautela no uso de material alcalino, uma vez que o $\mathrm{pH}$ acima de 6,5 pode provocar desequilíbrio nutricional, salinização e prejuízos no desenvolvimento e produtividade das culturas (ANDREOLI; PEGORINI; FERNANDES, 2001).

Fernandes, Andreoli e Domaszak (1996) observaram alterações das características agronômicas de lodo aeróbio e anaeróbio tratados com cal (50\% de cal em base seca), com a diminuição da concentração de alguns parâmetros e aumento de outros. A TABELA 3.5 
apresenta os valores obtidos pelos pesquisadores durante os anos de 1994 e 1995 para o lodo gerado na ETE Belém (lodo aeróbio) e em reatores tipo RALF (lodo anaeróbio).

Tabela 3.5 - Características médias ( 5 a 16 amostras) em porcentagem de base seca de lodo aeróbio (ETE Belém) e anaeróbio (reator tipo RALF), bruto e tratado com 50\% de cal em base seca, ao longo dos anos de 1994 e 1995

\begin{tabular}{ccccc}
\hline \multirow{2}{*}{ Parâmetros } & \multicolumn{2}{c}{$\begin{array}{c}\text { Lodo aeróbio } \\
\text { (\% em base seca) }\end{array}$} & \multicolumn{2}{c}{$\begin{array}{c}\text { Lodo anaeróbio } \\
\text { (\% em base seca) }\end{array}$} \\
\cline { 2 - 5 } & Bruto & Bruto + cal & Bruto & Bruto + cal \\
\hline N total & 4,91 & 2,94 & 2,22 & 1,48 \\
P2O5 sol. CNA* & 2,46 & 0,95 & 0,67 & 0,44 \\
P2O5 total & 3,70 & 2,20 & 0,95 & 0,63 \\
$\mathrm{~K}_{2} \mathrm{O}$ & 0,36 & 0,21 & 0,34 & 0,22 \\
$\mathrm{Ca}$ & 1,59 & 9,08 & 0,83 & 8,32 \\
$\mathrm{Mg}$ & 0,60 & 4,78 & 0,30 & 4,48 \\
$\mathrm{pH}$ & 5,9 & 11,4 & 6,1 & 12,0 \\
Cinzas & 37,2 & 52,5 & 55,3 & 77,0 \\
Matéria orgânica total & 69,4 & 37,6 & 36,2 & 23,0 \\
Carbono total & 32,1 & 20,5 & 20,1 & 13,0 \\
C/N & $6: 01$ & $6: 01$ & $9: 01$ & $9: 01$ \\
Umidade & 6,5 & 10,8 & 7,9 & -- \\
\hline
\end{tabular}

Fonte: Fernandes; Andreoli; Domaszak, 1996.

Nos estudos realizados por Malta (2002), essa tendência também foi confirmada, sendo que, à medida que se adicionou mais cal ao lodo, as concentrações de Nitrogênio Total, Fósforo Total, Potássio Total, Cobre Total, Zinco Total, Ferro Total Magnésio Total e Matéria Orgânica Total diminuíram, com exceção apenas do Magnésio que, nos resultados obtidos por Fernandes, Andreoli e Domaszak (1996) (TABELA 3.5), teve sua concentração aumentada. Em contrapartida, a concentração de Cálcio Total aumentou, a de Enxofre Total não apresentou um comportamento linear e a de Manganês Total praticamente não se alterou.

Em 1998, na Grécia, Akrivos et al (2000) usou lodo caleado com diferentes dosagens para avaliar as características físicas e químicas do lodo e da planta. O lodo foi tratado com 10\% de cal virgem e armazenado por três meses em espaço aberto. A dosagem da cal foi suficiente para manter o pH em 12 por duas horas e acima de 11,5 após 24 horas. Nesse caso, os valores de $\mathrm{N}, \mathrm{P}$ e $\mathrm{K}$ diminuíram, porém $\mathrm{N}$ e $\mathrm{P}$ apresentaram uma maior diminuição. $\mathrm{Na}$ e $\mathrm{Ca}$ aumentaram e $\mathrm{Mg}$ não alterou. Os metais analisados ( $\mathrm{Hg}, \mathrm{PB}, \mathrm{Ni}, \mathrm{Zn} . \mathrm{Cr}, \mathrm{Cd}$ e $\mathrm{Cu}$ ) diminuíram seus teores. 
Na Alemanha, em estudo realizado entre os anos de 1985 e 1991 com lodo caleado e não caleado, também foram observadas variações nos percentuais de alguns nutrientes presentes no lodo (FRANK, 1998) (TABELA 3.6). Os resultados obtidos por Frank (1998) foram bastante semelhantes aos apresentados por Fernandes; Andreoli; Domaszak (1996) (TABELA 3.4). Entretanto, destaca-se a diferença ocorrida na concentração de óxido de magnésio, que sugere que a cal utilizada por Fernandes, Andreoli e Domaszak (1996) era magnesiana. Podese ressaltar, ainda, a redução na concentração de nitrogênio percebida nos dois casos em razão da volatilização da amônia (stripping) decorrente da elevação do $\mathrm{pH}$, já citada anteriormente (LUE-HING; ZENZ; KUCHENRITHER, 1992; PINTO, 2001).

Tabela 3.6 - Variação de nutrientes em lodo com cal e sem cal presentes em lodo de esgotos da Alemanha durante os anos de 1985 e 1991

\begin{tabular}{ccc}
\hline Parâmetro & $\begin{array}{c}\text { Lodo sem cal } \\
\text { (\% em base seca) }\end{array}$ & $\begin{array}{c}\text { Lodo com cal } \\
\text { (\% em base seca) }\end{array}$ \\
\hline $\mathrm{N}$ total & 5,0 & 2,1 \\
$\mathrm{NH}_{4}-\mathrm{N}$ & 1,0 & 0,3 \\
$\mathrm{P}_{2} \mathrm{O}_{5}$ & 4,7 & 3,1 \\
$\mathrm{~K}_{2} \mathrm{O}$ & 0,7 & 0,4 \\
$\mathrm{CaO}$ & 5,4 & 32,4 \\
$\mathrm{MgO}$ & 0,7 & 0,8 \\
\hline
\end{tabular}

Fonte: FRANK, 1998.

\subsubsection{ALTERNATIVAS DE DISPOSIÇÃO FINAL DO LODO}

O destino final adequado dos resíduos gerados nos sistemas de tratamento de esgoto vem sendo alvo de muitos estudos diante dos significativos problemas causados pela disposição final inadequada desse tipo de material.

Andreoli e Pinto (2001) afirmam que dispor o lodo de forma adequada representa uma atividade de grande importância e complexidade, exigindo a integração com outros setores da sociedade, mas, na maioria das vezes, extrapola os limites das estações. Além disso, o destino inadequado do material pode acarretar ao seu gerador o enquadramento na lei de crimes ambientais, Lei $n^{\circ} 9.605$ de 12/02/98 ${ }^{14}$. De acordo com D'almeida e Vilhena (2000), o gerenciamento dos Resíduos Sólidos, que incluem o lodo de esgoto, pode ser de responsabilidade do poder público (Municipalidade) ou do próprio gerador. Como qualquer

\footnotetext{
${ }^{14}$ LEI 9605/1998 - Dispõe sobre as sanções penais e administrativas derivadas de condutas e atividades lesivas ao meio ambiente e dá outras providências.
} 
resíduo sólido, o Gerador do lodo oriundo em ETE é responsável pelo seu gerenciamento adequado desde o tratamento até a disposição final (grifo nosso).

Para a disposição final do lodo são adotadas alternativas diferenciadas que incluem aquelas que valorizam o potencial de seus componentes e as que não valorizam, representando apenas uma forma de disposição final sem aproveitamento ou reciclagem desses componentes. No caso das que não valorizam destacam-se as alternativas de tratamento no solo e disposição em aterros.

No sistema de tratamento no solo, não há o aproveitamento agrícola dos componentes do lodo. Trata-se especificamente da degradação da matéria orgânica pelos microrganismos presentes no solo e da retenção dos componentes inorgânicos na camada de solo com profundidade de $1,5 \mathrm{~m}$, conhecida como zona de tratamento. No entanto, no Brasil, esse processo tem sido mais utilizado no gerenciamento de resíduos gerados no tratamento de efluentes industriais (ANDREOLI; PEGORINI; FERNANDES, 2001).

O aterro sanitário é usado para a disposição de resíduos sólidos no solo, particularmente lixo domiciliar, fundamentado em critérios de engenharia e normas operacionais específicas que permitam a confinação segura relativamente a controle de poluição ambiental e proteção à saúde pública. O lodo pode ser disposto em aterros de forma exclusiva ou em codisposição com os resíduos domiciliares. Quando em aterros exclusivos, deve apresentar teores de sólidos totais elevados, acima de 40\%, e ainda, o ideal é que sejam misturados a outros materiais, como óxido de cálcio, para que sua resistência mecânica seja ideal para submeter-se à compactação (MIKI; ALEM SOBRINHO; VAN HAANDEL, 2006; TSUTIYA, 2000).

Entretanto, a disposição do lodo em aterro sanitário vem se tornando inviável sob os aspectos técnico e operacional. Isso porque essa alternativa não é sustentável em longo prazo, devido à saturação da capacidade dos aterros, à forte rejeição por parte da população do entorno, ao custo relativamente elevado das áreas existentes para sua implantação e às dificuldades de encontrar áreas que atendam às necessidades técnicas. Grecca (1994) destaca ainda os problemas advindos da lixiviação de líquidos percolados, a emissão de gases, a vida útil limitada e a dificuldade cada vez maior em encontrar locais apropriados para sua instalação em regiões metropolitanas. Além disso, de acordo com Saabye, Krüger e Schwinning (1994), a disposição em aterro requer tecnologia de adequação ambiental cada vez mais sofisticada, o que confere alto custo para cada tonelada de resíduo a ser disposto. 
Na Austrália, não é permitida a disposição de resíduos sólidos com teores de matéria orgânica superiores a 5\%, em aterros sanitários (PARRANVICINI et al., 2007). Em Québec, o governo estabeleceu uma política que favorece a recuperação de resíduos municipais; em face disso, instituiu a adoção da green tax referente ao valor de $10 \$$ por tonelada de resíduo municipal, tal como o biossólido, se for aterrado ou incinerado (HÉRBERT, 2007). Também, na Suécia essa forma de disposição final foi proibida desde janeiro de 2005 (LINDBERG et al., 2007).

Esses aspectos mostram que a disposição do lodo em aterro sanitário vem se apresentando como uma técnica cada vez mais impraticável. Nesse sentido buscar alternativas que venham a minimizar a geração e a favorecer a recuperação/reciclagem de resíduos é realmente a melhor condição a ser perseguida, sendo essa uma tendência mundial.

Em contrapartida, entre as alternativas que valorizam o potencial dos componentes do lodo, podem-se citar a utilização em áreas agrícolas e em plantações florestais, e também as formas que permitem seu emprego de maneira sustentável em áreas degradadas (ALMENDROCANDEL et al.; 2006). A utilização em áreas agrícolas será mais bem explorada nos itens seguintes por ser o principal foco desta pesquisa.

Com relação ao uso do lodo na recuperação de áreas degradadas, sua demanda, no Brasil, ocorre em razão do aumento considerável dessas áreas ao longo dos anos. Na maioria das vezes, estão associadas às atividades antrópicas, como construção de estradas e barragens, mineração e áreas agrícolas mal planejadas. Nesses casos, os solos sofrem profundas alterações físicas e/ou químicas e, consequentemente, apresentam condições impróprias ao desenvolvimento de vegetação. As propriedades físico-químicas do lodo poderão, então, ser incorporadas a essas áreas, visando a recuperar as características necessárias para o desenvolvimento das plantas (DUDA et al., 1999). No âmbito mundial, exemplificando, no Distrito de Sechelt, Canadá, o biossólido representa a maior parte dos compostos orgânicos utilizados na recuperação de áreas resultantes da exploração de minérios e jazidas de areia (VAN HAM et al., 2007).

É importante citar ainda a utilização de incinerador, que apresenta como principais vantagens a redução do volume e a destruição e/ou diminuição de componentes orgânicos tóxicos. Entretanto, não deve ser enquadrada, a rigor, como forma de disposição final, haja vista que, nos processos de secagem e combustão do lodo, são gerados gases, material particulado e, principalmente, cinza que necessitam de tratamento específico e disposição final adequada. 
No US EPA (1999), é apresentado que, com a incineração, o volume original de biossólido é reduzido aproximadamente até $20 \%$, representando uma grande vantagem da técnica. Segundo a mesma fonte, algumas regiões dos Estados Unidos usam os incineradores como unidades reservas quando outras opções de gerenciamento não podem ser executadas. Era considerada, até pouco tempo, uma técnica em que o beneficiamento do material não representava nenhuma condição de reaproveitamento. No entanto, nesse caso, os componentes do lodo não são reaproveitados diretamente, mas, de acordo com Spinoza (2007), o Japão já utiliza as cinzas como ingredientes para a indústria de cimento Portland e outros processos de solidificação termal. Porém, o autor destaca que o incremento crescente nos custos de energia se tem mostrado como um fator limitante na continuidade do processo.

Outras formas de disposição do lodo, até agora pouco utilizadas, mas altamente promissoras, incluem as alternativas de reuso industrial na fabricação de agregado leve para construção civil, fabricação de tijolos e telhas cerâmicas, produção de cimentos e componentes de mistura asfáltica (AL SAYED; MADANY; BUALI, 1995; AZIZ; KOE, 1990; LIEW, 2004; LUO; LIN, 2007; SCHWABE; LEÃO; CAVALCANTI, 2001; TARUYA; OKUNO; KANAYA, 2001; TERATANI; OKUNO; KOUNO, 2001). E, ainda, o coprocessamento do lodo com palha de arroz para produção de energia por intermédio da digestão anaeróbia que vem sendo usada no Japão (KOMATSU et al., 2007); o uso no crescimento e produção de enzimas específicas, em especial as proteases alcalinas, muito usadas na produção de detergentes, tendo em vista o fato de o lodo possuir concentrações razoáveis de carbono, nitrogênio, fósforo e outros nutrientes (DROUIN, 2007); e, Dickinson e Rutherford (2006) e Song et al. (2007) desenvolveram estudos que mostram a potencialidade do lodo como inoculante para a remediação de solo contaminado com óleo diesel. Há também tratamentos que são considerados como processos de disposição final, podendo-se destacar a conversão do lodo em óleo combustível, a pirólise e a oxidação úmida (TSUTIYA, 2002).

\subsection{UTILIZAÇÃO DO LODO (BIOSSÓLIDO) NA AGRICULTURA}

O principal objetivo do tratamento do esgoto é remover as impurezas ali presentes, de forma a adequar o lançamento do efluente tratado com qualidade desejada, protegendo tanto o meio ambiente sem poluir os solos, rios e mares, quanto a população que se utiliza, de forma direta ou indireta, desses ambientes. 
Os principais poluentes presentes no esgoto são: a matéria orgânica, cujos componentes relevantes são os compostos de proteínas, os carboidratos e a uréia; o nitrogênio e fósforo, que são elementos indispensáveis para o crescimento de algas e que, quando em elevadas concentrações no corpo receptor, podem ocasionar um crescimento exagerado desses organismos, provocando a eutrofização.

Como apresentado no item 3.1 (FIGURA 3.1), no tratamento do esgoto uma parcela da matéria orgânica é transformada e forma o lodo biológico, com isso a remoção desses elementos, a princípio poluentes, faz com que estes sejam incorporados ao lodo, resultante num material com elevada concentração de matéria orgânica e de nutrientes. Porém, essas características agregam ao material potencial favorável para sua utilização na agricultura. Segundo Soares (2005), os solos brasileiros, na sua maioria, são ácidos, apresentam baixos teores de nutrientes e baixos níveis de matéria orgânica que tendem a diminuir ainda mais em razão da intensiva exploração agrícola. Nesse sentido, novas práticas que contribuem com a melhoria das características do solo vêm sendo difundidas, como o uso do lodo, possibilitando, assim, a recuperação da fertilidade dos solos tropicais.

A utilização do biossólido na agricultura vem crescendo nas últimas décadas em todo o mundo. Exemplificando, em 1987, Lake (1987) apresentou dados sobre as formas de disposição final do lodo na Inglaterra onde, naquela época, do total de lodo produzido no país $67 \%$ eram dispostos no solo, sendo $41 \%$ aplicados no solo agrícola e o restante usado principalmente em aterro sanitário e em áreas degradadas. Do remanescente de lodo, 29\% eram dispostos no oceano (atualmente proibida), enquanto somente $4 \%$ eram incinerados. Tendência confirmada por Wright (2001), quando mostrou que esse número realmente vinha aumentando na Inglaterra, onde, em 1992, a disposição em solo agrícola passou para 45\% e, em 1998, para 56\%, sendo estimado que, em 2005, esse valor chegaria a $61 \%$, ficando a disposição em aterro sanitário com apenas $6 \%$ no mesmo ano.

Segundo dados apresentados em 2002 por NRC (2002), dos 5 milhões, aproximadamente, de lodo de esgoto seco gerado por ano nos Estados Unidos, 60\% são aplicados no solo. E, de acordo com Gerba e Smith (2005), em alguns estados, tal qual o Arizona, 95\% do biossólido gerado é aplicado em solo agrícola.

No caso do Canadá, várias regiões desenvolveram planos diretores de gerenciamento de lodo de esgoto, visando, dentre outras coisas, à implantação de uma gestão sustentável e realista, 
com alcance temporal bastante dilatado (2005 a 2021). Na região de Niágara, o lodo originário de nove ETE é aplicado na agricultura e, no plano diretivo realizado em 2001 com alcance até 2025, essa alternativa de disposição final foi mantida (BARROW et al, 2007). Em Durham, Ontário, estudos desenvolvidos sobre o gerenciamento do lodo para curto e longo prazo mostraram que a aplicação na agricultura, que já é realizada em duas ETE da região, deve, também, ser mantida (THOMPSON et al., 2007).

A potencialidade do lodo na disposição em áreas agrícolas já é comprovada. Tanto a literatura nacional como a internacional estão providas de publicações de diferentes naturezas sobre esse assunto. No Brasil, especificamente, várias pesquisas já foram realizadas com o objetivo de avaliar a utilização do lodo proveniente de Estações de Tratamento de Esgoto (ETE), gerado por diferentes processos, e esses estudos têm sido incentivados. O Programa de Pesquisas em Saneamento Básico (Prosab), por exemplo, tem possibilitado a publicação de vários livros sobre o tema, divulgando resultados de pesquisas realizadas em todo o país, entre os quais podem ser citados os trabalhos de Andreoli (2006), Andreoli, (2001), Cassini (2003) e Franci (2000).

Além do Prosab, a Sanepar, a Embrapa, a Sabesp, a Abes e publicações avulsas também têm contribuído com material específico sobre essa forma de disposição final.

Acredita-se que a disposição em solo agrícola não será reduzida provavelmente nos próximos anos, em face das restrições das outras possíveis formas de disposição final. Como exemplo o uso em aterro sanitário, que poderá ser severamente restringido em razão dos custos e da disponibilidade de área para sua implantação. Esse fato se tornou realidade em diferentes países desenvolvidos e em desenvolvimento, considerando, também, as mudanças climáticas.

\subsubsection{ASPECTOS POSITIVOS RELACIONADOS À UTILIZAÇÃO DO LODO NA AGRICULTURA}

Apesar de a composição do biossólido ser, de modo geral, muito variável, é um material rico em matéria orgânica (40-60\%), em nitrogênio e em alguns micronutrientes, como zinco, manganês e cobre (CHENG et al., 2007; LAKE, 1987). O USDA (1980) considera que o biossólido típico é aquele que possui $40 \%$ de matéria orgânica, 4\% de nitrogênio, 2\% de 
fósforo e $0,4 \%$ de potássio. Essas informações podem ser confirmadas nas TABELAS 3.7 e 3.8, que apresentam características de lodo gerado em ETE operadas no Brasil.

Tabela 3.7 - Características do lodo gerado em ETE no Brasil - teores de nutrientes e carbono

\begin{tabular}{|c|c|c|c|c|c|c|c|c|}
\hline \multirow{2}{*}{ Estação } & \multirow{2}{*}{ Tipo de lodo } & \multicolumn{6}{|c|}{ Teor (\% em base seca) } & \multirow{2}{*}{ Referência } \\
\hline & & $\mathbf{N}$ & $\mathbf{P}$ & $\mathbf{K}$ & C org. & Ca & Mg & \\
\hline Barueri (SP) ${ }^{(1)}$ & Lodo ativado & 2,25 & 1,48 & 0,01 & 25,5 & 7,29 & ND & Tsutiya et al. (2002) \\
\hline Barueri (SP) ${ }^{(2)}$ & Lodo ativado & 9,15 & 1,81 & 0,35 & 37,8 & 2,13 & 0,22 & Tsutiya et al. (2002) \\
\hline Suzano (SP) ${ }^{(3)}$ & Lodo ativado & 2,31 & 2,65 & 0,10 & 23,8 & 14,6 & 0,22 & Tsutiya et al. (2002) \\
\hline Franca $(\mathrm{SP})^{(2)}$ & Lodo ativado & 5,9 & 0,9 & 0,3 & 32,9 & - & - & Comparini (2001) \\
\hline Belém (PR) & Lodo ativado & 4,19 & 3,70 & 0,36 & 32,1 & 1,59 & 0,60 & Sanepar (1997) \\
\hline UASB (PR) & Anaeróbio & 2,22 & 0,67 & 0,95 & 20,1 & 0,83 & 0,30 & Sanepar (1997) \\
\hline ETE Sul (DF) & Aeróbio & 5,35 & 1,70 & 0,18 & 62,5 & 2,68 & 0,41 & $\begin{array}{l}\text { Silva, Dimas e } \\
\text { Sharma (2000) }\end{array}$ \\
\hline Eldorado (ES) & Lagoa anaeróbia & 2,00 & 0,20 & 0,04 & - & - & - & $\begin{array}{l}\text { Gonçalves, Lima, } \\
\text { Passamani (2000) }\end{array}$ \\
\hline Mata da Serra (ES) & $\begin{array}{l}\text { Lagoa facultativa } \\
\text { primária }\end{array}$ & 2,00 & 0,20 & 0,05 & - & - & - & $\begin{array}{l}\text { Gonçalves, Lima, } \\
\text { Passamani (2000) }\end{array}$ \\
\hline Valparaíso (ES) & $\begin{array}{c}\text { Lagoa de } \\
\text { sedimentação }\end{array}$ & 4,00 & 3,50 & 0,07 & - & - & - & $\begin{array}{l}\text { Gonçalves, Lima, } \\
\text { Passamani (2000) }\end{array}$ \\
\hline
\end{tabular}

Nota: ND - Não detectado; (1) e (3) Lodo ativado convencional, condicionamento do biossólido com cal e cloreto férrico; (2) Lodo ativado convencional, condicionamento do biossólido com polímero.

Tabela 3.8 - Características do lodo gerado em ETE no Brasil - teores de micronutrientes

\begin{tabular}{cccccccccc}
\hline \multirow{2}{*}{ Estação } & Tipo de lodo & \multicolumn{7}{c}{ Teor (ppm) } & Referência \\
\cline { 3 - 7 } & & B & Fe & Cu & Zn & Mn & Mo & \\
\hline Barueri (SP) & Lodo ativado & - & - & 660 & 2.328 & - & $<50$ & Tsutiya et al. (2002) \\
Barueri (SP) & $(2)$ & Lodo ativado & - & - & 850 & 1.870 & - & 13 & Tsutiya et al. (2002) \\
Suzano (SP) & Lodo ativado & - & - & 733 & 1.873 & - & 19 & Tsutiya et al. (2002) \\
Franca (SP) & Lodo ativado & - & - & 162,6 & 1.216 & - & 4,8 & Comparini (2001) \\
Belém (PR) & Lodo ativado & - & - & 439 & 864 & - & - & Sanepar (1997) \\
RALF (PR) & Anaeróbio & - & - & 89 & 456 & - & - & Sanepar (1997) \\
ETE Sul (DF) & Aeróbio & 22 & 20.745 & 186 & 1.060 & 143 & - & Silva, Dimas e Sharma \\
\end{tabular}

Nota: (1) e (3) Lodo ativado convencional, condicionamento do biossólido com cal e cloreto férrico; (2) Lodo ativado convencional, condicionamento do biossólido com polímero.

Cabe acrescentar que o termo biossólido, que tem sido citado neste trabalho, vem sendo empregado na literatura específica para valorizar o potencial agrícola do lodo e ressaltar as características positivas do material. O termo biossólido, de certa forma, desmistifica os aspectos negativos do material que, num primeiro momento, pode causar uma rejeição natural, tanto por parte do agricultor quanto de quem vai consumir o alimento que foi fertilizado com o material. Na verdade, o termo biossólido é empregado aos lodos 
provenientes dos esgotos sanitário que já tenham passado por etapas de tratamento adequadas e apresentam características apropriadas para serem usados na agricultura ou em outros usos benéficos ${ }^{15}$.

A aplicação de lodo de esgoto na agricultura tem como efeito uma maior disponibilidade de nutrientes no solo e, consequentemente, leva a um melhor desenvolvimento das plantas e a uma produtividade maior. Contém todos os nutrientes essenciais e benéficos para os vegetais, além de promover o aumento da população microbiana do solo, acarretando alterações nas suas propriedades bioquímicas (MELO; MARQUES, 2000).

Os principais benefícios do uso do biossólido na agricultura incluem: a redução da velocidade na liberação do nitrogênio; a liberação de fósforo, potássio e micronutrientes essenciais às plantas, como zinco e ferro; a possibilidade de possuir propriedade alcalina se tratado com cal; a melhoria da capacidade de retenção de água na estrutura do solo e no transporte de água (US EPA, 2000; WRIGHT, 2001). As vantagens da utilização do lodo na agricultura vão além dos benefícios relacionados à sua potencialidade agrícola, podendo ainda acrescentar a diminuição no uso de fertilizantes químicos e, com isso, a minimização dos impactos negativos ambientais e de saúde ocasionados pelo uso indiscriminado desses produtos.

\subsubsection{Potencial agronômico do lodo}

Quando utilizado na agricultura, o biossólido melhora as propriedades físicas, químicas e biológicas do solo devido à matéria orgânica existente. Dentre esses benefícios destacam-se os efeitos referentes à melhoria do estado de agregação das partículas do solo, a diminuição da sua densidade, o aumento da aeração (CHENG et al., 2007; PARKINSON et al., 2004), o aumento da capacidade de retenção de água (BARRETO, 1995; JORGE; CAMARGO; VALADARES, 1991), a melhoria da capacidade de troca catiônica durante o processo de mineralização, que contribui com o aumento da resistência do solo à erosão (MELO, MARQUES, 2000) e a capacidade da matéria orgânica do biossólido de se manter por longo tempo na estrutura e fertilidade do solo (LAKE, 1987).

\footnotetext{
${ }^{15}$ A expressão Uso Benéfico é usada, de acordo com Andreoli, Pegorini e Fernandes (2001, p. 319), quando a aplicação do lodo "objetiva beneficiar-se das propriedades do produto como fertilizante e condicionador do solo, e envolve práticas como a reciclagem agrícola e reflorestamentos, o uso em recuperação de áreas degradadas e a produção de substratos de mudas e fertilizantes".
} 
Vários autores, citados por Melo e Marques (2000), destacam que a utilização do lodo de esgoto no solo possibilita um aumento na disponibilidade de macro e micronutrientes. Um deles, o nitrogênio, aumenta o seu teor no solo de forma significativa. Segundo Cheng et al. (2007), o nitrogênio é considerado como o elemento-chave para o desenvolvimento e crescimento das plantas, fazendo parte da estrutura de um grande número de moléculas importantes para as células como as proteína, o ácido nucléico e a clorofila. Além disso, temse observado que a sua presença aumenta o pH do solo, diminuindo, assim, sua acidez. A associação entre o nitrogênio e o aumento do $\mathrm{pH}$ foi apontada por Berton, Camargo e Valadares (1989) como uma possível explicação para o fato e, segundo os autores, o aumento ocorre em virtude da oxidação do N-orgânico para a formação do íon amônio.

O fósforo é o segundo elemento essencial para o crescimento e desenvolvimento das plantas e encontra-se presente na sua estrutura celular (BRADY; WEIL, 1999, apud CHENG et al., 2007). Apesar de alguns autores levantarem dúvidas sobre o potencial do biossólido em aumentar a disponibilidade de fósforo no solo (CRIPPS; MATOCHA, 1991; ROS et al. 1993), a maioria das publicações aponta uma expressiva melhoria do solo com relação ao fósforo disponível. O fósforo no lodo apresenta uma biodisponibilidade de 40\% a 80\% do total contido no material (ANDREOLI; PEGORINI; FERNANDES, 2001; MELO; MARQUES, 2000). Outra questão importante relacionada ao fósforo é o fato de que as fontes naturais de fosfatos são finitas, havendo uma previsão de que, ao final deste século, os depósitos de fosfatos com baixas concentrações de substancias nocivas, como cádmio e urânio, estarão totalmente esgotadas. Isso aponta a necessidade de buscar fontes alternativas de fosfato, sendo esse elemento insubstituível na nutrição dos vegetais (MONTAG; GETHKE; PINNEKAMP, 2007).

O potássio é o terceiro elemento mais importante para o desenvolvimento e produtividade das plantas, depois do nitrogênio e do fósforo. A importância do potássio é, entre outras, a manutenção do estado da água nas plantas (CHENG et al., 2007). Ainda que o K esteja presente em quantidades reduzidas no biossólido, apresenta-se sob a forma inorgânica, estando prontamente disponível para ser assimilado pelas plantas; é, portanto, de grande interesse (PIERZYNSKI, 1994). Porém, em razão do seu baixo teor, não é descartada a possibilidade de ser realizada suplementação desse elemento por fertilizantes químicos quando aplicado biossólido como insumo agrícola (ANDREOLI; PEGORINI; FERNANDES, 2001). 
Quando comparado com fertilizantes químicos agrícolas, o lodo apresenta teores relativamente elevados de nitrogênio, mas concentrações reduzidas de fósforo e potássio. No entanto, confrontando com outros resíduos orgânicos, os teores de nitrogênio e fósforo mostram-se acima dos demais (TABELA 3.9). Tanto o lodo como os demais resíduos orgânicos podem apresentar variações em suas composições de acordo com o local de origem, e os valores edentificados não devem ser considerados como uma regra geral (TCHOBANOGLOUS; BURTON; STENSEL, 2002). Para Sanepar (1997), os biossólidos apresentam propriedades semelhantes a outros produtos orgânicos usados na agricultura e podem ser aplicados à maioria das culturas em razão dos excelentes resultados agronômicos.

Tabela 3.9 - Nível de nutrientes de fertilizantes químicos convencionais, lodo de esgoto e resíduos orgânicos

\begin{tabular}{|c|c|c|c|c|}
\hline Tipo de resíduo ou Fertilizante & $\begin{array}{c}\text { Nitrogênio } \\
(\%)\end{array}$ & $\begin{array}{c}\text { Fósforo } \\
(\%)\end{array}$ & $\begin{array}{c}\text { Potássio } \\
\text { (\%) }\end{array}$ & $\begin{array}{c}\text { Matéria } \\
\text { Orgânica } \\
\text { (\%) }\end{array}$ \\
\hline Lodo de esgoto & 6,27 & 8,15 & 0,36 & 51,5 \\
\hline Fertilizantes químicos típicos ${ }^{\text {(a) }}$ & 5 & 10 & 10 & - \\
\hline Esterco de galinha & 5,00 & 2,00 & 2,00 & - \\
\hline Húmus de minhoca & 1,50 & 1,90 & 0,20 & 80,0 \\
\hline Adubo de lixo & 0,70 & 0,56 & 0,68 & 35,0 \\
\hline
\end{tabular}

Fonte: CAESB, 1996; TCHOBANOGLOUS; BURTON; STENSEL, 2002.

Nota: (a) - A concentração de nutrientes pode variar conforme o tipo de solo e as necessidades das culturas.

Na Áustria, segundo informações de Kroiss e Zessner (2007), o uso dos componentes do lodo em substituição à fertilização química com nitrogênio e fósforo representa uma economia de, 1,5 a $2 € /$ habitante, aproximadamente. Caso todo o lodo gerado nas ETE seja usado na agricultura, isso representa algo em torno de $4 \%$ dos investimentos do país injetados na agricultura. Cabe destacar que, na Áustria, 90\% da população se encontra conectada ao sistema de tratamento de esgoto e, atualmente, menos de $20 \%$ do lodo é utilizado na agricultura.

Outro aspecto importante na utilização de biossólido, como insumo agrícola, foi a identificação do aumento do teor de carbono no solo com a promoção do acúmulo de C-CO atmosférico na matéria orgânica (BAYER et al., 2000). O aumento do estoque de carbono no solo, nesse caso, pode constituir-se numa alternativa para minimizar o aquecimento global, em virtude desse acúmulo no solo. Entretanto, o Protocolo de Kyoto não reconhece o sequestro de carbono no solo como uma alternativa para Mecanismos de Desenvolvimento 
Limpo (MDL). Porém, na reunião do Painel Intergovernamental sobre Mudanças Climáticas, ocorrido em 1990, foi discutida a possibilidade de se utilizarem práticas agrícolas convencionais que possibilitem o acúmulo de $\mathrm{C}$ no solo, mitigando assim o aumento de $\mathrm{CO}_{2}$ na atmosfera (WWF, 2007) ${ }^{16}$.

$\mathrm{Na}$ bibliografia especializada pesquisada para o desenvolvimento deste trabalho, foram encontradas publicações sobre a avaliação ou mesmo utilização do biossólido em diversas culturas. Dentre elas, vale destacar: arroz, soja (BETTIOL; CARVALHO; FRANCO, 1983), café (MARTINS, 2003), cana-de-açúcar (SILVA, F. C. et al., 2001), girassol (THOMAS et al., 2006), eucaliptos (FARIA; RODRIGUES, 2001), milho (CHEN et al., 2008; SOARES, 2005; WARMAN; TERMEER, 2005), milho e feijão consorciados (NOGUEIRA et al., 2006), feijão (LOURENÇO et al., 1996), inclusive alface (SANTOS, 1979), palmito, quiabo, tomate (PAULRAJ; RAMULU, 1994), agrião, cevada (FUENTES et al., 2006), couve-flor (MARTINEZ et al., 2001). Porém, algumas dessas culturas foram desenvolvidas e monitoradas apenas como experimentação, devendo a aplicação do biossólido em escala real obedecer à regulamentação sobre essa prática.

No estado do Espírito Santo, foram também realizadas pesquisas com biossólido na produção de mamão (COSTA et al., 2001), café (COSTA; KROHLING, 1998), repolho (PEREIRA JUNIOR; SOUZA; GONÇALVES, 1998) e espécies florestais (COSTA et al., 2000). Atualmente, segundo informações apresentadas em fôlder de divulgação elaborado por Costa et al. (2008), a Cesan, em parceria com o Incaper, iniciou em setembro de 2007, um projeto de pesquisa com biossólido que pretende: estabelecer os critérios para a seleção de áreas para a disposição de biossólido; implantar unidades de referência com aplicação do lodo de ETE e sua influência nos cultivos agrícolas e florestais; avaliar os efeitos da aplicação do lodo de ETE como fonte alternativa de matéria orgânica e sua influência nas características físicas, químicas e microbiológicas do solo, e também, a disponibilidade de nutrientes para as culturas; subsidiar a legitimação do uso e disposição de lodo de esgoto; e, capacitar gestores, técnicos e produtores rurais no uso e manejo do biossólido na agricultura. Com isso, os pesquisadores esperam que os resultados a serem obtidos possam subsidiar a elaboração de um Manual de Uso e Manejo do Biossólido para o Estado do Espírito Santo. A previsão é que tal projeto seja finalizado em setembro de 2010 .

\footnotetext{
${ }^{16} \mathrm{http}$ //www.wwf.org.br/natureza_brasileira/meio_ambiente_brasil/ clima/ painel_intergovernamental_de_mudancas_climaticas/index.cfm.
} 
Todos os argumentos apresentados fazem que o biossólido se caracterize como um insumo agrícola de grande potencial, principalmente em regiões onde ocorra o uso intensivo do solo ou onde haja a proposição de técnicas de reflorestamento (GOMES et al., 2001). E ainda o uso agrícola do biossólido tem provado que, quando adequadamente aplicado, apresenta o melhor custo efetivo e é a alternativa mais sustentável para o reuso do lodo (SPINOSA; VESILIND, 2001).

\subsubsection{RISCOS RELACIONADOS À UTILIZAÇÃO DO LODO NA AGRICULTURA}

Embora a disposição do lodo de esgoto em áreas agrícolas possa promover melhorias na qualidade do solo, tal prática apresenta algumas restrições de uso que devem ser investigadas, principalmente aquelas relacionadas à presença de metais pesados, fármacos, microrganismos patogênicos e poluentes orgânicos variados que podem ocasionar riscos sanitários e ambientais (ICON, 2001 ${ }^{17}$; NRC, 1996; RENOUX et al., 2007; SILVA, S. M. C. P. et al., 2001). Nesse sentido, merece destaque a possibilidade de contaminação dos trabalhadores que venham a manusear o material, dos produtos cultivados ou, ainda, das águas subterrâneas e superficiais com a lixiviação de alguns elementos (WRIGHT, 2001).

Vale lembrar que a presença desses elementos depende do esgoto que a eles deu origem e, também, do processo de tratamento usado, tanto do esgoto, quanto do biossólido. E, ainda, é importante ressaltar que o ideal é que sejam sempre realizadas atividades que promovam a prevenção da presença desses elementos no esgoto de origem doméstica em face das dificuldades encontradas para sua remoção.

\subsubsection{Substâncias inorgânicas - Metais pesados}

A presença de metais pesados em lodos de esgotos sanitário está associada a diferentes fontes. Inicialmente, vale destacar as próprias fezes, urina, águas cinza e papel sanitário, provenientes dos esgotos residenciais. Em estudo realizado por Jonsson et al. (2005) sobre a composição fragmentada dos esgotos gerados nas residências, foi apresentada a contribuição de metais pesados de cada pessoa por dia nesses esgotos, conforme apresentado na TABELA 3.10. Diante desses dados, percebe-se que a presença de metais nas águas residuárias tem uma parcela de contribuição pelos próprios indivíduos geradores dos esgotos.

\footnotetext{
${ }^{17}$ http://europa.eu.int
} 
Tabela 3.10 - Concentrações de metais pesados em urina, fezes mais papel sanitário e águas cinza

\begin{tabular}{ccccc}
\hline \multirow{2}{*}{ Metal } & \multicolumn{4}{c}{ Concentração em (mg/hab.dia) } \\
\cline { 2 - 5 } & Urina & Fezes e papel sanitário & Águas cinza & Total \\
\hline $\mathrm{Pb}$ & 0,012 & 0,040 & 1,3 & 1,35 \\
$\mathrm{Cd}$ & 0,0005 & 0,010 & 0,05 & 0,06 \\
$\mathrm{Hg}$ & 0,00082 & 0,009 & 0,005 & 0,01 \\
$\mathrm{Cu}$ & 0,10 & 1,10 & 10,3 & 11,50 \\
$\mathrm{Cr}$ & 0,010 & 0,13 & 1,3 & 1,44 \\
$\mathrm{Ni}$ & 0,011 & 0,19 & 1,6 & 1,80 \\
$\mathrm{Zn}$ & 0,3 & 10,7 & 13 & 24,0 \\
\hline
\end{tabular}

Fonte: Adaptado de JONSSON et al., 2005.

Produtos vinculados a atividades humanas (cosméticos, produtos de limpeza, tintas e vernizes, pesticidas, produtos automotivos) e aqueles usados em consultórios dentários, farmácias de manipulação, laboratórios de análises clínicas, entre outros, contêm na composição diversos metais, destacando-se o alumínio, o ferro, o cobre, o mercúrio, o titânio e o zinco (STEPHENSON, 1987). Tais produtos representam fontes potenciais para a ocorrência de metais nos esgotos sanitário.

Numa coletânea de informações realizada por Villar (2003), foram apresentadas classes de produtos usados rotineiramente no comércio e nas residências, que contribuem com o lançamento de metais pesados no esgoto (TABELA 3.11).

Tabela 3.11 - Metais pesados presentes em diferentes produtos usados no comércio e nas residências

\begin{tabular}{cc}
\hline Produto & Elemento \\
\hline Cosméticos & $\mathrm{Al}, \mathrm{Be}, \mathrm{Bi}, \mathrm{Cd}, \mathrm{Co}, \mathrm{Cu}, \mathrm{Fe}, \mathrm{Pb}, \mathrm{Mn}, \mathrm{Hg}, \mathrm{Ni}, \mathrm{Se}, \mathrm{Ag}, \mathrm{Sn}, \mathrm{Ti}, \mathrm{Zn}$ \\
Produtos de limpeza e desinfetantes & $\mathrm{Al}, \mathrm{Cr}, \mathrm{Cu}, \mathrm{Fe}, \mathrm{Hg}, \mathrm{Ti}, \mathrm{Zn}$ \\
Medicamentos e produtos odontológicos & $\mathrm{Al}, \mathrm{Sb}, \mathrm{As}, \mathrm{Bi}, \mathrm{Co}, \mathrm{Cu}, \mathrm{Fe}, \mathrm{Hg}, \mathrm{Zn}$ \\
Pesticidas & $\mathrm{Al}, \mathrm{Sb}, \mathrm{As}, \mathrm{Be}, \mathrm{Bi}, \mathrm{Cd}, \mathrm{Cr}, \mathrm{Co}, \mathrm{Cu}, \mathrm{Fe}, \mathrm{Pb}, \mathrm{Mn}, \mathrm{Hg}, \mathrm{Ni}, \mathrm{Se}, \mathrm{Sn}, \mathrm{Ti}, \mathrm{Zn}$ \\
Tintas e pigmentos & $\mathrm{Al}, \mathrm{As}, \mathrm{Cd}, \mathrm{Cr}, \mathrm{Cu}, \mathrm{Fe}, \mathrm{Pb}, \mathrm{Mn}, \mathrm{Hg}, \mathrm{Mo}, \mathrm{Zn}$ \\
Produtos fotográficos & $\mathrm{Al}, \mathrm{Cr}, \mathrm{Fe}, \mathrm{Pb}, \mathrm{Hg}, \mathrm{Ag}, \mathrm{Sn}$ \\
Produtos automotivos & $\mathrm{Al}, \mathrm{As}, \mathrm{Be}, \mathrm{Cr}, \mathrm{Co}, \mathrm{Fe}, \mathrm{Pb}, \mathrm{Mo}, \mathrm{Ti}, \mathrm{Zn}$ \\
\hline
\end{tabular}

Fonte: Adaptado de VILLAR, 2003.

Além dessas, outras fontes de contribuição promovem um incremento, muitas vezes significativo, na concentração de metais pesados do lodo. Entre elas, estão as indústrias que lançam seus efluentes nos SES sem nenhum tratamento prévio, contribuindo para o aumento nos níveis de metal pesado e compostos orgânicos tóxicos no lodo (KUCHAR et al., 2006; SILVA, S. M. C. P. et al., 2001), mesmo sendo essa uma prática ilegal no Brasil. Segundo a NBR 9800 da ABNT (1987), os efluentes industriais devem atender a padrões específicos 
para os metais arsênio, cádmio, chumbo, cobre, cromo, estanho, mercúrio, níquel, prata, selênio e zinco antes de serem lançados à rede coletora de esgoto. Apesar dos padrões estabelecidos, alguns autores entendem que a norma precisa ser revisada, por ser bastante genérica e não levar em consideração a qualidade do lodo produzido (SILVA, S. M. C. P. et al., 2001).

No trabalho apresentado por Chang et al. (2002) foram mostrados dados que possibilitam perceber o aumento da concentração de metais no lodo ocasionado pela contribuição industrial. Os autores mostram que o lodo, mesmo produzido muitos anos atrás, não estava livre da contaminação por metais. Dados publicados em 1942 por Rudolfs e Gehm (1942, apud CHANG et al., 2002) mostram que o lodo de esgoto municipal típico nos Estados Unidos apresentava, em base seca, de 160 a $400 \mathrm{mg} / \mathrm{kg}(\mathrm{Cu})$, de 80 a $320 \mathrm{mg} / \mathrm{kg}(\mathrm{Zn})$, de 930 a $1.860 \mathrm{mg} / \mathrm{kg}(\mathrm{Pb})$ e até $1.400 \mathrm{mg} / \mathrm{kg}(\mathrm{Cr})$. Porém, em 1984, Matthews (1984) explica que, quando os resíduos industriais tinham uma participação significativa na vazão de esgoto, o lodo passava a apresentar, em base seca, $12.000 \mathrm{mg} / \mathrm{kg}(\mathrm{Cu}), 62.000 \mathrm{mg} / \mathrm{kg}(\mathrm{ZN}), 26.000$ $\mathrm{mg} / \mathrm{kg}(\mathrm{Pb}), 41.000 \mathrm{mg} / \mathrm{kg}(\mathrm{Cr})$ e $1.500 \mathrm{mg} / \mathrm{kg}(\mathrm{Cd})$. Chang et al. (2002) acrescentam, ainda, que, em comunidades não industrializadas, as concentrações de metais pesados no lodo são significativamente mais baixas.

Outra fonte, que não está ligada diretamente às atividades humanas, mas também contribui para o aumento da concentração de metais no lodo, refere-se à água de infiltração, que é transportada nas redes coletoras junto com os esgotos sanitário. Isso porque são encontrados naturalmente, no solo, vários elementos considerados metais pesados, como $\mathrm{Ag}, \mathrm{As}, \mathrm{Cd}, \mathrm{Co}$, $\mathrm{Cr}, \mathrm{Cu}, \mathrm{Hg}, \mathrm{Ni}, \mathrm{Pb}, \mathrm{Sb}$, Se e Zn (BERTON, 2000; SILVA, S. M. C. P. et al., 2001), que podem ser lixiviados pela ação da percolação de águas pluviais pelo solo até as águas subterrâneas. Essas águas, então, ao se infiltrarem nas redes coletoras, promovem um aumento na concentração de metais do esgoto doméstico e, consequentemente, no lodo a ser gerado no tratamento desse esgoto (STEPHENSON, 1987).

Em estudo sobre a tratabilidade de águas residuárias que contêm poluentes perigosos, Morita (1993) declara que a remoção de metais do esgoto e seu acúmulo no lodo acontecem, principalmente, durante o tratamento biológico da fase líquida. Para Lake (1987), esse acúmulo se dá por processos de adsorção, precipitação ou formação de complexos. Isso ocorre, de acordo com Mellis (2006), devido à estreita relação entre os metais e a matéria 
orgânica, a qual se apresenta como um importante reservatório de metais e oferece ambiente ideal para troca de cátions, possibilitando ao metal, segundo Eysenbach (1994), ficar aderido ao carbono removido nesse tipo de tratamento. Stevenson (1991) ressalta que a presença na M.O. de ligantes ou grupos que formam complexos ou quelatos, é a principal causa da afinidade existente entre esses elementos.

Outro parâmetro importante é o $\mathrm{pH}$, que é o principal fator para as reações de adsorção de metais por colóides orgânicos e inorgânicos (UREN, 1992). Com a elevação do pH, vários metais podem-se resolubilizar, entre os quais, cádmio - $\mathrm{pH}$ acima de, aproximadamente, 11,2; chumbo - $\mathrm{pH}$ acima de, aproximadamente, 9,2; cobre - $\mathrm{pH}$ acima de 9; cromo - $\mathrm{pH}$ acima de, aproximadamente, 8,5; níquel - $\mathrm{pH}$ acima de, aproximadamente, 10,2; zinco - pH acima de, aproximadamente, 9,1. Portanto, observa-se que alguns metais podem apresentar solubilidade considerável para $\mathrm{pH}$ inferiores a esses valores (EYSENBACH, 1994). No entanto, vale destacar que, no caso do uso agrícola do lodo, o pH a ser considerado é após o lançamento do lodo ao solo.

Sendo assim, a concentração e a diversidade de metais pesados no lodo podem ser bastante distintas, dependendo das fontes geradoras dos efluentes e contribuições, do processo de tratamento de esgoto utilizado, do tratamento oferecido ao lodo, e, ainda, deve-se avaliar a forma como o metal se apresenta. Em ETE operadas no Brasil, as concentrações de metais pesados no lodo podem ser observadas em publicações apresentadas por Comparini (2001), França e Figueiredo (2000), Gonçalves, Lima e Passamani (2000), Sanepar (1997), Siva, Dimas e Sharma (2000), Silva, S. M. C. P. et al. (2001), Tsutiya et al. (2002) e Villar (2003). E, em trabalho publicado por Matthews (1997), foram apresentadas concentrações de metais pesados no lodo em vários países, entre os quais, China, Egito, França, Japão, Reino Unido e Suécia.

Com relação às ameaças que a presença do metal pesado no lodo pode representar, tanto para os seres humanos quanto para o meio ambiente, Villar (2003) afirma que a literatura destaca: o acúmulo na cadeia trófica, resultante de sua assimilação pelas plantas que poderão ser consumidas pelos seres humanos ou por animais destinados ao abate; a fitotoxicidade, que acarreta uma perda ou diminuição da produtividade agrícola; a alteração na diversidade microbiana do solo, que afeta a nutrição das plantas, que é assegurada pelos processos 
metabólicos; a contaminação das águas superficiais em virtude do arraste dos metais pelas águas pluviais. E claro que essas ameaças dependem da forma como se apresentam os metais.

Em ATSDR (2007) ${ }^{18}$ é apresentada uma lista, por ordem de prioridade, de substâncias que representam ameaça potencial para a saúde humana devido à sua toxicidade, e, na listagem de 2007, ocupando os três primeiros lugares estão o arsênio, o chumbo e o mercúrio. No ser humano, a contaminação por metais pesados pode causar sintomas tóxicos agudos, e sua concentração no sangue por longo período provoca danos irreversíveis à saúde, com efeitos cancerígenos e mutagênicos.

A presença de metal no lodo sempre foi visto como o principal problema relacionado à sua acumulação no solo, pois pode causar efeito fitotóxico ou ficar concentrado nas plantas (BENMOUSSA; TYAGI; CAMPBELL, 1997; CAMOBRECO et al., 1996; HARRISON; McBRIDE; BOULDIN, 1999). A absorção dos metais pesados pelas plantas varia conforme a espécie e o pH do solo, abrindo a possibilidade de se adaptarem os cultivos conforme o nível e o tipo de contaminação do solo. Geralmente, os níveis mais altos de concentração se dão nas folhas, e os mais baixos, nas sementes. Feijões, ervilhas, melões, tomates e pimentas apresentam baixos níveis de absorção de metais pesados (IRETSKAYA; CHIEN, 1998).

De maneira geral, tratando-se do efeito cumulativo do metal, o controle da taxa de aplicação do biossólido no solo é fundamental no gerenciamento do uso agrícola do material. A constante aplicação do biossólido pode trazer prejuízos ao perfil do solo depois de alguns anos. Esse efeito foi comprovado por McBride (1995) com base em cálculos referentes ao balanço de massa de metal presente no lodo quando aplicado ao solo. Diante disso, torna-se necessário o estabelecimento de limites relacionados às substâncias inorgânicas presentes no lodo, como forma de proteger o meio ambiente e a saúde humana.

Sobre a contaminação das águas superficiais, Ahlberg, Gustafsson e Wedel (2006) expõem que os metais contidos no lodo de esgoto não se movem para as camadas mais profundas do solo, ficando retidos na camada superficial. Nesse caso, segundo os autores, o risco de lixiviação e poluição do lençol freático foi visto como baixo ou não existente. Os mesmos autores destacam a grande capacidade de ligação entre o metal e a matéria orgânica do solo, e

\footnotetext{
${ }^{18}$ http://www.atsdr.cdc.gov/cercla/07list.html
} 
ainda apontam a possibilidade, em alguns casos, de se colocar argila mineral na camada superior do solo para melhor retenção do metal.

No entanto, vários cálculos de balanço de massa mostram uma elevada perda de metais no perfil do solo depois de alguns anos de aplicação de lodo (McBRIDE et al., 1997). Porém, o fato de os metais ficarem retidos nas camadas mais superficiais do solo possibilita a contaminação de outras áreas quando são transportados pelo escoamento superficial (ALONSO et al., 2002; ANGELIDIS; GIBBS,1991).

Com relação à remoção dos metais pesados do lodo, essa ainda não é uma prática usual no seu tratamento, pois, como são insolúveis, não são removidos nos tratamentos habituais do lodo (US EPA, 1995). Atualmente, os dados referentes à presença e aos níveis de metais no lodo são usados como uma avaliação seletiva para a escolha ou não de seu emprego como insumo agrícola, descartando assim, em alguns casos, tratamento específico para remoção desses poluentes em razão dos elevados custos requeridos.

Entretanto, várias pesquisas têm sido desenvolvidas sobre processos de remoção de metais do lodo, tanto no Brasil (FRANÇA, 2004; GARCIA JÚNIOR, 1991, TAKAMATSU, 1995; VILLAR, 2003) quanto em outros países (CHANG; LO; KO, 2007; KUCHAR et al., 2006; MARCHIORETTO et al., 2001; RENOUX et al., 2007; WONG; GU, 2007), na tentativa de se aprimorarem as técnicas já existentes.

Os processos podem ser químicos, por exemplo, com a adição de ácidos inorgânicos $\left(\mathrm{H}_{2} \mathrm{SO}_{4}\right)$; ou biológicos que são conhecidos como lixiviação bacteriana ou biolixiviação, ocasionados pela oxidação biológica. Os principais fatores associados à solubilização dos metais por processos químicos são a concentração e a natureza do ácido utilizado, a relação sólido/líquido do lodo, o tempo de contato, o pH e a concentração de sólidos totais do lodo (VILLAR, 2003).

Os resultados conseguidos com a adição de $\mathrm{H}_{2} \mathrm{SO}_{4}$ ao lodo têm apresentado, segundo Villar (2003), solubilização considerável, com valores acima de 80\% para os metais cádmio, zinco e níquel. Além do $\mathrm{H}_{2} \mathrm{SO}_{4}$, outros ácidos são utilizados, podendo-se destacar os estudos realizados por Ito et al. (2000), que adicionaram compostos de ferro III em amostras de lodo digerido anaerobiamente, sendo acidificadas até pH 3,0 e, nesse caso, os resultados finais 
foram semelhantes aos apresentados por $\mathrm{H}_{2} \mathrm{SO}_{4}$. Porém, para o cobre, apresentou $70 \%$ de solubilização final, enquanto, com ácido sulfúrico, o valor normalmente obtido chega a 36\%.

Em razão de sua elevada eficiência e viabilidade econômica, as técnicas de lixiviação bacteriana têm sido empregadas em vários setores. O processo é conduzido por diferentes espécies de microrganismos capazes de oxidar formas reduzidas de enxofre. Ocorre diretamente por metabolismo bacteriano ou indiretamente, por exemplo, pela ação de ácidos produzidos durante o metabolismo. Assim como nos processos químicos, o $\mathrm{pH}$ e a concentração de sólidos (característica do lodo) são fundamentais na eficiência e na cinética do processo de biolixiviação, além da produção de ácido sulfúrico para solubilização de formas metálicas diferentes de sulfetos, temperatura e o tratamento a que foi submetido o lodo (VILLAR, 2003).

Em estudo desenvolvido por Moura (2006) sobre remediação de áreas contaminadas com metais pesados, o autor relata que estudos de técnicas que usam microrganismos para o tratamento de solo e resíduos contaminados com metais pesados, vem sendo desenvolvidos e os resultados apontam que tal técnica é possível e viável. O pesquisador usou no seu estudo, Acidithiobacillus sp.

É importante ressaltar que, apesar dos efeitos tóxicos causados pelos metais, alguns deles são importantes no desenvolvimento das plantas, participando como catalisadores de enzimas integrantes do metabolismo vegetal, como o cobre, o ferro, o manganês e o zinco. Esses metais, inclusive, podem ser classificados como elementos úteis, quer dizer, elementos sem os quais as plantas conseguem sobreviver, porém, em condições desfavoráveis, pois contribuem para o crescimento, a produção e o aumento da resistência das plantas (MARQUES; MELO; MARQUES, 2002; NAGAR; SARKAR; DATTA, 2006).

\subsubsection{Organismos patogênicos e indicadores bacteriológicos}

A associação de fatores ambientais com a saúde humana é estudada e relatada desde muitos anos. Em qualquer atividade em que exista um envolvimento direto dos seres humanos com atividades nas quais é possível a presença de microrganismos patogênicos, a avaliação e o controle são bastante rigorosos. Fazendo um breve histórico, a mais de 2000 anos atrás, Hipócrates já expressava a ideia de que fatores ambientais podem influir na ocorrência de doenças. Entretanto, somente no século 19, John Snow associou a epidemia de cólera ocorrida 
na época, em Londres, dentre outras coisas, com a água de abastecimento público, marcando assim os princípios para a epidemiologia (BEAGLEHOLE; BONITA; KJELLSTRÖM, 1993). A partir daí, outros estudos foram realizados com descobertas importantes, como a de Pasteur, em 1857, que estabeleceu a teoria de que a diarréia infecciosa é causada por germes e bactéria e, em seguida, a identificação dos organismos patológicos por Koch (KIRBY, 1956, apud HÖGLUND, 2001).

Ainda hoje, novos microrganismos patogênicos são identificados e reconhecidos como causa principal de diversas enfermidades. Alguns deles são originados das fezes e têm a capacidade de transmissão de doenças, principalmente via alimento ou água. Várias doenças são causadas, direta ou indiretamente, pelo consumo de águas contaminadas, sobretudo por sistemas de esgotamento sanitário (DUMONTET et al., 2001; HÖGLUND, 2001; SIDHU; TOZE, 2009).

a) Ocorrência de patógenos no lodo de esgotos sanitário

Tratando-se de lodo proveniente de águas residuárias municipais, ele possui, em sua composição, uma enorme diversidade de organismos que podem ser patogênicos ou não (APEDAILE; COLE, 2002; DUMONTET et al., 2001; SILVA, S. M. C. P. et al., 2001). Entre os organismos causadores de doenças infecciosas que podem ser transmitidas diretamente pelo contato com o ambiente, destacam-se quatro grandes grupos: bactérias, protozoários, vírus e helmintos (FEACHEM et al., 1983; MAIER; PEPPER; GERBA, 2009; NRC, 2002; US EPA, 2003). Todos se encontram presentes no lodo, acrescentando-se, também, os ovos de parasitas (GERBA, 2001; SMITH et al., 2004; US EPA, 2003). Segundo Gerba e Smith (2005), mais de 150 patogênicos entéricos são conhecidos e podem estar presentes nos lodos não tratados.

Vírus entéricos, protozoários e parasitas são obrigatoriamente parasitas e, por essa razão, são incapazes de se multiplicarem em biossólidos, enquanto bactérias podem multiplicar-se em condições ambientais favoráveis (SIDHU et al., 2001; SKANAVIS; YANKO, 1994).

Sidhu e Toze (2009), em uma revisão de literatura sobre patógenos humanos e seus indicadores em biossólidos, compilaram informações de diferentes autores sobre o número de patógenos e indicadores em águas residuárias e lodo. Tendo essa pesquisa como referência, 
encontram-se apresentados, na TABELA 3.12, alguns desses dados, especificamente, com relação ao lodo de esgoto.

Tabela 3.12 - Quantidade de patógenos e indicadores presentes em lodo de esgoto

\begin{tabular}{|c|c|c|c|}
\hline \multirow{2}{*}{ Patógeno } & \multicolumn{2}{|c|}{ Quantidade (organismo/gST) } & \multirow{2}{*}{ Referência } \\
\hline & Faixa & Média & \\
\hline \multirow{2}{*}{ Vírus entéricos } & $4,4-7 \times 10^{2}$ & $3,5 \times 10^{2}$ & Soares et al. (1992) \\
\hline & $1,2 \times 10^{2}-1,3 \times 10^{4}$ & $6,5 \times 10^{3}$ & Gibbs et al. (1994) \\
\hline Coliforme total & $1,9 \times 10^{8}-1,1 \times 10^{10}$ & $5,6 \times 10^{9}$ & Soares et al. (1992) \\
\hline \multirow{2}{*}{ Coliforme fecal } & $9,2 \times 10^{7}-1,7 \times 10^{9}$ & $8,9 \times 10^{8}$ & Soares et al. (1992) \\
\hline & $9,3 \times 10^{6}-1,7 \times 10^{9}$ & $8,5 \times 10^{8}$ & Gibbs et al. (1994) \\
\hline E. coli & $4,4 \times 10^{5}-1,1 \times 10^{6}$ & - & Pourcher et al. (2005) \\
\hline \multirow{2}{*}{ Estreptococus fecal } & $3,7 \times 10^{5}-6,6 \times 10^{7}$ & $1,5 \times 10^{7}$ & Soares et al. (1992) \\
\hline & $3,5 \times 10^{5}-1,0 \times 10^{8}$ & $5,0 \times 10^{7}$ & Gibbs et al. (1994) \\
\hline Enterecocci & $7,2 \times 10^{5}-2,6 \times 10^{6}$ & - & Pourcher et al. (2005) \\
\hline Salmonella & $1,1 \times 10^{1}-6,6 \times 10^{7}$ & $2,9 \times 10^{3}$ & Gibbs et al. (1994) \\
\hline \multirow{2}{*}{ Giardia } & $3,1 \times 10^{4}-8,1 \times 10^{4}$ & $5,6 \times 10^{4}$ & Gibbs et al. (1994) \\
\hline & $7,7 \times 10^{1}-3,3 \times 10^{3}$ & $1,7 \times 10^{3}$ & Soares et al. (1992) \\
\hline
\end{tabular}

Fonte: Adaptado de SIDHU e TOZI (2009).

Vários são os distúrbios causados ao seres humanos pela presença desses organismos patogênicos no lodo. O QUADRO 3.3 relaciona alguns desses organismos e as possíveis doenças transmitidas por eles.

Segundo Metcalf, Melnick e Ester (1995) e US EPA (2003), a transmissão de doenças com a utilização do lodo no solo pode ocorrer por via direta ou indireta de contato entre pessoas ou animais e os microrganismos patogênicos. Diretamente, muitas vezes, pode acontecer por contato inadvertido na manipulação de solo e/ou produtos brutos provenientes do campo ou jardim onde foi aplicado o lodo de esgoto. Já a contaminação indireta, considerada uma importante rota de transmissão, é ocasionada pelo consumo de água ou alimento contaminado.

A contaminação indireta pode representar um perigo maior, pois a ingestão de organismos entéricos representa uma elevada dose infectiva quando comparada, por exemplo, com a ocorrida por inalação, resultante de aerossóis (DOWD et al., 2000).

Como foi apresentado no item 3.1, numa citação de Dumontet et al. (2001) e US EPA (1995), aspectos relacionados à saúde da população servida com o SES e ao processo de tratamento a que foi submetido o lodo estão diretamente associadas à presença e à diversidade das espécies de microrganismos e ao número de agentes patogênicos presentes no material. 
Quadro 3.3 - Principais organismos encontrados no lodo de esgoto sanitário e as respectivas doenças/sintomas

\begin{tabular}{|c|c|c|}
\hline \multicolumn{2}{|r|}{ Organismo } & Doença/Sintoma \\
\hline \multirow{5}{*}{ 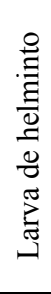 } & Ascaris lumbricoides & Distúrbios digestivos, vômito, dor abdominal \\
\hline & Ancylostoma duodenale & Anemia, emagrecimento \\
\hline & Trichuris trichiura & Diarréia, anemia, perda de peso, dor abdominal \\
\hline & Taenia solium & $\begin{array}{c}\text { Distúrbios digestivos, insônia, anorexia, dor abdominal, distúrbios } \\
\text { nervosos, irritação, emagrecimento }\end{array}$ \\
\hline & Taenia saginata & Distúrbios digestivos, insônia, anorexia, dor abdominal \\
\hline \multirow{5}{*}{ 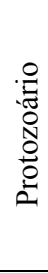 } & Echinococcus granulosus & Distúrbios digestivos, hepáticos e pulmonares \\
\hline & Entamoeba histolytica & Enterite aguda \\
\hline & Giardia lambia & Giardíase (inclui diarréia, dores abdominais, perda de peso) \\
\hline & Balantidium coli & Diarréia e disenteria \\
\hline & Cryptosporidium & Gastroenterite \\
\hline \multirow{6}{*}{ 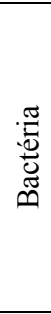 } & Salmonella typhi & Febre tifóide \\
\hline & Salmonella paratyphi & Febre paratifóide \\
\hline & Salmonella sp. & Salmonelose \\
\hline & Vibrio cholerae & Cólera \\
\hline & Escherichia coli & Gastroenterites \\
\hline & Leptospira sp. & Leptospirose \\
\hline \multirow{6}{*}{$\sum^{0}$} & Vírus de hepatite A & Hepatite infecciosa \\
\hline & Poliovírus & Poliomielite \\
\hline & Echovírus & Meningite, paralisia, encefalites, diarreia \\
\hline & Adenovírus & Doenças respiratórias, infecções nos olhos, diarreia \\
\hline & Rotavírus & Vômito, diarreia \\
\hline & Coxsackievirus & Meningite, pneumonia, hepatite \\
\hline
\end{tabular}

Fonte: DUMONTET et al., 2001; US EPA, 2003.

As bactérias contidas no lodo são oriundas das excretas humanas e se apresentam em grandes quantidades. Isso porque mesmo as pessoas sadias têm quantidades significativas de bactérias no seu organismo. Algumas delas são normalmente encontradas em países em desenvolvimento, como a Leptospira sp., a Salmonella typhi e a Salmonella paratyphi (CDC, $2000^{19}$; HÖGLUND, 2001; LEWIS-JONES; WINKLER , 1991). Apesar de o padrão higiênico da população de países desenvolvidos ser elevado, o grau de prevalência de organismos patogênicos é significativo, sendo atribuído aos alimentos e à água contaminados, ou aos animais de estimação domésticos que, na maioria das vezes, abrigam Salmonella sp. (DUMONTET et al., 2001; SCOTT, 1999; WOODWARD; KHAKHRIA; JOHNSON, 1997).

Entre as bactérias patogênicas presentes no lodo que são provenientes das excretas humanas, a Salmonella sp. é a que se apresenta em maior número, sendo conhecidos de 1.800 a 2.000

\footnotetext{
${ }^{19} \mathrm{http} / /$ www.cdc.gov/ncidod/dbmd/diseaseinfo/leptospirosis_g.htm
} 
diferentes tipos. Desse total, um grande número é considerado patogênico para os seres humanos (BITTON, 2005; SAHLSTRÖM, 2003; SMITH, 1996). Outras bactérias que normalmente se encontram nos lodos são: Escherichia coli., Vibrio cholerae, Staphylococcus sp. e Streptococcus sp. (ANDERSEN, 2001; STRAUB; PEPPER; GERBA, 1993).

Em publicação sobre a sobrevivência de bactérias em resíduos orgânicos relatada por Sahlström (2003), foram apresentadas informações de diferentes autores sobre a presença de Salmonella sp. em lodos de esgoto. Como exemplo, pode-se destacar que, em levantamento realizado na Suécia, observou-se que em mais de 50\% das amostras de lodo tratado proveniente de estações de tratamento de esgoto foi detectada a sua presença; em abordagem ocorrida na Noruega foi revelado que $10 \%$ das amostras são positivas para esse microrganismo; e, na Dinamarca é considerado que lodo de esgoto é positivo para Salmonella sp. se o sistema de tratamento de esgoto atender mais de 4.000 pessoas.

No caso da E. coli., são conhecidos 164 tipos, porém apenas uma pequena parcela é patogênica para os seres humanos (CARRINGTON, 1978, apud APEDAILE; COLE, 2002), podendo causar diarreia, colite hemorrágica e até a morte. São transmitidas ao homem por intermédio de alimento contaminado, água e contato direto com pessoas ou animais infectados (MEAD; GRIFFIN, 1998).

Entre os protozoários, o Cryptosporidium e a Giardia são os mais frequentes nos biossólidos (NRC, 2002). São conhecidos por serem altamente resistentes ao stress ambiental (CACCIO et al., 2003) e são os mais importantes causadores de gastrenterites devido a sua baixa dose infectiva (10 cistos para a Giardia e 30 (oo)cistos para o Cryptosporidium) (ADAM, 2001; FAYER; MORGAN; UPTON, 2000). Nos Estados Unidos, os parasitas causadores de doenças diarreicas mais frequentes são os protozoários Giardia lambia e Cryptosporidium; e, na Suécia, a G. lambia foi a terceira causa mais comum em casos de infecções gastrintestinais (SMI, 2000; TAUXE; COHEN, 1995). Entretanto, segundo NRC (2002) existe pouca pesquisa sobre a sobrevivência desse organismo em biossólido usado para melhorar as características do solo.

Com relação aos vírus, estima-se que mais de 150 diferentes tipos são excretados pelos seres humanos, podendo ser encaminhados para o lodo, quando do processo de tratamento do esgoto. São considerados como a maior causa de infecções gastrintestinais em seres humanos em países em desenvolvimento (BOSCH et al., 2008; CARTER, 2005; GERBA; SMITH, 
2005; NRC, 2002). Mesmo nos Estados Unidos, o número de enfermidades relacionadas aos vírus é bastante elevado. Estima-se que cerca de $80 \%$ dos casos apresentados sejam ocasionados por vírus (MEAD et al., 1999). Norovirus humano é a causa mais comum de gastrenterite aguda (BON et al., 2005; LODDER et al., 1999) e, os rotavirus são a maior causa dessa enfermidade em crianças (KIRKWOOD et al., 2004) e em indivíduos com baixa imunidade em todo o mundo (ANDERSON; WEBER, 2004).

Os vírus entéricos encontrados nos biossólidos com significância para a saúde pública podem ser divididos em dois grupos, ou seja, enterovírus (poliovírus, coxsackievirus e echovirus) e um grupo heterogêneo que inclui rotavírus, human calicivirus, astrovirus, adenovirus e vírus da hepatite A e E (SIDHU; TOZE, 2009). O termo vírus entéricos reúne todos os grupos de vírus que podem provocar doenças ou infecções e que se encontram no trato gastrointestinal. Entretanto, não podem se multiplicar no ambiente por serem considerados como parasitas intracelulares obrigatórios (BOSCH et al., 2008; CARTER, 2005).

Os adenovirus são os vírus mais comuns e persistentes detectados em águas residuárias (ENRIQUEZ; HURST; GERBA, 1995), e cerca de 40 tipos de adenovirus são encontrados em biossólido digerido anaerobiamente. Já os rotavírus, segundo NRC (2002), têm sido detectados em águas residuárias, mas nos Estados Unidos existem poucos dados disponíveis da sua ocorrência em biossólidos. Vários pesquisadores, entre os quais Pina et al. (1998) e Bofill-Mass et al. (2006), apontam os adenovirus como um candidato a indicador viral de contaminação fecal no meio ambiente, por terem maior estabilidade que as espécies de bactérias e outros vírus entéricos adotados atualmente.

Estima-se que uma fração elevada, em torno de $50 \%$ dos vírus presentes no esgoto bruto, está associada aos sólidos (PAYMENT; FORTIN; TRUDEL, 1986), e, por isso, o número de patógenos em biossólidos pode ser maior que em águas residuárias (NELL; STEER; VAN RENSBURG, 1983).

Infecções em seres humanos por helmintos têm-se apresentado como a principal causa de morbidade e mortalidade, particularmente em países em desenvolvimento. Entre os helmintos, o gênero Ascaris é o mundialmente mais conhecido (ELLIS; HURST; GOMEZ, 1993; HÖGLUND, 2001). Supõe-se que a maior parte dos ovos de helmintos presentes nas águas residuárias fica concentrada no lodo devido à sua elevada velocidade de sedimentação (NELSON, 2003). Em biossólido digerido, o número de Ascaris, Trichuris, Taenia e 
Toxocara encontra-se entre 0 e 9 ovos/gST (STRAUB; PEPPER, GERBA, 1993), sendo o Ascaris o mais comum (JIMENEZ; BARRIOS; MAYA, 2000). Lodos não digeridos proveniente de vinte estações de tratamento de esgoto na França foram avaliados quanto a presença de ovos de vários helmintos sendo percebido que esse número variou de $<0,25$ a 7 ovos/gST (SCHWARTZBROD; BANAS, 2003).

US EPA (1999) destaca que, embora a presença de agentes patogênicos no lodo não seja condição suficiente para a contaminação humana e animal, por apresentar em sua constituição outras substâncias potencialmente tóxicas como as substâncias inorgânicos e os compostos orgânicos tóxicos, ela representa a principal causa da baixa aceitação do produto em áreas agrícolas. Isso porque, para US EPA (1995), os patógenos presentes no lodo podem representar perigo à saúde pública quando aplicados ao solo, se forem transferidos para os alimentos ou transportados por vetores, como insetos, roedores e pássaros.

b) Fatores limitantes para a sobrevivência dos organismos patogênicos encontrados no lodo

O tempo de sobrevivência dos organismos patogênicos presentes no lodo é afetado por diversos fatores, como umidade (menor sobrevivência em ambiente com umidade baixa); $\mathrm{pH}$ (menor sobrevivência em solos ácidos), temperatura (maior sobrevivência em baixas temperaturas), capacidade de retenção de água ligada à textura, mais especificamente permeabilidade dos solos (menor sobrevivência em solo arenoso); presença de matéria orgânica (maior sobrevivência e possibilidade de recrescimento); competição entre as espécies e com a microflora do solo (sobrevivência maior em solo estéril) (MARTIN; BOSTAIN; STERN, 1990; PIETRONAVE et al., 2004; SIDHU et al., 2001; SILVA, F. C. et al., 2001; SMITH, 1996; THOMAZ-SOCCOL; PAULINO; CASTRO, 1997; US EPA, 2003). Outros fatores, como radiação solar, oxigênio, influenciam na inativação de patógenos. A influência de todos esses fatores pode variar de patógeno para patógeno, como também em razão do tipo de tratamento a que foi submetido o lodo (SIDHU; TOZE, 2009).

É senso comum entre Yeager e O'Brien (1983, apud COMPARINI, 2001), Dumontet et al. (2001) e Bonnet, Lara e Domaszak (2000) que a densidade de vários organismos é reduzida, de maneira significativa, pela radiação solar e desaguamento do lodo. Ainda de acordo com Yeager e O'Brien (1983, apud COMPARINI, 2001), a secagem do lodo ao ar, até atingir teores de sólidos de 95\%, possibilita a redução da concentração de bactérias de 0,5 a 4 log. 
Muitos microrganismos sobrevivem melhor em águas residuárias quando eles estão associados a partículas sólidas, especialmente, os sólidos em suspensão (SCHEUERMAN; FARRAH; BITTON, 1991; STRAUB; PEPPER; GERBA, 1992). É por essa razão que, esses microrganismos sobrevivam, provavelmente, longos tempos em biossólidos (SIDHU; TOZY, 2009).

O tempo de sobrevivência dos microrganismos é afetado por diferentes fatores, e, quando o biossólido é aplicado ao solo, as condições do próprio solo e do clima vão interferir nesse tempo (DAMGAARD-LARSEN et al., 1977; SMITH, 1996; STRAUB; PEPPER; GERBA, 1993). Provavelmente, em razão dessa diversidade de fatores, foram encontrados na literatura pesquisada tempos distintos da sobrevivência dos organismos no solo.

Em levantamento sobre o tempo de sobrevivência de organismos após a aplicação de biossólido no solo, o US EPA (1995) publicou os seguintes dados: 99\% das bactérias patogênicas morrem em 12 dias (Salmonella sp.) ou 18 dias (coliforme fecal), a uma temperatura de $15^{\circ} \mathrm{C}$; vírus normalmente sobrevive, no máximo, 19 dias em condições de temperatura também de $15^{\circ} \mathrm{C}$; protozoários sobrevivem por poucos dias, em torno de 2 dias; ovos viáveis de helmintos sobrevivem por longo tempo, cerca de 720 dias; a densidade de ovos viáveis de helmintos em lodo de esgoto aplicado superficialmente em gramados, por exemplo, é reduzida em mais de 90\% num intervalo de 3 a 4 meses.

Já Shuval et al. (1986), que apresentam resultados antes da publicação do US EPA, citam tempos diferentes dos apresentados por ele, porém não explicitam a que temperatura isso ocorre. Segundo os autores, os vírus patogênicos e as bactérias morrem dentro de um prazo de 1 a 3 meses, enquanto (oo)cistos de protozoários e ovos de helmintos podem sobreviver por mais de ano em águas residuárias e, possivelmente, muito mais no lodo.

Para Gerba e Smith (2005), bactérias podem sobreviver no solo de 2 meses a 1 ano; vírus, de 3 meses a 6 meses; protozoários, de 2 dias a 10 dias e helmintos, de 2 anos a 7 anos.

$\mathrm{Na}$ TABELA 3.13, estão listados os tempos de sobrevivência no solo de alguns microrganismos patogênicos apresentados por Straub, Pepper, Gerba (1993). Nesse caso, os autores realizaram uma seleção mais detalhada das espécies presentes no lodo. 
Tabela 3.13 - Tempo de sobrevivência de agentes patogênicos no solo.

\begin{tabular}{cc}
\hline Organismos & Tempo (dias) \\
\hline Coliformes totais & De 4 a 77 \\
Coliformes fecais & De 4 a -55 \\
Streptococos fecais & De 8 a mais de 70 \\
Leptospira & Menos de 15 \\
Mycobacterium & De 10 a 450 \\
Salmonella paratyphi & Mais de 259 \\
Salmonella typhi & De 11 a mais de 280 \\
Vibrio cholerae & 10 \\
Vírus & 90 \\
Protozoários & 2 \\
Cistos de protozoários & 2 \\
Ovos de helmintos & 720 \\
\hline
\end{tabular}

Fonte: Adaptado de STRAUB; PEPPER; GERBA, 1993.

A interferência do $\mathrm{pH}$ na sobrevivência de diversos organismos foi destaque no item 3.2.1.2 que abordou a higienização alcalina do lodo, relatando várias pesquisas que usaram a cal como produto desinfetante. Ainda no mesmo item, foi citada a capacidade de algumas bactérias de crescer novamente, ocorrendo uma recolonização, caso o pH atinja valores inferiores a 11,5, mesmo depois de sua inativação, principalmente em temperaturas amenas (DUMONTET et al., 2001; PASSAMANI, 2001; RAMIREZ; MALINA, 1980; STRAUB; PEPPER; GERBA, 1993; US EPA, 2002). Porém, cabe ressaltar, que o mesmo não acontece com os vírus, helmintos e protozoários. Esses não possuem capacidade de recrescimento a partir do momento em que foram inativados por qualquer processo de tratamento, não conseguindo reproduzir-se fora do seu organismo hospedeiro (US EPA, 2003).

Carrington (1978, apud APEDAILE; COLE, 2002) revela que o índice de diminuição de bactérias após aplicação do biossólido no solo é influenciado primeiramente por fatores metereológicos. De acordo com Cameron, Di e McLaren (1997), o número de bactérias e vírus, normalmente, é reduzido para valores insignificantes, depois de dois a três meses de aplicações de lodo no solo, dependendo das condições relacionadas à umidade, temperatura, entre outras. Smith (1996) cita que, para a Salmonella sp., pode-se esperar uma redução de até $90 \%$ da concentração inicial após três semanas de aplicação do biossólido no solo.

Apesar de US EPA (1995) apresentar que a Salmonella sp. morre em 12 dias a uma temperatura de $15^{\circ} \mathrm{C}$, após a aplicação do biossólido no solo, Sahlström (2003) destaca que essa bactéria pode sobreviver em pasta fluida por mais de 77 dias e crescer em temperaturas variando de 6 a $47^{\circ} \mathrm{C}$. 
Gantzer et al. (2001) apresentam os resultados do monitoramento de bactérias em dez ETE operadas na França com diferentes processos de tratamento do lodo, entre os quais, tratamento biológico, tratamento químico, tratamento térmico e estocagem de lodo digerido, desaguado e tratado com cal, entre os meses de outubro de 1997 e agosto de 1998. A Salmonella sp. foi totalmente eliminada no tratamento com $25 \%$ de cal virgem, $62 \%$ de cal hidratada, compostagem e tratamento térmico. Sua presença foi detectada nos tratamentos com $26 \%$ de cal hidratada, e, em alguns períodos do ano, nos tratamentos de digestão mesofílica anaeróbia e digestão termofílica aeróbia.

Tendo em vista que as bactérias e os protozoários são rapidamente reduzidos pelo efeito de condições locais, como temperatura e $\mathrm{pH}$, tornam-se pouco representativos como indicadores de proteção à saúde pública. Em contrapartida, avaliando comparativamente a concentração de parasitas entéricos em lodo, especificamente helmintos e os protozoários do gênero Giardia, em onze diferentes processos de tratamento de lodo, Gaspard e Schwartzbrod (2001) observaram a grande capacidade de sobrevivência dos ovos de helmintos. Fundamentados nos resultados obtidos, os autores concluíram que, em razão da maior capacidade de sobrevivência dos ovos de nematóides (helmintos), esses são mais interessantes como indicadores da contaminação por parasitas. O mesmo não ocorre com os cistos de protozoários, por serem pouco resistentes ao impacto do tratamento do lodo.

Os ovos de parasitas podem permanecer durante muitos anos no solo recuperado com a aplicação de biossólido, principalmente se essa região for usada para pasto. Em estudos realizados em Ontário, foi observado que os ovos podem sobreviver por menos tempo, quando o biossólido é misturado ao solo (GRAHAM, 1983). Ovos de Ascaris são resistentes às condições ambientais e podem permanecer infectivos por vários anos (BREWSTER et al., 2003; SMITH, 1998). Em estudos realizados por Johnson et al. (1998) foram encontrados ovos de Ascaris suum depois de 29 semanas em lodo digerido anaerobiamente e estocado. Outros autores afirmam que ovos de Ascaris podem sobreviver de 20 meses a 6 anos em lodo exposto em tanques de estocagem e, em lodo digerido e compostado (SIDHU; TOZE, 2009). Inativação termal é apresentada como a melhor opção para inativação de ovos de helmintos em biossólidos (AITKEN et al., 2005)

No caso dos vírus entéricos, esses possuem estabilidade em ambientes ácidos, além de persistirem vários dias à temperatura ambiente (ROMERO, 1999). De acordo com Enriquez, 
Hurst e Gerba (1995), as partículas dos adenovírus são mais estáveis que os poliovírus e outros enterovírus, apresentando relativa resistência à ação de solventes orgânicos e ácidos, permanecendo estável quando estão dentro da célula.

Os processos de tratamento usados para a inativação dos vírus entéricos baseiam-se na variação da temperatura, pH e umidade (MAIER; PEPPER; GERBA, 2009). Os rotavírus de origem humana, por exemplo, são inativados apenas em pH 11,5, sendo resistentes à variação do pH (MENG et al., 1987). Em geral, a temperatura e a umidade são os principais fatores relacionados à sobrevivência desse organismo quando o lodo é aplicado ao solo (GERBA; PEPPER; WHITEHEAD, 2001). A influência da temperatura é citada por vários autores, inclusive, Schwartzbrod (1995) aponta o tratamento térmico como o único método capaz de eliminar totalmente os vírus. Segundo Oliveira (1994), os adenovírus são inativados quando submetidos a uma temperatura de $56^{\circ} \mathrm{C}$ por um período de 10 minutos e, ainda, quando purificados perdem rapidamente sua infectividade. Como uma das opções para redução de vírus, US EPA (2003) inclui a remoção da umidade do lodo utilizando secagem ao ar.

Com relação à digestão anaeróbia, este processo de tratamento não é muito efetivo na redução do número de enterovírus do lodo (GIBBS et al., 1994; SOARES et al., 1994). E, ainda, de acordo com Lodder e Husman (2005), a redução do número de rotavírus durante a digestão anaeróbia é menor que a alcançada com reovírus e enterovírus. Segundo Arraj et al. (2005), isso ocorre, provavelmente, pela sua maior adsorção à fase sólida do lodo.

Os rotavírus apresentam sazonalidade em países de clima tropical. Ocorrem no hemisfério sul nos meses mais secos do ano enquanto que no hemisfério norte isto se dá nos meses mais frios. Entretanto, isso não ocorre com o adenovírus que possuem ausência de sazonalidade (COOK, et al., 1990; SHIM, BANKS, CASTILLO-CHAVEZ; 2006).

Os vírus possuem alta resistência aos fatores ambientais e a alguns métodos de tratamento e, também, apresentam uma baixa dose infectante (BOSCH et al., 2008), que é, aproximadamente, de 1 a 10 unidades formadoras de placa (UFP) (HAAS, 1999). É esperado que a sobrevivência e inativação de vírus entéricos sejam diferentes em biossólido quando comparado com o esgoto, devido à sua condição de agregação e adesão às partículas sólidas (SIDHU; TOZE, 2009). 
Damgaard-Larsen et al. (1977), utilizando lodo municipal contaminado com coxsackievirus, proveniente de uma estação experimental da Dinamarca, na recuperação do solo, perceberam a inativação do coxsackievirus após 23 semanas, durante o inverno normal dinamarquês. Com base nos resultados obtidos na pesquisa e também em resultados de literatura, concluíram que a inativação do vírus é um processo lento em condições naturais.

Outra questão relevante é a retenção do vírus no solo quando se aplica o lodo. Straub, Pepper e Gerba (1993), numa revisão de literatura, apresentaram que os vírus são conservados na matriz do solo, ficando adsorvidos ao floco de lodo e permanecendo imobilizados, a menos que ocorra um movimento de partículas de lodo pelo solo. Segundo Maier, Pepper e Gerba (2009), a sorção do vírus é controlada pelo pH do solo, isso porque os vírus, em sua maioria, são negativamente carregados, e, em solo com $\mathrm{pH}$ mais baixo, a adsorção é facilitada. De acordo com Engelbrecht (1978, apud APEDAILE; COLE, 2002), o movimento de vírus no solo, assim como o das bactérias, está relacionado diretamente com a permeabilidade e inversamente com o tamanho médio das partículas do solo. Nessa lógica, pode-se dizer que os solos argilosos geralmente apresentam maior capacidade de retenção de vírus que os arenosos.

Embora a ocorrência dos organismos patogênicos citados (bactéria, vírus, protozoários, helmintos) em lodo de esgoto seja bem conhecida e pesquisada, Dumontet, Dinel e Baloda (1999) e Ulfig (2003) revelam que pouco se sabe sobre a incidência de fungo patogênico no lodo. Nesse sentido, de acordo com Ulfig et al. (2007), estudos sobre o tema vêm sendo desenvolvidos e apontam a presença de fungo keratinolytic e de fungo non-keratinolytic; o primeiro sobrevive da decomposição de queratina e o segundo acompanha o fungo keratinolytic e se utiliza de componentes não proteicos da queratina ou de produtos da sua decomposição. Sendo assim, encontram no lodo de esgoto municipal ambiente favorável à sua existência, pois esse tipo de esgoto contém grandes quantidades de substrato de keratinous de origem humana e animal, principalmente de cabelo e células da epiderme.

Dessa forma, a diversidade e a quantidade de patógenos presentes em solo onde ocorreu a aplicação de biossólido variam em razão das especificidades de cada grupo de microrganismos que estão contidos no lodo. Além disso, segundo Gibbs et al. (1997), não se deve considerar um ambiente livre de patógenos no mínimo por um ano, após a aplicação do biossólido no solo. 


\subsubsection{Compostos orgânicos tóxicos}

Assim como a presença dos metais pesados, a de compostos orgânicos perigosos, na maioria das vezes, está associada às cidades extremamente industrializadas. Apesar dessa associação, têm-se observado inúmeros problemas em áreas urbanas de vários portes, com a detecção de compostos tóxicos em esgotos sanitário. São originados, principalmente, de postos de gasolina e ligações clandestinas de efluentes industriais. Dentre as indústrias potencialmente poluidoras, destacam-se as de plásticos, produtos químicos, produtos farmacêuticos, formulação de pesticidas, petróleo e beneficiamento da madeira (SILVA, S. M. C. P. et al., 2001).

De acordo com US EPA (1995) e Muller et al. (2007), além das fontes citadas, os compostos orgânicos estão também presentes em alguns produtos domésticos, na emissão dos veículos e nas águas do escoamento superficial pelo efeito das chuvas ácidas, porém em quantidades reduzidas. Enfim, são inúmeras as fontes de poluentes orgânicos que estão presentes nos esgotos sanitário e que, normalmente, ficam incorporados ao lodo, no tratamento da fase líquida em ETE.

A presença no lodo de diversos compostos em diferentes estações de tratamento de esgotos sanitário dos Estados Unidos foi citada em trabalho apresentado por Morita (1993). A detecção desses elementos no lodo tem feito com que seja dada maior atenção a uma variedade de compostos orgânicos na avaliação do material, tais como surfactantes, hidrocarbonetos clorados, pesticidas, bifelinas policlorados (PCB's), dioxinas, entre outros (CHANEY; RYAN; O'CONNOR, 1996; O’CONNOR et al., 2005; MELO; MARQUES; MELO, 2002; SILVA, S. M. C. P. et al., 2001).

Surfactantes podem ser encontrados em concentrações relativamente altas nos biossólidos, em torno de 0,5 a 4 g/kg em base seca (BRUNNER et al., 1988; GIGER et al., 1987, apud NRC, 1996). Entretanto, foi observado, em experimentos de campo e de laboratório sobre o uso do biossólido no solo, que os surfactante L.A.S. (Linear Alkylbenzene Sulfonate) são rapidamente removidos por biodegradação na zona das raízes das plantas, e não são transportados por lixiviação até o lençol subterrâneo (HOLT; MATTHIJS; WATERS, 1989).

Nos estudos sobre o comportamento dos PCBs no solo, Gan e Berthouex (1994) perceberam que com a aplicação do biossólido no solo, esses compostos não apresentam, assim como os 
surfactantes, riscos potenciais de contaminação do lençol subterrâneo, porém persistem sozinhos no solo e são capturados pelas plantas. NRC (1996) destaca, também, que os PCBs têm forte afinidade com materiais particulados e, sob certas circunstâncias, podem ficar adsorvidos às partículas do solo. Além disso, não são muito solúveis, sendo improvável que sejam lixiviados até o lençol subterrâneo.

Os surfactantes e os PCBs apresentam-se como a única classe de compostos orgânicos sintéticos presentes nos biossólidos em concentrações superiores aos produtos convencionais das culturas agrícolas (CHANEY; RYANB; O’CONNOR, 1996).

Pesquisas divulgadas sobre pesticidas têm sugerido que esses resíduos são adsorvidos pelas partículas do solo até serem degradados pela ação microbiana ou volatilizados (CORK; KRUEGER, 1991, apud NRC, 1996; SANCHES et al., 2003). Ainda segundo os autores, muitas espécies de microrganismos degradam uma variedade de compostos orgânicos, incluindo herbicidas, para derivarem energia e nutrientes para seu metabolismo. Com relação à lixiviação de pesticidas, tendo em vista que os esgotos domésticos contêm apenas traços desses compostos, a aplicação de biossólidos aos solos representa um potencial de risco muito menor que o da aplicação direta convencional desses produtos no controle de pragas. Entretanto, deve-se considerar que os problemas advindos desses compostos não são imediatos, ou seja, em curto prazo.

Os riscos para a saúde humana associados com a presença dos poluentes orgânicos no lodo dizem respeito ao seu potencial para toxicidade aguda, à existência de elementos cancerígenos, à capacidade de mutação e à existência de agentes provocadores de deformidade em feto (BOGH et al., 2001; KRETSCHMER; BALDWIN, 2005). Tornam-se mais acentuados em virtude da concentração dos poluentes e da sua forma de transferência para os seres humanos. As formas de contaminação mais comuns são pela ingestão de vegetais procedentes de culturas contaminadas, pelo contato direto com solo contaminado e pela ingestão de alimentos de origem animal, caso esses animais tenham sido alimentados com plantas ou tenham tido contato com solo contaminado (NRC, 1996).

Várias são as características dos compostos orgânicos tóxicos que representam riscos à saúde humana e ao meio ambiente, podendo-se destacar (SILVA, S. M. C. P. et al., 2001): grande parte dos compostos orgânicos perigosos são biodegradados muito lentamente e, por isso, permanecem no meio por longo tempo; outros são voláteis, sendo transferidos para a 
atmosfera, representando, assim, risco potencial, principalmente, aos operadores de ETE e de Estação Elevatória de Esgoto; alguns não representam graves riscos à saúde quando ingeridos, porém os seus metabólicos podem ser mais tóxicos do que os produtos originais; e, muitos são inflamáveis e explosivos.

Todas essas características fazem com que sejam tomados os devidos cuidados para evitar a presença desses elementos nos SES. Apesar da existência de norma que estabelece padrões de lançamento de efluentes industriais em SES no Brasil, NBR 9.800 (ABNT, 1987), já citada no item 3.3.2.1, alguns elementos permanecem sem regulamentação. A norma não leva em conta o tipo de substância presente no efluente, a sua toxicidade para o tratamento nem a sinergia entre as substâncias, merecendo com isso, uma reavaliação.

\subsubsection{Outros elementos presentes no lodo}

Embora os elementos apresentados anteriormente sejam os mais discutidos com relação aos riscos potenciais quando se usa o lodo na agricultura e, com isso, serem estudados de forma mais detalhada e constante, várias pesquisas têm sido desenvolvidas, focando outros elementos presentes no biossólido e que demandam certa atenção.

De acordo com Kümmerer (2001), a ocorrência de droga farmacêutica no meio ambiente temse tornado uma importante questão na última década. Antibióticos têm sido usados largamente em seres humanos e em animais (uso veterinário) para prevenir ou tratar infecções microbiais (SCHLÜSENER; BESTER, 2006). Com isso, o uso de esterco animal e de biossólido na agricultura pode contaminar o solo e, eventualmente, o lençol subterrâneo. Kroker (1983, apud SCHLÜSENER; BESTER, 2006) revela que de 50\% a 90\% desses antibióticos, ou os produtos do seu metabolismo, são rapidamente excretados depois de serem administrados tanto em seres humanos como em animais.

Os efeitos dos fármacos dependem das características físicas e químicas dos seus compostos específicos e, infelizmente, há um déficit de informações sobre essas características, principalmente sobre a sua biodegradabilidade (APEDAILE; COLE, 2002). 
Dados relatados pela Comissão Européia (ICON, 2001) ${ }^{20}$ destacam que mais de $30 \%$ das drogas produzidas entre 1992 e 1995 tenderam a acumular-se no biossólido durante o tratamento do esgoto, em razão das suas características.

Outro fato importante relacionado com a presença de antibióticos nas águas residuárias é que, no tratamento do esgoto, os antibióticos podem ficar adsorvidos ao lodo ou sair inalterados no efluente final das ETE para o corpo receptor (GIGER et al., 2003). Para Lindberg et al. (2007), após estudos realizados com efluente e lodo de ETE oriundos de hospitais na Suécia, a avaliação de risco ambiental não deve ser excluída com o uso desses resíduos devido à presença de diversos antibióticos.

Depois que o solo é fertilizado com biossólido que contém antibióticos, esses compostos podem passar por vários processos, resultando em uma eliminação parcial ou total do elemento de origem. Alguns antibióticos são persistentes no solo, podendo afetar a população bacteriana local (SCHLÜSENER; BESTER, 2006).

Com relação à presença de nitrogênio em biossólido, concentrações elevadas são ressaltadas como um aspecto positivo para sua utilização agronômica. No entanto, em solos tratados com biossólidos é fundamental conhecer o comportamento do nitrogênio, tanto por questões referentes à nutrição vegetal quanto aos riscos representados pela lixiviação do nitrato (CORREAA; WHITE; WEATHERLEY, 2005). A presença do nitrato na superfície do solo ou nas águas subterrâneas acarreta problemas à saúde pública, como methaemoglobinemia ou desconforto gástrico devido à ingestão de excesso de nitrato presente na água (MIRVISH, 1991, apud CAMERON et al., 1996).

Em estudo realizado por Corrêa, White e Weatherley (2005) em diferentes solos tratados com doses de 0,5 a 8,0 t/ha de biossólido fresco, biossólido compostado, biossólido caleado, biossólido seco a calor e biossólido irradiado por sol, foi observado o acúmulo de nitrato na camada superficial de $20 \mathrm{~cm}$ do solo, existindo a possibilidade de serem lixiviados. Entretanto, nesse caso, o risco de contaminação de aquíferos por lixiviação de nitrato nos solos tratados com uma dose única de biossólidos, entre 0,5 e 8,0 t/ha, foi considerado baixo.

\footnotetext{
${ }^{20} \mathrm{http}: / /$ europa.eu.int
} 


\subsection{ASPECTOS LEGAIS RELACIONADOS AO LODO}

Diante do aumento da produção de lodo gerado em ETE e sua crescente utilização em áreas agrícolas, ficou evidente a necessidade de criar legislações específicas para enquadrar, organizar, regulamentar e orientar o uso agrícola do lodo e de seus produtos derivados, garantindo a segurança ambiental e sanitária do seu gerenciamento. Com isso, estabelecer critérios para o uso agronômico do lodo, visando à adequação ambiental das áreas com potencial para aplicação do material e à seleção das culturas que serão exploradas, possibilita uma melhor aceitação e uma boa rentabilidade aos produtores rurais, garantindo, assim, a sustentabilidade dessa alternativa ao longo do tempo.

\subsubsection{ASPECTOS LEGAIS NO BRASIL}

\subsubsection{Resolução n $375 / 2006$ do Conama}

Em 29 de agosto de 2006, o Conselho Nacional do Meio Ambiente (Conama), órgão ligado ao Ministério do Meio Ambiente, publicou a Resolução $n^{0} 375$, que "define critérios e procedimentos para o uso agrícola de lodos de esgoto gerados em estações de tratamento de esgoto sanitário e seus produtos derivados, e dá outras providências" (BRASIL, 2006c).

Tendo em vista que a Resolução $n^{0} 375 / 2006$ do CONAMA trata exclusivamente do uso do lodo e seus produtos derivados na agricultura, vários aspectos foram abordados, visando não somente a obter benefícios agrícolas com a utilização dessa prática, como também evitar riscos à saúde e ao meio ambiente. Na resolução são citadas, inclusive, outras legislações que completam algumas questões importantes do gerenciamento e que deverão ser seguidas e respeitadas para uma completa abordagem do problema.

Já no Parágrafo Único da Seção 1, fica estabelecido que, além dos termos apresentados na resolução, a produção, a compra, a venda, a cessão, o empréstimo ou a permuta do lodo de esgoto e seus derivados, deverão seguir os disposto no Decreto $\mathrm{n}^{\mathrm{0}} 4.954$, de 14 de janeiro de 2004. Esse decreto regulamenta a Lei no 6.894 , de 16 de dezembro de 1980, que dispõe sobre a inspeção e fiscalização da produção e do comércio de fertilizantes, corretivos, inoculantes ou biofertilizantes destinados à agricultura. 
No escopo geral da resolução, o lodo é tratado como um produto que, sobretudo em virtude dos seus riscos potenciais, deve ser gerenciado adequadamente para que seus constituintes atendam a padrões específicos, a fim de que esses riscos sejam minimizados e até mesmo eliminados.

Tratando-se da caracterização do lodo a ser aplicado na agricultura, a norma privilegia aspectos do material, como a sua estabilidade, o seu potencial agronômico, a presença e a concentração de substâncias orgânicas e inorgânicas potencialmente tóxicas, bem como de indicadores bacteriológicos e agentes patogênicos.

Para a condição de estabilidade do lodo, referente à digestão dele, é levada em consideração a relação entre o teor de sólidos totais e o de sólidos voláteis (SV/ST), que deve ser menor que 0,7. Valores superiores poderiam gerar problemas de maus odores e atração de vetores. Foram definidos, então, sete processos para reduzir a atração de vetores: digestão anaeróbia, digestão aeróbia, compostagem, estabilização química, secagem, aplicação subsuperficial e incorporação no solo.

A potencialidade agronômica do lodo é fator fundamental para a aceitação do produto pelos produtores rurais. Nessa avaliação, são requeridas as análises de carbono orgânico, fósforo total, nitrogênio kjeldahl, nitrogênio amoniacal, nitrogênio nitrato/nitrito, potássio total, sódio total, enxofre total, cálcio total e magnésio. Além disso, são determinados umidade, sólidos totais, sólidos voláteis e $\mathrm{pH}$.

Com relação às substâncias orgânicas potencialmente tóxicas, a norma apresenta no Anexo V uma lista de substâncias que devem ser determinadas para a caracterização química do lodo. Porém acrescenta, no parágrafo $4^{\circ}$ do art. $7^{\circ}$, que, dependendo das características específicas da bacia de esgotamento sanitário e dos efluentes recebidos na ETE, a empresa poderá requerer ao órgão ambiental competente dispensa ou alteração da referida lista.

No caso das substâncias inorgânicas potencialmente tóxicas e dos indicadores bacteriológicos e agentes patogênicos, são estabelecidos limites máximos que o material poderá apresentar para que seu uso na agricultura seja permitido. Na TABELA 3.14, são apresentadas as concentrações máximas permitidas das substâncias inorgânicas e dos indicadores bacteriológicos e agentes patogênicos presentes no lodo. 
Tabela 3.14 - Parâmetros a serem monitorados para a utilização do lodo na agricultura e as respectivas concentrações máximas de acordo com a Resolução n 375/2006 do Conama

\begin{tabular}{|c|c|c|}
\hline Parâmetros & \multicolumn{2}{|c|}{ Concentração máxima permitida } \\
\hline \multicolumn{3}{|c|}{ Substâncias inorgânicas } \\
\hline & \multicolumn{2}{|c|}{$(\mathrm{mg} / \mathrm{kg}$, base seca $)$} \\
\hline Arsênio & \multicolumn{2}{|c|}{41} \\
\hline Bário & \multicolumn{2}{|c|}{1300} \\
\hline Cádmio & \multicolumn{2}{|c|}{39} \\
\hline Chumbo & \multicolumn{2}{|c|}{300} \\
\hline Cobre & \multicolumn{2}{|c|}{1500} \\
\hline Cromo & \multicolumn{2}{|c|}{1000} \\
\hline Mercúrio & \multicolumn{2}{|c|}{17} \\
\hline Molibdênio & \multicolumn{2}{|c|}{50} \\
\hline Níquel & \multicolumn{2}{|c|}{420} \\
\hline Selênio & \multicolumn{2}{|c|}{100} \\
\hline Zinco & \multicolumn{2}{|c|}{2800} \\
\hline \multicolumn{3}{|c|}{ Indicadores bacteriológicos e agentes patogênicos } \\
\hline & Classe A & Classe B \\
\hline Coliformes termotolerantes & $<10^{3} \mathrm{NMP} / \mathrm{g}$ de ST & $<10^{6} \mathrm{NMP} / \mathrm{g}$ de ST \\
\hline Ovos viáveis de helmintos & $<0,25$ ovo / g de ST & $<10$ ovos / g de ST \\
\hline Salmonella sp. & Ausência em $10 \mathrm{~g}$ de ST & - \\
\hline Vírus entéricos & $<0,25 \mathrm{UFP}$ ou UFF / g de ST & - \\
\hline
\end{tabular}

Fonte: BRASIL, 2006c.

Nota: ST: Sólidos Totais, NMP: Número Mais Provável, UFF: Unidade Formadora de Foco, UFP: Unidade Formadora de Placa.

A norma enquadra o lodo de esgoto ou produto derivado em Classe A ou Classe B, de acordo com as características referentes aos indicadores bacteriológicos e agentes patogênicos encontrados. O Classe A poderá ser utilizado para quaisquer culturas, sendo proibido o uso do material, não importando a classificação, em pastagens e cultivo de olerícolas, tubérculos e raízes e culturas inundadas, bem como as demais culturas cuja parte comestível entre em contato com o solo. Já o uso do material enquadrado como Classe B é restrito ao cultivo de café, silvicultura, culturas para produção de fibras e óleos, com a aplicação mecanizada, em sulcos ou covas, seguida de incorporação.

A fim de atender aos limites estabelecidos na resolução, são apresentados onze processos para redução de agentes patogênicos no Anexo I, sendo seis para possibilitar sua classificação como Classe A e cinco como Classe B. Encontra-se, ainda, no mesmo anexo, uma relação de sete processos para reduzir a atratividade de vetores e de critérios para verificar se o processo de tratamento adotado para o lodo de esgoto ou produto derivado reduz o potencial de 
disseminação de doenças por meio de vetores como, moscas, roedores e mosquitos. Dentre elas, podem-se destacar:

- a concentração de sólidos voláteis (SV) deve ser reduzida em 38\% ou mais, levando-se em consideração a concentração afluente ao processo de estabilização adotado, e a do material pronto para uso ou disposição;

- na utilização da compostagem ou outro processo aeróbio, a temperatura deve ser mantida acima de $40^{\circ} \mathrm{C}$, por pelo menos 14 dias, e a temperatura média durante esse período deve ser maior que $45^{\circ} \mathrm{C}$;

- para a estabilização química, deve-se adicionar ao lodo de esgoto ou produto derivado uma quantidade de álcali suficiente para que o $\mathrm{pH}$ seja elevado, pelo menos, até 12 por um período mínimo de 2 horas, mantendo-se acima de 11,5 por mais 22 horas, sem que seja feita uma aplicação adicional de álcali;

- após o processo de secagem por aquecimento ou ao ar para lodo de esgoto ou produto derivado que recebeu adição de lodos primários brutos, a concentração de sólidos deve alcançar, no mínimo, 90\% da matéria seca (M.S.), sem que haja a mistura de nenhum aditivo;

- a aplicação de lodo de esgoto ou produto derivado no solo na forma líquida será aceita como um processo de redução de vetores se não for verificada a presença de quantidade significativa de lodo de esgoto ou produto derivado na superfície do solo após uma hora de aplicação. No caso de material classe A, a injeção desse material deve ser realizada num período máximo de até oito horas, após a finalização do processo de redução de patógenos;

- para a aplicação de lodo de esgoto ou produto derivado no solo o material deve ser incorporado no solo antes que transcorram seis horas após a aplicação na área. Se o material for classe A, esse deve ser aplicado e incorporado quando decorridas, no máximo, oito horas após sua descarga do processo de redução de patógenos.

Independentemente da classificação, a resolução apresenta restrições referentes aos locais e à aptidão do solo das áreas de aplicação. Dentre as restrições apresentadas, destacam-se como locais onde a aplicação do material não é permitida: 
- $\quad$ unidades de conservação, com exceção das Áreas de Proteção Ambiental (APA);

- Áreas de Preservação Permanente (APP);

- Áreas de Proteção aos Mananciais (APM) e em outras áreas de captação de água para abastecimento público;

- um raio mínimo de distância de 100 m de poços rasos e residências;

- áreas onde a profundidade do nível do aquífero freático seja inferior a $1,5 \mathrm{~m}$ na cota mais baixa do terreno, entre outros.

Nenhum dos aspectos abordados na resolução, pelo CONAMA, se aplica a lodo gerado em tratamento de efluentes de processos industriais. É vetada, inclusive, a utilização de:

- material proveniente de estação de tratamento de efluentes de instalações hospitalares, de portos e de aeroportos;

- resíduos de gradeamento;

- resíduos de desarenador;

- material lipídico sobrenadante de decantadores primários, de caixas de gordura e de reatores anaeróbios;

- lodos provenientes de sistema de tratamento individual, coletados por veículos, antes de seu tratamento em uma estação de tratamento de esgoto;

- lodo de esgoto não estabilizado; e

- lodos classificados como perigosos de acordo com as normas brasileiras vigentes.

A resolução cita, também, as atribuições e obrigações pertinentes à Unidade de Gerenciamento de Lodo (UGL), que é responsável pelo recebimento, processamento, caracterização, transporte e destinação do lodo de esgoto produzido por uma ou mais estações de tratamento de esgoto sanitário, além do monitoramento dos efeitos ambientais, agronômicos e sanitários de sua aplicação em áreas agrícolas.

As questões que envolvem o carregamento, o transporte e a estocagem do lodo de esgoto ou produto derivado são abordadas na Seção VIII. A estocagem não pode ser superior a 15 dias e deve atender a uma série de critérios, como declividade da área de estocagem, distância mínima de corpos d'água, entre outros. O transporte do material que foi carregado e retirado 
da ETE ou da UGL só será permitido com a devida documentação do motorista e do caminhão, e o veículo deverá atender, ainda, a condições específicas para a segurança do transporte. Para o exercício dessas atividades, devem ser respeitados o Artigo 15, que trata das restrições locacionais e da aptidão do solo das áreas de aplicação, e o Anexo VII, que apresenta recomendações para o transporte.

Outras questões referentes ao uso do lodo de esgoto ou produto derivado na agricultura são apresentadas pela resolução, a saber:

- frequência de monitoramento;

- projeto agronômico e condições de uso;

- taxa de aplicação;

- monitoramento das áreas de aplicação do material; e

- responsabilidade pelo gerenciamento do material.

Antes da criação da Resolução n ${ }^{0}$ 375/2006 do Conama, algumas regiões brasileiras já haviam estabelecido critérios para o uso do lodo em áreas agrícolas. As principais legislações nacionais foram criadas pelos estados do Paraná e São Paulo e pelo Distrito Federal. A Cetesb, por exemplo, criou a própria norma em 4/12/1999, o que possibilitou a elaboração de manual específico para a utilização na agricultura do biossólido produzidos na ETE Franca, localizada na cidade de Franca - SP e operada pela Sabesp, registrando-o como condicionador de solos no Ministério da Agricultura (SANTOS, 2001).

No Paraná, as pesquisas com lodo começaram a serem desenvolvidas em 1989 e, em 1993, foi iniciado um programa multidisciplinar com o objetivo de gerar tecnologias e critérios seguros para o uso do lodo como fertilizante. O programa contou com a participação de várias instituições de ensino e pesquisa, institutos, prefeitura, além de órgãos financiadores para o desenvolvimento das pesquisas, que serviram de base para a publicação do Manual técnico para a utilização agrícola do lodo de esgoto no Paraná (SANEPAR, 1997). Após a criação da legislação federal (Resolução $n^{0} 375 / 2006$ do Conama), o Paraná foi o primeiro estado a publicar uma nova legislação adaptada à federal (ANDREOLI et al., 2007). 
No Distrito Federal, foi elaborado um texto explicativo sobre as propriedades do lodo e de como deve ser manejado e aplicado em diversos usos agrícolas e na recuperação de áreas degradadas (SANTOS, 2001).

Na TAB 3.15, são apresentados os limites estabelecidos pela Resolução $n^{0} 375 / 2006$ do Conama e os das outras regiões do Brasil, antes e depois da sua publicação.

Tabela 3.15 - Concentrações máximas permitidas de metais pesados e indicadores bacteriológicos de acordo com a Resolução n ${ }^{0}$ 375/2006 do Conama, os estados de São Paulo e Paraná e o Distrito Federal

\begin{tabular}{|c|c|c|c|c|}
\hline \multirow[b]{2}{*}{ Parâmetro } & \multicolumn{4}{|c|}{ Concentração máxima permitida no lodo } \\
\hline & $\begin{array}{c}\text { Brasil } \\
\text { Resolução no } 375 / 2006 \\
\text { (Conama) }\end{array}$ & $\begin{array}{c}\text { São Paulo } \\
\text { P4230/1999 } \\
\text { (Cetesb) }\end{array}$ & $\begin{array}{l}\text { Paraná } \\
\text { 001/2007 } \\
\text { (SEMA) }\end{array}$ & $\begin{array}{c}\text { Distrito } \\
\text { Federal } \\
(\text { 03-07/2006) }\end{array}$ \\
\hline \multicolumn{5}{|c|}{ Substâncias inorgânicas (mg/kg - base seca) } \\
\hline Arsênio & 41 & 75 & 41 & 20 \\
\hline Bário & 1300 & - & 1300 & - \\
\hline Cádmio & 39 & 85 & 39 & 26 \\
\hline Chumbo & 300 & 840 & 300 & 500 \\
\hline Cobre & 1500 & 4300 & 1500 & - \\
\hline Cromo & 1000 & - & 1000 & - \\
\hline Mercúrio & 17 & 57 & 17 & 15 \\
\hline Molibdênio & 50 & 75 & 50 & - \\
\hline Níquel & 420 & 420 & 300 & - \\
\hline Selênio & 100 & - & 100 & 100 \\
\hline Zinco & 2800 & 7500 & 2800 & 2800 \\
\hline \multicolumn{5}{|c|}{ Indicadores bacteriológicos e agentes patogênicos } \\
\hline $\begin{array}{l}\text { Coliformes } \\
\text { termotolerantes }\end{array}$ & $<10^{3} \mathrm{NMP} / \mathrm{g} \mathrm{ST}$ & $<2 \times 10^{6} \mathrm{NMP} / \mathrm{g} \mathrm{ST}$ & $<10^{3} \mathrm{NMP} / \mathrm{g} \mathrm{ST}$ & \\
\hline Ovos viáveis de helmintos & $<0,25 \mathrm{ovo} / \mathrm{g} \mathrm{ST}$ & - & $<0,25 \mathrm{ovo} / \mathrm{g} \mathrm{ST}$ & \\
\hline Salmonella sp. & Ausência em $10 \mathrm{~g}$ ST & $3 \mathrm{NMP} / 4 \mathrm{~g} \mathrm{ST}$ & Ausência em $10 \mathrm{~g}$ ST & \\
\hline Vírus entéricos & $<0,25 \mathrm{UFP}$ ou UFF/g ST & - & $\begin{array}{c}<0,25 \text { UFP ou } \\
\text { UFF/g ST }\end{array}$ & \\
\hline Cistos de protozoários & - & - & - & $<1 / 4 \mathrm{~g} \mathrm{ST}$ \\
\hline
\end{tabular}

Fonte: ANDREOLI et al., 2007; BRASIL, 2006c; CETESB, 1999.

Nota: ST: Sólidos Totais (matéria seca), NMP: Número Mais Provável, UFF: Unidade Formadora de Foco, UFP: Unidade Formadora de Placa.

Comparando os valores apresentados na TABELA 3.15, observa-se que os limites estabelecidos no Estado de São Paulo, para alguns parâmetros, são mais permissíveis que os da legislação federal. Em contrapartida, o Distrito Federal estabelece, para alguns parâmetros, valores mais restritivos. No entanto, com a publicação da Resolução $n^{0}$ 375/2006 do Conama, 
ficou estabelecido que os estados brasileiros terão 18 meses, a partir da data de sua publicação, para se adequarem à nova legislação.

\subsubsection{Outras legislações nacionais}

Além do Conama, outros órgãos da esfera federal têm tratado em suas legislações questões relativas ao lodo de esgoto. A Associação Brasileira de Normas Técnicas (ABNT) enquadra o lodo de esgoto como resíduo sólido, Classe IIA - não inertes ${ }^{21}$. Na definição de resíduos sólidos apresentada na NBR 10.004 (ABNT, 2004a), estão incluídos, entre outros materiais, os lodos provenientes de sistemas de tratamento de água e os gerados em equipamentos e instalações de controle de poluição. Isso posto, devem ser gerenciados conforme exigências dos órgãos reguladores específicos para esse tipo de material.

Já o Ministério da Agricultura, Pecuária e Abastecimento criou Instruções Normativas sobre a utilização do lodo de esgoto na agricultura. Na publicação de três Instruções Normativas, apresenta alguns aspectos e limites caso se pretenda registrar o lodo de esgoto como produto para utilização na agricultura, a saber:

\section{Instrução Normativa $\mathrm{N}^{\mathrm{0}} 23$}

A Instrução Normativa (IN) № 23, de 31 de agosto de 2005 (BRASIL, 2005), aprova as definições e normas sobre as especificações e as garantias, as tolerâncias, o registro, a embalagem e a rotulagem dos fertilizantes orgânicos simples, mistos, compostos, organominerais e biofertilizantes destinados à agricultura. Foi publicada no Diário Oficial da União de 08 de setembro de 2005.

Nesse caso, o lodo de esgoto, ou seja, aquele proveniente do sistema de tratamento de esgotos sanitário, que resulte em produto de utilização segura na agricultura, atendendo aos limites estabelecidos para contaminantes, é enquadrado como fertilizante orgânico composto, Classe D.

Especificações referentes à natureza física dos fertilizantes orgânicos e biofertilizantes são abordadas na IN 23, caracterizando o material em razão da granulometria apresentada por ele.

\footnotetext{
21 “Aqueles que não se enquadram nas classificações de resíduo classe I - Perigosos ou de resíduo classe IIB Inertes, nos termos desta norma. Os resíduos classe IIA - Não inertes podem ter propriedades, tais como: biodegradabilidade, combustibilidade ou solubilidade em água.” (ABNT, 2004a, p.5).
} 
O lodo de esgoto, que pode ser usado na forma de sólido, deverá ser classificado de acordo com o Capítulo III da IN, como granulado, pó, farelado e farelado grosso; no caso de estar na forma fluida, terá de apresentar informações, tais como densidade, percentagens mássicas (peso e nutrientes por peso de produto) e massa por volume (gramas por litro). Os fertilizantes sólidos terão, ainda, que apresentar a forma e a solubilidade dos macronutrientes primários (N-P-K) indicadas como percentagem mássica.

São também apresentados detalhes sobre os macronutrientes secundários e micronutrientes dos produtos na forma sólida ou líquida, inclusive com percentuais mínimos que deverão ser garantidos para que o material seja usado como fertilizante. Dentre eles podem-se destacar o $\mathrm{Ca}, \mathrm{Mg}$ e S que, em termos percentuais, não deverão ser inferiores a 1 e a 0,5 para o material sólido e líquido, respectivamente. Restrições máximas são descritas para a relação $\mathrm{C} / \mathrm{N}$, que não deverá ser superior a 18 e para a umidade, que não deve ultrapassar a 70\%, porém, determinada a $65^{\circ} \mathrm{C}$.

Mais detalhes sobre fertilizantes foliares e para fertirrigação, tolerâncias em relação às garantias do produto, registro de produtos, embalagens, rotulagens, entre outras questões, também são apresentadas nessa IN.

\section{Instrução Normativa $\mathrm{N}^{\mathrm{o}} 27$}

Publicada no Diário Oficial da União de 09 de junho de 2006 (BRASIL, 2006a), a IN 27 apresenta as concentrações máximas admitidas para agentes fitotóxicos, patogênicos ao homem, animais e plantas, metais pesados tóxicos, pragas e ervas daninhas, contidos nos fertilizantes, corretivos, inoculantes e biofertilizantes produzidos, importados ou comercializados.

Os limites estabelecidos para a maioria dos metais pesados são bastante restritivos quando comparados aos estabelecidos pela Resolução n ${ }^{0}$ 375/2006 do Conama (BRASIL, 2006c). Dependendo da finalidade a que se destina o lodo, os limites máximos são diferentes.

Como exemplo, para o lodo usado como corretivo de acidez do solo, o limite para cádmio é $20 \mathrm{mg} / \mathrm{kg}$ e, para chumbo, $1.000 \mathrm{mg} / \mathrm{kg}$. Porém, caso seja utilizado como substrato para plantas e condicionadores de solo, esses valores passam para $8 \mathrm{mg} / \mathrm{kg}$ e $300 \mathrm{mg} / \mathrm{kg}$, respectivamente. Para esse último, são exigidos limites máximos de outros metais, todos mais restritivos que os da Resolução $n^{0}$ 375/2006 do Conama, além de indicadores bacteriológicos 
e agentes patogênicos, como coliformes termotolerantes, ovos viáveis de helmintos e Salmonella sp. que, nesse caso, apresentam limites iguais aos do Conama.

Os limites máximos de contaminantes admitidos em fertilizantes orgânicos são ainda mais restritivos do que os permitidos para as formas de utilização apresentadas anteriormente. Os metais cádmio, chumbo, cromo, mercúrio e níquel apresentam limites máximos admitidos menores que a metade dos estabelecidos para condicionadores de solo. São ainda estabelecidos valores máximos para arsênio, selênio, coliformes termotolerantes, ovos viáveis de helmintos e Salmonella sp.

\section{Instrução Normativa $\mathrm{N}^{\mathrm{0}} 35$}

A IN 35 (BRASIL, 2006b) aprova as normas sobre especificações e garantias, tolerâncias, registro, embalagem e rotulagem dos corretivos de acide $^{22}$, de alcalinidade e de sodicidade ${ }^{23}$ e dos condicionadores de $\operatorname{solo}^{24}$, destinados à agricultura. Foi publicada no Diário Oficial da União de 12 de julho de 2006.

Para a classificação do lodo gerado no tratamento de despejos sanitários, é seguido o mesmo enquadramento da IN 23, que o define como produto orgânico composto Classe D. Sendo assim, deve seguir todas as peculiaridades descritas na IN 35 que, inclusive, destaca a necessidade de serem apresentados, no rótulo do produto, os cuidados com seu manuseio, especificando em que condições a sua aplicação deverá ser auxiliada por equipamentos mecanizados e quando os trabalhadores deverão usar equipamentos de proteção individual (EPI). E determina, ainda, que é proibida a utilização do produto no cultivo de hortaliças em geral e na aplicação em pastagens e capineiras.

\subsubsection{LIMITES RESTRITIVOS NO BRASIL E EM OUTROS PAÍSES}

Vários países já possuíam legislações próprias sobre o uso do lodo de esgoto na agricultura antes mesmo da publicação da Resolução $n^{0}$ 375/2006 do Conama. Essa forma de disposição final encontra-se difundida em todo o mundo.

\footnotetext{
${ }^{22}$ Produto que promove a correção da acidez do solo, além de fornecer cálcio, magnésio ou ambos (BRASIL, 2006b).

${ }^{23}$ Produto que promove a redução da alcalinidade do solo (corretivo de alcalinidade) ou da saturação de sódio no solo (corretivo de sodicidade) (BRASIL, 2006b).

${ }^{24}$ Produto que promove a melhoria das propriedades físicas, físico-químicas ou atividade biológica do solo, podendo recuperar solos degradados ou desequilibrados nutricionalmente (BRASIL, 2006b).
} 
Os Estados Unidos publicaram, em 22 de março de 1993, a norma norte-americana conhecida como 40 CFR Part 503 (Código de Regulamentos Federais № 40, Seção 503), promulgada pela Agência de Proteção Ambiental dos Estados Unidos (US EPA, 1995) e revisada em 2002 (US EPA, 2002) ${ }^{25}$. Além da Seção 503, que trata exclusivamente da disposição de biossólido como aplicação no solo, disposição superficial e incineração, existem também as Seções 257 e 258 que estão, de certa forma, relacionadas com o gerenciamento dos lodos. A primeira (Seção 257) estabelece regras para os sólidos gerados em instalações industriais e para lodos sépticos combinados com lodos industriais; a segunda (Seção 258) estabelece condições para a disposição de resíduos sólidos em aterros sanitários municipais, como níveis máximos de contaminantes, necessidades de impermeabilização e características físicas dos lodos.

A norma contempla exigências específicas com relação às características do lodo gerado em sistemas públicos de tratamento de esgoto, e estabelece concentrações máximas para metais pesados e microrganismos no controle de patógenos. São relacionados, ainda, tratamentos específicos para a redução de patógenos e para o controle da atratividade de vetores. Caracteriza o lodo como Classe A ou Classe B, assim como a Resolução n ${ }^{0}$ 375/2006 do Conama, dependendo do tratamento a que foi submetido o lodo e dos limites legais para os parâmetros a serem monitorados. Dentre as alternativas de tratamento que permitem a obtenção de lodo Classe A, destacam-se secagem térmica, compostagem confinada ou pilha aerada, tratamento térmico, digestão aeróbia termofílica a ar ou oxigênio, processos de irradiação com raios beta e processos de pasteurização.

Para o controle da atratividade de vetores e geração de odores, o lodo deve passar por tratamento adequado. As principais alternativas são digestão anaeróbia, digestão aeróbia e compostagem, que estão associadas à redução de sólidos voláteis do lodo; estabilização química e secagem, que estão associadas à redução da quantidade e/ ou atividade dos microrganismos presentes no lodo; e, aplicação subsuperficial e incorporação, que estão relacionadas à técnicas de aplicação.

No Brasil, a legislação norte-americana serviu de base para elaborar normas regionais (CARVALHO; CARVALHO, 2002) e também foi usada nas discussões para elaborar a legislação federal.

\footnotetext{
${ }^{25}$ www.epa.gov/ost/biosolids
} 
O uso do lodo em áreas agrícolas na Comunidade Europeia é regulamentado pela Diretiva 86/278/EEC, promulgada em 12 de junho de 1986 (mod. 91/692/EEC) (CEC, 1986) ${ }^{26}$ com o intuito de proteger o meio ambiente, em particular o solo, quando o lodo de esgoto é utilizado na agricultura. Nesse caso, a Diretiva fixa sempre limites máximos e, com isso, permite que os estados membros tenham as próprias legislações, contanto que não ultrapassem aqueles limites. Algumas regiões, como Dinamarca, Finlândia, Suécia e Países Baixos, seguidos pela Alemanha, Bélgica, França e Áustria, adotaram valores mais restritivos que a Diretiva. Entretanto, outros sete países, Grécia, Irlanda, Itália, Luxemburgo, Portugal, Espanha e Inglaterra, adotaram valores-limite similares aos especificados pela Diretiva (EUROPEAN COMMUNITIES, 2001).

A Diretiva não apresenta limites quanto à presença de organismos patogênicos e de compostos orgânicos no lodo, porém, alguns países membros da CEE, como França, Itália e Luxemburgo, estabeleceram limites para a presença de ovos de helmintos, enterovírus, enterobactérias e Salmonella sp. Já a Áustria, Bélgica-Flandres, Dinamarca, França, Alemanha e Suécia estabeleceram limites para compostos orgânicos (EUROPEAN COMMUNITIES, 2001).

Em 26 de abril de 1999, a Comunidade Europeia criou a Directiva 1999/31/EC, que trata das questões relacionadas aos aterros sanitários (EUROPEN COMMUNITIES, 1999) e, em 19 de dezembro de 2002, apresentou um adendo (2003/33/EC) à Diretiva 1999/31/EC, estabelecendo critérios e procedimentos para a aceitação de resíduos no aterro (EUROPEN COMMUNITIES, 2003). A Directiva preconiza uma tendência mundial, que é a contínua redução da disposição de resíduos biodegradáveis em aterros sanitários. Nesse sentido, Barroso e Machado (2005) revelam que qualquer Diretiva apresentada pela União Europeia sobre a gestão dos resíduos sólidos dá prioridade a três aspectos: em primeiro lugar, reduzir sua produção na fonte; em segundo, reutilizar, reciclar ou utilizar outras formas de valorização; em terceiro, minimizar os possíveis riscos e impactos ambientais resultantes do seu tratamento e disposição final.

Nas TABELAS 3.16 e 3.17, são apresentadas as concentrações limites de parâmetros a serem monitorados no lodo, definidos no Brasil e em outros países, para a sua utilização na agricultura.

\footnotetext{
${ }^{26} \mathrm{http}: / /$ eur-lex.europa.eu/Result.do?idReq=2\&page $=17$
} 
Tabela 3.16 - Concentrações máximas permitidas de substâncias inorgânicas para o uso de biossólidos na agricultura no Brasil e em diversos países

\begin{tabular}{|c|c|c|c|c|c|c|c|c|c|c|c|}
\hline \multirow{2}{*}{ País / Região } & \multicolumn{11}{|c|}{ Substância inorgânica (mg/kgST em base seca) } \\
\hline & As & Ba & Cd & $\mathbf{P b}$ & $\mathbf{C u}$ & $\mathbf{C r}$ & Hg & Mo & $\mathrm{Ni}$ & Se & $\mathbf{Z i}$ \\
\hline $\begin{array}{l}\text { Brasil } \\
\text { (Conama 375/2006) }\end{array}$ & 41 & 1300 & 39 & 300 & 1500 & 1000 & 17 & 50 & 420 & 100 & 2800 \\
\hline $\begin{array}{l}\text { Estados Unidos } \\
\text { (40 Part 503) }\end{array}$ & 75 & - & 85 & 840 & 4300 & 3000 & 57 & 75 & 420 & 100 & 7500 \\
\hline $\begin{array}{l}\text { CEE } \\
\text { (Diretiva 86/278/EEC) }\end{array}$ & - & - & $20-40$ & $750-1200$ & $1000-1750$ & - & $16-25$ & - & $300-400$ & - & $2500-4000$ \\
\hline Alemanha & - & - & 10 & 900 & 800 & 900 & 8 & - & 200 & - & 2500 \\
\hline \multicolumn{12}{|l|}{ Áustria } \\
\hline Região Sul & - & - & 2 & 100 & 300 & 50 & 2 & - & 25 & - & 1500 \\
\hline Região Norte & - & - & 10 & 400 & 500 & 500 & 10 & - & 100 & - & 2000 \\
\hline $\begin{array}{l}\text { Bélgica } \\
\text { (Flanders) }\end{array}$ & 150 & - & 6 & 300 & 375 & 250 & 5 & - & 100 & - & 900 \\
\hline \multicolumn{12}{|l|}{ Espanha } \\
\hline Solo $\mathrm{pH}<7$ & - & - & 20 & 750 & 1000 & 1000 & 16 & - & 300 & - & 2500 \\
\hline Solo $\mathrm{pH}>7$ & - & - & 40 & $120-0$ & 1750 & 1750 & 25 & - & 400 & - & 4000 \\
\hline Dinamarca & 25 & - & 0,8 & 120 & 1000 & 100 & 0,8 & - & 30 & - & 4000 \\
\hline Finlândia & & & 3 & 150 & 600 & 300 & 2 & - & 100 & - & 1500 \\
\hline França & - & - & $15^{(1)}$ & 800 & 1000 & 1000 & 10 & - & 200 & - & 3000 \\
\hline $\begin{array}{l}\text { Holanda } \\
\text { (Países Baixos) }\end{array}$ & - & - & 1,25 & 100 & 75 & 75 & 0,75 & - & 30 & - & 300 \\
\hline Itália & - & - & 20 & 750 & 1000 & - & 10 & - & 300 & - & 2500 \\
\hline Luxemburgo & - & - & $20-40$ & $750-1200$ & $1000-1750$ & $1000-1750$ & $16-25$ & - & $300-400$ & - & $2500-4000$ \\
\hline Polônia & - & - & 10 & 500 & 800 & 500 & 5 & - & 100 & - & 2500 \\
\hline Portugal & & & 20 & 750 & 1000 & 1000 & 16 & - & 300 & - & 2500 \\
\hline Suécia & - & - & 2 & 100 & 600 & 100 & 2,5 & - & 50 & - & 800 \\
\hline
\end{tabular}

Fonte: BRASIL, 2006c; EUROPEAN COMMUNITIES, 2001; US EPA, 2002.

Nota: (1) O valor que era de $20 \mathrm{mg} / \mathrm{KgST}$ em $1^{\circ}$ de janeiro de 2001 passará para $10 \mathrm{mg} / \mathrm{KgST}$ em $1^{\circ}$ de janeiro de 2004.

Tabela 3.17 - Concentrações máximas permitidas de indicadores bacteriológicos e agentes patogênicos para lodo Classe A no Brasil e em diversos países

\begin{tabular}{|c|c|c|c|c|c|}
\hline \multirow[b]{2}{*}{ País } & \multicolumn{5}{|c|}{ Indicador bacteriológico e agente patogênico } \\
\hline & Coliformes & $\begin{array}{l}\text { Ovos viáveis de } \\
\text { helmintos }\end{array}$ & Salmonella sp. & Vírus entéricos & Outros \\
\hline $\begin{array}{c}\text { Brasil } \\
\text { (Conama 375/2006) }\end{array}$ & $<103 \mathrm{NMP} / \mathrm{g} \mathrm{ST}^{(2)}$ & $<0,25$ ovo/g ST & Ausência em 10 g ST & $\begin{array}{c}<0,25 \text { UFP ou UFF/ } \\
\text { g ST }\end{array}$ & - \\
\hline $\begin{array}{l}\text { Estados Unidos } \\
(40 \text { Part 503) }\end{array}$ & $<103 \mathrm{NMP} / \mathrm{g} \mathrm{ST}^{(3)}$ & - & $3 \mathrm{NMP} / 4 \mathrm{~g} \mathrm{ST}$ & $\begin{array}{l}<1 \mathrm{UFP} \text { ou } \\
\mathrm{UFF} / 4 \mathrm{~g} \mathrm{ST}\end{array}$ & - \\
\hline França & - & $3 / 10 \mathrm{~g} \mathrm{ST}$ & $8 \mathrm{NMP} / 10 \mathrm{~g} \mathrm{ST}$ & $3 \mathrm{NMPC}^{(4)} / 10 \mathrm{~g} \mathrm{ST}$ & - \\
\hline Itália & - & - & $1000 \mathrm{NMP} / \mathrm{g} \mathrm{ST}$ & - & - \\
\hline Polônia & - & - & $\begin{array}{l}\text { Caso tenha presença } \\
\text { de Samonella não é } \\
\text { permitido seu uso na } \\
\text { agricultura. }\end{array}$ & - & Parasitas: $10 / \mathrm{kg} \mathrm{ST}$ \\
\hline
\end{tabular}

Fonte: BRASIL, 2000c; EUROPEAN COMMUNITIES, 2001; US EPA, 2002.

Nota: (1) O material deve atender ao limite para coliformes fecais ou Salmonella sp.; (2) Coliformes termotolerantes; (3) Coliformes fecais; (4) Número Mais Provável "Cytophatic". 
Os limites apresentados pela Resolução n ${ }^{0}$ 375/2006 do Conama são, na sua maioria, mais restritivos do que os observados em outros países. No que se refere aos microrganismos, essa diferença é devida à técnica de análise de risco utilizada na definição das concentraçõeslimite. Alguns países usam, em sua análise de risco, microrganismos presentes no solo, enquanto outros definem como organismos-alvo os seres humanos, animais e culturas agrícolas (RENNER, 2000; US EPA, 2002).

$\mathrm{Na}$ América Latina, apesar da condição sanitária precária de diversos países, aspectos relacionados ao gerenciamento do lodo já estão sendo introduzidos nas legislações de alguns países além do Brasil (QUADRO 3.4) .

Quadro 3.4 - Legislações específicas e os aspectos relacionados ao gerenciamento do lodo em alguns países da América Latina

\begin{tabular}{|c|c|c|}
\hline País & Aspectos relacionados ao gerenciamento do lodo & Legislação \\
\hline Argentina & $\begin{array}{l}\text { Regulamentou o manejo, o tratamento, a utilização e a } \\
\text { disposição das diferentes estaçõesantas de tratamento de } \\
\text { efluentes, visando a assegurar uma gestão sustentável dos } \\
\text { produtos, subprodutos e resíduos, oriundos desse tratamento }\end{array}$ & Resolução nº 97/01 - 22/11/2001 \\
\hline Chile & $\begin{array}{l}\text { Estabeleceu o manejo de lodos provenientes de Estações de } \\
\text { Tratamento de Águas Servidas, estabelecendo a classificação } \\
\text { sanitária dos lodos e das exigências sanitárias mínimas para seu } \\
\text { manejo, como também, as restrições, requisitos e condições } \\
\text { técnicas para a aplicação de lodos em determinados solos }\end{array}$ & $\begin{array}{l}\text { Decreto Supremo } N^{\circ} 123 / 06 \text { - } \\
\text { 30/08/2006 }\end{array}$ \\
\hline Colômbia & $\begin{array}{l}\text { Estabeleceu requisitos para os ensaios aos quais devem ser } \\
\text { submetidos os produtos orgânicos usados como esterco, } \\
\text { fertilizantes, ou como condicionadores de solo, não } \\
\text { especificando o tratamento para o lodo }\end{array}$ & $\begin{array}{l}\text { Norma Técnica Colombiana } \\
\text { NTC 5167/04 - 31/05/2004 }\end{array}$ \\
\hline México & $\begin{array}{l}\text { Instituiu os limites permissíveis de contaminantes em lodos e } \\
\text { biossolidos provenientes das plantas de tratamento de águas } \\
\text { residuárias, com a finalidade de possibilitar seu aproveitamento } \\
\text { ou disposição final e proteger o meio ambiente e a saúde }\end{array}$ & $\begin{array}{l}\text { Secretaria de Meio Ambiente e } \\
\text { Recursos Naturais NOM-004- } \\
\text { SEMARNAT-2002 }\end{array}$ \\
\hline
\end{tabular}

Fonte: Adaptado de PATRI, 2008.

\subsection{HIGIENIZAÇÃO/SECAGEM DO LODO EM ESTUFA AGRÍCOLA}

Certamente, a busca por técnicas e processos que melhorem a qualidade do lodo fez-se mais necessária quando algumas alternativas de disposição final passaram a exigir características específicas bastante restritivas. Considerando a disposição do lodo na agricultura, o estudo de novas técnicas para a etapa de higienização tem sido o foco de muitas pesquisas, por se tratar de uma das principais etapas de tratamento para essa forma de disposição final. Nota-se, no entanto, que os estudos atualmente apresentados visam a aperfeiçoar ou mesmo simplificar 
aquelas técnicas já existentes, com a inserção de novos elementos e métodos, na tentativa de sempre favorecer a associação das condições e disponibilidades locais da região com a viabilidade técnico-econômica.

Nesse sentido, este trabalho se propôs a estudar a utilização de estufa agrícola no processo de secagem e higienização de lodo digerido e lodo não submetido ao digestor, com e sem adição de cal. As estufas apresentam grande vantagem, que é a capacidade de maximizar a energia solar no aquecimento do lodo, retendo o calor e, com isso, acelerando o processo de secagem do material. A diminuição da umidade faz que sejam reduzidas as concentrações de microrganismos patogênicos e reduza consideravelmente o volume a ser disposto.

Na busca por referências sobre o assunto, observou-se que, até o momento, investigações e publicações quanto à utilização de estufa agrícola na secagem e higienização do lodo ainda são pouco divulgadas.

Algo semelhante ao objeto deste estudo tem sido aplicado pela PARKSON CORPORATION $(2007)^{27}$ e pela VEOLIA $(2007)^{28}$.

A PARKSON desenvolveu um sistema nomeado THERMO-SYSTEM Solar Dryer, designado a receber lodo líquido, denso, ou desaguado com teor de sólido próximo de $75 \%$. O sistema consiste numa câmara translúcida (estufa revestida com material translúcido) com sensores para monitorar as condições atmosféricas, sistema de exaustão, sistema de ventilação, equipamento móvel (Mole) para distribuir e revolver o lodo, e um microprocessador que controla todo o processo de secagem. A única fonte de energia para o desaguamento é a radiação solar. As variáveis climáticas internas são monitoradas pelo microprocessador, que também controla o ciclo operacional do Mole durante o revolvimento do lodo. Essa mistura possibilita o deslocamento do material mais úmido, presente no fundo da camada de lodo, para a superfície, além de injetar ar ao material, o que ajuda a reduzir o odor. Ao final do processo, o material granular peletizado, biologicamente estabilizado, enquadrado como Classe A (segundo a legislação americana), encontra-se com teor de sólidos acima de $90 \%$ e volume significativamente inferior ao inicial, reduzindo, assim, os custos com disposição final.

\footnotetext{
${ }^{27} \mathrm{http}$ ///www.parkson.com/Content.aspx?ntopicid=122

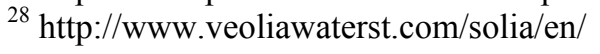


No caso da VEOLIA, o sistema batizado de Estufa Agrícola Solar para Desaguamento do Lodo opera com a combinação de dois processos: secagem ao ar e degradação aeróbia. O lodo é disposto em forma de pilha triangular, a fim de possibilitar uma maior troca da área superficial do lodo desaguado e a otimização do espaço da estufa agrícola, resultando, assim, numa grande quantidade de lodo a ser armazenado. Sob o efeito da radiação solar e da ação de um revolvedor automático de pilha de resíduo (SOLIMIX), a água do lodo evapora-se até a condição desejada para sua retirada da estufa. A fermentação é promovida pelo revolvimento regular da pilha de lodo, e a energia obtida com a oxidação da matéria orgânica presente acelera o processo de evaporação. Durante o processo de fermentação ocorre uma reação exotérmica que eleva a temperatura para 50 a $60^{\circ} \mathrm{C}$ e, por meio disso, promove-se a higienização do lodo paralelamente com o desaguamento. De acordo com as informações apresentadas, o material obtido ao final do processo atende às exigências da Diretiva Europeia para aplicação do lodo de esgoto no solo como insumo agrícola.

No Brasil, Andreoli, Ferreira e Chernicharo (2003) incorporaram no processo natural de desaguamento do lodo por leito de secagem uma cobertura plástica (estufa plástica), a fim de impedir a entrada de água de chuva e, com isso, acelerar o processo de secagem do lodo, utilizando-se das vantagens proporcionadas por essa técnica. Associadas a isso, foram colocadas tubulações de cobre no fundo do leito de secagem, para circulação de óleo aquecido termicamente pelo biogás proveniente de um reator anaeróbio do tipo RALF usado no tratamento da fase líquida. No estudo, apesar de ter sido injetado artificialmente calor subsuperficial, a estufa plástica possibilitou a otimização do leito de secagem com a aceleração da perda de umidade.

Outro estudo merecedor de destaque foi o desenvolvido por Comparini (2001), que pretendeu reduzir a densidade de microrganismos no lodo, utilizando uma estufa agrícola para secagem/higienização do material, e obteve resultados bastante expressivos. Isso fez com que fosse dado o mesmo direcionamento à pesquisa aqui apresentada e, por esse motivo, maior atenção será dedicada ao trabalho elaborado por aquele pesquisador. Além disso, este trabalho possibilitará confrontar melhor os resultados em razão de apresentar os, com mais detalhes, os parâmetros a serem monitorados. 


\subsubsection{PESQUISA QUE USA ESTUFA AGRÍCOLA NA SECAGEM E HIGIENIZAÇÃO DO LODO}

Comparini (2001) usou o lodo gerado na Estação de Tratamento de Esgoto de Franca, localizada no município de Franca (Estado de São Paulo) e operada pela Sabesp. A ETE trata esgotos sanitário predominantemente domésticos por processo de Lodos Ativados Convencional, tendo uma vazão anual média de $294 \mathrm{~L} / \mathrm{s}$.

O tratamento dado à fase sólida (lodo) na ETE, composta de lodos sedimentados nos decantadores primários e secundários, consiste em: tanque de mistura de lodos, para homogeneizar a mistura entre os lodos primários e secundários; adensador de lodo por gravidade, fazendo que a mistura de lodos atinja valores de sólidos totais na faixa de 1,5 a 3,0\%; três biodigestores anaeróbios, ou seja, dois primários e um secundário; nos primários (tempo de detenção de 16 a 32 dias) ocorre efetivamente a digestão do lodo e, no secundário (tempo de detenção de 8 a 16 dias), o adensamento do lodo digerido, gerando material com teores de sólidos de 1,6 e 2,0\%; e, finalmente, filtro-prensa de esteira (belt press) para o desaguamento do lodo condicionado com polieletrólito catiônico, resultando numa torta com teores de sólidos finais na faixa de 18 a 20\%. À época, o biossólido produzido era disposto em aterro em área contígua à ETE, de onde era encaminhado para aplicação em áreas agrícolas.

Para a realização da pesquisa, Comparini (2001) dispôs o lodo digerido e desaguado no interior da estufa agrícola em forma de leiras. A estufa possuía cobertura e paredes laterais fechadas com lona plástica translúcida. Não foi instalado nenhum equipamento que elevasse a temperatura dentro da estufa, sendo essa obtida apenas pelas condições ambientais da região.

Foram realizados três experimentos com tempo de duração aproximado de três meses cada um. No primeiro o lodo foi disposto em duas leiras com volume aproximado de 300 litros cada uma. Inicialmente, a umidade do lodo encontrava-se em torno de $80 \%$ e, à medida que o lodo secava, formavam-se leiras com altura aproximada de $50 \mathrm{~cm}$. As leiras eram revolvidas uma vez por semana. A segunda repetição seguiu os mesmos procedimentos da primeira, diferenciando-se na quantidade de lodo de cada leira, que foi de 1.500 litros.

Na terceira repetição foi utilizada a mesma quantidade de lodo usada na segunda, porém, nesse caso, o material foi inicialmente espalhado com altura de $10 \mathrm{~cm}$ nos primeiros 15 dias e, 
em seguida, formadas leiras com altura aproximada de $50 \mathrm{~cm}$. Enquanto encontrava-se espalhado, o material foi revolvido a cada dois dias. Em seguida, com a formação das leiras, o revolvimento foi semanal.

Para o monitoramento da pesquisa, foram acompanhadas as variações, ocorridas ao longo do tempo, de parâmetros biológicos, características físicas e químicas, propriedades de interesse agronômico e metais pesados. Foi, também, acompanhada a variação diária da temperatura dentro e fora da estufa, bem como no interior das leiras de lodo.

Com relação aos aspectos legais seguidos pelo pesquisador, adotaram-se os padrões estabelecidos pela normalização para o uso agrícola de biossólidos no estado de São Paulo (CETESB, 1999).

Em virtude das dificuldades encontradas para a realização da análise de vírus entéricos, exigida pela norma, foram feitas, então, análises da concentração de bacteriófagos RNA Fespecíficos, por se tratar de indicadores da presença de vírus entéricos em águas contaminadas com fezes (DO VAL, 1997).

\subsubsection{Caracterização do lodo utilizado no experimento}

Na caracterização do lodo gerado na ETE Franca, realizada em quatro épocas distantes, ou seja, em 2000, nos meses de agosto e outubro e em 2001, nos meses de fevereiro e maio, foram obtidos valores médios de coliformes totais de $1,10 \times 10^{7} \mathrm{NMP} / \mathrm{gST}$, E. coli de 2,34 x $10^{5} \mathrm{NMP} / \mathrm{gST}$, bacteriófagos de 4,27 x $10^{4} \mathrm{UFP} / 4 \mathrm{gST}$; e constatou-se a presença de Salmonella sp. em duas amostras e ausência em duas outras.

Os resultados encontrados de coliformes totais e de E. coli são compatíveis com as faixas indicadas por Feachem et al. (1983). Segundo o autor, em lodos digeridos, os índices de coliformes totais variam de $10^{6}$ a $10^{8}$ e, de fecais, de $10^{5}$ a $10^{7}$ por grama.

De acordo com Comparini (2001), os relatos mostrados na bibliografia especializada mostram que a digestão anaeróbia apresenta eficiência variável na remoção de Salmonella sp.. E, para o autor, já era esperada a ausência desse microrganismo em razão dos resultados obtidos desde 1999 do monitoramento rotineiro da qualidade do biossólido gerado na ETE. 
Com relação aos resultados de bacteriófagos, não foi possível compará-los com outros autores, porém se constatou que a digestão anaeróbia não é suficiente para inativar todos os casos de vírus.

Diante dos resultados qualitativos do lodo, as concentrações de E. coli mostraram que o material pode ser incluído como Classe $\mathrm{B}$, de acordo com os padrões definidos na norma P4230 (CETESB, 1999).

No caso dos resultados de ovos de helmintos, o pesquisador procedeu à análise de 8 tipos diferentes de microrganismos, apurando, ao final do estudo de caracterização, um total de 54,65 ovos totais/gST com percentual de viabilidade de 50\%, correspondente a 27,06 ovos viáveis/gST. O valor obtido foi bastante superior ao limite estabelecido pela norma da Cetesb (1999), que é de 0,25 ovo viável/gST para biossólido Classe A. Percebeu-se, também, uma variação na contagem de ovos entre os períodos de amostragem, atribuída às alterações ocorridas na rotina operacional da ETE, visto que fatores, como a temperatura, o tempo de detenção e a forma de operação estão diretamente relacionados à inativação de patógenos na digestão anaeróbia de lodos.

\subsubsection{Resultados obtidos com a higienização do lodo em estufa agrícola}

O experimento, que teve duração aproximada de 9 meses, ou seja, em torno de 90 dias para cada repetição descrita anteriormente, possibilitou avaliar o comportamento da secagem em estufa em diferentes estações do ano, em épocas muito úmidas e temperaturas mais elevadas, e em outras, mais secas e de temperaturas mais amenas.

\section{a) Temperatura}

Pôde-se perceber uma variação considerável da temperatura nos diferentes períodos estudados. A temperatura ambiente média das máximas diárias ocorridas dentro da estufa durante o experimento foi de $55,8^{\circ} \mathrm{C}$, sendo a ambiente (fora da estufa) de $37^{\circ} \mathrm{C}$. Já as médias das mínimas diárias dentro e fora da estufa chegaram a, respectivamente, $14,6^{\circ} \mathrm{C}$ e $12,9^{\circ} \mathrm{C} . \mathrm{Na}$ TABELA 3.18, estão apresentados o valores médios, máximos e mínimos de temperatura ocorridos durante o experimento. 
Diante dos resultados do monitoramento, constatou-se que a estufa possibilitou um aquecimento e um efeito de regularização na temperatura do biossólido. Isso foi observado durante as horas em que a temperatura no interior da estufa se encontrava elevada e as temperaturas médias dentro das leiras estavam mais baixas em até $21^{\circ} \mathrm{C}$; por outro lado, nas horas mais frias do dia, essa temperatura situava-se próxima a $10^{\circ} \mathrm{C}$ acima das observadas no interior da estufa.

Tabela 3.18 - Temperaturas médias ocorridas durante a secagem do biossólido em estufa agrícola

\begin{tabular}{|c|c|c|c|}
\hline \multirow{2}{*}{ Temperatura $\left({ }^{\circ} \mathrm{C}\right)$} & \multicolumn{3}{|c|}{$\begin{array}{c}\text { Repetição } \\
\text { (Período - dd/mm/aa) }\end{array}$} \\
\hline & $\begin{array}{c}1^{\underline{\underline{a}}} \\
(23 / 10 / 00 \text { a 29/01/01) } \\
\end{array}$ & $\begin{array}{c}2^{\mathrm{a}} \\
(12 / 02 / 01 \text { a } 07 / 05 / 01)\end{array}$ & $\begin{array}{c}3^{\mathrm{a}} \\
(21 / 05 / 01 \text { a } 30 / 07 / 01) \\
\end{array}$ \\
\hline Média das Médias Diárias - ar & 24,8 & 24,3 & 20,9 \\
\hline Média das Médias Diárias - estufa & 31,8 & 32,7 & 26,6 \\
\hline Média das Médias Diárias - Leira 1 & 32,9 & 33,4 & 26,9 \\
\hline Média das Médias Diárias - Leira 2 & 32,2 & 32,2 & 26,4 \\
\hline Média das Máximas Diárias - ar & 35,4 & 37,0 & 33,8 \\
\hline Média das Máximas Diárias - estufa & 51,2 & 55,8 & 46,1 \\
\hline Média das Máximas Diárias - Leira 1 & 37,5 & 37,5 & 32,7 \\
\hline Média das Máximas Diárias - Leira 2 & 35,7 & 35,6 & 32,1 \\
\hline Média das Mínimas Diárias - ar & 18,8 & 16,3 & 12,9 \\
\hline Média das Mínimas Diárias - estufa & 21,1 & 18,8 & 14,6 \\
\hline Média das Mínimas Diárias - Leira 1 & 29,7 & 30,4 & 23,0 \\
\hline Média das Mínimas Diárias - Leira 2 & 29,5 & 29,9 & 21,8 \\
\hline
\end{tabular}

Fonte: Adaptado de COMPARINI, 2001.

Durante as duas primeiras repetições, realizadas entre os meses de outubro/2000 a maio/2001, as temperaturas ocorridas não foram muito diferentes. Entretanto, na terceira repetição (maio/2001 a julho/2001), em certos horários do dia ocorreram temperaturas bem baixas.

b) Umidade, Sólidos Totais (ST) e Sólidos Voláteis (SV)

A umidade inicial do lodo estava em torno de $82 \%$ nas duas primeiras repetições e de $84 \%$ na terceira. Após 98 dias de monitoramento da primeira repetição, a umidade atingiu valor médio entre as duas leiras de biossólido de $9,7 \%$. No entanto, na segunda repetição, uma umidade semelhante, $10,3 \%$, foi obtida em 84 dias. A terceira repetição, apesar de apresentar temperaturas médias inferiores às anteriores, atingiu 11,45\% de umidade média com 70 dias de secagem do lodo. Isso foi atribuído às mudanças efetuadas no revolvimento do biossólido e na formação das leiras, que ocorreu 15 dias após o início da repetição, ficando o material, 
inicialmente, espalhado em camada de $10 \mathrm{~cm}$. Com essa alteração, foi possível perceber que a umidade reduziu cerca de $30 \%$ em 21 dias e $20 \%$ em 35 dias, enquanto, nas primeiras repetições, essas reduções ocorreram após 50 e 64 dias, aproximadamente.

Foi possível observar, também, que a perda de umidade no biossólido é caracterizada por três situações distintas. Com valores de umidade acima de $80 \%$ e em torno de $70 \%$, existe uma dificuldade maior de o biossólido perder umidade. Em seguida, em razão do aumento da porosidade, ocorre uma redução mais acelerada até valores próximos de $20 \%$, quando, daí em diante, a perda de umidade volta a se tornar lenta.

Os resultados de ST e SV demonstraram que houve um prosseguimento do processo de estabilização do biossólido durante a secagem, tendo em vista que a concentração de SV em relação à de ST reduziu 73\% no início dos experimentos a valores da ordem de 53\% ao final. Tal comportamento foi apresentado nas três repetições.

c) Parâmetros de interesse agronômico

$\mathrm{O} \mathrm{pH}$ do lodo manteve-se neutro durante todo o experimento, com valores variando de $6,0 \mathrm{a}$ 7,7. Foi observada uma leve tendência de elevação do pH nos primeiros 50 dias e, daí em diante, uma redução até o final do experimento. Na terceira repetição, foram encontrados valores de $\mathrm{pH}$ mais elevados quando comparados com os obtidos nas duas primeiras repetições.

Os micronutrientes e macronutrientes monitorados foram analisados no início e no final de cada repetição. O conteúdo de Carbono Orgânico (C-Orgânico), apesar de ter sofrido reduções na faixa de $21,7 \%$ a $25,5 \%$, apresentou teores elevados ao final do período de secagem, com uma média de $322,20 \mathrm{~g} / \mathrm{kgST}$ ou $32,2 \%$, confirmando seu potencial como condicionador de solos.

Quanto ao nitrogênio, foi possível constatar a qualidade do produto para o aproveitamento agrícola. O teor final de Nitrogênio Kjedahl foi de $50,63 \mathrm{~g} / \mathrm{kgST}$ ou $5,1 \%$, e o de Nitrogênio Amoniacal aumentou durante o processo de secagem.

A secagem não gerou prejuízos na qualidade do biossólido em relação ao conteúdo de Fósforo Total, apresentando concentração média final de 13,2 g/kgST ou 1,3\%. 
O valor médio de Potássio encontrado foi de $7,6 \mathrm{~g} / \mathrm{kgST}$ ou $0,76 \%$, com teores variando de 2,04 a $17,36 \mathrm{~g} / \mathrm{kgST}$.

Na TABELA 3.19, são apresentados os valores médios de outros elementos de interesse agronômico monitorados durante a pesquisa.

Tabela 3.19 - Teores finais de S-sulfato, $\mathrm{Na}, \mathrm{Ca}, \mathrm{Mg}, \mathrm{Fe}, \mathrm{Mn}$ e B em amostras de biossólido submetido à secagem em estufa agrícola

\begin{tabular}{cc}
\hline Parâmetro & Concentração $(\mathbf{m g} / \mathbf{k g S T})$ \\
\hline S-sulfato & 5847,1 \\
Sódio & 1086,1 \\
Cálcio & 29935,0 \\
Magnésio & 3170,6 \\
Ferro & 17576,4 \\
Manganês & 630,5 \\
Boro & 45,0 \\
\hline
\end{tabular}

Fonte: Adaptado de COMPARINI, 2001.

d) Metais pesados

As concentrações médias e máximas obtidas das substâncias inorgânicas encontram-se especificados na TABELA 3.20. Os resultados apresentados foram sempre inferiores aos limites estabelecidos pela Norma P-4230 (CETESB, 1999), adotada na época como referência. Foram também inferiores às concentrações máximas segundo a Resolução $\mathrm{n}^{\mathrm{o}}$ 375/2006 do Conama (BRASIL, 2006c).

Tabela 3.20 - Concentrações máximas e médias de metais pesados em amostras do biossólido submetido à secagem em estufa agrícola

\begin{tabular}{|c|c|c|c|c|c|c|c|c|c|c|}
\hline \multirow{2}{*}{$\begin{array}{l}\text { Concentração } \\
\text { (mg/kgST) }\end{array}$} & \multicolumn{10}{|c|}{ Metal Pesado } \\
\hline & As & Cd & $\mathrm{Cr}$ & $\mathbf{C u}$ & Hg & Mo & $\mathbf{N i}$ & $\mathbf{P b}$ & Se & Zn \\
\hline Valor Máximo & 0,33 & 3,08 & 349,14 & 234,23 & 2,88 & 6,14 & 54,73 & 85,09 & (1) & 1761,96 \\
\hline Valor Médio & 0,21 & 2,50 & 258,66 & 185,31 & 1,18 & 5,16 & 47,69 & 77,84 & (1) & 1135,00 \\
\hline
\end{tabular}

Fonte: Adaptado de COMPARINI, 2001.

Nota: (1) Não detectado, sendo o limite de detecção $0,067 \mathrm{mg} / \mathrm{kgST}$.

e) Características microbiológicas

As concentrações médias de bacteriófagos F-específicos do lodo encontradas no início do experimento foram de $1,26 \times 10^{4} \mathrm{UFP} / \mathrm{gST}$ (primeira repetição), $2,90 \times 10^{2} \mathrm{UFP} / \mathrm{gST}$ 
(segunda repetição) e 1,54 x $10^{4} \mathrm{UFP} / \mathrm{gST}$ (terceira repetição), demonstrando-se ausentes a partir do $56^{\circ}$ e $42^{\circ}$ dia de experimento na primeira e segunda repetições, respectivamente. $\mathrm{Na}$ terceira repetição, constatou-se a ausência do vírus logo na primeira determinação, ou seja, no $14^{\circ}$ dia. Esse fato, provavelmente, ocorreu graças à adoção de manejo diferenciado do biossólido em relação às primeiras repetições.

Avaliando a concentração de bacteriófagos em relação ao teor de umidade do biossólido, verificou-se que a secagem do material possibilitou a destruição completa desse microrganismo nas três repetições. Para valores de umidade em torno $70 \%$, a concentração de bacteriófagos já se encontrava reduzida a valores menores que $10^{3} \mathrm{UFP} / \mathrm{gST}$ nas três repetições. Segundo o autor, tendo em vista a existência de outros fatores que contribuíram para a inativação desse vírus, como a insolação, a temperatura e a competição, não foi possível afirmar que a umidade seja o único fator relevante, porém sabe-se que ela é fundamental no processo. Os resultados mostraram que o lodo, com teor de umidade em torno de $25 \%$, exposto à insolação e a temperaturas médias acima de $25^{\circ} \mathrm{C}$, revelou ausência de bacteriófagos F-específicos.

Apesar de não ter sido avaliada a concentração de vírus entéricos diretamente, os resultados encontrados para o indicador utilizado atenderam aos limites estabelecidos pela Cetesb (CETESB, 1999) e pelo Conama (BRASIL, 2006c) para enquadrar o material como Classe A.

As bactérias do grupo coliformes avaliadas foram coliformes totais e E. coli. Verificaram-se, também, as contagens de ovos de helmintos e a presença de Salmonella sp. ao longo do experimento (TABELA 3.21).

Os resultados obtidos para coliformes totais ao final da primeira repetição foram da mesma ordem de grandeza da concentração inicial, $10^{6} \mathrm{NMP} / \mathrm{gST}$, sugerindo, com isso, um possível recrescimento de bactérias. Nas outras repetições, as densidades encontradas foram bastante semelhantes, quando comparadas entre si, com reduções logarítmicas acima de 3 e concentração final da ordem de $10^{3} \mathrm{NMP} / \mathrm{gST}$. 
Tabela 3.21 - Densidade de coliformes totais, E. coli e a contagem de ovos de helmintos no lodo durante as três repetições e o teor de umidade correspondente

\begin{tabular}{|c|c|c|c|c|c|c|c|}
\hline \multirow[b]{2}{*}{ Data } & \multirow[b]{2}{*}{$\begin{array}{c}\text { Tempo } \\
\text { (dias) }\end{array}$} & \multirow[b]{2}{*}{$\begin{array}{l}\text { Coliformes totais } \\
\text { (Média }^{(1)} \text { ) } \\
\text { (NMP/gST) }\end{array}$} & \multirow[b]{2}{*}{$\begin{array}{c}\text { E. coli } \\
\left(\text { Média }{ }^{(1)}\right) \\
(\mathrm{NMP} / \mathrm{gST})\end{array}$} & \multicolumn{3}{|c|}{ Ovos de Helmintos } & \multirow[b]{2}{*}{$\begin{array}{c}\text { Teor de } \\
\text { Umidade } \\
\quad(\%)\end{array}$} \\
\hline & & & & $\begin{array}{c}\text { Ovos } \\
\text { Totais } \\
\text { (Média }^{(1)} \text { ) } \\
\left(\mathbf{n}^{\circ} / \text { g MS) }^{2}\right.\end{array}$ & $\begin{array}{c}\text { Ovos } \\
\text { Viáveis } \\
\text { (Média }^{(1)} \text { ) } \\
\text { (n% g MS) }\end{array}$ & $\begin{array}{c}\% \text { de } \\
\text { viabilidade }\end{array}$ & \\
\hline \multicolumn{8}{|c|}{$1^{\text {a }}$ Repetição } \\
\hline $23 / 10 / 00$ & 0 & $4,54 \times 10^{6}$ & $1,12 \times 10^{5}$ & 48,14 & 10,22 & 21,2 & 82,86 \\
\hline $06 / 11 / 00$ & 14 & $4,18 \times 10^{7}$ & $1,50 \times 10^{7}$ & 42,25 & 14,27 & 33,8 & 72,71 \\
\hline $20 / 11 / 00$ & 28 & $2,75 \times 10^{7}$ & $1,79 \times 10^{7}$ & 55,17 & 17,92 & 32,5 & 60,66 \\
\hline $04 / 12 / 00$ & 42 & $1,32 \times 10^{7}$ & $2,22 \times 10^{6}$ & 15,84 & 1,60 & 10,1 & 38,43 \\
\hline $18 / 12 / 00$ & 56 & $1,44 \times 10^{7}$ & $3,48 \times 10^{5}$ & 4,71 & 0,13 & 2,8 & 24,78 \\
\hline $02 / 01 / 01$ & 71 & $4,27 \times 10^{6}$ & $6,49 \times 10^{4}$ & 2,47 & 0,00 & 0,0 & 12,87 \\
\hline $15 / 01 / 01$ & 84 & $2,79 \times 10^{5}$ & $8,94 \times 10^{2}$ & 0,00 & 0,00 & 0,0 & 9,06 \\
\hline $29 / 01 / 01$ & 98 & $4,74 \times 10^{6}$ & $1,86 \times 10^{3}$ & 0,00 & 0,00 & 0,0 & 9,70 \\
\hline \multicolumn{8}{|c|}{$2^{\mathrm{a}}$ Repetição } \\
\hline $12 / 02 / 01$ & 0 & $9,60 \times 10^{6}$ & $2,97 \times 10^{5}$ & 55,74 & 27,50 & 49,3 & 81,53 \\
\hline $28 / 02 / 01$ & 16 & $1,74 \times 10^{7}$ & $9,07 \times 10^{6}$ & 52,05 & 22,98 & 44,2 & 78,04 \\
\hline $12 / 03 / 01$ & 28 & $4,41 \times 10^{6}$ & $8,91 \times 10^{5}$ & 47,16 & 4,09 & 8,7 & 71,25 \\
\hline $26 / 03 / 01$ & 42 & $1,12 \times 10^{5}$ & $1,22 \times 10^{5}$ & 24,44 & 0,09 & 0,4 & 46,64 \\
\hline 09/04/01 & 56 & $8,75 \times 10^{4}$ & $1,22 \times 10^{3}$ & 3,08 & 0,00 & 0,0 & 28,58 \\
\hline $23 / 04 / 01$ & 70 & $5,26 \times 10^{3}$ & $1,03 \times 10^{2}$ & 1,47 & 0,00 & 0,0 & 10,58 \\
\hline 07/05/01 & 84 & $4,93 \times 10^{3}$ & $1,00 \times 10^{2}$ & 0,89 & 0,00 & 0,0 & 10,30 \\
\hline \multicolumn{8}{|c|}{$3^{\text {a }}$ Repetição } \\
\hline $21 / 05 / 01$ & 0 & $1,54 \times 10^{7}$ & $2,34 \times 10^{5}$ & 60,98 & 30,95 & 50,8 & 84,23 \\
\hline $04 / 06 / 01$ & 14 & $6,62 \times 10^{6}$ & $6,56 \times 10^{5}$ & 25,07 & 10,53 & 42,0 & 68,18 \\
\hline $18 / 06 / 01$ & 28 & $1,10 \times 10^{5}$ & $7,43 \times 10^{4}$ & 10,16 & 0,72 & 7,0 & 23,41 \\
\hline $02 / 07 / 01$ & 42 & $2,45 \times 10^{4}$ & $1,32 \times 10^{4}$ & 2,64 & 0,08 & 3,0 & 20,18 \\
\hline $16 / 07 / 01$ & 56 & $9,39 \times 10^{3}$ & $5,73 \times 10^{3}$ & 0,60 & 0,01 & 1,9 & 14,72 \\
\hline $30 / 07 / 01$ & 70 & $7,50 \times 10^{3}$ & $2,99 \times 10^{2}$ & 0,67 & 0,0 & 0,0 & 11,45 \\
\hline
\end{tabular}

Fonte: Adaptado de COMPARINI, 2001.

Nota: (1) As amostras compostas de cada leira foram analisadas em triplicata; portanto, as médias indicadas correspondem à média de 6 análises individuais, sendo 3 em cada leira. (2) Redução expressa como o logaritmo da concentração inicial / concentração nas datas indicadas. (3) Ocorrência de crescimento bacteriano, com elevação da concentração.

No entanto, os resultados de E. coli apresentaram-se mais satisfatórios, com redução logarítmica média de 2,71 ao final dos experimentos e média abaixo de $10^{3} \mathrm{NMP} / \mathrm{gST}$. Segundo Comparini (2001), alguns autores afirmam que a secagem do lodo ao ar, até atingir teores de sólidos de 95\%, possibilita a redução da concentração de bactérias de 0,5 a $4 \log$.

A concentração de E. coli inferior a $10^{3} \mathrm{NMP} / \mathrm{gST}$ foi possível com teores de umidade em torno de $10 \%$ nas três repetições. Isso possibilitaria a inclusão do biossólido como Classe A 
para disposição final na agricultura, tanto pelo enquadramento da legislação da Cetesb (1999), como pela Resolução n ${ }^{0}$ 375/2006 do Conama (BRASIL, 2006c) atualmente em vigor.

No caso dos helmintos, foram monitoradas nas três repetições as contagens de ovos totais e de ovos viáveis. Além da contagem dos ovos, foi também realizada a identificação das espécies de parasitas presentes.

Os resultados obtidos revelaram que a viabilidade dos ovos de helmintos foi reduzida com a diminuição da umidade do material. Para melhor avaliar essa interferência, Comparini (2001) realizou correlações entre os valores de número de ovos (totais e viáveis)/gST e de umidade do biossólido nas três repetições, que confirmaram a influência direta da umidade nos valores de ovos de helmintos. Em relatos extraídos de diversas bibliografias pelo autor, foi constatado que a redução da umidade é eficaz na destruição de ovos de certos helmintos em lodos. Em alguns casos, quando a umidade do material é mantida em valores inferiores a $10 \%$, a destruição é assegurada para ovos de A. duodenale, $N$. americanus e Taenias. Para as espécies mais resistentes, como os ovos de Ascaris sp., a secagem dos lodos ao tempo não assegura sua destruição completa.

De acordo com os valores mostrados na TABELA 3.21, mesmo com teor de umidade em torno de $28 \%$, o biossólido apresentou viabilidade zero de ovos de helmintos (segunda repetição) nas condições em que o procedimento de secagem do lodo em estufa agrícola foi conduzido. Na primeira e na terceira repetição, tal fato ocorreu com umidade em torno de $10 \%$, apresentando coerência com a bibliografia consultada.

Os números de ovos viáveis já se apresentavam bastante reduzidos quando a umidades atingiu $38,43 \%$ (1,60 ovos/gST) e 46,64\% (0,09 ovo/gST), respectivamente, na primeira e segunda repetições com 42 dias de experimentação. Na terceira repetição, em virtude do manejo diferenciado de revolvimento do lodo, que possibilitou uma maior exposição do material aos raios solares, a redução de ovos viáveis ocorreu de forma mais acelerada, sendo que, aos 28 dias, o número de ovos viáveis no lodo foi de 0,72 ovo/gST, com $23,41 \%$ de umidade.

Apesar de baixas, os números de ovos totais de helmintos encontradas no biossólido ao final da segunda e da terceira repetições, foram, respectivamente, $0,89 \mathrm{ovo} / \mathrm{gST}$ e $0,67 \mathrm{ovo} / \mathrm{gST}$. Na primeira não foi detectada a presença desse microrganismo. 
Entre as espécies de helmintos estudadas, ovos viáveis de Toxocara foram detectados num maior período de tempo, 70 dias, na terceira repetição. As espécies que apresentaram o menor tempo, 28 dias, foram E. vermicularis (primeira repetição) e Trichuris sp. (terceira repetição).

O enquadramento do biossólido como Classe A, com concentração inferior a 0,25 ovo viável/gST, só foi possível com cerca de 70 dias de experimento e umidade na ordem de $11 \%$, atendendo ao limite estabelecido pela normalização para uso agrícola do lodo no estado de São Paulo (CETESB, 1999) e pela Resolução n ${ }^{0}$ 375/2006 do Conama (BRASIL, 2006c), que se encontra atualmente em vigor.

As bactérias Salmonella sp. foram monitoradas nas duas leiras, nas três repetições, a respeito da presença ou ausência do microrganismo. Nesse caso, não foi obtido, então, valor médio entre as leiras de biossólidos. Na primeira repetição, as amostras iniciais já apresentaram ausências dessa bactéria. Na segunda e terceira repetições, a presença de Salmonella sp. foi detectada em apenas uma das leiras.

Ao longo do experimento foi observado o recrescimento de Salmonella sp.. Na leira 1 da segunda repetição, por exemplo, após três amostras subsequentes com ausência de Salmonella sp., sua presença foi detectada em uma amostra com umidade bastante reduzida, de 10,58\%. Tal comportamento não era esperado, e, segundo Feachem et al. (1983), o tempo máximo de sobrevivência desses microrganismos, quando submetidos a processos de tratamento que incluem radiação solar e secagem, é de dois meses aproximadamente. A melhor explicação encontrada por Comparini foi a possibilidade de recontaminação ou por agentes externos, com a possível entrada de animais, como pássaros, moscas e baratas no interior da estufa, depositando ali suas fezes contaminadas, ou por intermédio dos operários que efetuaram o revolvimento das leiras com os calçados contaminados. O pesquisador reforça a possibilidade de recontaminação por agentes externos quando destaca a redução significativa nos níveis de bactérias do grupo coliforme que apresentam resistência ambiental semelhante às Salmonella sp. Sendo assim, é razoável supor que a secagem em estufa agrícola se tenha mostrado suficiente para a destruição, também, de Salmonella sp. nas condições operacionais estudadas.

Finalmente, destacam-se dentre as conclusões mais importantes apresentadas pelo autor: 
- a estufa agrícola "provoca aquecimento e um efeito de regularização na temperatura do biossólido", e com isso, para temperatura média ambiente perto de $24^{\circ} \mathrm{C}$, a temperatura no interior da estufa atingiu $32^{\circ} \mathrm{C}$ e, na leira de biossólidos, a $33^{\circ} \mathrm{C}$;

- ao final de 70 dias foram obtidos valores de umidade de $10 \%$;

- a metodologia usada "não provocou variações que pudessem ser consideradas como importantes no conteúdo de N-Kjeldahl e P-total";

- as reduções encontradas de SV/ST "de cerca de 73\% para valores da ordem de 53\%", e de C-orgânico "de 21,7\% a 25,5\%, não implicaram perda de potencial do biossólido como fonte de matéria orgânica para os solos e plantas”. As concentrações de Corgânico obtidas ao final dos períodos de secagem foram elevadas, apresentando, em média, 322,20 g/kgST;

- a secagem em estufa agrícola mostrou-se adequada à higienização do biossólido, apresentando para $E$. coli valores abaixo de $10^{3} \mathrm{NMP} / \mathrm{gST}$ (umidade da ordem de $10 \%$ ); inativação de Salmonellas e bacteriófagos (umidade da ordem de 25\%); e ovos viáveis de helmintos em valor próximo a zero (umidade da ordem de $10 \%$ e cerca de 70 dias de secagem). Esses resultados possibilitaram a inclusão do biossólido na Classe A (CETESB, 1999), favorecendo o seu uso na agricultura sem maiores restrições, sob o aspecto microbiológico. 


\section{MATERIAIS E MÉTODOS}

Para o desenvolvimento da pesquisa, foi usada uma área de estudo específica, que será apresentada, inicialmente, para melhor entendimento das questões pertinentes ao contexto envolvido neste trabalho.

\subsection{CARACTERIZAÇÃO DA ÁREA DE ESTUDO}

Em setembro de 2003, entraram em operação quatro grandes ETE que estão localizadas em diferentes municípios da Região Metropolitana da Grande Vitória (RMGV). Os municípios que integram a RMGV são Vitória, Vila Velha, Cariacica, Guarapari, Viana, Serra e Fundão, estando as estações localizadas nos quatro primeiros (FIGURA 4.1 e FIGURA 4.2), a saber:

- ETE MULEMBÁ - município de Vitória;

- ETE ARAÇÁS - município de Vila Velha;

- ETE BANDEIRANTES - município de Cariacica;

- ETE AEROPORTO - município de Guarapari.

Essas estações atendem parte da população dos municípios em que estão instaladas. Além delas, a RMGV conta, ainda, com outras estações que tratam esgoto doméstico, na sua maioria, por lagoas de estabilização.

A pesquisa foi desenvolvida na ETE Araçás (Vila Velha), apenas pelo fato de ela possibilitar melhores condições operacionais para a obtenção dos lodos utilizados na investigação. 


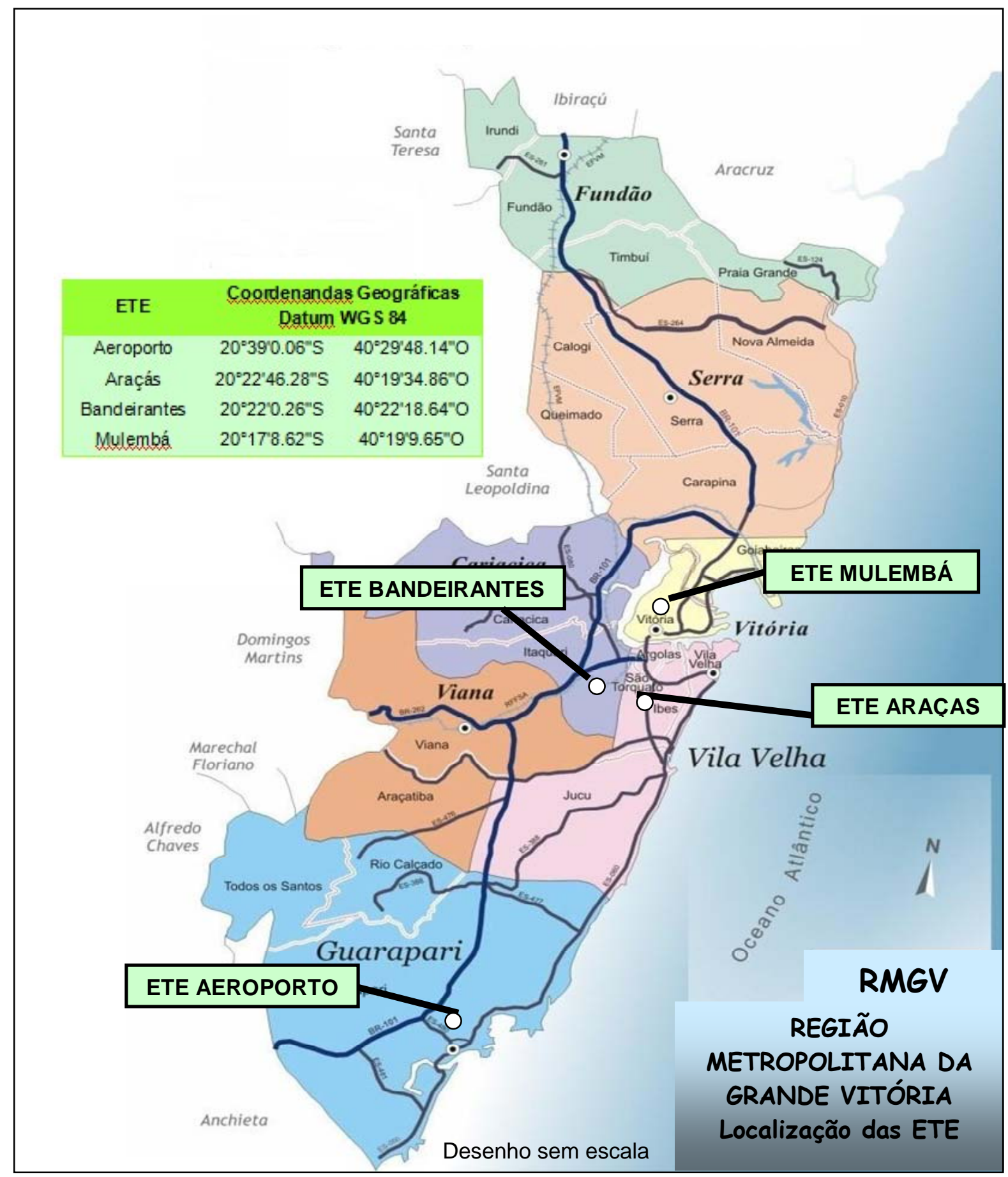

Figura 4.1 - Localização aproximada das quatro ETE nos respectivos municípios Fonte: Adaptado de ESPÍRITO SANTO (2005) ${ }^{29}$.

${ }^{29}$ www.ipes.es.gov.br, sendo IPES -Instituto de Apoio à Pesquisa e ao Desenvolvimento Jones dos Santos Neves 


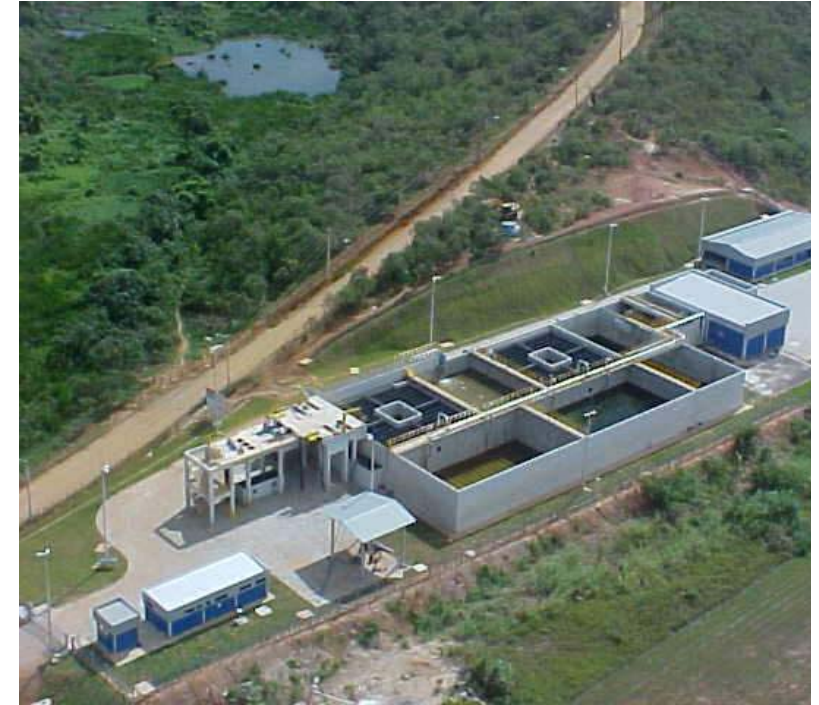

(a) ETE Aeroporto

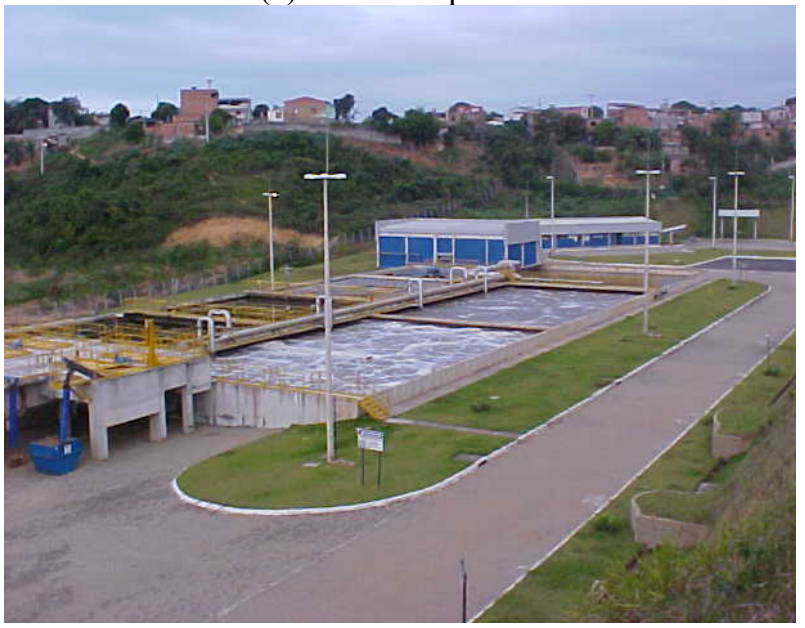

(c) ETE Bandeirantes

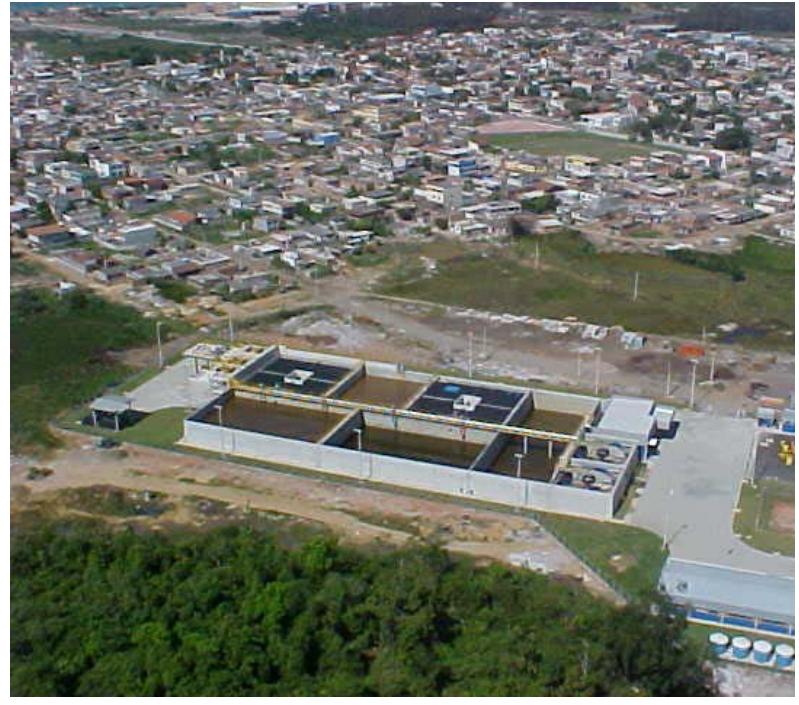

(b) ETE Araçás

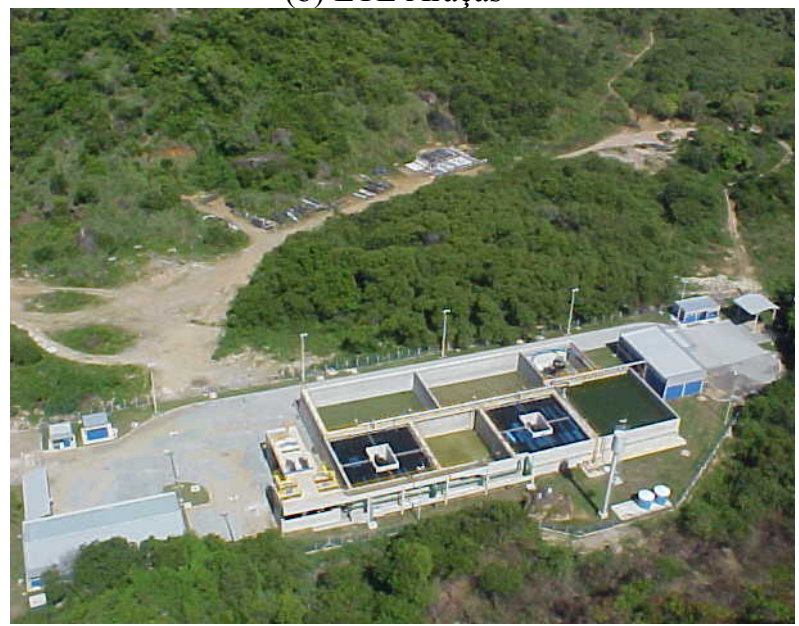

(d) ETE Mulembá

Figura 4.2 - Vista panorâmica das quatro ETE implantadas na RMGV que geram o lodo estudado na pesquisa

\subsubsection{DESCRIÇÃO DAS ETE}

As ETE implantadas na RMGV foram projetadas numa mesma concepção e, portanto, são fisicamente idênticas. Tratam esgoto doméstico com características médias e se diferenciam apenas no que diz respeito às dimensões dos reatores, confeccionados em concreto armado, e a aspectos que estão relacionados com a topografia do terreno onde se encontram instaladas. Por isso, a descrição apresentada a seguir refere-se a todas elas.

A TABELA 4.1 apresenta as vazões e as quantidades de lodo de excesso em cada estação para os anos de 2002, 2009, 2016 e 2023 (previsão de expansão), bem como o volume total de lodo gerado diariamente durante cada ano apresentado, segundo dados de projeto. 
Tabela 4.1 - Valores de vazão e quantidade de lodo produzido nas ETE de acordo com o projeto

\begin{tabular}{|c|c|c|c|c|c|c|c|c|}
\hline \multirow[b]{2}{*}{ ETE } & \multicolumn{2}{|c|}{2002} & \multicolumn{2}{|c|}{2009} & \multicolumn{2}{|c|}{2016} & \multicolumn{2}{|c|}{2023} \\
\hline & $\begin{array}{c}\text { Vazão } \\
\text { (L/s) }\end{array}$ & $\begin{array}{c}\text { Lodo } \\
\text { (m³/dia) }\end{array}$ & $\begin{array}{c}\text { Vazão } \\
\text { (L/s) }\end{array}$ & $\begin{array}{c}\text { Lodo } \\
\left(\mathrm{m}^{3} / \mathrm{dia}\right)\end{array}$ & $\begin{array}{c}\text { Vazão } \\
\text { (L/s) }\end{array}$ & $\begin{array}{c}\text { Lodo } \\
\left(\mathrm{m}^{3} / \mathrm{dia}\right)\end{array}$ & $\begin{array}{c}\text { Vazão } \\
\text { (L/s) }\end{array}$ & $\begin{array}{c}\text { Lodo } \\
\left(\mathrm{m}^{3} / \mathrm{dia}\right)\end{array}$ \\
\hline Aeroporto & 130 & 11 & 151 & 13 & 175 & 15 & 202 & 17 \\
\hline Araçás & 338 & 29 & 400 & 34 & 1.142 & 98 & 1.318 & 113 \\
\hline Bandeirantes & 209 & 18 & 255 & 22 & 472 & 41 & 662 & 53 \\
\hline Mulembá & 190 & 15 & 204 & 16 & 638 & 50 & 610 & 52 \\
\hline Total & & 73 & & 85 & & 204 & & 235 \\
\hline
\end{tabular}

Fonte: Adaptado de ANDREOLI et al., 2002.

Nota: A quantidade de lodo estimada leva em consideração que ele foi submetido ao desaguamento em centrífuga, resultando numa torta com $25 \%$ de sólidos (dados de projeto).

O sistema usado é o UNITANK aeróbio, que trata o esgoto de maneira similar à do processo de lodos ativados convencional, porém não apresenta tanques de decantação isolados nem sistema de retorno de lodo ao tanque de aeração. As informações apresentadas a seguir sobre as estações foram extraídas do Manual de Operação (2003) das referidas ETE.

No caso específico dessas ETE, a configuração utilizada visa a promover a remoção biológica de nitrogênio e, para tanto, constitui-se, basicamente, de um grande tanque retangular subdividido em 5 compartimentos ligados hidraulicamente entre em si (FIGURA 4.3).

A principal característica operacional do sistema é a mudança de sentido do fluxo e a possibilidade de dupla função de alguns compartimentos. O compartimento de entrada (C) funciona sempre como tanque anóxico, enquanto os localizados lateralmente a ele (D) funcionam ora como tanques de aeração/nitrificação, ora como tanques de sedimentação, sendo dotados de vertedores e canais de transbordamento. Os compartimentos intermediários (E) funcionam sempre como reatores de aeração/nitrificação. Por se tratar de uma operação cíclica, a sequência é controlada automaticamente por meio de válvulas e comportas pneumáticas. 


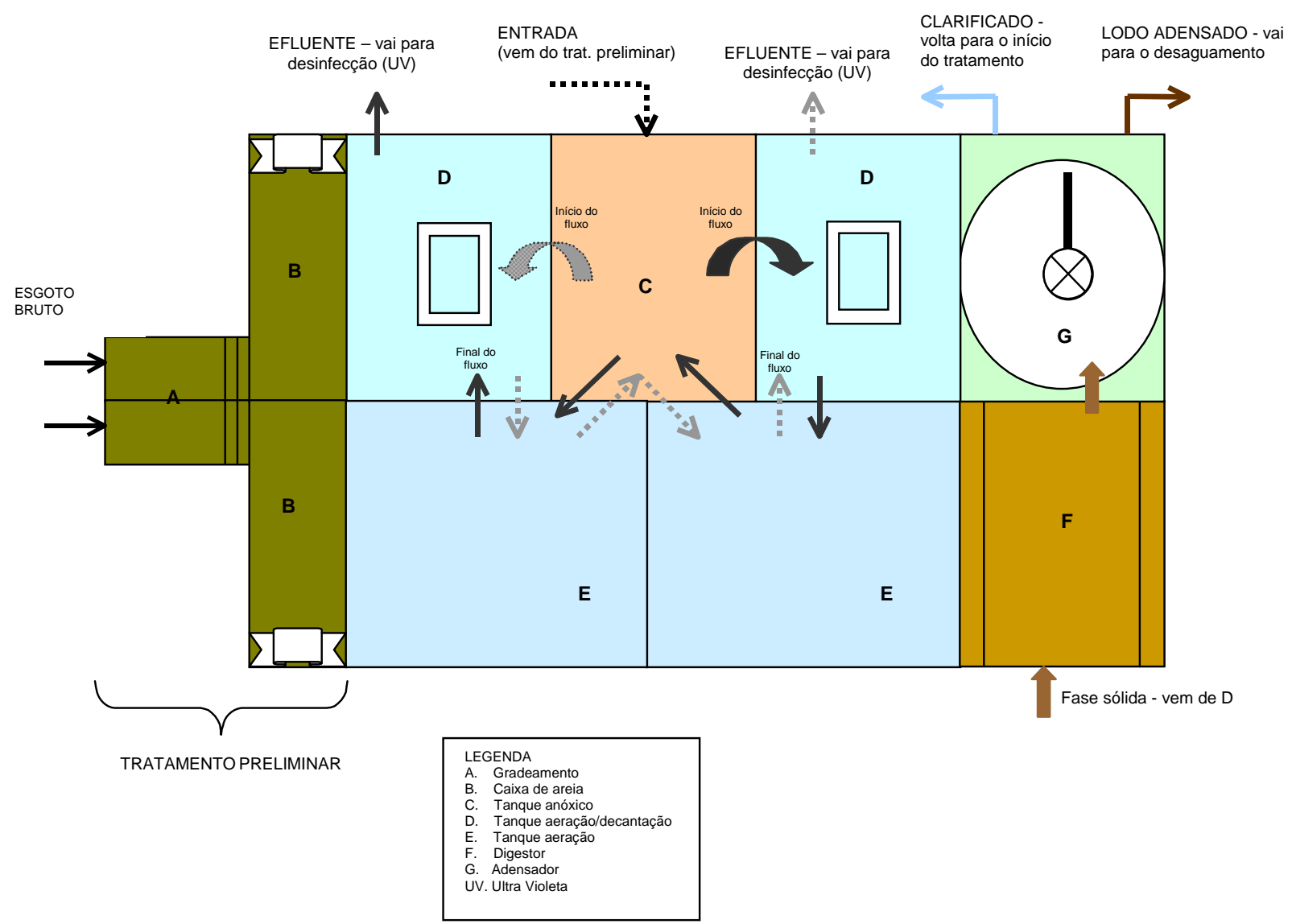

Nota: Depois que o esgoto sai do reator C, o início do fluxo é alternado, ora entra pelo reator D da direita, ora pelo da esquerda.

Figura 4.3 - Esquema simplificado, em vista superior, do fluxo da fase líquida e da fase sólida nas ETE

\subsubsection{Tratamento da fase líquida}

O esgoto bruto chega à ETE por intermédio de tubulação que o encaminha ao canal de entrada. Posteriormente é distribuído em três canais secundários onde ocorre o tratamento preliminar, composto de grade grossa manual, grade média curva mecanizada, desarenador e parafuso classificador (rosca sem fim). Os resíduos da grade grossa são transportados por rosca transportadora. O controle da vazão de entrada é monitorado por intermédio de um medidor ultrasônico instalado em Calha Parshall.

O tratamento biológico da fase líquida é realizado nos compartimentos (A, B, C, D e E) apresentados na FIGURA 4.3. O efluente entra pelo tanque anóxico e, nas etapas aeróbia e anóxica, a matéria orgânica biodegradável é removida pelo processo de oxidação. $\mathrm{O}$ 
nitrogênio é eliminado por assimilação celular e pelos processos de nitrificação e desnitrificação. A idade do lodo do sistema e em torno de 6 dias.

O esgoto tratado é separado do lodo ativado por sedimentação acelerada por meio dos sedimentadores tubulares. O lodo então sedimentado é bombeado ao digestor de lodo, enquanto o esgoto tratado é vertido do reator por canaletas vertedoras. De forma controlada e totalmente automatizada, parte do lodo produzido no processo biológico é descartada periodicamente dos compartimentos de sedimentação e enviada para o tratamento da fase sólida.

O efluente tratado biologicamente, antes de ser encaminhado para seu destino final, é descarregado por gravidade em um canal onde é efetuada medição e registro da vazão por meio de uma Calha Parshall e, em seguida, encaminhado para desinfecção ultravioleta.

\subsubsection{Tratamento da fase sólida}

O lodo em excesso gerado no tratamento biológico é bombeado ao digestor de lodo (F) para que ocorra a estabilização aeróbia mediante o processo de autodigestão. A etapa de digestão foi prevista para reduzir em até $30 \%$ os teores de sólidos voláteis. Já os sólidos fixos previstos após a estabilização são de $40 \%$, com tempo de retenção de oito dias.

O lodo estabilizado é encaminhado até o adensador, no qual ocorre a sedimentação por gravidade, formando uma maior concentração de sólidos ( $3 \%$ a $4 \%$ ST). O clarificado proveniente do adensador extravasa por gravidade ao tanque de drenagem, no qual será recalcado ao canal de alimentação, incorporando-se ao tratamento biológico da fase líquida.

O lodo estabilizado e adensado é extraído do fundo do adensador e encaminhado para a etapa de desaguamento com o auxílio de bombas. Essa etapa é efetuada por processo mecânico com a utilização de centrífuga que separa a fase sólida da líquida. Para melhorar a captura de sólidos e, com isso, facilitar a separação de sólido-líquido, é realizado um prévio condicionamento do lodo com polieletrólito catiônico. Segundo dados de projeto, a previsão é que o lodo desaguado atinja teor de sólidos de $25 \%$ ST.

A torta proveniente da centrífuga é armazenada em contêiner para, posteriormente, ser encaminhada a aterro sanitário particular localizado no município de Cariacica (pertencente à 
RMGV). O clarificado dessa etapa é descarregado em um segundo tanque de drenagem e bombeado até o canal de alimentação, sendo também incorporado ao tratamento biológico da fase líquida por intermédio de sistema de bombeamento.

Durante o período em que o lodo não está sendo centrifugado, as bombas recirculam o lodo adensado para o digestor, contribuindo para o aumento da concentração de sólidos e mineralização do lodo.

\subsubsection{ETE ARAÇÁS - CARACTERÍSTICAS GERAIS DA ETE, DO ESGOTO AFLUENTE E DO LODO BIOLÓGICO GERADO}

O experimento foi montado e desenvolvido na ETE Araçás, localizada no município de Vila Velha (FIGURAS 4.1 e 4.2b), e, por isso, serão apresentadas algumas características dessa ETE. Nas TABELAS 4.2 e 4.3, são apresentadas características das unidades existentes no tratamento das fases líquida e sólida, respectivamente.

Tabela 4.2 - Principais características das unidades (reatores/tanques) componentes do tratamento da fase líquida da ETE Araçás

\begin{tabular}{|c|c|c|}
\hline Unidade & $\begin{array}{l}\text { Dimensões }^{(*)} \\
\text { (cm) }\end{array}$ & Característica \\
\hline Grade grossa (x3) & $92 \times 100 \times 100$ & Barras de $3 / 8^{\prime \prime}$ com espaçamento de $50 \mathrm{~mm}$ e inclinação $60^{\circ}$. \\
\hline Grade média mecanizada & $92 \times 100 \times 100$ & Barras curvas de $3 / 8$ " 2 " com espaçamento de $15 \mathrm{~mm}$. \\
\hline Desarenador & $\varnothing 488$ & $\begin{array}{l}\text { Altura máx } 1.000 \mathrm{~mm} \text { e lâmina d'água } 560 \mathrm{~mm} \text {. } \\
\text { Parafuso classificador de compr. } 6.120 \mathrm{~mm} \text {, Ø } 305 \mathrm{~mm} \text { e incl. } 30^{\circ} \text {. }\end{array}$ \\
\hline TQ anóxico (x1) & $2.070 \times 2.450 \times 550$ & $\begin{array}{l}\text { Volume do reator } 2.789 \mathrm{~m}^{3} \text {. São utilizados agitadores submergidos } \\
\text { com potencia de agitação de } 5 \mathrm{w} / \mathrm{m}^{3} \text {. }\end{array}$ \\
\hline Calha parshal (x2) & Modelo W18" & Construída em fibra de vidro com resina ortoftálica. \\
\hline TQ aeração/decantação (x2) & $2.450 \times 2.450 \times 550$ & $\begin{array}{l}\text { Volume por reator } 3.389 \mathrm{~m}^{3} \text {. Cada tanque possui } 1.420 \text { difusores de } \\
\text { fundo para aeração. }\end{array}$ \\
\hline TQ aeração (x2) & $3.513 \times 2.210 \times 550$ & $\begin{array}{l}\text { Volume por reator } 4.269 \mathrm{~m}^{3} \text {. Cada tanque possui } 1.830 \text { difusores de } \\
\text { fundo para aeração. }\end{array}$ \\
\hline
\end{tabular}

Nota: $(*)$ largura, comprimento e altura.

Tabela 4.3 - Principais características das unidades (reatores/tanques) componentes do tratamento da fase sólida da ETE Araçás

\begin{tabular}{ccc}
\hline Unidade & $\begin{array}{c}\text { Dimensões } \\
(\mathbf{( c m})\end{array}$ & Característica \\
\hline Digestores (x2) & $1.730 \times 4.705 \times 550$ & $\begin{array}{c}\text { Volume por reator } 4.477 \mathrm{~m}^{3} \text {. Cada tanque possui } 1.196 \text { difusores de } \\
\text { fundo para aeração. }\end{array}$ \\
Adensador (x2) & $\varnothing 1.300$ & Volume do reator $930 \mathrm{~m}^{3}$. \\
Centrífuga (x1) & - & Centrífuga Pieralise Jumbo. \\
\hline
\end{tabular}

Nota: $(*)$ largura, comprimento e altura 
Devido à baixa adesão por parte dos moradores em providenciar a ligação do esgoto ao sistema coletor, o volume tratado ainda não havia alcançado a vazão definida em projeto durante o desenvolvimento da pesquisa. Em razão disso, segundo dados da operação, a idade do lodo média era entre 10 dias e 13 dias, com vazão média variando de $165 \mathrm{~L} / \mathrm{s}$ e $180 \mathrm{~L} / \mathrm{s}$ (DBO média entre $126 \mathrm{mg} / \mathrm{L}$ e $144 \mathrm{mg} / \mathrm{L}$ ) e não em torno de 6 dias como previsto em projeto.

Na TABELA 4.4, são apresentadas as características do esgoto e as vazões de operação ao longo do ano de 2007 e parte de 2008, que representa o período do desenvolvimento experimental.

Tabela 4.4 - Características médias do esgoto afluente e da vazão de operação da ETE Araçás durante o período do desenvolvimento experimental

\begin{tabular}{|c|c|c|c|c|c|c|c|c|}
\hline Mês/Ano & $\begin{array}{c}\text { Vazão } \\
\text { (L/s) }\end{array}$ & $\begin{array}{c}\text { DBO } \\
\left(\mathrm{mgO}_{2} / \mathrm{L}\right)\end{array}$ & $\begin{array}{c}\mathrm{DQO} \\
\left(\mathrm{mgO}_{2} / \mathrm{L}\right)\end{array}$ & $\begin{array}{c}\text { SST } \\
(\mathrm{mg} / \mathrm{L})\end{array}$ & $\begin{array}{c}\text { Nitrogênio } \\
\text { Total } \\
(\mathrm{mg} / \mathrm{L})\end{array}$ & $\begin{array}{c}\text { Fósforo } \\
\text { Total } \\
\text { (mg/L) }\end{array}$ & $\begin{array}{c}\text { Colif. Fecais } \\
\text { (NMP/100ml) }\end{array}$ & pH \\
\hline jan/07 & 65,02 & 137 & 235 & 153 & 49 & 5 & $2,97 \mathrm{E}+06$ & 6,88 \\
\hline fev/07 & 105,10 & 123 & 272 & 177 & 50 & 5 & $2,71 \mathrm{E}+06$ & 6,87 \\
\hline $\operatorname{mar} / 07$ & 127,06 & 132 & 307 & 146 & 38 & 4 & $2,40 \mathrm{E}+06$ & 7,01 \\
\hline $\mathrm{abr} / 07$ & 139,18 & 140 & 320 & 144 & 29 & 4 & $1,77 \mathrm{E}+06$ & 6,86 \\
\hline mai/07 & 139,75 & 125 & 295 & 118 & 26 & 4 & $3,55 \mathrm{E}+06$ & 6,85 \\
\hline jun/07 & 88,93 & 137 & 347 & 138 & 30 & 5 & $3,17 \mathrm{E}+06$ & 6,87 \\
\hline $\mathrm{jul} / 07$ & 94,10 & 136 & 351 & 145 & 38 & 5 & $3,63 \mathrm{E}+06$ & 6,85 \\
\hline ago/07 & 94,34 & 127 & 324 & 167 & 43 & 5 & $3,34 \mathrm{E}+06$ & 6,78 \\
\hline set/07 & 100,56 & 140 & 329 & 161 & 36 & 5 & $4,43 \mathrm{E}+06$ & 6,74 \\
\hline out $/ 07$ & 108,89 & 143 & 364 & 158 & 28 & 6 & $4,79 \mathrm{E}+06$ & 6,55 \\
\hline nov/07 & 118,44 & 134 & 353 & 175 & 74 & 5 & $4,13 \mathrm{E}+06$ & 6,65 \\
\hline $\operatorname{dez} / 07$ & 89,51 & 140 & 354 & 182 & 61 & 4 & $1,77 \mathrm{E}+06$ & 6,66 \\
\hline $\mathrm{jan} / 08$ & 61,01 & 145 & 340 & 144 & 40 & 4 & $2,04 \mathrm{E}+06$ & 6,45 \\
\hline fev/08 & 70,52 & 119 & 288 & 115 & 36 & 4 & $1,60 \mathrm{E}+06$ & 6,64 \\
\hline $\mathrm{mar} / 08$ & 77,11 & 84 & 218 & 105 & - & 3 & $7,62 \mathrm{E}+06$ & 6,82 \\
\hline $\mathrm{abr} / 08$ & 125,10 & 103 & 294 & 125 & 79 & 5 & $3,08 \mathrm{E}+06$ & 6,94 \\
\hline $\mathrm{mai} / 08$ & 139,86 & 177 & 332 & 113 & - & 6 & $3,22 \mathrm{E}+06$ & 7,03 \\
\hline jun $/ 08$ & 150,95 & 146 & 318 & 125 & 59 & 6 & $5,28 \mathrm{E}+06$ & 7,03 \\
\hline $\mathrm{jul} / 08$ & 163,37 & 137 & 336 & 151 & 53 & 6 & $5,09 \mathrm{E}+06$ & 6,93 \\
\hline ago/08 & 154,43 & 123 & 311 & 131 & 48 & 6 & $4,37 \mathrm{E}+06$ & 6,91 \\
\hline set/08 & 170,27 & 114 & 295 & 125 & 78 & 6 & $4,89 \mathrm{E}+06$ & 7,01 \\
\hline
\end{tabular}

Nota: Dados extraídos das planilhas de monitoramento da ETE Araçás.

Com relação ao lodo, atualmente, apenas os dados relacionados aos teores de sólidos totais são monitorados, tendo em vista que o lodo gerado na ETE Araçás é encaminhado para um aterro sanitário particular localizado no município de Cariacica (TABELA 4.5). 
Tabela 4.5 - Características médias do lodo digerido desaguado em centrífuga da ETE Araçás durante o período do desenvolvimento experimental

\begin{tabular}{cccccc}
\hline \multirow{2}{*}{ Mês/Ano } & \multicolumn{2}{c}{ Lodo digerido desaguado em centrífuga } & \multirow{2}{*}{ Mês/Ano } & \multicolumn{2}{c}{ Lodo digerido desaguado em centrífuga } \\
\cline { 2 - 3 } & Sólidos totais (\%) & Umidade (\%) & & Sólidos totais (\%) & Umidade (\%) \\
\hline jan/07 & 14,50 & 85,50 & dez/07 & 14,70 & 85,30 \\
$\mathrm{fev} / 07$ & 15,10 & 84,90 & jan/08 & 13,70 & 86,30 \\
$\mathrm{mar} / 07$ & 14,70 & 85,30 & $\mathrm{fev} / 08$ & 15,43 & 84,57 \\
$\mathrm{abr} / 07$ & 13,10 & 86,90 & $\mathrm{mar} / 08$ & 14,56 & 85,44 \\
$\mathrm{mai} / 07$ & 16,70 & 83,30 & $\mathrm{abr} / 08$ & 13,70 & 86,30 \\
$\mathrm{jun} / 07$ & 16,30 & 83,70 & $\mathrm{mai} / 08$ & 13,93 & 86,07 \\
$\mathrm{jul} / 07$ & 14,00 & 86,00 & jun/08 & 14,50 & 85,50 \\
$\mathrm{ago} / 07$ & 13,30 & 86,70 & jul/08 & 16,66 & 83,34 \\
$\mathrm{set} / 07$ & 14,70 & 85,30 & $\mathrm{ago} / 08$ & 14,50 & 85,50 \\
out/07 & 14,20 & 85,80 & set/08 & 16,70 & 83,30 \\
nov/07 & 14,90 & 85,10 & & & \\
\hline
\end{tabular}

Nota: Dados extraídos das planilhas de monitoramento da ETE Araçás

\subsection{DESENVOLVIMENTO EXPERIMENTAL}

O trabalho foi caracterizado por estudar o comportamento das características físicas, químicas e microbiológicas de lodo, quando submetido a tratamento em estufa agrícola, visando a conferir ao material condições ideais para uma disposição final adequada, além de avaliar os custos de investimentos envolvidos nessa operação. Para tanto, parte da metodologia usada no tratamento do lodo em estufa foi adaptada dos estudos realizados por Comparini (2001).

A FIGURA 4.4 apresenta, em forma de um fluxograma, as condições a que o lodo foi submetido no desenvolvimento da pesquisa e as questões pertinentes a cada fase explicitada no referido fluxo. 


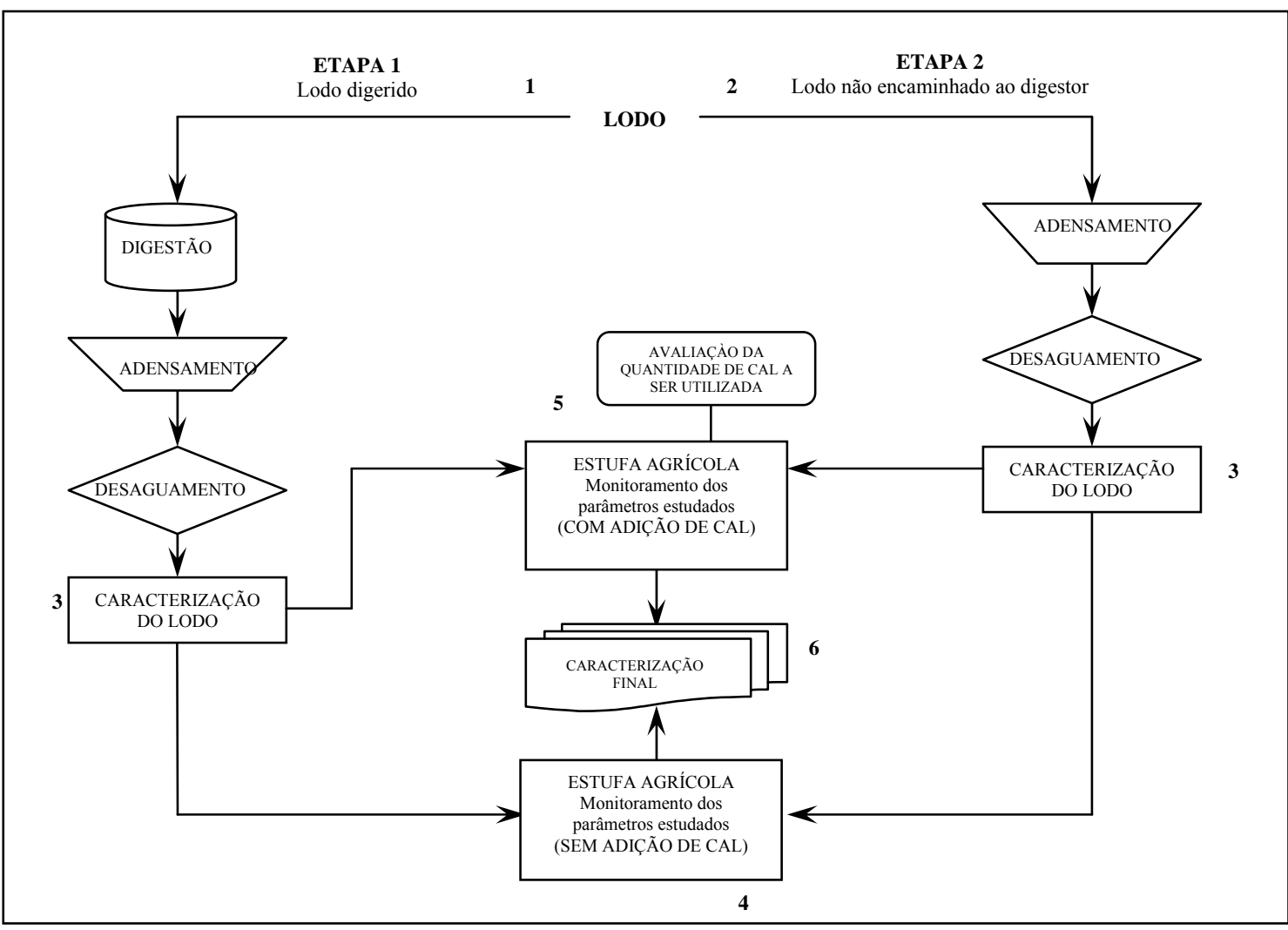

Figura 4.4 - Fluxograma das condições operacionais adotadas para o desenvolvimento da pesquisa

Etapa 1 - Tratamento em estufa agrícola de lodo estabilizado aerobiamente, inicialmente adensado e, em seguida, desaguado em centrífuga a aproximadamente 18\% ST (1).

$\underline{\text { Etapa } 2}$ - Tratamento em estufa agrícola de lodo não encaminhado ao digestor aeróbio, sendo inicialmente adensado e, em seguida, desaguado em centrífuga a aproximadamente $18 \% \mathrm{ST}$ (2).

Em ambos os casos, o lodo foi submetido à secagem e higienização em estufa agrícola sem adição de cal (4), e com adição de cal (5), a fim de promover a remoção da umidade, a destruição dos microrganismos patogênicos e a redução dos possíveis odores. Porém, no segundo caso (Etapa 2), realizou-se, também, a estabilização do material quando utilizado lodo que não foi encaminhado ao digestor (2). Cada etapa foi composta de três séries de repetições (ciclos). Para distinguir os ciclos de cada etapa, eles foram nominados como Ciclos 1/1, 2/1 e 3/1 - Etapa 1 - e Ciclos 1/2, 2/2 e 3/2 - Etapa 2. Os ciclos foram interrompidos quando o teor de sólidos atingiu valor acima de 90\%. Isso porque, diante dos resultados obtidos por Comparini (2001) e dos relatos apresentados por Dumontet et al. (2001), Bonnet, 
Lara e Domaszak (2000) e Yeager e O’Brien (1983, apud COMPARINI, 2001), essa condição garante a eliminação dos microrganismos patogênicos.

Além da caracterização do lodo no início e no final de cada ciclo do experimento (3 e 6), foram monitorados diversos parâmetros durante o desenvolvimento dos ciclos (4 e 5). Pretendeu-se, inicialmente, atingir ao final de cada ciclo, os padrões exigidos para lodo Classe A, visando a sua utilização na agricultura, de acordo com a Resolução $n^{0}$ 375/2006 do Conama (BRASIL, 2006c).

Como o experimento foi montado na ETE Araçás, por ela possibilitar melhores condições operacionais para a obtenção de lodo digerido (Etapa 1) e lodo não submetido à digestão (Etapa 2), para o desenvolvimento da pesquisa foi utilizado o lodo gerado na própria ETE.

A estufa agrícola utilizada no estudo seguiu os padrões adotados por Comparini (2001), com cobertura e revestimento lateral em lona plástica translúcida, para evitar a entrada de água de chuva no seu interior e possibilitar a penetração da radiação solar. A altura das paredes laterais era de 2,0 m, a largura e o comprimento eram de $6,0 \mathrm{~m}$ e $15,0 \mathrm{~m}$, respectivamente. $\mathrm{O}$ piso era de material impermeável (pavimentação asfáltica) para impedir a infiltração no solo da água contida no lodo. Construiu-se, também, uma pequena mureta no entorno da estufa para bloquear a entrada de águas do escoamento superficial. Foram realizadas aberturas laterais (janelas), para possibilitar a circulação de ar dentro da estufa, principalmente nos primeiros dias de cada ciclo, para diminuir a umidade dentro da estufa, que se torna elevada com a evaporação da água livre contida no lodo. Essas janelas eram mantidas abertas durante os horários de coleta das amostras e, permaneciam fechadas durante todo o desenvolvimento do experimento

Internamente, a estufa foi dividida em quatro partes denominadas células, nas quais o material foi disposto, sendo duas para o lodo sem cal (L1 e L2) e duas para o lodo com cal (LC1 e LC2). As FIGURAS 4.5 e 4.6 mostram detalhes da estufa usada durante o desenvolvimento experimental. 


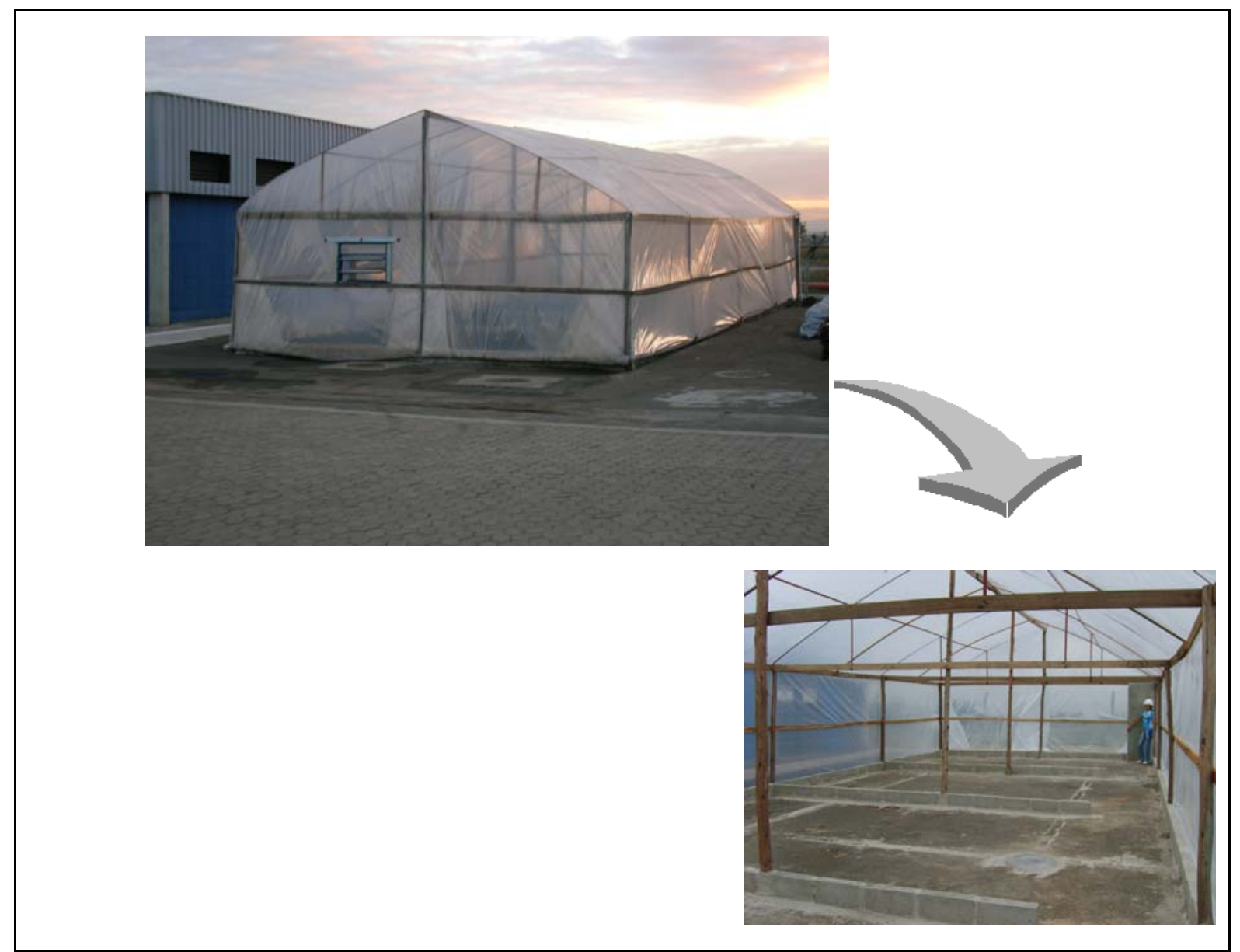

Figura 4.5 - Vista externa e interna da estufa agrícola usada na pesquisa

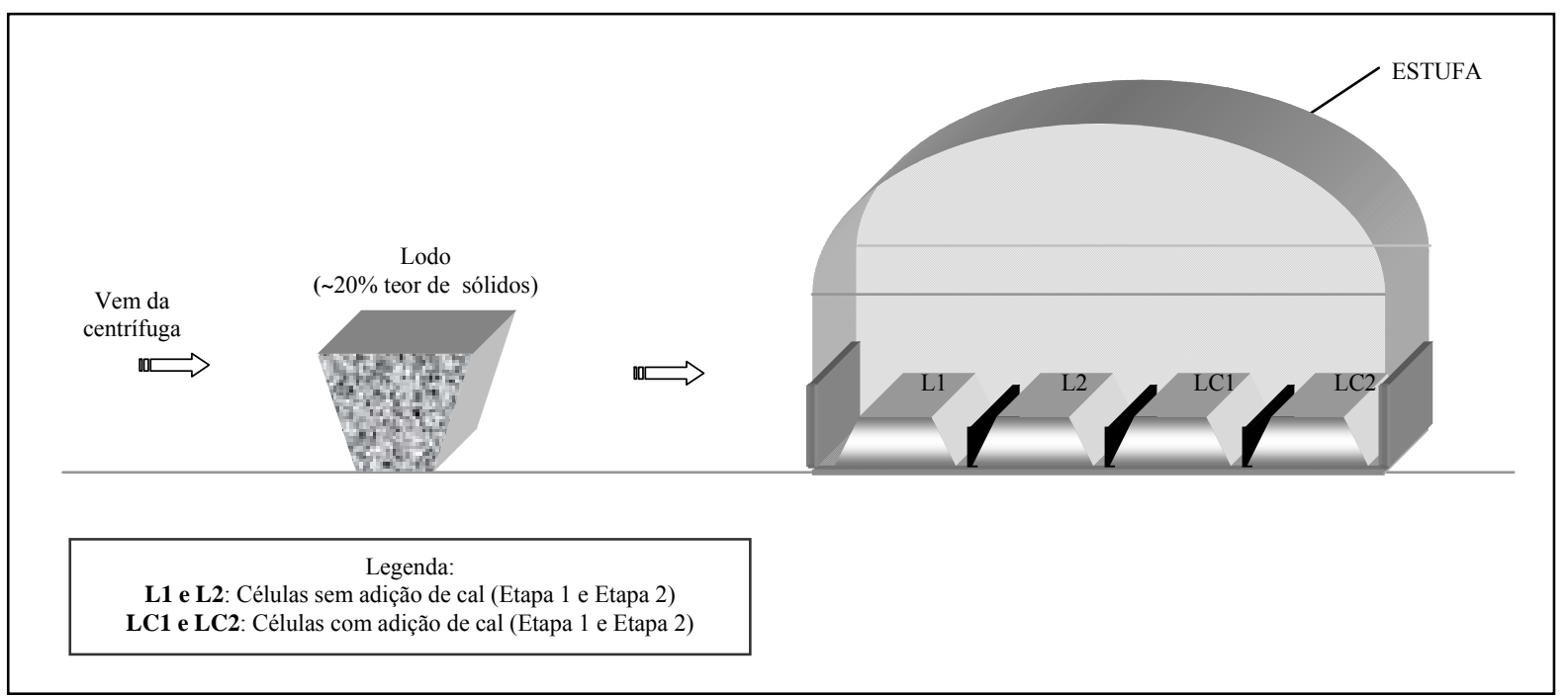

Figura 4.6 - Disposição das células de lodo dentro da estufa para o desenvolvimento da pesquisa 
Antes do início de cada etapa, foram realizados testes preliminares (pré-teste) para determinar a quantidade necessária de cal a ser adicionada aos dois tipos de lodos estudados, em atendimento às especificações apresentadas na Resolução $n^{0}$ 375/2006 do Conama (BRASIL, 2006c). Segundo essa resolução, a porcentagem de cal em base seca de lodo deve ser suficiente para que o $\mathrm{pH}$ seja elevado até os valores próximos a 12, por um período mínimo de 2 horas, permanecendo acima de 11,5 por mais 22 horas. Para tanto, diferentes dosagens de cal foram adicionadas a uma mesma quantidade de lodo, com teor de sólidos totais conhecido.

\subsubsection{DESENVOLVIMENTO DOS CICLOS DURANTE AS ETAPAS}

Tanto na Etapa 1 quanto na Etapa 2 foram seguidos os mesmos procedimentos metodológicos, ou seja, três ciclos operacionais, igualmente conduzidos em relação à frequência de revolvimento do lodo e forma de disposição do material nas células. As etapas ocorreram em períodos subsequentes, sendo a Etapa 2 iniciada logo após o término da Etapa 1. Cada etapa teve em média um tempo de duração de 9 meses e, assim, foi possível avaliar e comparar as possíveis variações dos parâmetros monitorados em diferentes meses do ano e em diferentes condições metodológicas.

A quantidade de lodo usada em cada célula foi de 1.000 litros (aproximadamente $0,18 \mathrm{t}$ de massa seca), totalizando 4.000 litros de lodo em cada ciclo.

As duas células formadas com lodo sem cal (L1 e L2) receberam diretamente a torta oriunda da centrífuga. Já para a montagem das células que receberam o lodo misturado à cal (LC1 e LC2), ele foi retirado da centrífuga e levado para uma betoneira em que foi adicionada a cal e promovida a mistura por tempo suficiente, em torno de 5 minutos, para obter um material completamente homogêneo.

A disposição do lodo em cada célula foi realizada diferentemente nos ciclos com a intenção de avaliar a melhor forma de dispor o material, com base nos resultados obtidos dos parâmetros monitorados durante o experimento. 


\subsubsection{Desenvolvimento do Ciclo 1}

Nesse ciclo, o lodo foi disposto de forma espalhada, em camada de, aproximadamente, $10 \mathrm{~cm}$ de altura em todas as células. O revolvimento, que era manual, ocorreu a cada dois dias até o material obter umidade em torno de 65\%. Em seguida, foram formadas leiras com, aproximadamente, $50 \mathrm{~cm}$ de altura e, daí em diante, o revolvimento do material aconteceu de 7 em 7 dias (FIGURA 4.7). De acordo com Comparini (2001), esse teor de umidade é suficiente para garantir a estabilidade das leiras. Esta configuração foi a mesma adotada por Comparini (2001), na $3^{\text {a }}$ repetição, com o intuito de acelerar o processo de higienização e otimizar a área da estufa.

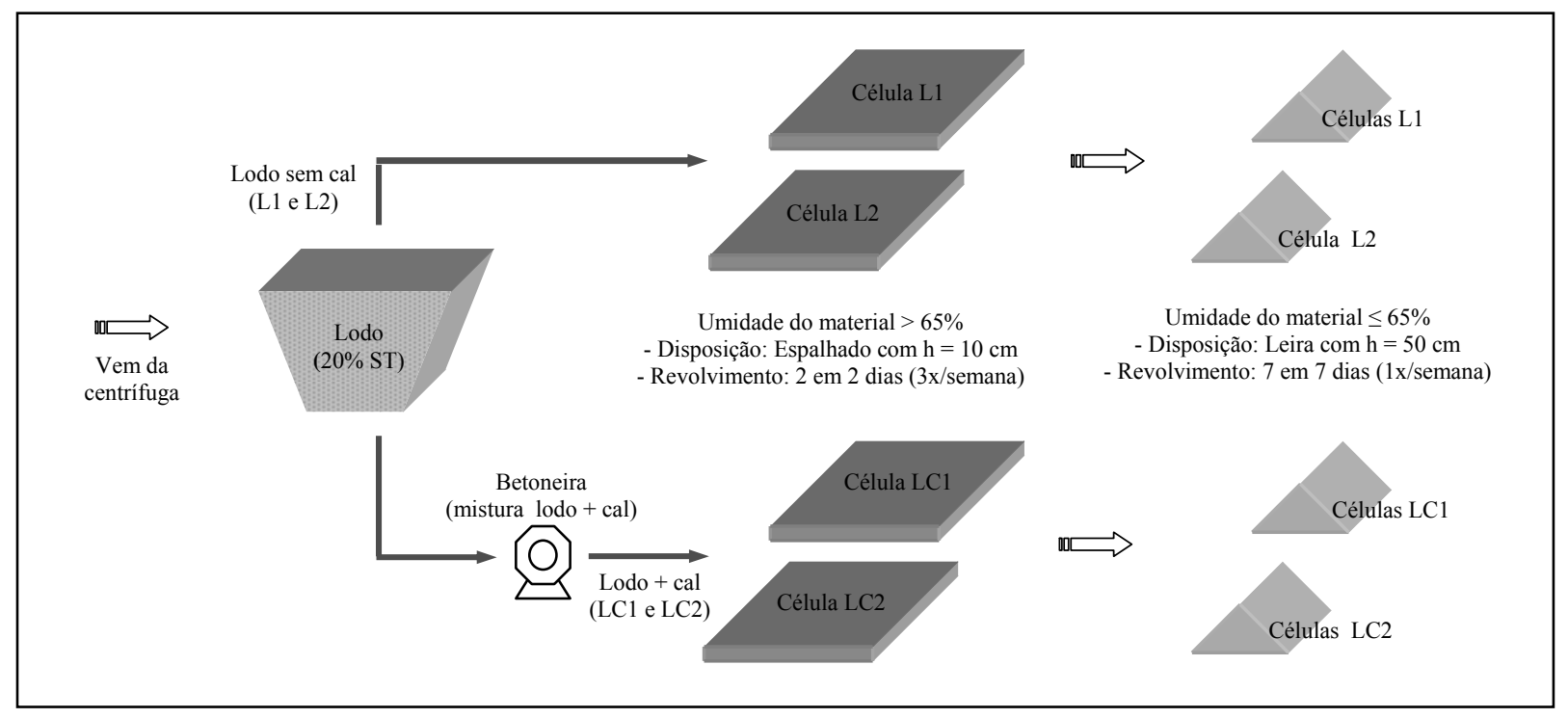

Figura 4.7 - Disposição do lodo nas células e período de revolvimento durante o Ciclo 1

\subsubsection{Desenvolvimento do Ciclo 2}

Com a intenção de avaliar o comportamento do lodo com a formação ou não de leiras, quando o material atingiu 65\% de sólidos totais, nesse ciclo as células L1 e LC1 permaneceram com o lodo espalhado (camada de $10 \mathrm{~cm}$ ) até o final do ciclo e as L2 e LC2 seguiram os mesmos procedimentos adotados no Ciclo 1. Porém, diferentemente do Ciclo 1, o lodo foi revolvido três vezes por semana durante todo o ciclo, para acelerar a sua secagem (FIGURA 4.8). 


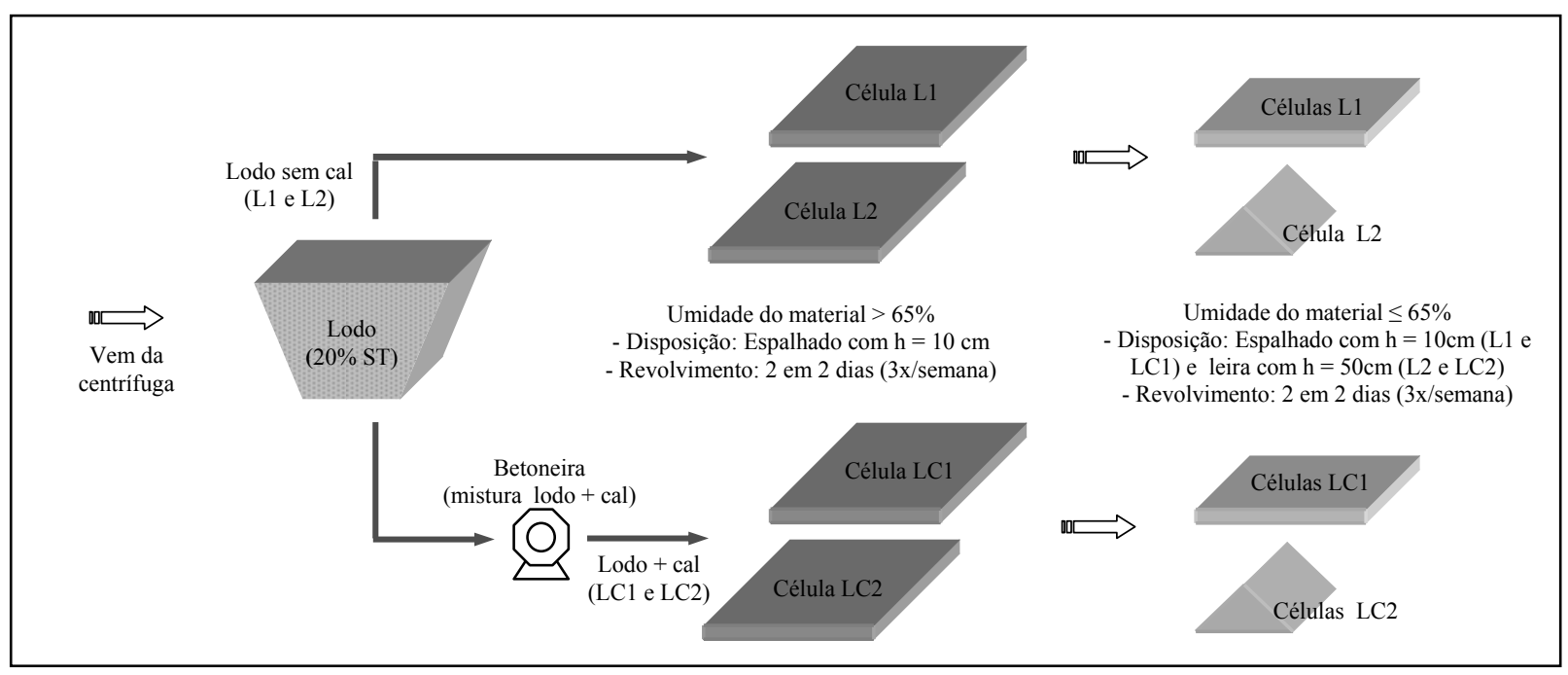

Figura 4.8 - Disposição do lodo nas células e período de revolvimento durante o Ciclo 2

\subsubsection{Desenvolvimento do Ciclo 3}

No Ciclo 3 as células L1 e LC1, inicialmente, tiveram o lodo espalhado em camada de $10 \mathrm{~cm}$ de altura como ocorrido nos ciclos anteriores, porém, nas células L2 e LC2, o lodo foi espalhado com altura de $20 \mathrm{~cm}$. Com essa configuração foi possível avaliar a otimização da área superficial ocupada pelo material dentro da estufa e, com isso, verificar a possibilidade de diminuir a área útil da estufa. A configuração adotada para a disposição do lodo nas células foi mantida até o final do ciclo. O revolvimento do material seguiu o procedimento adotado no Ciclo 2, ou seja, três vezes por semana durante todo o ciclo (FIGURA 4.9).

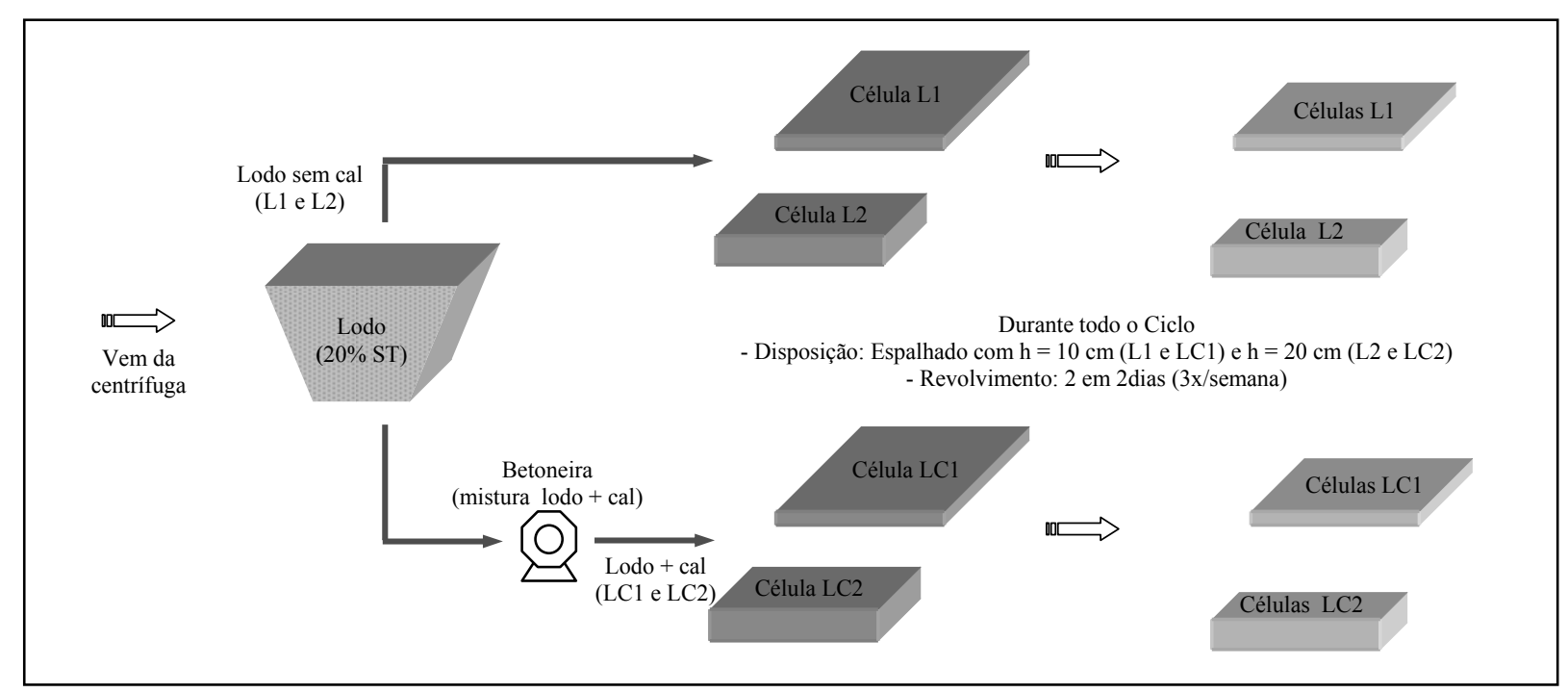

Figura 4.9 - Disposição do lodo nas células e período de revolvimento durante o Ciclo 3 
No QUADRO 4.1, encontram-se compiladas de forma resumida todas as informações referentes às condições metodológicas adotadas e os períodos em que foram realizados os três Ciclos das duas etapas.

Quadro 4.1 - Condições metodológicas adotadas e período de monitoramento de todos os ciclos das duas etapas

\begin{tabular}{|c|c|c|c|c|}
\hline \multirow{2}{*}{ Ciclo } & \multirow{2}{*}{$\begin{array}{l}\text { Forma de disposição lodo nas } \\
\text { células }\end{array}$} & \multirow{2}{*}{ Revolvimento do lodo } & \multicolumn{2}{|c|}{ Período } \\
\hline & & & Etapa 1 & Etapa 2 \\
\hline Ciclo 1 & $\begin{array}{l}\text { Primeiros } 14 \text { dias }- \text { lodo espalhado com } \\
\text { altura de } 10 \mathrm{~cm} \text { (L1, L2, LC1 e LC2). } \\
\text { A partir do } 14^{\circ} \text { dia }- \text { lodo em forma de } \\
\text { leira com } 50 \mathrm{~cm} \mathrm{de} \text { altura (L1, L2, LC1 e } \\
\text { LC2). }\end{array}$ & $\begin{array}{l}\frac{\text { Primeiros } 14 \text { dias }}{\text { vezes por semana. }} \text { três } \\
\frac{\text { A partir do } 14^{\circ} \text { dia }}{\text { vez por semana }} \text { uma } \\
\text { vem }\end{array}$ & $\begin{array}{l}29 / 01 / 2007 \\
\text { a } 09 / 04 / 2007 \\
\text { (70 dias) }\end{array}$ & $\begin{array}{c}12 / 12 / 2007 \\
\text { a } 20 / 02 / 2008 \\
(70 \text { dias })\end{array}$ \\
\hline Ciclo 2 & $\begin{array}{l}\text { Primeiros } 14 \text { dias }- \text { lodo espalhado com } \\
\text { altura de } 10 \mathrm{~cm} \text { (L1, L2, LC1 e LC2). } \\
\text { A partir do } 14^{\circ} \text { dia }- \text { lodo espalhado com } \\
\text { altura de } 10 \mathrm{~cm}(\mathrm{~L} 1 \mathrm{e} \text { LC1); lodo em } \\
\text { forma de leira com } 50 \mathrm{~cm} \text { de altura (L2 e } \\
\text { LC2). }\end{array}$ & $\frac{\text { Durante todo o Ciclo }}{\text { três vezes por semana. }}$ & $\begin{array}{l}18 / 04 / 2007 \\
\text { a } 20 / 06 / 2007 \\
\text { (63 dias) }\end{array}$ & $\begin{array}{c}12 / 03 / 2008 \\
\text { a } 25 / 05 / 2008 \\
\quad(70 \text { dias })\end{array}$ \\
\hline Ciclo 3 & $\begin{array}{l}\text { Durante todo o Ciclo - lodo espalhado } \\
\text { com altura de } 10 \mathrm{~cm} \text { (L1, LC1) e com } \\
\text { altura de } 20 \mathrm{~cm}(\mathrm{~L} 2, \mathrm{LC} 2) .\end{array}$ & $\frac{\text { Durante todo o Ciclo }}{\text { três vezes por semana. }}$ & $\begin{array}{l}05 / 07 / 2007 \\
\text { a } 12 / 09 / 2007 \\
\text { (70 dias) }\end{array}$ & $\begin{array}{c}04 / 06 / 2008 \\
\text { a } 13 / 08 / 2008 \\
\quad(70 \text { dias })\end{array}$ \\
\hline
\end{tabular}

Nota: Primeiros 14 dias, umidade acima de $65 \%$; a partir do $14^{\circ}$ dia, umidade igual ou inferior a $65 \%$.

Para facilitar o reconhecimento da metodologia adotada, foram utilizadas as seguintes simbologias: lodo espalhado com altura de $10 \mathrm{~cm}$ nos primeiros 14 dias e em forma de leira com altura de $50 \mathrm{~cm}$ a partir do $14^{\circ}$ dia $(10 \mathrm{~cm}$ e m); lodo espalhado com $10 \mathrm{~cm}$ de altura $(10 \mathrm{~cm})$; lodo espalhado com altura de $20 \mathrm{~cm}(20 \mathrm{~cm})$; lodo revolvido três vezes por semana nos primeiros 14 dias e, uma vez por semana, a partir do $14^{\circ}$ dia $(3 \mathrm{x}+1 \mathrm{x})$; lodo revolvido três vezes por semana $(3 \mathrm{x})$.

Sendo assim, tem-se: Ciclo $1(10 \mathrm{~cm}$ e $\mathrm{m} / 3 \mathrm{x}+1 \mathrm{x})$ para todas as células de lodo; Ciclo $2(10 \mathrm{~cm}$ e m/3x) para L2 e LC2, e $(10 \mathrm{~cm} / 3 x)$ para L1 e LC1; Ciclo $3(10 \mathrm{~cm} / 3 x)$ para L1 e LC1, e $(20 \mathrm{~cm} / 3 \mathrm{x})$ para L2 e LC2. 


\subsubsection{DETERMINAÇÃO DA QUANTIDADE DE CAL UTILIZADA EM CADA ETAPA DA PESQUISA}

Para o lodo utilizado na Etapa 1 (digerido), foram adicionadas quantidades de cal relativas às dosagens de 5\% (amostra 1/1), 10\% (amostra 2/1), 15\% (amostra 3/1), 20\% (amostra 4/1), $25 \%$ (amostra 5/1) e 30\% (amostra 6/1) em base seca de lodo para uma mesma quantidade de lodo (21,00 kg). E, para o lodo da Etapa 2 (não encaminhado ao digestor aeróbio), as dosagens foram de 5\% (amostra 1/2), 10\% (amostra 2/2), 15\% (amostra 3/2), 20\% (amostra 4/2), 25\% (amostra 5/2), 30\% (amostra 6/2), 35\% (amostra 7/2) e 40\% (amostra 8/2) em base seca de lodo, também, para uma mesma quantidade de lodo $(21,00 \mathrm{~kg})$. A faixa de dosagens testadas para o lodo da Etapa 2 foi aumentada por tratar-se de um lodo totalmente desconhecido.

Para a determinação da massa correspondente às dosagens de cal utilizadas nas duas etapas, foi estimado teor de Sólidos Totais (ST) do lodo desaguado igual a 20\% ST (valor aproximado para lodo desaguado em centrífuga), pois ainda não se tinham os resultados das análises de sólidos dos lodos estudados. Nesse caso, em razão do teor de sólidos considerado, adotou-se densidade do lodo de 1,05 (massa específica $1050 \mathrm{~kg} / \mathrm{m}^{3}$ ) (VON SPERLING; GONÇALVES, 2001). O valor real de ST foi obtido como a média calculada com base na determinação de ST de três diferentes amostras do mesmo lodo com massa igual a 21,00 kg cada amostra.

A cal usada no experimento foi a cal hidratada que apresenta, conforme informações do fabricante (Ical - Indústria de Calcinação LTDA), as seguintes características:

- Hidróxido de Cálcio $\left(\mathrm{Ca}[\mathrm{OH}]_{2}\right)$ - mínimo de 90\%;

- Substâncias reativas ao $\mathrm{HCL}\left(\mathrm{em}_{\mathrm{CaCO}}\right)$ - máximo de 5,5\%;

- Hidróxido de Magnésio $\left(\mathrm{Mg}[\mathrm{OH}]_{2}\right)$ - máximo de 2,2\%;

- Óxido de Ferro (em $\mathrm{Fe}_{2} \mathrm{O}_{3}$ ) - máximo de 0,2\%;

- Retido na peneira 100 Mesh - máximo 2,2\%;

- Limites máximos (mg/kg): - Arsênio 1,5; Cromo 7,6; Chumbo 1,5; Prata 7,6; Cádmio 0,76; Selênio 1,5; Dioxina e Furanos (ausentes). 
A escolha por se utilizar a cal hidratada e não a cal virgem baseou-se nos resultados apresentados por diversos autores que comprovaram que a elevação do $\mathrm{pH}$ é fator suficiente para higienização alcalina do lodo (CHRISTY, 1990; FRANCO-HERNANDEZ et al., 2001; MALTA, 2002; PEGORINI et al., 2006a; PEGORINI et al., 2006b; RAMIREZ; MALINA, 1980). Além disso, a própria Cesan optou Em contrapartida, o fato de a cal hidratada não promover a elevação da temperatura representa uma maior simplicidade e segurança no seu manuseio. Nesse caso, o percentual de hidróxido de cálcio da cal utilizada no experimento é maior que 90\%, sugerindo tratar-se de uma cal calcítica. Segundo Pegorini et al. (2006a) e Pegorini et al. (2006b), essas cales apresentam uma capacidade de reatividade superior quando comparadas às outras cales.

\subsection{MONITORAMENTO DA PESQUISA}

\subsubsection{PARÂMETROS MONITORADOS E METODOLOGIAS ANALÍTICAS USADAS}

Os parâmetros monitorados nas Etapas 1 e 2 da pesquisa foram:

- Potencial agronômico: carbono orgânico, fósforo total, nitrogênio total, cálcio, enxofre, manganês, boro, magnésio, sódio e potássio, $\mathrm{pH}$, umidade, sólidos totais e sólidos voláteis.

- Indicadores bacteriológicos e agentes patogênicos: coliformes termotolerantes, Salmonella sp., ovos viáveis de helmintos e vírus entéricos (somente na Etapa 2).

- Substâncias inorgânicas: arsênio, cádmio, cromo, cobre, mercúrio, molibidênio, níquel, chumbo, bário, selênio e zinco.

No caso específico das análises de vírus entéricos, não foi possível realizá-las durante a Etapa

1 , tendo em vista que os laboratórios estavam se adequando para atender às exigências do Conama (BRASIL, 2006c) e aqueles que o faziam apresentavam custos bastante elevados. Com a aprovação de projetos de pesquisa em órgãos de fomento à pesquisa, na Etapa 2, o Laboratório de Vírus Entéricos Humanos e Animais do Departamento de Microbiologia do Instituto de Ciências Biomédicas da USP realizou tais análises.

No QUADRO 4.2, encontram-se apresentadas as metodologias utilizadas na determinação dos parâmetros monitorados, bem como a frequência e os laboratórios responsáveis pelas análises. 
Quadro 4.2 - Parâmetros monitorados na pesquisa, frequência, métodos e laboratórios responsáveis

\begin{tabular}{|c|c|c|c|}
\hline Parâmetro & $\begin{array}{c}\text { Referência da } \\
\text { técnica analítica } \\
\end{array}$ & $\begin{array}{l}\text { Laboratório } \\
\text { responsável }\end{array}$ & $\begin{array}{c}\text { Freqüência das } \\
\text { análises }\end{array}$ \\
\hline Sólidos totais (umidade) e Sólidos voláteis & APHA, 1998 & \multirow{2}{*}{$\begin{array}{l}\text { CEFETES }^{(2)} \mathrm{e} \\
\text { LABSAN }^{(3)}\end{array}$} & \multirow{2}{*}{7 em 7 dias } \\
\hline $\mathrm{pH}$ & US EPA, 1980 & & \\
\hline Coliformes termotolerantes & APHA, 1998 & \multirow{2}{*}{ AGROLAB $^{(4)}$} & \multirow{3}{*}{$15 \mathrm{em} 15$ dias } \\
\hline Salmonella sp. & APHA 1992 & & \\
\hline Ovos viáveis de helmintos & $\begin{array}{c}\text { Thomaz-Soccol; } \\
\text { Paulino; Castro, 2000 }\end{array}$ & LABSAN & \\
\hline Vírus entéricos & $(*)$ & $\mathrm{USP}^{(5)}$ & $\begin{array}{l}\text { Início, meio e final de } \\
\text { cada ciclo }\end{array}$ \\
\hline Metais pesados & APHA, 1998 & LABSAN & $\begin{array}{c}\text { Início e final de cada } \\
\text { ciclo }\end{array}$ \\
\hline Carbono orgânico, N, P, K, Ca, S, Mg e Na & Embrapa, 1999 & INCAPER $^{(6)}$ & $\begin{array}{l}\text { Início e final de cada } \\
\text { ciclo }\end{array}$ \\
\hline
\end{tabular}

Nota: (1) - Todas as análises seguiram os critérios estabelecidos pela Resolução n ${ }^{0}$ 375/2006 do Conama ANEXO II (BRASIL, 2006c); (2) - Centro Federal de Educação Tecnológica do Espírito Santo; (3) - Laboratório de Saneamento da Universidade Federal do Espírito Santo; (4) AGROLAB Análise e Controle de Qualidade LTDA - laboratório particular; (5) - Instituto de Ciências Biomédicas II - USP (6) - Instituto Capixaba de Pesquisa, Assistência Técnica e Extensão Rural - Centro Regional de Desenvolvimento Rural Centro Serrano Venda Nova do Imigrante.

(*) - Os métodos para detecção de vírus estão descritos no corpo da tese.

A determinação do $\mathrm{pH}$ foi efetuada potenciometricamente em suspensão, água deionizadalodo; sólidos totais foram determinados com auxílio de estufa a $120^{\circ} \mathrm{C}$ e sólidos voláteis de mufla a $600^{\circ} \mathrm{C}$; os metais foram determinados pela técnica de Espectrometria de Absorção Atômica com Chama; no caso dos parâmetros agronômicos, a matéria orgânica foi determinada por oxidação; o nitrogênio, pelo método Kjeldahl; para o potássio e o fósforo foram usados extrator Mchelich, o cálcio extrator $\mathrm{KCl}$ e o enxofre extrator fosfato monocálcico em àcido acético; para a determinação de ovos viáveis de helmintos foi realizada, inicialmente, a contagem de ovos totais em Câmara de Sedwick e Ratter depois de a amostra ter sido diluída e centrifugada; em seguida, a viabilidade foi definida após incubação a $28^{\circ} \mathrm{C}$ por quatro semanas; coliformes termotolerantes pelo método de fermentação em Tubos Multíplos; e, Salmonella sp. pelo método de incubação. Nesse caso, as análises foram feitas em triplicatas.

Essa metodologias já estão difundidas e são realizadas rotineiramente nos laboratórios de análises ambientais no Brasil. Entretanto, a metodologia utilizada na detecção de vírus ainda não está disseminada e acessível a todos os laboratórios, por não existirem, ainda, no Brasil, estudos sistemáticos para avaliar a qualidade virológica de lodo de esgoto. Assim, optou-se por detalhar essa metodologia de forma resumida. 
Com relação às análises de vírus, de acordo com Mehnert (2008), foram usadas metodologias que se mostram mais factíveis e menos onerosas para a realização no Brasil, diferentemente da adotada pela US EPA (2003), que é complexa, demorada e difícil de ser implantada em larga escala. Apesar da observação feita por Mehnert sobre o custo das análises, percebe-se que ainda são bastante elevados para um monitoramento rotineiro do lodo a ser utilizado na agricultura.

Para a detecção de adenovírus foi usada reação em cadeia de polimerase (PCR); para vírus da hepatite A, reação de transcrição reversa e de reação em cadeia de polimerase (RT-PCR) e, para rotavírus, reação imunoperoxidase direta (IPx).

Os vírus foram selecionados com base na sua importância epidemiológica, uma vez que são responsáveis por grande número de casos de diarreia em crianças (rotavírus), hepatite A (HAV) e quadros diversos de diarreia, conjuntivites e problemas respiratórios (adenovírus). Além disso, todos esses vírus são de excreção fecal prolongada e são muito resistentes às condições ambientais e aos tratamentos das águas residuárias usualmente adotados no país, sendo detectados nos mais diversos tipos de águas ao longo de todo o ano, não apresentando uma variação sazonal (BARRELA, 2008; GARRAFA, 2009)

Os protocolos experimentais utilizados para a determinação dos vírus entéricos monitorados, adenovírus, vírus da Hepatite A (VHA) e rotavírus, foram:

Processamento das amostras: a detecção de vírus entéricos humanos (adenovírus e vírus da Hepatite A) foi realizada conforme método descrito por Ahmed e Sorensen (1995), com modificações de Barrella (2008), que se baseiam na adsorção e eluição utilizando solução proteica de extrato de carne a 3\% e glicina 0,05M com pH 9 (Difco ${ }^{\mathrm{TM}}$ Extract, Le Pont de Claix, France). Até a sua utilização, as amostras ficaram estocadas em refrigerador apropriado a $20^{\circ} \mathrm{C}$ negativos.

\section{Detecção e quantificação de patógenos virais:}

- Detecção de adenovírus (PCR) e vírus da Hepatite A (RT-PCR): a extração de RNA (Hepatite A) e DNA (Adenovírus) foi realizada utilizando-se solução de fenol (Trizol®, BRL/ Life Technologies) e clorofórmio, obedecendo às instruções do fabricante. Para a detecção dos adenovírus pelo PCR, utilizou-se o par de primers hex AA1885 e hex AA1913, que 
amplifica o gene da proteína hexon, comum a todos os adenovírus, originando uma sequência de 301 pares de base (ALLARD; ALBISSON; WANDELL, 1990). A reação de Nested-PCR foi realizada como ensaio confirmatório utilizando o par de primers, nehexAA1893 e nehexAA1905, para amplificação de um fragmento de 143 pares de bases (ALLARD; ALBISSON; WADELL, 1992). Para a detecção do vírus da Hepatite A foi utilizado o par desenhado por De Leon et al. (1990) com modificações inseridas por Sassaroli (2002). As amostras foram estocadas a $20^{\circ} \mathrm{C}$ negativos até o momento de uso.

- Detecção e quantificação de rotavírus por reação Imunoperoxidase Direta (IPx): a detecção e a quantificação dos rotavírus presentes nas amostras de lodo foi realizada pela reação de Imunoperoxidase Direta (IPx), utilizando soro de coelho antirrotavírus conjugado com peroxidase. As células utilizadas nos ensaios de quantificação foram as de linhagem MA-104 (células de linhagem estabelecida de rim fetal de macaco verde africano) (MEHNERT; STEWIEN, 1993).

Determinação de infectividade viral: Para os adenovírus foi realizado, também, teste de infectividade que, nesse caso, em razão do método usado, possibilita confirmar a presença não somente desse vírus, como também de outros vírus do gênero Enterovírus. Para tanto, foram realizados ensaios em cultura celular, utilizando microtécnica (LENNETTE; SCHMIDT, 1979) que consistiu em: (1) inocular alíquotas de $100 \mu \mathrm{L}$ das amostras a cada uma de duas cavidades que contém monocamada celular de HEp-2 previamente cultivadas; (2) adicionar Meio Mínimo Essencial Eagle para um volume final de $200 \mu \mathrm{L}$, após a adsorção viral a $37^{\circ} \mathrm{C}$ por uma hora; (3) manter células não inoculadas como controle; (4) manter as culturas em câmaras únicas a $37^{\circ} \mathrm{C}$ e observar diariamente ao microscópio, por um período de 7 dias, para a detecção de efeito citopático.

De acordo com Barrela (2008), a metodologia utilizada para a deteção de adenovírus recupera cerca de $10 \%$ de adenovírus tipo 5 (HAdV-5).

Além dos parâmetros apresentados no QUADRO 4.2, foram monitorados: (1) as temperaturas dentro e fora da estufa, diariamente, num intervalo de tempo de 30 minutos, com auxílio de termômetro digital, obtidas a uma altura aproximada de 2,00 $\mathrm{m}$ do nível do piso; (2) o comportamento da densidade do lodo durante o experimento, para obter informações sobre as variações da massa e do volume do material, que poderão auxiliar na definição de equipamentos e veículos a serem utilizados no gerenciamento do material. 
Para o cálculo da densidade, utilizou-se dos cálculos apresentadas por Tchobanoglous, Burton e Stensel (2002). Com base nos valores de sólidos totais, sólidos voláteis, sólidos fixos e no teor de umidade, é possível determinar a densidade dos sólidos contidos no lodo e assim, determinar a densidade do lodo (sólidos e água). A expressão básica utilizada foi:

$$
\frac{W S}{S s \times \rho w}=\frac{W f}{S f \times \rho w}+\frac{W v}{S v \times \rho w}
$$

onde:

$W_{S} \quad=$ Massa de sólidos

Ss $\quad=$ Gravidade específica de sólidos

$\rho w \quad=$ Densidade da água

$W f \quad=$ Massa de sólidos fixos

Sf = Gravidade específica de sólidos fixos

$W v \quad=$ Massa de sólidos voláteis

So $=$ Gravidade específica de sólidos voláteis

\subsubsection{COLETA DAS AMOSTRAS}

O monitoramento dos parâmetros foi realizado para o lodo de cada célula, ou seja, L1, L2, LC1 e LC2, utilizando-se de uma amostra composta, obtida de 8 amostras simples, retiradas em posições e profundidades diferentes do material disposto nas células. Essas amostras foram, então, misturadas (homogeneizadas) e, em seguida, efetuou-se o quarteamento (ASSOCIAÇÃO, 2004b) para a obtenção da amostra representativa com aproximadamente $2,00 \mathrm{~kg}$.

As amostras foram coletadas com extremo rigor experimental para que não houvesse nenhumr problema relacionado à contaminação delas. Baldes, bacias e espátulas específicas auxiliaram na coleta. Após a coleta da amostra de lodo de uma célula, os recipientes/instrumentos eram devidamente lavados em água corrente para o procedimento de coleta da célula seguinte. Para as análises dos parâmetros biológicos, as coletas seguiram as recomendações apresentadas por US EPA (2003), de acordo com a Resolução n ${ }^{0}$ 375/2006 do Conama (BRASIL, 2006c) e instruções dos laboratórios responsáveis pelas análises. 
Todas as amostras eram transportadas aos laboratórios em caixas de isopor, usadas somente para esse fim, logo após a coleta e o acondicionamento delas em sacos plásticos específicos, esterilizados. Apenas as amostras encaminhadas para as análises de vírus eram congeladas e despachadas pelos correios para o laboratório da USP. Nesse caso, foi utilizada caixa de isopor, na qual as amostras eram dispostas e envolvidas em gelo para impedir o descongelamento delas.

Diferentemente dos outros organismos monitorados na pesquisa, no caso dos vírus foram coletadas amostras no início, no meio e no final de cada ciclo da Etapa 2. As amostras intermediárias (no meio do ciclo) eram coletadas após ter transcorrido, aproximadamente, metade do tempo total esperado para cada ciclo. A periodicidade reduzida em relação aos demais organismos foi em virtude dos custos ainda elevados das análises laboratoriais para a detecção de vírus entéricos.

\subsection{AVALIAÇÃO ESTATÍSTICA DOS RESULTADOS OBTIDOS}

Para avaliar o comportamento das características do lodo durante o experimento levando-se em consideração as diferentes variáveis testadas, foi utilizada estatística descritiva e inferencial. Para cada avaliação estatística verificou-se variação dos parâmetros monitorados nos tempos 0 a 70 dias, segundo os seguintes fatores de variação:

a) Tipo de lodo - lodo digerido e não encaminhado ao digestor (digerido e não digerido).

b) Cal - lodo sem cal e lodo com adição de cal (sem cal e com cal).

c) Modo de disposição/revolvimento - modo de disposição do lodo nas células e período de revolvimento. Nesse caso foram adotadas as mesmas simbologias apresentadas no item 4.2.1.

Na TABELA 4.6 estão apresentados os diferentes fatores de variação e categorias utilizados na avaliação estatística, bem como os respectivos números de eventos planejados e realizados no tempo para os diversos parâmetros, respeitando o plano experimental definido. 
Tabela 4.6 -Número de eventos planejados e realizados no tempo para os diversos parâmetros em função dos diferentes fatores de variação e categorias utilizados na avaliação estatística dos resultados

\begin{tabular}{|c|c|c|c|c|c|c|c|c|c|c|c|c|c|c|}
\hline \multirow{3}{*}{$\begin{array}{c}\text { Fator de } \\
\text { variação }\end{array}$} & \multirow{3}{*}{ Categoria } & \multirow{3}{*}{\multicolumn{2}{|c|}{ Parâmetro }} & \multicolumn{11}{|c|}{ Número de eventos planejados e realizados para cada tempo } \\
\hline & & & & \multicolumn{11}{|c|}{ Tempo (dia) } \\
\hline & & & & $\mathbf{0}$ & 7 & 14 & 21 & 28 & 35 & 42 & 49 & 56 & 63 & 70 \\
\hline \multirow{11}{*}{ Tipo lodo } & \multirow{6}{*}{ Digerido } & \multicolumn{2}{|c|}{ Planejado } & 12 & 12 & 12 & 12 & 12 & 12 & 12 & 12 & 12 & 12 & 12 \\
\hline & & \multirow{5}{*}{ Realizado } & Umidade & 12 & 12 & 12 & 8 & 12 & 12 & 12 & 12 & 8 & 12 & 8 \\
\hline & & & $\mathrm{SV} / \mathrm{ST}$ & 12 & 12 & 12 & 8 & 12 & 12 & 10 & 12 & 5 & 12 & 8 \\
\hline & & & $\mathrm{pH}$ & & & & & & & & & & & \\
\hline & & & $\mathrm{CTt}^{(1)}$ & 12 & - & 12 & - & 12 & - & 10 & - & 8 & - & 12 \\
\hline & & & $\mathrm{OVH}^{(2)}$ & 12 & - & 12 & - & 12 & - & 12 & - & 8 & - & 12 \\
\hline & \multirow{5}{*}{$\begin{array}{l}\text { Não submetido } \\
\text { à digestão }\end{array}$} & \multicolumn{2}{|c|}{ Planejado } & 12 & 12 & 12 & 12 & 12 & 12 & 12 & 12 & 12 & 12 & 12 \\
\hline & & & Umidade & 12 & 12 & 12 & 12 & 12 & 12 & 8 & 12 & 4 & 12 & 12 \\
\hline & & Realizado & $\begin{array}{c}\mathrm{SV} / \mathrm{ST} \\
\mathrm{pH}\end{array}$ & 12 & 12 & 11 & 12 & 11 & 11 & 8 & 11 & 4 & 12 & 12 \\
\hline & & & $\mathrm{CTt}$ & 12 & - & 12 & - & 12 & - & $8(*)$ & - & $4\left(^{*}\right)$ & - & 12 \\
\hline & & & $\mathrm{OVH}$ & 12 & - & 12 & - & 12 & - & 8 & - & 4 & - & 12 \\
\hline \multirow{12}{*}{ Uso cal } & \multirow{6}{*}{ Sem cal } & \multicolumn{2}{|c|}{ Planejado } & 12 & 12 & 12 & 12 & 12 & 12 & 12 & 12 & 12 & 12 & 12 \\
\hline & & \multirow{5}{*}{ Realizado } & Umidade & 12 & 12 & 12 & 10 & 12 & 12 & 10 & 10 & 6 & 12 & 10 \\
\hline & & & $\mathrm{SV} / \mathrm{ST}$ & & & 11 & 10 & & & 9 & 11 & 5 & & 10 \\
\hline & & & $\mathrm{pH}$ & & & & & & & & & & & \\
\hline & & & $\mathrm{CTt}$ & 12 & - & 12 & - & 12 & - & $9(*)$ & - & $6\left(^{*}\right)$ & - & 12 \\
\hline & & & $\mathrm{OVH}$ & 12 & - & 12 & - & 12 & - & 10 & - & 6 & - & \\
\hline & \multirow{6}{*}{ Com cal } & \multicolumn{2}{|c|}{ Planejado } & 12 & 12 & 12 & 12 & 12 & 12 & 12 & 12 & 12 & 12 & 12 \\
\hline & & & Umidade & 12 & 12 & 12 & 10 & 12 & 12 & 10 & 10 & 6 & 12 & 10 \\
\hline & & & $\mathrm{SV} / \mathrm{ST}$ & 12 & 12 & 12 & 10 & 11 & 11 & 9 & 12 & 4 & 12 & 10 \\
\hline & & Realizado & $\mathrm{pH}$ & & & & & & & & & & & \\
\hline & & & CTt & 12 & - & 12 & - & 12 & - & $9(*)$ & - & 6 & - & 12 \\
\hline & & & $\mathrm{OVH}$ & 12 & - & 12 & - & 12 & - & 10 & - & 6 & - & 12 \\
\hline & & & & 8 & 8 & 8 & 8 & 8 & 8 & 8 & 8 & 8 & 8 & 8 \\
\hline & & & Umidade & 12 & 12 & 12 & 4 & 12 & 12 & 12 & 12 & 4 & 12 & 12 \\
\hline & $10 \mathrm{~cm}+\mathrm{m} / 3 \mathrm{x}+1 \mathrm{x}$ & & $\mathrm{SV} / \mathrm{ST}$ & 12 & 12 & 12 & 4 & 7 & 7 & 12 & 12 & 4 & 12 & 12 \\
\hline & & Realizado & $\mathrm{pH}$ & & & & & & & & & & & \\
\hline & & & $\mathrm{CTt}$ & 12 & - & 12 & - & 12 & - & 12 & - & 4 & - & 12 \\
\hline & & & $\mathrm{OVH}$ & 12 & - & 12 & - & 12 & - & 12 & - & 4 & - & 12 \\
\hline & & & & 4 & 4 & 4 & 4 & 4 & 4 & 4 & 4 & 4 & 4 & 4 \\
\hline & & & Umidade & 12 & 12 & 12 & 12 & 12 & 12 & 2 & 12 & 2 & 12 & 2 \\
\hline & $10 \mathrm{~cm}+\mathrm{m} / 3 \mathrm{x}$ & & $\mathrm{SV} / \mathrm{ST}$ & 12 & 12 & 3 & 12 & 12 & 12 & 2 & 12 & 2 & 12 & 2 \\
\hline & ה & Realizado & $\mathrm{pH}$ & & & & & & & & & & & \\
\hline & & & $\mathrm{CTt}$ & 12 & - & 12 & - & 12 & - & * & - & 2 & - & 12 \\
\hline Disposição/ & & & $\mathrm{OVH}$ & 12 & - & 12 & - & 12 & - & 2 & - & 2 & - & 12 \\
\hline Revolvimento & & & & 8 & 8 & 8 & 8 & 8 & 8 & 8 & 8 & 8 & 8 & 8 \\
\hline & & & Umidade & 12 & 12 & 12 & 12 & 12 & 12 & 6 & 12 & 4 & 12 & 6 \\
\hline & $10 \mathrm{~cm} / 3 \mathrm{x}$ & & $\mathrm{SV} / \mathrm{ST}$ & 12 & 12 & 12 & 12 & 12 & 12 & 4 & 12 & 3 & 12 & 6 \\
\hline & & Realizado & $\mathrm{pH}$ & & & & & & & & & & & \\
\hline & & & $\mathrm{CTt}$ & 12 & - & 12 & - & 12 & - & $4\left(^{*}\right)$ & - & $4\left(^{*}\right)$ & - & 12 \\
\hline & & & $\mathrm{OVH}$ & 12 & - & 12 & - & 12 & - & 6 & - & 4 & - & 12 \\
\hline & & & & 4 & 4 & 4 & 4 & 4 & 4 & 4 & 4 & 4 & 4 & 4 \\
\hline & & & Umidade & 12 & 12 & 12 & 12 & 12 & 12 & 12 & 12 & 2 & 12 & 12 \\
\hline & $20 \mathrm{~cm} / 3 \mathrm{x}$ & & $\mathrm{SV} / \mathrm{ST}$ & 12 & 12 & 12 & 12 & 12 & 12 & 12 & 3 & 2 & 12 & 12 \\
\hline & & Realizado & $\mathrm{pH}$ & & & & & & & & & & & \\
\hline & & & $\mathrm{CTt}$ & 12 & - & 12 & - & 12 & - & 12 & - & $2\left(^{*}\right)$ & - & 12 \\
\hline & & & $\mathrm{OVH}$ & 12 & - & 12 & - & 12 & - & 12 & - & 2 & - & 12 \\
\hline
\end{tabular}

Nota: (1) CTt - Coliforme termotolerante; (2) OVH - Ovos viáveis de helmintos; (*) Não houve imputação de valores.

Nos casos em que o número de eventos realizados foi menor que os planejados, utilizaram-se do artifício de imputação de dados com os seguintes critérios: 
- nos tempos intermediários os dados faltantes foram substituídos pela média do tempo anterior e posterior. Nesses casos, supôs-se que o decaimento ao longo do tempo é linear.

- no último tempo o valor do tempo anterior foi repetido. Nesse caso, a interrupção do experimento ocorreu em virtude de já se ter obtido a umidade esperada.

Para o parâmetro coliforme termotolerante os valores imputados acontecerem apenas nos casos em que a concentração já havia se estabilizado, ou seja, as concentrações do tempo anterior e posterior eram menores que 3,6 NMP/gST. Porém, optou-se por não imputar valores em quatro amostras no $42^{\circ}$ dia e duas no $56^{\circ}$ dia por não apresentarem um decaimento linear.

Sendo assim, o número de medidas planejadas, imputadas e não imputadas para cada parâmetro avaliado encontram-se na TABELA 4.7.

Tabela 4.7 -Número de medidas planejadas, imputadas, não imputadas e respectivos percentuais para os parâmetros avaliados estatisticamente

\begin{tabular}{cccccc}
\hline Parâmetro & \multirow{2}{*}{$\begin{array}{c}\text { Número de medidas } \\
\text { planejadas }\end{array}$} & $\begin{array}{c}\text { Número de } \\
\text { medidas } \\
\text { imputadas }\end{array}$ & $\begin{array}{c}\text { Número de } \\
\text { medidas não } \\
\text { imputadas }\end{array}$ & \multicolumn{2}{c}{ Percentual (\%) } \\
\cline { 5 - 6 } & $264(24 \times 11)$ & 24 & - & 9,10 & Imputado \\
Não imputado \\
\hline Umidade & $264(24 \times 11)$ & 30 & - & 11,36 & - \\
$\mathrm{pH} / \mathrm{ST}$ & $264(24 \times 11)$ & & - & & - \\
$\begin{array}{c}\text { Coliforme } \\
\text { termotolerante }\end{array}$ & $144(24 \times 6)$ & 12 & 6 & 8,33 & 4,17 \\
$\begin{array}{c}\text { Ovos viáveis de } \\
\text { helmintos }\end{array}$ & $144(24 \times 6)$ & 16 & - & 11,11 & - \\
\hline
\end{tabular}

$\mathrm{Na}$ estatística descritiva, a partir das médias e desvios padrões, verificou-se a variação dos parâmetros nos tempos de 0 a 70 dias, segundo os fatores de variação avaliados. Já na estatística inferencial foram realizadas ANOVAS para medida repetida ao longo do tempo para os mesmos fatores de variação. Foram realizados testes a posteriori de Tukey para identificar as diferenças estatisticamente significantes dois a dois. O nível de significância adotado foi de 5\%. Os parâmetros analisados foram umidade, $\mathrm{pH}$, relação $\mathrm{SV} / \mathrm{ST}$, coliformes termotolerantes e ovos viáveis de helmintos. Para os parâmetros de interesse agronômico foram realizados testes $\mathrm{t}$ para amostras pareadas para comparar as médias obtidas no início e no final dos ciclos de cada etapa. No caso dos íons metálicos foi utilizada apenas estatística 
descritiva para comparar as médias no início e no final dos ciclos de cada etapa, por apresentarem resultados sempre muito baixos quando comparados com os limites estabelecidos pelo Conama. Não foram avaliados os parâmetros Salmonella sp., por apresentar resultados qualitativos e terem apresentado ausência na maioria das amostras; e, vírus entéricos por terem sido monitorados apenas na Etapa 2.

\subsection{ESTIMATIVA DA ÁREA E DO CUSTO DE INVESTIMENTO DA ESTUFA}

A definição das condições ideais para a estimativa das dimensões da estufa foi estabelecida ponderando-se as circunstâncias testadas a partir dos resultados obtidos no experimento, tratados estatisticamente, e dados de projeto. Foi calculada a área necessária de estufa para o tratamento do lodo gerado em cada ETE, separadamente. Essa condição foi estabelecida pela própria CESAN.

$\mathrm{Na}$ avaliação, levou-se em consideração, o enquadramento do material como Classe $\mathrm{A}$, de acordo com o Conama (BRASIL, 2006c) e as condições favoráveis para um melhor gerenciamento do lodo. Aspectos como a operacionalização do sistema; a otimização da área da estufa; e o volume final do biossólido após a secagem, que interferirá nas etapas seguintes do seu gerenciamento, inclusive, o transporte, foram avaliados.

Assim, foi possível definir o tempo de secagem, a forma de disposição do lodo, o período de revolvimento, o tipo de lodo a ser usado, a condição de adicionar cal ou não ao lodo, os teores de ST inicial e final, o volume a ser encaminhado para a estufa e o volume final de lodo após secagem na etufa.

De possa das dimensões das estufas foi realizado contato com a empresa especializada na montagem de estufa agrícola para que avaliasse os custos necessários para a construção e instalação das estufas, além do equipamento necessário para espalhamento e revolvimento do lodo. 


\section{RESULTADOS}

Os resultados são apresentados separadamente de acordo com o tipo de lodo usado, ou seja, lodo digerido (Etapa 1) e lodo não encaminhado ao digestor (Etapa 2). Para cada etapa são exibidos os resultados do comportamento, no tempo, dos lodos sem cal (L1 e L2) e com cal dos três ciclos. No capítulo de discussões, Capítulo 6, esses foram usados como dados para subsidiar a comparação entre as duas etapas na análise estatísitica empregada.

\subsection{ETAPA 1 - LODO DIGERIDO}

O lodo usado na Etapa 1 foi submetido a todas as operações de tratamento da fase sólida realizadas rotineiramente na ETE. As características físicas apresentadas pelo lodo foram satisfatórias para possibilitar grande facilidade no seu manuseio, não apresentando problemas que pudessem dificultar a montagem e o preparo das células de lodo dentro da estufa. Também, não ocorreu nenhum inconveniente decorrente do surgimento de odores ofensivos, causados pela putrefação de organismos presentes no lodo, mostrando que se tratava de material com elevado nível de estabilização.

Durante a primeira semana do desenvolvimento dos ciclos percebeu-se um forte odor dentro da estufa, efeito da volatilização da amônia, resultante da adição da cal ao lodo. O odor foi facilmente controlado com a abertura das janelas e porta que possibilitavam uma melhor circulação do ar. Houve, também, o aparecimento de áreas esbranquiçadas (fungos) que desapareceram já nos próximos dias com o revolvimento do lodo.

Nas duas primeiras semanas dos ciclos, os elevados teores de umidade do material dificultaram a operação de revolvimento, principalmente o fundo da camada de lodo em que a umidade era maior. Nessa fase, o revolvimento, mesmo manual, foi bastante criterioso para possibilitar uma homogeneização completa do material.

Ao longo do experimento, com a secagem do material, observou-se que o biossolido sem cal (L1 e L2) apresentava torrões bastante enrijecidos e grandes (com diâmetro aproximado de três centímetros), muitas vezes difícil de ser rompido; em contrapartida, os torrões resultantes no lodo com cal eram menores e mais quebradiços. 


\subsubsection{DETERMINAÇÃO DA QUANTIDADE DE CAL A SER USADA NA ETAPA 1}

Os dados usados para a determinação da quantidade de cal foram os seguintes:

- Massa da amostra de lodo utilizada nos testes $(\mathrm{m})=21,00 \mathrm{~kg}$;

- Teor de sólidos totais inicial $\left(\mathrm{ST}_{\mathrm{i}}\right)=20 \%$;

- Teores de cal inicialmente considerados $\left(\mathrm{T}_{\text {cal }}\right)=5 \%, 10 \%, 15 \%, 20 \%, 25 \%$ e $30 \%$ em base seca

\subsubsection{Cálculo da massa de cal considerando $S T_{i}=20 \%$}

$$
\mathrm{M}_{\mathrm{cal}}=\mathrm{M}_{\text {sólidos }} \mathrm{x}\left(\mathrm{T}_{\mathrm{cal}} / 100\right)
$$

onde:

$\mathrm{M}_{\mathrm{cal}} \quad=$ Massa de cal $(\mathrm{kg})$

$\mathrm{M}_{\text {sólidos }}=$ Massa de sólidos em amostra de lodo com $20 \% \mathrm{ST}_{\mathrm{i}}(\mathrm{kg})$

$\mathrm{T}_{\mathrm{cal}}=$ Teor de cal inicialmente considerado $(\%)$

Nesse caso:

$\mathrm{M}_{\text {sólidos }}=\mathrm{mx}\left(\mathrm{ST}_{\mathrm{i}} / 100\right) \quad \Rightarrow \quad \mathrm{M}_{\text {sólidos }}=21 \times 0,2$

$\mathrm{M}_{\text {sólidos }}=4,2 \mathrm{~kg}$

Logo, para $\mathrm{T}_{\text {cal }}=5 \%$ em base seca (eq. (5.1)):

$\mathrm{M}_{\text {cal }}=\mathrm{M}_{\text {sólidos }} \mathrm{x}\left(\mathrm{T}_{\text {cal }} / 100\right) \quad \Rightarrow \quad \mathrm{M}_{\text {cal }}=4,2 \times 0,05$

$\mathbf{M}_{\text {cal }}=\mathbf{0 , 2 1} \mathbf{~ k g}$ (para 5\% de teor de cal em base seca - amostra 1$)$

Portanto, para $21 \mathrm{~kg}$ de lodo com 20\% de Sólidos Totais, tem-se uma massa de sólidos de 4,2 $\mathrm{kg}$ de ST (base seca). Nesse caso, considerando 5\% de teor de cal em base seca, é necessário usar $0,21 \mathrm{~kg}$ de cal. Para a determinação da massa de cal a ser adicionada ao lodo para os outros percentuais, ou seja, 10\%, 15\%, 20\%, 25\% e 30\%, utilizou-se a mesma base de cálculo apresentada para o teor de 5\%, obtendo-se, respectivamente, os seguintes resultados: 0,42; 0,$63 ; 0,84 ; 1,05$ e $1,26 \mathrm{~kg}$ de cal.

\subsubsection{Cálculo do teor de sólidos totais real}

$\mathrm{O}$ teor de $\mathrm{ST}_{\mathrm{r}}$ foi calculado com base na média dos valores obtidos de ST de três amostras diferentes de lodo de massas iguais. Com os resultados de sólidos das amostras 
$\mathrm{A}_{1}(\mathrm{ST}=15,3 \%), \mathrm{A}_{2}(\mathrm{ST}=15,5 \%)$ e $\mathrm{A}_{3}(\mathrm{ST}=15,8 \%)$, foi obtido o valor médio de $15,5 \%$ ST. De posse desse valor, foi possível determinar o percentual de cal na base seca, efetivamente, usado no teste (TABELA 5.1).

\subsubsection{Cálculo do teor de cal real para 15,5\% ST}

Para o cálculo do teor de cal real, utiliza-se a eq.(5.1), onde:

$\mathrm{M}_{\mathrm{cal}}=\mathrm{M}_{\text {sólidos }} \mathrm{x}_{\mathrm{cal}} \quad \Rightarrow \quad \mathrm{T}_{\text {cal real }}=\left(\mathrm{M}_{\mathrm{cal}} / \mathrm{M}_{\text {sólidos real }}\right) \mathrm{x} 100$

onde:

$\mathrm{M}_{\mathrm{cal}} \quad=$ Massa de cal para $15,5 \% \mathrm{ST}_{\mathrm{r}}((\mathrm{kg})$

$\mathrm{M}_{\text {sólidos real }}=$ Massa de sólidos real na amostra de lodo com 15,5\% ST(kg)

Nesse caso:

$\mathrm{M}_{\text {sólidos real }}=\mathrm{m} \times\left(\mathrm{ST}_{\mathrm{r}} / 100\right) \quad \Rightarrow \quad \mathrm{M}_{\text {sólidos real }}=21 \times 0,155$

$\mathrm{M}_{\text {sólidos real }}=3,26 \mathrm{~kg}$

Logo, para $\mathrm{M}_{\text {cal }}=0,21 \mathrm{~kg}$ (item 5.1.1.1):

$\mathrm{T}_{\text {cal real }}=\left(\mathrm{M}_{\text {cal }} / \mathrm{M}_{\text {sólidos real }}\right) \mathrm{x} 100 \quad \Rightarrow \quad \mathrm{T}_{\text {cal real }}=(0,21 / 3,26) \times 100$

$\mathbf{T}_{\text {cal real }}=\mathbf{6 , 5 \%}$ (teor de cal realmente usado na amostra 1 em base seca)

Então, 0,21 kg de cal corresponde a um teor real de cal igual a 6,5\% em base seca, considerando o lodo com $15,5 \%$ ST. Para a determinação do teor de cal real para as outras quantidades usadas, ou seja, 0,$42 ; 0,63 ; 0,84 ; 1,05$ e $1,26 \mathrm{~kg}$, utilizou-se a mesma base de cálculo apresentada para a massa de $0,21 \mathrm{~kg}$ de cal, obtendo-se, respectivamente, os seguintes resultados: 12,$9 ; 19,4 ; 25,8 ; 32,3 ; 38,7 \%$ de cal em base seca.

Na TABELA 5.1, estão apresentadas as quantidades de cal determinadas segundo os cálculos desenvolvidos anteriormente, bem como o $\mathrm{pH}$ obtido inicialmente, e 2 horas e 24 horas após a mistura, determinados em laboratório. Considerando que a cal usada contém cerca de $90 \%$ de hidróxido de cálcio, são apresentados, também, os teores de $\mathrm{Ca}[\mathrm{OH}]_{2}$ adicionados ao lodo para as diferentes dosagens de cal.

De acordo com os resultados obtidos, a amostra 1 (6,5\% de cal em base seca) e a amostra 2 $(12,9 \%$ de cal em base seca) apresentaram valores inferiores aos recomendados pela legislação. Acima de 19,4\% de cal os valores de pH foram sempre superiores a 13 (TABELA 5.1). Os valores determinados depois de 24 horas do início do experimento para as dosagens acima de $12,9 \%$ de cal em base seca foram superiores a 11,5. 
Tabela 5.1 - Teores de cal testados e respectivos valores de $\mathrm{pH}$ para a determinação da quantidade de cal a ser adicionada ao lodo da Etapa 1 nos diferentes tempos definidos pela Resolução 375/2006 do

Conama

\begin{tabular}{|c|c|c|c|c|c|c|}
\hline \multirow{2}{*}{ 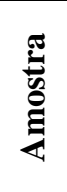 } & \multicolumn{2}{|c|}{$\begin{array}{l}\text { Quantidade de cal } \\
\text { em massa seca } \\
\text { (ST = 15,5\%) }\end{array}$} & \multirow{2}{*}{$\begin{array}{c}\text { Quantidade } \mathrm{Ca}(\mathrm{OH})_{2} \text { em } \\
\text { massa seca }(\mathrm{ST}=15,5 \%) \\
(\%)\end{array}$} & \multicolumn{3}{|c|}{$\begin{array}{l}\text { pH Mistura } \\
\text { (lodo + cal) }\end{array}$} \\
\hline & $(\%)$ & (kg) & & Inicial & 2h depois & $24 \mathrm{~h}$ depois ${ }^{(1)}$ \\
\hline $1 / 1$ & 6,5 & 0,21 & 5,85 & 9,65 & 9,60 & 9,58 \\
\hline $2 / 1$ & 12,9 & 0,42 & 11,61 & 11,77 & 11,72 & 11,62 \\
\hline $3 / 1$ & 19,4 & 0,63 & 17,46 & Acima de 13 & Acima de 13 & 12,80 \\
\hline $4 / 1$ & 25,8 & 0,84 & 23,22 & Acima de 13 & Acima de 13 & Acima de 13 \\
\hline $5 / 1$ & 32,3 & 1,05 & 29,07 & Acima de 13 & Acima de 13 & Acima de 13 \\
\hline $6 / 1$ & 38,7 & 1,26 & 34,83 & Acima de 13 & Acima de 13 & Acima de 13 \\
\hline
\end{tabular}

NOTA: $\mathrm{pH}$ do lodo digerido sem adição de cal $=6,52$; densidade adotada para ST de $20 \%=1,05$; $^{(1)}$ Tempo referente ao início da mistura; $\mathrm{pH}$ com valores acima de 13 foram em razão da detecção do equipamento usado.

Com o auxílio do GRÁFICO 5.1, pode-se definir qual o percentual de cal necessário para atender às exigências legais. Nesse caso, apesar de o menor valor encontrado apresentar-se entre $14 \%$ e $15 \%$, adotou-se o teor de $15 \%$ de cal em base seca, como margem de segurança para uma possível variação do teor de sólidos decorrentes dos procedimentos operacionais da ETE, como também, perda da cal durante a mistura com o lodo. Sendo assim, a quantidade de $\mathrm{Ca}[\mathrm{OH}]_{2}$ adicionada em massa seca de lodo foi de $13,5 \%$.

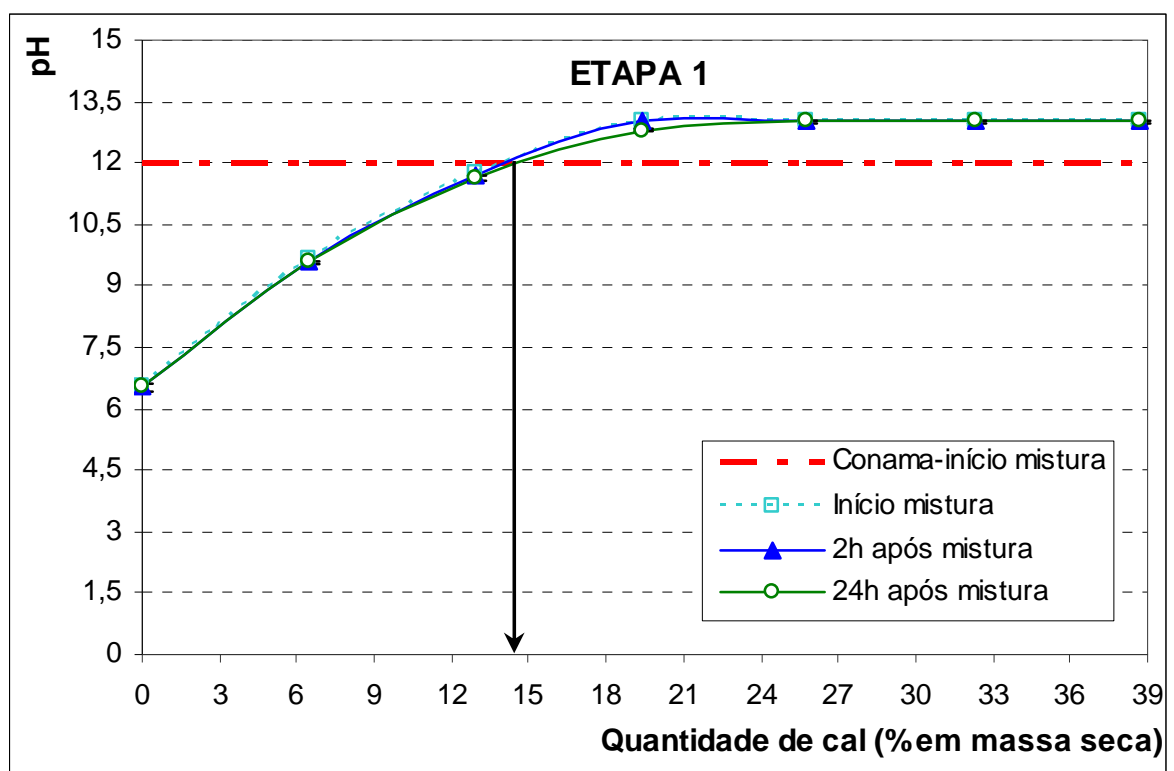

Gráfico 5.1 - Valores de pH considerando diferentes porcentagem de cal, para o lodo da Etapa 1

A quantidade de cal encontrada para satisfazer as exigências legais é inferior à dos percentuais sugeridos por alguns pesquisadores. Dependendo dessa quantidade, acabam por 
inviabilizar esse método pelo aumento do volume e do custo da mistura final (FERNANDES et al., 1996; FERNANDES, 2000).

\subsubsection{TEMPERATURA DENTRO E FORA DA ESTUFA}

A intenção de possibilitar ao lodo condições ambientais favoráveis para acelerar o processo de secagem com a uso da estufa foi percebida nos três ciclos estudados. $\mathrm{O}$ fato de os ciclos terem ocorrido em diferentes meses do ano, ou seja, o Ciclo 1/1 ocorreu no período entre o final de janeiro e o início de abril, o Ciclo 2/1 entre abril e junho, e o Ciclo 3/1 entre julho e setembro, possibilitou avaliar as variações ocorridas da temperatura em razão da sazonalidade.

Os valores de temperatura ambiente (T1) e de temperatura no interior da estufa (T2), referentes às médias das médias horárias, máximas horárias e mínimas horárias ocorridas em cada ciclo da Etapa 1, encontram-se apresentados na TABELA 5.2.

Tabela 5.2 - Temperaturas médias das médias horárias, máximas horárias e mínimas horárias dentro e fora da estufa durante a Etapa 1

\begin{tabular}{|c|c|c|c|c|c|c|c|}
\hline \multirow{3}{*}{$\frac{0}{ن}$} & \multirow{3}{*}{ 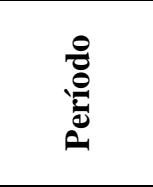 } & \multicolumn{6}{|c|}{ Temperatura $\left({ }^{\circ} \mathrm{C}\right)$} \\
\hline & & \multicolumn{2}{|c|}{ Média das médias horárias } & \multicolumn{2}{|c|}{ Máxima horária } & \multicolumn{2}{|c|}{ Mínima horária } \\
\hline & & $\begin{array}{c}\text { T1 } \\
\text { (Dentro da estufa) }\end{array}$ & $\begin{array}{c}\mathrm{T} 2 \\
\text { (Fora da estufa) }\end{array}$ & $\begin{array}{c}\text { T1 } \\
\text { (Dentro da estufa) }\end{array}$ & $\begin{array}{c}\mathrm{T} 2 \\
\text { (Fora da estufa) }\end{array}$ & $\begin{array}{c}\text { T1 } \\
\text { (Dentro da estufa) }\end{array}$ & $\begin{array}{c}\mathrm{T} 2 \\
\text { (Fora da estufa) }\end{array}$ \\
\hline $1 / 1$ & $\begin{array}{c}29 / 01 / 07 \mathrm{a} \\
09 / 04 / 07\end{array}$ & 29,4 & 22,2 & 50,8 & 34,2 & 20,1 & 14,2 \\
\hline $2 / 1$ & $\begin{array}{c}18 / 04 / 07 \mathrm{a} \\
20 / 06 / 07\end{array}$ & 28,9 & 25 & 46,1 & 35,2 & 19,7 & 17,2 \\
\hline $3 / 1$ & $\begin{array}{c}05 / 07 / 07 \mathrm{a} \\
12 / 09 / 07\end{array}$ & 27,5 & 23,6 & 48,5 & 36,7 & 15,3 & 14,4 \\
\hline
\end{tabular}

Nota: A temperatura definida como fora da estufa refere-se à temperatura do ar.

Nos resultados apresentados por Comparini (2001), na cidade de Franca - SP, a $2^{\mathrm{a}}$ e $3^{\mathrm{a}}$ repetições ocorreram praticamente nos mesmos períodos que os Ciclos 1/1 e 2/1, respectivamente, e mostraram temperaturas bem baixas em certos horários do dia. Essas diferenças são aceitáveis tendo em vista a localização geográfica das cidades onde se desenvolveram as pesquisas.

Para uma melhor visualização das variações das temperaturas dentro e fora da estufa nos três ciclos, são apresentados, no GRÁFICO 5.2, os valores médios das médias horárias bem como os máximos e os mínimos horários ao longo de cada ciclo da Etapa 1. 


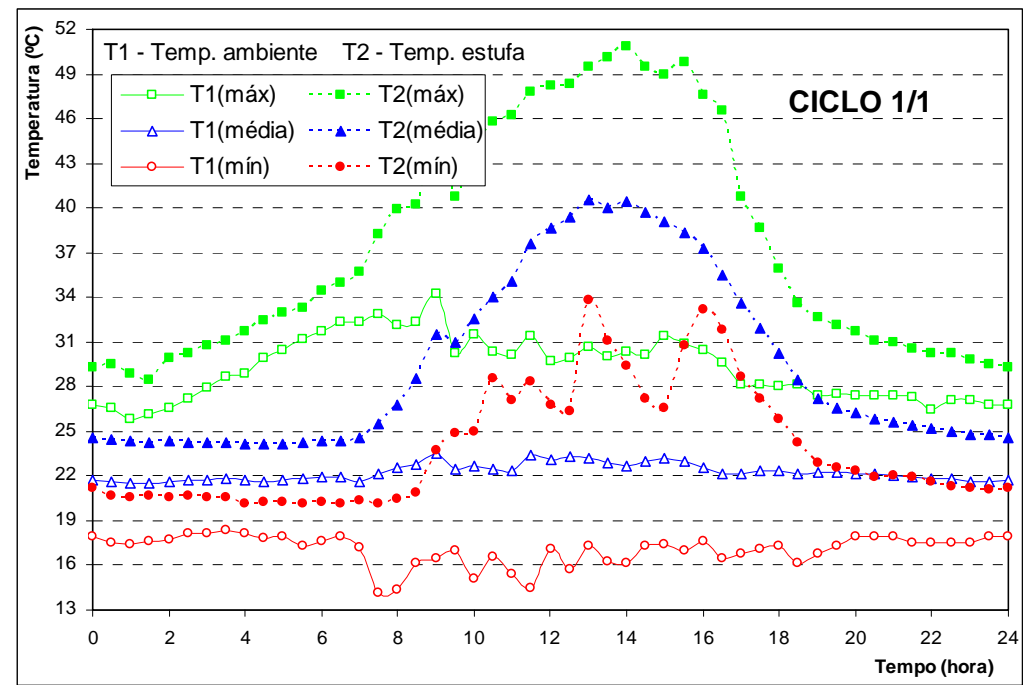

$(5.2 a)-10 \mathrm{~cm} \mathrm{e} \mathrm{m} / 3 \mathrm{x}+1 \mathrm{x}(\mathrm{L} 1, \mathrm{~L} 2, \mathrm{LC} 1 \mathrm{e}$ LC2 $)$

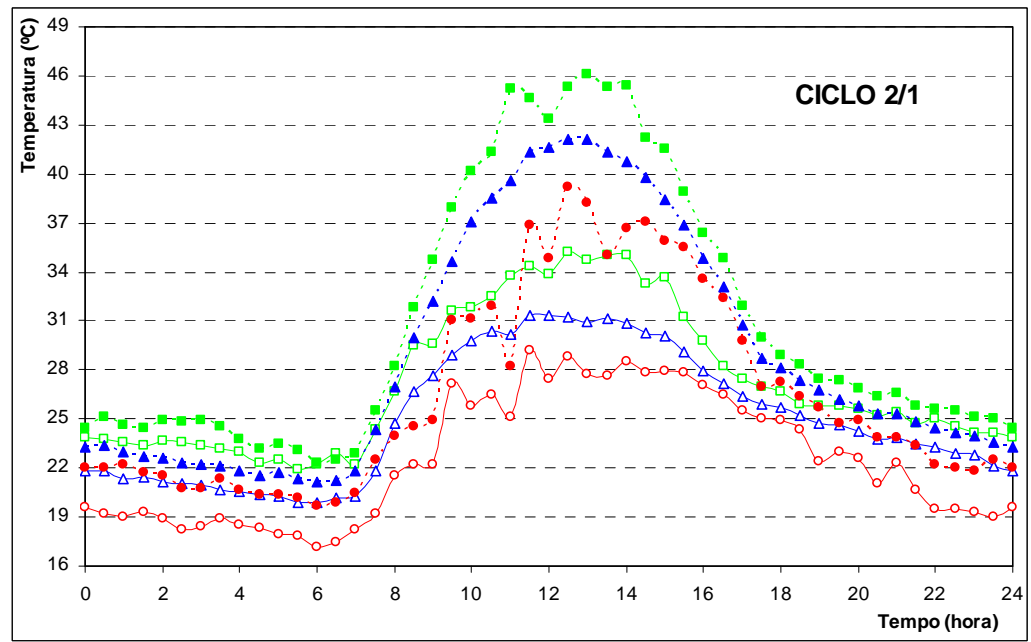

(5.2b) $-10 \mathrm{~cm} / 3 \mathrm{x}$ (L1 e LC1); 10cm e m/3x (L2 e LC2)

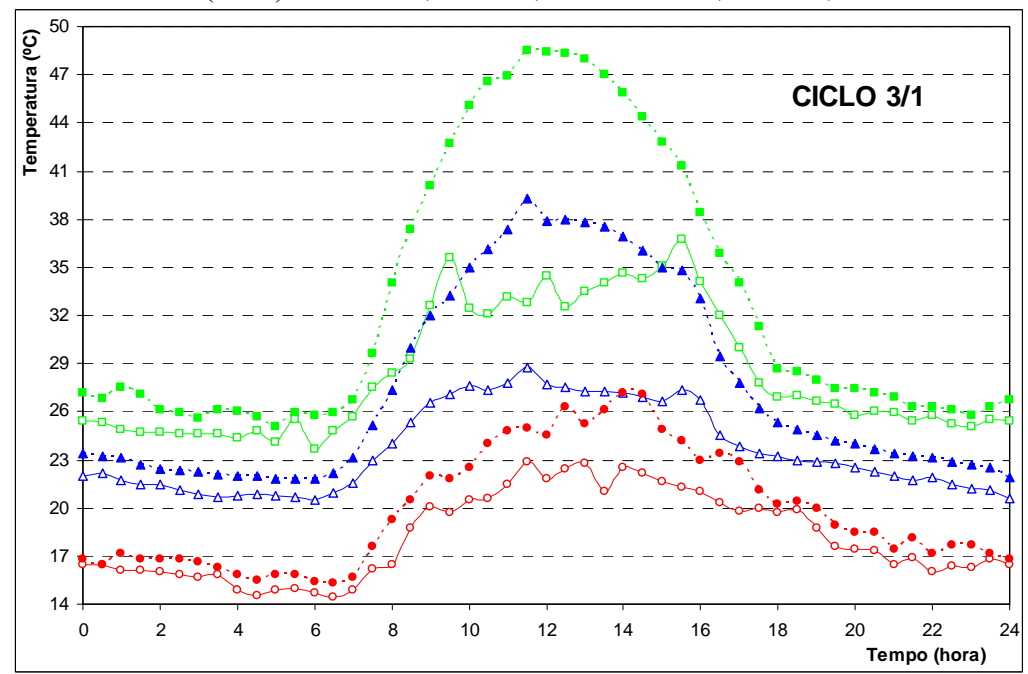

$(5.2 \mathrm{c})-10 \mathrm{~cm} / 3 \mathrm{x}$ (L1 e LC1);- 20cm /3x (L2 e LC2)

Gráfico 5.2 - Variação das temperaturas média das médias horárias, máximas horárias e mínimas horárias dentro e fora da estufa, durante a Etapa 1 - Ciclo 1/1 (5.2a), Ciclo 2/1 (5.2b) e Ciclo 3/1 (5.2c) 
Diante das informações explicitadas no GRÁFICO 5.2, considerando apenas os valores médios de temperatura obtidos dentro da estufa, percebe-se que, a partir das 10 horas da manhã, essas já se encontram acima de $34^{\circ} \mathrm{C}$, mantendo-se elevadas até, aproximadamente, 17 horas. Isso mostra que a estufa possibilita a manutenção de temperaturas internas elevadas mesmo em horários quando a externa já apresenta valores reduzidos. Os resultados demonstraram que, durante o Ciclo 2/1, a variação da temperatura em diferentes dias não foi expressiva, ou seja, não houve uma variação brusca da temperatura durante o período da pesquisa, ficando a média das médias horárias próxima aos valores máximos e mínimos horários, o que não ocorreu nos Ciclos $1 / 1$ e 3/1. Essas variações percebidas nos Ciclos 1/1 e $3 / 1$ podem ser atribuídas às mudanças bruscas de temperaturas que ocorrem frequentemente durante os meses em que se desenvolveram os ciclos. Porém, isso não afetou a capacidade da estufa em manter temperaturas médias elevadas durante um extenso período do dia, de $10 \mathrm{~h}$ a 17h. Essa condição foi constatada, também, por Comparini (2001).

\subsubsection{PARÂMETROS: UMIDADE, SÓLIDOS E POTENCIAL HIDROGENIÔNICO}

A TABELA 5.3 apresenta os valores obtidos de umidade, relação entre SV/ST e pH para o lodo sem adição de cal (L1 e L2) e com adição de cal (LC1 e LC2) durante o monitoramento dos Ciclos 1/1, 2/1 e 3/1.

Apesar de todos os procedimentos operacionais terem sido realizados com bastante critério durante o desenvolvimento da pesquisa, é possível notar pequenas variações nos valores encontrados, que podem ser atribuídas ao posicionamento da célula dentro da estufa, ao manuseio do lodo durante o revolvimento e a amostragem e aos fatores intervenientes da própria técnica analítica. 
Tabela 5.3 - Valores de umidade, SV/ST e pH do lodo sem cal (L1 e L2) e com cal (LC1 e LC2) durante os Ciclos 1/1, 2/1 e 3/1

\begin{tabular}{|c|c|c|c|c|c|c|c|c|c|c|c|c|c|}
\hline \multirow{3}{*}{ Data } & \multirow{3}{*}{$\begin{array}{c}\text { Tempo } \\
\text { (dia) }\end{array}$} & \multicolumn{4}{|c|}{ Umidade (\%) } & \multicolumn{4}{|c|}{ SV/ST (\%) } & \multicolumn{4}{|c|}{ pH } \\
\hline & & \multicolumn{2}{|c|}{ Lodo sem cal } & \multicolumn{2}{|c|}{ Lodo com cal } & \multicolumn{2}{|c|}{ Lodo sem cal } & \multicolumn{2}{|c|}{ Lodo com cal } & \multicolumn{2}{|c|}{ Lodo sem cal } & \multicolumn{2}{|c|}{ Lodo com cal } \\
\hline & & L1 & $\mathbf{L} 2$ & LC1 & LC2 & $\mathbf{L 1}$ & $\mathbf{L 2}$ & LC1 & LC2 & $\mathbf{L 1}$ & $\mathbf{L 2}$ & LC1 & LC2 \\
\hline \multicolumn{14}{|c|}{ CICLO $1 / 1-10 \mathrm{~cm}$ e $\mathrm{m} / 3 \mathrm{x}+1 \mathrm{x}(\mathrm{L} 1, \mathrm{~L} 2, \mathrm{LC} 1 \text { e LC2 })^{(*)}$} \\
\hline $29 / 01 / 07$ & 0 & 84,41 & 84,00 & 82,29 & 81,99 & 59,19 & 59,35 & 52,25 & 50,69 & 6,25 & 6,25 & 12,37 & 12,33 \\
\hline 05/02/07 & 7 & 77,38 & 76,58 & 73,85 & 75,11 & 57,87 & 58,12 & 49,46 & 48,69 & 6,47 & 6,36 & 9,37 & 9,73 \\
\hline $12 / 02 / 07$ & 14 & 51,03 & 41,62 & 36,26 & 47,79 & 57,82 & 55,37 & 47,37 & 47,96 & 5,38 & 5,41 & 8,19 & 8,07 \\
\hline $19 / 02 / 07$ & 21 & \multicolumn{12}{|c|}{ Não foi realizada coleta de amostras } \\
\hline $26 / 02 / 07$ & 28 & 27,07 & 14,63 & 20,19 & 28,16 & 54,44 & 55,97 & 48,53 & 48,85 & 5,00 & 5,43 & 8,23 & 8,19 \\
\hline 05/03/07 & 35 & 28,51 & 13,66 & 17,41 & 22,27 & 52,49 & 47,33 & 47,89 & 40,74 & 5,32 & 5,93 & 8,57 & 8,54 \\
\hline $12 / 03 / 07$ & 42 & 13,94 & 6,66 & 7,68 & 11,01 & 50,01 & 51,69 & 49,24 & 45,11 & 5,16 & 5,38 & 8,07 & 8,14 \\
\hline $19 / 03 / 07$ & 49 & 14,77 & 8,83 & 9,99 & 13,75 & 44,13 & 45,24 & 41,34 & 40,26 & 5,37 & 5,73 & 8,32 & 8,42 \\
\hline $26 / 03 / 07$ & 56 & 9,15 & 6,67 & 8,24 & 9,07 & 44,88 & 43,91 & 39,54 & 38,64 & 5,21 & 5,34 & 8,02 & 8,09 \\
\hline $02 / 04 / 07$ & 63 & 8,64 & 7,40 & 7,84 & 7,92 & 43,18 & 41,75 & 39,00 & 34,27 & 5,00 & 5,34 & 8,24 & 8,29 \\
\hline $9 / 4 / 2007$ & 70 & 5,73 & 5,58 & 6,32 & 7,24 & 43,93 & 44,49 & 39,51 & 37,18 & 5,18 & 5,25 & 8,06 & 8,11 \\
\hline \multicolumn{14}{|c|}{ CICLO 2/1 - 10cm/3x (L1 e LC1); 10cm e m/3x (L2 e LC2) ${ }^{(*)}$} \\
\hline $18 / 04 / 07$ & 0 & 85,68 & 85,68 & 82,71 & 82,71 & 60,20 & 60,20 & 50,05 & 50,05 & 5,62 & 5,62 & 12,32 & 12,32 \\
\hline $25 / 04 / 07$ & 7 & 77,50 & 79,60 & 76,34 & 77,14 & 52 & 53 & 42 & 42,57 & 5,34 & 5,52 & 11,44 & 11,32 \\
\hline $02 / 05 / 07$ & 14 & 63,51 & 64,09 & 57,14 & 61,59 & 51,37 & 51,54 & 42,17 & 45,38 & 5,40 & 5,53 & 8,48 & 8,17 \\
\hline 09/05/07 & 21 & 32,76 & 42,80 & 22,93 & 52,61 & 43,53 & 45,78 & 39,01 & 41,04 & 5,10 & 4,70 & 8,45 & 8,62 \\
\hline $16 / 05 / 07$ & 28 & 8,39 & 21,33 & 9,63 & 20,10 & 42,32 & 43,20 & 37,53 & 42,08 & 5,32 & 5,10 & 8,06 & 8,16 \\
\hline $23 / 05 / 07$ & 35 & 10,34 & 27,96 & 9,31 & 26,72 & 43,11 & 44,31 & 37,46 & 40,57 & 5,52 & 5,06 & 8,42 & 8,56 \\
\hline $30 / 05 / 07$ & 42 & 6,64 & 19,90 & 7,01 & 17,93 & 40,01 & 43,99 & 38,40 & 41,73 & 5,26 & 5,11 & 7,87 & 7,98 \\
\hline $06 / 06 / 07$ & 49 & 9,27 & 17,21 & 8,72 & 16,74 & 39,38 & 39,67 & 39,14 & 39,45 & 5,69 & 5,10 & 8,67 & 8,37 \\
\hline $13 / 06 / 07$ & 56 & \multicolumn{12}{|c|}{ Não foi realizada coleta de amostras } \\
\hline $20 / 06 / 07$ & 63 & 6,97 & 11,35 & 6,22 & 12,94 & 38,54 & 40,02 & 38,93 & 39,64 & 5,19 & 5,08 & 7,76 & 7,82 \\
\hline \multicolumn{14}{|c|}{ CICLO 3/1 - 10cm/3x (L1 e LC1); - 20cm /3x (L2 e LC2) ${ }^{(*)}$} \\
\hline 05/07/07 & 0 & 85,13 & 85,13 & 82,77 & 82,77 & 58,27 & 58,27 & 48,02 & 48,02 & 6,24 & 6,24 & 12,23 & 12,23 \\
\hline $11 / 07 / 07$ & 7 & 82,35 & 83,10 & 77,77 & 78,16 & 55,40 & 50,03 & 48,40 & 47,76 & 5,92 & 6,12 & 11,84 & 12,07 \\
\hline $18 / 07 / 07$ & 14 & 74,01 & 80,44 & 69,57 & 76,30 & 59,51 & 55,36 & 47,48 & 47,37 & 5,65 & 6,13 & 8,59 & 9,50 \\
\hline $25 / 07 / 07$ & 21 & 61,85 & 69,75 & 58,10 & 71,08 & 52,28 & 51,36 & 43,31 & 44,49 & 5,42 & 5,66 & 8,22 & 8,89 \\
\hline $01 / 08 / 07$ & 28 & 50,21 & 69,99 & 38,38 & 64,85 & 49,50 & 53,63 & 43,16 & 45,43 & 5,43 & 5,56 & 8,31 & 8,27 \\
\hline 08/08/07 & 35 & 32,41 & 61,36 & 20,72 & 53,70 & 36,90 & 46,45 & 37,70 & 38,17 & 4,42 & 4,48 & 7,86 & 7,69 \\
\hline $15 / 08 / 07$ & 42 & 17,84 & 55,75 & 18,83 & 47,24 & NR & 45,98 & NR & 36,66 & 5,31 & 5,35 & 8,11 & 8,08 \\
\hline $22 / 08 / 07$ & 49 & 16,31 & 50,15 & 11,32 & 40,77 & 40,30 & 42,38 & 34,91 & 34,14 & 4,82 & 4,60 & 7,82 & 8,20 \\
\hline $29 / 08 / 07$ & 56 & 10,66 & 43,24 & 11,85 & 34,53 & 46,61 & NR & $\mathrm{NR}$ & NR & 5,21 & 5,28 & 8,02 & 7,95 \\
\hline 05/09/07 & 63 & 12,49 & 31,84 & 9,94 & 23,59 & 44,37 & 40,19 & 36,72 & 34,58 & 4,74 & 4,24 & 7,52 & 7,26 \\
\hline $12 / 09 / 07$ & 70 & 7,67 & 23,56 & 8,50 & 18,74 & 46,57 & 43,85 & 39,20 & 33,15 & 5,15 & 5,22 & 7,94 & 8,01 \\
\hline
\end{tabular}

Nota: Não foram realizadas coletas em 19/02/07 por ser carnaval e em 13/06/07 por problemas operacionais; alguns resultados de SV/ST foram desprezados em virtude de problemas na determinação laboratorial;

(*) - Forma de disposição do lodo nas células / período do revolvimento. 


\subsubsection{Umidade}

Diante do comportamento da umidade em cada ciclo, observa-se que não houve diferença expressiva na variação da umidade entre o lodo sem cal (L1 e L2) e o lodo misturado à cal (LC1 e LC2), durante o Ciclo 1/1, quando as condições metodológicas foram as mesmas em todas as células. Na verdade, as diferenças mais significativas ocorreram com a forma de disposição do material dentro das células, observadas nas curvas (5.3b) e (5.3c) do GRÁFICO 5.3 que configuram os Ciclos $2 / 1$ e 3/1, respectivamente. As curvas apresentadas possibilitam avaliar o comportamento temporal da umidade durante cada ciclo.

A variação temporal da umidade nos casos em que o lodo foi disposto com $10 \mathrm{~cm}$ de altura, aparentemente, sofreu em todos os ciclos comportamentos semelhantes. Apresentou períodos em que a perda da umidade é mais acentuada e, em outros, os teores de umidade praticamente não se alteraram. Nesse último caso, isso ficou visível para a condição em que a umidade atingiu teores entre $10 \%$ e 20\% (GRÁFICO 5.3).

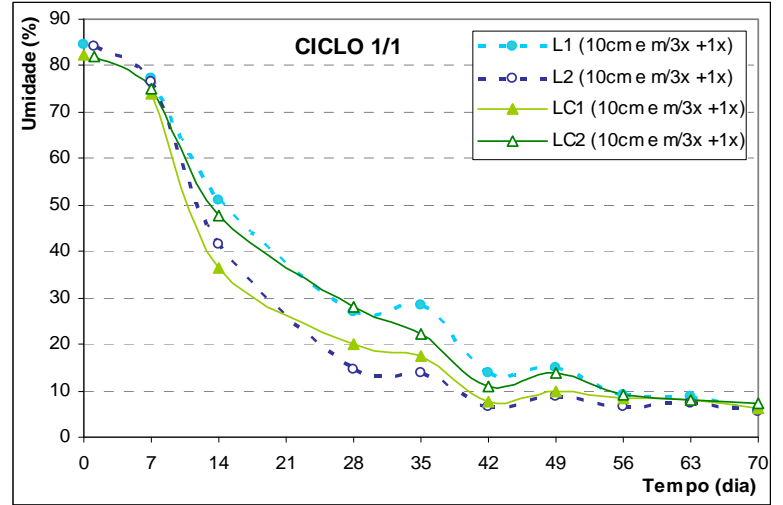

(5.3a)

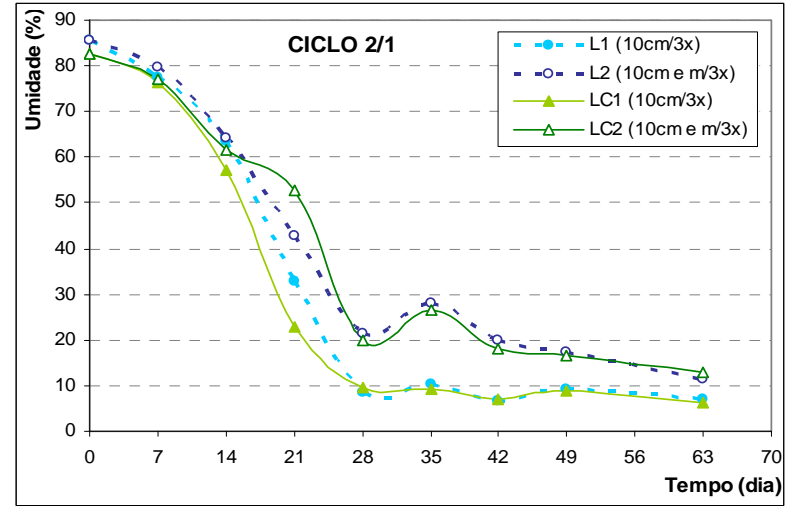

$(5.3 b)$

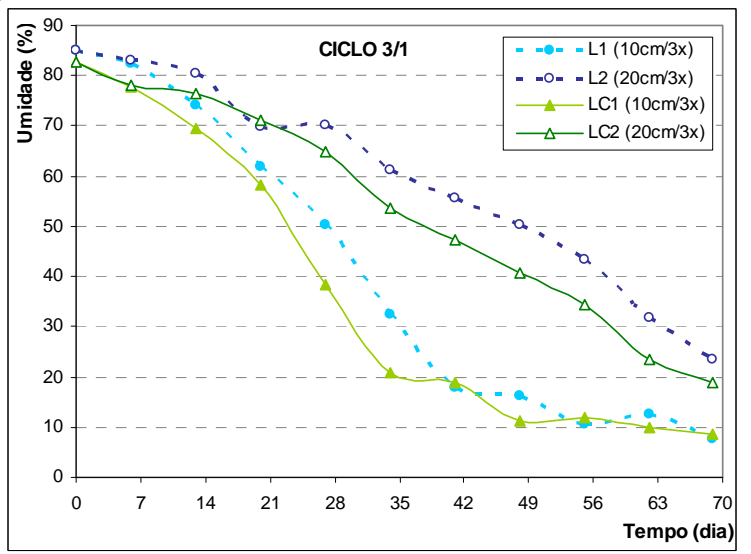

$(5.3 \mathrm{c})$

Gráfico 5.3 - Variação da umidade do lodo sem cal (L1 e L2) e com cal (LC1 e LC2) durante os ciclos da Etapa 1 - Ciclos 1/1 (5.3a), 2/1 (5.3b) e 3/1 (5.3c) 
Outra condição muito importante a ser ressaltada é a diminuição considerável do volume do material com a perda da umidade, percebido visualmente durante a pesquisa. Observa-se, na FIGURA 5.1, que a área ocupada pelo lodo da célula L1 com $84,41 \%$ de umidade (5.1a) é praticamente o dobro do lodo com 63,51\% de umidade (5.1c), após 14 dias de monitoramento, trabalhando com as mesmas condições operacionais.

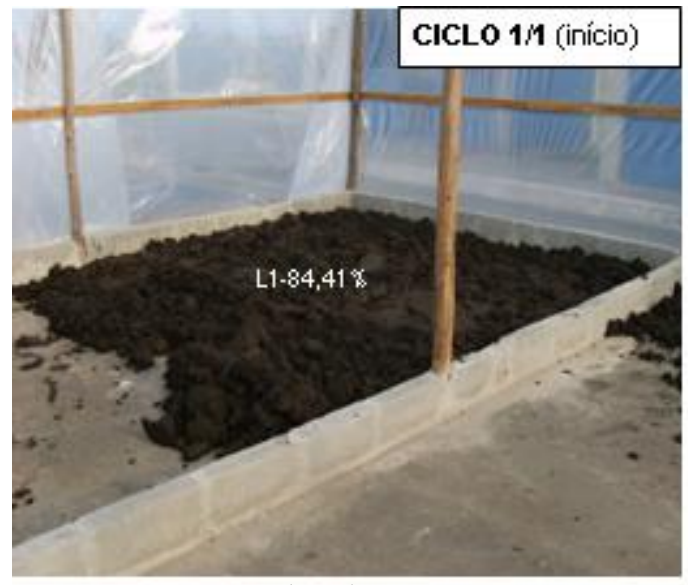

(5.1a)

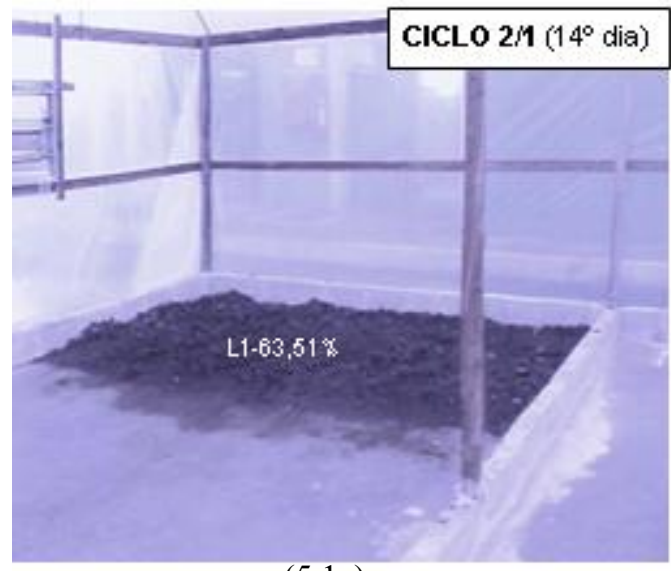

(5.1c)

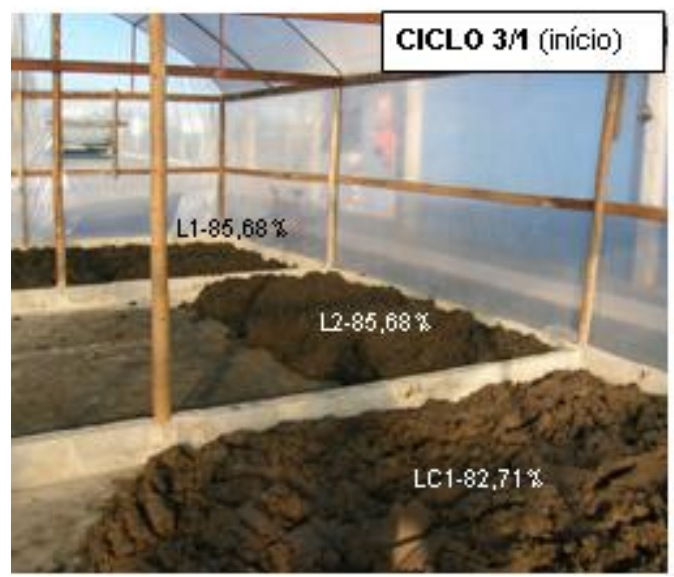

$(5.1 \mathrm{e})$

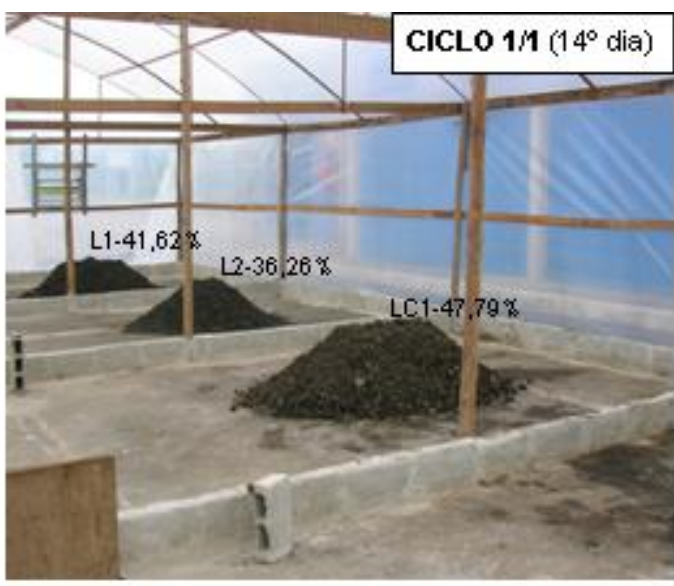

(5.1b)

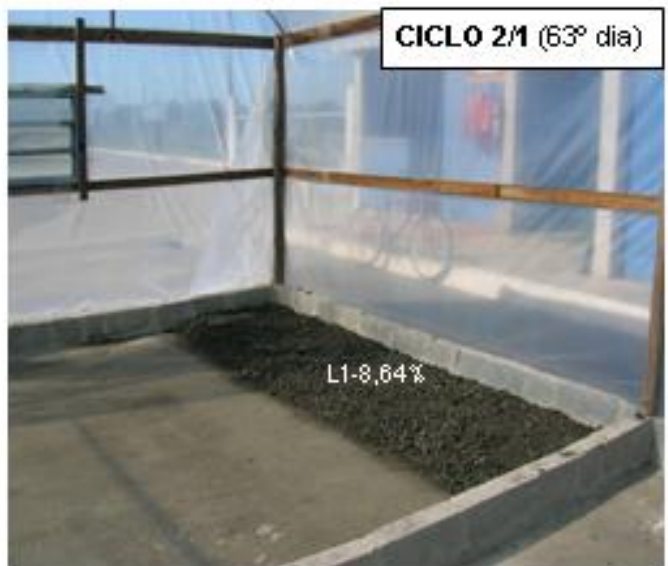

(5.1d)

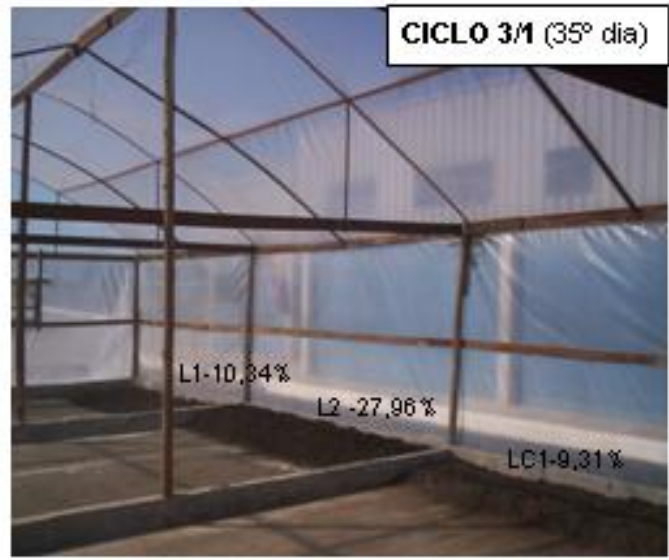

$(5.1 \mathrm{f})$

Nota: Ciclo 1/1 - 10cm e m/3x + 1x (Todas); Ciclo $2 / 1-10 \mathrm{~cm} / 3 \mathrm{x}$ (L1 e LC1); 10cm e m/3x (L2 e LC2); Ciclo $3 / 1-10 \mathrm{~cm} / 3 \mathrm{x}(\mathrm{L} 1$ e LC1); $-20 \mathrm{~cm} / 3 \mathrm{x}$ (L2 e LC2).

Figura 5.1 - Característica visual do lodo nas células durante os três ciclos em diferentes dias e as umidades correspondentes 
Com as FIGURAS (5.1d) e (5.1f), nota-se que o lodo com umidade abaixo de 10\% ocupou uma estreita faixa dentro da célula. Pode-se perceber, ainda, na FIGURA (5.1f), que o lodo espalhado com altura de $20 \mathrm{~cm}$ (L2) não possibilitou uma otimização do espaço dentro da estufa, pois, no $35^{\circ}$ dia do experimento, a faixa de lodo nas células L1 e LC1, com altura de $10 \mathrm{~cm}$, já estava menor que a observada em L2. Isso ocorreu porque a perda da umidade do lodo disposto com $20 \mathrm{~cm}$ de altura foi bem mais lenta que com $10 \mathrm{~cm}$ de altura.

Comparando as FIGURAS (5.1b) e (5.1c), percebe-se que pode haver uma otimização do espaço quando o lodo é disposto em forma de leira. Porém, deve-se levar em conta que a perda da umidade, nesse caso, ocorreu mais lentamente e, considerando a implantação do sistema em larga escala, poderão ocorrer dificuldades na formação da leira e no manuseio do material, principalmente com a mecanização da operacionalização do processo.

\subsubsection{Relação entre sólidos voláteis e sólidos totais}

Os resultados obtidos da relação entre sólidos voláteis e sólidos totais (SV/ST) mostraram que o lodo usado na Etapa 1 se encontrava estável, com bom nível de digestão, com valores em torno de $60 \%$.

Em todos os ciclos, ficou evidenciado que ocorreu uma redução gradual nos valores SV/ST que chegou a atingir, ao final, um abatimento de 36\% do valor inicial (L1 - Ciclo 2/1). No lodo sem cal, os valores observados de SV/ST ao final dos ciclos (aproximadamente 70 dias), variaram de $38 \%$ a $46 \%$.

No início de todos os ciclos, percebe-se que a adição da cal ao lodo resultou numa diminuição dessa relação (TABELA 5.3). Os lodos das células L1 e L2 apresentaram SV/ST sempre superiores quando comparados com os das células LC1 e LC2, em razão do incremento do teor de sólidos.

De acordo com os resultados obtidos, a forma de disposição do lodo nas células e o período de revolvimento não caracterizaram, a princípio, condições que interferissem de forma significativa na diminuição dessa relação, representando uma aceleração do processo de estabilização do lodo. Tomando-se como base os valores apresentados no Ciclo 1/1, observase que, no lodo de todas as células, independentemente de adicionar cal ou não, as reduções 
finais variaram de $25 \%$ a $27 \%$. Entretanto, no Ciclo 2/1, apesar de o lodo da célula L2 ter apresentado $34 \%$ de redução, em LC2, essa redução foi apenas de $21 \%$. Vale lembrar que a disposição do lodo nas células L2 e LC2 foi a mesma usada em todas as células do Ciclo 1/1, porém o período de revolvimento foi alterado, passando a ser menor.

\subsubsection{Potencial Hidrogeniônico (pH)}

No GRÁFICO 5.4, encontram-se apresentadas as variações temporais do $\mathrm{pH}$ do material disposto nas células L1 e L2 (lodo sem adição de cal) e LC1 e LC2 (lodo com adição de cal), durante o período de monitoramento dos três ciclos.

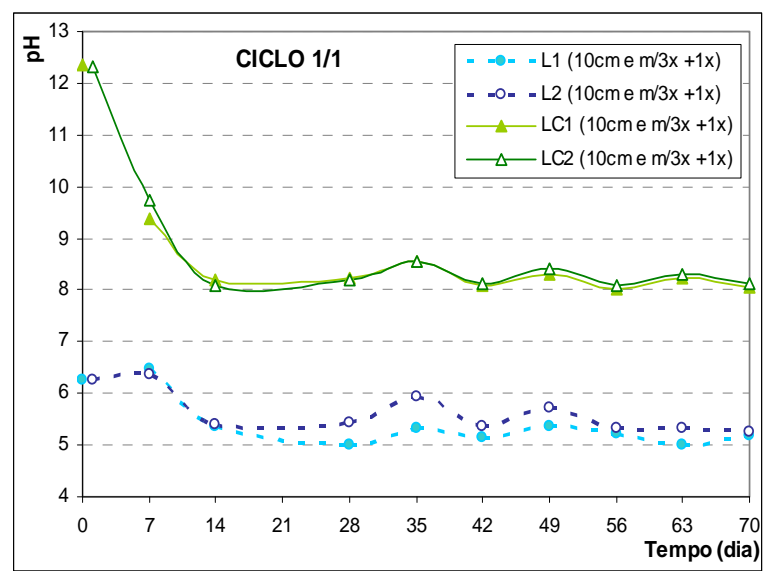

(5.4a)

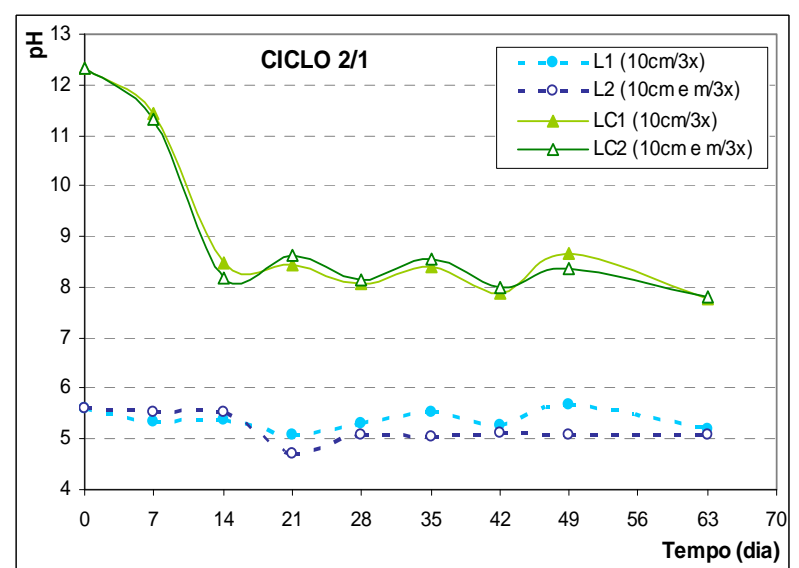

$(5.4 b)$

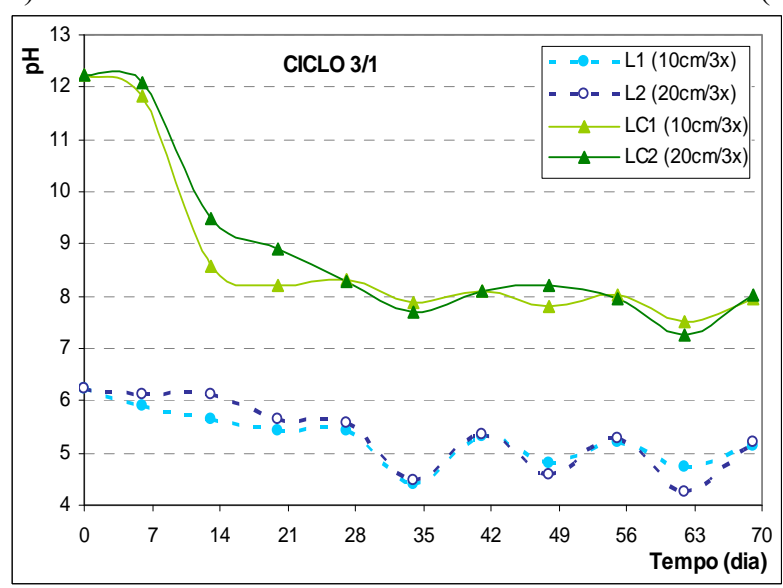

$(5.4 \mathrm{c})$

Gráfico 5.4 - Variação do pH do lodo sem cal (L1 e L2) e com cal (LC1 e LC2) durante os ciclos da Etapa 1 - Ciclos 1/1 (5.4a), 2/1 (5.4b) e 3/1 (5.4c) 
No lodo com cal (LC1 e LC2), durante o monitoramento realizado nos primeiros dias de cada ciclo, constatou-se que o $\mathrm{pH}$ foi mantido acima de 12 nas primeiras 2 horas e acima de 11,5 por mais 22 horas, atendendo às exigências estabelecidas na Resolução $n^{0}$ 375/2006 (BRASIL, 2006c).

Os lodos das células L1 e L2 (sem cal), apesar de apresentaram valores de pH no início do Ciclo 1/1, quase 1 unidade acima do lodo das mesmas células do Ciclo 2/1, mantiveram-se com valores entre 5 e 6 durante o restante dos dois ciclos. No Ciclo 3/1, houve uma ligeira queda do $\mathrm{pH}$ a partir do $30^{\circ}$ dia, apresentando, em alguns momentos, $\mathrm{pH}$ entre 4 e 5 . No lodo com cal (LC1 e LC2), o pH que partiu de valores próximo a 12 e atingiu, no $14^{\circ}$ dia, aproximadamente 8, mantendo-se assim até o final dos ciclos (TABELA 5.3 e GRÁFICO $5.4)$.

\subsubsection{INDICADORES BACTERIOLÓGICOS E AGENTES PATOGÊNICOS}

A TABELA 5.4 apresenta os valores obtidos de coliformes termotolerantes (CTt), Salmonella sp. e ovos viáveis de helmintos $(\mathrm{OVH})$, durante o período de monitoramento dos Ciclos 1/1, 2/1 e 3/1 para o lodo digerido sem cal (L1 e L2) e com cal (LC1 e LC2). A variabilidade apresentada nos valores desses parâmetros pode ser atribuída tanto ao fato de que os lodos usados nos experimentos foram coletados em períodos diferentes, quanto a questões operacionais da ETE, ou mesmo a fatores relacionados à técnica analítica empregada. 
Tabela 5.4 - Ocorrência de coliformes termotolerantes, ovos viáveis de helmintos e Salmonella sp. do lodo digerido com e sem cal, durante os Ciclos 1/1, 2/1 e 3/1

\begin{tabular}{|c|c|c|c|c|c|c|c|c|c|c|c|c|c|}
\hline \multirow{3}{*}{ Data } & \multirow{3}{*}{ 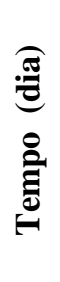 } & \multicolumn{4}{|c|}{ 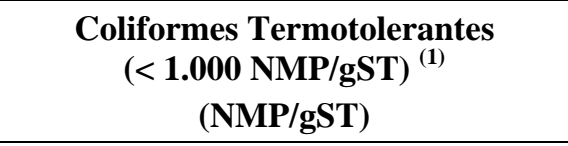 } & \multicolumn{4}{|c|}{$\begin{array}{c}\text { Ovos viáveis helmintos } \\
\text { (< 0,250vo/gST) }^{(1)} \\
\text { (ovo/gST })^{(0 v a t}\end{array}$} & \multicolumn{4}{|c|}{$\begin{array}{l}\text { Salmonella sp. } \\
\text { (A em 10gST) }^{(1)} \\
\text { (em 10gST) }^{\text {(em 10g }}\end{array}$} \\
\hline & & \multicolumn{2}{|c|}{ Lodo sem cal } & \multicolumn{2}{|c|}{ Lodo com cal } & \multicolumn{2}{|c|}{$\begin{array}{l}\text { Lodo sem } \\
\text { cal }\end{array}$} & \multicolumn{2}{|c|}{$\begin{array}{l}\text { Lodo com } \\
\text { cal }\end{array}$} & \multicolumn{2}{|c|}{$\begin{array}{c}\text { Lodo sem } \\
\text { cal }\end{array}$} & \multicolumn{2}{|c|}{$\begin{array}{c}\text { Lodo com } \\
\text { cal }\end{array}$} \\
\hline & & L1 & L2 & LC1 & LC2 & L1 & $\mathbf{L 2}$ & LC1 & LC2 & L1 & $\mathbf{L 2}$ & LC1 & LC2 \\
\hline \multicolumn{14}{|c|}{ CICLO $1 / 1-10 \mathrm{~cm}$ e m/3x + 1x (L1, L2, LC1 e LC2 $)^{(*)}$} \\
\hline $29 / 01 / 07$ & 0 & $1,10 \mathrm{E}+04$ & $1,10 \mathrm{E}+04$ & $<3,6$ & $<3,6$ & 0,13 & 0,13 & 0,19 & 0,19 & $\mathrm{P}$ & $\mathrm{P}$ & A & A \\
\hline $12 / 02 / 07$ & 14 & $4,30 \mathrm{E}+01$ & $4,60 \mathrm{E}+03$ & $2,40 \mathrm{E}+02$ & $2,40 \mathrm{E}+04$ & 0,22 & 0,07 & 0,06 & 0,10 & $\mathrm{P}$ & A & A & A \\
\hline $26 / 02 / 07$ & 28 & $3,60 \mathrm{E}+00$ & $4,30 \mathrm{E}+01$ & $<3,6$ & $<3,6$ & 0,10 & 0,00 & 0,07 & 0,04 & A & A & A & A \\
\hline $12 / 03 / 07$ & 42 & $<3,6$ & $<3,6$ & $<3,6$ & $<3,6$ & 0,10 & 0,11 & 0,08 & 0,00 & A & A & A & A \\
\hline $26 / 03 / 07$ & 56 & $<3,6$ & $<3,6$ & $<3,6$ & $<3,6$ & 0 & 0,08 & 0 & 0,03 & A & A & A & A \\
\hline $9 / 4 / 2007$ & 70 & $<3,6$ & $<3,6$ & $<3,6$ & $<3,6$ & 0,04 & 0,09 & 0 & 0,04 & A & A & A & A \\
\hline \multicolumn{14}{|c|}{ CICLO $2 / 1-10 \mathrm{~cm} / 3 \mathrm{x}$ (L1 e LC1); 10cm e m/3x (L2 e LC2) ${ }^{(*)}$} \\
\hline $18 / 04 / 07$ & 0 & $4,60 \mathrm{E}+03$ & $4,60 \mathrm{E}+03$ & $<3,6$ & $<3,6$ & 0,23 & 0,23 & 0,12 & 0,12 & A & A & A & A \\
\hline $02 / 05 / 07$ & 14 & $9,30 \mathrm{E}+01$ & $2,40 \mathrm{E}+02$ & $4,60 \mathrm{E}+02$ & $4,30 \mathrm{E}+01$ & 0,22 & 0 & 0,06 & 0,11 & A & A & A & A \\
\hline $16 / 05 / 07$ & 28 & $2,40 \mathrm{E}+02$ & $4,30 \mathrm{E}+01$ & $<3,6$ & $<3,6$ & 0 & 0,09 & 0 & 0,09 & A & A & A & A \\
\hline $30 / 05 / 07$ & 42 & $<3,6$ & $<3,6$ & $<3,6$ & $<3,6$ & 0,04 & 0,10 & 0 & 0 & A & A & A & A \\
\hline $13 / 06 / 07$ & 56 & \multicolumn{12}{|c|}{ Não foi realizada coleta de amostras } \\
\hline $20 / 06 / 07$ & 63 & $<3,6$ & $<3,6$ & $<3,6$ & $<3,6$ & 0,05 & 0,09 & 0 & 0 & A & A & A & A \\
\hline \multicolumn{14}{|c|}{ CICLO $3 / 1-10 \mathrm{~cm} / 3 \mathrm{x}(\mathrm{L} 1$ e LC1 $) ;-20 \mathrm{~cm} / 3 \mathrm{x}(\mathrm{L} 2 \text { e LC2 })^{(*)}$} \\
\hline $05 / 07 / 07$ & 0 & $2,40 \mathrm{E}+02$ & $2,40 \mathrm{E}+02$ & $<3,6$ & $<3,6$ & 0,35 & 0,35 & 0,13 & 0,13 & $\mathrm{~A}$ & $\mathrm{~A}$ & A & A \\
\hline $18 / 07 / 07$ & 14 & $9,20 \mathrm{E}+00$ & $4,30 \mathrm{E}+01$ & $3,60 \mathrm{E}+00$ & $<3,6$ & 0,27 & 0,14 & 0,13 & 0,12 & A & A & A & A \\
\hline $01 / 08 / 07$ & 28 & $<3,6$ & $3,60 \mathrm{E}+00$ & $2,30 \mathrm{E}+01$ & $3,60 \mathrm{E}+00$ & 0,15 & 0,16 & 0 & 0,09 & A & A & A & A \\
\hline $15 / 08 / 07$ & 42 & $<3,6$ & $<3,6$ & $<3,6$ & $<3,6$ & 0,11 & 0,09 & 0,03 & 0 & A & A & A & A \\
\hline $29 / 08 / 07$ & 56 & $<3,6$ & $<3,6$ & $<3,6$ & $<3,6$ & 0,07 & 0,10 & 0,06 & 0,04 & $\mathrm{~A}$ & A & A & A \\
\hline $18 / 09 / 07$ & 70 & $<3,6$ & $<3,6$ & $<3,6$ & $<3,6$ & 0 & 0,08 & 0,09 & 0 & A & A & A & A \\
\hline
\end{tabular}

Nota: ${ }^{(1)}$ Padrão Resolução n ${ }^{0}$ 375/2006 do Conama (BRASIL, 2006c);

$\mathrm{A}=$ Ausência; $\mathrm{P}=$ Presença.

$(*)$ - Forma de disposição do lodo nas células / período do revolvimento.

\subsubsection{Coliformes termotolerantes}

No Ciclo 1/1, no lodo digerido sem a adição da cal (L1 e L2), o tempo necessário para a higienização do material, segundo o atendimento ao Conama, foi em torno do $28^{\circ}$ dia, com umidade média de $21 \%$ (TABELAS 5.3 e 5.4, GRÁFICO 5.5). No entanto, a umidade poderia ser ainda maior em razão de não ter sido efetuado análise entre o $14^{\circ}$ dia e o $28^{\circ}$ dia e as densidades de $\mathrm{CTt}$ apresentadas no $14^{\circ}$ já eram reduzidas.

Para o Ciclo 2/1, o padrão estabelecido pelo Conama para CTt para o lodo digerido sem cal, foi atingido no $14^{\circ}$ dia de monitoramento, com umidade média em torno de $64 \%$. 
O lodo usado no Ciclo 3/1 já apresentava valores desprezíveis de CTt, quando comparados aos limites estabelecidos pelo Conama.

No caso específico do lodo com adição de cal (LC1 e LC2), foram constatados recrescimentos no $14^{\circ}$ dia (Ciclo $1 / 1$ e Ciclo $2 / 1$ ) e no $28^{\circ}$ dia (Ciclo 3/1). Mesmo com o recrescimento, a maioria apresentou densidades de CTt reduzidas em relação aos padrões do Conama. E, nas semanas seguintes, as concentrações detectadas foram sempre inferiores a 3,6 NMP/gST até o final dos ciclos.

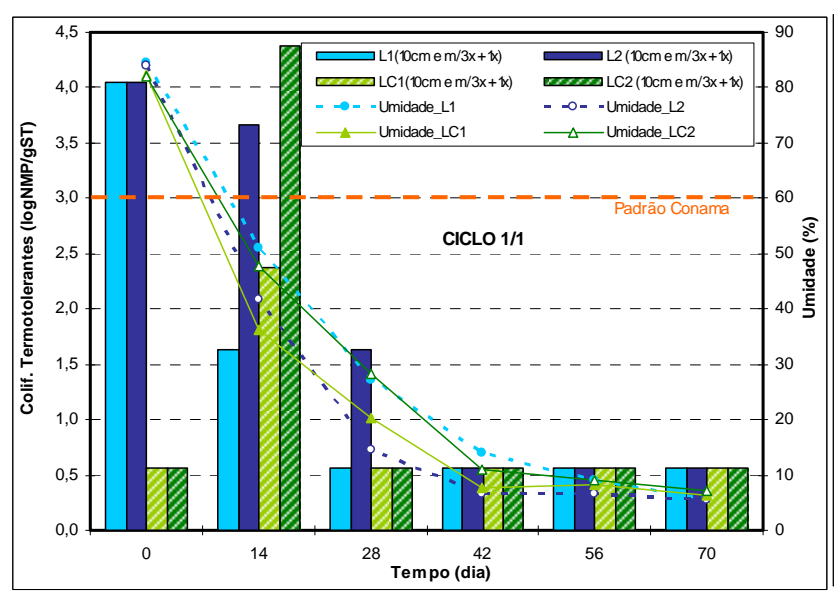

(5.5a)

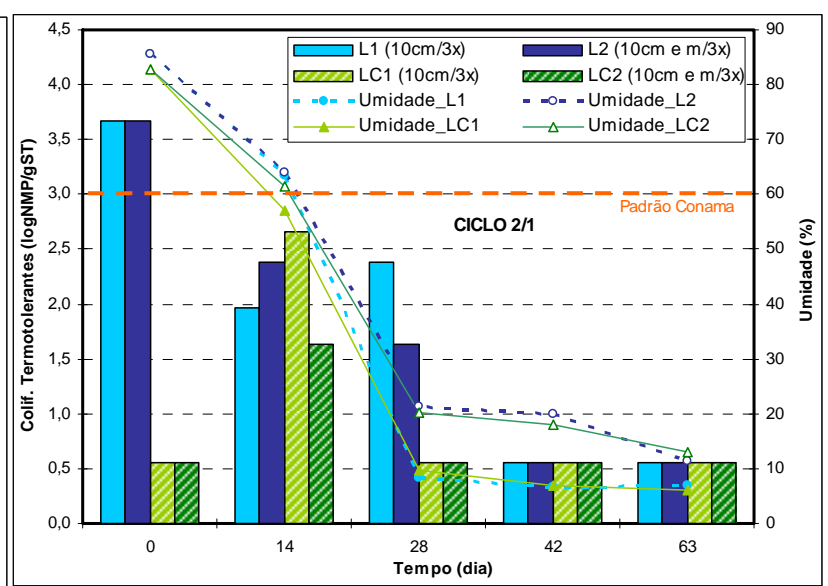

$(5.5 b)$

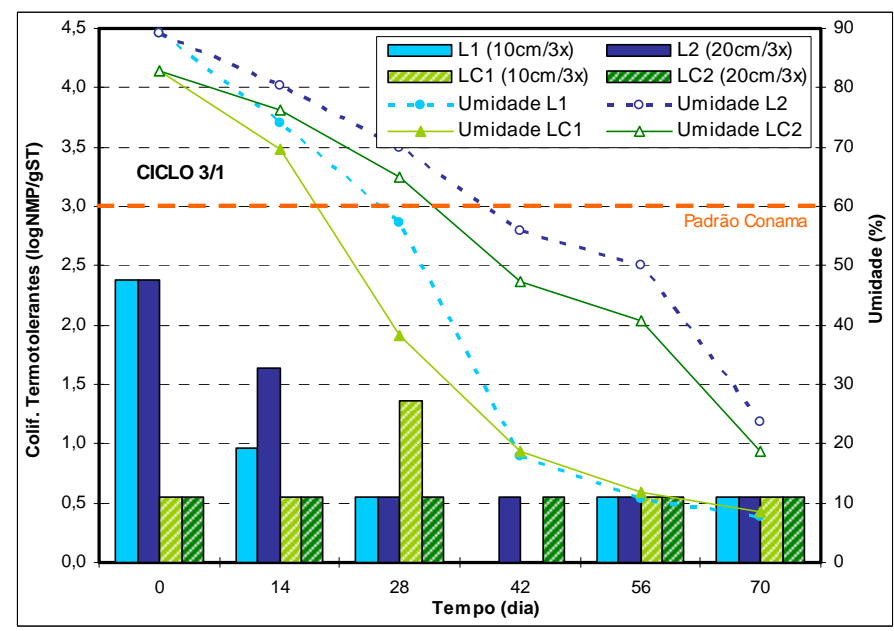

$(5.5 \mathrm{c})$

Gráfico 5.5 - Variação da densidade de coliformes termotolerantes e umidade no lodo digerido sem cal (L1 e L2) e com cal (LC1 e LC2) durante os ciclos da Etapa 1 - Ciclos 1/1 (5.5a), 2/1 (5.5b) e 3/1 $(5.5 \mathrm{c})$

\subsubsection{Ovos viáveis helmintos}

Os valores apresentados na TABELA 5.4 e no GRÁFICO 5.6 mostram que houve uma diminuição da densidade de $\mathrm{OVH}$ ao longo do tempo, porém em alguns casos, não apresentam uma tendência de decaimento bem definida, provavelmente em razão dos baixos 
valores detectados. Os valores reduzidos de $\mathrm{OVH}$ foram confirmados com análises do lodo realizadas pela bióloga Silvana Audra Cutolo (Escola de Saúse Pública da USP); e análises do esgoto realizadas pelo laboratório AGROLAB, em diferentes etapas do tratamento da fase líquida, que verificou, inclusive, ausência de ovos de he lmintos no esgoto bruto.

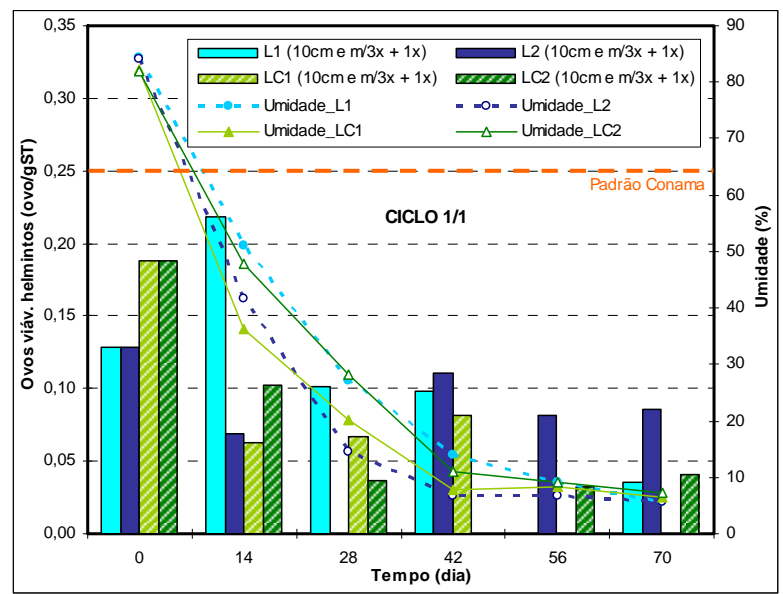

(5.6a)

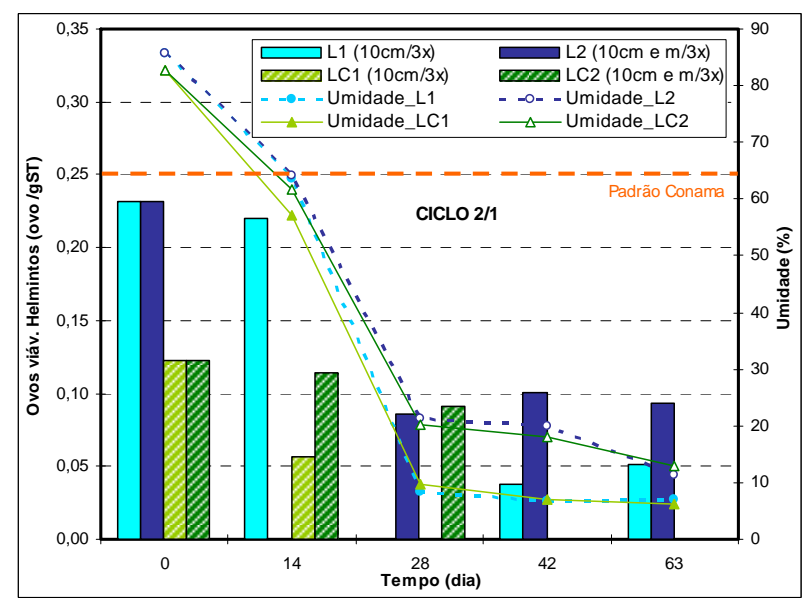

$(5.6 \mathrm{~b})$

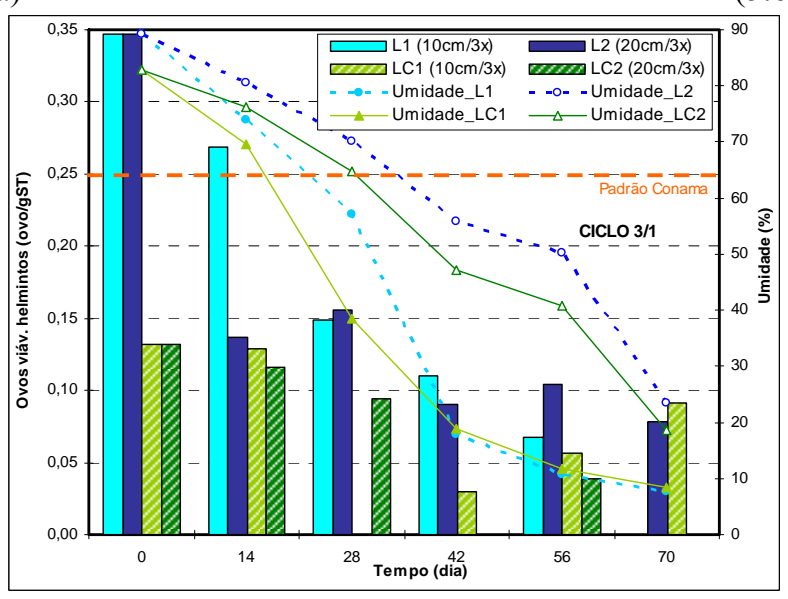

(5.6c)

Gráfico 5.6 - Variação da quantidade de ovos viáveis de helmintos e umidade no lodo digerido sem cal (L1 e L2) e com cal (LC1 e LC2) durante os ciclos da Etapa 1 - Ciclos 1/1 (5.6a), 2/1 (5.6b) e 3/1 $(5.6 \mathrm{c})$

O que se pode observar é que o fato de a umidade ter atingido valores próximos a $10 \%$, e, ainda, associado às condições da temperatura, não foi condição suficinte para fazer que os ovos de helmintos fossem inviabilizados completamente, ressaltando que já eram valores bem reduzidos quando comparados aos padrões do Conama (BRASIL, 2006c). Apesar de muito reduzidos, foram observados $\mathrm{OVH}$ no lodo com cal mesmo com teores de umidade baixos (TABELAS 5.3 e 5.4). Os valores de ovos de helmintos totais encontrados nos lodos de cada célula, nos três ciclos da Etapa 1, encontram-se apresentados no APÊNDICE 1. 
O lodo digerido usado nos Ciclos $1 / 1$ e 2/1, já apresentava valores de OVH bastante reduzidos, inclusive sempre abaixo de 0,25 ovo/gST, que é o limite estabelecido pela Resolução no 375/2006 do Conama (BRASIL, 2006c). Apenas no Ciclo 3/1, a densidade de OVH no lodo usado no experimento apresentou valor acima do limite estabelecido pelo Conama. No lodo sem cal (L1 e L2), valores inferiores ao padrão foram obtidos no $14^{\circ}$ dia na amostra de lodo de L2 (umidade igual a 80,44\%) e no $28^{\circ}$ dia de L1 (umidade igual a $50,21 \%)$.

Apenas no Ciclo 3/1, a densidade de OVH no lodo usado no experimento apresentou valor acima do limite estabelecido pelo Conama. No lodo sem cal (L1 e L2), valores inferiores ao padrão foram obtidos no $14^{\circ}$ dia na amostra de lodo de L2 (umidade igual a $80,44 \%$ ) e no $28^{\circ}$ dia de L1 (umidade igual a 50,21\%).

Verificou-se, em alguns casos, que a densidade de OVH diminuiu com a adição da cal. No Ciclo $2 / 1$ os valores passaram de 0,23 ovo/gST para 0,12 ovo/gST e, no Ciclo 3/1 de 0,35 ovo/gST para 0,13 ovo/gST (TABELA 5.4). Condição verificada também por Passamani (2001) e Thomaz-Soccol, Paulino e Castro (1998).

\subsubsection{Salmonella sp.}

A existência de Salmonella sp. no lodo usado no experimento não se mostrou uniforme. Isso porque, os lodos usados nos Ciclos 2/1 e 3/1 já apresentavam ausência de Salmonella sp., o que não ocorreu no Ciclo 1/1 (TABELA 5.4). Sendo assim, a diminuição/eliminação desse microrganismo só pode ser observada no Ciclo 1/1. Nesse caso, foi constatada a ausência de Salmonella sp., após o $28^{\circ}$ dia de monitoramento no lodo de L1 e L2 (lodo sem cal) (umidade média de $21 \%$ ). E, após adicionar cal ao lodo, foi observada a ausência desse organismo nas amostras do lodo de LC1 e LC2, até o final do ciclo, não ocorrendo recolonização dessa bactéria.

\subsubsection{PARÂMETROS DE INTERESSE AGRONÔMICO}

Os parâmetros de interesse agronômico monitorados foram determinados, no início e no final de cada ciclo, no lodo sem cal e com cal. Como não foi percebida nenhuma variação significativa entre os resultados obtidos nos ciclos, são apresentados, na TABELA 5.5, apenas 
a média, o máximo e o desvio padrão determinados nas amostras analisadas de lodo sem cal e com cal. Os resultados obtidos no monitoramento dos três ciclos e que deram origem às concentrações apresentadas na TABELA 5.5, encontram-se no APÊNDICE 2.

Tabela 5.5 - Concentrações médias, máximas e desvio padrão dos parâmetros de interesse agronômico no material das células de lodo digerido sem cal (L1 e L2) e com cal (LC1 e LC2), no início e no final dos ciclos da Etapa 1

\begin{tabular}{|c|c|c|c|c|c|c|c|c|c|c|c|c|}
\hline \multirow{3}{*}{ Parâmetro } & \multicolumn{6}{|c|}{$\begin{array}{l}\text { Lodo sem cal (L1 e L2) } \\
\text { (\% em base seca) }\end{array}$} & \multicolumn{6}{|c|}{$\begin{array}{c}\text { Lodo com cal (LC2 e LC2) } \\
\text { (\% em base seca) }\end{array}$} \\
\hline & \multicolumn{3}{|c|}{$\begin{array}{l}\text { Início dos Ciclos } \\
\qquad(n=6)\end{array}$} & \multicolumn{3}{|c|}{$\begin{array}{l}\text { Final dos Ciclos } \\
\qquad(n=6)\end{array}$} & \multicolumn{3}{|c|}{$\begin{array}{l}\text { Início dos Ciclos } \\
\qquad(n=6)\end{array}$} & \multicolumn{3}{|c|}{$\begin{array}{l}\text { Final dos Ciclos } \\
\qquad(n=6)\end{array}$} \\
\hline & Méd. & Max. & $\mathbf{D P} \mathbf{P}^{(1)}$ & Média & Max. & D P & Méd. & Max. & DP & Méd. & Max. & DP \\
\hline Carbono orgânico & 35,48 & 35,96 & 0,44 & 34,71 & 38,28 & 1,85 & 31,61 & 34,22 & 1,50 & 32,97 & 38,86 & 4,08 \\
\hline $\mathrm{N}$ & 3,35 & 3,60 & 0,21 & 3,32 & 3,70 & 0,21 & 2,96 & 3,00 & 0,05 & 2,48 & 2,80 & 0,23 \\
\hline $\mathrm{P}$ & 1,68 & 1,73 & 0,04 & 1,34 & 1,65 & 0,20 & 1,24 & 1,49 & 0,18 & 1,34 & 1,43 & 0,07 \\
\hline K & 0,53 & 0,66 & 0,12 & 0,54 & 0,78 & 0,15 & 0,27 & 0,41 & 0,12 & 0,64 & 0,78 & 0,08 \\
\hline $\mathrm{Ca}$ & 1,00 & 1,17 & 0,11 & 1,06 & 1,40 & 0,29 & 4,76 & 5,53 & 0,70 & 9,22 & 12,10 & 1,94 \\
\hline $\mathrm{Mg}$ & 0,24 & 0,28 & 0,02 & 0,24 & 0,34 & 0,08 & 0,20 & 0,25 & 0,03 & 0,29 & 0,33 & 0,04 \\
\hline S & 0,57 & 0,76 & 0,14 & 0,67 & 0,95 & 0,17 & 0,60 & 0,68 & 0,07 & 0,75 & 0,82 & 0,05 \\
\hline $\mathrm{Na}$ & 0,08 & 0,09 & 0,01 & 0,11 & 0,15 & 0,03 & 0,08 & 0,09 & 0,01 & 0,11 & 0,12 & 0,01 \\
\hline Relação C/N & $11 / 1$ & $11 / 1$ & - & $10,5 / 1$ & $12 / 1$ & - & $10 / 1$ & $11 / 1$ & - & $12,8 / 1$ & $16 / 1$ & - \\
\hline
\end{tabular}

Nota: ${ }^{(1)}$ - Desvio padrão; o tempo relativo a cada Ciclo foi: Ciclo $1 / 1-70$ dias, Ciclo 2/1 - 63 dias, Ciclo 3/1 69 dias.

A maioria dos parâmetros apresentou concentrações ao final do ciclo bem parecidas com as iniciais, independentemente de ter sido usada a cal ou não, exceto as concentrações de cálcio que, como era de esperar, foram elevadas nos lodos de LC1 e LC2 (com adição de cal) quando comparados com os de L1 e L2.

\subsubsection{SUBSTÂNCIAS INORGÂNICAS (ÍONS METÁLICOS)}

Para avaliar as substâncias inorgânicas contidas no material estudado, os resultados obtidos nos três ciclos da Etapa 1 foram agrupados, no início e no final dos ciclos. Como efetuados na avaliação dos parâmetros de interesse agronômico, foram determinadas as médias e os desvios padrões de cada parâmetro monitorado, diferenciando apenas o fato de ter adicionado cal ou não ao lodo. Isso porque, independentemente da configuração utilizada da metodologia, o processo estudado não possibilita remover tais substâncias. Desse modo, pode-se ter uma caracterização inicial e final do material sem cal e com cal.

A TABELA 5.6 apresenta a média, o valor máximo e o desvio padrão das concentrações obtidas dos diversos íons metálicos monitorados no início e no final dos ciclos, durante a 
Etapa 1, para o lodo de L1 e L2 (sem cal) e de LC1 e LC2 (com cal), inclusive, os padrões exigidos pela Resolução n ${ }^{0}$ 375/2006 do Conama (BRASIL, 2006a). No APÊNDICE 3, encontram-se todos os valores obtidos no monitoramento dos íons metálicos.

Tabela 5.6 - Concentrações médias, máximas e desvio padrão de íons metálicos no material das células de lodo digerido sem cal (L1 e L2) e com cal (LC1 e LC2), no início e no final dos ciclos da Etapa 1

\begin{tabular}{|c|c|c|c|c|c|c|c|c|c|c|c|c|c|}
\hline \multirow{3}{*}{ 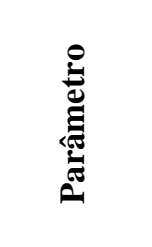 } & \multirow{3}{*}{ 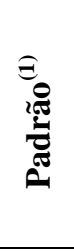 } & \multicolumn{6}{|c|}{$\begin{array}{l}\text { Lodo sem cal (L1 e L2) } \\
\text { (mg/kg em base seca) }\end{array}$} & \multicolumn{6}{|c|}{$\begin{array}{l}\text { Lodo com cal (LC2 e LC2) } \\
\text { (mg/kg em base seca) }\end{array}$} \\
\hline & & \multicolumn{3}{|c|}{$\begin{array}{l}\text { Início dos Ciclos } \\
\quad(n=6)\end{array}$} & \multicolumn{3}{|c|}{$\begin{array}{l}\text { Final dos Ciclos } \\
\quad(n=6)\end{array}$} & \multicolumn{3}{|c|}{$\begin{array}{l}\text { Início dos Ciclos } \\
(\mathrm{n}=6)\end{array}$} & \multicolumn{3}{|c|}{$\begin{array}{l}\text { Final dos Ciclos } \\
\quad(n=6)\end{array}$} \\
\hline & & Méd. & Max. & $\mathbf{D P} \mathbf{P}^{(2)}$ & Méd. & Max. & DP & Méd. & Max. & DP & Méd. & Max. & DP \\
\hline Arsênio & 41 & 8 & 12 & 2,28 & 14 & 18 & 3,32 & 13 & 18 & 3,35 & 13 & 21 & 4,10 \\
\hline Bário & 1300 & 198 & 245 & 49,18 & 208 & 280 & 57,06 & 175 & 220 & 31,20 & 174 & 220 & 39,73 \\
\hline Cádmio & 39 & 2 & 4 & 0,61 & 3 & 5 & 0,94 & 2 & 4 & 0,92 & 2 & 3 & 0,57 \\
\hline Chumbo & 300 & 12 & 18 & 4,02 & 17 & 22 & 4,46 & 15 & 18 & 2,29 & 16 & 30 & 6,88 \\
\hline Cobre & 1500 & 373 & 512 & 126,94 & 321 & 445 & 82,12 & 383 & 501 & 100,58 & 320 & 542 & 141,75 \\
\hline Cromio & 1000 & 287 & 358 & 71,73 & 310 & 391 & 50,33 & 289 & 337 & 48,75 & 302 & 365 & 32,64 \\
\hline Mercúrio & 17 & 0,09 & 0,10 & 0,01 & 0,15 & 0,17 & 0,02 & 0,11 & 0,15 & 0,04 & 0,11 & 0,14 & 0,03 \\
\hline Molibdênio & 50 & 21 & 30 & 5,63 & 15 & 22 & 4,56 & 18 & 22 & 2,49 & 15 & 18 & 3,02 \\
\hline Níquel & 420 & 39 & 56 & 10,83 & 55 & 82 & 16,35 & 45 & 60 & 10,38 & 52 & 71 & 16,34 \\
\hline Selênio & 100 & 2 & 3 & 0,79 & 2 & 2 & 0,23 & 1 & 2 & 0,37 & 2 & 3 & 0,49 \\
\hline Zinco & 2800 & 673 & 767 & 63,51 & 541 & 766 & 157,94 & 718 & 805 & 69,10 & 578 & 680 & 87,11 \\
\hline
\end{tabular}

Nota: ${ }^{(1)}-\mathrm{mg} / \mathrm{kg}$ base seca - Resolução $\mathrm{n}^{\mathrm{0}} 375 / 2006$ do Conama (BRASIL, 2006c); ${ }^{(2)}$ - Desvio padrão.

Nesse caso, o próprio lodo usado na pesquisa já apresentava concentração dos íons metálicos abaixo dos padrões exigidos pela Resolução do Conama (BRASIL, 2006c).

\subsubsection{DENSIDADE DO LODO}

A densidade do lodo foi calculada com auxílio da eq. (4.1). De acordo com Tchobanoglous, Burton e Stensel (2002), duas novas expressões dessa equação são apresentadas para o cálculo da densidade do lodo (água e sólidos). A eq. (5.2), usada para determinar a densidade do lodo, é função das frações de sólidos (teor de sólidos secos - ST) e água (teor de umidade), contidos no material. Para tanto, é necessário conhecer a densidade dos sólidos do lodo eq. (5.3) que é calculada com auxílio dos percentuais de sólidos voláteis e fixos em relação ao teor de sólidos totais. Ainda, segundo os autores, a densidade de sólidos fixos do lodo situa-se em torno de 2,5 e de sólidos voláteis 1,0 . 
Então, a densidade do lodo (água e sólidos) pode ser calculada por:

$$
\frac{1}{S s l}=\frac{F S l}{S s}+\frac{F A l}{\rho w}
$$

onde:

Ssl $=$ Densidade do lodo

Ss $=$ Densidade dos sólidos do lodo

$F S l=$ Fração de sólidos no lodo $-\mathrm{ST}$, expressa em decimais

$F A l=$ Fração de água no lodo - teor de umidade, expressa em decimais

$\rho w \quad=$ Densidade da água $(1,0)$

A densidade dos sólidos do lodo $(S s)$ pode ser definida por:

$$
\frac{1}{S S}=\frac{(S F / S T)}{2,5}+\frac{(S V / S T)}{1,0}
$$

onde:

Ss $\quad=$ Densidade dos sólidos do lodo

$S F=$ Sólidos Totais Fixos

$S T=$ Sólidos Totais

$S V=$ Sólidos Totais Voláteis

Com a aplicação das equações apresentadas, tem-se a variação da densidade do lodo em função unicamente de características físicas do material, ou seja, esta passa por alterações apenas com as variações do teor de umidade e sólidos do material. Sendo assim, optou-se, então, por avaliar o seu comportamento independentemente das condições metodológicas adotadas em cada ciclo desenvolvido, como o período de revolvimento e a forma de disposição do lodo dentro da estufa. Nesse caso, os resultados de L1 e L2 foram agrupadas, assim como LC1 e LC2, a fim de avaliar a interferência causada na densidade com a adição de cal ao lodo. Os dados utilizados e os respectivos valores de densidade encontrados estão apresentados no APÊNDICE 4, referentes ao lodo sem cal e com cal.

O GRÁFICO 5.7 apresenta a tendência da densidade em relação ao teor de sólidos totais (ST), com a definição da melhor curva ajustada na regressão linear, nas duas condições avaliadas, com e sem adição de cal ao lodo. Os coeficientes de correlação linear, determinados nos dois casos, indicam uma forte correspondência entre os resultados relacionados, com valores de: $\mathrm{R}^{2}=0,9528$ (L1 e L2) e $\mathrm{R}^{2}=0,9413$ (LC1 e LC2), ajustados para uma curva exponencial. Observa-se que a densidade do material se comportou com uma tendência de crescimento imaginado, variando com o aumento do teor de ST. 
Como era esperado, o lodo que recebeu a cal apresentou valores de densidade mais elevados que o sem cal, em razão do aumento do teor de ST. Isso foi bem realçado quando o lodo foi perdendo umidade, pois a diferença ficou mais evidenciada. Até o teor de, aproximadamente, $20 \%$ ST, observa-se que a densidade apresentada para os dois casos é praticamente a mesma e, a partir daí, com a elevação do teor de sólidos, o lodo com cal apresentou densidade sempre superior ao sem cal. Ao atingir 90\% ST, por exemplo, o lodo sem cal apresentou densidade de 1,39 enquanto o com cal 1,46 (GRÁFICO 5.7).

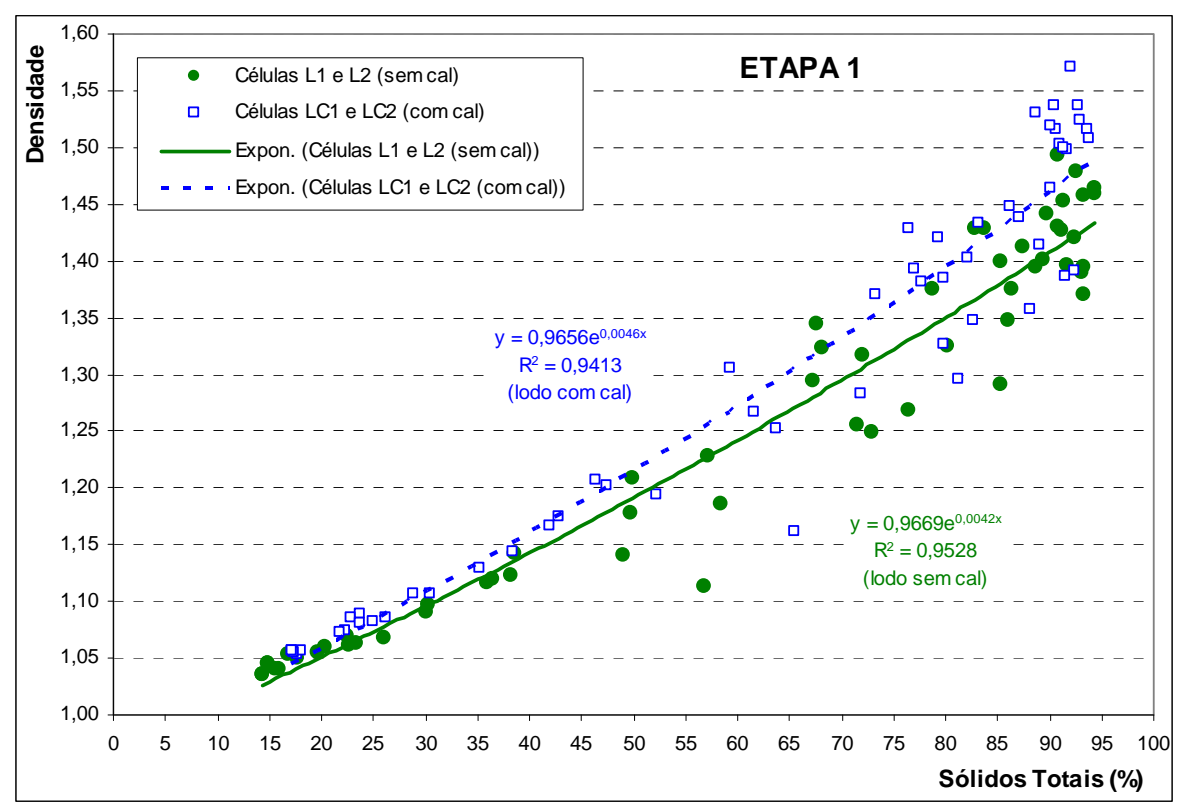

Gráfico 5.7 - Variação da densidade do lodo em relação ao teor de sólidos totais (ST), com base nos valores obtidos nos Ciclos 1/1, 2/1 e 3/1 de lodo digerido sem cal (L1 e L2) e com cal (LC1 e LC2) durante a Etapa 1

\subsection{ETAPA 2 - LODO NÃO ENCAMINHADO AO DIGESTOR}

A diferença fundamental entre o lodo usdo na Etapa 1 e na Etapa 2 é que o segundo não foi submetido a digestão aeróbia. O lodo removido dos tanques de aeração/decantação, durante o tratamento da fase líquida, foi encaminhado para o adensador e em seguida para o desaguamento em centrífuga, após o condicionamento com polímero.

Durante o desenvolvimento da Etapa 2, buscou-se observar características desse lodo que diferenciassem do lodo digerido usado na Etapa 1. Inicialmente, pressupôs-se que o lodo exalaria cheiro desagradável pelo excesso de material ainda instável e que isso dificultaria a montagem das células de lodo, principalmente, em razão de o trabalho ser executado 
manualmente. No entanto, a sua manipulação foi realizada de forma tranquila e o odor emanado foi suportável, apesar de diferente (mais forte) do apresentado no lodo da Etapa 1.

Em contrapartida, o material resultante da mistura lodo mais cal comportou-se de forma bastante pegajosa que dificultou sua retirada da betoneira e sua manipulação. Além disso, no $14^{\circ}$ dia, houve o aparecimento de ovos, larvas e pupas $^{30}$, componentes do ciclo de vida das moscas (COVISA, 2009), nos lodos de LC1 e LC2 (lodo com cal). Nesse mesmo período, verificou-se a presença de um odor muito desagradável dentro da estufa que não se estendeu para os seus arredores externos. Nos lodos de L1 e L2, esse fato não ocorreu e, felizmente, conseguiu-se impedir que eles fossem contaminados.

Com o andamento da pesquisa, foi percebido o aparecimento de pouquíssimas moscas em torno do $18^{\mathrm{a}}$ dia. De acordo com a COVISA (2009), após o aparecimento da pupa, as moscas permanecem nessa fase por um período de 4 dias a 5 dias e, que quanto maior a temperatura e a umidade, mais rápido ocorrerá o seu ciclo de vida (Ovo $>$ Larva $>$ Pupa $>$ Adulto). Dito isso, acredita-se que com a manutenção do revolvimento do material e a perda da umidade os ovos, larvas e purpas foram desaparecendo, acorrendo, assim, uma quebra no ciclo de vida da mosca.

Como na Etapa 1, também apareceram fungos na primeira semana dos ciclos, e, com o revolvimento, desapareceram por completo.

\subsubsection{DETERMINAÇÃO DA QUANTIDADE DE CAL A SER UTILIZADA NA ETAPA 2}

A base de cálculo empregada na determinação da quantidade de cal foi a mesma adotada na Etapa 1. A diferença entre as duas etapas está relacionada apenas aos teores de cal testados. $\mathrm{Na}$ Etapa 2, optou-se por investigar uma faixa maior de teores por tratar-se de um lodo completamente desconhecido. Nesse caso, foram avaliados oito teores de cal em base seca de lodo que variaram de 5\% a 40\%. Os dados usados na Etapa 2 estão apresentados a seguir:

- Massa da amostra de lodo utilizada nos testes $(\mathrm{m})=21,00 \mathrm{~kg}$;

- Teor de Sólidos Totais inicial $\left(\mathrm{ST}_{\mathrm{i}}\right)=20 \%$;

\footnotetext{
${ }^{30}$ Pupa - após as larvas abandonarem a matéria orgânica em que estavam instaladas, a camada externa de pele das larvas se endurece formado uma casca (casulo), dentro da qual começa a haver transformação para a mosca adulta, recebendo o nome de pupa (COVISA, 2009).
} 
- Teores de cal inicialmente considerados $\left(\mathrm{T}_{\mathrm{cal}}\right)=5 \%, 10 \%, 15 \%, 20 \%, 25 \%, 30 \%, 35 \% \mathrm{e}$ $40 \%$ em base seca.

O teor de sólidos totais real foi calculado a partir da média dos valores obtidos de ST de três amostras diferentes de lodo de massas iguais. Com os resultados de sólidos das amostras $\mathrm{A}_{1}$ $(\mathrm{ST}=14,69 \%), \mathrm{A}_{2}(\mathrm{ST}=14,91 \%)$ e $\mathrm{A}_{3}(\mathrm{ST}=13,78 \%)$, foi obtido o valor médio de $14,5 \% \mathrm{ST}$. Utilizando, então, a sequência de cálculo descrita na Etapa 1, determinaram-se as massas de cal para $\mathrm{ST}_{\mathrm{i}}=20 \%$ e os teores de cal reais correspondentes ao teor de sólidos totais real do lodo usado no teste.

Na TABELA 5.7, estão relacionados, além das quantidades de cal determinadas, os valores de pH obtidos no momento da mistura (inicial), 2 horas e 24 horas após a mistura, determinados em laboratório, como, também, os teores de $\mathrm{Ca}[\mathrm{OH}]_{2}$ adicionados ao lodo. No GRÁFICO 5.8 são apresentadas as variações do $\mathrm{pH}$ para as diferentes dosagens de cal nos diferentes intervalos de tempo.

Tabela 5.7 - Teores de cal testados e respectivos valores de $\mathrm{pH}$ para a determinação da quantidade de cal a ser adicionada ao lodo da Etapa 2 nos diferentes tempos definidos pela Resolução 375/2006 do Conama

\begin{tabular}{|c|c|c|c|c|c|c|}
\hline \multirow{2}{*}{ 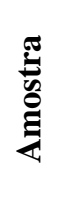 } & \multicolumn{2}{|c|}{$\begin{array}{l}\text { Quantidade de cal } \\
\text { em massa seca } \\
(\mathrm{ST}=14,5 \%)\end{array}$} & \multirow{2}{*}{$\begin{array}{c}\text { Quantidade } \mathrm{Ca}(\mathrm{OH})_{2} \text { em } \\
\text { massa seca }(\mathrm{ST}=14,5 \%) \\
(\%)\end{array}$} & \multicolumn{3}{|c|}{$\begin{array}{c}\text { pH Mistura } \\
\text { (lodo + cal) }\end{array}$} \\
\hline & $(\%)$ & (kg) & & Inicial & 2h depois & $24 \mathrm{~h}$ depois ${ }^{1}$ \\
\hline $1 / 2$ & 6,92 & 0,21 & 6,2 & 11,27 & 11,17 & 10,16 \\
\hline $2 / 2$ & 13,83 & 0,42 & 12,5 & 11,82 & 11,99 & 11,88 \\
\hline $3 / 2$ & 20,75 & 0,63 & 18,7 & 11,84 & 12,02 & 11,87 \\
\hline $4 / 2$ & 27,66 & 0,84 & 24,9 & 11,89 & 11,99 & 11,85 \\
\hline $5 / 2$ & 34,58 & 1,05 & 31,1 & 11,82 & 12,03 & 11,92 \\
\hline $6 / 2$ & 41,49 & 1,26 & 37,3 & 12,01 & 12,05 & 11,87 \\
\hline $7 / 2$ & 48,51 & 1,47 & 43,7 & 11,97 & 12,03 & 11,77 \\
\hline $8 / 2$ & 55,33 & 1,68 & 49,8 & 12,09 & 12,07 & 11,86 \\
\hline
\end{tabular}

NOTA: $\mathrm{pH}$ do lodo não digerido sem adição de cal $=6,87$; densidade adotada para ST de 20\% $=1,05$; ${ }^{(1)}$ Tempo referente ao início da mistura.

Apesar de tratar-se de um lodo com características diferentes do utilizado na Etapa 1, observase, no GRÁFICO 5.8, que o menor teor de cal a ser adicionado ao lodo para atender às exigências legais (BRASIL, 2006c) ficou, também, em torno de 14\%. Sendo assim, o mesmo percentual foi adotado, ou seja, $15 \%$ de cal em base seca de lodo $\left(13,5 \% \mathrm{Ca}[\mathrm{OH}]_{2}\right.$ em base seca), fazendo valer as mesmas observações inferidas na Etapa 1. 


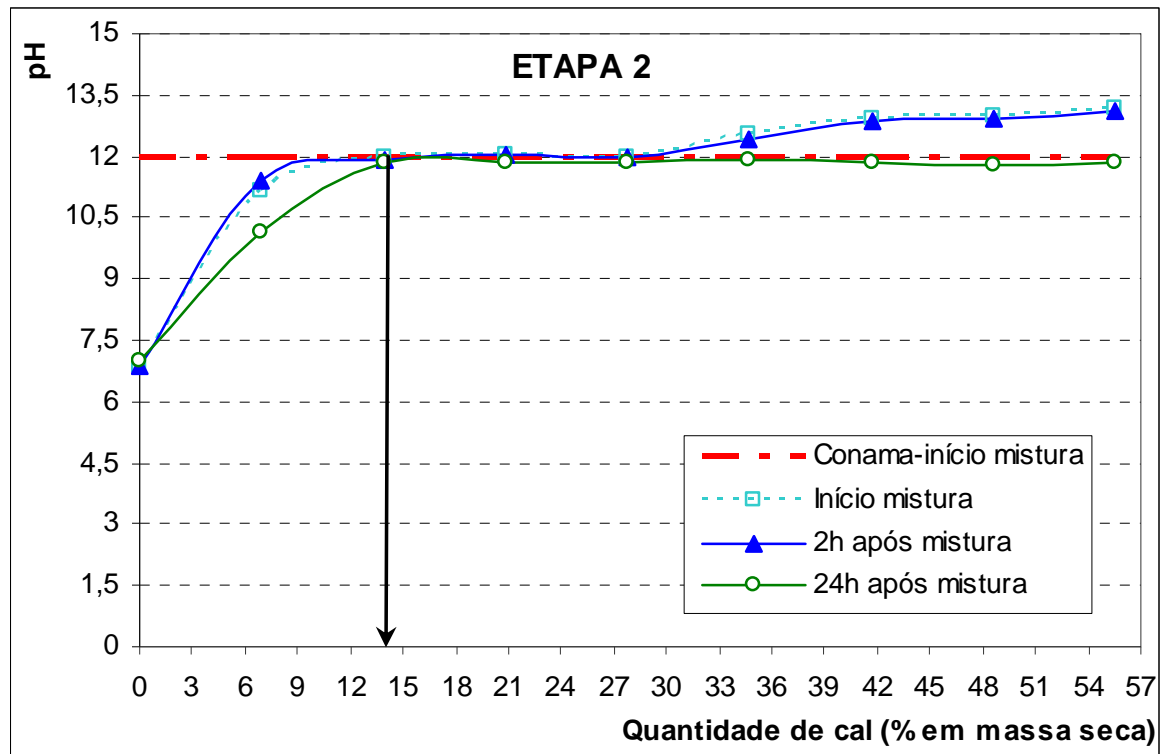

Gráfico 5.8 - Valores de pH considerando diferentes porcentagem de cal, para o lodo da Etapa 2

\subsubsection{TEMPERATURAS DENTRO E FORA DA ESTUFA}

Na TABELA 5.8, estão apresentados os valores de temperatura ambiente (T1) e de temperatura no interior da estufa (T2), referentes às médias das médias horárias, máximas horárias e mínimas horárias ocorridas em cada ciclo da Etapa 2.

Tabela 5.8 - Temperaturas médias das médias horárias, máximas horárias e mínimas horárias dentro e fora da estufa durante a Etapa 2

\begin{tabular}{|c|c|c|c|c|c|c|c|}
\hline \multirow{3}{*}{ 을 } & \multirow{3}{*}{ 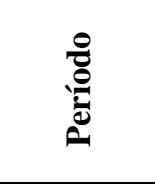 } & \multicolumn{6}{|c|}{ Temperatura $\left({ }^{\circ} \mathrm{C}\right)$} \\
\hline & & \multicolumn{2}{|c|}{ Média das médias horárias } & \multicolumn{2}{|c|}{ Máxima horária } & \multicolumn{2}{|c|}{ Mínima horária } \\
\hline & & $\begin{array}{c}\text { T1 } \\
\text { (Dentro da estufa) }\end{array}$ & $\begin{array}{c}\mathrm{T} 2 \\
\text { (Fora da estufa) }\end{array}$ & $\begin{array}{c}\text { T1 } \\
\text { (Dentro da estufa) }\end{array}$ & $\begin{array}{c}\text { T2 } \\
\text { (Fora da estufa) }\end{array}$ & $\begin{array}{c}\text { T1 } \\
\text { (Dentro da estufa) }\end{array}$ & $\begin{array}{c}\mathrm{T} 2 \\
\text { (Fora da estufa) }\end{array}$ \\
\hline $1 / 2$ & $\begin{array}{c}12 / 12 / 07 \mathrm{a} \\
20 / 02 / 08\end{array}$ & 28,6 & 25,2 & 55,4 & 36,2 & 15,3 & 14,4 \\
\hline $2 / 2$ & $\begin{array}{c}12 / 03 / 08 \mathrm{a} \\
02 / 05 / 08\end{array}$ & 31,5 & 26,9 & 53,2 & 38,8 & 21,7 & 19,7 \\
\hline $3 / 2$ & $\begin{array}{c}04 / 06 / 08 \mathrm{a} \\
13 / 08 / 08\end{array}$ & 28,2 & 23,1 & 46,1 & 37,4 & 17,9 & 15,4 \\
\hline
\end{tabular}

A estufa usada no experimento possibilitou uma temperatura interna média das médias horárias acima de $28^{\circ} \mathrm{C}$, enquanto a externa (temperatura ambiente) encontrava-se em torno de $25^{\circ} \mathrm{C}$. O GRÁFICO 5.9 mostra o comportamento das temperaturas nos 3 ciclos, especificamente, as médias horárias e as temperaturas máximas e mínimas horárias, todas dentro e fora da estufa. Considerando os valores médios de temperatura obtidos dentro da 
estufa, durante o intervalo de tempo entre 10 horas e 17 horas os valores de temperatura foram sempre acima de $32{ }^{\circ} \mathrm{C}$, confirmando a potencialidade da estufa em manter temperaturas internas elevadas por um extenso período do dia, mesmo em horários quando a externa já apresenta valores bem mais inferiores.

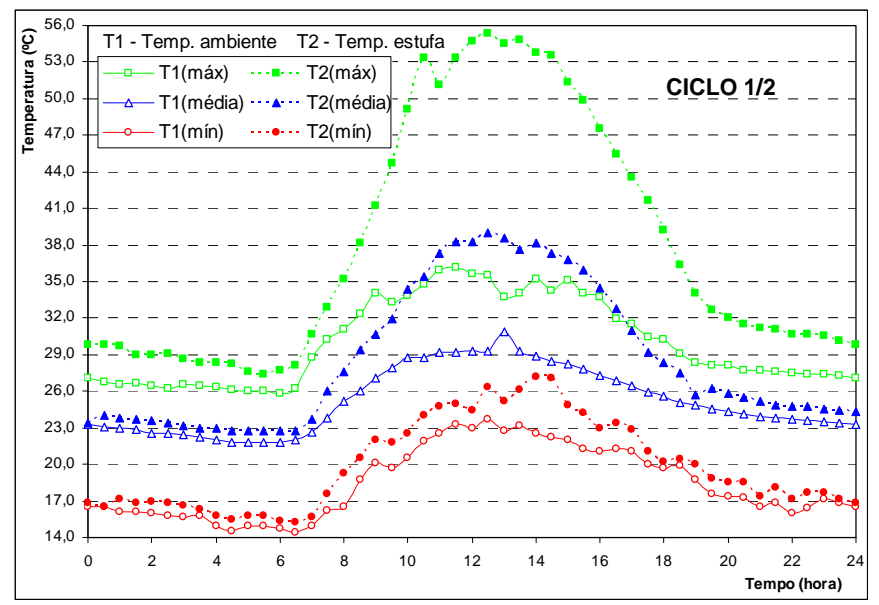

(5.9a) $-10 \mathrm{~cm}$ e m/3x $+1 \mathrm{x}(\mathrm{L} 1, \mathrm{~L} 2, \mathrm{LC} 1$ e LC2 $)$

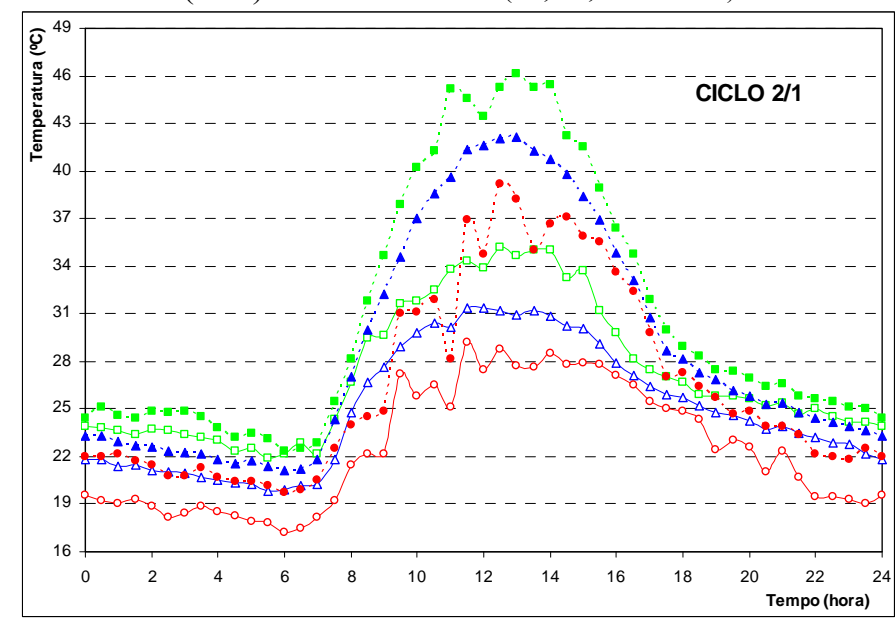

$(5.9 b)-10 \mathrm{~cm} / 3 x(L 1$ e LC1); $10 \mathrm{~cm}$ e m/3x (L2 e LC2)

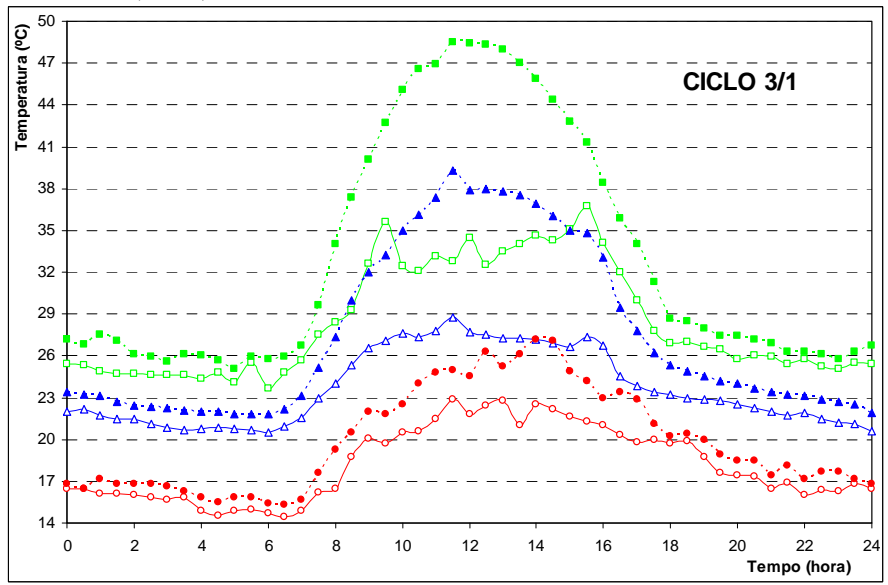

$(5.9 \mathrm{c})-10 \mathrm{~cm} / 3 \mathrm{x}$ (L1 e LC1);- 20cm /3x (L2 e LC2)

Gráfico 5.9 - Variação das temperaturas média das médias horárias, máximas horárias e mínimas horárias, dentro e fora da estufa, durante a Etapa 2 - Ciclo 1/2 (5.9a), Ciclo 2/2 (5.9b) e Ciclo 3/2 $(5.9 \mathrm{c})$ 


\subsubsection{PARÂMETROS - UMIDADE, SÓLIDOS E POTENCIAL HIDROGENIÔNICO}

A TABELA 5.9 mostra os resultados de umidade, SV/ST e pH no lodo sem cal (L1 e L2) e com cal (LC1 e LC2), nos três ciclos da Etapa 2.

Tabela 5.9 - Valores de umidade, SV/ST e pH do lodo sem cal (L1 e L2) e com cal (LC1 e LC2) durante os Ciclos $1 / 2,2 / 2$ e $3 / 2$

\begin{tabular}{|c|c|c|c|c|c|c|c|c|c|c|c|c|c|}
\hline \multirow{3}{*}{ Data } & \multirow{3}{*}{$\begin{array}{c}\text { Tempo } \\
\text { (dia) }\end{array}$} & \multicolumn{4}{|c|}{ Umidade (\%) } & \multicolumn{4}{|c|}{ SV/ST (\%) } & \multicolumn{4}{|c|}{ pH } \\
\hline & & \multicolumn{2}{|c|}{ Lodo sem cal } & \multicolumn{2}{|c|}{ Lodo com cal } & \multicolumn{2}{|c|}{ Lodo sem cal } & \multicolumn{2}{|c|}{ Lodo com cal } & \multicolumn{2}{|c|}{ Lodo sem cal } & \multicolumn{2}{|c|}{ Lodo com cal } \\
\hline & & $\mathbf{L 1}$ & L2 & LC1 & LC2 & L1 & $\mathbf{L 2}$ & LC1 & LC2 & $\mathbf{L 1}$ & L2 & LC1 & LC2 \\
\hline \multicolumn{14}{|c|}{ CICLO $1 / 2-10 \mathrm{~cm} \mathrm{e} \mathrm{m/3x} \mathrm{+} \mathrm{1x} \mathrm{(L1,} \mathrm{L2,} \mathrm{LC1} \mathrm{e} \mathrm{LC2})^{(*)}$} \\
\hline $12 / 12 / 07$ & 0 & 89,12 & 89,12 & 84,41 & 84,41 & 78,80 & 78,80 & 60,79 & 60,79 & 7,28 & 7,28 & 12,26 & 12,26 \\
\hline 19/12/07 & 7 & 77,64 & 80,34 & 76,81 & 78,85 & 55,23 & 64,48 & 53,44 & 54,37 & 6,21 & 6,33 & 12,09 & 11,91 \\
\hline $26 / 12 / 07$ & 14 & 53,55 & 58,97 & 51,83 & 62,08 & 51,05 & 55,60 & 49,65 & 56,24 & 7,13 & 7,18 & 9,10 & 8,91 \\
\hline $02 / 01 / 08$ & 21 & 39,10 & 36,34 & 37,20 & 37,77 & 43,44 & 52,56 & 40,79 & 42,27 & 7,40 & 7,00 & 8,19 & 8,24 \\
\hline 09/01/08 & 28 & 18,83 & 24,51 & 20,38 & 21,83 & 51,42 & 56,44 & 47,75 & NR & 7,02 & 7,14 & 8,34 & 8,55 \\
\hline $16 / 01 / 08$ & 35 & 26,79 & 20,93 & 20,32 & 21,67 & 40,72 & 49,57 & 38,14 & 39,84 & 7,24 & 6,99 & 8,50 & 8,40 \\
\hline $23 / 01 / 08$ & 42 & 12,05 & 12,14 & 9,31 & 11,80 & 49,65 & NR & 40,51 & 40,57 & 6,78 & 6,60 & 8,00 & 7,91 \\
\hline $30 / 01 / 08$ & 49 & 16,43 & 12,91 & 12,64 & 13,87 & 38,33 & 47,50 & 37,62 & 36,33 & 6,22 & 5,93 & 7,82 & 7,78 \\
\hline 06/02/08 & 56 & \multicolumn{12}{|c|}{ Não foi realizada coleta de amostras } \\
\hline $13 / 02 / 08$ & 63 & 11,37 & 10,92 & 9,50 & 9,54 & 39,98 & 44,18 & 34,17 & 36,50 & 6,53 & 6,39 & 8,23 & 8,16 \\
\hline $20 / 02 / 08$ & 70 & 5,93 & 6,29 & 5,76 & 6,16 & 36,02 & 43,92 & 34,41 & 35,39 & 6,44 & 6,36 & 7,66 & 7,67 \\
\hline \multicolumn{14}{|c|}{ CICLO $2 / 2$ - 10cm/3x (L1 e LC1); 10cm e m/3x (L2 e LC2) ${ }^{(*)}$} \\
\hline $12 / 03 / 08$ & 0 & 85,21 & 85,21 & 82,28 & 82,28 & 64,57 & 64,57 & 52,09 & 52,09 & 6,88 & 6,88 & 12,42 & 12,42 \\
\hline $19 / 03 / 08$ & 7 & 76,86 & 83,22 & 75,02 & 76,22 & 49,53 & 51,73 & 44,41 & 45,26 & 6,45 & 6,50 & 12,15 & 12,20 \\
\hline $26 / 03 / 07$ & 14 & 70,30 & 71,75 & 67,08 & 65,28 & 48,12 & NR & 48,27 & 51,06 & 6,60 & 6,72 & 9,00 & 8,80 \\
\hline $02 / 04 / 08$ & 21 & 56,16 & 66,20 & 52,30 & 58,19 & 44,97 & 46,91 & 37,58 & 35,84 & 6,50 & $\mathrm{NR}$ & 8,70 & 8,99 \\
\hline 09/04/08 & 28 & 43,29 & 59,04 & 37,80 & 51,88 & 43,08 & 45,59 & 39,97 & 37,49 & 6,20 & 6,60 & 8,25 & 8,30 \\
\hline $16 / 04 / 08$ & 35 & 29,07 & 41,62 & 18,03 & 36,80 & 42,85 & 43,90 & 37,09 & 36,74 & 5,81 & NR & 8,54 & 8,77 \\
\hline $23 / 04 / 08$ & 42 & \multicolumn{12}{|c|}{ Não foi realizada coleta de amostras } \\
\hline $30 / 04 / 08$ & 49 & 12,94 & 33,23 & 14,94 & 26,43 & 43,11 & 38,11 & 33,54 & 32,05 & 6,04 & NR & 8,36 & 8,57 \\
\hline 07/05/08 & 56 & 9,82 & 27,90 & 16,12 & 22,53 & 42,65 & 40,77 & 33,86 & 33,44 & 5,81 & 5,70 & 8,10 & 8,72 \\
\hline $14 / 05 / 08$ & 63 & 10,62 & 25,45 & 9,64 & 20,77 & 42,62 & 41,87 & 34,70 & 34,89 & 6,05 & NR & 8,24 & 8,60 \\
\hline $21 / 05 / 08$ & 70 & 8,10 & 18,75 & 10,08 & 14,49 & 41,54 & 41,51 & 35,08 & 34,87 & 5,56 & 5,22 & 8,08 & 8,13 \\
\hline \multicolumn{14}{|c|}{ CICLO $3 / 2-10 \mathrm{~cm} / 3 \mathrm{x}$ (L1 e LC1);-20cm /3x (L2 e LC2) ${ }^{(*)}$} \\
\hline $04 / 06 / 08$ & 0 & 89,27 & 89,27 & 87,92 & 87,92 & 79,72 & 79,72 & 66,46 & 66,46 & 6,24 & 6,24 & 11,95 & 11,95 \\
\hline $11 / 06 / 08$ & 7 & 85,28 & 87,66 & 85,52 & 86,15 & 62,65 & 61,75 & 47,59 & 44,66 & 6,82 & 6,70 & 12,54 & 12,56 \\
\hline $18 / 06 / 08$ & 14 & 73,66 & 80,46 & 68,67 & 78,20 & 56,31 & 61,35 & 51,49 & 46,98 & 5,61 & 5,58 & 8,91 & 8,88 \\
\hline $25 / 06 / 08$ & 21 & 63,74 & 77,25 & 51,52 & 71,39 & 52,86 & 55,84 & 41,69 & 46,48 & 5,90 & 6,29 & 8,37 & NR \\
\hline $02 / 0708$ & 28 & 43,94 & 68,02 & 34,43 & 68,65 & 50,34 & 53,78 & 41,47 & 47,41 & 5,40 & 5,29 & 8,45 & 8,31 \\
\hline 09/07/08 & 35 & 35,32 & 72,34 & 30,48 & 67,42 & 50,30 & 51,70 & 35,97 & 41,88 & 5,12 & 5,37 & 8,45 & 8,83 \\
\hline $16 / 07 / 08$ & 42 & 25,82 & 60,20 & 20,65 & 53,42 & 48,26 & 48,74 & 38,33 & 40,95 & 5,17 & 5,15 & 8,20 & 8,17 \\
\hline $23 / 07 / 08$ & 49 & 15,21 & 62,71 & 14,95 & 50,09 & 45,90 & NR & 35,29 & 39,20 & 6,28 & 5,16 & 7,90 & 8,47 \\
\hline $30 / 07 / 08$ & 56 & \multicolumn{12}{|c|}{ Não foi realizada coleta de amostras } \\
\hline 06/08/08 & 63 & 13,39 & 40,40 & 13,05 & 27,97 & 44,09 & 46,33 & 33,36 & 35,02 & 5,50 & 4,60 & 7,24 & 7,40 \\
\hline $13 / 08 / 08$ & 70 & 12,29 & 27,96 & 11,05 & 21,90 & 37,73 & 45,74 & 34,43 & 33,02 & 5,11 & 5,09 & 8,12 & 8,09 \\
\hline
\end{tabular}

Nota: Não foram realizadas coletas em 06/02/08, 23/04/08 e 30/07/08 por problemas operacionais; alguns resultados de SV/ST e pH foram desprezados em virtude de problemas na determinação laboratorial.

(*) - Forma de disposição do lodo nas células / período do revolvimento 


\subsubsection{Umidade}

Durante todo Ciclo 1/2, os comportamentos da umidade do material de todas as células são bem semelhantes, não havendo nenhuma indicação de que a adição da cal tenha causado maior ou menor dificuldade na perda da umidade do lodo. Observa-se que, a partir do $7^{\circ}$ dia, a umidade cai rapidamente atingindo, aproximadamente, $20 \%$ no $28^{\circ}$ dia, semelhante ao acorrido na Etapa 1 (GRÁFICO 5.10).

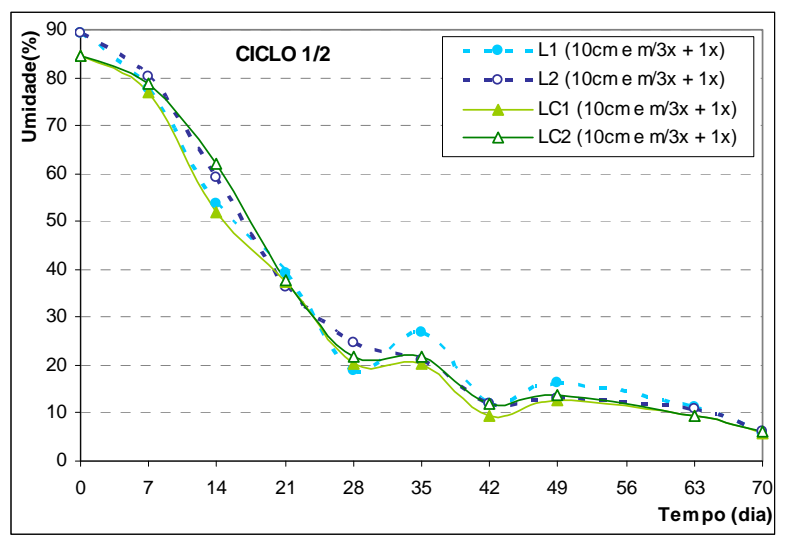

(5.10a)

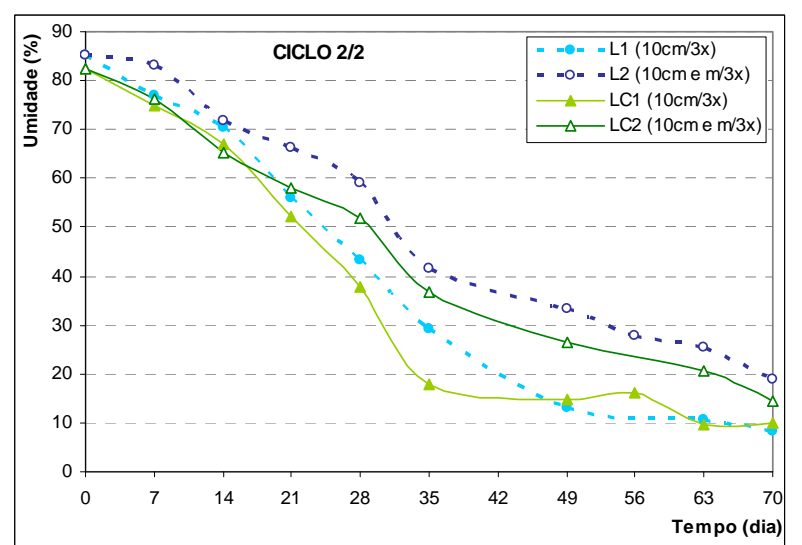

$(5.10 \mathrm{~b})$

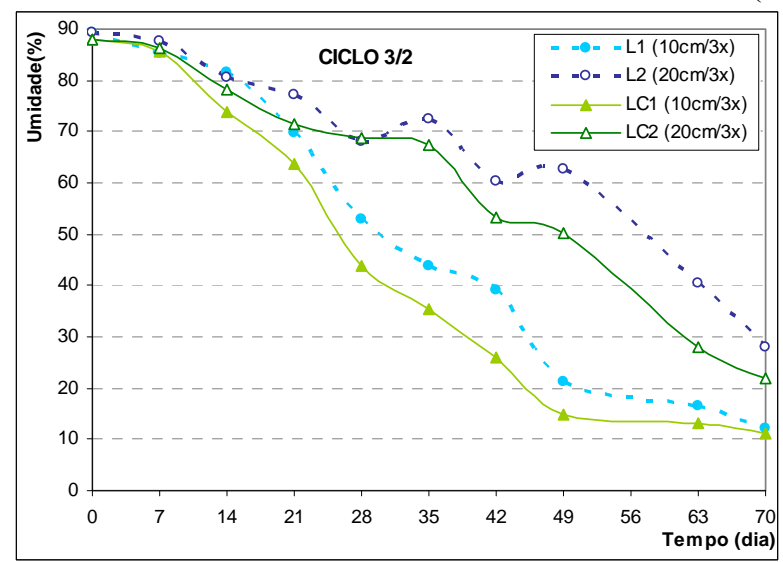

(5.10c)

Gráfico 5.10 - Variação da umidade do lodo sem cal (L1 e L2) e com cal (LC1 e LC2) durante os ciclos da Etapa 2 - Ciclos 1/2 (5.10a), 2/2 (5.10b) e 3/2 (5.10c)

No Ciclo 2/2, os resultados apresentados sugerem que a formação das leiras dificultou a perda da umidade. O lodo disposto em camada de $10 \mathrm{~cm}$ de altura, células L1 e LC1, apresentou teores de umidades inferiores às demais, com o mesmo tempo de secagem.

Apesar do revolvimento do lodo durante os Ciclos 2/2 e 3/2 ocorrer três vezes por semana, não resultou nenhuma perda de umidade mais acentuada. Ao contrário disso, tomando L1 
como exemplo, no $14^{\circ}$ dia do Ciclo $1 / 2$, a umidade do lodo era 53,55\%, enquanto, no Ciclo 2/2 foi 70,30\% e, no Ciclo 3/2, 73,66\% (TABELA 5.9 e GRÁFICO 5.10).

Com base nas informações de temperatura apresentadas na TABELA 5.9 e no GRÁFICO 5.10 percebe-se que o Ciclo 3/2 apresentou temperaturas mais brandas que os outros dois ciclos. Porém, o ciclo 2/2 apresentou temperatura média das médias horárias superior aos Ciclos $1 / 2$ e $3 / 2$. O desempenho inferior observado nesse ciclo pode ser atribuído às especificidades do próprio lodo usado na pesquisa.

Com relação aos aspectos relativos à diminuição do volume observados na Etapa 1, foi constatado o mesmo comportamento no monitoramento do lodo da Etapa 2.

\subsubsection{Relação entre Sólidos Voláteis e Sólidos Totais (SV/ST)}

Os lodos usados nos Ciclos 1/2 e 3/2 apresentaram valores de SV/ST superiores à 70\%. Nos dois ciclos, foi possível perceber o potencial da estufa em contribuir para o processo de estabilização do lodo em razão de os resultados da primeira semana já apresentarem valores inferiores a 0,70 . Porém, no Ciclo 2/2, o valor de SV/ST encontrado na caracterização do lodo foi de $62,41 \%$ que, a princípio, se caracteriza como lodo digerido.

Também é possível notar nos três ciclos que a adição de cal ao lodo bruto diminuiu a relação SV/ST, já que promoveu a elevação dos teores de ST presentes no lodo. Como na Etapa 1, os valores apresentados de SV/ST não possibilitaram avaliar se a forma de disposição do lodo nas células e o período de revolvimento afetaram essa relação.

Provavelmente em razão dos elevados valores de SV/ST no lodo usado na Etapa 2, houve uma redução considerável dessa relação ao final dos ciclos, com variação de $32 \%$ a $46 \%$, atingindo valores de SV/ST entre $33 \%$ e $45 \%$.

\subsubsection{Potencial Hidrogeniônico (pH)}

O GRÁFICO 5.11 apresenta a variação do pH dos lodos das células L1, L2, LC1 e LC2 durante o tratamento do lodo em estufa agrícola no decorrer dos três ciclos da Etapa 2. 
O lodo sem cal (L1 e L2) iniciou os ciclos com $\mathrm{pH}$ próximos a 6 e 7, porém os comportamentos das curvas ao longo do período de monitoramento foram bastante distintos e não contribuíram para uma avaliação mais criteriosa da variação desse parâmetro. No Ciclo $1 / 2$, os valores permaneceram próximos a 7 até o $42^{\circ}$ dia, passando, a partir daí, a apresentar valores entre 6 e 7. Para o Ciclo 2/2 observa-se um decrescimento gradual do $\mathrm{pH}$ atingindo, ao final, valores entre 5 e 6 . Já no Ciclo $3 / 2$ o comportamento do $\mathrm{pH}$ foi bastante variável, apresentando valores próximos a 5 no $70^{\circ}$ dia de experimento (TABELA 5.9 e GRÁFICO $5.11)$.

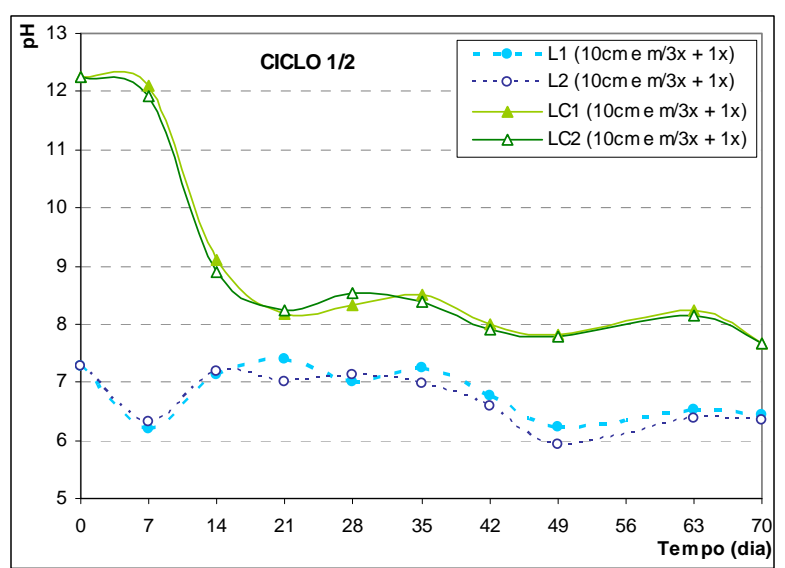

(5.11a)

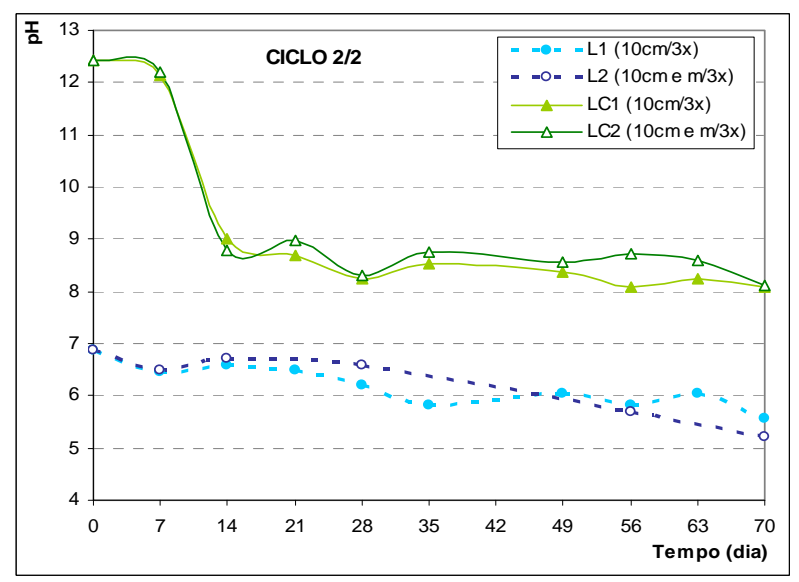

(5.11b)

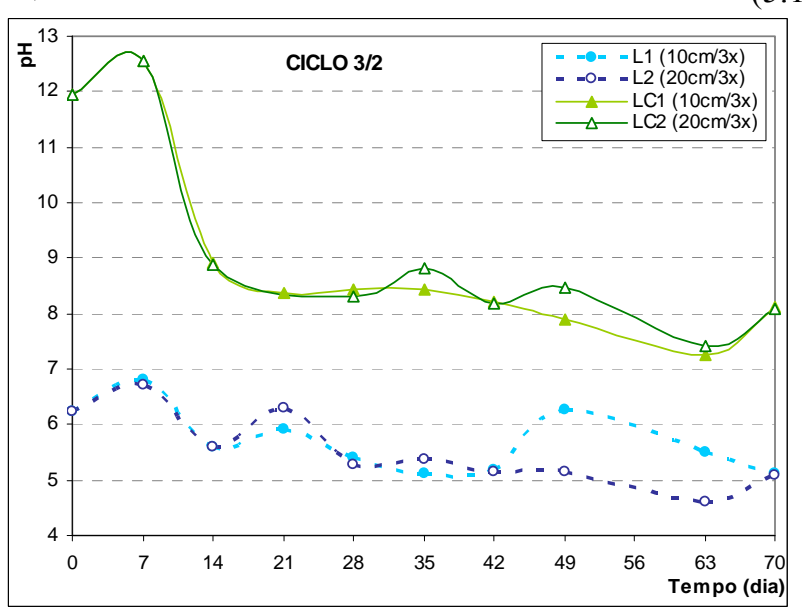

(5.11c)

Gráfico 5.11 - Variação do pH do lodo sem cal (L1 e L2) e com cal (LC1 e LC2) durante os ciclos da Etapa 2 - Ciclos 1/2 (5.11a), 2/2 (5.11b) e 3/2 (5.11c)

$\mathrm{Na}$ avaliação inicial do comportamento do $\mathrm{pH}$ dos lodos das células LC1 e LC2, que receberam o lodo com a cal nos três ciclos, verificou-se o atendimento à Resolução $n^{\circ}$ 375/2006 do CONAMA (BRASIL, 2006c), quando o pH foi mantido acima de 12 nas 2 primeiras horas e acima de 11,5 nas 22 horas seguintes. Durante o Ciclo 1/2, a partir do $14^{\circ}$ 
dia de monitoramento, o pH dos lodos das células LC1 e LC2, que inicialmente era 12, passa a apresentar valores próximos a 8, mantendo-se assim até o final do ciclo. No Ciclo 2/2, o comportamento do $\mathrm{pH}$ do lodo dessas células foi bastante semelhante, porém os valores se mantiveram entre 8 e 9 até o final. Já no Ciclo 3/2, nota-se a mesma variação ocorrida no Ciclo 2/2, mas, no $63^{\circ}$ dia, foi detectado $\mathrm{pH}$ em torno de 7,5.

\subsubsection{INDICADORES BACTERIOLÓGICOS E AGENTES PATOGÊNICOS}

Os valores obtidos de coliformes termotolerantes (CTt), Salmonella sp. e ovos viáveis de helmintos $(\mathrm{OVH})$ durante o período de monitoramento dos Ciclos 1/2, 2/2 e 3/2 para o lodo que não foi encaminhado ao digestor, encontram-se apresentados na TABELA 5.10.

Tabela 5.10 - Ocorrência de coliformes termotolerantes, ovos viáveis de helmintos e Salmonella sp. do lodo não encaminhado ao digestor com e sem cal, durante os Ciclos 1/2, 2/2 e 3/2

\begin{tabular}{|c|c|c|c|c|c|c|c|c|c|c|c|c|c|}
\hline \multirow{3}{*}{ Data } & \multirow{3}{*}{ 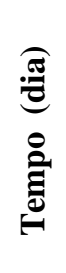 } & \multicolumn{4}{|c|}{ 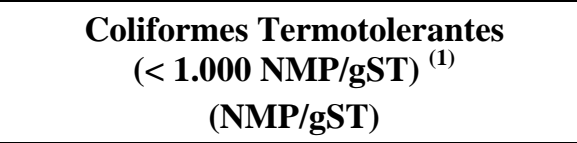 } & \multicolumn{4}{|c|}{$\begin{array}{c}\text { Ovos viáveis helmintos } \\
\text { (<0,25ovo/gST) }^{(1)} \\
\text { (ovo/gST) }^{(0)}\end{array}$} & \multicolumn{4}{|c|}{$\begin{array}{l}\text { Salmonella sp. } \\
\text { (A em 10gST) }^{(1)} \\
\text { (em 10gST) }^{\text {(em 10g }}\end{array}$} \\
\hline & & \multicolumn{2}{|c|}{ Lodo sem cal } & \multicolumn{2}{|c|}{ Lodo com cal } & \multicolumn{2}{|c|}{$\begin{array}{c}\text { Lodo sem } \\
\text { cal }\end{array}$} & \multicolumn{2}{|c|}{$\begin{array}{l}\text { Lodo sem } \\
\text { cal }\end{array}$} & \multicolumn{2}{|c|}{$\begin{array}{c}\text { Lodo } \\
\text { com cal }\end{array}$} & \multicolumn{2}{|c|}{$\begin{array}{c}\text { Lodo } \\
\text { sem cal }\end{array}$} \\
\hline & & L1 & L2 & LC1 & L1 & $\mathbf{L 2}$ & LC1 & L1 & L2 & LC1 & L1 & $\mathbf{L 2}$ & LC1 \\
\hline \multicolumn{14}{|c|}{ CICLO $1 / 2-10 \mathrm{~cm}$ e $\mathrm{m} / 3 \mathrm{x}+1 \mathrm{x}(\mathrm{L} 1, \mathrm{~L} 2, \mathrm{LC} 1 \text { e LC2 })^{(*)}$} \\
\hline $12 / 12 / 07$ & 0 & $4,60 \mathrm{E}+04$ & $4,60 \mathrm{E}+04$ & $<3,6$ & $<3,6$ & 0,26 & 0,26 & 0,31 & 0,31 & $P$ & $\mathrm{P}$ & A & A \\
\hline $26 / 12 / 07$ & 14 & $2,40 \mathrm{E}+04$ & $1,10 \mathrm{E}+05$ & $2,40 \mathrm{E}+02$ & $4,60 \mathrm{E}+03$ & 0,31 & 0,23 & 0,27 & 0,19 & A & A & A & A \\
\hline 09/01/08 & 28 & $<3,6$ & $<3,6$ & 3,6 & 23 & 0,27 & 0,26 & 0,16 & 0,11 & A & A & A & A \\
\hline $23 / 01 / 08$ & 42 & $<3,6$ & $<3,6$ & $<3,6$ & $<3,6$ & 0,15 & 0,19 & 0,20 & 0,06 & A & A & A & A \\
\hline $06 / 02 / 08$ & 56 & \multicolumn{12}{|c|}{ Não foi realizada coleta de amostras } \\
\hline $20 / 02 / 08$ & 70 & $<3,6$ & 93 & $<3,6$ & $<3,6$ & 0,16 & 0,14 & 0,16 & 0,10 & A & A & A & A \\
\hline \multicolumn{14}{|c|}{ CICLO $2 / 2-10 \mathrm{~cm} / 3 \mathrm{x}$ (L1 e LC1); $10 \mathrm{~cm}$ e m/3x (L2 e LC2) ${ }^{(*)}$} \\
\hline $12 / 03 / 08$ & 0 & $1,10 \mathrm{E}+05$ & $1,10 \mathrm{E}+05$ & $<3,6$ & $<3,6$ & 0,21 & 0,21 & 0,17 & 0,17 & $\mathrm{P}$ & $\mathrm{P}$ & A & A \\
\hline $26 / 03 / 07$ & 14 & $2,40 \mathrm{E}+04$ & $1,10 \mathrm{E}+04$ & $9,30 \mathrm{E}+01$ & $1,10 \mathrm{E}+03$ & 0,23 & 0,20 & 0,22 & 0,14 & A & A & A & A \\
\hline 09/04/08 & 28 & $1,10 \mathrm{E}+05$ & $9,30 \mathrm{E}+03$ & $4,30 \mathrm{E}+02$ & $4,30 \mathrm{E}+03$ & 0,19 & 0,13 & 0,22 & 0,18 & $\mathrm{P}$ & $\mathrm{P}$ & A & A \\
\hline $23 / 04 / 08$ & 42 & \multicolumn{12}{|c|}{ Não foi realizada coleta de amostras } \\
\hline $07 / 05 / 08$ & 56 & $<3,6$ & $<3,6$ & $<3,6$ & $<3,6$ & 0,15 & 0,09 & 0,05 & 0,18 & A & A & A & A \\
\hline $21 / 05 / 08$ & 70 & 3,6 & $<3,6$ & $<3,6$ & $<3,6$ & 0,13 & 0,11 & 0,09 & 0,11 & A & A & A & A \\
\hline \multicolumn{14}{|c|}{ CICLO $3 / 2-10 \mathrm{~cm} / 3 \mathrm{x}$ (L1 e LC1); $-20 \mathrm{~cm} / 3 \mathrm{x}(\mathrm{L} 2 \text { e LC2 })^{(*)}$} \\
\hline $04 / 06 / 08$ & 0 & $1,10 \mathrm{E}+05$ & $1,10 \mathrm{E}+05$ & $<3,6$ & $<3,6$ & 0,29 & 0,29 & 0,26 & 0,26 & $\mathrm{P}$ & $\mathrm{P}$ & A & A \\
\hline $18 / 06 / 08$ & 14 & $1,10 \mathrm{E}+05$ & $1,10 \mathrm{E}+05$ & $<3,6$ & $<3,6$ & 0,30 & 0,28 & 0,23 & 0,26 & A & A & A & A \\
\hline $02 / 07 / 08$ & 28 & $4,30 \mathrm{E}+03$ & $2,40 \mathrm{E}+04$ & $9,20 \mathrm{E}+00$ & $9,30 \mathrm{E}+03$ & 0,24 & 0,10 & 0,18 & 0,21 & $\mathrm{P}$ & A & A & $\mathrm{P}$ \\
\hline $16 / 07 / 08$ & 42 & $4,30 \mathrm{E}+03$ & $9,30 \mathrm{E}+03$ & $9,30 \mathrm{E}+01$ & 3,6 & 0,10 & 0,12 & 0,12 & 0,09 & A & A & A & A \\
\hline $30 / 07 / 08$ & 56 & \multicolumn{12}{|c|}{ Não foi realizada coleta de amostras } \\
\hline $13 / 08 / 08$ & 70 & $2,40 \mathrm{E}+02$ & $9,20 \mathrm{E}+00$ & $<3,6$ & $1,50 \mathrm{E}+01$ & 0,11 & 0,12 & 0,11 & 0,10 & A & A & A & A \\
\hline
\end{tabular}




\subsubsection{Coliformes termotolerantes}

As densidades obtidas de CTt durante o desenvolvimento da Etapa 2 mostraram claramente a potencialidade da estufa agrícola na higienização do lodo. No Ciclo 1/2, o lodo com umidade em torno de $20 \%$ (tempo de secagem de 28 dias), apresentou valores bem abaixo do exigido pelo Conama em todos os casos (L1, L2 e LC1 e LC2). Essa umidade pode ser ainda maior, em razão do intervalo de tempo entre as coletas ter sido de 14 dias. Nos Ciclos 2/2 e 2/3 o tempo necessário para tal condição foi superior. Isso pode ter ocorrido em razão de o lodo usado no Ciclo 1/2 apresentar densidade de CTt menor que os utilizados nos Ciclos 2/2 e 3/2 (GRÁFICO 5.12).

No Ciclo 2/2, mesmo não tendo sido realizada coleta no $42^{\circ}$ dia do monitoramento, observase que, na campanha seguinte, $56^{\circ}$ dia, os valores já se apresentavam bastante reduzidos, sugerindo que o enquadramento do material, como lodo Classe A, possa ter ocorrido antes desse tempo. Nesse caso, a umidade variou de $10 \%$ a $28 \%$, para o lodo sem cal, e de $16 \%$ a $23 \%$, para o lodo com cal.

Já no Ciclo 3/2, o lodo da célula L1, que foi a pior situação, apresentou densidade de CTt na ordem de $10^{2}$ no final do ciclo, com umidade de $12,29 \%$. No entanto, nesse caso, o intervalo entre as coletas foi de 28 dias, sugerindo que o enquadramento possa ter ocorrido com valor de umidade maior. O decaimento da densidade de CTt foi menos acentuado no Ciclo 3/2, provavelmente, em virtude de a perda da umidade ocorrer de forma mais lenta. Nota-se que, no $35^{\circ}$ dia, o lodo da célula L1 do Ciclo $2 / 2$ apresentava umidade de 29,07\%, enquanto, no Ciclo 3/2, o lodo da mesma célula apresentou 35,32\%. Vale lembrar que a forma de disposição lodo e o período de revolvimento eram os mesmos nos dois casos (TABELAS 5.9 e 5.10).

A adição da cal foi satisfatória já no ato da sua aplicação, quando os valores de CTt se apresentaram insignificantes. Houve recrescimento dessas bactérias no lodo, quando o $\mathrm{pH}$ atingiu valores inferiores a 11,5 . No Ciclo $2 / 2$, os recrescimentos ocorridos até o $28^{\circ}$ dia, principalemnte em LC1 (umidade em torno de $37^{\circ} \mathrm{C}$ e $\mathrm{pH}$ igual a 8,25), podem ser atribuídos à menor perda de umidade registrada no período, o que favoreceu o aumento da população desses organismos. Esse fato não foi relevante, visto que as concentrações detectadas nas semanas seguintes foram sempre inferiores a 3,6 NMP/gST até o final dos ciclos. 


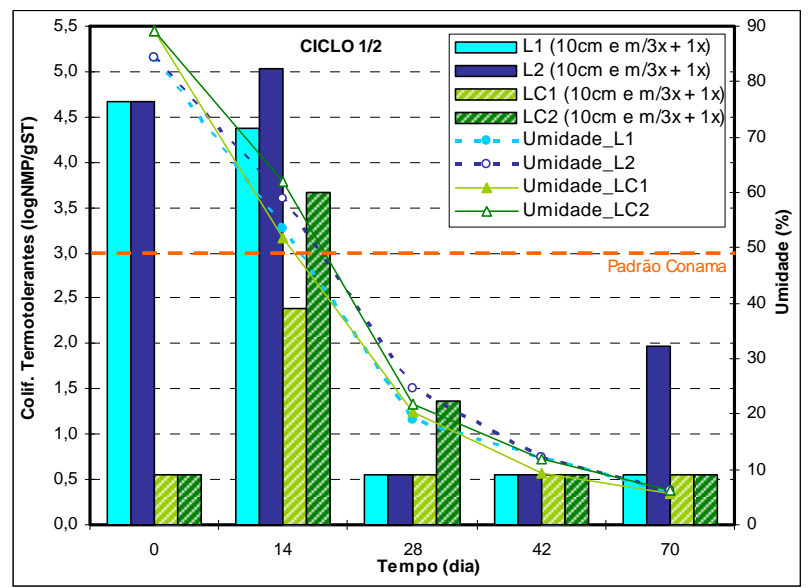

(5.12a)

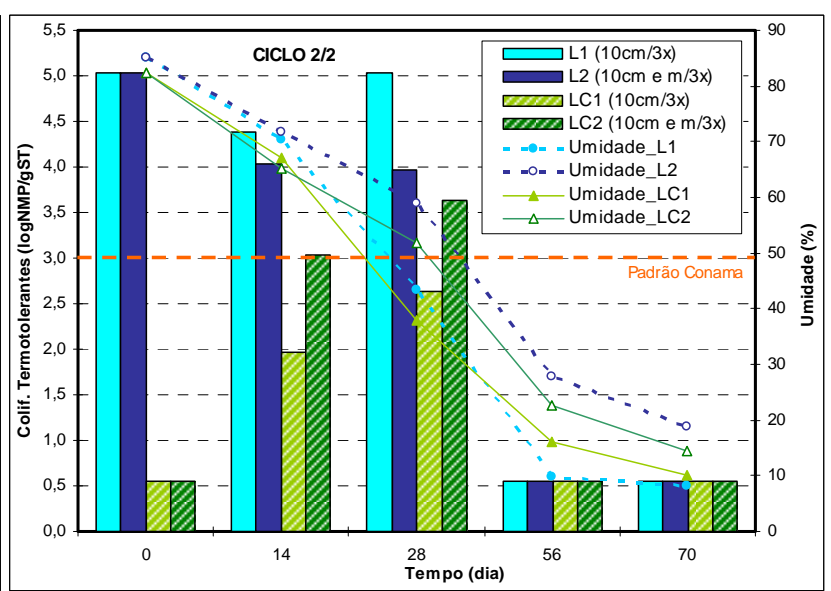

$(5.12 b)$

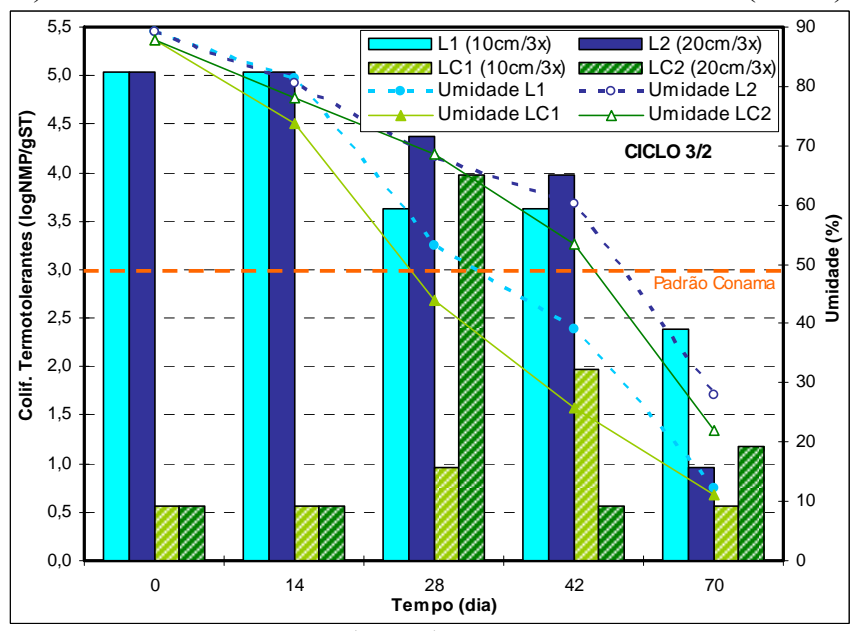

$(5.12 \mathrm{c})$

Gráfico 5.12 - Variação da densidade de coliforme termotolerante e umidade do lodo não encaminhado ao digestor sem cal (L1 e L2) e com cal (LC1 e LC2) durante os ciclos da Etapa 2 Ciclos 1/2 (5.12a), 2/2 (5.12b) e 3/2 (5.12c)

\subsubsection{Ovos Viáveis de Helmintos}

No Ciclo 1/2, o enquadramento do lodo sem cal como lodo Classe A, segundo a Resolução $\mathrm{n}^{0}$ 375/2006 do Conama (BRASIL, 2006c), foi atingido nas amostras coletadas no $42^{\circ}$ dia (umidade em torno de 12\%). Essa umidade pode ser maior, sendo que nas amostras coletadas no $28^{\circ}$ dia (umidade em torno de $25 \%$ ) os valores de $\mathrm{OVH}$ já eram bastantes reduzidos. Para o lodo com cal, a pior situação para o enquadramento (LC1) oconteceu no $28^{\circ}$ dia, quando a umidade era de $20,38 \%$.

$\mathrm{O}$ número de $\mathrm{OVH}$ do lodo usado no Ciclo $2 / 2$, já se encontrava abaixo do exigido pelo Conama (TABELA 5.10). 
Para o Ciclo $3 / 2$, no $28^{\circ}$ dia do experimento (umidade variando de $44 \%$ a $68 \%$ ) as amostras apresentavam valores abaixo do padrão recomendado pela legislação, independentemente de se ter adicionado cal ou não ao lodo (TABELAS 5.9 e 5.10).

De acordo com os resultados obtidos desse parâmetro, o processo de higienização com a cal não se mostrou muito eficiente. Nesse caso, as diferenças não foram muito expresivas. Os valores registrados nos lodos das células em que a cal foi adicionada ao lodo (LC1 e LC2) não se apresentaram muito diferentes dos encontrados nos lodos das células em que não houve a adição de cal (L1 e L2) (TABELA 5.10 e GRÁFICO 5.13). Os valores de ovos de helmintos totais encontrados nos lodos de cada célula, nos três ciclos da Etapa 2, encontram-se apresentados no APÊNDICE 5.

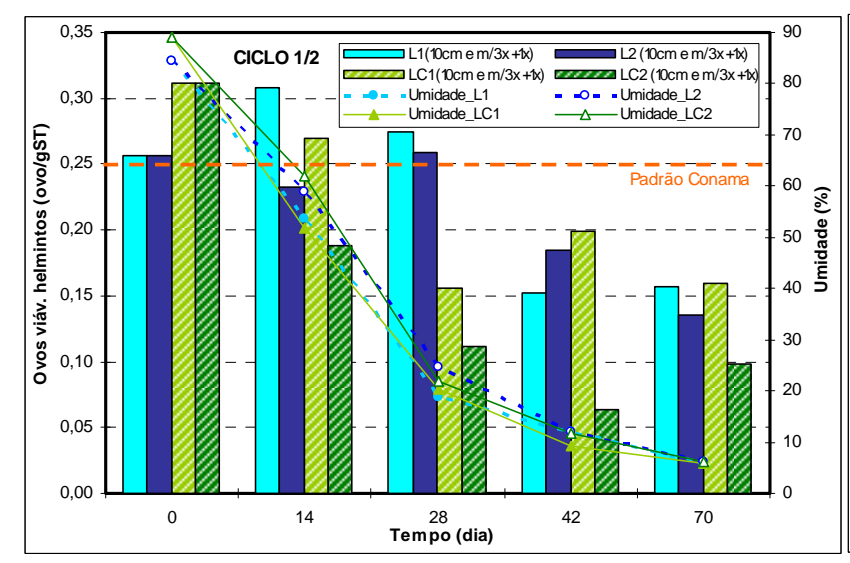

(5.13a)

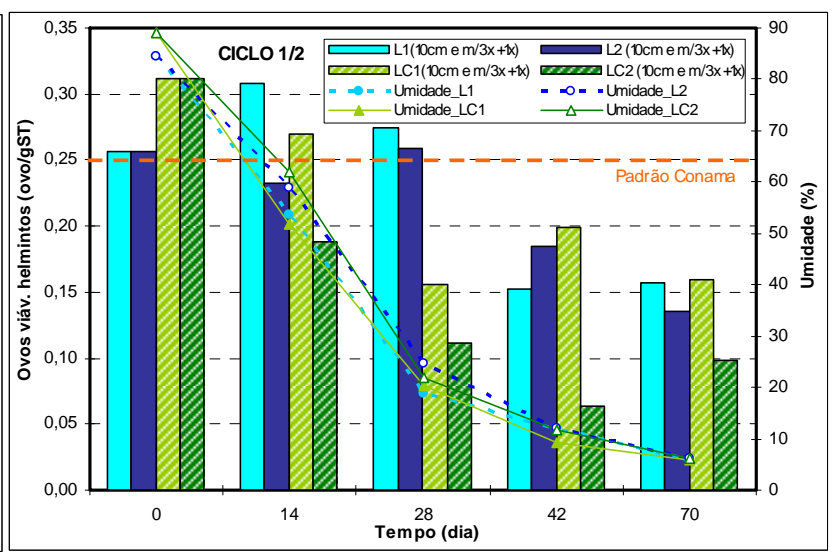

$(5.13 b)$

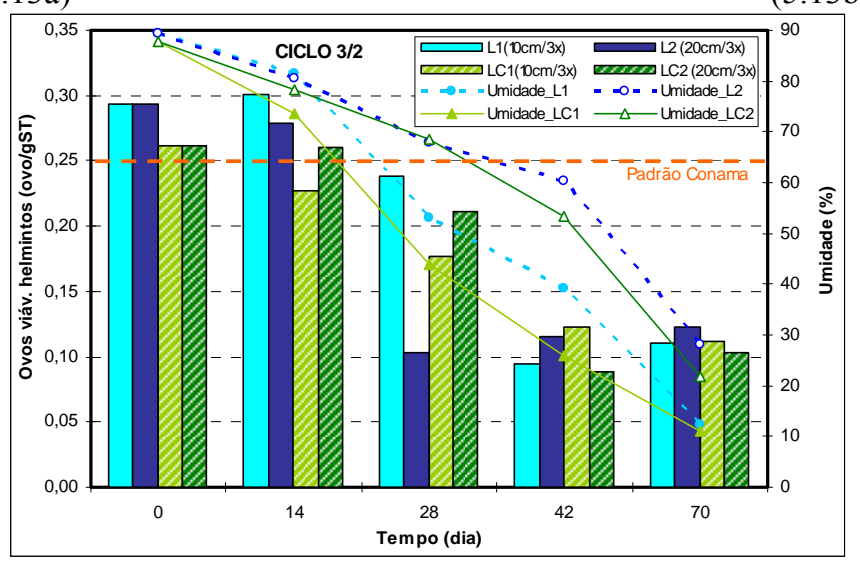

$(5.13 \mathrm{c})$

Gráfico 5.13 - Variação da quantidade de ovos viáveis de helmintos e umidade no lodo não encaminhado ao digestor sem cal (L1 e L2) e com cal (LC1 e LC2) durante os ciclos da Etapa 2 Ciclos 1/2 (5.13a), 2/2 (5.13b) e 3/2 (5.13c)

\subsubsection{Salmonella sp.}

De acordo com os resultados obtidos durante o Ciclo 1/2, a presença de Salmonella sp. somente foi percebida nas amostras do lodo usado no experimento (tempo "0"). A partir da 
primeira quinzena, o material de todas as células já apresentava ausência de Salmonella sp. em $10 \mathrm{gST}$. Nos Ciclos $2 / 2$ e 3/2, foi detectada a presença dessa bactéria no $28^{\circ}$ dia (umidade variando de $43 \%$ a $68 \%$ ) em L1 e L2 mesmo com a ausência no $14^{\circ}$ dia (umidade entre $70 \%$ a 80\%). Daí em diante, todas as amostras apresentaram ausência do patógeno.

A adição de cal foi significativa na eliminção de Salmonella sp., com a sua ausência em todas as amostras do lodo usado nas células LC1 e LC2, nos tres ciclos. Entretanto, ocorreu um reaparecimento no $28^{\circ}$ dia no lodo da célula LC2 (Ciclo 3/2), que apresentava umidade em torno de $68 \%$ e pH 8,31 (TABELAS 5.9 e 5.10).

\subsubsection{Vírus entéricos}

Tanto para adenovírus como para vírus da Hepatite A (VHA) os resultados foram expressos qualitativamente, sendo confirmada a sua presença ou não nas amostras analisadas. Já os rotavírus foram quantificados em UFF/gST. No APÊNDICE 6, encontram-se apresentados os resultados de VHA, Adenovírus e Rotavírus nas amostras de lodo sem cal (L1 e L2) e com cal (LC1 e LC2) no início, meio e final de cada ciclo, inclusive resultados de PCR de algumas amostras. Essas análises não foram feitas em triplicatas.

Os resultados obtidos para vírus da Hepatite A foram negativos quase que na totalidade das amostras. Das 30 amostras analisadas apenas duas confirmaram a sua presença. Isso, provavelmente, ocorreu devido à baixa incidência de Hepatite A na população atendida pelo sistema de esgotamento sanitário. Desse modo, não foi possível expressar qualquer opinião sobre a atuação da diminuição da umidade e da adição da cal, como possíveis fatores para a eliminação desse vírus.

Para o adenovírus e o rotavírus, observa-se que não houve nenhuma tendência de decaimento deles, considerando a perda da umidade, a adição da cal, a forma de disposição do lodo nas células e o período de revolvimento. No caso da umidade, os resultados da pesquisa não confirmaram os relatos de vários autores que revelam que a diminuição de água no ambiente afeta a sobrevivência dos vírus (GERBA; PEPPER; WHITEHEAD, 2001; MAIER; PEPPER; GERBA, 2009; US EPA, 2003). Já a adição da cal, que possibilita a elevação do pH, é considerada como condição suficiente para inativar os vírus ao afetar algumas de suas proteínas estruturais (BEAN et al., 2007; MENG et al., 1987), o que, nesse caso, não ocorreu, 
mesmo o pH atingindo valores acima de 12 por 7 dias. Porém, segundo US EPA (2003), é esperada a redução efetiva de bactérias e vírus quando o $\mathrm{pH}$ é elevado para 12 por duas horas.

Das 30 amostras investigadas para detecção de adenovírus, 11 (37\%) manifestaram ausência do vírus em diferentes momentos do desenvolvimento da pesquisa. Porém, os testes de infectividade realizados, apresentaram efeito citopático sugestivo da presença de adenovírus e/ou gênero Enterovirus, na primeira passagem, mesmo nessas amostras negativas para PCR. Com isso, todas as amostras foram consideradas positivas para adenovírus e/ou gênero Enterovirus.

Apesar de alguns pesquisadores sugerirem os adenovirus como o candidato a indicador viral (BOFILL-MASS et al., 2006; PINA et al., 1998), com os resultados desta pesquisa não foi possível manifestar qualquer opinião a respeito. A inconstância apresentada, não indicou uma tendência definida que apontasse para possíveis fatores que afetam a sobrevivencia dos adenovirus.

No caso dos rotavírus, até mesmo o efeito da sazonalidade relatada por vários autores (COOK, et al., 1990; SHIM, BANKS, CASTILLO-CHAVEZ; 2006) não foi observado, mesmo com o monitoramento abrangendo diferentes estações do ano. Também, percebe-se que as concentrações nos finais dos ciclos foram maiores que as apresentadas no início, quando, no final, as umidades se encontravam, muitas vezes, abaixo de $10 \%$.

Essas variabilidades são difíceis de explicar, considerando as questões já levantadas e o fato de que os outros microrganismos monitorados na pesquisa apresentaram tendências claras e uma redução expressiva dos seus valores. Cabe ressaltar que as alíquotas análisadas pelos laboratórios eram provenientes da mesma amostra coletada. Além disso, foram adotados todos os rigores experimentais desde a coleta até o encaminhamento das amostras aos laboratórios, segundo os critérios para amostragem apresentados na Resolução n ${ }^{\circ}$ 375/2006 (BRASIL, 2006c) e recomendações repassadas pelos laboratórios responsáveis.

Os resultados dos outros indicadores bacteriológicos e agentes patogênicos pesquisados, e, também, as concentrações de metais pesados no lodo, atenderam perfeitamente às exigências legais estabelecidas (BRASIL, 2006c). Assim, quanto ao uso desse biossólido na agricultura, fica a dúvida apenas com relação aos vírus. 
Em contrapartida, deve-se considerar que alguns autores já expressam a possibilidade de adoção de outros indicadores, em substituição aos vírus, para águas de abastecimento e esgoto (BOSCH, 1998; GRABOW, 2001) e lodo (BEAN et al., 2007). Citam os bacteriófagos como um possível canditado, por apresentarem condiçõs suficientes para essa substituição. Além disso, para Martins (2006), as tecnologias para quantificação de vírus apresentam custo inviável para a rotina das plantas de tratamento, como a técnica da reação em cadeia da polimerase (PCR) em tempo real usada nesses casos.

Dessa forma, esses resultados são inconclusivos e não demonstraram segurança para apontar quais seriam as considerações ou alterações necessárias acerca do processo estudado para a obtenção de biossólido Classe A. Entretanto, caso seja confirmada a presença de vírus no biossólido após a secagem e higienização na estufa, como o volume final gerado é bastante reduzido, acredita-se que, nesse caso, considerando uma faixa de segurança, o material submetido por 2 horas a uma temperatura de, aproximadamente, $60^{\circ} \mathrm{C}$, pode ser indicada como uma técnica de pós-tratamento para eliminação dos vírus. Segundo Oliveira (1994), os adenovírus são inativados quando submetidos a uma temperatura de $56^{\circ} \mathrm{C}$ por um período de 10 minutos.

Em face da prática adquirida nesta pesquisa e dos resultados obtidos, pode-se perceber que os métodos analíticos e o monitoramento dos vírus em lodo de esgoto ainda demandam de uma atenção especial, com muitas discussões e ponderações. Pode-se destacar que o limite definido pela Resolução n $n^{0}$ 375/2006 do Conama (BRASIL, 2006c) é 0,25 UFF/gST, porém a sensibilidade do método usado para rotavírus é de $0,3 \mathrm{UFF} / \mathrm{gST}$.

$\mathrm{Na}$ verdade, percebe-se que essa questão não se encerra na adequação dos laboratório com a adoção de procedimentos de controle de qualidade analítica, como prevê o parágrafo $4^{\circ}$, do Art. 10, da Seção II, da Resolução n ${ }^{0}$ 375/06 do Conama. Entende-se que o monitoramento do lodo deva seguir critérios e procedimentos detalhados no preparo, no manuseio, na coleta, no acondicionamento, na preservação, no transporte das amostras e na metodologia a ser implantada, não permitindo, assim, possíveis falhas em algum ponto da cadeia do gerenciamento. 


\subsubsection{PARÂMETROS DE INTERESSE AGRONÔMICO}

Como na Etapa 1, não foi percebida nenhuma variação significativa entre os resultados obtidos no início e no final dos ciclos. Sendo assim, na TABELA 5.11 são apresentados apenas os valores médio, máximo e respectivo desvio padrão dos parâmetros monitorados, para o lodo sem cal (L1 e L2) e com cal (LC1 e LC2). Os resultados obtidos no monitoramento dos três ciclos e que deram origem às concentrações apresentadas na TABELA 5.11, encontram-se no APÊNDICE 7.

Tabela 5.11 - Concentrações médias, máximas e desvio padrão dos parâmetros de interesse agronômico no material das células de lodo não encaminhado ao digestor sem cal (L1 e L2) e com cal (LC1 e LC2), no início e no final dos ciclos da Etapa 2

\begin{tabular}{|c|c|c|c|c|c|c|c|c|c|c|c|c|}
\hline \multirow{3}{*}{ Parâmetro } & \multicolumn{6}{|c|}{$\begin{array}{c}\text { Lodo sem cal (L1 e L2) } \\
\text { (\% em base seca) }\end{array}$} & \multicolumn{6}{|c|}{$\begin{array}{c}\text { Lodo com cal (LC2 e LC2) } \\
\text { (\% em base seca) }\end{array}$} \\
\hline & \multicolumn{3}{|c|}{$\begin{array}{l}\text { Início dos Ciclos } \\
\qquad(n=6)\end{array}$} & \multicolumn{3}{|c|}{$\begin{array}{l}\text { Final dos Ciclos } \\
\qquad(n=6)\end{array}$} & \multicolumn{3}{|c|}{$\begin{array}{l}\text { Início dos Ciclos } \\
\qquad(n=6)\end{array}$} & \multicolumn{3}{|c|}{$\begin{array}{l}\text { Final dos Ciclos } \\
\qquad(n=6)\end{array}$} \\
\hline & Méd. & Max. & DP ${ }^{(1)}$ & Méd. & Max. & DP & Méd. & Max. & DP & Méd. & Max. & DP \\
\hline Carbono orgânico & 38,47 & 38,86 & 0,60 & 37,41 & 39,44 & 2,16 & 34,80 & 35,96 & 1,37 & 33,93 & 43,50 & 4,75 \\
\hline $\mathrm{N}$ & 4,63 & 4,80 & 0,14 & 4,37 & 5,20 & 0,45 & 3,83 & 4,00 & 0,26 & 2,65 & 3,00 & 0,26 \\
\hline $\mathrm{P}$ & 1,56 & 1,83 & 0,21 & 1,60 & 2,14 & 0,45 & 1,04 & 1,49 & 0,50 & 1,40 & 1,83 & 0,32 \\
\hline K & 0,69 & 0,86 & 0,15 & 0,69 & 0,84 & 0,09 & 0,43 & 0,71 & 0,25 & 0,64 & 0,78 & 0,09 \\
\hline $\mathrm{Ca}$ & 1,64 & 1,97 & 0,26 & 1,59 & 2,14 & 0,45 & 8,53 & 9,76 & 1,21 & 8,66 & 11,06 & 2,66 \\
\hline $\mathrm{Mg}$ & 0,43 & 0,45 & 0,03 & 0,46 & 0,54 & 0,06 & 0,31 & 0,37 & 0,04 & 0,35 & 0,44 & 0,06 \\
\hline S & 0,37 & 0,41 & 0,06 & 0,47 & 0,62 & 0,16 & 0,71 & 1,16 & 0,40 & 0,90 & 1,35 & 0,32 \\
\hline $\mathrm{Na}$ & 0,10 & 0,11 & 0,01 & 0,11 & 0,15 & 0,02 & 0,10 & 0,12 & 0,02 & 0,11 & 0,14 & 0,02 \\
\hline Relação C/N & $8 / 1$ & $8 / 1$ & - & $8,5 / 1$ & $9 / 1$ & - & $9 / 1$ & $9 / 1$ & - & $12,7 / 1$ & $17 / 1$ & - \\
\hline
\end{tabular}

Nota: ${ }^{(1)}$ - Desvio Padrão; O tempo relativo a cada Ciclo foi: Ciclo $1-70$ dias, Ciclo $2-70$ dias, Ciclo $3-70$ dias.

O Carbono Orgânico sofreu uma pequena redução, de 1,9\% (média L1-L2) com média final de 37,41 (374 g/kgST). Para o fósforo o valor médio foi de $1,60 \%(16,0 \mathrm{~g} / \mathrm{kgST})$ e o Nitrogênio Total 4,37\% (43,7 g/kgST) para o lodo sem cal (L1 e L2). Vale acrescentar, ainda, que as concentrações no início e no final dos três ciclos foram semelhantes, sendo caracterizadas pelos baixos valores de desvio padrão encontrados na maioria dos parâmetros analisados.

\subsubsection{SUBSTÂNCIAS INORGÂNICAS (ÍONS METÁLICOS)}

Na avaliação dos resultados obtidos das substâncias inorgânicas durante a Etapa 2, foi adotada a mesma análise realizada na Etapa 1, ou seja, os resultados foram agrupados, no início e no 
final dos ciclos, e, em seguida, calculados a média e o desvio padrão de cada parâmetro analisado. Os valores determinados para os lodos das células L1 e L2 (sem cal) e LC1 e LC2 (com cal), inclusive, os padrões exigidos pela Resolução n ${ }^{0}$ 375/2006 do Conama (BRASIL, 2006c), estão apresentados na TABELA 5.12. No APÊNDICE 8, encontram-se todos os valores obtidos no monitoramento dos íons metálicos.

Tabela 5.12 - Concentrações médias, máximas e desvio padrão de íons metálicos no material das células de lodo não encaminhado ao digestor sem cal (L1 e L2) e com cal (LC1 e LC2), no início e no final dos ciclos da Etapa 2

\begin{tabular}{|c|c|c|c|c|c|c|c|c|c|c|c|c|c|}
\hline \multirow{3}{*}{ 导 } & \multirow{3}{*}{ 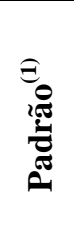 } & \multicolumn{6}{|c|}{$\begin{array}{l}\text { Lodo sem cal (L1 e L2) } \\
\text { (mg/kg em base seca) }\end{array}$} & \multicolumn{6}{|c|}{$\begin{array}{l}\text { Lodo com cal (LC2 e LC2) } \\
\text { (mg/kg em base seca) }\end{array}$} \\
\hline & & \multicolumn{3}{|c|}{$\begin{array}{l}\text { Início dos Ciclos } \\
\qquad(n=6)\end{array}$} & \multicolumn{3}{|c|}{$\begin{array}{l}\text { Final dos Ciclos } \\
\qquad(n=6)\end{array}$} & \multicolumn{3}{|c|}{$\begin{array}{l}\text { Início dos Ciclos } \\
\qquad(n=6)\end{array}$} & \multicolumn{3}{|c|}{$\begin{array}{l}\text { Final dos Ciclos } \\
\quad(n=6)\end{array}$} \\
\hline & & Méd. & Max. & $\mathbf{D P}^{(2)}$ & Méd. & Max. & DP & Méd. & Max. & DP & Méd. & Max. & DP \\
\hline Arsênio & 41 & 8 & 11 & 2,16 & 14 & 19 & 3,14 & 11 & 16 & 3,40 & 14 & 17 & 2,99 \\
\hline Bário & 1300 & 148 & 170 & 15,84 & 196 & 238 & 38,36 & 205 & 219 & 10,20 & 200 & 235 & 27,03 \\
\hline Cádmio & 39 & 2 & 3 & 0,48 & 3 & 4 & 0,68 & 2 & 3 & 0,59 & 3 & 4 & 0,66 \\
\hline Chumbo & 300 & 14 & 21 & 4,99 & 20 & 29 & 5,22 & 13 & 17 & 2,62 & 24 & 33 & 5,82 \\
\hline Cobre & 1500 & 333 & 463 & 99,87 & 256 & 435 & 135,84 & 332 & 430 & 77,35 & 345 & 501 & 96,47 \\
\hline Cromio & 1000 & 262 & 370 & 76,45 & 295 & 400 & 60,54 & 254 & 320 & 49,09 & 312 & 347 & 21,27 \\
\hline Mercúrio & 17 & $\mathbf{0}$ & 0 & 0,03 & $\mathbf{0}$ & 0 & 0,05 & $\mathbf{0}$ & 0 & 0,04 & o & 0 & 0,05 \\
\hline Molibdênio & 50 & 21 & 27 & 7,32 & 26 & 35 & 7,97 & 26 & 32 & 4,50 & 26 & 35 & 5,23 \\
\hline Níquel & 420 & 30 & 45 & 10,87 & 41 & 58 & 12,51 & 35 & 52 & 12,83 & 38 & 53 & 11,02 \\
\hline Selênio & 100 & 1 & 2 & 0,45 & 1 & 2 & 0,55 & 1 & 1 & 0,08 & 2 & 3 & 0,61 \\
\hline Zinco & 2800 & 509 & 608 & 96,59 & 602 & 703 & 80,39 & 532 & 590 & 70,15 & 602 & 710 & 53,80 \\
\hline
\end{tabular}

Nota: ${ }^{(1)} \mathrm{mg} / \mathrm{kg}$ base seca - Resolução ${ }^{0} 375 / 2006$ do Conama (BRASIL, 2006c); ${ }^{(2)}$ - Desvio Padrão.

As concentrações dos íons metálicos monitorados na Etapa 2 sempre estiveram abaixo dos padrões exigidos pelo Conama, não apresentando alteração entre os três ciclos. As médias obtidas entre os três ciclos foram sempre menores que a metade dos limites máximos estabelecidos pela legislação vigente, em todos os casos (TABELA 5.12). Sendo assim, com relação aos íons metálicos, não há nenhum comprometimento do uso do lodo não encaminhado ao digestor na agricultura.

\subsubsection{DENSIDADE DO LODO}

Todas as equações e considerações utilizadas no cálculo da densidade, e que foram apresentadas na Etapa 1 (item 5.1.7), serviram de base, também, para a determinação da densidade do lodo não digerido. No APÊNDICE 8, encontram-se os dados e os respectivos 
valores de densidade encontrados para o lodo sem cal (L1 e L2) e com cal (LC1) e (LC2) que deram origem ao GRÁFICO 5.14.

Para a relação entre o teor de sólidos totais (ST) e a densidade, apresentada no GRÁFICO 5.14, a curva exponencial foi a que melhor se ajustou na regressão linear. Foram encontrados coeficientes de correlação pouco menores que os da Etapa 1. No entanto, indicaram, também, uma forte correspondência entre os resultados relacionados; para o lodo sem cal o coeficiente de correlação foi $\mathrm{R}^{2}=0,9625$ (L1 e L2) e para o com cal $\mathrm{R}^{2}=0,9705$ (LC1 e LC2).

Nesse caso, como o lodo da Etapa 1, também, com o aumento do teor de ST, o lodo que recebeu a cal apresentou valores de densidade mais elevados que o sem cal. Com a elevação do teor de sólidos, a partir de aproximadamente $20 \%$ ST, o lodo com cal apresentou densidade sempre superior ao sem cal. Para o lodo não encaminhado ao digestor, ao atingir $90 \% \mathrm{ST}$, o lodo sem cal apresentou densidade de 1,42 enquanto o com cal, 1,51.

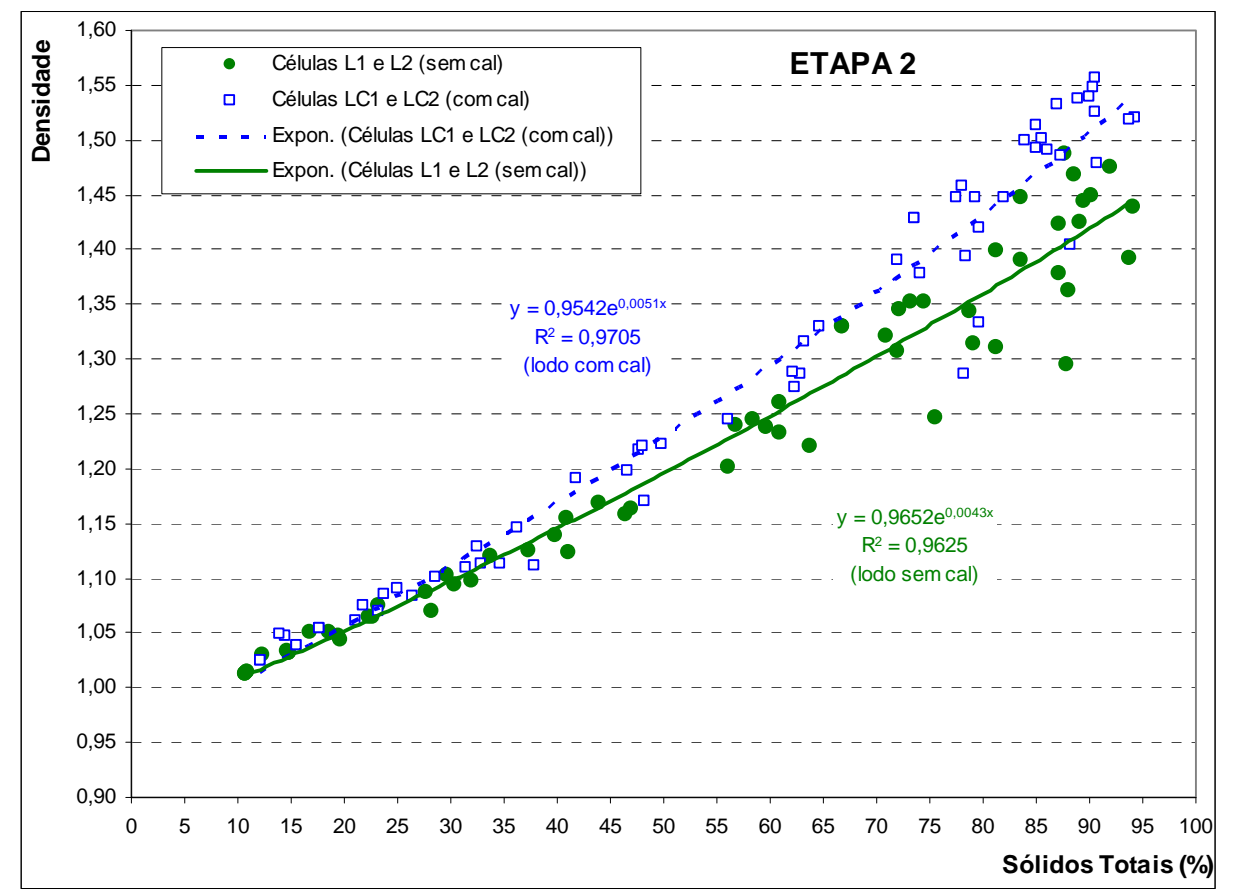

Gráfico 5.14 - Variação da densidade do lodo em relação ao teor de sólidos totais (ST), com base nos valores obtidos nos Ciclos 1/2, 2/2 e 3/2 de lodo não encaminhado ao digestor sem cal (L1 e L2) e com cal (LC1 e LC2) durante a Etapa 2 


\section{DISCUSSÃO}

Com base nos resultados mostrados nas duas etapas da pesquisa, optou-se por apresentar nas discussões uma análise comparativa entre as Etapas 1 e 2, as quais foram desenvolvidas com a mesma metodologia experimental. Para alguns parâmetros, a discussão baseou-se, também, nos resultados da análise estatística.

\subsection{TEMPERATURA}

A variação da temperatura observada nas duas etapas demonstrou que a estufa mantém em seu interior temperaturas elevadas durante o período das $10 \mathrm{~h}$ às $17 \mathrm{~h}$, aproximadamente. A temperatura no interior da estufa começa a ficar maior que a temperatura ambiente a partir das $7 \mathrm{~h}$ e tende a se aproximar novamente da temperatura externa a partir das 19h. Esse tempo é bastante significativo para o aproveitamento da capacidade da estufa em manter temperaturas internas elevadas, favorecendo a perda da umidade do lodo (GRÁFICOS 5.2 e 5.9).

Nas duas etapas, os ciclos que foram desenvolvidos entre os meses de dezembro a maio foram aqueles que apresentaram temperaturas mais elevadas dentro da estufa. Na Etapa 1, a temperatura média das médias horárias dentro e fora da estufa chegou a apresentar, aproximadamente, $7^{\circ} \mathrm{C}$ de diferença no Ciclo $1 / 1$, ocorrido entre os meses de janeiro e abril. As máximas horárias conseguidas dentro da estufa foram acima de $50^{\circ} \mathrm{C}$ (externa $34,2^{\circ} \mathrm{C}$ ), e as mínimas horárias sempre superiores a $20^{\circ} \mathrm{C}$ (externa $14,2^{\circ} \mathrm{C}$ ). Nos Ciclos $1 / 2$ e $2 / 2$ da Etapa 2 , desenvolvidos entre os meses de dezembro e maio, foram conseguidas dentro da estufa temperaturas acima de $53^{\circ} \mathrm{C}$ (externa acima de $36^{\circ} \mathrm{C}$ ).

Por outro lado, o Ciclo 3/1 (Etapa 1) foi o que apresentou menor média das médias horárias obtidas dentro da estufa. Isso pode ser atribuído ao fato de que esse ciclo foi desenvolvido durante o inverno que, apesar de não ser, na região onde foi desenvolvida a pesquisa, uma estação rigorosa com temperaturas muito baixas, apresenta temperaturas inferiores às dos demais períodos do ano. O mesmo aconteceu no Ciclo $3 / 2$ da Etapa 2, desenvolvido praticamente no mesmo período. 
A temperatura interna da estufa foi relevante na secagem do lodo. No experimento realizado por Comparini (2001), apesar de o lodo usado ter sido digerido anaerobiamente, ressaltando os aspectos de temperatura dentro da estufa, o pesquisador alcançou umidade de $11,45 \%$ em 70 dias de secagem do lodo com temperatura média das médias horárias dentro da estufa de 26,6 ${ }^{\circ} \mathrm{C}$. No entanto, no Ciclo $1 / 1$, quando foram usados os mesmos procedimentos operacionais, tal umidade foi atingida entre 35 dias e 42 dias (média entre L1 e L2), com temperatura média das médias horárias de $29,4^{\circ} \mathrm{C}$. No geral, o potencial da estufa em manter temperaturas internas elevadas, visando à secagem e a higienização do lodo, foi interessante para a região estudada. Fato este confirmado, também, por Comparini (2001).

\subsection{PARÂMETROS: UMIDADE, SÓLIDOS E pH}

Com o auxílio da estatística, foi realizada a avaliação, entre as diferentes condições metodológicas testadas, para definir aquela que possibilitou a secagem e a higienização do lodo num menor intervalo de tempo possível. Para tanto, efetuaram-se testes ANOVA ara medida repetida com fator dependente o tempo e fator independente aquele que está sendo avaliado (tipo de lodo, presença de cal e modo de disposição/revolvimento) separadamente, apresentados no item 4.4. Os resultados encontram-se apresentados na TABELA 6.1.

Tabela 6.1 - Resultados dos testes ANOVA para medida repetida, com fator dependente o tempo e fator independente o tipo de lodo, a presença de cal e o modo de disposição/revolvimento para os parâmetros umidade, SV/ST e pH

\begin{tabular}{cccccccc}
\hline & \multirow{2}{*}{ Fator } & & \multicolumn{2}{c}{ Umidade } & \multicolumn{2}{c}{ SV/ST } & \multicolumn{2}{c}{ pH } \\
\cline { 3 - 8 } & & F & p-valor & F & p-valor & F & p-valor \\
\hline \multirow{3}{*}{ Tipo de lodo } & Lodo & 2,1577 & 0,156011 & 0.191 & 0.666134 & 0.7656 & 0.391023 \\
& Tempo & 295,04 & 0,0001 & 125.023 & 0.000000 & 30.6053 & 0.000000 \\
& Tempo x Lodo & 1,0391 & 0,411521 & 11.356 & 0.000000 & 0.5488 & 0.853979 \\
\hline \multirow{2}{*}{ Cal } & Cal & 0,4082 & 0,5294 & 37.235 & 0.000004 & 235.642 & 0.000000 \\
& Tempo & 283,11 & 0,0001 & 88.562 & 0.000000 & 94.113 & 0.000000 \\
& Tempo x Cal & 0,1071 & 0,9997 & 1.628 & 0.099967 & 47.339 & 0.000000 \\
\hline \multirow{2}{*}{ Disposição/ } & Disp_Rev & 24,638 & 0,0001 & 1.276 & 0.309649 & 0.0555 & 0.982279 \\
Revolv. & Tempo & 295,04 & 0,0001 & 77.919 & 0.000000 & 26.9290 & 0.000000 \\
& Tempo x Disp_Rev & 583,38 & 0,0001 & 1.275 & 0.165863 & 0.6576 & 0.913803 \\
\hline
\end{tabular}

Nota: $\mathrm{F}=$ distribuição $\mathrm{F}$ de Snedecor; as células destacadas indicam os fatores que apresentaram diferenças estatisticamente significantes para a variável (parâmetro) testada, com nível de significância de 5\%. 
Observa-se que houve diferença significativa, com nível de significância de 5\%, para alguns fatores testados, considerando os parâmetros analisados. Essas diferenças são discutidas e detalhadas nos itens seguintes. Porém, no caso específico do fator tempo, esse apresentou diferença significativa, em todos os casos. Isso porque, o tempo é o fator fundamental na variação dos parâmetros analisados.

\subsubsection{UMIDADE}

\subsubsection{Fator tipo de lodo}

Os resultados da ANOVA indicaram não haver diferença significativa entre os tipos de lodo $(\mathrm{F}=2,1577 ; \mathrm{p}=0,156011)$ nem na interação tempo e tipo de lodo $(\mathrm{F}=1,0391 ; \mathrm{p}=0,411521)$ (TABELA 6.1). Assim, independentemente do lodo passar ou não pelo digestor, a perda da umidade ao longo do tempo não apresentou diferença significativa.

Observando-se o GRÁFICO 6.1, percebe-se que a perda da umidade ao longo do tempo para as duas condições, se manteve sempre bem próxima ao intervalo de confiança de $95 \%$ nos dois casos.

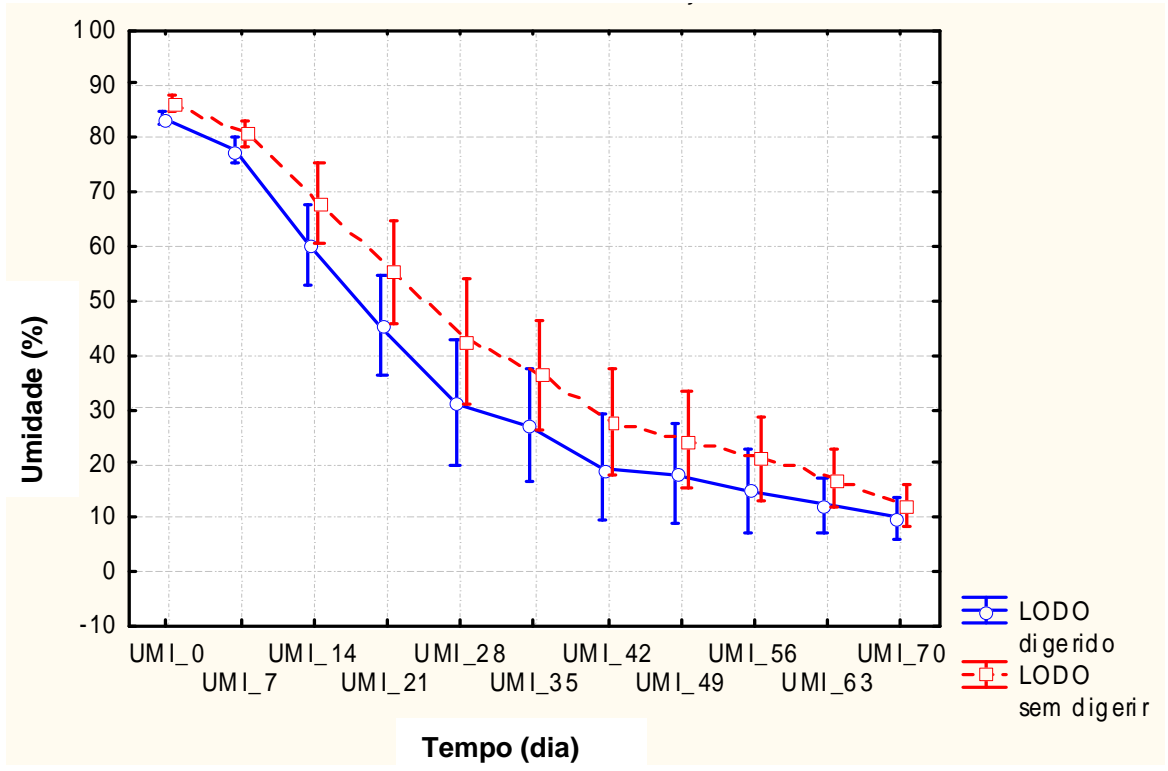

Gráfico 6.1 - Perfil temporal das médias de umidade e respectivos intervalos de confiança de $95 \%$, considerando todos os resultados obtidos nas Etapas 1 e 2 de acordo com o fator tipo de lodo 
No APÊNDICE 10, encontram-se apresentados os resultados (p-valores) dos testes a posteriori de Tukey e o GRÁFICO 6.2 ilustra os resultados do teste de Tukey.

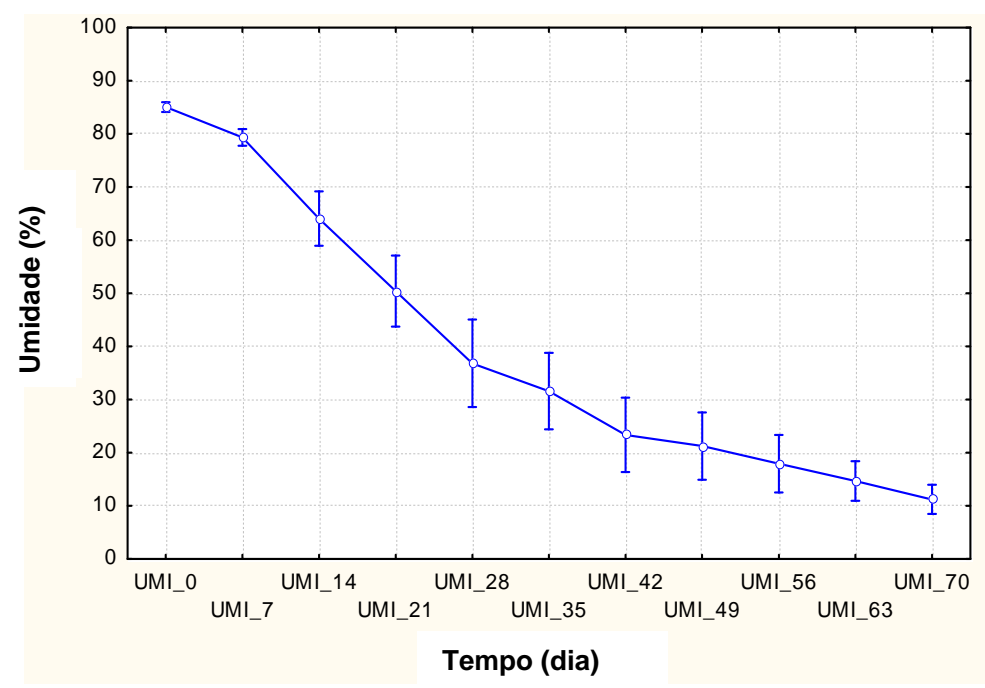

Gráfico 6.2 - Perfil temporal das médias de umidade e respectivos intervalos de confiança de $95 \%$ para os resultados obtidos no teste de Tukey

A tendência apresentada no GRÁFICO 6.2 mostra que o comportamento da perda da umidade do lodo foi bem semelhante ao ocorrido na pesquisa desenvolvida por Comparini (2001), que é confirmado pelos resultados de (p-valores) dos testes a posteriori de Tukey com nível de significância de 5\% (APÊNDICE 10). As informações revelam que existiram três situações distintas na remoção da umidade, a saber:

- 0 a 7 dias - Os (p-valores) mostraram não haver diferença significativa entre os resultados apresentados nesse intervalo. Isso mostra que o material manifestou dificuldade em perder umidade nesse período, apresentando uma variação dos valores não significativa. Isso ocorreu, aproximadamente, entre $85 \%$ e $79 \%$ de umidade. A dificuldade pode ser atribuída à quantidade elevada de água livre contida no fundo da camada de lodo da célula impossibilitada de evaporar em razão da própria massa do material.

- 7 a 42 dias - Os (p-valores) indicaram haver diferença significativa entre os resultados apresentados no tempo. Nesse intervalo ocorre uma redução bastante acentuada da umidade com variação significativa dos valores no tempo. A faixa de umidade nesse intervalo de tempo foi de, aproximadamente, $79 \%$ a $22 \%$. Isso ocorreu, possivelmente, 
pela maior porosidade do material possibilitando uma melhor circulação do ar dentro da camada de lodo pela perda da água livre.

- 42 a 70 dias - Os (p-valores) mostraram, novamente, não haver diferença significativa entre os resultados apresentados nesse intervalo, indicando dificuldade na perda de umidade quando os valores se encontram abaixo de $20 \%$. A dificuldade pode ter ocorrido pelo fato de a água residual estar aderida às partículas sólidas do lodo.

\subsubsection{Fator cal}

Nesse caso, a ANOVA realizada indicou não haver diferença significativa entre os grupos com e sem cal $(\mathrm{F}=0,4082 ; \mathrm{p}=0,5294)$ nem na interação tempo e presença de cal $(\mathrm{F}=0,1071$; $\mathrm{p}=0,9997$ ) (TABELA 6.1). Isso mostra que o fato de ter sido adicionada cal ao lodo, também, não apresentou diferença significativa na variação da variável umidade. $\mathrm{O}$ GRÁFICO 6.3 ilustra as médias de umidade e os intervalos de confiança de $95 \%$ ao longo do tempo, para o fator cal.

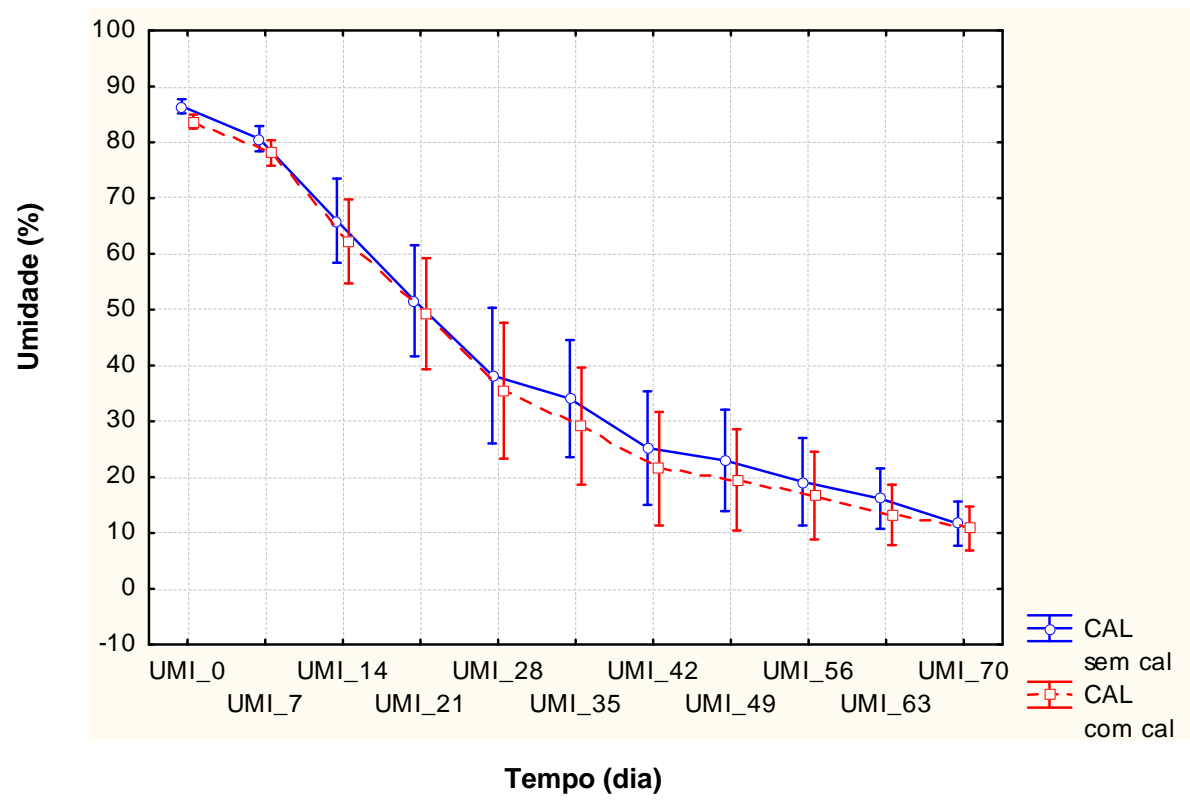

Gráfico 6.3 - Perfil temporal das médias de umidade e respectivos intervalos de confiança de $95 \%$, considerando todos os resultados obtidos nas Etapas 1 e 2 de acordo com o fator cal

Como se pode observar no GRÁFICO 6.3, a proximidade entre o comportamento das curvas foi ainda maior que a ocorrida com o fator tipo de lodo (GRÁFICO 6.1). 
Os resultados do teste a posteriori de Tukey são os mesmos do fator tipo de lodo (APÊNDICE 10).

\subsubsection{Fator disposição/revolvimento}

Para o fator disposição/revolvimento os resultados da ANOVA indicaram haver diferença significativa entre os modos de disposição/revolvimento $(F=24,638 ; p=0,0001)$ (TABELA 6.1). Com isso, as mudanças na forma de dispor o lodo nas células e no período do revolvimento acarretaram em diferenças significativas para a variável umidade. O GRÁFICO 6.4 apresenta as médias de umidade e os intervalos de confiança de $95 \%$ ao longo do tempo, para o fator disposição do lodo nas células e período de revolvimento.

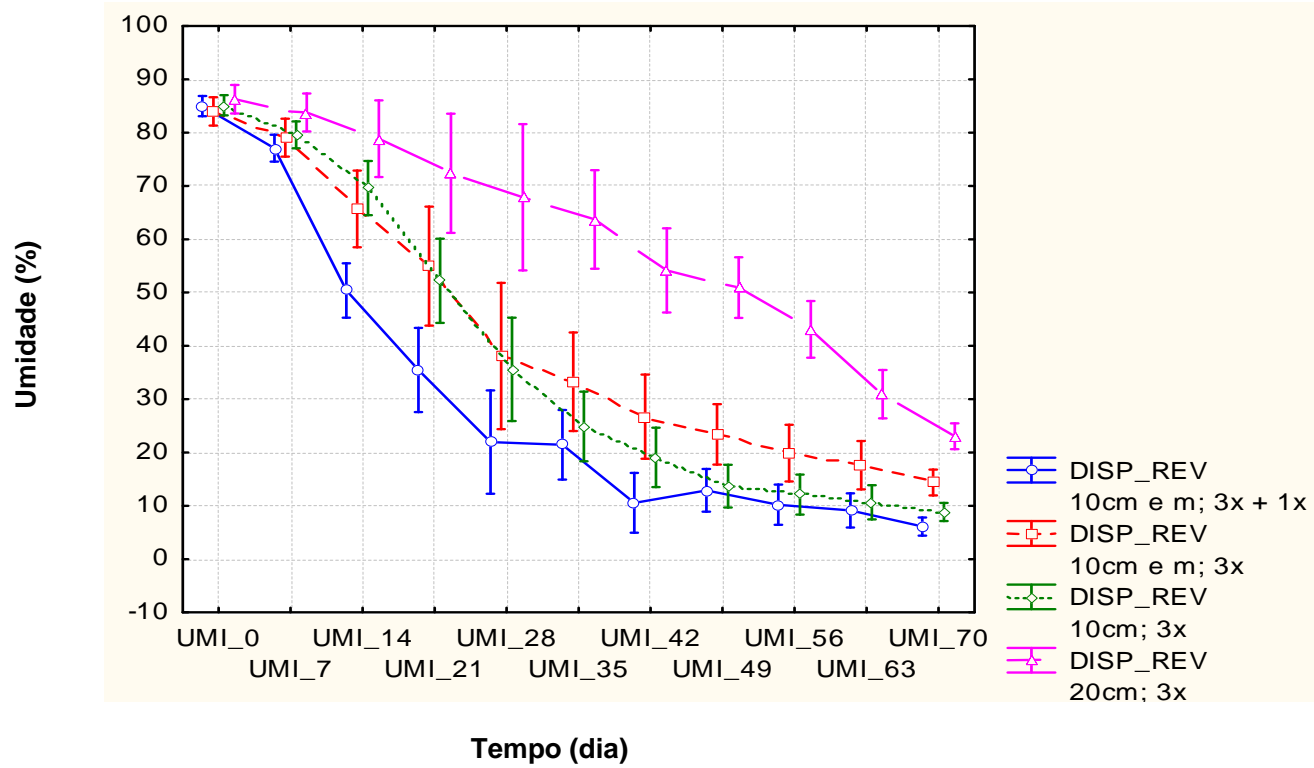

Gráfico 6.4 - Perfil temporal das médias de umidade e respectivos intervalos de confiança de $95 \%$, considerando todos os resultados obtidos nas Etapas 1 e 2 de acordo com o fator disposição/revolvimento

Os resultados indicaram, também, haver diferença significativa na interação entre tempo e modo de disposição/revolvimento e $(\mathrm{F}=583,38 ; \mathrm{p}=0,0001)$, para um nível de significância de 5\% (TABELA 6.1).

No caso dos resultados apresentados por Comparini (2001) (TABELA 3.21), a metodologia usada na $3^{\text {a }}$ repetição foi a mesma usada no Ciclo 1 para os dois tipos de lodo, ou seja, $(10 \mathrm{~cm}$ e $\mathrm{m} / 3 \mathrm{x}+1 \mathrm{x})$. No entanto, o lodo atingiu cerca de $15 \%$ de umidade aos 56 dias e, nesta 
pesquisa, umidade em torno de $12 \%$, já foi observada no $42^{\circ}$ dia (GRÁFICO 6.4). Essas variações podem ser atribuídas ao tipo de lodo usado nas pesquisas e/ou às diferenças entre as temperaturas apresentadas nas regiões onde aconteceram os experimentos.

Na TABELA 6.2, são mostrados os resultados de p-valores do teste de Tukey para os modos de disposição/revolvimento, no APÊNDICE 11, os resultados de p-valores dos testes a posteriori de Tukey para a variável umidade.

Tabela 6.2 - Resultados do teste de Tukey (p-valores) para os modos de disposição/revolvimento do lodo refrerentes ao parâmetro umidade

\begin{tabular}{cccc}
\hline \multirow{2}{*}{ Fator disposição/revolvimento } & \multicolumn{3}{c}{ Fator disposição/revolvimento } \\
\cline { 2 - 4 } & $\mathbf{( 1 0 c m ~ e ~ m / 3 x )}$ & $\mathbf{( 1 0 c m / 3 x )}$ & $\mathbf{( 2 0 c m / 3 x )}$ \\
\hline $\mathbf{( 1 0 c m ~ e ~ m / 3 x ~ + ~ 1 x ) ~}$ & 0,0243 & 0,1211 & 0,0002 \\
$(\mathbf{1 0 c m} \mathbf{~ m} / \mathbf{3 x})$ & & 0,6164 & 0,0010 \\
$\mathbf{( 1 0 c m / 3 x )}$ & & & 0,0002 \\
\hline
\end{tabular}

A combinação $(20 \mathrm{~cm} / 3 x)$ foi a condição que apresentou diferença significativa em relação a todas as outras formas de disposição/revolvimento. Isso pode ser percebido, também, no GRÁFICO 6.4. Por outro lado, $(10 \mathrm{~cm} / 3 \mathrm{x})$ apresentou diferença significativa apenas em relação a $(20 \mathrm{~cm} / 3 x)$.

Com o auxílio do GRÁFICO 6.4, percebe-se que $(10 \mathrm{~cm}$ e $\mathrm{m} / 3 \mathrm{x}+1 \mathrm{x})$ foi a condição que possibilitou uma perda de umidade mais acelerada até o $42^{\circ}$ dia. No entanto, o teste a posteriori de Tukey (APENDICE 11) mostra que, a começar do $28^{\circ}$ dia, os p-valores determinados para $(10 \mathrm{~cm} / 3 \mathrm{x})$ não apresentaram diferenças significativas em relação à combinação $(10 \mathrm{~cm}$ e m/3x $+1 \mathrm{x})$.

As estatísticas descritivas, média e desvio padrão, da variável umidade nos tempos 0 a 70 dias, segundo os fatores de variação tipo de lodo (digerido e não encaminhado ao digestor) e cal (sem cal e com cal) encontram-se apresentadas na TABELA 6.3. E, segundo a forma de disposição do lodo na célula e o período de revolvimento, na TABELA 6.4. 
Tabela 6.3 - Médias e desvios padrões da umidade ao logo do tempo considerando todos os resultados obtidos nas Etapas 1 e 2 de acordo com o tipo de lodo e a condição de adicionar ou não cal ao lodo

\begin{tabular}{ccccccccc}
\hline \multirow{2}{*}{$\begin{array}{c}\text { Tempo } \\
\text { (dia) }\end{array}$} & \multicolumn{9}{c}{ Lodo digerido } & \multicolumn{9}{c}{ Lodo sem digerir ${ }^{(\mathbf{1})}$} & \multicolumn{2}{c}{ Lodo sem cal } & \multicolumn{2}{c}{ Lodo com cal } \\
\cline { 2 - 10 } & Média & DP & Média & DP & Média & DP & Média & DP \\
\hline Umi_0 & 83,77 & 1,38 & 86,37 & 2,71 & 86,44 & 2,09 & 83,71 & 2,12 \\
Umi_7 & 77,91 & 2,68 & 80,80 & 4,51 & 80,63 & 3,67 & 78,08 & 3,89 \\
Umi_14 & 60,28 & 13,95 & 67,89 & 9,94 & 65,93 & 12,81 & 62,23 & 12,39 \\
Umi_21 & 45,44 & 16,78 & 55,45 & 14,81 & 51,59 & 17,02 & 49,29 & 16,22 \\
Umi_28 & 31,08 & 20,62 & 42,60 & 18,17 & 38,20 & 21,62 & 35,48 & 18,89 \\
Umi_35 & 27,03 & 16,09 & 36,19 & 17,93 & 34,08 & 18,25 & 29,14 & 16,73 \\
Umi_42 & 19,20 & 16,00 & 27,53 & 17,08 & 25,22 & 18,48 & 21,51 & 15,38 \\
Umi_49 & 18,15 & 13,28 & 24,36 & 16,44 & 23,00 & 17,06 & 19,52 & 13,04 \\
Umi_56 & 14,84 & 11,66 & 21,03 & 13,78 & 19,17 & 15,44 & 16,71 & 10,25 \\
Umi_63 & 12,26 & 7,73 & 17,13 & 9,75 & 16,15 & 10,68 & 13,24 & 7,00 \\
Umi_70 & 10,07 & 5,73 & 12,40 & 7,17 & 11,68 & 7,64 & 10,78 & 5,32 \\
\hline
\end{tabular}

Nota: ${ }^{(1)}$ Lodo não encaminhado ao digestor; ${ }^{(2)}$ Desvio Padrão.

Tabela 6.4 - Médias e desvios padrões da umidade ao logo do tempo considerando todos os resultados obtidos nas Etapas 1 e 2 de acordo com a forma de disposição do lodo na célula e o período de revolvimento

\begin{tabular}{|c|c|c|c|c|c|c|c|c|}
\hline \multirow{3}{*}{$\begin{array}{c}\text { Tempo } \\
\text { (dia) }\end{array}$} & \multicolumn{8}{|c|}{ Umidade (\%) } \\
\hline & \multicolumn{2}{|c|}{$(10 \mathrm{~cm}$ e $\mathrm{m} / 3 \mathrm{x}+1 \mathrm{x})$} & \multicolumn{2}{|c|}{$(10 \mathrm{~cm}$ e m/3x) } & \multicolumn{2}{|c|}{$(10 \mathrm{~cm} / 3 x)$} & \multicolumn{2}{|c|}{$(20 \mathrm{~cm} / 3 x)$} \\
\hline & Média & $\mathbf{D P} \mathbf{P}^{(1)}$ & Média & DP & Média & DP & Média & DP \\
\hline Umi_0 & 84,97 & 2,74 & 83,97 & 1,72 & 85,12 & 2,53 & 86,27 & 2,90 \\
\hline Umi_7 & 77,07 & 2,03 & 79,05 & 3,13 & 79,58 & 4,17 & 83,77 & 4,19 \\
\hline Umi_14 & 50,39 & 8,50 & 65,68 & 4,33 & 69,59 & 7,33 & 78,85 & 2,00 \\
\hline Umi_21 & 35,48 & 4,59 & 54,95 & 9,83 & 52,20 & 16,12 & 72,37 & 3,33 \\
\hline Umi_28 & 21,95 & 4,48 & 38,09 & 20,28 & 35,58 & 17,21 & 67,88 & 2,18 \\
\hline Umi_35 & 21,45 & 4,75 & 33,28 & 7,15 & 24,90 & 12,33 & 63,71 & 8,04 \\
\hline Umi_42 & 10,57 & 2,48 & 26,72 & 9,35 & 19,08 & 10,39 & 54,15 & 5,40 \\
\hline Umi_49 & 12,90 & 2,47 & 23,40 & 7,93 & 13,71 & 4,09 & 50,93 & 9,01 \\
\hline Umi_56 & 10,22 & 2,34 & 19,89 & 6,53 & 12,11 & 3,95 & 43,09 & 9,04 \\
\hline Umi_63 & 9,14 & 1,46 & 17,63 & 6,64 & 10,66 & 3,31 & 30,95 & 7,14 \\
\hline Umi_70 & 6,13 & 0,53 & 14,38 & 3,18 & 8,86 & 2,09 & 23,04 & 3,84 \\
\hline
\end{tabular}

Nota: ${ }^{(1)}$ Desvio Padrão. 


\subsubsection{RELAÇÃO ENTRE SÓLIDOS VOLÁTEIS E SÓLIDOS TOTAIS (SV/ST)}

\subsubsection{Fator tipo de lodo}

Em face dos resultados da ANOVA, foi possível comprovar não haver diferença entre os tipos de lodo $(\mathrm{F}=0,191 ; \mathrm{p}=0,666134)$, para a relação entre SV/ST (TABELA 6.1). Assim, a variável SV/ST não apresentou diferença significativa, independentemente de o lodo ter passado ou não pelo digestor.

No entanto, com os resultados da ANOVA, verificou-se que houve diferença significativa na interação tempo e tipo de lodo $(\mathrm{F}=11,356 ; \mathrm{p}=0,00000)$ (TABELA 6.1). Inclusive, é possível perceber no GRÁFICO 6.5 que no tempo zero, os valores de SV/ST para os dois tipos de lodo eram bem diferentes, estando fora do intervalo de confiança de $95 \%$.

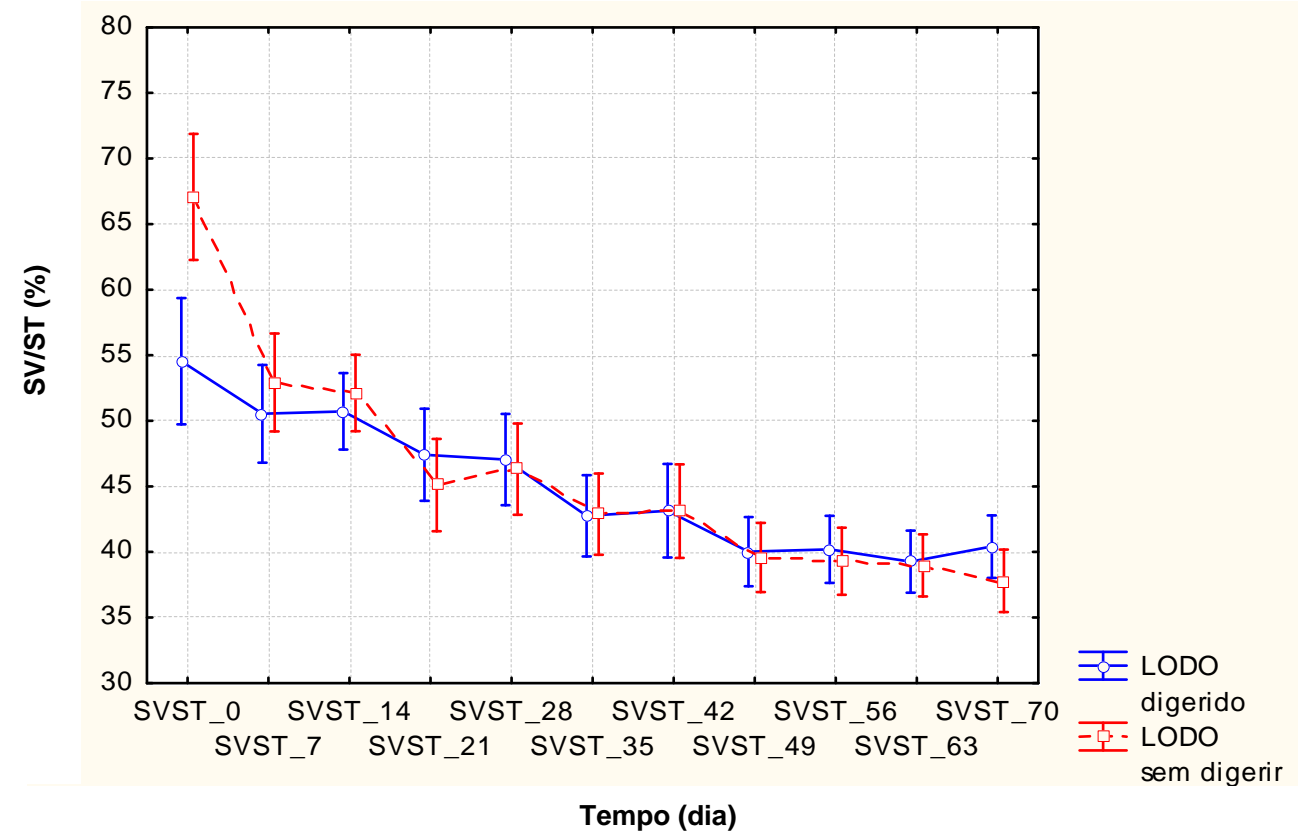

Gráfico 6.5 - Perfil temporal das médias de SV/ST e respectivos intervalos de confiança de $95 \%$, considerando todos os resultados obtidos nas Etapas 1 e 2 de acordo com o fator tipo de lodo

Os testes a posteriori de Tukey indicaram não haver diferença significativa dos resultados, praticamente, a partir do $35^{\circ}$ dia para o lodo digerido e o não encaminhado ao digestor (APÊNDICE 12), com valores médios de SV/ST em torno de 43\% nos dois casos (TABELA $6.5)$. 
No tempo zero, início da secagem em estufa, a relação entre SV/ST era inferior a 70\%, considerando o intervalo de confiança de 95\%, apenas no lodo digerido, caracterizando-se como um material estável, com bom nível de digestão (BRASIL, 2006c; MALINA, 1993a; US EPA, 1995). Entretanto, o lodo não submetido à digestão apresentou valores acima de $70 \%$ no tempo zero. Nos dois casos, ocorreu uma diminuição gradativa dos valore de SV/ST em face da continuidade do processo de estabilização do lodo ocasionado, principalmente, pela redução da umidade (BOROWSKI; SZOPA, 2007; LAKE, 1987) (GRÁFICO 6.5).

Valores inferiores a $40 \%$ de SV/ST foram atingidos em tempos de secagem superiores a 49 dias. Para Comparini (2001), essa relação foi de cerca de 56\% ( $3^{\mathrm{a}}$ repetição) para um tempo de secagem de 70 dias, para o lodo digerido anaerobiamente. O lodo usado pelo pesquisador apresentou SV/ST inicial em torno de $73 \%$.

\subsubsection{Fator cal}

Os resultados da ANOVA mostraram haver diferença significativa entre os grupos com e sem cal $(\mathrm{F}=37,235 ; \mathrm{p}=0,000004)$ (TABELA 6.1). O GRÁFICO 6.6 ilustra a variação das médias de SV/ST e dos intervalos de confiança de $95 \%$ de SV/ST para o fator cal ao longo do tempo.

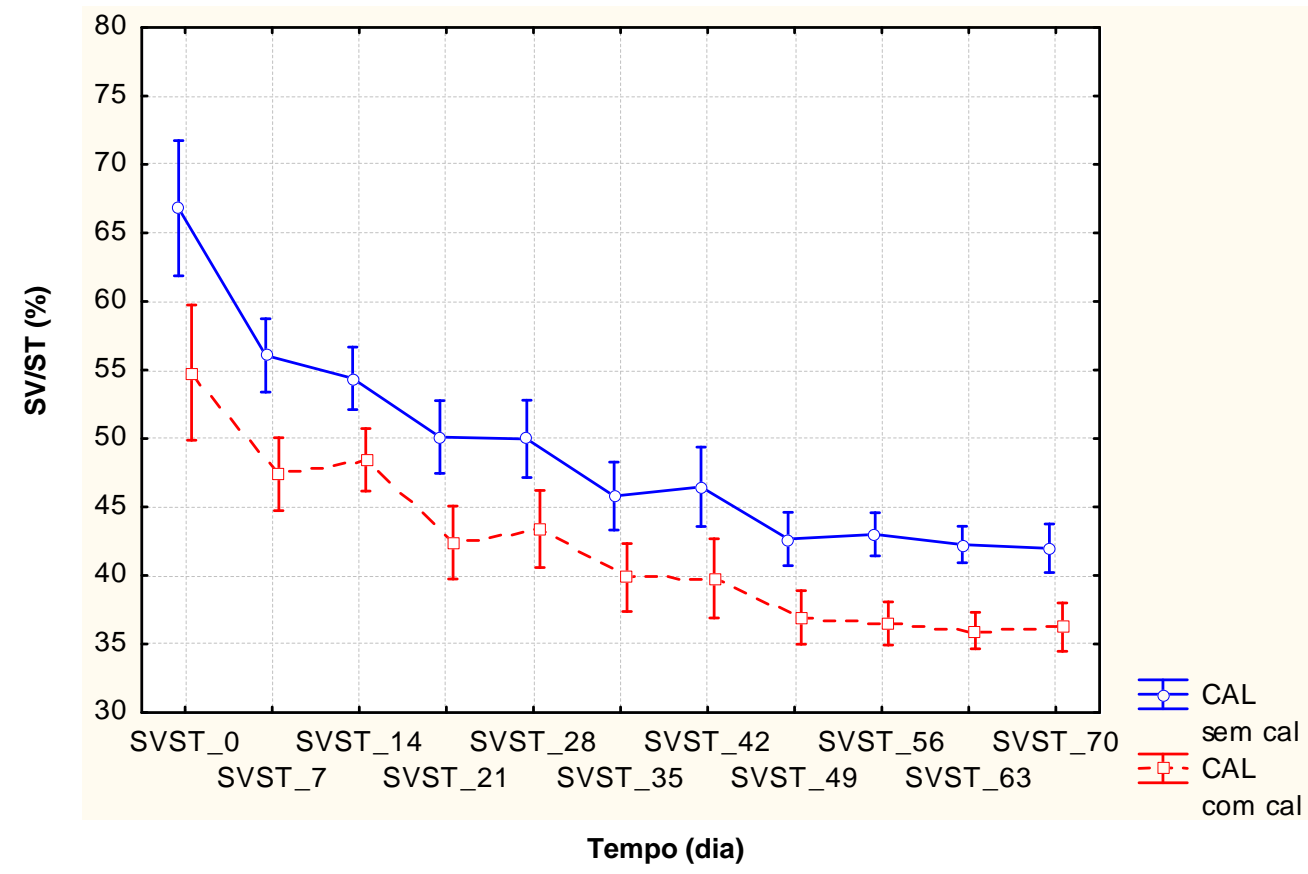

Gráfico 6.6 - Perfil temporal das médias de SV/ST e respectivos intervalos de confiança de $95 \%$, considerando todos os resultados obtidos nas Etapas 1 e 2 de acordo com o fator cal 
Com a adição da cal, os valores de SV/ST foram sempre inferiores em relação ao lodo sem cal. Isso pode ser atribuído ao fato de que, com a adição da cal ao lodo (LC1 e LC2), ocorre um aumento nos teores de ST e, consequentemente, uma diminuição nessa relação (ANDREASEN, 2001; US EPA, 1999).

Entretanto, os resultados da ANOVA mostraram que não houve diferença na interação tempo e presença de cal $(\mathrm{F}=1,628 ; \mathrm{p}=0,099967)$ (TABELA 6.1), ou seja, a tendência do decaimento foi praticamente a mesma. Os testes a posteriori de Tukey indicaram não haver diferença significativa dos resultados a partir do $49^{\circ}$ dia (APÊNDICE 13), para os dois tipos de lodo, com média de SV/ST em torno de 43\% (lodo sem cal) e 37\% (lodo com cal) (TABELA 6.5).

\subsubsection{Fator disposição/revolvimento}

Nesse caso, não houve diferença significativa na variação da relação SV/ST, entre os modos de disposição/revolvimento analisados $(\mathrm{F}=1,276 ; \mathrm{p}=0,309649)$ (TABELA 6.1). Sendo assim, as mudanças na forma de dispor o lodo nas células e os períodos de revolvimento adotados não interferiram na variação de SV/ST. O GRÁFICO 6.7 apresenta as médias de SV/ST e os intervalos de confiança de $95 \%$, para o fator disposição do lodo nas células e período de revolvimento ao longo do tempo.

Também, não houve diferença significativa na variação da relação SV/ST, na interação entre o tempo e os modos de disposição/revolvimento $(\mathrm{F}=1,275 ; \mathrm{p}=0,165863)$ (TABELA 6.1). Os testes a posteriori de Tukey indicaram não haver diferença significativa dos resultados, a partir do $49^{\circ}$ dia (APÊNDICE 14), para todos os casos, estando os valores de SV/ST entre, aproximadamente, $37 \%$ e $43 \%$ (TABELA 6.6). 


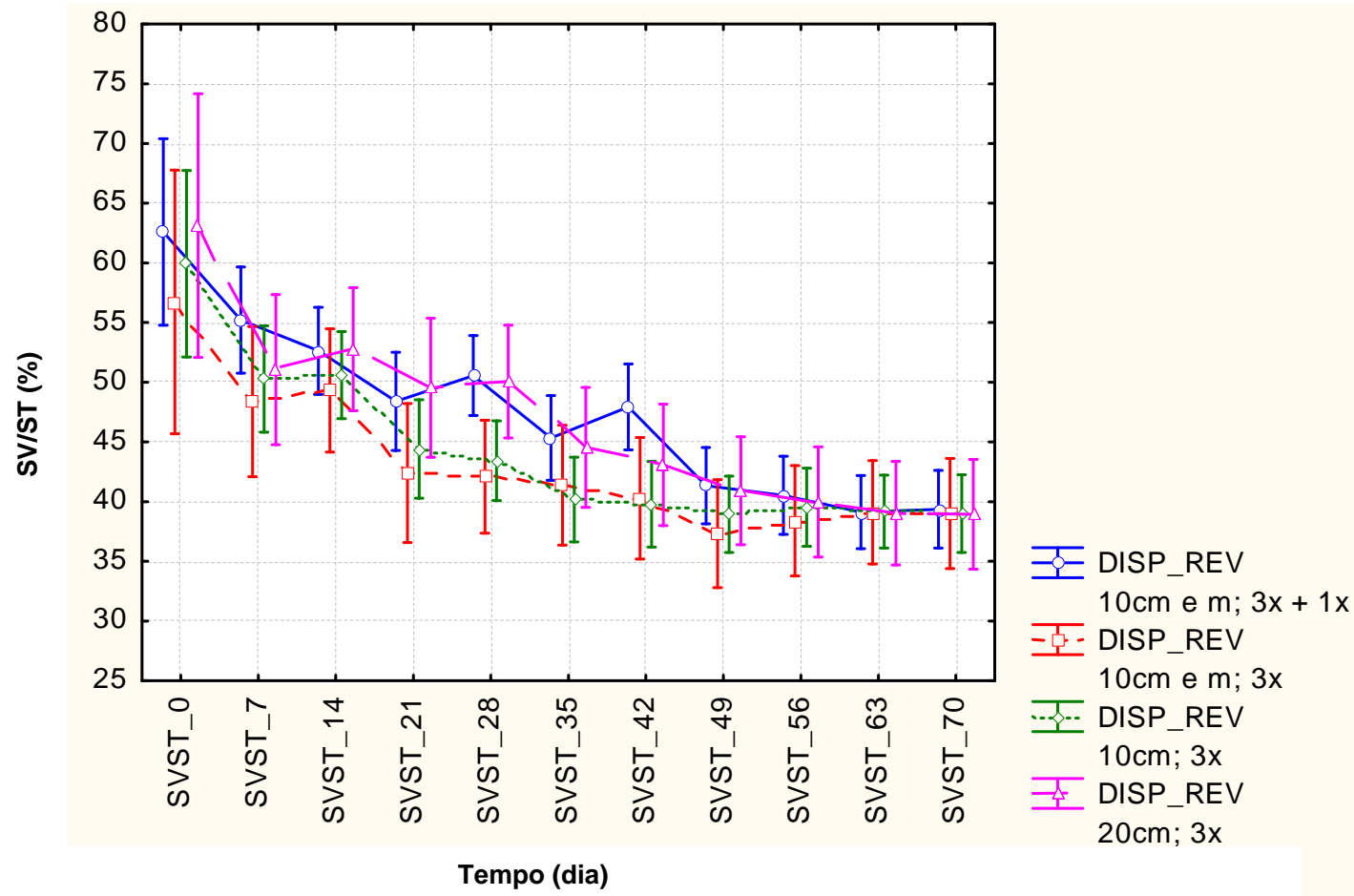

Gráfico 6.7 - Perfil temporal das médias de SV/ST e respectivos intervalos de confiança de $95 \%$, considerando todos os resultados obtidos nas Etapas 1 e 2 de acordo com o fator disposição/revolvimento

As estatísticas descritivas, média e desvio padrão, da variável SV/ST nos tempos 0 a 70 dias, segundo os fatores de variação tipo de lodo (digerido e não encaminhado ao digestor) e cal (sem cal e com cal) encontram-se apresentadas na TABELA 6.5. E, segundo a forma de dispor o lodo nas células e o período de revolvimento, na TABELA 6.6.

Tabela 6.5 - Médias e desvios padrões de SV/ST ao logo do tempo considerando todos os resultados obtidos nas Etapas 1 e 2 de acordo com o tipo de lodo e a condição de adicionar ou não cal ao lodo

\begin{tabular}{|c|c|c|c|c|c|c|c|c|}
\hline \multirow{3}{*}{$\begin{array}{c}\text { Tempo } \\
\text { (dia) }\end{array}$} & \multicolumn{8}{|c|}{ SV/ST (\%) } \\
\hline & \multicolumn{2}{|c|}{ Lodo digerido } & \multicolumn{2}{|c|}{ Lodo sem digerir ${ }^{(1)}$} & \multicolumn{2}{|c|}{ Lodo sem cal } & \multicolumn{2}{|c|}{ Lodo com cal } \\
\hline & Média & $\mathbf{D} \mathbf{P}^{(2)}$ & Média & DP & Média & DP & Média & DP \\
\hline SVST_0 & 54,55 & 5,06 & 67,07 & 10,16 & 66,80 & 9,43 & 54,81 & 6,87 \\
\hline SVST_7 & 50,54 & 5,22 & 52,92 & 7,10 & 56,07 & 4,99 & 47,40 & 3,86 \\
\hline SVST_14 & 50,72 & 5,34 & 52,12 & 4,32 & 54,39 & 4,12 & 48,45 & 3,47 \\
\hline SVST_21 & 47,41 & 5,55 & 45,10 & 6,18 & 50,11 & 4,89 & 42,41 & 3,95 \\
\hline SVST_28 & 47,05 & 5,71 & 46,32 & 5,91 & 49,98 & 5,22 & 43,39 & 4,13 \\
\hline SVST_35 & 42,76 & 5,01 & 42,89 & 5,34 & 45,80 & 4,71 & 39,85 & 3,49 \\
\hline SVST_42 & 43,14 & 5,34 & 43,12 & 6,52 & 46,47 & 5,36 & 39,79 & 4,25 \\
\hline SVST_49 & 40,03 & 3,22 & 39,58 & 5,35 & 42,67 & 3,51 & 36,94 & 2,98 \\
\hline SVST_56 & 40,20 & 3,54 & 39,30 & 4,89 & 43,00 & 2,95 & 36,50 & 2,26 \\
\hline SVST_63 & 39,27 & 3,06 & 38,98 & 4,68 & 42,26 & 2,29 & 35,98 & 2,15 \\
\hline SVST_70 & 40,42 & 3,70 & 37,80 & 4,25 & 41,99 & 3,33 & 36,23 & 2,52 \\
\hline
\end{tabular}

Nota: ${ }^{(1)}$ Lodo não encaminhado ao digestor; ${ }^{(2)}$ Desvio Padrão. 
Tabela 6.6 - Médias e desvios padrões de SV/ST ao logo do tempo considerando todos os resultados obtidos nas Etapas 1 e 2 de acordo com a forma de disposição do lodo na célula e o período de revolvimento

\begin{tabular}{|c|c|c|c|c|c|c|c|c|}
\hline \multirow{3}{*}{$\begin{array}{c}\text { Tempo } \\
\text { (dia) }\end{array}$} & \multicolumn{8}{|c|}{ SV/ST (\%) } \\
\hline & \multicolumn{2}{|c|}{$(10 \mathrm{~cm}$ e $\mathrm{m} / 3 \mathrm{x}+1 \mathrm{x})$} & \multicolumn{2}{|c|}{$(10 \mathrm{~cm}$ e $\mathrm{m} / 3 x)$} & \multicolumn{2}{|c|}{$(10 \mathrm{~cm} / 3 x)$} & \multicolumn{2}{|c|}{$(20 \mathrm{~cm} / 3 x)$} \\
\hline & Média & $\mathbf{D P} \mathbf{P}^{(1)}$ & Média & DP & Média & DP & Média & DP \\
\hline SVST_0 & 54,55 & 5,06 & 67,07 & 10,16 & 66,80 & 9,43 & 54,81 & 6,87 \\
\hline SVST_7 & 50,54 & 5,22 & 52,92 & 7,10 & 56,07 & 4,99 & 47,40 & 3,86 \\
\hline SVST_14 & 50,72 & 5,34 & 52,12 & 4,32 & 54,39 & 4,12 & 48,45 & 3,47 \\
\hline SVST_21 & 47,41 & 5,55 & 45,10 & 6,18 & 50,11 & 4,89 & 42,41 & 3,95 \\
\hline SVST_28 & 47,05 & 5,71 & 46,32 & 5,91 & 49,98 & 5,22 & 43,39 & 4,13 \\
\hline SVST_35 & 42,76 & 5,01 & 42,89 & 5,34 & 45,80 & 4,71 & 39,85 & 3,49 \\
\hline SVST_42 & 43,14 & 5,34 & 43,12 & 6,52 & 46,47 & 5,36 & 39,79 & 4,25 \\
\hline SVST_49 & 40,03 & 3,22 & 39,58 & 5,35 & 42,67 & 3,51 & 36,94 & 2,98 \\
\hline SVST_56 & 40,20 & 3,54 & 39,30 & 4,89 & 43,00 & 2,95 & 36,50 & 2,26 \\
\hline SVST_63 & 39,27 & 3,06 & 38,98 & 4,68 & 42,26 & 2,29 & 35,98 & 2,15 \\
\hline SVST_70 & 40,42 & 3,70 & 37,80 & 4,25 & 41,99 & 3,33 & 36,23 & 2,52 \\
\hline
\end{tabular}

Nota: ${ }^{(1)}$ Desvio Padrão.

\subsubsection{POTENCIAL HIDROGENIÔNICO - pH}

\subsubsection{Fator tipo de lodo}

Os resultados da ANOVA mostraram que a variável $\mathrm{pH}$ não apresentou diferença significativa, independentemente de o lodo ter passado ou não pelo digestor $(\mathrm{F}=0,7656 ; \mathrm{p}=$ 0,391023) (TABELA 6.1). O GRÁFICO 6.8 apresenta a variação das médias de $\mathrm{pH}$ e dos intervalos de confiança de $95 \%$, em relação ao tempo, para o lodo digerido e para o lodo não encaminhado ao digestor.

Também, em face dos resultados da ANOVA, percebe-se que o parâmetro $\mathrm{pH}$ não apresentou diferença significativa na interação tempo e tipo de lodo $(F=0,5488 ; p=0,853979)$ (TABELA 6.1). Apesar de os testes da ANOVA não apresentarem diferença significativa, o GRÁFICO 6.8 mostra que os valores de $\mathrm{pH}$ do lodo não submetido à digestão sempre foram ligeiramente superiores quando comparados ao que passou por digestão aeróbia. No entanto, as médias sempre estão dentro do intervalo de confiança de $95 \%$. Nos dois casos, o decaimento do $\mathrm{pH}$ foi gradativo, diferentemente do comportamento apresentado por Comparini (2001), provavelmente em razão de o lodo usado na pesquisa ter sido digerido anaerobiamente. 


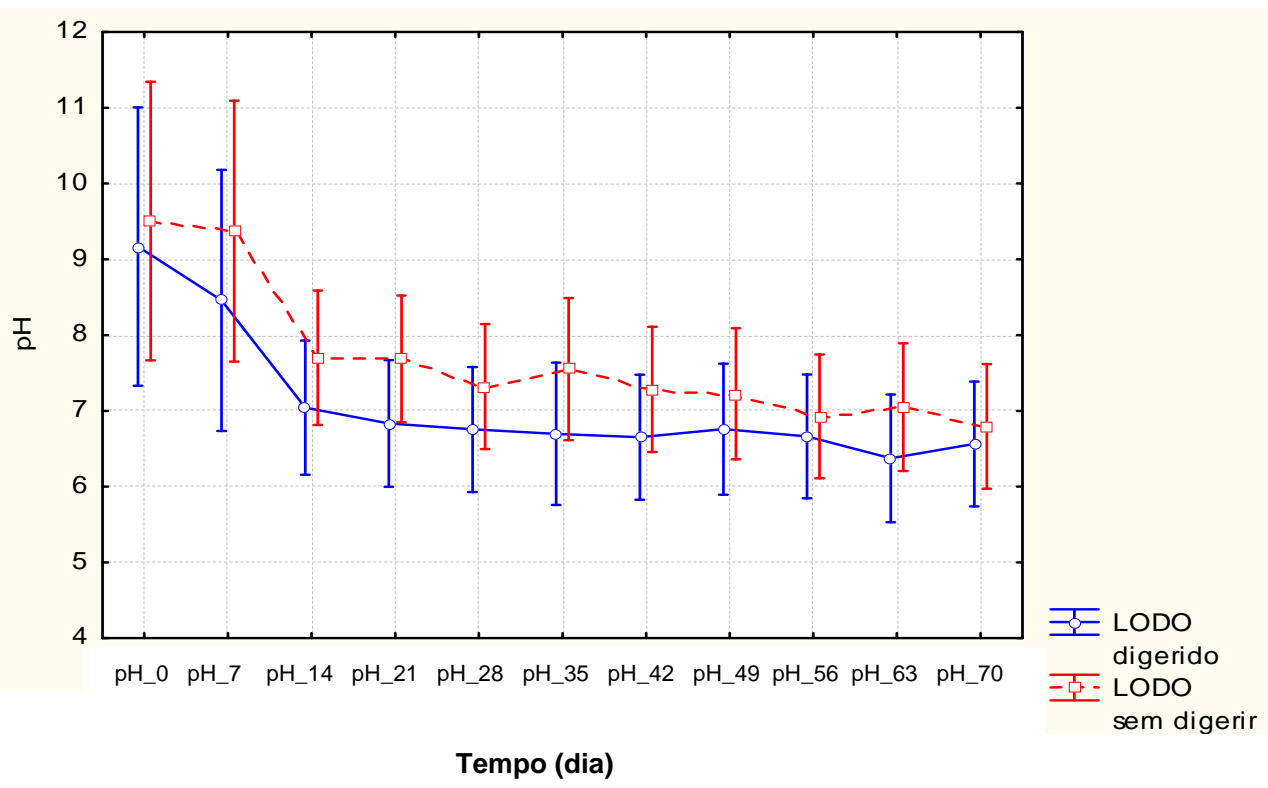

Gráfico 6.8 - Perfil temporal das médias de $\mathrm{pH}$ e respectivos intervalos de confiança de $95 \%$, considerando todos os resultados obtidos nas Etapas 1 e 2 de acordo com o fator tipo de lodo

Os testes a posteriori de Tukey indicaram não haver diferença significativa dos resultados a partir do $14^{\circ}$ dia para o lodo digerido e o não encaminhado ao digestor (APÊNDICE 15) com valores de $\mathrm{pH}$ em torno de 7,04\% e 7,70\%, respectivamente (TABELA 6.7).

\subsubsection{Fator cal}

Nesse caso, os resultados da ANOVA mostraram haver diferença significativa entre os grupos com e sem cal $(F=235,642 ; p=0,0000)$, como era de esperar (TABELA 6.1). Isso confirma que a presença da cal apresenta diferença significativa na variável $\mathrm{pH}$.

No lodo com cal o $\mathrm{pH}$ foi acima de 12 no tempo 0 , apresentando um decaimento bastante representativo até o $14^{\circ}$ dia e, daí em diante, as médias permaneceram entre 8 e 9 . O decaimento do $\mathrm{pH}$ na mistura lodo/cal é resultado da perda da umidade do lodo que, após atingir um equilíbrio com o meio, permanece constante até o final dos ciclos. Para o lodo sem a adição da cal, o pH apresentou valores pouco acima de 6 nos primeiros dias, apresentando médias entre 5.2 e 6 até o final do experimento (GRÁFICO 6.9).

Sob aspectos agronômicos, os valores mais elevados de pH do lodo com a adição da cal, podem ser uma condição interessante para promover a correção do $\mathrm{pH}$ do solo que se apresenta ácido (AKRIVOS et al., 2000; PLANCHÁ et al., 2008). Porém, com a faixa de pH 
entre 5,5-6,5, ocorre a diminuição dos efeitos tóxicos sobre as plantas quando há presença em excesso de $\mathrm{Cu}, \mathrm{Fe}, \mathrm{Mn}, \mathrm{Zn}$ e $\mathrm{Al}$ e a disponibilização de nutrientes, como P, Ca, S, N, K, B, $\mathrm{Mo}, \mathrm{Cl}$ e outros (FIA; MATOS; AGUIRRE, 2005) ${ }^{31}$. Nesse caso, atenção especial deve ser dada à dosagem utilizada do material, pois $\mathrm{pH}$ do solo acima de 6,5 pode provocar desequilíbrio nutricional, salinização e prejuízos no desenvolvimento e produtividade das culturas (ANDREOLI; PEGORINI; FERNANDES, 2001).

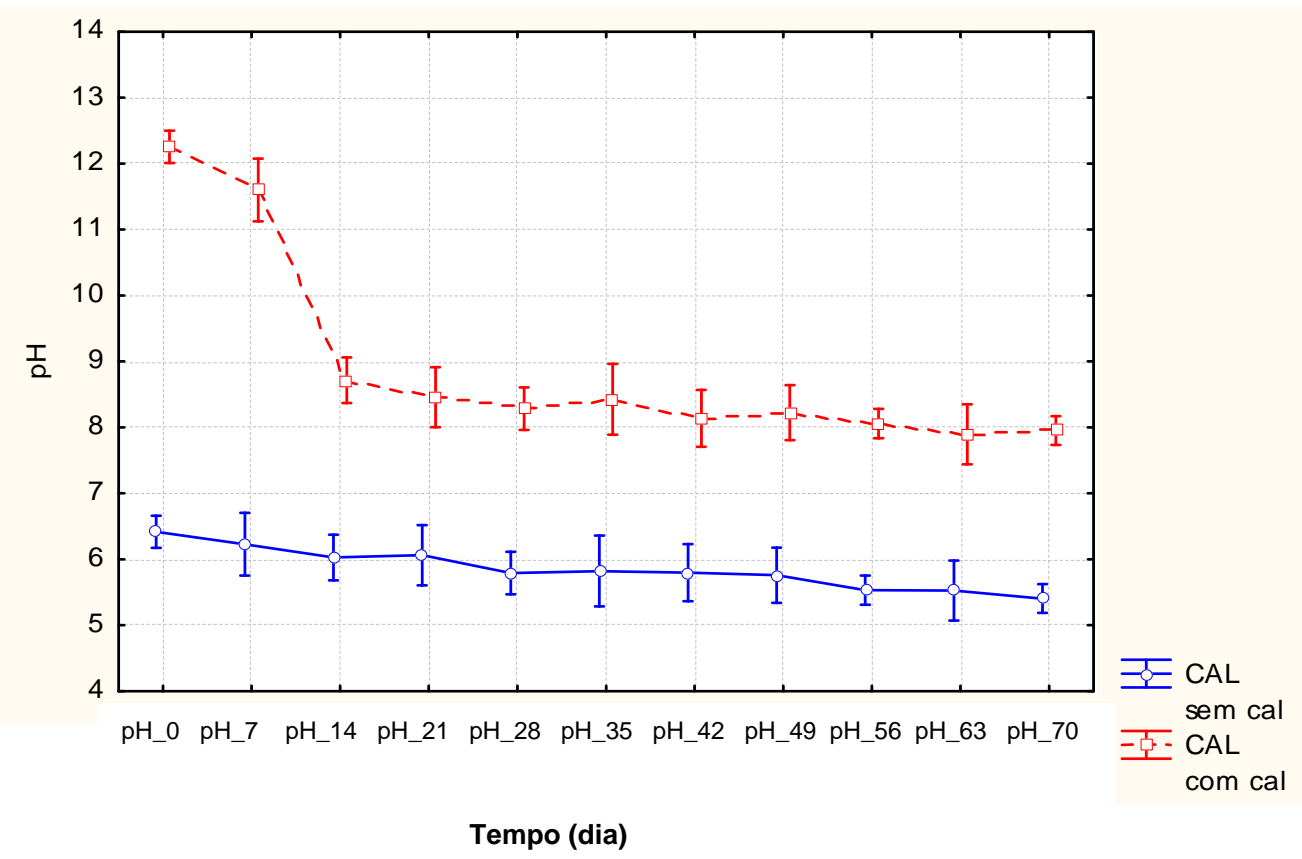

Gráfico 6.9 - Perfil temporal das médias de $\mathrm{pH}$ e respectivos intervalos de confiança de $95 \%$, considerando todos os resultados obtidos nas Etapas 1 e 2 de acordo com o fator cal

Os resultados da ANOVA mostraram, também, haver diferença significativa na interação tempo e presença de cal $(\mathrm{F}=47,339 ; \mathrm{p}=0,0000)$ (TABELA 6.1).

Os testes a posteriori de Tukey indicaram não haver diferença significativa dos resultados a partir do $14^{\circ}$ dia para o lodo sem cal e do $21^{\circ}$ para o com cal (APÊNDICE 16), com valores de em torno de 6 (lodo sem cal) e 8,5 (lodo com cal) (TABELA 6.7).

\footnotetext{
${ }^{31}<$ http://www.ufv.br/dea/reveng/arquivos/Vol13/v13n4p287-299.pdf>
} 


\subsubsection{Fator disposição/revolvimento}

Os resultados da ANOVA mostraram não haver diferença significativa quanto ao fator disposição/revolvimento ( $\mathrm{F}=0,0555 ; \mathrm{p}=0,982279)$ (TABELA 6.1). Isso mostra que o fato de ter efetuado mudanças metodológicas na forma de dispor o lodo nas células e no período de revolvimento, não traduziu em diferença significativa na variável $\mathrm{pH}$. O GRÁFICO 6.10 ilustra a variação das médias de $\mathrm{pH}$ e dos intervalos de confiança de $95 \%$, para o fator disposição/revolvimento, ao longo do tempo.

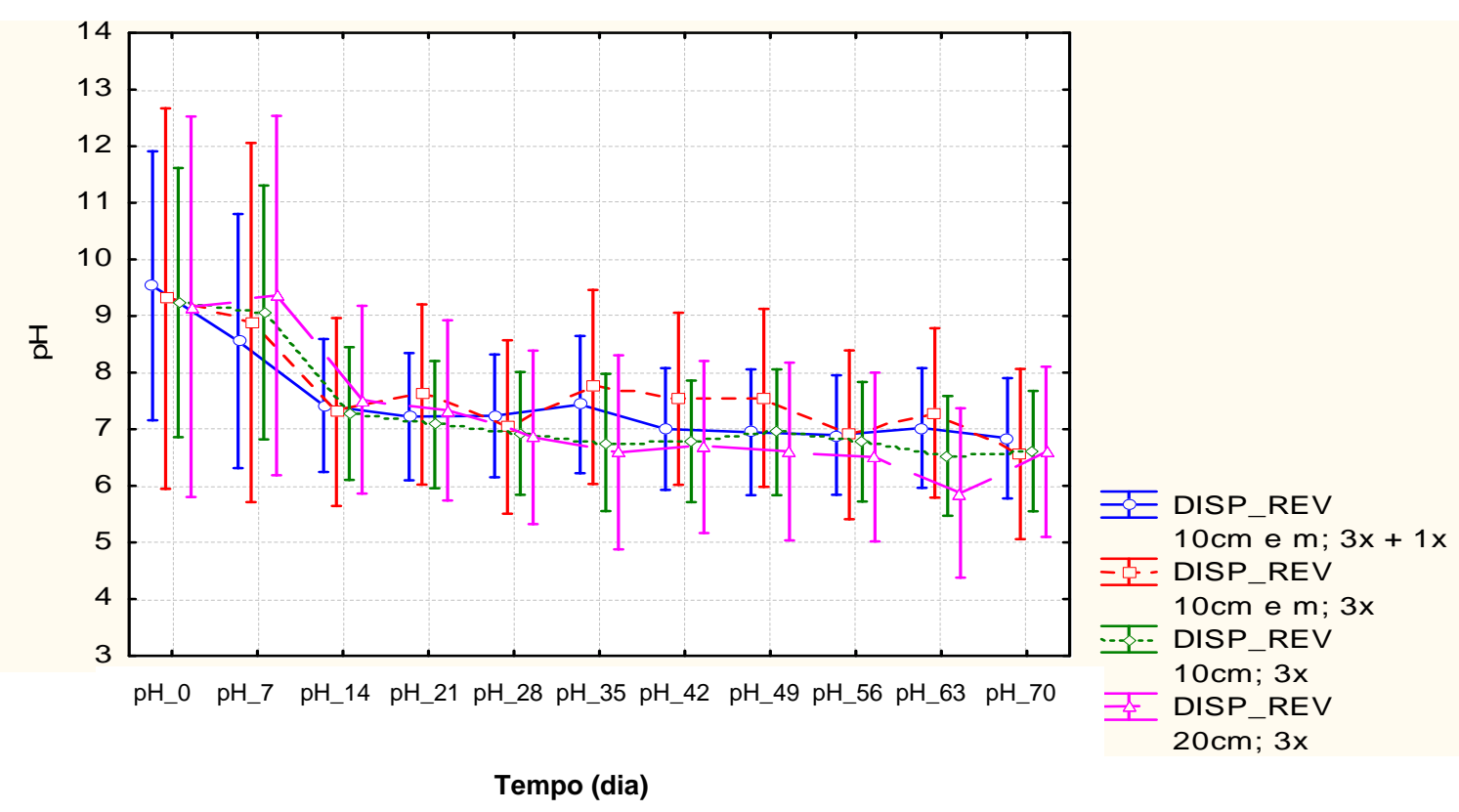

Gráfico 6.10 - Perfil temporal das médias de $\mathrm{pH}$ e respectivos intervalos de confiança de $95 \%$, considerando todos os resultados obtidos nas Etapas 1 e 2 de acordo com o fator disposição/revolvimento

Para a interação entre o tempo os modos de disposição/revolvimento, os resultados da ANOVA mostraram, também, que não há diferença significativa $(F=0,6576 ; p=0,913803)$, para um nível de significância de 5\% (TABELA 6.1). Os testes a posteriori de Tukey indicaram não haver diferença significativa dos resultados a partir do $14^{\circ}$ dia (APÊNDICE 17), para todos os casos, estando os valores de $\mathrm{pH}$ entre 7,2 e 7,5 (TABELA 6.8).

As estatísticas descritivas, média e desvio padrão, da variável $\mathrm{pH}$ nos tempos 0 a 70 dias, segundo os fatores de variação tipo de lodo (digerido e não encaminhado ao digestor) e cal 
(sem cal e com cal) encontram-se apresentadas na TABELA 6.7. E, segundo a forma de disposição do lodo nas células e o período de revolvimento, na TABELA 6.8.

Tabela 6.7 - Médias e desvios padrões de $\mathrm{pH}$ ao logo do tempo considerando todos os resultados obtidos nas Etapas 1 e 2 de acordo com o tipo de lodo e a condição de adicionar ou não cal ao lodo

\begin{tabular}{|c|c|c|c|c|c|c|c|c|}
\hline \multirow{3}{*}{$\begin{array}{c}\text { Tempo } \\
\text { (dia) }\end{array}$} & \multicolumn{8}{|c|}{$\mathbf{p H}$} \\
\hline & \multicolumn{2}{|c|}{ Lodo digerido } & \multicolumn{2}{|c|}{ Lodo sem digerir $^{(1)}$} & \multicolumn{2}{|c|}{ Lodo sem cal } & \multicolumn{2}{|c|}{ Lodo com cal } \\
\hline & Média & $\mathbf{D P} \mathbf{P}^{(2)}$ & Média & DP & Média & DP & Média & DP \\
\hline pH_0 & 9,17 & 3,28 & 9,51 & 2,85 & 6,42 & 0,55 & 12,26 & 0,16 \\
\hline pH_7 & 8,46 & 2,74 & 9,37 & 3,01 & 6,23 & 0,45 & 11,60 & 1,03 \\
\hline pH_14 & 7,04 & 1,58 & 7,70 & 1,38 & 6,03 & 0,70 & 8,72 & 0,43 \\
\hline pH_21 & 6,83 & 1,68 & 7,61 & 1,05 & 6,06 & 1,04 & 8,46 & 0,30 \\
\hline pH_28 & 6,76 & 1,52 & 7,32 & 1,22 & 5,79 & 0,75 & 8,29 & 0,13 \\
\hline pH_35 & 6,70 & 1,71 & 7,55 & 1,41 & 5,82 & 1,22 & 8,43 & 0,33 \\
\hline pH_42 & 6,65 & 1,46 & 7,28 & 1,30 & 5,80 & 1,00 & 8,14 & 0,23 \\
\hline pH_49 & 6,76 & 1,65 & 7,23 & 1,20 & 5,76 & 0,94 & 8,23 & 0,32 \\
\hline pH_56 & 6,66 & 1,47 & 6,93 & 1,25 & 5,53 & 0,45 & 8,06 & 0,26 \\
\hline pH_63 & 6,37 & 1,55 & 7,05 & 1,25 & 5,53 & 0,97 & 7,90 & 0,46 \\
\hline pH_70 & 6,56 & 1,45 & 6,79 & 1,30 & 5,40 & 0,48 & 7,95 & 0,18 \\
\hline
\end{tabular}

Nota: (*) Lodo não encaminhado ao digestor; ${ }^{(2)}$ Desvio Padrão.

Tabela 6.8 - Médias e desvios padrões de $\mathrm{pH}$ ao logo do tempo considerando todos os resultados obtidos nas Etapas 1 e 2 de acordo com a forma de disposição do lodo na célula e o período de revolvimento

\begin{tabular}{|c|c|c|c|c|c|c|c|c|}
\hline \multirow{3}{*}{$\begin{array}{c}\text { Tempo } \\
\text { (dia) }\end{array}$} & \multicolumn{8}{|c|}{$\mathbf{p H}$} \\
\hline & \multicolumn{2}{|c|}{$(10 \mathrm{~cm}$ e $\mathrm{m} / 3 \mathrm{x}+1 \mathrm{x})$} & \multicolumn{2}{|c|}{$(10 \mathrm{~cm} \mathrm{e} \mathrm{m} / 3 x)$} & \multicolumn{2}{|c|}{$(10 \mathrm{~cm} / 3 x)$} & \multicolumn{2}{|c|}{$(20 \mathrm{~cm} / 3 x)$} \\
\hline & Média & $\mathbf{D P} \mathbf{P}^{(1)}$ & Média & DP & Média & DP & Média & DP \\
\hline $\mathrm{pH} \_0$ & 9,54 & 2,99 & 9,24 & 3,22 & 9,31 & 3,57 & 9,17 & 3,38 \\
\hline $\mathrm{pH} \_7$ & 8,56 & 2,55 & 9,06 & 3,18 & 8,89 & 3,36 & 9,36 & 3,42 \\
\hline pH_14 & 7,42 & 1,43 & 7,28 & 1,61 & 7,31 & 1,47 & 7,52 & 1,95 \\
\hline pH_21 & 7,22 & 1,27 & 7,08 & 1,51 & 7,62 & 1,97 & 6,95 & 1,71 \\
\hline pH_28 & 7,24 & 1,37 & 6,93 & 1,46 & 7,04 & 1,51 & 6,86 & 1,66 \\
\hline pH_35 & 7,44 & 1,28 & 6,77 & 1,72 & 7,75 & 1,79 & 6,59 & 2,01 \\
\hline pH_42 & 7,01 & 1,22 & 6,79 & 1,49 & 7,54 & 1,64 & 6,69 & 1,66 \\
\hline pH_49 & 6,95 & 1,26 & 6,95 & 1,41 & 7,56 & 1,64 & 6,61 & 2,01 \\
\hline pH_56 & 6,90 & 1,26 & 6,78 & 1,31 & 6,90 & 1,78 & 6,51 & 1,66 \\
\hline pH_63 & 7,02 & 1,38 & 6,53 & 1,32 & 7,29 & 1,53 & 5,88 & 1,69 \\
\hline pH_70 & 6,84 & 1,20 & 6,61 & 1,47 & 6,56 & 1,64 & 6,60 & 1,67 \\
\hline
\end{tabular}

Nota: ${ }^{(1)}$ Desvio Padrão. 


\subsection{INDICADORES BACTERIOLÓGICOS E AGENTES PATOGÊNICOS}

Diferentemente do lodo utilizado na Etapa 1, o da Etapa 2 apresenta valores mais elevados de patógenos, principalmente, CTt e OVH (TABELAS 5.4 e 5.10). Percebe-se com isso que, pelo fato de o lodo não ter sido submetido à digestão aeróbia, as características apresentadas mostram que esse lodo demanda uma atenção especial para a sua disposição final adequada. Nesse sentido, o tratamento em estufa agrícola configurou-se numa técnica interessante com uma diminuição significativa dos microrganismos, possibilitando seu enquadramento segundo os padrões do Conama para lodo Classe A.

Nesse caso, a estatística, também, auxiliou na avaliação dos resultados para definir, entre as diferentes condições metodológicas testadas, aquela que possibilitou a secagem e higienização do lodo num menor intervalo de tempo possível, atendendo aos padrões estabelecidos pelo Conama. Para tanto, foi usado o mesmo teste apresentado na avaliação dos parâmetros umidade, sólidos voláteis e pH, itens 4.4 e 6.2 (TABELA 6.9).

Tabela 6.9 - Resultados dos testes ANOVA para medida repetida, com fator dependente o tempo e fator independente o tipo de lodo, a presença de cal e o modo de disposição/revolvimento para os parâmetros coliforme termotolerante e ovos viáveis de helmintos

\begin{tabular}{cccccc}
\hline \multirow{2}{*}{ Fator } & & \multicolumn{2}{c}{ CTt } & \multicolumn{2}{c}{ OVH } \\
\cline { 3 - 6 } & & F & p-valor & F & p-valor \\
\cline { 3 - 6 } Tipo de lodo & Lodo & 1.6279 & 0.220202 & 45.2178 & 0.000001 \\
& Tempo & 9.1174 & 0.000001 & 37.8928 & 0.000000 \\
& Tempo x Lodo & 0.2773 & 0.924306 & 1.6187 & 0.160989 \\
\hline \multirow{2}{*}{ Cal } & Cal & 14.7509 & 0.001443 & 2.6878 & 0.115343 \\
& Tempo & 19.5633 & 0.000000 & 35.7415 & 0.000000 \\
& Tempo x Cal & 12.7679 & 0.000000 & 0.2778 & 0.924434 \\
\hline \multirow{2}{*}{ Disposição/ Revolv. } & Disp_Rev & 1.20361 & 0.344643 & 0.1570 & 0.923916 \\
& Tempo & 6.29240 & 0.000071 & 31.9535 & 0.000000 \\
\hline
\end{tabular}

Nota: $\mathrm{F}=$ distribuição $\mathrm{F}$ de Snedecor; as células destacadas indicam os fatores que apresentaram diferenças estatisticamente significantes para a variável (parâmetro) testada, com nível de significância de 5\%.

A mesma consideração explicitada no item 6.2, com relação ao fator tempo, também é válida para esses parâmetros. 


\subsubsection{COLIFORMES TERMOTOLERANTES}

\subsubsection{Fator tipo de lodo}

Para os coliformes termotolerantes o fator tipo de lodo não expressou diferença significativa $(\mathrm{F}=1,6279 ; \mathrm{p}=0,220202)$ nem a interação tempo e tipo de lodo $(\mathrm{F}=0,2773 ; \mathrm{p}=0,924306)$ (TABELA 6.9). No entanto, observa-se no GRÁFICO 6.11 que o lodo não submetido à digestão apresentou, inicialmente, densidade de coliformes superiores ao padrão estabelecido pela Resolução $n^{\circ} 375 / 2006$ do Conama (3 logNMP/gST). Somente a partir do $28^{\circ}$ dia a densidade apresentada foi abaixo do padrão.

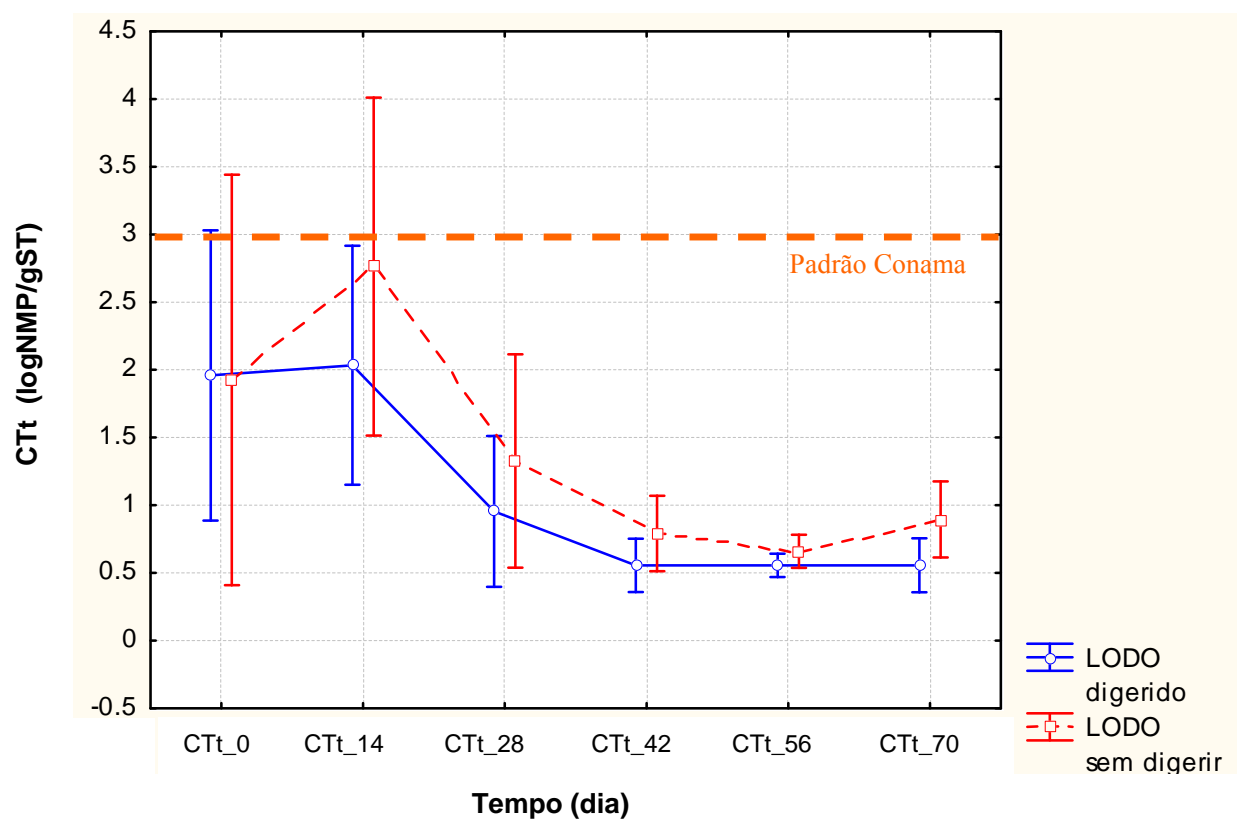

Gráfico 6.11 - Perfil temporal das médias de CTt e respectivos intervalos de confiança de $95 \%$, considerando todos os resultados obtidos nas Etapas 1 e 2 de acordo com o fator tipo de lodo

Apesar de, nesse caso, as densidades de CTt serem semelhantes às de E. coli. do lodo utilizado por Comparini (2001), os valores atingidos ao final dos ciclos foram inferiores aos apresentados pelo pesquisador. Isso ocorreu, provavelmente, em razão do tipo de lodo e das diferentes caracterísiticas entre as duas regiões onde foram desenvolvidas as pesquisas.

Os testes a posteriori de Tukey indicaram não haver diferença significativa dos resultados a partir do $28^{\circ}$ dia para o lodo digerido e para o lodo não encaminhado ao digestor (APÊNDICE 
18), com densidade de CTt igual a 0,95 e 2,60 $\operatorname{logNMP} / \mathrm{gST}$, respectivamente (TABELA $6.10)$.

\subsubsection{Fator cal}

Para esse caso, a ANOVA realizada indicou haver diferença significativa entre os grupos com e sem cal $(\mathrm{F}=14,7509 ; \mathrm{p}=0,001443)$ e, também, na interação tempo e cal $(\mathrm{F}=12,7679 ; \mathrm{p}=$ 0,00000) (TABELA 6.9). Isso quer dizer, que o fato de ter sido adicionada cal ao lodo ocorreu uma diferença significativa no decaimento da densidade de CTt. O GRÁFICO 6.12 apresenta as densidades médias e os intervalos de confiança de 95\% de CTt para o fator cal.

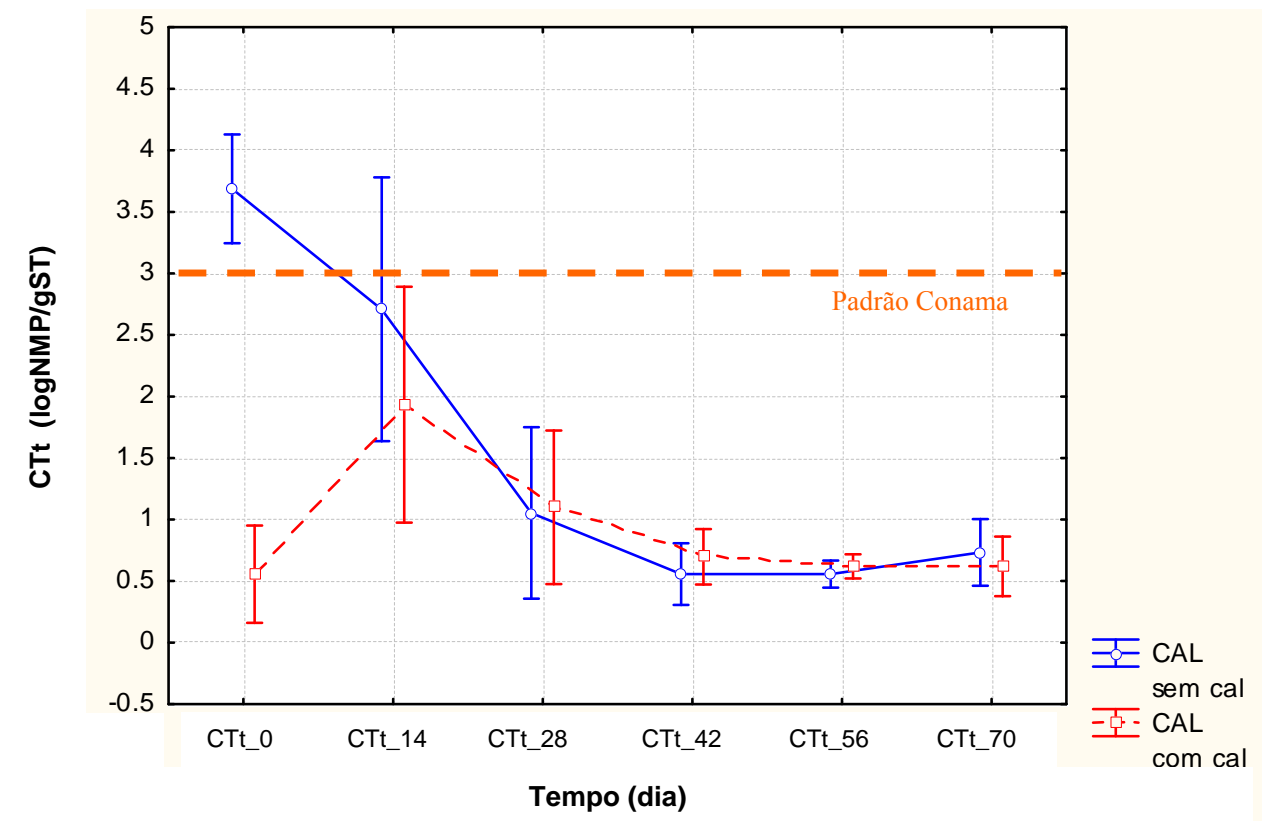

Gráfico 6.12 - Perfil temporal das médias de CTt e respectivos intervalos de confiança de $95 \%$, considerando todos os resultados obtidos nas Etapas 1 e 2 de acordo com o fator cal

Os testes a posteriori de Tukey indicaram não haver diferença significativa dos resultados a partir do $28^{\circ}$ dia para o lodo sem cal e com cal (APÊNDICE 19), com densidades de CTt iguais a 2,12 e 1,44 $\operatorname{logNMP} / \mathrm{gST}$, respectivamente (TABELA 6.10).

De acordo com Silva S. M. C. P. et al. (2001), Smith (1996), Thomaz-Soccol, Paulino e Castro (1997) e US EPA (2003), a sobrevivência dos microrganismos presentes no lodo é 
afetada por diversos fatores, entre os quais a umidade. O decaimento de CTt confirma as informações relatadas por esses pesquisadores.

Com os resultados mostrados no GRÁFICO 6.12, densidades reduzidas de CTt foram observadas a partir do $28^{\circ}$ dia, quando a umidade se encontrava em torno de $38 \%$ (lodo sem cal) e 35\% (lodo com cal) (TABELA 6.3). No entanto, os resultados apresentados separadamente para cada ciclo (itens 5.1.4.1 e 5.2.4.1) sugerem que a umidade necessária para o atendimento aos padrões estabelecidos pelo Conama é inferior. Assim, entende-se que na avaliação final para o enquadramento do lodo como Classe A, segundo o padrão para CTt, deve-se considerar, também, os resultados obtidos em cada ciclo. Na pesquisa realizada por Comparini (2001), foram monitorados coliformes totais e E. coli. Concentrações de E. coli inferiores a $10^{3} \mathrm{NMP} / \mathrm{gST}$ foram conseguidas apenas com teores de umidade abaixo de $10 \%$. Vale destacar que a concentração de E. coli do lodo utilizado no experimento se apresentava com ordem de grandeza de $10^{5} \mathrm{NMP} / \mathrm{gST}$ (TABELA 3.21).

A adição de cal teve aspecto positivo, sendo obtidos valores bem abaixo do padrão nas primeiras amostras analisadas, após a aplicação do material alcalino, com remoção acima de 99,86\%. Isso confirma as citações de Fernandes, Andreoli e Domaszak (1996), Malta (2002) e Outwater (1994), que conseguiram remoções semelhantes para coliformes fecais, ao avaliaram diferentes dosagens de cal na estabilização cálcica do lodo.

O recrescimento ocorrido no $14^{\circ}$ dia no lodo com cal, confirma as condições detectadas nas avaliações por ciclo e relatadas por diversos autores (DUMONTET et al., 2001; RAMIREZ; MALINA, 1980; STRAUB; PEPPER; GERBA, 1993; US EPA, 2002). Vale destacar que, segundo Ramirez e Malina (1980), o pH de 11,5 é suficiente para obter efetiva remoção de bactérias. No entanto, caso o pH atinja valores inferiores a 11,5, é possível ocorrer a recolonização das bactérias, e, nesse caso, o pH estava próximo a 8. Passamani (2001) também constatou o recrescimento de bactérias (coliformes fecais) quando se adicionou cal hidratada em lodo proveniente de reator UASB. Com isso, o recrescimento de bactérias deve ser sempre considerado quando se adiciona cal ao lodo.

\subsubsection{Fator disposição/revolvimento}

Para o fator disposição/revolvimento, os resultados da ANOVA indicaram não haver diferença significativa entre os modos de disposição/revolvimento $(F=1,20361 ; p=0,344643)$, 
(TABELA 6.9). Com isso, as mudanças na forma de dispor o lodo nas células e no período do revolvimento não apresentaram diferenças significativas na redução da densidade de CTt. O GRÁFICO 6.13 apresenta as médias das densidades de CTt e os intervalos de confiança de 95\%, para o fator disposição do lodo nas células e período de revolvimento adotados, ao longo do tempo.

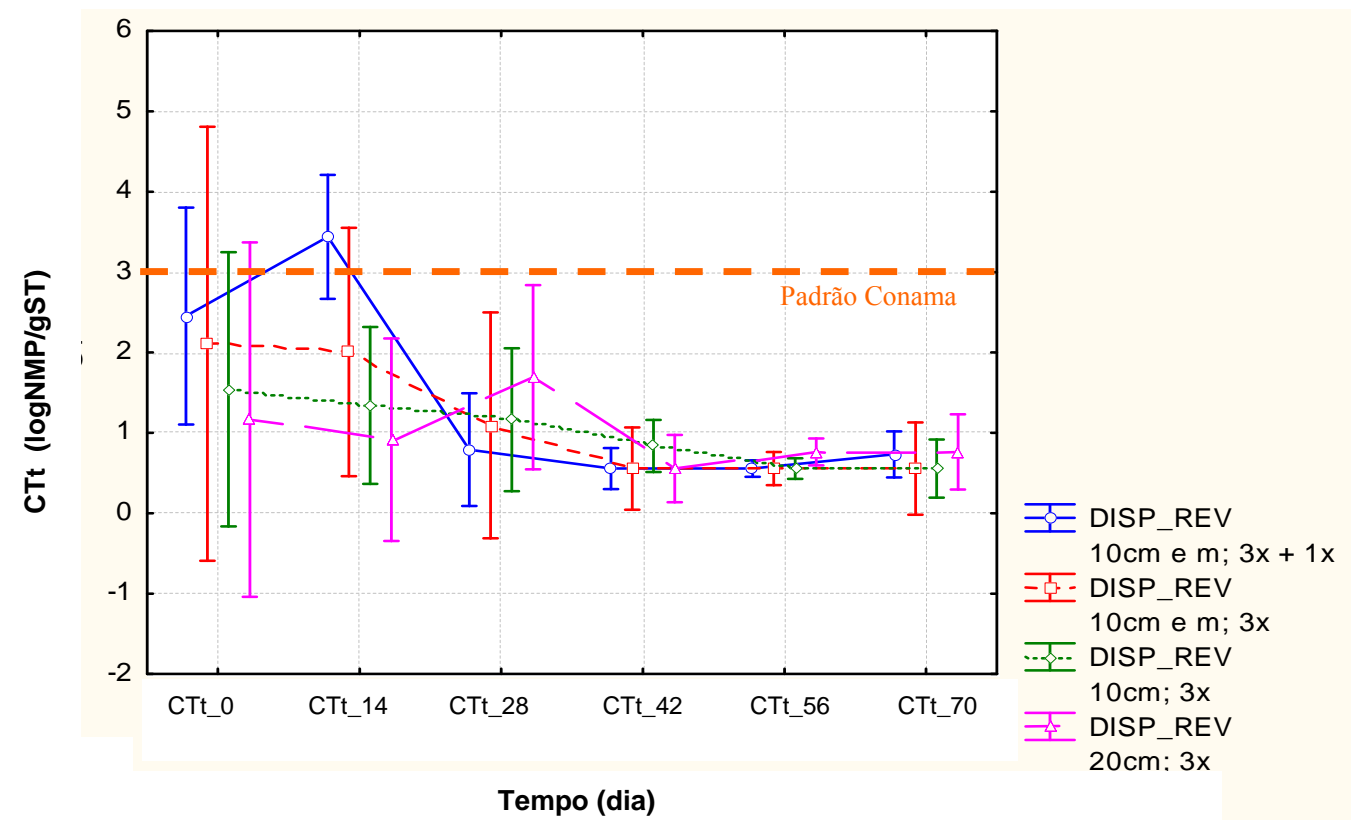

Gráfico 6.13 - Perfil temporal das médias de CTt e respectivos intervalos de confiança de $95 \%$, considerando todos os resultados obtidos nas Etapas 1 e 2 de acordo com o fator disposição/revolvimento

Como mostra o GRÁFICO 6.13 para as combinações $(10 \mathrm{~cm} / 3 \mathrm{x})$ e $(20 \mathrm{~cm} / 3 \mathrm{x})$ o lodo apresentou densidade inferior ao padrão a partir do $14^{\circ}$ dia e para $(10 \mathrm{~cm}$ e $\mathrm{m} / 3 \mathrm{x}+1 \mathrm{x})$ e $(10 \mathrm{~cm}$ e $\mathrm{m} / 3 \mathrm{x})$ a partir do $28^{\circ}$ dia.

Porém, com os resultados da ANOVA, percebe-se que há diferença significativa na interação tempo e disposição/revolvimento $(\mathrm{F}=1,91870 ; \mathrm{p}=0,035562)$ (TABELA 6.9). Os testes a posteriori de Tukey indicaram não haver diferença significativa dos resultados a partir do $28^{\circ}$ dia para $(10 \mathrm{~cm}$ e $\mathrm{m} / 3 \mathrm{x}+1 \mathrm{x})$ (APÊNDICE 20), com densidade de CTt igual a 0,79 $\operatorname{logNMP} / \mathrm{gST}$. Para as outras condições, os resultados mostraram não haver diferença significativa já no tempo zero, com densidades de 2,45 logNMP/gST (10 cm e m/3x); 2,29 $\operatorname{logNMP} / \mathrm{gST}(10 \mathrm{~cm} / 3 \mathrm{x})$ e $2,13 \operatorname{logNMP} / \mathrm{gST}(20 \mathrm{~cm} / 3 \mathrm{x})($ TABELA 6.11$)$. 
As estatísticas descritivas, média e desvio padrão, da variável CTt nos tempos 0 a 70 dias, segundo os fatores de variação tipo de lodo (digerido e não encaminhado ao digestor) e cal (sem cal e com cal) encontram-se apresentadas na TABELA 6.10. E, segundo a forma de disposição do lodo nas células e o período de revolvimento, na TABELA 6.11.

Tabela 6.10 - Médias e desvios padrões da densidade de CTt ao logo do tempo considerando todos os resultados obtidos nas Etapas 1 e 2 de acordo com o tipo de lodo e a condição de adicionar ou não cal ao lodo

\begin{tabular}{ccccccccc}
\hline \multirow{2}{*}{$\begin{array}{c}\text { Tempo } \\
\text { (dia) }\end{array}$} & \multicolumn{9}{c}{ Lodo digerido } & \multicolumn{2}{c}{ Lodo sem digerir ${ }^{(1)}$} & \multicolumn{2}{c}{ Lodo sem cal } & \multicolumn{2}{c}{ Lodo com cal } \\
\cline { 2 - 10 } & Média & $\mathbf{D P}^{(2)}$ & Média & DP & Média & DP & Média & DP \\
\hline CTt_0 & 1,96 & 1,56 & 2,74 & 2,28 & 4,14 & 0,98 & 0,56 & 0,00 \\
CTt_14 & 2,03 & 1,16 & 3,34 & 1,65 & 3,35 & 1,53 & 2,03 & 1,30 \\
CTt_28 & 0,95 & 0,63 & 2,60 & 1,70 & 2,12 & 1,71 & 1,44 & 1,26 \\
CTt_42 & 0,56 & 0,00 & 1,54 & 1,48 & 1,21 & 1,37 & 0,70 & 0,45 \\
CTt_56 & 0,56 & 0,00 & 0,62 & 0,20 & 0,56 & 0,00 & 0,61 & 0,18 \\
CTt_70 & 0,56 & 0,00 & 0,91 & 063 & 0,86 & 0,63 & 0,61 & 0,18 \\
\hline
\end{tabular}

Nota: ${ }^{(1)}$ Lodo não encaminhado ao digestor; ${ }^{(2)}$ Desvio Padrão.

Tabela 6.11 - Médias e desvios padrões da densidade de CTt ao logo do tempo, considerando todos os resultados obtidos nas Etapas 1 e 2 de acordo com a forma de disposição do lodo na célula e o período de revolvimento

\begin{tabular}{|c|c|c|c|c|c|c|c|c|}
\hline \multirow{3}{*}{$\begin{array}{c}\text { Tempo } \\
\text { (dia) }\end{array}$} & \multicolumn{8}{|c|}{ Coliforme termotolerante (log NMP/gST) } \\
\hline & \multicolumn{2}{|c|}{$(10 \mathrm{~cm}$ e $\mathrm{m} / 3 \mathrm{x}+1 \mathrm{x})$} & \multicolumn{2}{|c|}{$(10 \mathrm{~cm}$ e $\mathrm{m} / 3 \mathrm{x})$} & \multicolumn{2}{|c|}{$(10 \mathrm{~cm} / 3 x)$} & \multicolumn{2}{|c|}{$(20 \mathrm{~cm} / 3 x)$} \\
\hline & Média & $\mathbf{D P} \mathbf{P}^{(1)}$ & Média & DP & Média & DP & Média & DP \\
\hline CTt_ 0 & 2,45 & 2,04 & 2,45 & 2,26 & 2,29 & 2,04 & 2,13 & 2,12 \\
\hline CTt_14 & 3,44 & 1,19 & 2,77 & 1,02 & 2,26 & 1,69 & 1,95 & 2,12 \\
\hline CTt_28 & 0,79 & 0,44 & 2,45 & 1,63 & 2,14 & 1,60 & 2,37 & 2,10 \\
\hline CTt_42 & 0,56 & 0,00 & 0,56 & 0,00 & 1,30 & 1,27 & 1,41 & 1,71 \\
\hline CTt_56 & 0,56 & 0,00 & 0,56 & 0,00 & 0,56 & 0,00 & 0,76 & 0,36 \\
\hline CTt_70 & 0,73 & 0,50 & 0,56 & 0,00 & 0,78 & 0,64 & 0,81 & 0,31 \\
\hline
\end{tabular}

Nota: ${ }^{(1)}$ Desvio Padrão.

\subsubsection{OVOS VIÁVEIS HELMINTOS}

\subsubsection{Fator tipo de lodo}

Os resultados da ANOVA indicaram haver diferença significativa entre os tipos de lodo $(\mathrm{F}=45,2178 ; \mathrm{p}=0,000001)$ para os ovos viáveis de helmintos (OVH) (TABELA 6.9). Sendo 
assim, nesse caso, pelo fato de o lodo não ter passado pelo digestor, os valores de OVH foram sempre superiores aos apresentados pelo lodo digerido, com diferença significativa. No GRÁFICO 6.14 encontram-se as variações de OVH no tempo para o fator tipo de lodo.

Pode-se perceber que as quantidades de OVH, apresentaram uma tendência de decaimento ao longo das semanas, com a diminuição da umidade. Para o lodo digerido a densidade média de OVH foi sempre inferior às definidas pela Resolução do Conama ( 0,25 ovo/gST), mesmo considerando o intervalo de confiança de $95 \%$. Por outro lado, para o do lodo não submetido à digestão, as médias mantiveram-se inferiores ao padrão do Conama, a partir do $28^{\circ}$ dia (umidade em torno de 42\%). Porém, na avaliação por ciclo (item 5.2.4.2), os resultados sugerem que o enquadramento do lodo como Classe A, para OVH, ocorre com umidade inferior. Nesse caso, vale, também, a mesma consideração destacada para CTt (item 6.3.1.2) para o enquadramento do lodo como Classe A.

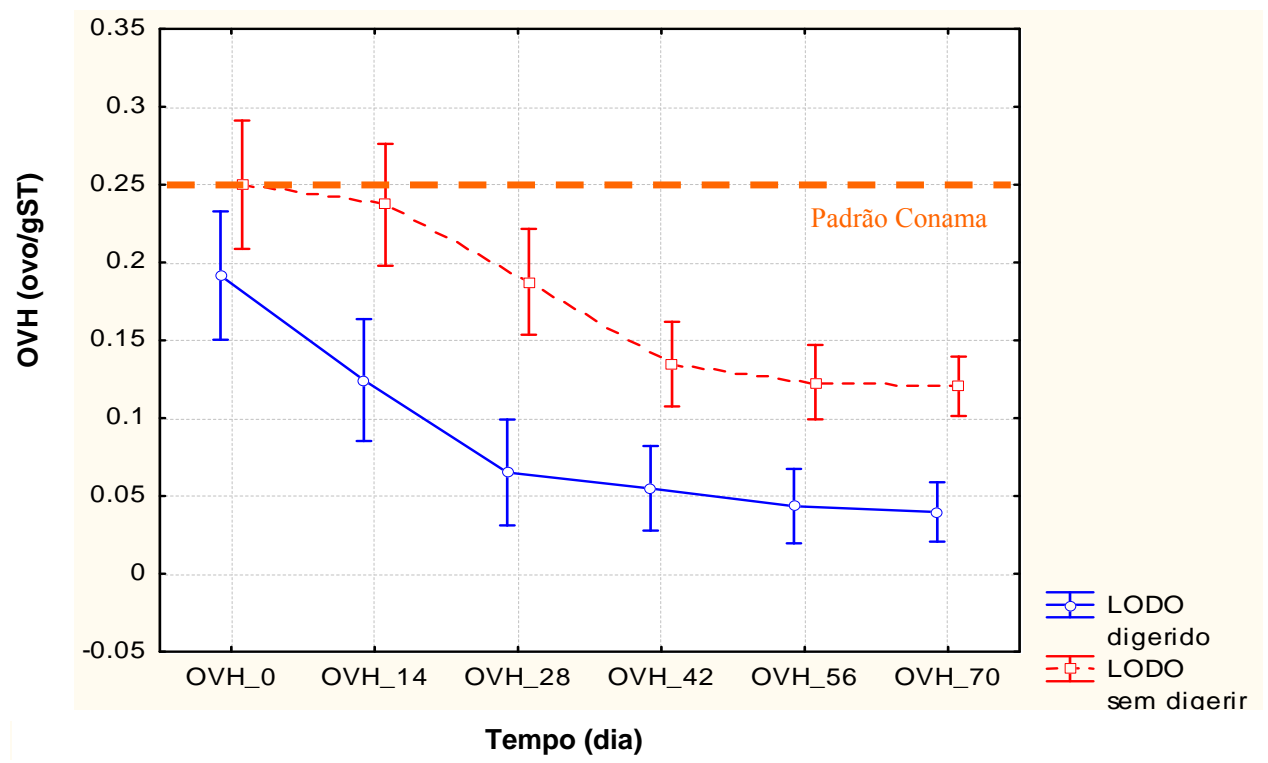

Gráfico 6.14 - Perfil temporal das médias de OVH e respectivos intervalos de confiança de $95 \%$, considerando todos os resultados obtidos nas Etapas 1 e 2 de acordo com o fator tipo de lodo

Os resultados da ANOVA mostraram não haver diferença significativa na interação tempo e lodo $(\mathrm{F}=1,6187 ; \mathrm{p}=0,160989)$ para OVH (TABELA 6.9). Os testes a posteriori de Tukey indicaram não haver diferença significativa dos resultados a partir do $42^{\circ}$ dia (APÊNDICE 21), para os dois tipos de lodo, com valores de OVH iguais a 0,06 ovo/gST (umidade 19,2\%) para o lodo digerido e 0,14 ovo/gST (umidade $27,5 \%$ ) para o lodo não encaminhado ao digestor (TABELAS 6.3 e 6.12). 
Para Comparini (2001), a variação de OVH foi bastante diferenciada, quando comparada com os resultados desta pesquisa. Isso porque, o lodo usado pelo pesquisador apresentava número de OVH elevado, com valores variando de 10,22 a 30,95 ovo/gST e, com isso, o valor de umidade necessário para o atendimento ao padrão legal, foi menor (TABELA 3.21).

\subsubsection{Fator cal}

Nesse caso, os resultados da ANOVA indicaram não haver diferença significativa para a variável OVH, com um nível de significância de $5 \%(\mathrm{~F}=2,6878 ; \mathrm{p}=0,115343)$, para o lodo sem cal e com cal e nem na interação tempo e cal $(\mathrm{F}=0,2778 ; \mathrm{p}=0,924434)$ (TABELA 6.9).

Apesar disso, a adição da cal possibilitou uma redução na densidade de OVH que apresentou valores inferiores aos definidos pelo Conama desde o tempo 0. Porém, percebe-se que a redução do número de $\mathrm{OVH}$ ao longo do tempo para as duas condições, se manteve sempre bem próxima ao intervalo de confiança de 95\%, não representando com isso, uma redução expressiva dos valores. Para o lodo sem adição de cal, o enquadramento ocorreu a partir do $28^{\circ}$ dia, considerando o intervalo de confiança de 95\% (GRÁFICO 6.15).

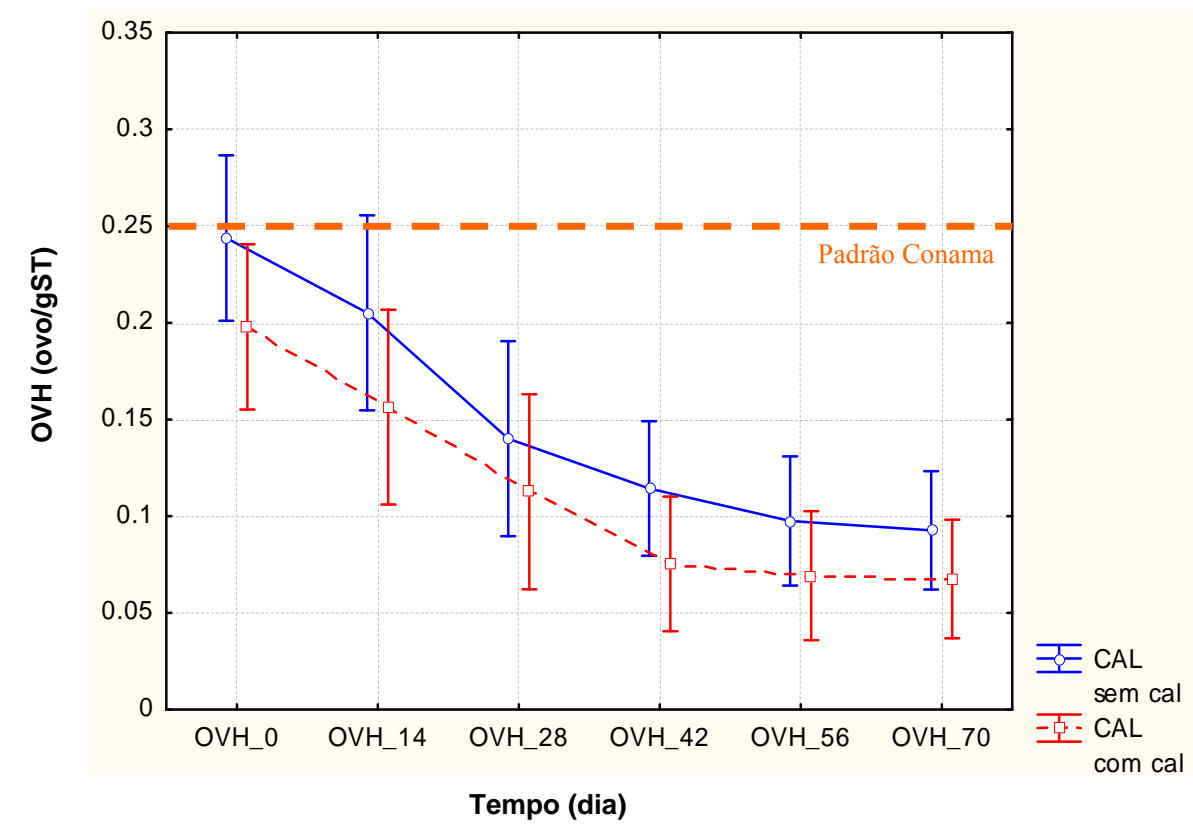

Gráfico 6.15 - Perfil temporal das médias de OVH e respectivos intervalos de confiança de $95 \%$, considerando todos os resultados obtidos nas Etapas 1 e 2 de acordo com o fator cal 
A inviabilização dos ovos de helmintos com a elevação do $\mathrm{pH}$, já foi relatada por outros pesquisadores (PASSAMANI, 2001; THOMAZ-SOCOOL et al., 1998). Porém, o que se observa são algumas diferenças no tempo de contato para a inativação dos ovos, que pode ser atribuída ao tipo de lodo e ao tratamento do esgoto.

Os testes a posteriori de Tukey indicaram não haver diferença significativa dos resultados a partir do $42^{\circ}$ dia para os dois casos (APÊNDICE 22) com valores de OVH iguais a 0,11 ovo/gST (lodo sem cal) e 0,08 ovo/gST (lodo com cal) (TABELA 6.12).

\subsubsection{Fator disposição/revolvimento}

Para o fator disposição/revolvimento, os resultados da ANOVA indicaram não haver diferenças significativas para a variável $\mathrm{OVH}(\mathrm{F}=0,1570 ; \mathrm{p}=0,923916)$ nem na interação tempo e disposição/revolvimento $(\mathrm{F}=1,0512 ; \mathrm{p}=0,411289)$ (TABELA 6.9). O GRÁFICO 6.16 apresenta as médias de OVH e os intervalos de confiança de 95\%, para o fator disposição do lodo nas células e período de revolvimento adotados, ao longo do tempo.

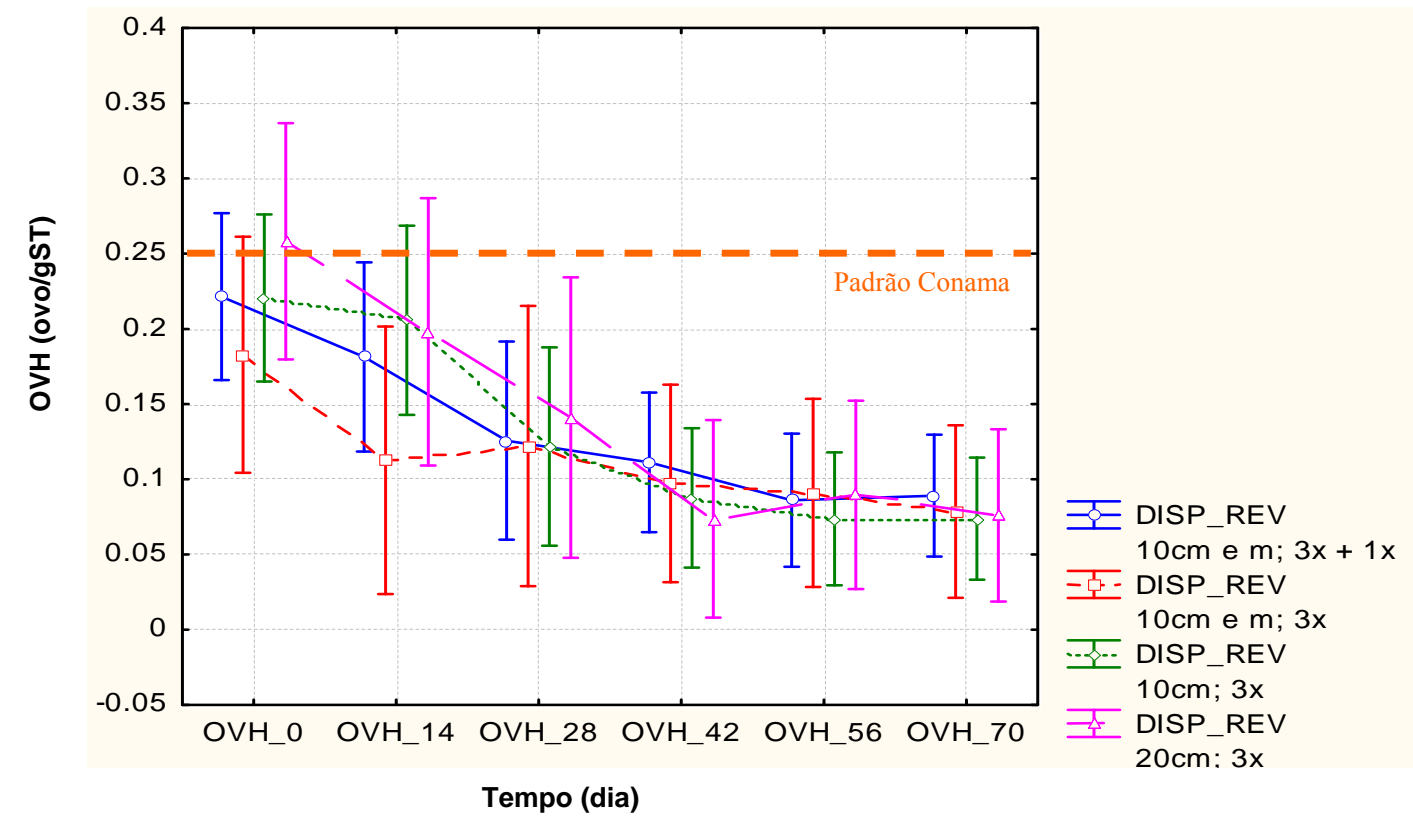

Gráfico 6.16 - Perfil temporal das médias de OVH e respectivos intervalos de confiança de $95 \%$, considerando todos os resultados obtidos nas Etapas 1 e 2 de acordo com o fator disposição/revolvimento 
Pode-se observar no GRÁFICO 6.16 que as combinações $(10 \mathrm{~cm}$ e m/3x $+1 \mathrm{x})$ e $(10 \mathrm{~cm}$ e $\mathrm{m} / 3 \mathrm{x})$ possibilitaram valores inferiores ao padrão a partir do $14^{\circ}$ dia e para $(10 \mathrm{~cm} / 3 \mathrm{x})$ e $(20 \mathrm{~cm} / 3 \mathrm{x})$ a partir do $28^{\circ}$ dia.

Os testes a posteriori de Tukey indicaram não haver diferença significativa dos resultados a partir do $42^{\circ}$ dia (APÊNDICE 23) para as diferentes combinações entre a forma de disposição e período de revolvimento do lodo, com valores de OVH entre 0,07 e 0,11 ovo/gST (TABELA 6.13).

As estatísticas descritivas, média e desvio padrão, da variável OVH nos tempos 0 a 70 dias, segundo os fatores de variação tipo de lodo (digerido e não encaminhado ao digestor) e cal (sem cal e com cal) encontram-se apresentadas na TABELA 6.12. E, segundo a forma de disposição do lodo nas células e o período de revolvimento, na TABELA 6.13.

Tabela 6.12 - Médias e desvios padrões do número de OVH ao logo do tempo considerando todos os resultados obtidos nas Etapas 1 e 2 de acordo com o tipo de lodo e a condição de adicionar ou não cal ao lodo

\begin{tabular}{ccccccccc}
\hline \multirow{2}{*}{$\begin{array}{c}\text { Tempo } \\
\text { (dia) }\end{array}$} & \multicolumn{9}{c}{ Lodo digerido } & \multicolumn{2}{c}{ Lodo sem digerir ${ }^{(\mathbf{1})}$} & \multicolumn{2}{c}{ Lodo sem cal } & \multicolumn{2}{c}{ Lodo com cal } \\
\cline { 2 - 10 } & Média & $\mathbf{D P}^{(2)}$ & Média & DP & Média & DP & Média & DP \\
\hline OVH_0 & 0,19 & 0,08 & 0,25 & 0,05 & 0,24 & 0,07 & 0,20 & 0,07 \\
OVH_14 & 0,12 & 0,08 & 0,24 & 0,05 & 0,21 & 0,09 & 0,16 & 0,07 \\
OVH_28 & 0,07 & 0,06 & 0,19 & 0,06 & 0,14 & 0,09 & 0,11 & 0,08 \\
OVH_42 & 0,06 & 0,05 & 0,14 & 0,04 & 0,11 & 0,04 & 0,08 & 0,07 \\
OVH_56 & 0,04 & 0,04 & 0,12 & 0,04 & 0,10 & 0,05 & 0,07 & 0,06 \\
OVH_70 & 0,04 & 0,04 & 0,12 & 0,02 & 0,09 & 0,05 & 0,07 & 0,06 \\
\hline
\end{tabular}

Nota: ${ }^{(1)}$ Lodo não encaminhado ao digestor; ${ }^{(2)}$ Desvio Padrão.

Tabela 6.13 - Médias e desvios padrões do número de OVH ao logo do tempo considerando todos os resultados obtidos nas Etapas 1 e 2 de acordo com a forma de disposição do lodo na célula e o período de revolvimento

\begin{tabular}{|c|c|c|c|c|c|c|c|c|}
\hline \multirow{3}{*}{$\begin{array}{c}\text { Tempo } \\
\text { (dia) }\end{array}$} & \multicolumn{8}{|c|}{ Ovos viáveis de helmintos (ovo/gST) } \\
\hline & \multicolumn{2}{|c|}{$(10 \mathrm{~cm} \mathrm{e} \mathrm{m} / 3 \mathrm{x}+1 \mathrm{x})$} & \multicolumn{2}{|c|}{$(10 \mathrm{~cm} \mathrm{e} \mathrm{m/3x)}$} & \multicolumn{2}{|c|}{$(10 \mathrm{~cm} / 3 x)$} & \multicolumn{2}{|c|}{$(20 \mathrm{~cm} / 3 x)$} \\
\hline & Média & $\mathbf{D P} \mathbf{P}^{(1)}$ & Média & DP & Média & DP & Média & DP \\
\hline OVH_O & 0,22 & 0,07 & 0,18 & 0,05 & 0,22 & 0,08 & 0,26 & 0,09 \\
\hline OVH_14 & 0,18 & 0,09 & 0,11 & 0,08 & 0,21 & 0,08 & 0,20 & 0,08 \\
\hline OVH_28 & 0,13 & 0,10 & 0,12 & 0,05 & 0,12 & 0,10 & 0,14 & 0,05 \\
\hline OVH_42 & 0,11 & 0,07 & 0,10 & 0,07 & 0,09 & 0,06 & 0,07 & 0,05 \\
\hline OVH_56 & 0,09 & 0,07 & 0,09 & 0,07 & 0,07 & 0,05 & 0,09 & 0,04 \\
\hline OVH_70 & 0,09 & 0,06 & 0,08 & 0,05 & 0,07 & 0,05 & 0,08 & 0,05 \\
\hline
\end{tabular}

Nota: ${ }^{(1)}$ Desvio Padrão. 


\subsubsection{SALMONELLA sp.}

O padrão estabelecido pela Resolução $n^{0}$ 375/2006 do Conama (BRASIL, 2006c) para o monitoramento de Salmonella sp. em lodo de esgoto é a sua ausência/10gST (TABELA 3.17). Assim, os resultados apresentados foram apenas qualitativos, indicando a sua ausência ou não nas amostras analisadas.

Para o lodo digerido aerobiamente, apenas no lodo usado no Ciclo $1 / 1$, foi detectada a sua presença (TABELA 5.4). Já o lodo não encaminhado ao digestor apresentou presença de Salmonella sp. nas três amostras usadas nos Ciclos 1/2, 2/2 e 3/2 (TABELA 5.10).

Com o monitoramento do Ciclo 1/1 (lodo digerido), observa-se que, apesar de o lodo da célula L1 ter sido disposto e revolvido da mesma maneira que o lodo da célula L2 (lodo digerido sem cal), a ausência de Salmonella sp. foi confirmada em tempos diferentes. Para o lodo de L1, a ausência ocorreu após o $28^{\circ}$ dia quando a umidade média estava em torno de $27 \%$. E, para o lodo de L2 esse fato ocorreu num tempo menor, $14^{\circ}$ dia, com umidade média de $41 \%$. No caso de o lodo da célula L1, é possível que a ausência de Salmonella sp. tenha ocorrido com umidade ainda maior, em razão de não ter sido efetuada análise no $21^{\circ}$ dia.

Para o lodo não encaminhado ao digestor (Etapa 2) houve variação nos tempos de secagem para a higienização do lodo, considerando o parâmetro Salmonella sp. Nos Ciclos 1/2 e 3/2, o lodo da célula L2 apresentou ausência de Salmonella sp. em tempos iguais, $14^{\circ}$ dia, porém com umidades bastante diferentes, em torno de $59 \%$ e $80 \%$, respectivamente. Isso porque, a forma de disposição do lodo e o período de revolvimento eram diferentes. O lodo da célula L1 (Ciclo 1/2) também apresentou ausência de Salmonella sp. no $14^{\circ}$ dia, com a umidade em torno de $53 \%$. Nos Ciclos $2 / 2$ e $3 / 2$, as ausências no lodo da célula L1 ocorreram no $56^{\circ}$ dia (umidade aproximada de $10 \%$ ) e no $42^{\circ}$ dia (umidade aproximada de $26 \%$ ), respectivamente. Entretanto, principalmente no Ciclo $2 / 2$, o fato de ter ocorrido um intervalo de tempo grande entre as coletas, 28 dias, a ausência de Salmonella sp. pode ter acontecido com uma umidade maior.

O comportamento da Salmonella sp. confirmou os relatos apresentados por diversos autores, apresentando fragilidade aos processos que incluem radiação solar e desidratação, 
(FEACHEM et al., 1983; SILVA, S. M. C. P. et al., 2001; SMITH, 1996; THOMAZSOCCOL; PAULINO; CASTRO, 1997; US EPA, 1995;).

$\mathrm{Na}$ pesquisa desenvolvida por Comparini (2001), a pior situação em relação ao monitoramento de Salmonella sp., foi a detecção da sua presença com a umidade do lodo em torno de 23\%. No entanto, foi percebido o reaparecimento de Salmonella sp., após três amostras subsequentes com ausência, em amostra com cerca de $10 \%$ de umidade. $\mathrm{O}$ pesquisador atribuiu a agentes externos às recontaminações ocorridas durante o experimento.

Para os dois tipos de lodo e em todos os ciclos, o processo de higienização do lodo com cal demonstrou-se eficiente na eliminação do patógeno em questão, uma vez que não foi constatada a sua presença nas amostras de lodo das células LC1 e LC2, salvo o reaparecimento, no $28^{\circ}$ dia, no lodo não encaminhado ao digestor da célula LC2 (Ciclo 3/2), que apresentava umidade em torno de 68\% (TABELAS 5.9 e 5.10). Porém, não houve nenhum acontecimento que justificasse essa recontaminação. Caso tenha ocorrido por algum agente externo, isso não foi percebido pela pesquisadora.

Alguns pesquisadores citam o uso da cal para a eliminação de Salmonella sp. (GANTZER et al., 2001; FRANCO-HERNANDEZ et al., 2001; PLANCHÁ et al., 2008). No entanto, fica difícil fazer uma comparação mais detalhada, pois, normalmente, as informações sobre as características da cal usada na experimentação são incompletas.

\subsection{PARÂMETROS DE INTERESSE AGRONÔMICO}

Tendo em vista que os parâmetros de interesse agronômico foram analisados no início e no final de cada ciclo, não foi possível avaliar a variação deles no decorrer dos ciclos. Porém, pôde-se perceber que a forma de disposição do lodo nas células e o período relativo ao revolvimento não interferiram nos seus teores (APÊNDICES 2 e 7).

Analisando comparativamente os resultados das duas etapas, percebem-se algumas diferenças nas médias apresentadas. Isso provavelmente ocorreu devido às peculiaridades das características dos lodos usados nas duas etapas. Foi verificado que, entre os parâmetros monitorados, apenas o enxofre e o fósforo do lodo usado na Etapa 2 (lodo não encaminhado ao digestor) apresentaram valores inferiores aos do lodo da Etapa 1 (lodo digerido). Para os 
demais, as concentrações obtidas foram sempre maiores. Com relação às concentrações finais, praticamente todos os valores obtidos ao final da Etapa 2, independentemente de se adicionar cal ou não ao lodo, apresentaram valores ligeiramente superiores aos apresentados na Etapa 1. Apenas o enxofre (lodo sem cal) e o cálcio (loco com cal) foram inferiores (TABELAS 5.5 e $5.11)$.

Os resultados obtidos dos parâmetros agronômicos foram comparados em pares, considerando considerando o lodo com cal e sem cal, no início e no final dos ciclos de cada etapa. $\mathrm{Na}$ TABELA 6.14, encontram-se apresentados os (p-valores) obtidos na avaliação estatística dos pares de dados.

Tabela 6.14 -Resultados de p-valores dos testes a posteriori de Tukey para os parâmetros de interesse agronômico dos lodos usados nas Etapas 1 e 2

\begin{tabular}{ccccc}
\hline \multirow{2}{*}{ Parâmetro_Dia } & \multicolumn{2}{c}{ Etapa 1 (lodo digerido) } & \multicolumn{2}{c}{ Etapa 2 (lodo não encaminhado ao digestor) } \\
\cline { 2 - 4 } & Sem cal & Com cal & Sem cal & Com cal \\
\hline CO_0-CO_70 & 0,387 & 0,504 & 0,359 & 0,722 \\
N_0-N_70 & 0,530 & 0,003 & 0,232 & 0,000 \\
P_0-P_70 & 0,011 & 0,274 & 0,870 & 0,221 \\
K_0-K_70 & 0,859 & 0,000 & 0,987 & 0,141 \\
Ca_0-Ca_70 & 0,623 & 0,002 & 0,801 & 0,872 \\
Mg_0-Mg_70 & 0,890 & 0,000 & 0,286 & 0,300 \\
S_0-S_70 & 0,351 & 0,005 & 0,214 & 0,116 \\
Na_0-Na_70 & 0,093 & 0,002 & 0,153 & 0,203 \\
\hline
\end{tabular}

Nota: CO-Carbono Orgânico; N-Nitrogênio total; P-Fósoforo total ; K-Potássio; Ca-Cálcio; Mg-Magnésio; S-Enxofre; Na-Sódio; as células destacadas indicam os fatores que apresentaram diferenças estatisticamente significantes para a variável (parâmetro) analisada, com nível de significância de 5\%.

O Carbono Orgânico sofreu uma pequena variação entre os valores médios iniciais e finais nas duas etapas. Na Etapa 1, houve uma diminuição de 2,17\% (média L1 e L2 - sem cal) e elevação de 4,30\% (média LC1 e LC2 - com cal); na Etapa 2, uma redução de 2,76\% (média L1 e L2 - sem cal) e 2,50\% (média LC1 e LC2 - com cal) (TABELAS 5.5 e 5.11). Entretanto, os resultados estatísticos mostraram que não existe diferença entre as médias iniciais e finais para cada condição testada (TABELA 6.14). As reduções podem ter ocorrido em virtude da utilização do carbono em processos metabólicos de alguns microrganismos. $\mathrm{O}$ mesmo comportamento foi observado por Fernandes, Andreoli e Domaszak (1996) e Malta (2002) em estudos realizados com lodo aeróbio e anaeróbio. Por outro lado, pode-se considerar que as reduções apresentadas não são representativas e que os teores encontrados ao final do período de testes foram elevados com uma média de 347,1 g/ $\mathrm{kgST}$ (Etapa 1) e $374,1 \mathrm{~g} / \mathrm{kgST}$ (Etapa 2) nos lodos sem cal; 329,7 g/kgST (Etapa 1) e 339,3 g/kgST (Etapa 2) 
nas com cal, confirmando o potencial do material como condicionador de solos (TABELAS 5.5 e 5.11). As concentrações médias obtidas por Comparini (2001) foram de $280 \mathrm{~g} / \mathrm{kgST}$ e $380 \mathrm{~g} / \mathrm{kgST}$ ao final da secagem do lodo digerido anaerobiamente em estufa agrícola. Para Tchobanoglous, Burton e Stensel (2002), o valor médio para lodo de esgoto é $300 \mathrm{~g} / \mathrm{kgST}$ que são bem próximos aos apresentados por Tsutiya (2000) e Sanepar (1997).

O Nitrogênio Total encontrado representa um produto de qualidade para o aproveitamento agrícola, com valores médios de 33,2 g/kgST (Etapa 1) e 43,7 g/kgST (Etapa 2) para o biossólido sem cal e 24,8 g/kgST (Etapa 1) e 26,5 g/kgST (Etapa 2) para o com cal. Isso pode ser confirmado na relação C/N que foi mantida em torno de 11/1 no biossólido sem cal, chegando a 16/1 quando adicionada a cal (TABELAS 5.5 e 5.11). Os valores de $\mathrm{N}$ apresentados na literatura variam em razão do tipo de tratamento a que foi submetido o esgoto e o lodo, podendo variar, no Brasil, de $20 \mathrm{~g} / \mathrm{kgST}$ até valores próximos a $90 \mathrm{~g} / \mathrm{kgST}$ (GONÇALVES; LIMA; PASSAMANI, 2000; SANEPAR, 2007; SILVA; DIMAS; SHARMA, 2000; TSUTIYA, 2000). Para Comparini (2001), que não utilizou material alcalino, os valores médios de Nitrogênio Kjeldahl encontrados ao final do experimento variaram de $43 \mathrm{~g} / \mathrm{kgST}$ a $58 \mathrm{~g} / \mathrm{kgST}$. Não foram identificadas diferenças estatisticamente significante entre as médias do início e final das Etapas 1 e 2 do biossólido sem cal. Entretanto, o mesmo não ocorreu para o biossólido com cal nas duas etapas (Etapa 1, $\mathrm{p}=0,003)$ e (Etapa 2, $\mathrm{p}=0,000)$ (TABELA 6.14). Isso porque, nos lodos das células LC1 e LC2 (lodo com cal), houve uma redução na concentração de $\mathrm{N}$ devido à volatilização da amônia (stripping) ocasionada pela elevação do pH com a adição da cal (LUE-HING; ZENZ; KUCHENRITHER, 1992; PINTO, 2001).

Em razão de as plantas necessitarem de pequenas quantidades de Fósforo para seu desenvolvimento vegetativo e produção, os teores de $\mathrm{P}$ apresentados ao final das etapas foram satisfatórios para a aplicação do material na agricultura. Valores médios de $13,4 \mathrm{~g} / \mathrm{kgST}$ foram obtidos no bissólido digerido sem e com adição de cal na Etapa 1, na Etapa 2, os valores foram $16 \mathrm{~g} / \mathrm{kgST}$ (lodo sem cal) e $14 \mathrm{~g} / \mathrm{kgST}$ (lodo com cal) (TABELAS 5.5 e 5.11). Os menores valores para o lodo com cal em relação ao sem cal, de acordo com Sanepar (1997), podem ser atribuídos ao fato de que a calagem reduz a disponibilidade de fósoforo no lodo. Representam, segundo vários autores, uma contribuição expressiva com uma biodisponibilidade de $40 \%$ a $80 \%$ do total contido no material (ANDREOLI; PEGORINI; FERNANDES, 2001; MELO; MARQUES, 2000). Comparini (2001) obteve concentrações 
médias entre $11,8 \mathrm{~g} / \mathrm{kgST}$ e $15 \mathrm{~g} / \mathrm{kgST}$ ao final do experimento. Apesar de a redução ocorrida entre as médias do início e do final da Etapa 1 do lodo sem cal apresentar uma diferença estatisticamente significante $(\mathrm{p}=0,011)$ (TABELA 6.14), a concentração final encontra-se dentro das variações apresentadas pela literatura (GONÇALVES; LIMA; PASSAMANI, 2000; SANEPAR, 2007; SILVA; DIMAS; SHARMA, 2000; TSUTIYA, 2000).

Apesar das baixas concentrações de Potássio apresentadas, característica normal da maioria dos lodos, sabe-se que todo esse macronutriente presente encontra-se na forma inorgânica e está prontamente disponível às plantas, sendo, portanto, de grande interesse agronômico (PIERZYNSKI, 1994). Os valores finais das duas etapas variaram de 5,4 a $6,9 \mathrm{~g} / \mathrm{kgST}$ (TABELAS 5.5 e 5.11), que, muitas vezes, foram maiores que alguns valores apresentados por vários autores (COMPARINI, 2001; GONÇALVES; LIMA; PASSAMANI, 2000; SANEPAR, 2007; SILVA; DIMAS; SHARMA, 2000; TSUTIYA, 2000;).

Comparando os resultados de Cálcio, percebe-se que as concentrações finais do lodo com cal apresentaram valores elevados, sendo 92,2 g/kgST (Etapa 1) e 86,6 g/kgST (Etapa 2), enquanto o lodo sem cal apresentou 10,6 g/kgST (Etapa 1) e 15,9 g/kgST (Etapa 2) (TABELAS 5.5 e 5.12). Essa diferença era esperada em razão da incorporação do cálcio ao material com a adição da cal. Estas concentrações são semelhantes às apresentadas por Fernandes, Andreoli e Domaszak (1996) com o mesmo comportamento conseguido por Malta (2002). Já Comparini (2001), com a secagem do lodo anaeróbio sem adição de material alcalino em estufa agrícola, obteve média de 29,94 g/kgST, superior às apresentadas nesse experimento. No entanto, não foi percebida a mesma elevação da concentração inicial de cálcio no lodo digerido (Etapa 1), observada no lodo da Etapa 2 (lodo não encaminhado ao digestor). Isso provavelmente ocorreu, de acordo com Stumm e Morgan (1981), em virtude de o $\mathrm{CO}_{2}$ (óxido ácido), presente no lodo digerido aerobiamente, ter reagido com o $\mathrm{CaO}$ (óxido básico) e, consequentemente, ter formado o $\mathrm{CaCO}_{3}$ (sal), praticamente insolúvel, permitindo pouca disponibilidade do cálcio e assim não sendo detectado pela técnica analítica usada. Porém, com a diminuição do $\mathrm{pH}$, essa disponibilidade é conseguida, tornando o cálcio solúvel $\left(\mathrm{H}^{+}+\mathrm{HCO}_{3}{ }^{-}=\mathrm{CO}_{2}+\mathrm{H}_{2} \mathrm{O}\right.$, a diminuição do $\mathrm{pH}$ desloca o equilíbrio da reação no sentido de aumentar $\left[\mathrm{CO}_{2}\right]$ e, com isso, em $\mathrm{Ca}^{2+}+2 \mathrm{HCO}_{3}{ }^{-}=\mathrm{CaCO}_{3}+\mathrm{CO}_{2}+\mathrm{H}_{2} \mathrm{O}$, o aumento de $\left[\mathrm{CO}_{2}\right]$ desloca o equilíbrio da reação no sentido de aumentar $\left[\mathrm{Ca}^{2+}\right]$ ), possibilitando, assim, o aumento da concentração de cálcio ao final dos ciclos da Etapa 1 (lodo digerido). 
Apesar de terem ocorrido diferenças significativas nas concentrações do lodo com cal da Etapa 1 de magnésio, enxofre e sódio, isso não contribuiu para uma variação representativa nos valores finais obtidos. As concentrações de Magnésio nas duas etapas não apresentaram incremento com a adição da cal, apesar de a cal utilizada no experimento possuir no máximo 2,2\% de hidróxido de magnésio. Os valores médios apresentados ao final dos ciclos, nas duas etapas, são coerentes com os citados por vários autores, podendo ocorrer alguma variação em virtude do tipo de cal adicionada na higienização do material (COMPARINI, 2001; FERNANDES; ANDREOLI; DOMASZAK, 1996; SANEPAR, 2007; SILVA; DIMAS; SHARMA, 2000; TSUTIYA, 2000).

As concentrações finais de enxofre foram $6,7 \mathrm{~g} / \mathrm{kgST}$ (Etapa 1) e 4,7 g/kgST (Etapa 2) no lodo sem cal e 7,5 g/kgST (Etapa 1) e 9,0 g/kgST (Etapa 2) no lodo com cal. Comparini (2001) apresentou como resultado final a concentração média de S-sulfato, resultante da oxidação do S (HOROWITZ; MEURER, 2006), igual a 5,85 g/kgST do lodo anaeróbio, sem adição de material alcalino.

Já as concentrações médias de sódio no final dos ciclos nas duas etapas foram as mesmas no lodo sem cal e com cal $(1,1 \mathrm{~g} / \mathrm{kgST})$. Valor semelhante foi conseguido, também, por Comparini (2001) (1,09 g/kgST).

Desse modo, pode-se perceber que a secagem dos dois tipos de lodo estudado em estufa agrícola não apresentou alterações nos valores dos parâmetros agronômicos analisados que implicassem um menor interesse para o uso agrícola do material.

Os GRÁFICOS (6.17a) e (6.17b) apresentam as médias obtidas no início e no final de cada ciclo dos parâmetros de interesse agronômico monitorados nas duas etapas, assim como os desvios padrões do lodo sem cal e com cal respectivamente (TABELAS 5.5 e 5.11). Em razão de a ordem de grandeza da concentração do carbono orgânico apresentar-se superior aos demais parâmetros, ele foi dividido por 10 para uma melhor visualização gráfica. 


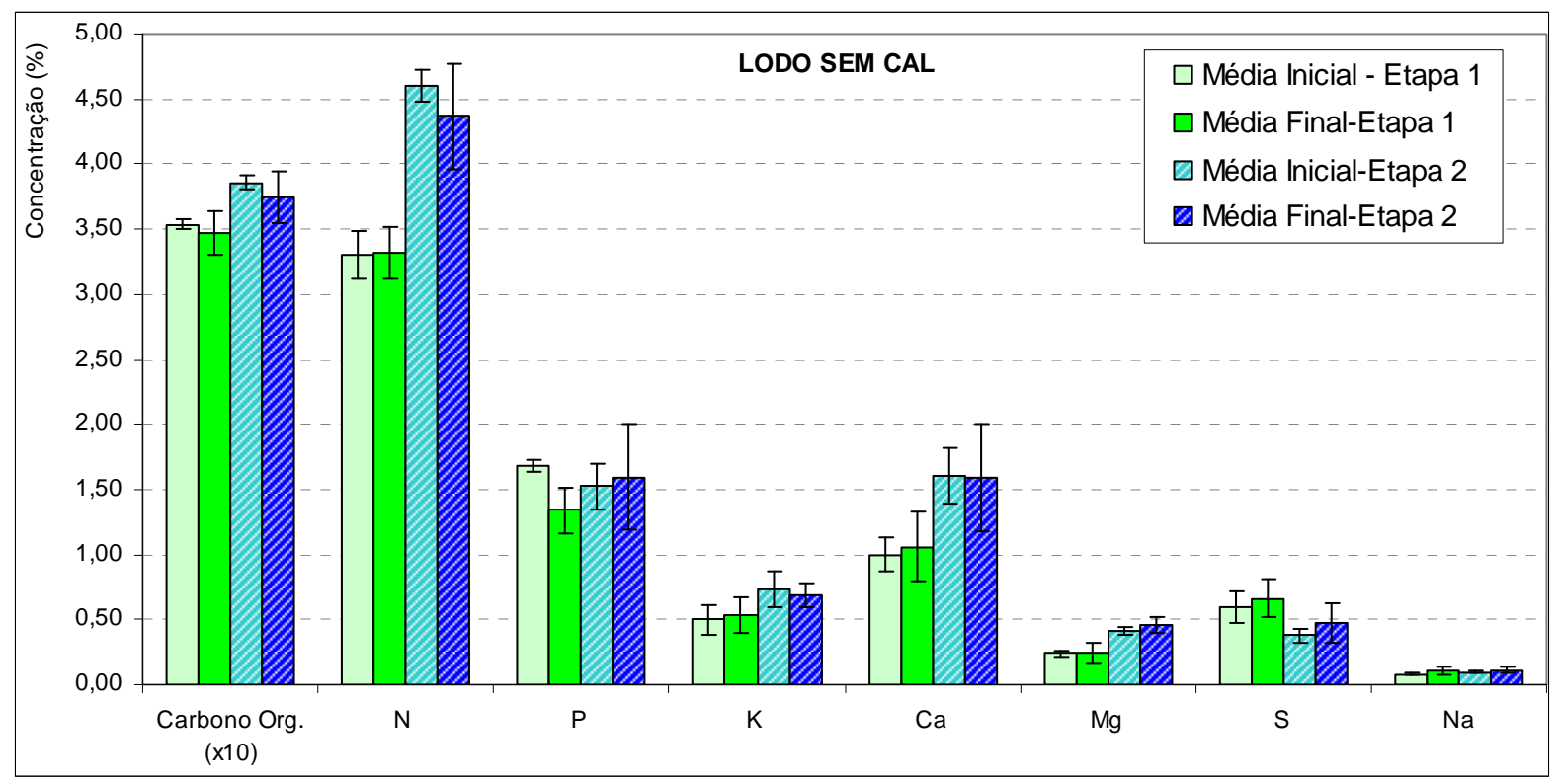

$(6.17 \mathrm{a})$

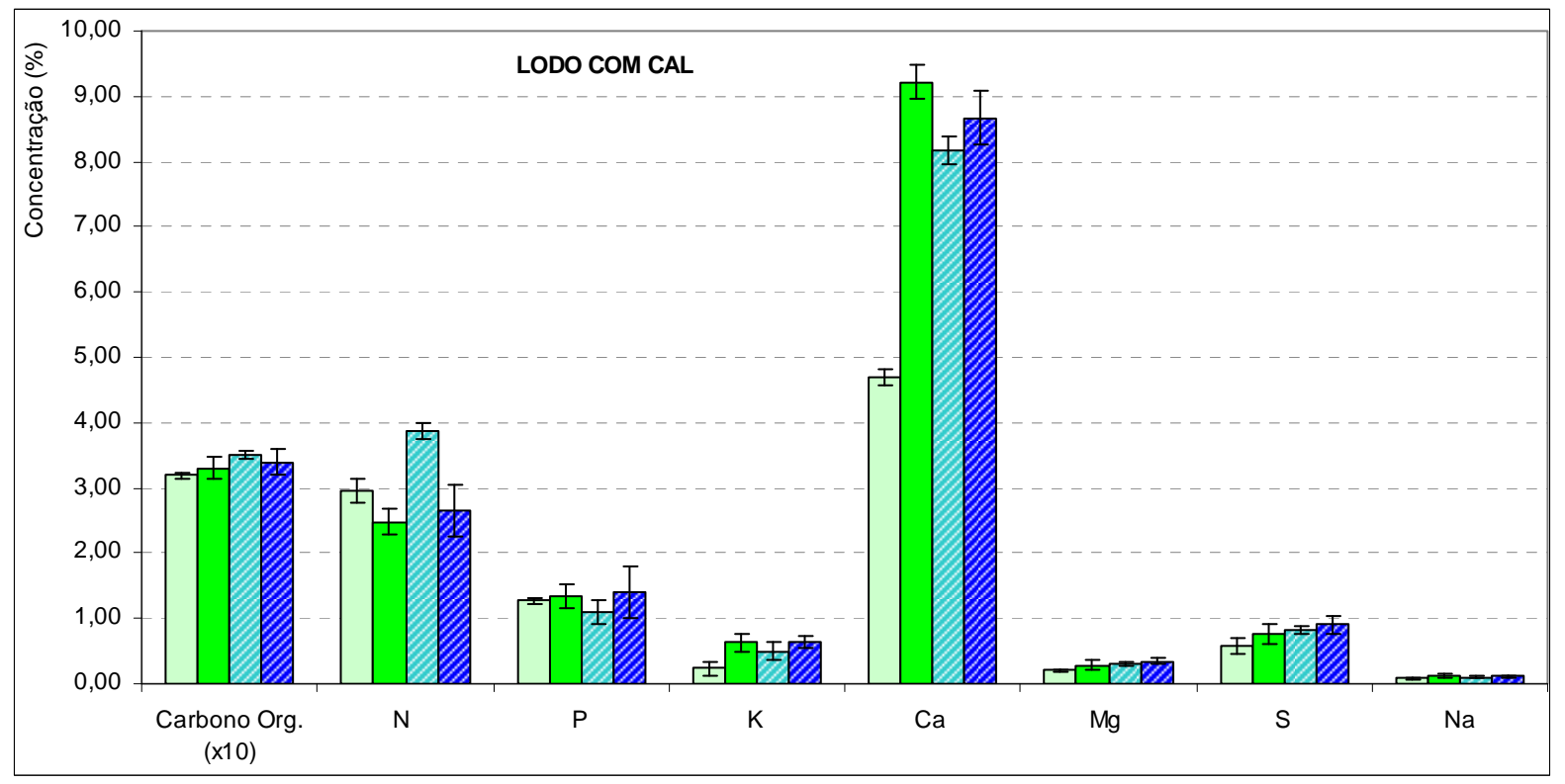

(6.17b)

Gráfico 6.17 - Concentrações médias e desvios padrões dos parâmetros de interesse agronômico no início e final dos Ciclos das Etapas 1 e 2 - Lodo sem cal (6.17a), Lodo com cal (6.17b)

\subsection{SUBSTÂNCIAS INORGÂNICAS (ÍONS METÁLICOS)}

Como se observa nas TABELAS 5.6 e 5.12 e nos GRÁFICOS (6.18a) e (6.18b), as concentrações médias obtidas das substâncias inorgânicas entre os três ciclos e em ambas as Etapas, foram sempre menores que a metade dos limites máximos estabelecidos pela Resolução n ${ }^{0}$ 375/2006 do Conama (BRASIL, 2006c). Os desvios padrões mantiveram-se sempre numa faixa aceitável, não contribuindo com um incremento nas médias que alterassem 
o valor final de forma a ultrapassarem os padrões impostos pela legislação vigente. Assim, não há nenhum comprometimento do material quanto a seu uso na agricultura.

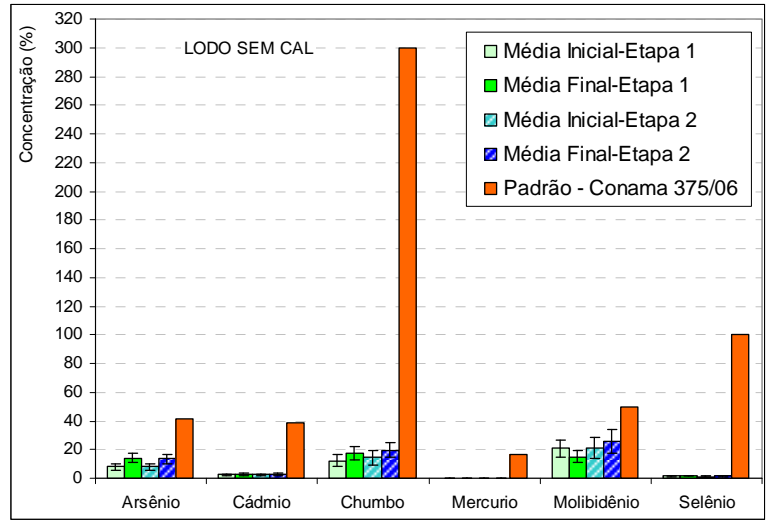

$(6.18 \mathrm{a})$

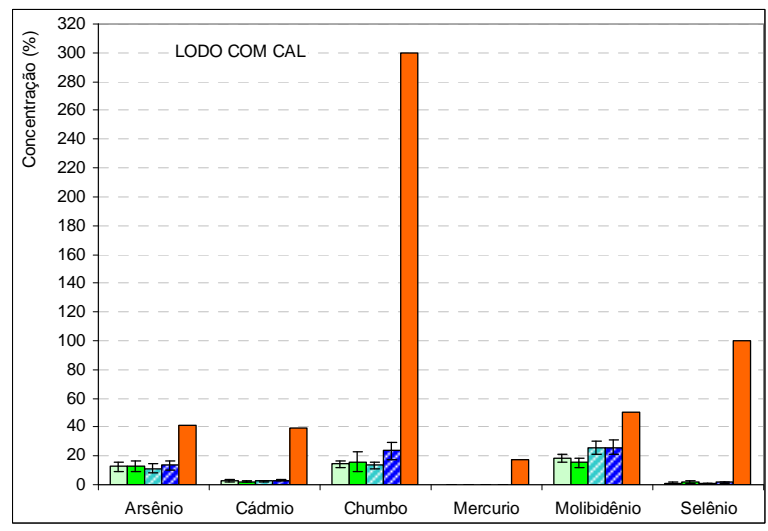

$(6.18 \mathrm{c})$

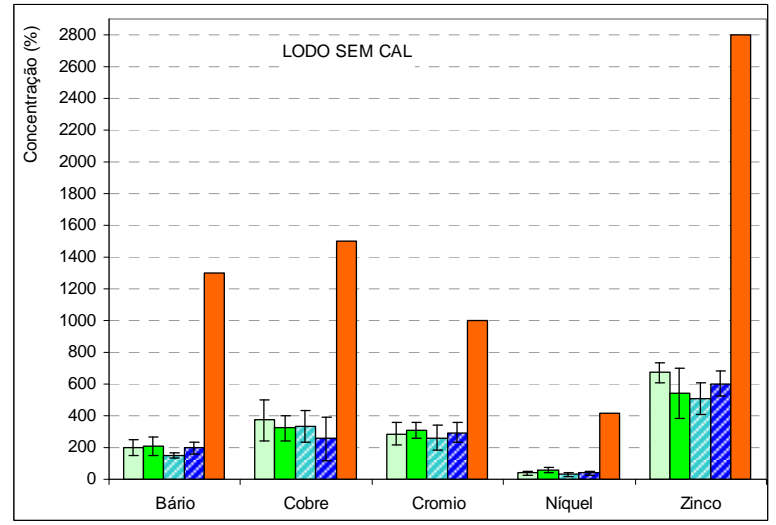

$(6.18 b)$

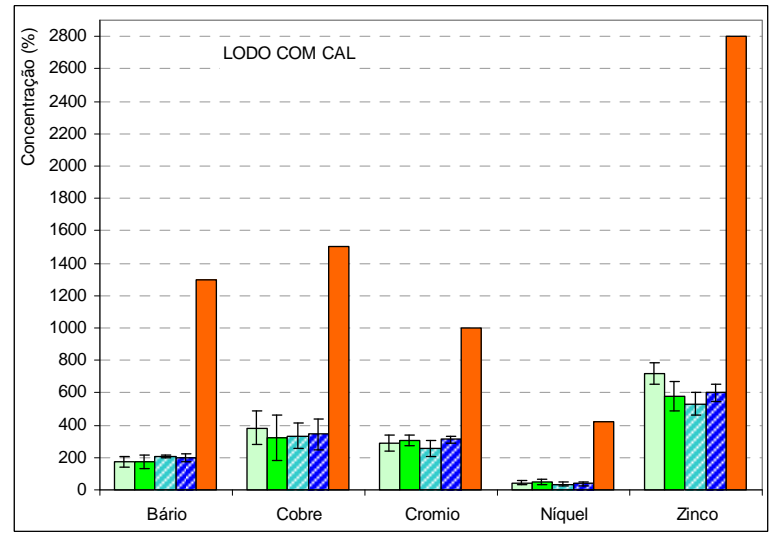

(6.18d)

Gráfico 6.18 - Concentrações médias e desvios padrões das substâncias inorgânicas (íons metálicos) no início e final dos Ciclos das Etapas 1 e 2, comparadas com o padrão estabelecido pela Resolução ${ }^{\circ}$ 375/2006 do Conama - Lodo sem cal (6.18a e 6.18b), Lodo com cal (6.18c e 6.18d)

As concentrações obtidas corroboram o fato de que a região atendida pelo sistema de esgotamento sanitário é constituída de bairros residenciais. Cabe acrescentar que, infelizmente, mesmo nessas condições, a interferência de ligações clandestinas nas redes coletoras de esgoto de empresas potencialmente poluidoras ainda é uma prática bastante comum no país. Entretanto, não foi observada nenhuma suspeita de que isso estivesse acontecendo nessa área.

Vale citar que, apesar de os elementos Cobre, Zinco e Molibdênio pertencerem ao grupo de metais pesados em razão da sua elevada massa molar e por isso demandarem de uma atenção especial, são micronutrientes essenciais ao crescimento das plantas quando em quantidades suficientes para serem assimiladas por elas (MELO; MARQUES; MELO, 2002; NAGAR; 
SARKAR; DATTA, 2006). As concentrações apresentadas por esses elementos tornam o material ainda mais atraente sob aspecto agronômico.

\subsection{DENSIDADE}

As curvas ajustadas na regressão linear que representam a melhor tendência das densidades apresentadas para o lodo da Etapa 1 (digerido) e da Etapa 2 (não encaminhado ao digestor), com e sem cal, estão apresentadas no GRÁFICO 6.19.

Nos dois casos, a densidade do lodo com a adição da cal foi sempre superior à do lodo sem cal. Como foi citado, isso ocorreu em razão do aumento do teor de sólidos totais com a adição da cal. A diferença é realçada à partir de, aproximadamente, $20 \%$ ST.

As tendências apresentadas pelo lodo sem adição de cal nas duas etapas foram praticamente as mesmas. Entretanto, no lodo com cal da Etapa 2, os valores da densidade apresentaram-se superiores aos da Etapa 1 a partir de, aproximadamente, 35\% ST. Com as informações disponíveis, não foi possível atribuir nenhum fato a essa diferença. Por sua vez, representou um aumento na densidade de sólidos do lodo e, consequentemente, um aumento da densidade do lodo.

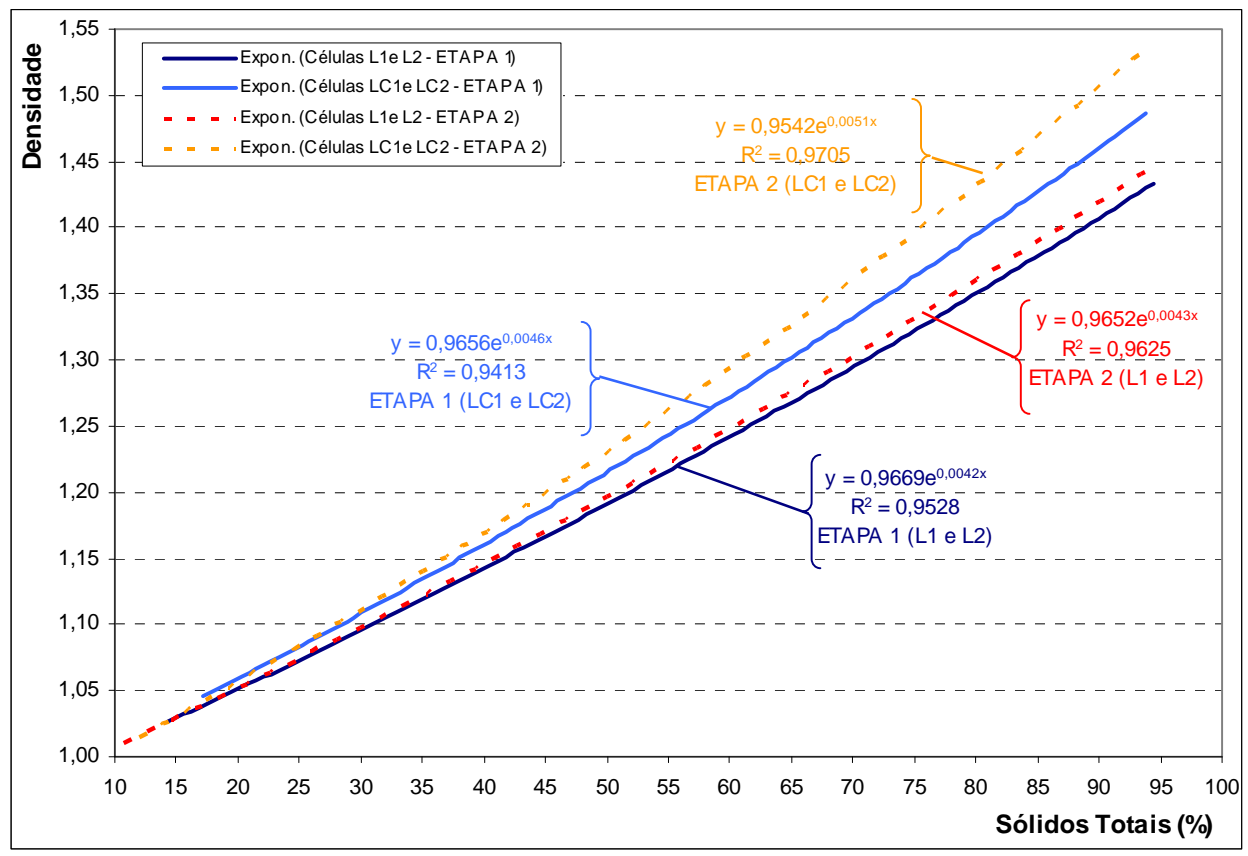

Gráfico 6.19 - Curvas ajustadas na regressão linear das densidades do lodo em relação ao teor de sólidos totais (ST), do lodo digerido sem cal (L1 e L2) e com cal (LC1 e LC2) durante as Etapas 1 e 2 


\section{ESTIMATIVA DE ÁREA E DE CUSTO PARA A INSTALAÇÃO DA ESTUFA}

Para a realização do dimensionamento da estufa, serão levantadas inicialmente as condições ideais para a utilização da estufa agrícola, considerando todas as informações pertinentes para o cálculo.

\subsection{CONDIÇÕES PARA A ESTIMATIVA DE ÁREA DA ESTUFA}

Inicialmente, para avaliar o tempo necessário que o lodo deve permanecer na estufa, utilizouse dos resultados dos parâmetros CTt e OVH. Isso porque, para o enquadramento do lodo como Classe A, esses parâmetros devem atender aos limites estabelecidos pelo Conama (BRASIL, 2006c). Na TABELA 7.1, encontram-se os resultados da avaliação estatística para CTt e OVH. Os resultados de vírus não foram usados nesta avaliação em razão das questões já discutidas anteriormente nos itens 5.2.4.4.

Tabela 7.1 - Resultados obtidos na avaliação estatística das variáveis coliformes termotolerantes e ovos viáveis de helmintos de acordo com os fatores analisados

\begin{tabular}{cccccccccc}
\hline \multirow{2}{*}{ Variável } & \multicolumn{2}{c}{ Fator tipo de lodo } & \multicolumn{2}{c}{ Fator cal } & \multicolumn{3}{c}{ Fator disposição/revolvimento } \\
\cline { 2 - 9 } & Digerido & Sem digerir $^{(*)}$ & $\begin{array}{c}\text { Lodo } \\
\text { sem cal }\end{array}$ & $\begin{array}{c}\text { Lodo } \\
\text { com cal }\end{array}$ & $\mathbf{( 1 0 c m ~} \mathbf{~ m / 3 x + 1 x )}$ & $\mathbf{( 1 0 c m ~ e ~ m / 3 x ) ~}$ & $\mathbf{( 1 0 c m / 3 x )}$ & $\mathbf{( 2 0 c m / 3 x )}$ \\
\hline CTt (dia) & 14 & 28 & 28 & 0 & 28 & 28 & 14 & 14 \\
OVH (dia) & 0 & 28 & 28 & 0 & 14 & 14 & 28 & 28 \\
\hline
\end{tabular}

Nota: as células destacadas indicam os fatores que apresentaram diferenças estatisticamente significantes para o fator testado, com nível de significância de 5\%.

${ }^{(*)}$ Lodo não encaminhado ao digestor.

Diante dos resultados apresentados na TABELA 7.1, o tempo de 28 dias (cerca de 38\% de umidade) foi suficiente, para o enquadramento do material como biossólido Classe A (BRASIL, 2006c), considerando as condições analisadas. Apesar de haver diferença significativa quanto ao fator cal para CTt e ao tipo de lodo para $\mathrm{OVH}$, em todas as condições o tempo máximo foi de 28 dias, inclusive, esse tempo foi aceitável para o lodo não submetido à digestão e sem adição de cal.

Porém, entende-se que deva ser considerado um fator de segurança para que se atenda aos limites estabelecidos pelo Conama em circunstâncias adversas. Nesse caso, preferiu-se adotar 
o tempo de secagem necessário para o lodo atingir, aproximandamente, $25 \%$ de umidade. A partir dessa umidade, percebe-se que a secagem do lodo ocorre de forma mais lenta (GRÁFICO 6.2), não alterando consideravelmente as características do material. Diante dos resultados apresentados para Salmonella sp., acredita-se que essa condição garanta também o atendimento aos padrões estabelecidos pelo Conama. Outra questão importante a ser considerada é o menor volume de biossólido a ser disposto para a umidade de $25 \%$.

Com relação ao tipo de lodo, digerido ou não encaminhado ao digestor, optou-se pelo lodo digerido, mesmo tendo sido observado que com $25 \%$ de umidade os dois tipos de lodo atenderiam aos padrões estabelecidos pelo Conama. Se fosse escolhido o lodo não encaminhado ao digestor, o consumo de energia requerido para a estabilização aeróbia poderia ser apontado como uma das possível vantagens na otimização do processo atualmente usado nas ETE. No entanto, o fato de o lodo não passar pelo processo de digestão acarretaria um incremento do seu volume, que é consequencia da não destruição de SV durante a digestão. Ocorre que, apenas com os resultados obtidos nesta pesquisa, seria prematuro inferir sobre as reais diferenças e vantagens existentes entre os tipos de lodo estudados. O lodo não encaminhado ao digestor demanda ainda de estudos mais específicos, para que se conheça melhor seu comportamento e características.

Para a variável umidade, a avaliação estatística mostrou haver diferença significativa apenas no fator disposição/revolvimento. Nesse caso, os resultados indicaram a configuração $(10 \mathrm{~cm}$ e $\mathrm{m} / 3 \mathrm{x}+1 \mathrm{x}$ ) como a que possibilitou perda da umidade mais acelerada. Porém, a combinação $(10 \mathrm{~cm} / 3 \mathrm{x})$ não apresentou diferença significativa em relação a $(10 \mathrm{~cm}$ e m/3x $+1 \mathrm{x})$ e $(10 \mathrm{~cm}$ e m/3x) (TABELA 6.2). Assim, como a formação de leira não acelerou o processo de higienização, acredita-se que a condição $(10 \mathrm{~cm} / 3 \mathrm{x})$ seja considerada a melhor opção em virtude de não haver necessidade de formar leiras, o que poderia dificultar a operacionalização do sistema. Além disso, o teste de Tukey (APENDICE 11) mostra que, a partir do $28^{\circ}$ dia, os (p-valores) apresentados para $(10 \mathrm{~cm} / 3 \mathrm{x})$ não apresentaram diferenças significativas na perda da umidade relativamente à combinação $(10 \mathrm{~cm} \mathrm{e} \mathrm{m/3x}+1 \mathrm{x})$. Então, $o$ tempo necessário para que a umidade do lodo atinja 25\% (75\% ST) para a condição de $(10 \mathrm{~cm} / 3 \mathrm{x})$ é, aproximadamente, de 36 dias (GRÁFICO 6.4). Isso resulta numa diminuição do volume bastante expressiva, de cerca de $76 \%$. A densidade obtida para $75 \%$ ST é de 1,33, considerando lodo digerido sem cal (GRÁFICO 6.19). 
Quanto ao fator cal, optou-se por considerar a não adição de cal. Para os CTt, que apresentaram diferença significativa com relação a esse fator, o tempo necessário para a higienização do lodo sem cal foi o mesmo para as demais condições, ou seja, 28 dias. Assim, não implicou uma diminuição significativa no tempo de higienização para o enquadramento do material como lodo Classe A (BRASIL, 2006c). A adição da cal aumentaria o volume final a ser disposto, além de apresentar dificuldades na homogeneização da mistura com umidade de lodo elevada.

Para a definição do volume de lodo a ser submetido à secagem e higienização na estufa, foi considerada a quantidade de lodo estimada para o ano de 2023 (TABELA 4.1). Como o volume apresentado na TABELA 4.1 foi determinado para ST igual a $25 \%$, o volume foi recalculado, considerando valor de $18 \% \mathrm{ST}$. Assim, as condições definidas para estimar a área da estufa encontram-se apresentadas no QUADRO 7.1.

Quadro 7.1 - Condições definidas para a estimativa da área da estufa, considerando dados de projeto e fatores analisados na pesquisa

\begin{tabular}{|c|c|c|}
\hline \multicolumn{2}{|c|}{ Descrição } & Característica \\
\hline \multicolumn{2}{|c|}{ Tempo de secagem - Ciclo } & 36 dias \\
\hline \multicolumn{2}{|c|}{ Forma de disposição do lodo } & $\mathrm{h}=10 \mathrm{~cm}$ \\
\hline \multicolumn{2}{|c|}{ Revolvimento } & 3 vezes por semana \\
\hline \multicolumn{2}{|c|}{ Tipo de lodo } & Digerido \\
\hline \multicolumn{2}{|c|}{$\mathrm{Cal}$} & Sem adição de cal \\
\hline \multicolumn{2}{|c|}{ Umidade inicial } & Em torno de $82 \%(18 \% \mathrm{ST})$ \\
\hline \multicolumn{2}{|c|}{ Umidade final } & Em torno de $25 \%(75 \% \mathrm{ST})$ \\
\hline \multirow{4}{*}{ Volume de lodo (18\% ST) } & ETE Araçás & $157 \mathrm{~m}^{3} / \mathrm{dia}$ \\
\hline & ETE Aeroporto & $24 \mathrm{~m}^{3} / \mathrm{dia}$ \\
\hline & ETE Bandeirantes & $74 \mathrm{~m}^{3} / \mathrm{dia}$ \\
\hline & ETE Mulembá & $73 \mathrm{~m}^{3} / \mathrm{dia}$ \\
\hline
\end{tabular}

\subsection{CÁLCULO DE ÁREA DA ESTUFA}

Para calcular a área da estufa agrícola, foi considerada a otimização da área ocupada pelo lodo por causa da diminuição da umidade e, consequentemente, do volume. Inicialmente, fixou-se uma largura e, em seguida, a variação da área foi definida para um intervalo de tempo de três dias (período de revolvimento). Dessa forma, a cada três dias será realizada uma reorganização do lodo nas células em virtude da diminuição do volume. A curva apresentada 
no GRÁFICO 6.4, referente à condição de $(10 \mathrm{~cm} / 3 \mathrm{x})$, foi usada para definir a variação da umidade ao longo do tempo.

Nas TABELAS 7.2, 7.3, 7.4 e 7.5, estão apresentadas as condições definidas para o dimensionamento das estufas para os lodos gerados nas ETE, Araçás, Aeroporto, Bandeirantes e Mulembá, respectivamente, considerando dados de projeto e resultados desta pesquisa. Foi calculada a área de estufa necessária para o tratamento do lodo gerado em cada ETE, segundo a definição apresentada pela CESAN.

Tabela 7.2- Condições usadas para estimar a área de estufa necessária para o tratamento do lodo gerado na ETE Araçás (Vila Velha)

\begin{tabular}{ccccccc}
\hline Dia & $\begin{array}{c}\text { Teor umidade } \\
(\mathbf{\%})\end{array}$ & $\begin{array}{c}\text { Teor ST } \\
\mathbf{( \% )}\end{array}$ & $\begin{array}{c}\text { Volume lodo } \\
\mathbf{( m}^{\mathbf{3}} \mathbf{)}\end{array}$ & $\begin{array}{c}\text { Área }(\mathbf{h}=\mathbf{1 0} \mathbf{c m}) \\
\left.\mathbf{( m}^{2} / \mathbf{c e ́ l u l a}\right)\end{array}$ & $\begin{array}{c}\text { Largura células } \\
(\mathbf{m})\end{array}$ & $\begin{array}{c}\text { Comprimento } \\
(\mathbf{m} / \mathbf{c e ́ l u l a})\end{array}$ \\
\hline 0 & 82 & 18 & 157,00 & $1.570,00$ & 35,00 & 44,86 \\
3 & 82 & 18 & 157,00 & $1.570,00$ & 35,00 & 44,86 \\
6 & 80 & 20 & 141,30 & $1.413,00$ & 35,00 & 40,37 \\
9 & 77 & 23 & 122,87 & $1.228,70$ & 35,00 & 35,11 \\
12 & 73 & 27 & 104,67 & $1.046,70$ & 35,00 & 29,91 \\
15 & 68 & 32 & 88,31 & 883,10 & 35,00 & 25,23 \\
18 & 60 & 40 & 70,65 & 706,50 & 35,00 & 20,19 \\
21 & 52 & 48 & 58,88 & 588,80 & 35,00 & 16,82 \\
24 & 45 & 55 & 51,38 & 513,80 & 35,00 & 14,68 \\
27 & 38 & 62 & 45,58 & 455,80 & 35,00 & 13,02 \\
30 & 32 & 68 & 41,56 & 415,60 & 35,00 & 11,87 \\
33 & 28 & 72 & 39,25 & 392,50 & 35,00 & 11,21 \\
36 & 24 & 76 & 37,18 & 371,80 & 35,00 & 10,62 \\
\hline
\end{tabular}

Tabela 7.3-Condições usadas para estimar a área de estufa necessária para o tratamento do lodo gerado na ETE Aeroporto (Guarapari)

\begin{tabular}{|c|c|c|c|c|c|c|}
\hline Dia & $\begin{array}{c}\text { Teor umidade } \\
\text { (\%) }\end{array}$ & $\begin{array}{c}\text { Teor ST } \\
(\%)\end{array}$ & $\begin{array}{c}\text { Volume lodo } \\
\left(\mathrm{m}^{3}\right)\end{array}$ & $\begin{array}{c}\text { Área (h=10cm) } \\
\left(\mathrm{m}^{2} / \text { célula }\right)\end{array}$ & $\begin{array}{c}\text { Largura células } \\
\text { (m) }\end{array}$ & $\begin{array}{c}\text { Comprimento } \\
\text { (m/célula) }\end{array}$ \\
\hline 0 & 82 & 18 & 24,00 & 240,00 & 35,00 & 6,86 \\
\hline 3 & 82 & 18 & 24,00 & 240,00 & 35,00 & 6,86 \\
\hline 6 & 80 & 20 & 21,60 & 216,00 & 35,00 & 6,17 \\
\hline 9 & 77 & 23 & 18,78 & 187,80 & 35,00 & 5,37 \\
\hline 12 & 73 & 27 & 16,00 & 160,00 & 35,00 & 4,57 \\
\hline 15 & 68 & 32 & 13,50 & 135,00 & 35,00 & 3,86 \\
\hline 18 & 60 & 40 & 10,80 & 108,00 & 35,00 & 3,09 \\
\hline 21 & 52 & 48 & 9,00 & 90,00 & 35,00 & 2,57 \\
\hline 24 & 45 & 55 & 7,85 & 78,50 & 35,00 & 2,24 \\
\hline 27 & 38 & 62 & 6,97 & 69,70 & 35,00 & 1,99 \\
\hline 30 & 32 & 68 & 6,35 & 63,50 & 35,00 & 1,81 \\
\hline 33 & 28 & 72 & 6,00 & 60,00 & 35,00 & 1,71 \\
\hline 36 & 24 & 76 & 5,68 & 56,80 & 35,00 & 1,62 \\
\hline
\end{tabular}


Tabela 7.4- Condições usadas para estimar a área de estufa necessária para o tratamento do lodo gerado na ETE Bandeirantes (Cariacica)

\begin{tabular}{ccccccc}
\hline Dia & $\begin{array}{c}\text { Teor umidade } \\
(\mathbf{\%})\end{array}$ & $\begin{array}{c}\text { Teor ST } \\
(\mathbf{\%})\end{array}$ & $\begin{array}{c}\text { Volume lodo } \\
\mathbf{( m}^{\mathbf{3}} \mathbf{)}\end{array}$ & $\begin{array}{c}\text { Área (h=10cm) } \\
\left(\mathbf{m}^{\mathbf{2}} / \mathbf{c e ́ l u l a}\right)\end{array}$ & $\begin{array}{c}\text { Largura células } \\
(\mathbf{m})\end{array}$ & $\begin{array}{c}\text { Comprimento } \\
(\mathbf{m} / \mathbf{c e ́ l u l a})\end{array}$ \\
\hline 0 & 82 & 18 & 740,00 & 35,00 & 21,14 & 740,00 \\
3 & 82 & 18 & 740,00 & 35,00 & 21,14 & 740,00 \\
6 & 80 & 20 & 666,00 & 35,00 & 19,03 & 666,00 \\
9 & 77 & 23 & 579,10 & 35,00 & 16,55 & 579,10 \\
12 & 73 & 27 & 493,30 & 35,00 & 14,09 & 493,30 \\
15 & 68 & 32 & 416,30 & 35,00 & 11,89 & 416,30 \\
18 & 60 & 40 & 333,00 & 35,00 & 9,51 & 333,00 \\
21 & 52 & 48 & 277,50 & 35,00 & 7,93 & 277,50 \\
24 & 45 & 55 & 242,20 & 35,00 & 6,92 & 242,20 \\
27 & 38 & 62 & 214,80 & 35,00 & 6,14 & 214,80 \\
30 & 32 & 68 & 195,90 & 35,00 & 5,60 & 195,90 \\
33 & 28 & 72 & 185,00 & 35,00 & 5,29 & 185,00 \\
36 & 24 & 76 & 175,30 & 35,00 & 5,01 & 175,30 \\
\hline
\end{tabular}

Tabela 7.5- Condições usadas para estimar a área de estufa necessária para o tratamento do lodo gerado na ETE Mulembá (Vitória)

\begin{tabular}{|c|c|c|c|c|c|c|}
\hline Dia & $\begin{array}{c}\text { Teor umidade } \\
\text { (\%) }\end{array}$ & $\begin{array}{c}\text { Teor ST } \\
(\%)\end{array}$ & $\begin{array}{c}\text { Volume lodo } \\
\left(\mathrm{m}^{3}\right)\end{array}$ & $\begin{array}{c}\text { Área (h=10cm) } \\
\left(\mathrm{m}^{2} / \text { célula }\right)\end{array}$ & $\begin{array}{l}\text { Largura células } \\
\text { (m) }\end{array}$ & $\begin{array}{c}\text { Comprimento } \\
\text { (m/célula) }\end{array}$ \\
\hline 0 & 82 & 18 & 73,00 & 730,00 & 35,00 & 20,86 \\
\hline 3 & 82 & 18 & 73,00 & 730,00 & 35,00 & 20,86 \\
\hline 6 & 80 & 20 & 65,70 & 657,00 & 35,00 & 18,77 \\
\hline 9 & 77 & 23 & 57,13 & 571,30 & 35,00 & 16,32 \\
\hline 12 & 73 & 27 & 48,67 & 486,70 & 35,00 & 13,91 \\
\hline 15 & 68 & 32 & 41,06 & 410,60 & 35,00 & 11,73 \\
\hline 18 & 60 & 40 & 32,85 & 328,50 & 35,00 & 9,39 \\
\hline 21 & 52 & 48 & 27,38 & 273,80 & 35,00 & 7,82 \\
\hline 24 & 45 & 55 & 23,89 & 238,90 & 35,00 & 6,83 \\
\hline 27 & 38 & 62 & 21,19 & 211,90 & 35,00 & 6,05 \\
\hline 30 & 32 & 68 & 19,32 & 193,20 & 35,00 & 5,52 \\
\hline 33 & 28 & 72 & 18,25 & 182,50 & 35,00 & 5,21 \\
\hline 36 & 24 & 76 & 17,29 & 172,90 & 35,00 & 4,94 \\
\hline
\end{tabular}

Com base nos valores apresentados nas TABELAS 7.2, 7.3, 7.4 e 7.5, foi possível definir o melhor lay out da estufa, ponderando, também, as condições ideais para a operação e a manutenção do sistema. O sistema de cada ETE, será composto de três estufas de mesmas dimensões, que receberão lodo de 12 dias, alternados a cada 3. Isso possibilitará o revolvimento do lodo no período proposto (de 3 em 3 dias) com o tempo de secagem definido de 36 dias. A largura de 35,00m foi definida com base na largura útil possibilitada por cada vão da estrutura da estufa. A configuração final da estufa, para cada ETE, se encontra na TABELA 7.6 e, no ANEXO 1, se encontra o desenho, em planta baixa e perspectiva, da 
estufa dimensionada para a ETE Araçás. As estufas das demais ETE acompanham o mesmo lay out mostrado para a ETE Araçás, salvo as devidas proporções. Optou-se por um sistema de exaustão automatizado que poderá auxiliar na aceleração da secagem do lodo. A definição da área para implantação do sistema das ETE Bandeirantes e Mulembá demandam uma atenção especial, por estarem inseridas em áreas densamente povoadas, e, a ETE Araçás, em razão da demanda requerida, por ser essa a ETE com maior produção de lodo.

Tabela 7.6- Características gerais da estufa, do lodo e do biossólido gerado nas ETE - Araçás, Aeroporto, Bandeirantes, Mulembá

\begin{tabular}{|c|c|c|c|c|}
\hline Características & $\begin{array}{l}\text { ETE Araçás } \\
\text { (Vila Velha) }\end{array}$ & $\begin{array}{c}\text { ETE Aeroporto } \\
\text { (Guarapari) }\end{array}$ & $\begin{array}{c}\text { ETE Bandeirantes } \\
\text { (Cariacica) }\end{array}$ & $\begin{array}{c}\text { ETE Mulembá } \\
\text { (Vitória) }\end{array}$ \\
\hline Dimensões da estufa (m) (x 3) & $40,00 \times 270,00$ & $40,00 \times 45,00$ & $40,00 \times 135,00$ & $40,00 \times 130,50$ \\
\hline Área total da estufa $\left(\mathrm{m}^{2}\right)$ & $32.400,00$ & $5.400,00$ & $16.200,00$ & $15.660,00$ \\
\hline Tempo de secagem do lodo - Ciclo (dia) & 36 & 36 & 36 & 36 \\
\hline Teor inicial ST - lodo (\%) & 18 & 18 & 18 & 18 \\
\hline Teor final ST - biossólido (\%) & 76 & 76 & 76 & 76 \\
\hline $\begin{array}{l}\text { Volume lodo encaminhado à estufa }-18 \% \mathrm{ST} \\
\left(\mathrm{m}^{3} / \mathrm{dia}\right)\end{array}$ & 157,00 & 24,00 & 74,00 & 73,00 \\
\hline $\begin{array}{l}\text { Relação entre a área da estufa e o volume de } \\
\text { lodo tratado por ciclo }-36 \text { dias }\left(\mathrm{m}^{2} / \mathrm{m}^{3}\right)\end{array}$ & 5,73 & 6,25 & 6,08 & 5,96 \\
\hline $\begin{array}{l}\text { Volume de biossólido gerado após a secagem - } \\
76 \% \text { ST }\left(\mathrm{m}^{3} / \mathrm{dia}\right)\end{array}$ & 37,20 & 5,70 & 17,50 & 17,30 \\
\hline Densidade do biossólidos para ST $=76 \%$ & 1,33 & 1,33 & 1,33 & 1,33 \\
\hline $\begin{array}{l}\text { Massa de biossólido após a secagem }-76 \% \text { ST } \\
(\mathrm{t} / \text { dia) }\end{array}$ & 49,50 & 7,60 & 23,30 & 23,00 \\
\hline Massa seca de biossólido após a secagem (t/dia) & 38 & 6 & 18 & 18 \\
\hline
\end{tabular}

\subsection{CUSTO DE INVESTIMENTO DA ESTUFA}

Pelo fato de não se ter uma área definida para instalação das estufas, será apresentada a estimativa do custo de investimentos, para cada ETE, considerando a configuração definida para alcance de projeto de final de plano - 2023 (TABELA 4.1). Nesse sentido, não serão considerados os custos de transporte e operação/manutenção do sistema. Na TABELA 7.7, são apresentados os componentes usados na estimativa do custo de investimentos da estufa, para o tratamento do lodo gerado em cada ETE.

Os descritivos dos componentes exibidos na TABELA 7.7, são apresentados no ANEXO 2, que trata do orçamento encaminhado pela empresa especializada em fabricação e montagem de estufas. E, a estimativa de custos de investimentos relativos à população atendida, à quantidade de lodo tratado e às dimensões físicas das estufas, são apresentadas na TABELA 7.8 . 
Tabela 7.7- Custo de investimento estimado da estufa, considerando a configuração definida para cada ETE para alcance de projeto de 2023

\begin{tabular}{|c|c|c|c|c|}
\hline \multirow[b]{2}{*}{ Componentes } & \multicolumn{4}{|c|}{ Custo em R\$ } \\
\hline & $\begin{array}{l}\text { ETE Araçás } \\
\text { (Vila Velha) }\end{array}$ & $\begin{array}{l}\text { ETE Aeroporto } \\
\text { (Guarapari) }\end{array}$ & $\begin{array}{c}\text { ETE Bandeirantes } \\
\text { (Cariacica) }\end{array}$ & $\begin{array}{c}\text { ETE Mulembá } \\
\text { (Vitória) }\end{array}$ \\
\hline Estrutura metálica & $1.318 .444,00$ & $252.292,00$ & $673.420,00$ & $644.277,00$ \\
\hline Fundações e mureta & $46.562,00$ & $17.049,00$ & $39.359,00$ & $38.632,00$ \\
\hline Perfis de fechamentos e portas & $75.524,00$ & $42.900,00$ & $56.122,00$ & $55.725,00$ \\
\hline $\begin{array}{l}\text { Sistema de exaustão (exaustores e } \\
\text { janelas) }\end{array}$ & $234.510,00$ & $101.375,00$ & $169.164,00$ & $169.164,00$ \\
\hline $\begin{array}{l}\text { Filme para a cobertura e } \\
\text { fechamentos }\end{array}$ & $124.282,00$ & $24.304,00$ & $58.520,00$ & $58.423,00$ \\
\hline Total estrutura básica (1) & $1.799 .322,00$ & $437.920,00$ & $996.585,00$ & $966.221,00$ \\
\hline $\begin{array}{l}\text { Piso de concreto com esp. } 5,0 \mathrm{~cm} \\
\text { (materiais e mão de obra) }\end{array}$ & $952.962,00$ & $175.928,00$ & $472.034,00$ & $460.779,00$ \\
\hline $\begin{array}{l}\text { Revolvedor do lodo ( } 05 \\
\text { equipamentos por estufa }\end{array}$ & $825.000,00$ & $705.000,00$ & $750.000,00$ & $750.000,00$ \\
\hline Total componentes opcionais (2) & 1.777.962,00 & $880.928,00$ & $1.222 .034,00$ & $1.210 .779,00$ \\
\hline Total Geral (1) + (2) & 3.577.284,00 & $1.318 .848,00$ & 2.218.619,00 & $2.177 .000,00$ \\
\hline
\end{tabular}

Nota: Ref. nov/2009.

Tabela 7.8- Custo de investimento estimado da estufa, relativo às dimensões físicas da estufa, à população atendida e à quantidade de lodo a ser tratado, para cada ETE

\begin{tabular}{|c|c|c|c|c|c|}
\hline & Descrição & $\begin{array}{l}\text { ETE Araçás } \\
\text { (Vila Velha) }\end{array}$ & $\begin{array}{l}\text { ETE Aeroporto } \\
\text { (Guarapari) }\end{array}$ & $\begin{array}{l}\text { ETE Bandeirantes } \\
\text { (Cariacica) }\end{array}$ & $\begin{array}{l}\text { ETE Mulembá } \\
\text { (Vitória) }\end{array}$ \\
\hline Dimensõ & $\mathrm{s}$ da estufa (m) (x3) & $40,00 \times 270,00$ & $40,00 \times 45,00$ & $40,00 \times 135,00$ & $40,00 \times 130,50$ \\
\hline Área tota & $\left(\mathrm{m}^{2}\right)(3$ estufas $)$ & $32.400,00$ & $5.400,00$ & $16.200,00$ & $15.660,00$ \\
\hline Populaçã & atendida (hab) & 633.000 & 97.000 & 318.000 & 293.000 \\
\hline $\begin{array}{l}\text { Volume } \\
-18 \% \text { ST }\end{array}$ & $\begin{array}{l}\text { lodo a ser tratado em } 36 \text { dias } \\
\left(\mathrm{m}^{3}\right)\end{array}$ & $5.652,00$ & 864,00 & $2.664,00$ & $2.628,00$ \\
\hline $\begin{array}{l}\text { Massa de } \\
18 \% \text { ST }\end{array}$ & $\begin{array}{l}\text { lodo a ser tratado em } 36 \text { dias - } \\
\text { onelada) }\end{array}$ & $5.878,00$ & 899,00 & $2.771,00$ & $2.733,00$ \\
\hline Custo Tr & al da Estufa (R\$) & $3.577 .284,00$ & $1.318 .848,00$ & 2.218.619,00 & $2.177 .000,00$ \\
\hline \multirow{5}{*}{$\begin{array}{l}\text { Custo } \\
\text { Relativo } \\
\text { da } \\
\text { Estufa }\end{array}$} & $\left(\mathrm{R} \$ / \mathrm{m}^{2}\right)$ & 110,41 & 244,23 & 136,95 & 139,02 \\
\hline & (R\$/hab) & 5,65 & 13,60 & 6,98 & 7,43 \\
\hline & $\begin{array}{l}\left(\mathrm{R} \$ / \mathrm{m}^{3} \text { lodo }\right) 18 \% \mathrm{ST} \text { - Ciclo } \\
\text { de } 36 \text { dias }\end{array}$ & 632,92 & $1.526,44$ & 832,81 & 828,39 \\
\hline & $\begin{array}{l}\text { (R } \$ / t \text { lodo) } 18 \% \text { ST - Ciclo de } \\
36 \text { dias }\end{array}$ & 608,59 & $1.467,02$ & 800,66 & 796,56 \\
\hline & $\begin{array}{l}\text { (R\$/t lodo em MS) - Ciclo de } \\
36 \text { dias }\end{array}$ & $3.381,05$ & $8.150,09$ & $4.448,09$ & $4.425,34$ \\
\hline
\end{tabular}

Nota: Ref. nov/2009.

A ETE Aeroporto, por ser a de menor porte entre as quatro, apresenta um custo relativo mais elevado, em razão, principalmente, do equipamento de revolvimento. Em contrapartida, a ETE Araçás, maior entre elas, já apresenta custo relativo mais reduzido.

Com o intuito de avaliar o custo de investimento requerido pelo processo proposto, esse será confrontado com a secagem térmica de lodo (TABELA 7.9). Os resultados obtidos para a 
ETE Bandeirantes serão usados para a comparação. Como apresentado anteriormente, não será realizado cálculo comparativo completo, envolvendo atividades como transporte, por não se ter definida, ainda, a área para instalação do sistema.

Tabela 7.9- Custo de investimento estimado de secador térmico para tratamento do lodo gerado na ETE Bandeirantes

\begin{tabular}{lc}
\hline \multicolumn{2}{c}{ Características usadas para o cálculo do Secador Térmico - ETE Bandeirantes } \\
\hline Teor inicial ST - lodo (\%) & 18 \\
Teor final ST - biossólido (\%) & 76 \\
Volume lodo encaminhado à estufa - 18\% ST (1/dia) & 71.000 \\
Volume de biossólido gerado após a secagem - 76\% ST (1/dia) & 13.000 \\
Quantidade de água a ser evaporada por dia (1/dia) & 55.100 \\
População atendida (hab) & 318.000 \\
Custo do Secador Térmico TDE-900 - VOMM (capacidade de evaporação de água & $\mathrm{R} \$ 4.500 .000,00$ \\
$8001 / \mathrm{h})$ - 3 secadores & $\mathrm{R} \$ 450.000,00$ \\
Custo estimado para fundação, instalação elétrica e galpão & $\mathbf{1 5 , 5 7}$ \\
\hline Custo por habitante (R\$/hab) - Secador Térmico &
\end{tabular}

Nota: Ref. nov/2010.

No caso de secador térmico, deve-se levar em consideração o custo relativo ao combustível a ser usado durante a operação do secador. Optando pelo gás natural, estima-se que o custo mensal esteja em torno de $\mathrm{R} \$ 420,00$ a tonelada em massa seca de lodo. Assim, com um custo de investimento de, aproximadamente, $\mathrm{R} \$ 6,98 / \mathrm{hab}$, a estufa se apresenta mais viável economicamente. Mesmo com a demanda de área requerida para implantação, tratar-se de uma técnica simplificada bastante interessante, não havendo a necessidade de instalações sofisticadas para a operacionalização do sistema, apresentando baixos custos de operação e manutenção. A princípio, os principais custos são referentes à recursos humanos (ETE Bandeirantes - 3 operários) e ao consumo de energia, apenas, para operação dos exaustores e dos equipamentos de revolvimento. Com isso, pode-se agregar também, viabilidades técnica e ambiental ao sistema, adequando-se às necessidades de países em desenvolvimento como Brasil. 


\section{CONCLUSÕES E RECOMENDAÇÕES}

A estufa agrícola apresenta-se como um processo bastante interessante para a secagem e a melhoria da qualidade sanitária do biossólido para as condições testadas. O biossólido atinge valores compatíveis com a Resolução n ${ }^{0}$ 375/2006 do Conama, com ressalvas aos vírus, com tempo de secagem bastante reduzido, independentemente de se adicionar cal ou não a ele. Como conclusões específicas, pode-se destacar:

- A estufa apresenta capacidade de manter temperaturas médias acima de $35^{\circ} \mathrm{C}$ durante um extenso período do dia, de $10 \mathrm{~h}$ a $17 \mathrm{~h}$, independentemente da época do ano, mesmo em horários quando a temperatura externa já apresentava valores reduzidos, muitas vezes em torno de $22^{\circ} \mathrm{C}$. Entre os meses de dezembro e fevereiro, consegue-se, dentro da estufa, temperatura interna média das médias horárias bastante elevadas, chegando a atingir valores acima de $55^{\circ} \mathrm{C}$.

- Caso seja utilizada a cal, a quantidade encontrada para satisfazer as exigências legais, é bastante reduzida, com percentual de $15 \%$ de cal hidratada em massa seca de lodo ou 13,5\% de $\mathrm{Ca}[\mathrm{OH}]_{2}$, tanto para o lodo digerido quanto para o não encaminhado ao digestor.

- Com a perda da umidade, ocorre uma diminuição considerável do volume inicial de lodo, independentemente do lodo ter passado ou não pelo digestor. A diminuição da umidade ao longo do tempo é configurada por três situações distintas, definidas pela facilidade ou não em se perder umidade. Não há diferença expressiva na diminuição da umidade do lodo digerido ou do lodo não encaminhado ao digestor, e nem o fato de se adicionar cal ou não ao lodo. A forma de disposição e o período de revolvimento interferem na perda da umidade do lodo. A combinação $(20 \mathrm{~cm} / 3 x)$ é a condição que apresenta diferença significativa em relação a todas as outras formas de disposição/revolvimento testadas e $(10 \mathrm{~cm} / 3 \mathrm{x})$ apresenta diferença significativa apenas em relação a $(20 \mathrm{~cm} / 3 \mathrm{x})$.

- O lodo digerido encontra-se estável, com bom nível de digestão, com valores de SV/ST em torno de $60 \%$. O lodo não encaminhado ao digestor apresenta valores médios de SV/ST acima de 0,70 . Há uma diminuição considerável da relação SV/ST com a secagem do lodo, em face da continuidade do processo de estabilização. A partir do $49^{\circ}$ dia não há diferença significativa entre os resultados, para os dois tipos de lodo, com SV/ST em torno de 43\% para lodo sem cal e 37\% para lodo com cal. As reduções observadas nos valores de SV/ST não 
implicam perda de potencial do biossólido como insumo agrícola, diante das concentrações de C-orgânico obtidas ao final dos períodos de secagem, que variam de $330 \mathrm{~g} / \mathrm{kgST}$ a $374 \mathrm{~g} / \mathrm{kgST}$. O decaimento da relação SV/ST ao longo do tempo, não apresenta diferença significativa entre as diversas formas de disposição e revolvimento do lodo avaliados.

- Para os dois tipos de lodo, a adição da cal permite uma elevação do pH, que, partindo de valores próximos a 12 , atinge cerca de 8 no $14^{\circ}$ dia, mantendo-se próximo a esse valor até o final dos ciclos. Assim, não há gandes vantagens do uso do lodo com cal para o ajuste do $\mathrm{pH}$ do solo. $\mathrm{O}$ pH do lodo digerido sem cal não apresenta variações muito bruscas, com valores no final dos ciclos entre 5 e 6 . Para o lodo não encaminhado ao digestor, o pH apresenta valores pouco acima daqueles do lodo digerido, com valores entre 6 e 7. A variação do $\mathrm{pH}$ ao longo do tempo, não apresenta diferença significativa entre as diversas formas de disposição e revolvimento do lodo avaliadas.

- As densidades iniciais de CTt no lodo não encaminhado ao digestor são maiores que as do lodo digerido. Com a umidade em torno de $20 \%$, independentemente do tipo de lodo, a densidade de CTt no biossólido atende aos padrões para lodo Classe A, porém essa umidade pode ser maior devido ao extenso intervalo de tempo ocorrido entre as coletas das amostras. Apesar de a adição da cal possibilitar a diminuição da densidade de CTt, nos dois tipos de lodo, com remoção acima de 99,86\%, é confirmado o recrescimento de CTt com a diminuição do $\mathrm{pH}$ para valores inferiores a 11,5, requerendo atenção especial. A diminuição da densidade de CTt ao longo do tempo não apresenta diferença significativa entre as diferentes formas de disposição e revolvimento do lodo avaliadas.

- Independentemente das condições metodológicas adotadas, e do tipo de lodo, a ausência de Salmonella sp. ocorre quando a umidade do biossólido se encontra em torno de $27 \%$. Essa umidade pode ser maior em razão do intervalo de tempo ocorrido entre as coletas das amostras. A adição da cal ao lodo mostra-se eficiente, resultando na ausência de Salmonella sp. nas amostras coletadas logo após a mistura.

- O lodo não encaminhado ao digestor apresenta densidades de OVH superiores às encontradas no lodo digerido. A higienização do lodo não encaminhado ao digestor, sem cal, ocorre quando a umidade se encontra em torno de $12 \%$, no $42^{\circ}$ dia (Ciclo $\left.1 / 2\right)$, podendo a umidade necessária ser maior, em razão de a coleta anterior, que já apresentava valores reduzidos de $\mathrm{OVH}$, ter sido realizada 14 dias antes. A adição da cal possibilitou uma redução 
no número de $\mathrm{OVH}$, no entanto, não representou uma redução expressiva, possivelmente em razão dos lodos já apresentarem valores reduzidos desse parâmetro. Na análise estatística, não houve diferença segnificativa entre o lodo sem cal e com cal. A redução dos OVH no lodo não apresenta, ao longo do tempo, diferença significativa entre as diversas formas de disposição e revolvimento avaliadas.

- Os resultados de vírus para o lodo não encaminhado ao digestor foram inconclusivos com valores bastante inconsistentes, divergindo, em alguns casos, das informações apresentadas pela literatura especializada, não sendo usados nas considerações finais acerca do processo avaliado.

- Os parâmetros de interesse agronômico monitorados, carbono orgânico, nitrogênio, fósforo, potássio, potássio, cálcio, magnésio, enxofre e sódio apresentam valores atraentes, ao final dos ciclos, para os dois tipos de lodo, considerando o uso agrícola do biossólido. A redução de $\mathrm{N}$ ocorrida no biossólido com cal devido à volatilização da amônia (stripping), ocasionada pela elevação do $\mathrm{pH}$, não implica perda do potencial do biossólido como insumo agrícola, com concentrações médias em torno de $24,8 \mathrm{~g} / \mathrm{kgST}$ (lodo digerido) e 26,5g/kgST (lodo não encaminhado ao digestor).

- As concentrações dos íons metálicos arsênio, cádmio, cromo, cobre, mercúrio, molibdênio, níquel, chumbo, bário, selênio, e zinco não apresentam variações significativas ao final dos ciclos, para os dois tipos de lodo, mantendo-se sempre abaixo da metade dos valores preconizados pela Resolução $n^{\circ} 375 / 2006$ do Conama para lodo Classe A.

- Existe uma forte correspondência entre os valores de densidade e $\mathrm{ST}$, com valores de $\mathrm{R}^{2}=$ 0,9528 (lodo sem cal) e $\mathrm{R}^{2}=0,9413$ (lodo com cal), ajustados para uma curva exponencial. $\mathrm{O}$ lodo que recebeu a cal apresentou valores de densidade mais elevados que o sem cal, em razão do aumento do teor de sólidos totais, independentemente do tipo de lodo usado. Até o teor de $20 \%$ ST, a densidade apresentada para o lodo sem cal e com cal é praticamente a mesma e, daí em diante, com a elevação do teor de sólidos, o lodo com cal apresentou densidade sempre superior ao sem cal.

- Em face dos resultados da análise estatística dos dados e dos resultados apresentados em cada ciclo, é razoável concluir que entre as condições metodológicas testadas, a melhor configuração para a uso da estufa agrícola na secagem e higienização do lodo é: lodo 
digerido; tempo de secagem aproximado de 36 dias; forma de disposição do lodo com altura igual a $10 \mathrm{~cm}$; período de revolvimento de três vezes por semana; sem adição de cal ao lodo. Com essa configuração é possível obter umidade final igual a, aproximadamente, $75 \%$ (25\% ST) e uma diminuição do volume bastante expressiva, de cerca de $76 \%$.

- As dimensões e os custos de investimentos estimados de estufa para a secagem e higienização do lodo para a configuração apresentada são: para a ETE Araçás, três estufas de (40,00 x 270,00)m, com custo estimado de R \$5,65/hab; para a ETE Aeroporto, três estufas de (40,00 x 45,00)m, com custo estimado de R $\$ 13,60 /$ hab; para a ETE Bandeirantes, três estufas de $(40,00 \times 135,00) \mathrm{m}$, com custo estimado de R $\$ 6,98 /$ hab; e, para a ETE Mulembá, três estufas de $(40,00 \times 130,50) \mathrm{m}$, com custo estimado de $\mathrm{R} \$ 7,43 / \mathrm{hab}$.

Como recomendações principais, destacam-se estudos complementares que poderiam elucidar alguns resultados obtidos nesta pesquisa, a saber:

- Avaliação quanto à presença de vírus no biossólido gerado após o tratamento em estufa agrícola, com a configuração apresentada na pesquisa, para o enquadramento do lodo como Classe A. Porém, caso o biossólido não atenda às condições estabelecidas pelo Conama, e, considerando que o volume final de biossólido gerado é bastante reduzido nesse tratamento, acredita-se que o material submetido por 2 horas a uma temperatura de, aproximadamente, $60^{\circ} \mathrm{C}$, pode ser indicada como uma técnica de pós-tratamento para eliminação dos vírus.

- Com a prática adquirida nesta pesquisa e com os resultados obtidos, pode-se perceber que o monitoramento dos vírus em lodo de esgoto, ainda demanda uma atenção especial. Nesse caso, são apontadas algumas recomendações: (1) realização de estudos para garantir a regulamentação de critérios e procedimentos detalhados desde o preparo, manuseio, coleta, acondicionamento, preservação e transporte das amostras, inclusive uma maior discussão sobre a metodologia a ser implementada, não permitindo, assim, possíveis falhas em algum ponto da cadeia do gerenciamento; (2) avaliação de técnicas para quantificação de vírus com custo mais acessível, ou a avaliação de possíveis indicadores em substituição aos vírus. As técnicas atualmente empregadas para vírus, apresentam custos bastante elevados e que podem inviabilizar o uso do lodo como insumo agrícola. 
- A realização de novos estudos com o lodo não encaminhado ao digestor possibilitará conhecer melhor suas características e seu comportamento, e assim, apontar as possíveis condições e vantagens do tratamento desse lodo em estufa agrícola. 


\section{REFERÊNCIA}

ADAM, R. D. Biology of Giardia lamblia. Clinical Microbiology Reviews, v. 14, n. 3, p. 447475, 2001.

AHLBERG, G.; GUSTAFSSON, O.; WEDEL, P. Leaching of metals from sewage sludge during one year and their relationship to particle size. Environmental Pollution, v. 144, p. 545-553, 2006.

AHMED, A. U.; SORENSEN, D. L. Kinetics of pathogen destruction during storage of dewatered biosolids. Water Environmental Research, v. 67, n. 2, p. 143-150, 1995.

AITKEN, M. D.; SOBSEY, M. D; BLAUTH, K. E.; SHEHEE, M.; CRUNK, P. L.; WALTERS, G. W. Inactivation of Ascaris suum and poliovirus in biosolids under thermophilic anaerobic digestion conditions. Environmental Science Technology, v. 39, n. 15, p. 5804-5809, 2005.

ÅKERLUND, A. Evaluation of a disintegration technique for increased biogas production from excess activated sludge, 2008. Disponível em: http://www.stockholmvatten.se/ Stockholmvatten/commondata/rapporter/avlopp/Processer/R03_2008_Anna_Akerlund_exame nsarbete.pdf. Acesso em: 08 jan. 2009

AKRIVOS, J.; MAMAIS, D.; KATSARA, K.; ANDREADAKIS, A. Agricultural utilisation of lime treated sewage sludge . Water Science and Technology, v. 42, n. 9, p. 203-210, 2000.

AL SAYED, M. H.; MADANY L. M.; BUALI A. R. M. Use of sewage sludge ash in asphaltic paving mixes in hot regions. Construction and Building Materials, v. 9, n. 1, p. 1923, 1995.

ALÉM SOBRINHO, P. Tratamento de esgoto e geração de lodo. In: TSUTIYA, M. T. et al. Biossólidos na agricultura. 2. ed. São Paulo: Abes/SP, 2002, cap. 2, p. 7-40.

ALLARD, A.; ALBISSON, B.; WADELL, G. Detection of adenoviruses in stools from healthy persons and patients with diarrhea by two-step polymerase chain reaction. Journal of Medical Virology, v. 37, n. 2, p. 149-157, 1992.

ALMENDRO-CANDEL, M. B.; JORDÁN, M. M.; NAVARRO-PEDREÑO, J.; MATAIXSOLERA, J.; GÓMEZ-LUCAS, I. Environmental evaluation of sewage sludge application to reclaim limestone quarries wastes as soil amendments. Soil Biology \& Biochemistry, v. 39, p. 1328-1332, 2006.

ALONSO, E.; CALLEJÓN, M.; JIMÉNEZ, J. C.; TERNERO, M. Heavy metal extractable forms in sludge from wastewater treatment plants. Chemosphere, v. 47, p. 765-775, 2002.

ANDERSEN, A. Disposal and recycling routes for sewage sludge - Scientific and technical subcommittee report. Report Prepared for the European Commission DG Environment, 2001.

ANDERSON, E. J.; WEBER, S. G. Rotavirus infection in adults. The Lancet Infectious Diseases, v. 4, p. 91-99, 2004. 
ANDREASEN, P. Chemical stabilization. In: SPINOSA, L.; VESILLIND, P. Sludge into biosolids. London: IWA, 2001. cap. 14, p. 242-258.

ANDREOLI, C. V.; LARA, A. I.; FERNANDES, F. (org.) Reciclagem de biossólido Transformando problemas em solução. Curitiba: Sanepar/FINEP, 1999. 288 p.

ANDREOLI, C. V.; BONNET, B. R. P. (Coord.). Manual de métodos para análises microbiológicas e parasitológicas em reciclagem agrícola de lodo de esgoto. 2. ed. Curitiba: Companhia de Saneamento do Paraná - Sanepar, 2000. 80 p.

ANDREOLI, C. V. (Coord.). Resíduos sólidos do saneamento: processamento, reciclagem e disposição final. Rio de Janeiro: RiMa, Abes, 2001. xxiv, 282 p.

ANDREOLI, C. V.; PEGORINI, E. S.; FERNANDES, F. Disposição do lodo no solo. In: ANDREOLI, C. V.; VON SPERLING, M.; FERNANDES, F. Lodo de esgoto: tratamento e disposição final. Belo Horizonte: Departamento de Engenharia Sanitária e Ambiental-UFMG; Companhia de Saneamento do Paraná, 2001. v. 6, cap. 8, p. 319-397.

ANDREOLI, C. V.; PINTO, M. A. T. Introdução. In: ANDREOLI, C. V. (Coord.). Resíduos sólidos do saneamento: processamento, reciclagem e disposição final. Rio de Janeiro: RiMa, Abes, 2001. Introdução, p. XXI-XXIV.

ANDREOLI, C. V.; VON SPERLING, M.; FERNANDES, F. Lodo de esgoto: tratamento e disposição final. Belo Horizonte: Departamento de Engenharia Sanitária e Ambiental-UFMG; Companhia de Saneamento do Paraná, 2001. v. 6, 484 p.

ANDREOLI, C. V.; FERNANDES, F.; PAULA, M. L.; FURLAN, F. B. Plano de gerenciamento de lodo de esgoto e resíduos do tratamento preliminar das ETEs Aeroporto (Guarapari), Mulembá (Vitória), Araças (Vila Velha) e Bandeirantes (Cariacica). Edital BIRD $\mathrm{n}^{\mathrm{o}}$ 001/2000 - SETR. Construtora Norberto Odebrecht SA/AQUACONSULT - Consultoria e Projetos de Engenharia LTDA, 2002. Relatório.

ANDREOLI, C. V.; FERREIRA, A. C.; CHERNICHARO, C. A. Secagem e higienização de lodos com aproveitamento do biogás. In: CASSINI, S. T. (Coord.). Digestão de resíduos sólidos orgânicos e aproveitamento do biogás . Rio de Janeiro: Abes, RiMa, 2003. cap. 5, p. 121-165.

ANDREOLI, C. V. (Coord.). Alternativas de uso de resíduos do saneamento. Rio de Janeiro: Abes, 2006. $417 \mathrm{p}$.

ANDREOLI, C. V.; GARBOSSA, L. H. P.; LUPATINI, G.; PEGORINI, E. S. Wastewater sludge management: A brazilian approach. In: Wasterwater Biosolids Sustainability: technical, managerial, and public synergy, 2007, New Brunsvick - Canadá. Proceedings...Canadá: IWA, 2007. p. 117-130.

ANGELIDIS, M., GIBBS, R. J. Heavy metals in urban sewage sludges: chemical forms and possible availability. In: L'HERMITE, P. (Ed.). Proceedings of the treatment and use of sewage sludge and liquid agricultural wastes symposium. Elsevier, London, 1991, p. 400404. 
APEDAILE, E.; COLE, D. Health aspects of biosolids land application. Prepared for City of Ottawa. University of Toronto. Department of Public Health Sciences Faculty of Medicine, march. 2002.

APHA - American Public Health Association. Compendium of Methods for the Microbiological Examination of Foods. $3^{\text {th }}$ ed., Washington, DC., 1992.

; AWWA - American Water Works Association; WPCF - Water Pollution Control Federation. Standard Methods for the Examination of Water and Wastewater, $20^{\text {th }}$ ed., Washington, DC., 1998.

ARRAJ, A.; BOHATIER, J.; LAVERAN, H.; TRAORE, O. Comparison of bacteriophage and enteric virus removal in pilot scale activated sludge plants. Journal of Applied Microbiology, v. 98, n. 2, p. 516-524, 2005.

ASSOCIAÇÃO BEASILEIRA DE NORMAS TÉCNICAS. NBR 9.800: Critérios para lançamento de efluentes líquidos industriais no sistema coletor público de esgoto sanitário. São Paulo, 1987.

. NBR 10.004: Resíduos sólidos. 2. ed. Rio de Janeiro, 2004a

. NBR 10.007: Amostragem de resíduos sólidos. 2. ed. Rio de Janeiro, $2004 \mathrm{~b}$.

ATSDR. Priority List of Hazardous Substances - CERCLA. 2007. Disponível em: http://www.atsdr.cdc.gov/cercla/07list.html. Acesso em: 25 maio 2009.

AZIZ, M. A.; KOE, L. C. C. Potential utilization of sewage sludge. Water Science and Technology, v. 22, Issue 12, p. 277-285, 1990.

BARRELLA, K. M. Pesquisa de vírus entéricos humanos em lodos de esgoto originários de duas ETEs do Estado de São Paulo: estabelecimento de metodologia para a recuperação e detecção viral. 2008. 151 f. Tese (Doutorado) - ICB-USP, São Paulo, 2008.

BARRETO, M. C. V. Degradação da fração orgânica de resíduos e efeitos em algumas propriedades químicas e fisicas de dois solos. 1995. 106 f. Tese (Doutorado) - Piracicaba: ESALQ-USP, 1995.

BARROSO, A. P.; MACHADO, V. H. A Gestão Logística dos Resíduos em Portugal. 2005. Tese (Doutorado) - Faculdade de Ciências e Tecnologia, Universidade Nova de Lisboa, Associação Portuguesa de Investigação Operacional, Lisboa, 2005.

BARROW, D.; BIS, G. Biosolids Management Planning: A Diversified Approach. In: Wasterwater Biosolids Sustainability: technical, managerial, and public synergy, 2007, New Brunsvick - Canadá. Proceedings...Canadá: IWA, 2007.p. 1011-1016.

BAYER, C.; MIELNICZUK, J.; AMADO, T. J. C.; MARTIN NETO, L.; FERNANDES, S. V. Organic matter storage in a sandy clay loam Acrisol affected by tillage and cropping systems in southern Brazil. Soil \& Tillage Research, v. 54, p.101-109, 2000. 
BEAGLEHOLE, R.; BONITA, R.; KJELLSTRÖM, T. Basic epidemiology. World Health Organization, Geneva, Switzerland. 1993.

BEAN, C. L.; HANSEN, J. J.; MARGOLIN, A. B.; BALKIN, H.; BATZER, G.; WIDMER, G. Class B alkaline stabilization to achieve pathogen inactivation. International Journal of Environmental Research and Public Health, v. 4, p. 53-60, 2007.

BENMOUSSA, H.; TYAGI, R. D.; CAMPBELL, P. G. C. Simultaneous sewage sludge digestion and metal leaching using an internal loop reactor. Water Research, v. 31, n. 10, p. 2638-2654, 1997.

BERTON, R. S. Riscos de contaminação do agroecossistema com metais pesados. In: BETTIOL, W.; CAMARGO, O. A. (coord). Impacto ambiental do uso agrícola do lodo de esgoto. Jaguariúna: Embrapa Meio Ambiente, 2000. cap. 16, p. 259-268.

BERTON, R. S.; CAMARGO, A. O.; VALADARES, J. M. A. S. Absorção de nutrientes pelo milho em resposta à adição de lodo de esgoto a cinco solos paulistas. Revista Brasileira de Ciência do Solo, v. 13, p. 187-192, 1989.

BETTIOL, W.; CAMARGO, O. A. (coord). Impacto ambiental do uso agrícola do lodo de esgoto. Jaguariúna: Embrapa Meio Ambiente, 2000.

BetTIOL, W; CARVAlHO, P. C. T.; FRANCO, B. J. D. C. Utilização do lodo de esgoto como fertilizante. $O$ Solo, v. 75, n. 1, p. 44-54, 1983.

BITTON, G. Wastewater microbiology. 3.ed. New Jersey: Wiley-Liss, 2005. 765 p.

BOFILL-MASS, S.; ALBINANA-GIMENEZ, N.; CLEMENTE-CASARES, P.; HUNDESA, A.; RODRIGUEZ-MANZANO, J.; ALLARD, A.; CALVO, M.; GIRONES, R. Quantification and stability of human adenoviruses and polyomavirus JCPyV in wastewater matrices. Appl. Environ. Microbiol. v. 72, p. 7894-7896, 2006.

BOGH, I. B.; CHRISTENSEN, P.; DATNTZER, V.; GROOT, M.; THOFNER, I. C. N.; RASMUSSEN, R. K.; SCHMIDT, M.; GREVE, T. Endocrine disrupting compounds: Effect of octylphenol on reproduction over three generations. Theriogenology, v. 55, n. 1, p. 131$150,2001$.

BON, F.; AMBERT-BALAY, K.; GIRAUDON, H.; KAPLON, J.; LE GUYADER, S.; POMMEPUY, M. GALLAY, A.; VAILLANT, V.; VALK, H.; CHIKHI-BRACHET, R.; FLAHAUT, A.; POTHIER, P.; KOHLI, E. Molecular epidemiology of caliciviruses detected in sporadic and outbreak cases of gastroenteritis in France from December 1998 to February 2004. Journal of Clinical Microbiology, v. 43, p. 4659-4664, 2005.

BONNET, B. R. P.; LARA, A. I.; DOMASZAK, S. C. Indicadores biológicos de qualidade sanitária do lodo de esgoto. In: ANDREOLI, C. V.; BONNET, B. R. P. (Coord.). Manual de métodos para análises microbiológicas e parasitológicas em reciclagem agrícola de lodo de esgoto. 2. ed. Curitiba: Companhia de Saneamento do Paraná - Sanepar, 2000. cap. 1, p. 11 26. 
BOROWSKI, S.; SZOPA, J. S. Experiences with the dual digestion of municipal sewage sludge. Bioresource Technology, v. 98, p. 1199-1207, 2007.

BOSCH, A.; GUIX, S.; SANO, D.; PÍNTÓ, R. M. New tools for the study and direct surveillance of viral pathogens in water. Current Opinion in Biotechnology, v. 19, p. 295-301, 2008.

BRADY, N. C.; WEIL, R. R. The nature and properties of soils. 12. ed. New Jersey: Prentice Hall, 1999. 881p. apud CHENG, H.; XU, W.; LIU, J.; ZHAO, Q.; HE, Y.; CHEN, G. Application of composted sewage sludge (CSS) as a soil amendment for turfgrass growth. Ecological Engineering, v. 29, p. 96-104, 2007.

BRASIL. Ministério da Agricultura, Pecuária e Abastecimento-Secretaria de Defesa Agropecuária. Instrução Normativa n. 23, 31 de agosto de 2005. Definições e normas sobre as especificações e as garantias, as tolerâncias, o registro, a embalagem e a rotulagem dos fertilizantes orgânicos simples, mistos, compostos, organominerais e biofertilizantes destinados à agricultura. Brasília, DF. 2005.

Instrução Normativa n. 27, 05 de junho de 2006. Dispõe sobre fertilizantes, corretivos, inoculantes e biofertilizantes, para serem produzidos, importados ou comercializados, deverão atender aos limites estabelecidos nos Anexos I, II, III, IV e V desta Instrução Normativa no que se refere às concentrações máximas admitidas para agentes fitotóxicos, patogênicos ao homem, animais eplantas,metais pesados tóxicos, pragas e ervas daninhas. Brasília, DF. 2006a.

Instrução Normativa n. 35, 04 de julho de 2006. Fica aprovada as normas sobre especificações e garantias, tolerâncias, registro, embalagem e rotulagem dos corretivos de acidez, de alcalinidade e de sodicidade e dos condicionadores de solo, destinados à agricultura, na forma do Anexo a esta Instrução Normativa. Brasília, DF. 2006b.

BRASIL - Ministério do Meio Ambiente. Resolução do Conama que dispõe sobre a Regulamentação do Uso Agrícola do Lodo de Esgoto. Disponível em: $<$ http://www.mma.gov.br/port/CONAMA>. Acesso em: 30 set. 2006c.

BREWSTER, J.; OLESZKIEWICZ, J.; BUJOCZEK, G.; REIMERS, R. S.; ABU-ORF, M.; BOWMAN, D.; FOGART, E. Inactivation of Ascaris suum eggs in digested and dewatered biosolids and lime and fly ash at bench scale and full scale. J. Environ. Eng. Sci., v. 2, n. 5, p. 395-400, 2003.

BRUNNER, P. H.; CAPRI, S.; MARCOMINI, A.; GIGER. W. Occurrence and behavior of linear alkylbenzenesulphonates, nonylphenol, nonylphenol mono- and nonylphenol diethoxylates in sewage and sewage sludge treatment. Water Research, v. 22, p. 1465-1472, 1988.

CACCIO, S. M.; GIACOMO, M. D.; AUliCINO, F. A.; POZIO, E. Giardia cysts in wastewater treatment plants in Italy. Appl Environ Microbiol, v. 69, n. 6, p. 3393-3398, 2003.

CAESB- COMPANHIA DE ÁGUAS E ESGOTO DE BRASÍLIA. O lodo de esgotos na agricultura. Brasília, 1996. 
CAMERON, K. C.; RATE, A. W.; NOONAN, M. J.; MOORE, S.; SMITH, N. P.; KERR, L. E. Lysimeter study of the fate of nutrients following subsurface injection and surface application of dairy pond sludge to pasture. Agriculture, Ecosystems and Environment, v. 58, p. 187-197, 1996.

CAMERON, K. C.; DI, H. J.; MCLAREN, R. G. Is soil an appropriate dumping ground for our wastes?. Australian Journal of Soil Research, v. 35, p. 995-1035, 1997.

CAMOBRECO, V. J.; RICHARDS, B. K.; STEENHUIS, T. S.; PEVERLY, J. H.; McBRIDE, M. B. Movement of heavy metals through undisturbed and homogenized soil columns. Soil Science, v. 161, p.740-750, 1996.

CARRINGTON, E. G. The contribution of sewage sludges to the dissemination of pathogenic microorganisms in the environment. Technical Report TR71 Water Research Center, 1978 apud APEDAILE, E.; COLE, D. Health aspects of biosolids land application. Prepared for City of Ottawa. University of Toronto. Department of Public Health Sciences Faculty of Medicine, march. 2002.

CARTER, M. J. A Review: Enterically infection viruses: pathogenicity, transmission and significance for food and waterborne infection. J Appl Microbiol., v. 98, p. 1354-1380, 2005.

CARVALHO, P. C. T.; CARVALHO F. J. P. C. Legislação sobre biossólido. In: TSUTIYA, M. T. et al. Biossólidos na agricultura. 2 ed. São Paulo: Abes/SP, 2002. cap. 7, p. 209-226.

CASSINI, S. T. (Coord.). Digestão de resíduos sólidos orgânicos e aproveitamento do biogás. Rio de Janeiro: Abes, RiMa, 2003. 210p.

CDC. Leptospirosis. Centers for Disease Control and Prevention, 2000. Disponível em: $<\mathrm{http}$ //www.cdc.gov/ncidod/dbmd/diseaseinfo/leptospirosis_g.htm>. Acesso em: 29 nov. 2007.

CEC - COUNCIL OF THE EUROPEAN COMMUNITIES. Council Directive 86/278/EEC of 12 June 1986 on the protection of the environment, and in particular of the soil, when sewage sludge is used in agriculture. Official Journal, v. L 181, p. 6-18, 1986. Disponível em: $<$ http://eur-lex.europa.eu/Result.do?idReq=2\&page=17>. Acesso em: 02 nov. 2007.

CETESB: Companhia de Tecnologia Ambiental. Aplicação de biossólidos em áreas agrícolas: Critérios para Projeto e Operação. Manual técnico. Norma P4230. São Paulo, ago.1999.

CHANEY, R. L.; RYAN, J. A.; O'CONNOR, G. A. Organic contaminants in municipal biosolids: risk assessment, quantitative pathways analysis, and current research priorities. The Science of the Total Environment, v. 185, p. 187-216, 1996.

CHANG, A. C.; PAN, G.; PAGE, A. L.; ASANO, T. Developing human health-related chemical guidelines for reclaimed water and sewage sludge applications in agriculture. World Health Organization (WHO), Geneva - Switzerland, 2002. 
CHANG, F. C.; LO, S. L.; KO, C. H. Recovery of copper and chelating agents from sludge extracting solutions. Separation and Purification Technology, v. 53, p. 49-56, 2007.

CHENG, H.; XU, W.; LIU, J.; ZHAO, Q.; HE, Y.; CHEN, G. Application of composted sewage sludge (CSS) as a soil amendment for turfgrass growth. Ecological Engineering, v. 29, p. 96-104, 2007.

CHEN, W.; CHANG, A. C.; WU; L.; ZHANG, Y. Metal uptake by corn grown on media treated with particle-size fractionated biosolids. Science of the Total Environmental. v. 392, p. 166-173, 2008.

CHERNICHARO, C. A. L. Reatores anaeróbios. Belo Horizonte: Departamento de Engenharia Sanitária e Ambiental - UFMG, 1997. v. 5, 246p.

CHRISTY, R. W. Sludge disposal. Using lime. In: Water Environment \& Technology. Washington, 1990. Disponível em: http://www.rdptech.com/tch1wet.htm. Acesso em: 20 set. 2007.

CLAPP, C. E.; LARSON, W. E.; DOWDY, R. H. (Ed.). Sewage sludge: land utilization and the environment. Madison. WI, USA: American Society of Agonomy: Crop Science Society of America, 1994. 258 p.

COLIN, F.; GAZBAR, S. Distribution of water in sludges in relation to their mechanical dewatering. Water Research, v. 29, n. 8, p. 2000-2005, 1995.

COMPARINI, J. B. Estudo do decaimento de patógenos em biossólidos estocados em valas e em biossólidos submetidos à secagem em estufa. 2001. 278 f. Tese (Doutorado) - Escola Politécnica, Universidade de São Paulo, São Paulo, 2001.

COOK, S.M.; GLASS, R.I.; LEBARON, C.W.; HO, MEI-SHANG. Global seasonality of rotavirus infections. Bulletin of the World Health Organization, v. 66, n. 2, p. 171-177, 1990.

CORK, D. J.; KRUEGER, J. P. Microbial transformations of herbicides and pesticides. Advances in Applied Microbiology, v. 36, p. 1-66, 1991 apud NRC- National Research Council. Committee on the Use of Treated Municipal Wastewater Effluents and Sludge in the Production of Crops for Human Comsuption. Use of reclaimed water and sludge in food crop production. Washington, D.C.: National Academy Press, 1996. p.178.

CORRÊA, R. S.; WHITE, R. E.; WEATHERLEY, A. J. Modelling the risk of nitrate leaching from two soils amended with five different biosolids. Revista Brasileira de Ciência do Solo, v. 29, n. 4, jul./ago. 2005.

COSTA, A. N.; KROHLING, B. Efeito do processo de higienização do lodo de esgoto com a cal virgem no desenvolvimento do cafeeiro Coffea canephora. In: Anais SEMINÁRIO SOBRE GERENCIAMENTO DE BIOSSÓLIDOS DO MERCOSUL, 1., 1998, Curitiba. Trabalhos técnicos... São Paulo: Sanepar/Abes, 1998. p. 285-289. 
COSTA, A. N.; RODRIGUES, C.; TELES, C. R.; KROHLING, B. Reciclagem agrícola do lodo de lagoas de estabilização. In: GONÇALVES, R. F. (Coord.). Gerenciamento do lodo de lagoas de estabilização não mecanizadas. Rio de Janeiro: Abes, 2000. cap. 8, p. 69-76.

COSTA, A. N.; COSTA, A. F. S.; MARQUES, M. O.; SANTANA, R. C. Estudo de caso Utilização de lodo de estação de tratamento de esgoto (ETE) na cultura de mamoeiro no norte do Estado do Espírito Santo. In: ANDREOLI, C. V. (Coord.). Resíduos sólidos do saneamento: processamento, reciclagem e disposição final. Rio de Janeiro: RiMa, Abes, 2001. cap. 8, p. 189-214.

COSTA et al. Lodo de esgoto: utilização sustentável - Folder INCAPER - Documento No 167, ISSN 1519-2059, Editor DCM/Incaper, Vitória (ES) - out. 2008 - Tiragem 2.500.

COVISA - Coordenação de Vigilância em Saúde - Secretaria Municipal de Saúde. Animais sinantrópicos. Disponível em: $\quad<$ http://www2.prefeitura.sp.gov.br/secretarias/saude/ vigilancia_saude/ccz/0024>. Acesso em: 07 mar. 2009.

CRIPPS, R. W.; MATOCHA, J. E. Effects of sewage sludge application to ameliorate iron deficiency of grain sorghum. Communications in Soil Science and Plant Analysis, v. 25, p. 1931-1940, 1991.

CRITES, R.; TCHOBANOGLOUS, G. Tratamiento de águas residuales em pequenas poblaciones. McGraw-Hill, Colômbia, 2000. 776p.

D’ALMEIDA, M. L. O.; VILHENA, A. (Coord.). Lixo municipal: manual de gerenciamento integrado. 2. ed. São Paulo: IPT/CEMPRE, 2000.

DAMGAARD-LARSEN, S.; JENSEN, K. O.; LUND, E.; NISSEN, B. Survival and movement of enterovirus in connection with land disposal of sludges. Water Research, v. 11, p. 509- 508, 1977.

DE LEON, R.; SHIEH, C.; BARIC, R. S.; SOBSEY, M. D. Detection of enterovirus and hepatitis A virus in environmental samples by gene probes and polymerase chain reaction. In: Advances of water analysis and treatment, Proceedings... Water Quality Technology Conference. Denver: American Water Works Association. p. 833-853, 1990.

DICKINSON S. J.; RUTHERFORD P. M. Utilization of Biosolids during the Phytoremediation of Hydrocarbon-Contaminated Soil. J. Environ. Qual. v. 35, p. 982- 991, 2006.

DO VAL, R. R. Estudo da biodiversidade de colifagos somáticos isolados de ambientes aquáticos e de fezes humanas e animais. 1997, 87f. Dissertação (Mestrado) - Instituto de Ciências Biomédicas, Universidade de São Paulo, São Paulo, 1997.

DOWD, S. E.; GERBA, C. P.; PEPPER, I. L.; PILLAI, S. D. Bioaerosol transport modeling and risk assessment in relation to biosolids placement. Journal Environmental Quality, v. 29, p. 343-348, 2000. 
DROUIN, M.; LAI, C. K.; TYAGI, R. D.; SURAMPALLI, R, Y. Bacillus Licheniformis proteases an high value added products from fermentation of wastewater sludge: pretreatment of sludge to increase the performance of the process. In: Wastewater Biosolids Sustainability: technical, managerial and public synergy, 2007, New Brunsvick - Canadá. Proceedings...Canadá: IWA, 2007. p. 599-605.

DUDA, G. P.; CAMPELLO, E. F. C.; MENDONÇA, E. S.; LOURDES, J. L.; DOMINGOS, M. Avaliação de frações de matéria orgânica do solo para a caracterização de áreas degradadas. Revista Brasileira de Ciência do Solo, v. 23, p. 723-728, 1999.

DUMONTET, S., DINEL, H., BALODA, S. B. Pathogen reduction in sewage sludge by composting and other biological treatments: a review. Biological Agriculture and Horticulture, v. 16, p. 409-430, 1999.

DUMONTET, S.; SCOPA, A.; KERJE, S.; KROVACEK, K. The importance of pathogenic organisms in sewage and sewage sludge. Air \& Waste Management Association, v. 51, p. 848-860, 2001.

ELliS, K. V,; HURST, C. J.; GOMEZ, C. L. Parasite ova and cysts in waste stabilization ponds. Water Research, v. 27, p. 1455-1460, 1993.

EMBRAPA - Empresa Brasileira de Pesquisa Agropecuária. Manual de análises químicas de solos, plantas e fertilizantes. Brasília: Embrapa Solos/Embrapa Informática Agropecuária/Embrapa Comunicação para Transferência de Tecnologia, 1999. 370p.

ENGELBRECHT, R. S. Microbial hazards associated with the land application of wastewater and sludge public. Health Engineer, v. 6, n. 4, p. 219-226, 1978 apud APEDAILE, E.; COLE, D. Health aspects of biosolids land application. Prepared for City of Ottawa. University of Toronto. Department of Public Health Sciences Faculty of Medicine, march. 2002.

ENRIQUEZ, C. E.; HURST, C. J.; GERBA, C. P.. Survival of the enteric adenoviruses 40 and 41 in tap, sea, and wastewater. Water Research, v. 29, n. 11, p. 2548-2553, 1995.

ESPÍRITO SANTO. Governo do Estado. Região Metropolitana da Grande Vitória. Vitória, 2005. Mapa da Região Metropolitana da Grande Vitória. Disponível em: $<$ www.ipes.es.gov.br>. Acesso em: 12 set. 2005.

EUROPEAN COMMUNITIES. On the landfill of waste. Council Directive 1999/31/EC, 1999.

Disposal and recycle routes for sewage sludge. Part 2: regulatory report. Luxembourg, 2001. Disponível em: <http://ec.europa.eu/ environment/waste/sludge/pdf/sludge_disposal2.pdf>. Acesso em: 11 out. 2007.

. On the protection of the environment, and in particular of the soil, when sewage sludge is used in agriculture. CONSLEG: 1986L0278, 2003.

EYSENBACH, E. (Coord.) Pretreatment of industrial wastes - Manual of practice FD - 3. Alexandria, USA: Water Environment Federation, 1994. 252p. 
FARIA, L. C.; RODRIGUEZ, L. C. E. Demanda potencial por biossólido em povoamentos de eucalipto no entorno da ETE de Barueri, SP. Engenharia Sanitária e Ambiental. v. 6 , p. 123-130, 2001.

FAYER, R.; MORGAN, U.; UPTON, S. J. Epidemiology of Cryptosporidium: transmission, detection and identification. Int. J. Parasitol., v. 30, p. 1305-1322, 2000.

FEACHEM, R. G., BRADLEY, D. J., GARELICK, H.; MARA, D. D. Sanitation and disease - Health aspects of excreta and wastewater management. John Wiley and Sons, Chichester, UK. 1983.

FERNANDES, F.; ANDRAUS, S.; ANDREOLI, C. V.; BONNET, B. J. C. CANTO, L. A.; MEDEIROS, M. L. B. Eficiência dos processos de desinfecção do lodo da ETE - Bélem com vista a seu uso agrícola. Sanare, v.5, n.5 , p. 46-58, 1996.

FERNANDES, F.; ANDREOLI, C.V.; DOMASZAK, S.C. Caracterização preliminar dos principais tipos de lodo de esgoto do Paraná para um programa de reciclagem agrícola. Sanare, v. 6, n. 6, p.15-21, 1996.

FERNANDES, F. (Coord.). Uso e Manejo do Lodo de Esgoto na Agricultura. Rio de Janeiro: PROSAB, Programa de Pesquisa em Saneamento Básico. 1999. 98p.

FERNANDES, F. Estabilização e higienização de biossólidos. In: BETTIOL, W.; CAMARGO, O. A. Impacto ambiental do uso agrícola do lodo de esgoto. Jaguariúna: Embrapa Meio Ambiente, 2000. p. 45-67.

FIA, R; MATOS, A. T; AGUIRRE, C. I. Características químicas de solo adubado com doses crescentes de lodo de esgoto caleado. Disponível em <http://www.ufv.br/dea/reveng/ arquivos/Vol13/v13n4p287-299.pdf>; p. 291. Acesso em 25/07/2007.

FRANÇA, R. G. Remoção de metais de lodo de esgoto por biolixiviação. Revista Engenharia Civil, Portugal, n. 19, 2004.

FRANÇA, R. G.; FIGUEIREDO, R. F. Quantificação do teor de metais pesados nos lodos gerados em estações de tratamento de esgotos (ETE's). In: SIMPÓSIO LUSO-BRASILEIRO DE ENGENHARIA SANITÁRIA E AMBIENTAL, 9., 2000, Porto Seguro. Anais ... Abes, 2000. p. 1704-1710. 1 CD-ROM.

FRANCI, R. (Coord.) Gerenciamento do lodo de lagoas de estabilização não mecanizadas. Rio de Janeiro: Abes, 2000. 95p.

FRANCO-HERNANDEZ, O.; MCKELLIGAN-GONZALEZ, A. N.; LOPEZ-OLGUIN, A. M.; ESPINOSA-CERON, F.; ESCAMILLA-SILVA, E.; DENDOOVEN, L. Treatment of sludge from a waste water plant to reduce pathogens and its effect on dynamics of $\mathrm{C}, \mathrm{N}$ and $\mathrm{P}$ in soil. In: CONFERENCE IWA, 2001, Acapulco - México. Proceedings...IWA, 2001. p. 620-623.

FRANK, R. The use of biosolids from wastewater treatment plants in agriculture. Environmental Management and Health, v. 9 n. 4, p. 165-169, 1998. 
FUENTES, A.; LLORÉNS, M.; SÁEZ, J.; AGUILAR, M. I.; PÉREZ-MARÍN, A. B; ORTUÑO, J. F.; MESEGUER, V. F. Ecotoxicity, phytotoxicity and extractability of heavy metals from different stabilized sewage sludges. Environmental Pollution, v. 143, p. 355-360, 2006.

GAN, D. R.; BERTHOUEX, P. M. Disappearance and crop uptake of PCBs from sludgeamended farmland. Water Environmental Research, v. 66, p. 54-69, 1994.

GANTZER, C.; GASPARD, P.; GALVEZ, L.; HUYARD, A.; DUMOUTHIER, N.; SCHWARTZBROD, J. Monitoring of bacterial and parasitological contamination during various treatment of sludge. Water Research, v. 35, n. 16, p. 3763-3770, 2001.

GARCIA JÚNIOR, O. Isolation and purification of Thiobacillus ferrooxidans and Thiobacillus thiooxidans from some coal and uranium mines of Brazil. Revista de Microbiologia, v. 22, n. 1, p. 1-6, 1991.

GARRAFA, P. Avaliação da qualidade virológica do efluente doméstico tratado e disponibilizado para reuso na cidade de São Paulo. 2009. 146 f. Tese (Doutorado) - ICBUSP, São Paulo, 2009.

GASPARD, P.; SCHWARTZBROD, J. Helminths and protozoa in stabilized sludge for agricultural use: search for an indicator of parasite contamination. In: CONFERENCE IWA, 2001, Acapulco - México. Proceedings...IWA, 2001. p. 9-14.

GAVALA, H. N.; YENAL, U.; SKIADAS, I. V.; WESTERMANN, P.; AHRING, B. K. Mesophilic and thermophilic anaerobic digestion of primaryand secondarysludge. Effect of pre-treatment at elevated temperature. Water Research, v. 37, p. 4561-4572, 2003.

GERARDI, M. H. The Microbiology of Anaerobic Digesters. New York: John Wiley \& Sons, Inc., 2003.

GERBA, C. P. Approaches and needs for the development of guindelines and standards for pathogenic microorganisms in biosolids. In: CONFERENCE IWA, 2001, Acapulco - México. Proceedings...IWA, 2001. p. 1-8.

GERBA, C. P.; PEPPER, I. L.; WHITEHEAD, L. F. A risk assessment of emerging pathogens of concern in the land application of biosolids. In: CONFERENCE IWA, 2001, Acapulco - México. Proceedings...IWA, 2001.p. 457-464.

GERBA, C. P.; SMITH Jr, J. E. Sources of pathogenic microorganisms and their fate during land application of wastes. J Environ Qual., v. 34, p. 42-48, 2005.

GIBBS, R.; HU, C. J.; HO, G. E.; UNKOVICH, I.; PHILLIPS, P. Die-off of human pathogens in stored wastewater sludge and sludge applied to land. UWRAA Research Project., v. 91, n. 58, p. 55-51, 1994.

GIBBS, R. A.; HU, C. J.; HO, G. E.; UNKOVICH, I. Regrowth of fecal coliforms and Salmonellae in stored biosolids and soil amended with biosolids. Water Science and Technology, v. 35, n. 11-12, p. 269-275, 1997. 
GIGER, W.; AHEL, M.; KOCH, M.; LAUBSCHER, H. U.; SCHAFFNER, C.; SCHNEIDER, J. Behavior of alkylphenol polyethoxylate surfactants and of nitrilotriacetate in sewage treatment. Water Science and Technology, v. 19, n. 3-4, p. 449-460, 1987 apud NRCNational Research Council. Committee on the Use of Treated Municipal Wastewater Effluents and Sludge in the Production of Crops for Human Comsuption. Use of Reclaimed Water and Sludge in Food Crop Production. Washington, D.C.: National Academy Press, 1996. p.178.

GIGER, W.; ALDER, A. C.; GOLET, E. M.; KOHLER, H. P. E.; MCARDELL, C. S.; MOLNAR, E.; SIEGRIST, H.; SUTER, M. J. F. Occurrence and fate of antibiotics as trace contaminants in wastewaters sewage sludge and surface waters. Chimia, v. 57, p. 485-491, 2003.

GOMES, L. P.; COELHO, O. W.; COSTA, A. N.; MARQUES, M. O. Critérios de seleção de áreas para reciclagem agrícola de lodos de estações de tratamento de esgotos (ETEs). In: ANDREOLI, C. V. (Coord.). Resíduos sólidos do saneamento: processamento, reciclagem e disposição final. Rio de Janeiro: RiMa, Abes, 2001. cap. 7, p. 165-187.

GONÇALVES, R. F. (Coord). Gerenciamento de lodo de lagoas de estabilização não mecanizadas. Rio de Janeiro: Abes, 2000. 95 p.

GONÇALVES, R. F.; LIMA, M. R. P.; PASSAMANI, F. R. F. Características físicoquímicas e microbiológicas do lodo de lagoas. In: GONÇALVES, R. F. (Coord). Gerenciamento de lodo de lagoas de estabilização não mecanizadas. Rio de Janeiro: Abes, 2000. cap. 4, p. 25-37.

GRAHAM; H. J. Parasites and the land application of sewage sludge in Ontario. In: WALLIS, P. M.; LEHMANN, D. L. (Ed.). Biological health risks of sludge disposal to land in cold climates. Canadá: University of Calgary Press, 1983. p. 153-178.

GRABOW, W. Bacteriophages: Update on application as models for viruses in water. Water $S A$, v. 27, n. 2, p. 251-258, 2001.

GRECA, D. Acondicionamento, armazenamento e transporte de resíduos industriais perigosos. In: Simpósio sobre Destinação de Resíduos Sólidos Industriais. 1994, Anais... Curitiba: UFPR, p. 12, 1994.

HAAS, C. N.; Desinfection. In: Letterman, R. D. (Ed.). Water Quality and Treatment: A Handbook of Community Water Supplies. 5 ed. New York: American Water Works Association. McGraw-Hill, Inc; 1999. cap. 14, p.14.1 - 14.60.

HARRISON, E. Z.; McBRIDE, M. B,; BOULDIN, D. R.; Recommendations for land application of sewage sludges and an appraisal of the us EPA's part 503 sludge rules. Cornell Waste Management Institute Working Paper, NY, 1999.

HÉRBERT, M. Public acceptance and independent certification of biosolids in Canada. In: Wastewater Biosolids Sustainability: technical, managerial and public synergy, 2007, New Brunsvick - Canadá. Proceedings...Canadá: IWA, 2007. p. 897-903. 
HÖGLUND, C. Evaluation of microbial health risks associated with the reuse of sourceseparated human urine. 2001. 78 f. Tese (Doutorado) - Swedish Institute for Infectious Disease Control, Royal Institute of Technology, Estolcomo, 2001.

HOLT, M.S., MATTHIJS, E.; WATERS, J. The concentrations and fate of linear alkylbenzene sulphonate in sludge-amended soils. Water Research, v. 23, p. 749-759. 1989.

HOROWITZ, N.; MEURER, E. J. Oxidação do enxofre elementar em solos tropicais. Ciência Rural, v. 36, n. 3, p. 822-828. 2006.

ICON, IC Consultants. Pollutants in urban waste water and sewage sludge. Prepared by ICON, IC Consultants for the European Commission Directorate - General Environment, 2001. Disponível em: http://europa.eu.int. Acesso em: 26 dez. 2007.

ILHENFELD, R. G.; ANDREOLI, C. A.; LARA, A. I. Higienização do Lodo de Esgoto. In: FERNANDES, F. et al. Uso e Manejo do Lodo de Esgoto na Agricultura. Rio de Janeiro: PROSAB, Programa de Pesquisa em Saneamento Básico. 1999. cap. 14, p. 27-40.

IRETSKAYA, S. N.; CHIEN, S. H. Comparison of cadmium uptake by five different food grain crops grown on three soils of varying $\mathrm{pH}$. Communications Soil Science and Plant Analysis, v. 30, p. 441-448, 1998.

ITO, A.; UMITA, T.; AIZAWA, J.; TAKACHI, T.; MORINAGA, K. Removal of heavy metals from anaerobically digested sewage sludge by a new chemical method using ferric sulfate. Water Research, v. 34, n. 3, p. 751-758, 2000.

JIMENEZ, B.; BARRIOS, J. A.; MAYA, C. Class B biosolids production fromwastewater sludge with high pathogenic content generated in an advanced primary treatment. Water Sci Technol, v. 42, n. 9, p. 103-110, 2000.

JOHNSON, P. W.; DIXON, R.; ROSS, A. D. An in-vitro test for assessing the viability of Ascaric sum eggs exposed to various sewage treatment processes. Int J Parasitol., v. 28, p. 627-633, 1998.

JOLLY M.; NEMETH, L.; ARANT, S.; WILSON, T.V. B. Recent advances in biosolids stabilization 2004: Case histories. 2004. Disponível em: http://www.earthtech.com/ documents/Advanced_in_BioSolids_Stabilization.pdf. Acesso em: 19 maio 2009. Dione 2009.

JONSSON, H.; BAKY, A.; JEPPSSON, U.; HELLSTROM, D.; KARRMAN, E. Composition of urine, faeces, greywater and bio-waste for utilization in the URWARE model. Urban water Report, v. 6, 2005.

JORGE, J. A.; CAMARGO, O. A.; VAlAdARES, J. M. A. S. Condições físicas de um latossolo vermelho-escuro quatro anos após aplicação de lodo de esgoto e calcário. Revista Brasileira de Ciência do Solo, v. 15, p. 237-240, 1991. 
KEPP, U.; SOLHEIM, O. E. Meeting increased demands on sludge quality - experience with full scale plant for thermal disintegration. In: World Congress, Anaerobic Conversion for Sustainability, 9., 2001, Antwerpen - Belgium, Proceedings...Belgium, 2001. .

KIRBY, R.S. Engineering in history. McGraw-Hill, New York, NY, USA. 1956 apud HÖGLUND, C. Evaluation of microbial health risks associated with the reuse of sourceseparated human urine. 2001. 78 f. Tese (Doutorado) - Swedish Institute for Infectious Disease Control, Royal Institute of Technology, Estolcomo, 2001.

KIRKWOOD, C.; BOGDANOVIC-SAKRAN, N.; BARNES, G.; BISHOP, R. Rotavirus serotype G9P[8] and acute gastroenteritis outbreak in children, northern Australia. Emerg Infect Dis., v. 10, n. 9, p. 1593-1600, 2004.

KOMATSU, T.; KUDO, K.; INOUE, Y.; HIMENO, S. Anaerobic codigestion of sewage sludge and rice straw. In: Wastewater Biosolids Sustainability: technical, managerial and public synergy, 2007, New Brunsvick - Canadá. Proceedings...Canadá: IWA, 2007. p. 495501.

KRETSCHMER, X. C.; BALDWIN, W. S. CAR and PXR: Xenosensors of endocrine disrupters?. Chemico-Biological Interactions. v. 155, p. 111-128, 2005.

KROISS, H.; ZESSNER, M. Ecological and Economical Relevance of Sludge Treatment and Disposal Options. In: Wasterwater Biosolids Sustainability: technical, managerial, and public synergy, 2007, New Brunsvick - Canadá. Proceedings...Canadá: IWA, 2007. p. 47-54.

KROKER, R. Aspects of the elimination of antibiotics after treatment of domestic animals. Wissenschaft und Umwelt. n. 4, p. 305-308, 1983 apud Schlüsener, M. P.; Bester, K. Persistence of antibiotics such as macrolides, tiamulin and salinomycin in soil. Environmental Pollution, n. 143, p. 565-571, 2006.

KUCHAR, D.; FUKUTA, T.; ONYANGO, M. S.; MATSUDA, H. Sulfidation treatment of copper-containing plating sludge towards copper resource recovery. Journal of Hazardous Materials B138, p. 86-94, 2006.

KÜMMERER, K. Drugs in the environment: emission of drugs, diagnostic aids and disinfectants into wastewater by hospitals in relation to other sources e a review. Chemosphere, v. 45, p. 957-969, 2001.

L'HERMITE, P. (Ed.), Proceedings of the Treatment and Use of Sewage Sludge and Liquid Agricultural Wastes Symposium. Elsevier, London, 1991.

LAKE, D. L. Sludge disposal to land. In: LESTER, J. N. Heavy metals in wastewater and sludge treatment process. Boca Raton: CRC Press, 1987. v. 2, p. 91-130.

LAKE, D. L.; KIRK, P. W. W.; LESTER J. N. Heavy metal solids association in sewage sludges. Water Research, v. 23, Issue 3, p. 285-291, 1989.

LAUBENBERGER, G.; HARTMANN, L. Physical structure of activated sludge in aerobic stabilization. Water Research, v. 5, Issue 6, p. 335-341, 1971. 
LEBLANC, R. J.; MATTHEWS, P.; RICHARD, R. P. Global atlas of excreta, wastewater sludge, and biosolids management: moving forward the sustainable and welcome uses of a global resource, pela United Nations Human Settlements Programme. Kenya: United Nations Human Settlements Programme (UN-HABITAT), 2008. Disponível em: http://esa.un.org/iys/docs/san_lib_docs/habitat2008.pdf. Acesso em: 29 set. 2009.

LENNETTE, E. H.; SCHMIDT, N. J. Diagnostic procedures for viral, ricketsial and chlamydial infections. Washington: American Public Health Association. p. 229-249, 1979.

LESTER, J. N. (Ed.). Heavy metals in wastewater and sludge treatment processes. Boca Raton, Fla.: CRC Press, 1987. v. 1.

LEWIS-JONES, R.; WINKLER, M. Sludge parasites and other pathogens. Ellis Horwood Series in Water and Wastewater Technology, Chichester, UK, 1991. 192p.

LIEW, A. G. Incorporation of sewage sludge in clay brick and its characterization. Waste Management \& Research, v. 22, p. 226-233, 2004.

LINDBERG, R. H.; BJÖRKLUND, K.; RENDAHL, P.; JOHANSSON, M. I.; TYSKLIND, M.; ANDERSSON, B. A.V. Environmental risk assessment of antibiotics in the Swedish environment with emphasis on sewage treatment plants. Water Research, v. 41, p. $613-619$, 2007.

LODDER, W. J.; VINJE, J.; VAN DE HEIDE, R.; DE RODA HUSMAN, A. M.; LEENEN, E. J. T. M.; KOOPMANS, M. P. G. Molecular detection of Norwalk-like caliciviruses in sewage. Appl Environ Microbiol., v. 65, n. 12, p. 5624-5627, 1999.

LODDER, W. J; DE RODA HUSMAN A. M. Presence of noroviruses and other enteric viruses in sewage and surface waters in the Netherlands. Appl Environ Microbiol., v. 71, n. 3, p. 1453-1461, 2005.

LOURENÇO, R. S.; ANJOS, A. R. M.; LIBARDI, P. L. MEDRADO, M. J. S. Efeito do lodo de esgoto na produtividade de milho e feijão, no sistema de produção da Bracatinga. Sanare, Curitiba, v. 5, n. 5, p. 90-92, 1996.

LUDUVICE, M. Processos de estabilização de lodos. In: ANDREOLI, C. V.; VON SPERLING, M.; FERNANDES, F. Lodo de esgoto: tratamento e disposição final. Belo Horizonte: Departamento de Engenharia Sanitária e Ambiental-UFMG; Companhia de Saneamento do Paraná, 2001. v. 6, cap. 4, p. 123-157.

LUE-HING, C.; ZENZ D. R.; KUCHENRITHER R. Municipal sewage management processing, utilization and disposal. Lancaster: Technomic Publishing, v. 4, 1992. 663p.

LUO, H. L.; LIN, D. F. Study the surface color of sewage sludge mortar at high temperature. Construction and Building Materials, v. 21, p. 90-97, 2007.

MAIER, R. M.; PEPPER, I. L.; GERBA, C. P. Environmental microbiology. 2.ed. Oxford, UK: Academic Press, Elsevier Inc. ISBN 978-0-12-370519-8, 2009. 598p. 
MALINA, J. F. Sludge handling, treatment and disposal. In: Seminário de Transferência de Tecnologia - Tratamento e destino final de lodo. 2., 1993, Rio de Janeiro. Anais...Rio de Janeiro: Abes/WEF, 1993a. p. 1-12.

MALINA, J. F. Anaerobic digestion. In: II Seminário de transferência de tecnologia/tratamento e destino final do lodo. Rio de Janeiro. Anais...: Rio de Janeiro. Abes/WEF, 1993b. p. 36-44.

MALTA, L. R. S. Otimização da estabilização cálcica do biossólido para uso agrícola. Estudo de caso: ETE Lavapés / São José dos Campos. 2002. Dissertação (Mestrado) - Escola Politécnica, Universidade de São Paulo, São Paulo, 2002.

MANUAL DE OPERAÇÃO - Planta de tratamento de efluentes de Vila Velha: Projeto

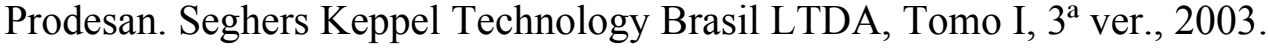

MARCHIORETTO, M. M.; BRUNING, H.; LOAN, N. T. P.; RULKENS, W. H. Heavy metal extraction from anaerobically digested sludge. . In: CONFERENCE IWA, 2001, Acapulco - México. Proceedings...IWA, 2001. p. 77-84.

MARQUES, M. O.; MELO, W. J.; MARQUES, T. A. Metais pesados e o uso de biossólido na agricultura. In: TSUTIYA, M. T. et al. Biossólidos na agricultura. 2 ed. São Paulo: Abes/SP, 2002. cap. 12, p. 365-403.

MARTIN, J. H.; BOSTAIN, H. E.; STERN, G. Reduction of enteric microorganisms during aerobic sludge digestion. Water Research, v. 24, p. 1377-1385, 1990.

MARTINEZ, J. C.; HINOJOSA, J. T.; ROMERO, L. H.; OLIVARES, E. S.; MONTES, F. C.; BOLIVAR, S. S. Residual effect of biosolids in cauliflower (Brassica oleracea var. Botrytis) regarding yield, essential and heavy metal concentration in heads and soil. In: CONFERENCE IWA, 2001, Acapulco - México. Proceedings...IWA, 2001. p. 620-623.

MARTINS, D. R. Estado nutricional e qualidade de bebida em cafeeiros tratados com lodo de esgoto. 2003. 98 f. Dissertação (Mestrado). Instituto Agronômico de Campinas, Campinas, São Paulo, 2003.

MARTINS, S. S. Adenovirus e rotavírus como indicadores biológicos em águas residuárias de esgotos sanitários após passagem por tratamento por processo anaeróbio e disposição controlada no solo. 2006. 63f. Dissertação (Mestrado). Universidade Estadual de Campinas, Campinas, São Paulo, 2006.

MATTHEWS, P. J. Control of metal application rates from sewage sludge utilization in agriculture. CRC Critical Reviews Environmental Control, v. 14, p. 199-250, 1984.

MATTHEWS, P. A global atlas of wastewater sludge and biosolids use and disposal. Scientific and Technical Report No 4, London: IAWQ, 1997. 197p.

McBRIDE, M. B. Toxic metal accumulation from agricultural use of sludge: are USEPA regulations protective? Journal of Environmental Quality, n. 24, 1995. p. 5-18. 
McBRIDE, M. B.; RICHARDS, B. K.; STEENHUIS. T.; RUSSO, J. J.; SAUVE, S.; Mobility and solubility of toxic metals and nutrients in soil fifteen years after sludge application. Soil Science, v. 162, p. 487-500, 1997.

MEAD, P. S.; GRIFFIN, P. M. Escherichia coli O157:H7. The Lancet, v. 352, p. 1207-1212, 1998.

MEAD, P. S.; SLUTSKER, L.; DIETZ, V.; McCAIG, L. F.; BRESEE, J. S.; SHAPIRO, C.; GRIFFIN, P. M.; TAUXE, R. V. Food-related illness and death in the United States. Emerging Infectious Diseases, v. 5, n. 5, p. 607-625, 1999.

MEHNERT, D. U.; STEWIEN, K. E. Detection and Distribution of Rotavirus in Raw Sewage and Creeks in Sao Paulo, Brazil. Applied and Environmental Microbiology, v. 59, n. 1, p. 140-143, 1993.

MEHNERT, D. U.; Pesquisa de virus entéricos em lodo de esgoto. Relatório 1, ICB-USP, 2008

MELLIS, E. V. Adsorção e dessorção de Cd, Cu, Ni e Zn, em solo tratado com lodo de esgoto. 2006. 174 f. Tese (Doutorado) - Escola Superior de Agricultura Luiz de Queiroz, Piracicaba, 2006.

MELO, W. J.; MARQUES, M. O. Potencial do lodo de esgoto como fonte de nutrientes para as plantas. In: BETTIOL, W. e CAMARGO, O. A. (Coord). Impacto ambiental do uso agrícola do lodo de esgoto. Jaguariúna: Embrapa Meio Ambiente, 2000. cap. 5, p. 109-141.

MELO, W. J.; MARQUES, M. O.; MELO, V. P. O uso agrícola do biossólido e as propriedades do solo. In: TSUTIYA, M. T. et al. Biossólidos na agricultura. 2 ed. São Paulo: Abes/SP, 2002. cap. 11, p. 289-363.

MENG, Z.; BIRCH, C.; HEALTH, R.; GUST, I. Physicochemical stability and inactivation of human and simian rotaviruses. Appl Environ Microbiol., v. 53, p. 727-730, 1987.

METCALF T. G.; MELNICK, J. L.; ESTER, M. K. Environmental virology: from detection of virus in sewage and water by isolation to identification by molecular biology - a trip of over 50 years. Ann. Ver. Microbiology, v. 49, p. 461-487, 1995.

MIKI, M. K.; ALEM SOBRINHO, P.; VAN HAANDEL, A. C. Tratamento da fase Sólida em Estações de tratamento de Esgotos - Condicionamento, Desaguamento Mecanizado e Secagem Térmica do Lodo. In: ANDREOLI, C. V (coordenador). Alternativas de Uso de resíduos do Saneamento. Rio de Janeiro: ABES, 2006.

MINEROPAR. Caracterização tecnológica de rochas calcárias para corretivo de solos. Disponível em $<$ http://www.pr.gov.br/mineropar/htm/rocha/carctcorretivo.html $>$. Acesso em: 20 set. 2007.

MIRVISH, S. S. The significance for human health of nitrate, nitrite, and N-nitroso compounds. In: BOGARDI, I.; KUZELKA, R. D. (Ed.). Nitrate Contamination. Springer, Berlin, p. 253-266. 1991 apud CAMERON, K. C.; RATE, A. W.; NOONAN, M. J.; 
MOORE, S.; SMITH, N. P.; KERR, L. E. Lysimeter study of the fate of nutrients following subsurface injection and surface application of dairy pond sludge to pasture. Agriculture, Ecosystems and Environment, v. 58, p. 187-197, 1996.

MONNEY, L. Beneficial use program for New York city's sludge. BioCycle Emmaus, v. 22, n. 8, p.72-73, 1992.

MONTAG, D.; GETHKE, K; PINNEKAMP J. A Feasible Approach of Integrating Phosphate Recovery as Strutive at Waste Water Treatment Plants. In: Wasterwater Biosolids Sustainability: technical, managerial, and public synergy, 2007, New Brunsvick - Canadá. Proceedings...Canadá: IWA, 2007. p. 551- 558.

MORACE, G.; AULICIANO, F. A.; ANGELOZZI, C.; COSTANZO, L.; DONADIO, F.; RAPICETTA, M. Microbial quality of wastewater: detection of hepatitis A vírus by reverse transcriptase-polymerase chain reaction. Journal of Applied Microbiology, v. 92, p. 826-836, 2002.

MORITA, D. M. Tratabilidade de águas residuárias contendo poluentes perigosos: estudo de caso. 1993. 885 f. Tese (Doutorado) - Escola Politécnica, Universidade de São Paulo, São Paulo, 1993.

MOURA, A. N. Remediação de áreas contaminadas com metais pesados utilizando Acidithiobacillus sp. 2006. 251 f. Tese (Doutorado) - Escola Politécnica, Universidade de São Paulo, São Paulo, 2006.

MOURIM, R. No caminho da universalização. Revista Brasileira de Saneamento e Meio Ambiente, Rio de Janeiro, ano XVI, n. 41, p. 30-35, jan./mar. 2007.

MUlleR, M.; PATUREAU, D.; BALAGUER, P.; DELGENES, N.; DAGNINO, S.; DELGENES, J. P.; HERNANDEZ-RAQUET, G. Assessment of estrogenic and xenobiotic receptor ctivities in combination with chemical analysis of micropollutants during wastewater biosolids composting. In: CONFERENCE IWA, 2007, Canadá. Proceedings...WEF, 2007. p. 655-663.

NAGAR, R.; SARKAR, D.; DATTA, R. Effect of sewage sludge addition on soil quality in terms of metal concentrations. Environmental Contamination Toxicology. v. 76, p. 823-830, 2006.

NELL, J. H.; STEER, A. G.; VAN RENSBURG, P. A. J. Hygienic quality of sewage sludge compost. Water Science Technology, v. 15, p. 181-194, 1983.

NELSON, K. L. Concentrations and inactivation of Ascaris eggs and pathogen indicator organisms in wastewater stabilization pond sludge. Water Science Technology, v. 48, n. 2, p. 89-95, 2003.

NOGUEIRA, T. A. R.; SAMPAIO, R. A.; FERREIRA, C. S.; FONSECA, I. M. Produtividade de milho e de feijão consorciados adubados com diferentes formas de lodo de esgoto. Revista de Biologia e Ciências da Terra. v. 6, n. 1, p. 122-131, 2006. 
NRC- National Research Council. Committee on the Use of Treated Municipal Wastewater Effluents and Sludge in the Production of Crops for Human Comsuption. Use of Reclaimed Water and Sludge in Food Crop Production. Washington, D.C.: National Academy Press, 1996. $178 \mathrm{p}$.

NRC - National Research Council. Biosolids applied to land: advancing standards and practices. Washington DC: National Academy Press, 2002. 178p.

O’CONNOR, G. A.; ELLIOT, H. A.; BASTA, N. T.; BASTIAN, R. K.; PIERZYNSKI, G. M.; SIMS, R. C.; SMITH JR, J. E. Sustainable land application: An overview. Journal Environmental Quality, v. 34, p. 7-17, 2005.

OLIVEIRA, L. H. S. Adenoviridae. In: Virologia Humana. Rio de Janeiro: Cultura Médica, 1994. cap. 21, p. 232-240.

OUTWATER, A. B. Reuse of sludge and minor wastewater residuals. Florida: CRC Press, 1994. 179p.

PARKINSON, R., GIBBS, P., BURCHETT, S., MISSELBROOK, T. Effect of turning regime and seasonal weather conditions on nitrogen and phosphorus losses during aerobic composting of cattle manure. Bioresource Technology. v. 91, p. 171-178, 2004.

PARKSON CORPORATION, 2007. Disponível em: <http://www.parkson.com/ Content.aspx?ntopicid=137\&parent=process\&processID=156> Acesso em: $11 \mathrm{dez} .2007$.

PARRAVICINI, V.; SVARDAL, K.; HORNEK, R.; KROISS, H. Aeration of anaerobically digested sewage sludge for COD and Nitrogen removal: optimization at large-scale. In: Wastewater Biosolids Sustainability: technical, managerial and public synergy, 2007, New Brunsvick - Canadá. Proceedings...Canadá: IWA, 2007. p. 691-698.

PASSAMANI, F. R. F. Remoção de coliformes fecais e ovos de helmintos em uma ETE do tipo UASB + Biofiltro aerado submerso tratando esgoto sanitário e em lodo anaeróbio submetido à higienização por calagem ou por pasteurização. Dissertação (Mestrado) Universidade Federal do Espírito Santo, Vitória, 2001.

PATRI, M. P. M. Legislación sobre lodos en Ámerica Latina: un análisis comparativo. In: CONGRESO INTERAMERICANO AIDIS, 31, 2008, Santiago - Chile. Palestra ...Chile: AIDIS, 2008.

PAULRAJ, C; RAMULU, U. S. Effect of soil application of low levels of urban sewage sludge on the uptake of nutrients and yield of certain vegetables. Journal of the Indian Society of Soil Science, v. 42, n. 3, p. 485-487, 1994.

PAYMENT, P.; FORTIN, S.; TRUDEL, M. Elimination of enteric viruses during conventional wastewater treatment by activated sludge. Canadian Journal Microbioogy, v. 32, p. 922-925, 1986. 
PECKENHAM, J. M. The use of biosolids in Maine: A review. 2005. Disponível em: $<$ http://www.umaine.edu/waterresearch/outreach/biosolids_white_paper.htm $>$. Acesso em : 15 dez. 2007.

PEGORINI, E. S.; HOPPEN, C.; TAMANINI, C. R.; ANDRADE, F. L.; TORREZAN, H. T. Aperfeiçoamento do processo de higienização através da caleação: I potencial de alcalinização prolongada. In: Simpósio Ítalo Brasileiro de Engenharia Sanitária e Ambiental, 8., 2006, Fortaleza. Anais... Rio de Janeiro: Abes, 2006b. 1 CD-ROM.

PEGORINI, E. S.; TAMANINI, C. R.; HOPPEN, C.; LEITE, B. Z.; WEIGERT, G. Aperfeiçoamento do processo de higienização através da caleação: I potencial de pasteurização. In: Simpósio Ítalo Brasileiro de Engenharia Sanitária e Ambiental, 8., 2006, Fortaleza. Anais...Rio de Janeiro: Abes, 2006a. 1 CD-ROM.

PEREIRA JUNIOR, A. B.; SOUZA, J. L.; GONÇALVES, R. F. Utilização de lodo gerado em processo anaeróbio tipo tanque Imhoff como insumo agrícola para a cultura do repolho (Brascica oleracia L.). In: Anais SEMINÁRIO SOBRE GERENCIAMENTO DE BIOSSÓLIDOS DO MERCOSUL, 1., 1998, Curitiba. Trabalhos técnicos... São Paulo: Sanepar/Abes, 1998. p. 257-265.

PIERZYNSKI, G. M. Plantnutrient aspects of sewage sludge. In: CLAPP, C. E.; LARSON, W. E.; DOWDY, R. H. (Ed.). Sewage sludge: land utilization and the environment. Madison. WI, USA: American Society of Agonomy: Crop Science Society of America, 1994. p. 21-25.

PIETRONAVE, S.; FRACCHIA, L.; RINALDI, M.; MARTINOTTI, M. G. Influence of biotic and abiotic factors on human pathogens in a finished compost. Water Research, v. 38, p. 1963-1970, 2004.

PINA, S.; PUIG, M.; LUCENA, F.; JOFRE, J.; GIRONES, R. Viral pollution in the environment and in shellfish: human adenovirus detection by PCR as an index of human viruses. Appl. Environ. Microbiol. V. 64, p. 3376-3382, 1998.

PINTO, M. T. Higienização de lodos. In: ANDREOLI, C. V.; VON SPERLING, M.; FERNANDES, F. Lodo de esgoto: tratamento e disposição final. Belo Horizonte: Departamento de Engenharia Sanitária e Ambiental-UFMG; Companhia de Saneamento do Paraná, 2001. v. 6, cap. 6, p.261-296.

PLANCHÁ, I.; VENGLOVSKÝ, J.; MAKOVÁ, Z.; MARTINÉZ, J. The elimination of Salmonella typhimurium in sewage sludge by aerobic mesophilic stabilization and lime hydrated stabilization. Bioresource Technology, v. 99, p. 4269-4274, 2008.

QASIM, S. R. Wastewater treatment plants - Planning, design and operation. Florida, USA: CRC Press LLC, 1999. 1107p.

RAMIREZ, A.; MALINA, J. F. Chemicals desinfect sludge. Water and Sewage Works, v. 127, n. 4, p. 52-5, 1980.

RENNER, R. Sewage sludge: Pros \& Cons. Environmental Science and Technology, v. 34, p. 430A-435A, 2000. 
RENOUX, A. Y.; ROCHELEAU, S.; SARRAZIN, M.; SUNAHARA, G. I.; BLAIS , J. F. Assessment of a sewage sludge treatment on cadmium, copper and zinc bioavailability in barley, ryegrass and earthworms. Environmental Pollution, v. 145, p. 41-50, 2007.

RITTER, D. Gravity belt thickening and lime stabilization. Water Environmental Technology, December, 1990 apud OUTWATER, A. B. Reuse of sludge and minor wastewater residuals. Florida: CRC Press, 1994. 179p.

RITTO, A. C. A.; MACHADO FILHO, N. O caminho da escola virtual: um ensaio carioca. Rio de Janeiro: Consultor: Faculdade Carioca, 1995.

ROMERO, J. R. Reverse -Transcription polymerase chain reaction: Detection of the enteroviruses. Pediatric Infectious Disease Journal, v. 123, p. 1161-1169, 1999.

ROS, C. O.; AITA, C.; CERETTA, C. A.; FRIES, M. R. Lodo de esgoto: efeito imediato no milheto e residual na associação aveia-preta-ervilhaca. Revista Brasileira de Ciência do Solo, v. 17, p. 257-261, 1993.

ROS, M.; ZUPANCIC, G. D. Thermophilic aerobic digestion of waste activated sludge. Acta Chimica Slovenica, v. 49, p. 931-943, 2002.

RUDOLFS, W.; GEHM, H. W. Chemical composition of sewage sludges, with particular reference to their phosphoric acid contents. Bulletin 699, New Jersey: Agricultural Experiment Station, Rutgers University, New Brunswick, USA. 1942 apud CHANG, A. C.; PAN, G.; PAGE, A. L.; ASANO, T. Developing human health-related chemical guidelines for reclaimed water and sewage sludge applications in agriculture. WHO - World Health Organization, 2002.

SAABYE, A. ; KRÜGER, A. S. ; SCHWINNING, H. G. Treatment and beneficial use of sewage sludge in the European Union. ISWA Times 3, p. 1-6, 1994.

SAHLSTRÖM, L. A review of survival of pathogenic bacteria in organic waste used in biogas plants. Bioresource Technology, v. 87, p. 161-166, 2003.

SANCHES, S. M.; SILVA, C. H. T. P. DA; CAMPOS, S. X. DE; VIEIRA, E. M. Pesticidas e seus respectivos riscos associados à contaminação da água. Ecotoxicologia e Meio Ambiente, Curitiba, v. 3, p 53-58, jan/dez. 2003.

SANEPAR, Manual técnico para utilização agrícola do lodo de esgoto do Paraná: Sanepar, 1997. 96p.

SANTOS, H. F. Aplicação do lodo de estações de tratamento de esgoto em solos agrícolas. Revista DAE, v. 39, n. 122, p. 31-38, 1979.

SANTOS, H. F. Normatização para o uso agrícola dos biossólidos no exterior e no Brasil. In: ANDREOLI, C. V.; VON SPERLING, M.; FERNANDES, F. Lodo de esgoto: tratamento e disposição final. Belo Horizonte: Departamento de Engenharia Sanitária e Ambiental-UFMG; Companhia de Saneamento do Paraná, 2001. v. 6, cap. 10, p. 425-464. 
SASSAROLI, A. Virus da Hepatite A: A presença e identificação dos genótipos circulantes nas águas de esgoto e de superfície da cidade de São Paulo, Brasil. 2002.118 f. Dissertação (Mestrado) - ICB/USP, São Paulo, 2002.

SCHEUERMAN, P. R.; FARRAH, S. R.; BITTON, G. Laboratory studies of virus survival during anaerobic digestion of sewage sludge. Water Research, v. 3, p. 241-245, 1991.

SCHLÜSENER, M. P.; BESTER, K. Persistence of antibiotics such as macrolides, tiamulin and salinomycin in soil. Environmental Pollution, n. 143, p. 565-571, 2006.

SCHWABE, W. K.; LEÃO, M. M. D.; CAVALCANTI, L. F. N. Tratamento e disposição final de lodos de unidades de tratamento biológico e físico-químico. In: CONGRESSO BRASILEIRO DE ENGENHARIA SANITÁRIA E AMBIENTAL, 21., 2001, João Pessoa. Anais...Abes, 2001. 1 CD-ROM.

SCHWARTZBROD, L. Effect of human viruses on public health associated withthe use of wastewater and sludge in agriculture and aquaculture. Geneva: WHO, 1995. 179p.

SCHWARTZBROD, J. S.; BANAS, S. Parasite contamination of liquid sludge from urban wastewater treatment plants. Water Science Technology, v. 47, n. 3, p. 163-166, 2003.

SCOTT, E. Hygiene issues in the home. Association for Professionals in Infection Control and Epidemiology, v. 27, n. 6, 1999.

SHIM, E; BANKS, H.T.; CASTILLO-CHAVEZ, C. Seasonality of Rotavirus Infection with its Vaccination. North Carolina: Statistical and applied mathematical sciences institute SAMSI, 2006. 21 p. Technical Report.

SHUVAL, H. I.; ADIN, A.; FATTAL, B.; RAWITZ, E.; YEKUTIEL, P. Wastewater irrigation in developing countries: health effects and technical solutions. World Bank Tech, Washington (DC), n. 51, 1986.

SIDHU, J.; GIBBS, G. A.; HO, G. E.; UNKOVICH, I. The role of indigenous microorganisms in suppression of Salmonella regrowth in composted biosolids. Water Research, v. 35, n. 4, p. 913-920, 2001.

SIDHU, J. P. S.; TOZE, S. G. Human pathogens and their indicators in biosolids: A literature review. Environment International, v. 35, p. 187-201, 2009.

SILVA, J. E.; DIMAS, V. S. R.; SHARMA, R. D. Alternativa agronômica para o biossólido: a experiência de Brasília. In: BETTIOL, W.; CAMARGO, O. A. (Coord). Impacto ambiental do uso agrícola do lodo de esgoto. Jaguariúna: Embrapa Meio Ambiente, 2000, p. 143-162.

SILVA, F. C.; BOARETTO, A. E.; BERTON, R. S.; ZOTELLI, H. B.; PEXE, C. A.; BERNARDES, E. M. Efeito de lodo de esgoto na fertilidade de um argissolo vermelhoamarelo cultivado com cana-se-açúcar. Pesquisa Agropecuária Brasileira, Brasília, v. 36, n. 5, 2001. p. 831-840. 
SILVA, S. M. C. P.; FERNANDES, F.; THOMAZ-SOCCOL, V.; MORITA, D. M. Principais contaminantes do lodo. In: ANDREOLI, C. V.; VON SPERLING, M.; FERNANDES, F. Lodo de esgoto: tratamento e disposição final. Belo Horizonte: Departamento de Engenharia Sanitária e Ambiental-UFMG; Companhia de Saneamento do Paraná, 2001. v. 6, cap. 3, p. 69-121.

SKANAVIS, C.; YANKO, W. A. Evaluation of composted sewage sludge based soil amendments for potential risks of salmonellosis. Journal Environmental Health, v. 56, n. 7, p. 19-23, 1994.

SMI. Infectious diseases 1999. Swedish Institute for Infectious Disease Control, Stockholm, Sweden. 2000.

SMITH, S.R. Pathogenic organisms in agricultural recycling of sewage sludge and the environment. CAB International, Wallingford, UK, 1996.

SMITH, H. V. Detection of parasites in the environment. Parasitology, v. 117, p. 113-141, 1998.

SMITH JR, J. E.; MILLNER, P. D.; JAKUBOWSKI, W.; GOLDSTEIN, N.; RYNK, R. (Ed.) Contemporary perspectives on infectious disease agents in sewage sludge and manure. Emmaus, Pennsylvania: The JG Press, Inc., 2004. ISBN 0932424-28-7.

SOARES, A. C.; STRAUB, T. M.; PEPPER, I. L.; GERBA, C. P. Effect of anaerobic digestion on the occurrence of enteroviruses and Giardia cysts in sewage sludge. Journal Environmental Science Health, Part A Environmental Science Engineering, v. 29, p. 18871897, 1994.

SOARES, E. M. B. Impacto de aplicações sucessivas de lodo de esgoto sobre os compartimentos de carbono orgânico em latossolo cultivado com milho. Dissertação (Mestrado) - Universidade Federal de Lavras, Lavras. 2005.

SONG, Y. C.; NGUYEN, T. T.; KIM, S. H.; KIM, G. J.; PARK, H. S, KO, S. J.; LEE, C. Y. Cultivation of Functional Microbial Consortium Using Biosolids and Its Effectiveness for Remediation of Soil Contaminated with Diesel Oil. In: Wastewater Biosolids Sustainability: technical, managerial and public synergy, 2007, New Brunsvick - Canadá. Proceedings...Canadá: IWA, 2007. p. 1123-1128.

SPELLMAN, F. R. Dewatering biosolids. Technomic Publishing Company, Inc., 1997.

SPINOSA, L.; VESILIND, P. Sludge into Biosolids, processing, disposal, utilization. IWA Publishing, United Kingdom, 2001. 394 p.

SPINOSA, L. Status and perspectives of sludge management. In: Wastewater Biosolids Sustainability: technical, managerial and public synergy, 2007, New Brunsvick - Canadá. Proceedings...Canadá: IWA, 2007. p. 103-108. 
STEPHENSON, T. Sources of heavy metals in wastewater. In: LESTER, J. N. (Ed.). Heavy metals in wastewater and sludge treatment processes. Boca Raton, Fla.: CRC Press, 1987. v. 1, cap. 2, p. 31-63.

STEVENSON, F. J. Organic matter-micronutrient reactions in soil. In MORTVEDT, J. J.; COX, F. R.; SHUMAM, L. M.; WELCH, R. M. (Ed.) Micronutrients in agriculture. Madison: Soil Science Society of America, 1991. p.145-186.

STRAUB, T. M.; PEPPER, I. L.; GERBA, C. P. Persistence of viruses in desert soils amended with anaerobically digested sewage sludge. Applied Environmental Microbiology, v. 58, n. 2, p. 636-641, 1992.

STRAUB, T. M.; PEPPER, I. L.; GERBA, C. P. Hazards from pathogenic microorganisms in landdisposed sewage sludge. Environmental Contamination Toxicology, v. 132, p. 55-91, 1993.

TAKAMATSU, A. A. Avaliação da biolixiviação de metais pesados por bactérias do gênero Thiobacillus em lodos biológicos para utilização agrícola como fertilizante. $1995.95 \mathrm{f}$. Dissertação (Mestrado em Ciência do Solo) - Universidade Federal do Paraná, Curitiba, 1995.

TARUYA, T.; OKUNO, N.; KANAYA, K. Reuso of sewage sludge as raw material of portland cement in Japan. In: CONFERENCE IWA, 2001, Acapulco - México. Proceedings...IWA, 2001. p. 594-599.

TASK FORCE ON SLUDGE STABILIZATION. Sludge stabilization. Washington, D.C.: Water Pollution Control Federation, 1985. 106 p.

TAUXE, R. V.; COHEN, M. L. Epidemiology of diarrheal diseases in developed countries. In: BLASER, M. J.; SMITH, P. D.; RAVDIN, J. I.; GREENBERG, H.B. (Ed.) Infections of the gastrointestinal tract. Raven Press, Ltd., New York, NY, USA. 1995. p. 37-51.

TCHOBANOGLOUS, G.; BURTON, F. L.; STENSEL, H. D. Wastewater engineering: treatment, disposal, and reuse. 4rd ed. Metcalf \& Eddy, Inc. New York: McGraw Hill, 2002. 1848 p.

TERATANI, T.; OKUNO, N.; KOUNO, K. New technology to manufacture fine spherical ceramic from sewage sludge. In: CONFERENCE IWA, 2001, Acapulco - México. Proceedings... IWA, 2001. p. 296-303.

THOMAS, C. N.; BAUERLE, W. L.; CHASTAIN, J. P.; OWINO, T. O.; MOORE, K. P.; KLAINE, S. J. Effects of scrubber by-product-stabilized dairy lagoon sludge on growth and physiological responses of sunflower (Helianthus annuus L.). Chemosphere. v. 64, p. 152$160,2006$.

THOMAZ-SOCCOL, V.; PAUlinO, R. C.; CASTRO, E. A. Helminth eggs viability in sewage and biosolids sludge in Curitiba, Paraná, Brazil. Brazilian Archives of Biology and Technology, v. 40, n. 4, p. 829-836, 1997. 
THOMAZ-SOCCOL, V.; PAULINO, R. C.; CASTRO, E. A.; TRACZ, J. Eficácia dos diferentes processos de tratamento do lodo na redução da viabilidade de ovos viáveis de helmintos. Sanare, v. 8, n. 8, p. 24-32, 1998.

THOMAZ-SOCCOL, V.; PAUlinO, R. C.; CASTRO, E. A. Metodologia de Análise Parasitológica em Lodo de esgoto e Esgoto.. In: ANDREOLI, C. V.; BONNET, B. R. P. (Orgs.). Manual de métodos para análises microbiológicas e parasitológicas em reciclagem agrícola de lodo de esgoto. Curitiba: Sanepar; Prosab, 2000.

THOMAZ-SOCCOL, V. Aspectos sanitários do lodo de esgoto. In: Anais SEMINÁRIO SOBRE GERENCIAMENTO DE BIOSSÓLIDOS DO MERCOSUL, 1., 1998, Curitiba. Palestras... São Paulo: Sanepar/Abes, 1998. p. 65-72.

THOMPSON, J.; SLOLEY, T.; JANIEC, J. P. Award process for a quality-based biosolids management program in Durham region. In: Wasterwater Biosolids Sustainability: technical, managerial, and public synergy, 2007, New Brunsvick - Canadá. Proceedings...Canadá: IWA, 2007. p. 875-880.

TSUTIYA, M. T. Alternativas de disposição final de biossólidos gerados em estações de tratamento de esgotos. In: BETTIOL, W.; CAMARGO, O. A. (Coord). Impacto ambiental do uso agrícola do lodo de esgoto. Jaguariúna: Embrapa Meio Ambiente, 2000. cap. 4, p. 69105.

TSUTIYA, M. T. Características de biossólidos gerados em estações de tratamento de esgotos. In: TSUTIYA et al. (Eds.). Biossólidos na agricultura. São Paulo: Sabesp, 2002. cap. 4, p. 89-131.

TSUTIYA, M. T.; COMPARINI, J. B.; ALÉM SOBRINHO, P.; HESPANHOL, I.; CARVAlHO, P. C. T.; MELFI, A. J.; MELO, W. J.; MARQUES, M. O. Biossólidos na agricultura. 2. ed. São Paulo: Abes/SP, 2002. 468 p.

ULFIG, A. The factors influencing the incidence of keratinolytic and keratinophilic fungi in sewage sludge. Scientific Bulletin of Łodz' Technical University, n. 932, 2003.

ULFIG K.; PLAZA, G.; TERAKOWSKI, M.; MANKO, T. Investigation of keratinolytic and non-keratinolytic fungi grown above or below a $1-\mathrm{cm}$ sewage sludge blanket. International Biodeterioration \& Biodegradation, v. 59, p. 119-124, 2007.

UREN, N.C. Forms, reactions and availability of nickel in soils. Advances in agronomy, New York, v. 48, p. 141-203, 1992.

US EPA - UNITED STATES ENVIRONMENTAL PROTECTION AGENCY. Land application of sewage sludge and domestic septage - Process design manual. EPA/625/R95/001: Cincinnati, 1995. 290p.

Biosolids generation, use, and disposal in the United States. EPA/530/R-99/009: Cincinnati, 1999. 74p. 
Water biosolids/sewage sludge use and disposal. EPA/822/F-92/002: Cincinnati, 2000.

Control of pathogens and vector attraction in sewage sludge. EPA/625/R-92/013: Cincinnati, 2003. 177p.

Test Methods for Evaluating Solid Waste, Physical Chemical Methods. Washington: SW-846, 3 ed, 1980. Disponível em: < http://www.epa.gov/epaoswer/hazwaste/test/ sw846.htm>. Acesso em: 16 abr. 2007.

Biosolids applied to land: advancing standards and practices. Washington: National Academy Press, 2002. 266 p. Disponível em: <http://www.epa.gov/ost/biosolids $>$. Acesso em: 15 nov. 2007.

USDA Study Team on Organic Farming. Report and recommendation on organic farming. Washington (DC): The Dept., US Government Printing Office, 1980. 94 p.

VAN HAANDEL, A. C.; LETTINGA, G. Tratamento anaeróbio de esgotos. Um manual para regiões de clima quente. Campina Grande: Epgraf, 1994. 125p. apud VON SPERLING, M.; GONÇALVES, R. F. Lodo de esgoto: características e produção. In: ANDREOLI, C. V.; VON SPERLING, M.; FERNANDES, F. Lodo de esgoto: tratamento e disposição final. Belo Horizonte: Departamento de Engenharia Sanitária e Ambiental-UFMG; Companhia de Saneamento do Paraná, 2001. v. 6, cap. 2, p.17-67.

VAN HAANDEL, A. C.; MARAIS, G. O comportamento do sistema de lodo ativado: Teoria e aplicações para projetos e operação. Campina Grande: Epgraf, 1999. 488p.

VAN HAANDEL, A. C.; ALÉM SOBRINHO, P. Produção, composição e constituição de lodo de esgoto. In: ANDREOLI, C. V. (Coord.). Alternativas de uso de resíduos do saneamento. Rio de Janeiro: Abes, 2006. cap. 2, p. 7-28.

VAN HAM, M. D.; HUTCHISON, J. S.; DAMPIER, L. M. B.; VIEIRA, D. B. A regional approach to biosolids management: The Sechelt experience. In: Wastewater Biosolids Sustainability: technical, managerial and public synergy, 2007, New Brunsvick - Canadá. Proceedings...Canadá: IWA, 2007. p. 897-903.

VEOLIA Water Solutions \& Technologies. Disponível em: <http://www.veoliawaterst.com/ solia/en/?org=vws.en>. Acesso em: 11 dez. 2007.

VESILIND, P. A. - Sludge dewatering: why the water will win every time. In:. PROCEEDINGS OF THE $49^{\text {th }}$ INDUSTRIAL WASTE CONFERENCE. Indiana: Purdue University, Lewis Publishers, 1995, p. 1-8.

VILLAR, L. D. Estudo da lixiviação bacteriana de metais presentes em lodo de esgoto sanitário. 2003. 126 f. Tese (Doutorado) - Instituto de Química, Universidade Estadual Paulista, Araraquara, 2003.

VON SPERLING, M; ANDREOLI, C. V. Introdução. In: ANDREOLI, C. V.; VON SPERLING, M.; FERNANDES, F. Lodo de esgoto: tratamento e disposição final. Belo 
Horizonte: Departamento de Engenharia Sanitária e Ambiental-UFMG; Companhia de Saneamento do Paraná, 2001. v. 6, cap. 1, p.13-14.

VON SPERLING, M.; GONÇALVES, R. F. Lodo de esgoto: características e produção. In: ANDREOLI, C. V.; VON SPERLING, M.; FERNANDES, F. Lodo de esgoto: tratamento e disposição final. Belo Horizonte: Departamento de Engenharia Sanitária e Ambiental-UFMG; Companhia de Saneamento do Paraná, 2001. v. 6, cap. 2, p.17-67.

WARMAN, P. R.; TERMEER, W. C. Evaluation of sewage sludge, septic waste and sludge compost applications to corn and forage: yields and N, P and $\mathrm{K}$ content of crops and soils. Bioresource Technology. v. 96, p. 955-961, 2005.

WATTIE, E; CHAMBERS, C.W. Relative resistence of coliform organisms and certain enteric pathogens to excess-lime treatment. Journal American Water Works Association. v. 35, n. 6, p.709-20, 1943 apud MALTA, L. R. S. Otimização da estabilização cálcica do biossólido para uso agrícola. Estudo de caso: ETE Lavapés/São José dos Campos. 2002. Dissertação (Mestrado) - Escola Politécnica, Universidade de São Paulo, São Paulo, 2002.

WEISZ, N.; KEPP, U.; NORLI, M.; PANTER, K.; SOLHEIM, O. E. Sludge disintegration with thermal hydrolysis - cases from Norway, Denmark and United Kingdom. In: World Water Congress, 1., 2000, Paris - França. Proceedings...França: IWA, 2000. p. 288-295. (?)

WESTPHAL, A.; CHRISTENSEN, G.L. Lime stabilization: effectiveness of two process modifications. Journal Water Pollution Control Federation, v. 55, n.11, 1983. p. 1381-86 apud MALTA, L. R. S. Otimização da estabilização cálcica do biossólido para uso agrícola. Estudo de caso: ETE Lavapés / São José dos Campos. 2002. Dissertação (Mestrado) - Escola Politécnica, Universidade de São Paulo, São Paulo, 2002.

WONG, J. W. C.; GU, X. Y. Optimization of Fe2+/solids content ratio for a novel sludge heavy metal bioleaching process. In: Wastewater Biosolids Sustainability: technical, managerial and public synergy, 2007, New Brunsvick - Canadá. Proceedings...Canadá: IWA, 2007. p. 255-261.

WOODWARD, D. L.; KHAKHRIA, R.; JOHNSON, W. M. Human salmonellosis associated with exotic pets. Journal of Clinical Microbiology, v. 35, p. 2786-2790, 1997.

WRIGHT, J. Biosolid recycling and food safety issus. Environmental Science and Technology, n. 15, p.43-78, 2001.

WWF - Brasil. Disponível em: http://www.wwf.org.br/natureza_brasileira/ meio_ambiente_brasil/clima/painel_intergovernamental_de_mudancas_climaticas/index.cfm clima/painel_intergovernamental_de_mudancas_climaticas/index.cfm. Acesso em: 04 dez. 2007.

YEAGER, J. G.; O'BRIEN, R. T. Irradiation as a means to minimize public health risks from sludge-borne pathogens. Water Pollution Control Federation, v. 55, Issue 7, 1983 apud COMPARINI, J. B. Estudo do decaimento de patógenos em biossólidos estocados em valas e em biossólidos submetidos à secagen en estufa. 2001. 278 f. Tese (Doutorado) - Escola Politécnica, Universidade de São Paulo, São Paulo, 2001. 


\section{APÊNDICE}

APÊNDICE 1 - Resultados de ovos de helmintos totais, viáveis e inviáveis - Etapa 1

\begin{tabular}{|c|c|c|c|c|c|c|c|c|c|c|c|}
\hline \multicolumn{4}{|c|}{$1^{\text {a }}$ CICLO } & \multicolumn{4}{|c|}{$2^{\mathrm{a}}$ CICLO } & \multicolumn{4}{|c|}{$3^{\text {a }}$ CICLO } \\
\hline \multicolumn{4}{|c|}{ (n ${ }^{\mathrm{a}}$ ovos/gMS) } & \multicolumn{4}{|c|}{ (n ${ }^{\mathrm{a}}$ ovos/gMS) } & \multicolumn{4}{|c|}{ (n ${ }^{\text {a }}$ ovos/gMS) } \\
\hline \multicolumn{4}{|c|}{ 20/01/07 } & \multicolumn{4}{|c|}{$18 / 04 / 07$} & \multicolumn{4}{|c|}{ 05/07/07 } \\
\hline Amostras & Totais & Viáveis & Inviáveis & Amostras & Totais & Viáveis & Inviáveis & Amostras & Totais & Viáveis & Inviáveis \\
\hline $\mathbf{L 1}$ & 0,541 & 0,128 & 0,413 & $\mathbf{L 1}$ & 0,548 & 0,232 & 0,317 & \multirow[t]{2}{*}{ L1/L2 } & \multirow[t]{2}{*}{0,891} & \multirow[t]{2}{*}{0,347} & \multirow[t]{2}{*}{0,544} \\
\hline L2 & 0,541 & 0,128 & 0,413 & L2 & 0,548 & 0,232 & 0,317 & & & & \\
\hline LC1 & 0,866 & 0,189 & 0,678 & LC1 & 0,642 & 0,123 & 0,519 & \multirow[t]{2}{*}{ LC1/LC2 } & \multirow[t]{2}{*}{0,843} & \multirow[t]{2}{*}{0,132} & \multirow[t]{2}{*}{0,711} \\
\hline LC2 & 0,866 & 0,189 & 0,678 & LC2 & 0,642 & 0,123 & 0,519 & & & & \\
\hline \multicolumn{4}{|c|}{$12 / 02 / 07$} & \multicolumn{4}{|c|}{$\frac{1}{02 / 05 / 07}$} & \multicolumn{4}{|c|}{$\frac{1}{18 / 07 / 07}$} \\
\hline Amostras & Totais & Viáveis & Inviáveis & Amostras & Totais & Viáveis & Inviáveis & Amostras & Totais & Viáveis & Inviáveis \\
\hline $\mathbf{L 1}$ & 0,463 & 0,218 & 0,245 & $\mathbf{L 1}$ & 0,451 & 0,220 & 0,232 & L1 & 0,702 & 0,269 & 0,433 \\
\hline L2 & 0,183 & 0,069 & 0,114 & $\mathbf{L 2}$ & 0,201 & 0 & 0,201 & L2 & 0,514 & 0,137 & 0,376 \\
\hline LC1 & 0,168 & 0,063 & 0,105 & LC1 & 0,246 & 0,057 & 0,189 & LC1 & 0,341 & 0,129 & 0,212 \\
\hline LC2 & 0,255 & 0,102 & 0,153 & LC2 & 0,254 & 0,114 & 0,140 & LC2 & 0,314 & 0,116 & 0,198 \\
\hline \multicolumn{4}{|c|}{$26 / 02 / 07$} & \multicolumn{4}{|c|}{$\frac{16 / 05 / 07}{16}$} & \multicolumn{4}{|c|}{$\frac{1}{01 / 08 / 07}$} \\
\hline Amostras & \begin{tabular}{|l} 
Totais \\
\end{tabular} & Viáveis & Iniviáveis & Amostras & \begin{tabular}{|l|} 
Totais \\
\end{tabular} & Viáveis & Inviáveis & Amostras & Totais & Viáveis & Inviáveis \\
\hline L1 & 0,238 & 0,101 & 0,137 & L1 & 0,149 & 0 & 0,149 & L1 & 0,408 & 0,149 & 0,259 \\
\hline L2 & 0,146 & 0 & 0,146 & L2 & 0,271 & 0,086 & 0,184 & L2 & 0,346 & 0,156 & 0,191 \\
\hline LC1 & 0,259 & 0,067 & 0,192 & LC1 & 0,148 & 0 & 0,148 & LC1 & 0,192 & 0 & 0,192 \\
\hline LC2 & 0,232 & 0,037 & 0,195 & LC2 & 0,203 & 0,091 & 0,111 & LC2 & 0,297 & 0,094 & 0,203 \\
\hline \multicolumn{4}{|c|}{$12 / 03 / 07$} & & $30 / 0$ & $5 / 07$ & & & $15 / 0$ & $8 / 07$ & \\
\hline Amostras & \begin{tabular}{|l|} 
Totais \\
\end{tabular} & Viáveis & Inviáveis & Amostras & \begin{tabular}{|l|} 
Totais \\
\end{tabular} & Viáveis & Inviáveis & Amostras & Totais & Viáveis & Inviáveis \\
\hline L1 & 0,210 & 0,098 & 0,122 & L1 & 0,214 & 0,038 & 0,176 & L1 & 0,249 & 0,110 & 0,139 \\
\hline L2 & 0,214 & 0,111 & 0,104 & L2 & 0,244 & 0,100 & 0,143 & L2 & 0,239 & 0,085 & 0,154 \\
\hline LC1 & 0,298 & 0,082 & 0,216 & LC1 & 0,135 & 0 & 0,135 & LC1 & 0,194 & 0,031 & 0,163 \\
\hline LC2 & 0,246 & 0 & 0,246 & LC2 & 0,101 & 0 & 0,101 & LC2 & 0,114 & 0 & 0,114 \\
\hline & $26 / 0$ & $3 / 07$ & & & $20 / 0$ & 6/07 & & & $29 / 0$ & $8 / 07$ & \\
\hline Amostras & Totais & Viáveis & Inviáveis & Amostras & \begin{tabular}{|l|} 
Totais \\
\end{tabular} & Viáveis & Inviáveis & Amostras & Totais & Viáveis & Inviáveis \\
\hline L1 & 0,168 & 0 & 0,168 & L1 & 0,264 & 0,052 & 0,212 & L1 & 0,251 & 0,067 & 0,183 \\
\hline L2 & 0,174 & 0,082 & 0,092 & L2 & 0,233 & 0,093 & 0,140 & L2 & 0,242 & 0,104 & 0,138 \\
\hline LC1 & 0,194 & 0 & 0,194 & LC1 & 0,112 & 0 & 0,112 & LC1 & 0,161 & 0,057 & 0,104 \\
\hline LC2 & 0,218 & 0,032 & 0,187 & LC2 & 0,098 & 0 & 0,098 & LC2 & 0,127 & 0,039 & 0,088 \\
\hline & $9 / 04$ & & & & & & & & $18 / 0$ & $9 / 07$ & \\
\hline Amostras & Totais & Viáveis & Inviáveis & & & & & Amostras & Totais & Viáveis & Inviáveis \\
\hline L1 & 0,140 & 0,036 & 0,104 & & & & & L1 & 0,116 & 0 & 0,116 \\
\hline L2 & 0,182 & 0,086 & 0,095 & & & & & L2 & 0,203 & 0,078 & 0,125 \\
\hline LC1 & 0,052 & 0 & 0,052 & & & & & LC1 & 0,175 & 0,091 & 0,084 \\
\hline LC2 & 0,175 & 0,041 & 0,134 & & & & & LC2 & 0,101 & 0 & 0,101 \\
\hline
\end{tabular}


APÊNDICE 2 - Parâmetros de interesse agronômico - Etapa 1

\begin{tabular}{|c|c|c|c|c|c|c|c|c|}
\hline \multirow{3}{*}{ Parâmetro } & \multicolumn{9}{|c|}{ LodCLO 1/1 (29/01/2007 a 04/04/2007) } \\
\cline { 2 - 11 } & \multicolumn{2}{|c|}{ L1 (\%) } & \multicolumn{2}{c|}{ L2 (\%) } & \multicolumn{2}{c|}{ LC1 (\%) } & \multicolumn{2}{c|}{ LC2 (\%) } \\
\cline { 2 - 10 } & Início & Final & Início & Final & Início & Final & Início & Final \\
\hline Matéria Orgânica & 60 & 60 & 61 & 59 & 59 & 55 & 54 & 54 \\
\hline Carbono orgânico & 34,80 & 34,80 & 35,38 & 34,22 & 34,22 & 31,90 & 31,32 & 31,32 \\
\hline $\mathrm{N}$ & 3,10 & 3,20 & 3,20 & 3,10 & 3,00 & 2,7 & 3,00 & 2,8 \\
\hline $\mathrm{P}$ & 1,60 & 1,25 & 1,73 & 1,05 & 1,31 & 1,43 & 1,49 & 1,31 \\
\hline $\mathrm{K}$ & 0,50 & 0,42 & 0,34 & 0,35 & 0,20 & 0,63 & 0,10 & 0,55 \\
\hline $\mathrm{Ca}$ & 1,17 & 0,84 & 0,82 & 0,59 & 5,53 & 7,42 & 3,48 & 7,14 \\
\hline $\mathrm{Mg}$ & 0,28 & 0,16 & 0,23 & 0,13 & 0,25 & 0,31 & 0,16 & 0,22 \\
\hline $\mathrm{S}$ & 0,76 & 0,53 & 0,63 & 0,58 & 0,55 & 0,8 & 0,52 & 0,7 \\
\hline Relação C/N & $11 / 1$ & $11 / 1$ & $11 / 1$ & $11 / 1$ & $11 / 1$ & $12 / 1$ & $10 / 1$ & $11 / 1$ \\
\hline
\end{tabular}

\begin{tabular}{|c|c|c|c|c|c|c|c|c|}
\hline \multicolumn{9}{|c|}{ CICLO 2/1 (18/04/2007 a 20/06/2007) } \\
\hline \multirow{3}{*}{ Parâmetro } & \multicolumn{4}{|c|}{ Lodo sem cal } & \multicolumn{4}{|c|}{ Lodo com cal } \\
\hline & \multicolumn{2}{|c|}{ L1 (\%) } & \multicolumn{2}{|c|}{ L2 (\%) } & \multicolumn{2}{|c|}{ LC1 (\%) } & \multicolumn{2}{|c|}{ LC2 (\%) } \\
\hline & Início & Final & Início & Final & Início & Final & Início & Final \\
\hline Matéria Orgânica & 62 & 58 & 62 & 57 & 52 & 51 & 52 & 50 \\
\hline Carbono orgânico & 35,96 & 33,64 & 35,96 & 33,06 & 30,16 & 29,58 & 30,16 & 29,00 \\
\hline $\mathrm{N}$ & 3,60 & 3,4 & 3,60 & 3,2 & 2,90 & 2,3 & 2,90 & 2,2 \\
\hline $\mathrm{P}$ & 1,70 & 1,31 & 1,70 & 1,42 & 1,03 & 1,31 & 1,03 & 1,32 \\
\hline K & 0,66 & 0,52 & 0,66 & 0,58 & 0,41 & 0,78 & 0,41 & 0,6 \\
\hline $\mathrm{Ca}$ & 1,01 & 1,18 & 1,01 & 1,4 & 5,07 & 10,4 & 5,07 & 12,1 \\
\hline $\mathrm{Mg}$ & 0,22 & 0,25 & 0,22 & 0,28 & 0,20 & 0,28 & 0,20 & 0,3 \\
\hline $\mathrm{S}$ & 0,41 & 0,52 & 0,41 & 0,64 & 0,68 & 0,7 & 0,68 & 0,76 \\
\hline Relação C/N & $10 / 1$ & $10 / 1$ & $10 / 1$ & $10 / 1$ & $10 / 1$ & $13 / 1$ & $10 / 1$ & $10 / 1$ \\
\hline
\end{tabular}

\begin{tabular}{|c|c|c|c|c|c|c|c|c|}
\hline \multicolumn{9}{|c|}{ CICLO 3/1 (05/07/2007 a 12/09/2007) } \\
\hline \multirow{3}{*}{ Parâmetro } & \multicolumn{4}{|c|}{ Lodo sem cal } & \multicolumn{4}{|c|}{ Lodo com cal } \\
\hline & \multicolumn{2}{|c|}{ L1 (\%) } & \multicolumn{2}{|c|}{ L2 (\%) } & \multicolumn{2}{|c|}{ LC1 (\%) } & \multicolumn{2}{|c|}{ LC2 (\%) } \\
\hline & Início & Final & Início & Final & Início & Final & Início & Final \\
\hline Matéria Orgânica & 61 & 59 & 61 & 66 & 55 & 67 & 55 & 64 \\
\hline Carbono orgânico & 35,38 & 34,22 & 35,38 & 38,28 & 31,90 & 38,86 & 31,90 & 37,12 \\
\hline $\mathrm{N}$ & 3,30 & 3,70 & 3,30 & 3,30 & 2,97 & 2,50 & 2,97 & 2,40 \\
\hline $\mathrm{P}$ & 1,68 & 1,36 & 1,68 & 1,65 & 1,28 & 1,40 & 1,28 & 1,25 \\
\hline $\mathrm{K}$ & 0,50 & 0,58 & 0,50 & 0,78 & 0,24 & 0,64 & 0,24 & 0,62 \\
\hline $\mathrm{Ca}$ & 1,00 & 1,14 & 1,00 & 1,22 & 4,69 & 10,00 & 4,69 & 8,24 \\
\hline $\mathrm{Mg}$ & 0,24 & 0,31 & 0,24 & 0,34 & 0,20 & 0,28 & 0,20 & 0,33 \\
\hline $\mathrm{S}$ & 0,60 & 0,77 & 0,60 & 0,95 & 0,58 & 0,82 & 0,58 & 0,71 \\
\hline Relação C/N & $11 / 1$ & $9 / 1$ & $11 / 1$ & $12 / 1$ & $10 / 1$ & $16 / 1$ & $10 / 1$ & $15 / 01$ \\
\hline
\end{tabular}


APÊNDICE 3 - Íons Metálicos - Etapa 1

\begin{tabular}{|c|c|c|c|c|c|c|c|c|c|}
\hline \multicolumn{10}{|c|}{ CICLO 1/1 (29/01/2007 a 04/04/2007) } \\
\hline \multirow{3}{*}{ Parâmetro } & \multirow{3}{*}{ Padrão (1) } & \multicolumn{4}{|c|}{ Lodo sem cal } & \multicolumn{4}{|c|}{ Lodo com cal } \\
\hline & & \multicolumn{2}{|c|}{$\begin{array}{c}\mathrm{L1} \\
\text { (mg/kg base seca) }\end{array}$} & \multicolumn{2}{|c|}{$\begin{array}{c}\text { L2 } \\
\text { (mg/kg base seca) }\end{array}$} & \multicolumn{2}{|c|}{$\begin{array}{c}\text { LC1 } \\
\text { (mg/kg base seca) } \\
\end{array}$} & \multicolumn{2}{|c|}{$\begin{array}{c}\text { LC2 } \\
\text { (mg/kg base seca) } \\
\end{array}$} \\
\hline & & Início & Final & Início & Final & Início & Final & Início & Final \\
\hline Arsênio & 41 & 8 & 12 & 12 & 15 & 11 & 9 & 18 & 21 \\
\hline Bário & 1300 & 115 & 120 & 245 & 150 & 138 & 145 & 220 & 105 \\
\hline Cádmio & 39 & 3,5 & 4,5 & 2 & 1,8 & 2,4 & 2,0 & 3,5 & 2 \\
\hline Chumbo & 300 & 8 & 11 & 18 & 20 & 12 & 9 & 15 & 13 \\
\hline Cobre & 1500 & 512 & 416 & 486 & 445 & 461 & 460 & 501 & 542 \\
\hline Cromio & 1000 & 330 & 365 & 358 & 391 & 289 & 255 & 337 & 294 \\
\hline Mercurio & 17 & 0,08 & 0,12 & 0,1 & 0,15 & 0,12 & 0,08 & 0,1 & 0,14 \\
\hline Molibidênio & 50 & 20 & 22 & 18 & 10 & 18 & 15 & 15 & 15 \\
\hline Níquel & 420 & 27 & 37 & 33 & 35 & 31 & 26 & 42 & 34 \\
\hline Selênio & 100 & 2,0 & 2,0 & 2,5 & 1,5 & 1,8 & 2,5 & 1,2 & 1,7 \\
\hline Zinco & 2800 & 670 & 381 & 588 & 550 & 720 & 490 & 612 & 658 \\
\hline
\end{tabular}

Nota: (1) - mg/kg base seca - Resolução n ${ }^{0} 375 / 2006$ do Conama (BRASIL, 2006c).

\begin{tabular}{|c|c|c|c|c|c|c|c|c|c|}
\hline \multicolumn{10}{|c|}{ CICLO 2/1 (18/04/2007 a 20/06/2007) } \\
\hline \multirow{3}{*}{ Parâmetro } & \multirow{3}{*}{ Padrão (1) } & \multicolumn{4}{|c|}{ Lodo sem cal } & \multicolumn{4}{|c|}{ Lodo com cal } \\
\hline & & \multicolumn{2}{|c|}{$\begin{array}{c}\mathrm{L1} \\
\text { (mg/kg base seca) } \\
\end{array}$} & \multicolumn{2}{|c|}{$\begin{array}{c}\text { L2 } \\
\text { (mg/kg base seca) } \\
\end{array}$} & \multicolumn{2}{|c|}{$\begin{array}{c}\text { LC1 } \\
\text { (mg/kg base seca) } \\
\end{array}$} & \multicolumn{2}{|c|}{$\begin{array}{c}\text { LC2 } \\
\text { (mg/kg base seca) } \\
\end{array}$} \\
\hline & & Início & Final & Início & Final & Início & Final & Início & Final \\
\hline Arsênio & 41 & 7 & 9 & 7 & 18 & 12 & 13 & 12 & 11 \\
\hline Bário & 1300 & 215 & 280 & 215 & 255 & 155 & 195 & 155 & 220 \\
\hline Cádmio & 39 & 2,4 & 1,9 & 2,4 & 3,1 & 2,9 & 2,5 & 2,9 & 2,7 \\
\hline Chumbo & 300 & 9 & 12 & 9 & 22 & 13 & 15 & 13 & 18 \\
\hline Cobre & 1500 & 233 & 280 & 233 & 310 & 260 & 345 & 260 & 180 \\
\hline Cromio & 1000 & 288 & 291 & 288 & 278 & 320 & 291 & 320 & 307 \\
\hline Mercurio & 17 & 0,10 & 0,15 & 0,10 & 0,17 & 0,05 & 0,09 & 0,05 & 0,10 \\
\hline Molibidênio & 50 & 15 & 20 & 15 & 14 & 18 & 16 & 18 & 9 \\
\hline Níquel & 420 & 56 & 61 & 56 & 65 & 60 & 58 & 60 & 71 \\
\hline Selênio & 100 & 0,5 & 1,5 & 0,5 & 1,6 & 0,8 & 2,0 & 0,8 & 1,0 \\
\hline Zinco & 2800 & 767 & 766 & 767 & 670 & 805 & 580 & 805 & 622 \\
\hline
\end{tabular}

Nota: (1) - mg/kg base seca - Resolução $n^{0} 375 / 2006$ do Conama (BRASIL, 2006c).

\begin{tabular}{|c|c|c|c|c|c|c|c|c|c|}
\hline \multicolumn{10}{|c|}{ CICLO 3/1 (05/07/2007 a 12/09/2007) } \\
\hline \multirow{3}{*}{ Parâmetro } & \multirow{3}{*}{ Padrão (1) } & \multicolumn{4}{|c|}{ Lodo sem cal } & \multicolumn{4}{|c|}{ Lodo com cal } \\
\hline & & \multicolumn{2}{|c|}{$\begin{array}{c}\text { L1 } \\
\text { (mg/kg base seca) }\end{array}$} & \multicolumn{2}{|c|}{$\begin{array}{c}\mathrm{L} 2 \\
\text { (mg/kg base seca) }\end{array}$} & \multicolumn{2}{|c|}{$\begin{array}{c}\text { LC1 } \\
\text { (mg/kg base seca) }\end{array}$} & \multicolumn{2}{|c|}{$\begin{array}{c}\text { LC2 } \\
\text { (mg/kg base seca) }\end{array}$} \\
\hline & & Início & Final & Início & Final & Início & Final & Início & Final \\
\hline Arsênio & 41 & 6 & 12 & 6 & 18 & 9 & 9 & 9 & 14 \\
\hline Bário & 1300 & 215 & 205 & 215 & 240 & 185 & 170 & 185 & 210 \\
\hline Cádmio & 39 & 2 & 2,8 & 2 & 2 & 1 & 1,5 & 1 & 1 \\
\hline Chumbo & 300 & 14 & 17 & 14 & 22 & 18 & 11 & 18 & 30 \\
\hline Cobre & 1500 & 260 & 225 & 260 & 250 & 310 & 185 & 310 & 205 \\
\hline Cromio & 1000 & 170 & 250 & 170 & 285 & 210 & 300 & 210 & 365 \\
\hline Mercurio & 17 & 0,09 & 0,12 & 0,09 & 0,17 & 0,15 & 0,08 & 0,15 & 0,14 \\
\hline Molibidênio & 50 & 30 & 15 & 30 & 10 & 22 & 18 & 22 & 18 \\
\hline Níquel & 420 & 38 & 51 & 38 & 82 & 46 & 65 & 46 & 58 \\
\hline Selênio & 100 & 1 & 2 & 1 & 1,5 & 1,5 & 2,2 & 1,5 & 1,5 \\
\hline Zinco & 2800 & 665 & 305 & 665 & 573 & 735 & 440 & 735 & 680 \\
\hline
\end{tabular}

Nota: (1) - mg/kg base seca - Resolução n ${ }^{\circ}$ 375/2006 do Conama (BRASIL, 2006c). 
APÊNDICE 4 - Valores de densidade para o lodo sem adição de cal (L1 e L2) durante a Etapa 1

\begin{tabular}{|c|c|c|c|c|c|c|c|c|c|c|c|c|c|c|c|c|c|}
\hline \multirow{2}{*}{$\mathbf{N}$} & \multirow{2}{*}{$\begin{array}{l}\text { Ciclo/ } \\
\text { Etapa }\end{array}$} & \multicolumn{2}{|c|}{ ST (\%) } & \multicolumn{2}{|c|}{ SV (\%) } & \multicolumn{2}{|c|}{ SF (\%) } & \multicolumn{2}{|c|}{ SV/ST } & \multicolumn{2}{|c|}{ SF/ST } & \multicolumn{2}{|c|}{$\begin{array}{c}\text { Umidade } \\
(\%)\end{array}$} & \multicolumn{2}{|c|}{$\begin{array}{c}\text { Densidade } \\
\text { sólidos }\end{array}$} & \multicolumn{2}{|c|}{$\begin{array}{c}\text { Densidade } \\
\text { lodo }\end{array}$} \\
\hline & & $\begin{array}{c}\mathbf{L 1} \\
\mathbf{L 2}^{(*)}\end{array}$ & $\begin{array}{c}\text { LC1 } \\
\text { LC2 } \\
(* *)\end{array}$ & $\begin{array}{l}\text { L1 } \\
\text { L2 }\end{array}$ & $\begin{array}{l}\text { LC1 } \\
\text { LC2 }\end{array}$ & $\begin{array}{l}\text { L1 } \\
\text { L2 }\end{array}$ & $\begin{array}{l}\text { LC1 } \\
\text { LC2 }\end{array}$ & $\begin{array}{l}\text { L1 } \\
\text { L2 }\end{array}$ & $\begin{array}{l}\text { LC1 } \\
\text { LC2 }\end{array}$ & $\begin{array}{l}\text { L1 } \\
\text { L2 }\end{array}$ & $\begin{array}{l}\text { LC1 } \\
\text { LC2 }\end{array}$ & $\begin{array}{l}\text { L1 } \\
\text { L2 }\end{array}$ & $\begin{array}{l}\text { LC1 } \\
\text { LC2 }\end{array}$ & $\begin{array}{l}\text { L1 } \\
\text { L2 }\end{array}$ & $\begin{array}{l}\text { LC1 } \\
\text { LC2 }\end{array}$ & $\begin{array}{l}\text { L1 } \\
\text { L2 }\end{array}$ & $\begin{array}{l}\text { LC1 } \\
\text { LC2 }\end{array}$ \\
\hline 1 & \multirow{20}{*}{$1 / 1$} & 15,59 & 17,71 & 9,23 & 9,25 & 6,36 & 8,46 & 0,59 & 0,52 & 0,41 & 0,48 & 84,41 & 82,29 & 1,324 & 1,40 & 1,04 & 1,05 \\
\hline 2 & & 16,00 & 18,01 & 9,50 & 9,13 & 6,50 & 8,88 & 0,59 & 0,51 & 0,41 & 0,49 & 84,00 & 81,99 & 1,323 & 1,42 & 1,04 & 1,06 \\
\hline 3 & & 22,62 & 24,89 & 13,09 & 12,12 & 9,53 & 12,77 & 0,58 & 0,49 & 0,42 & 0,51 & 77,38 & 75,11 & 1,338 & 1,44 & 1,06 & 1,08 \\
\hline 4 & & 23,42 & 26,15 & 13,61 & 12,93 & 9,81 & 13,22 & 0,58 & 0,49 & 0,42 & 0,51 & 76,58 & 73,85 & 1,336 & 1,44 & 1,06 & 1,09 \\
\hline 5 & & 48,97 & 52,21 & 28,31 & 25,04 & 20,65 & 27,17 & 0,58 & 0,48 & 0,42 & 0,52 & 51,03 & 47,79 & 1,339 & 1,45 & 1,14 & 1,19 \\
\hline 6 & & 58,38 & 63,74 & 32,32 & 30,19 & 26,05 & 33,54 & 0,55 & 0,47 & 0,45 & 0,53 & 41,62 & 36,26 & 1,366 & 1,46 & 1,19 & 1,25 \\
\hline 7 & & 71,49 & 71,84 & 37,53 & 35,10 & 33,96 & 36,75 & 0,52 & 0,49 & 0,48 & 0,51 & 28,51 & 28,16 & 1,399 & 1,44 & 1,26 & 1,28 \\
\hline 8 & & 72,93 & 77,73 & 39,70 & 31,67 & 33,23 & 46,06 & 0,54 & 0,41 & 0,46 & 0,59 & 27,07 & 22,27 & 1,376 & 1,55 & 1,25 & 1,38 \\
\hline 9 & & 85,23 & 79,81 & 37,61 & 38,74 & 47,62 & 41,08 & 0,44 & 0,49 & 0,56 & 0,51 & 14,77 & 20,19 & 1,504 & 1,45 & 1,40 & 1,33 \\
\hline 10 & & 85,37 & 82,59 & 47,78 & 39,55 & 37,59 & 43,03 & 0,56 & 0,48 & 0,44 & 0,52 & 14,63 & 17,41 & 1,359 & 1,45 & 1,29 & 1,35 \\
\hline 11 & & 86,06 & 86,25 & 43,04 & 34,73 & 43,02 & 51,53 & 0,50 & 0,40 & 0,50 & 0,60 & 13,94 & 13,75 & 1,428 & 1,56 & 1,35 & 1,45 \\
\hline 12 & & 86,34 & 88,99 & 40,86 & 40,14 & 45,47 & 48,85 & 0,47 & 0,45 & 0,53 & 0,55 & 13,66 & 11,01 & 1,462 & 1,49 & 1,38 & 1,41 \\
\hline 13 & & 90,85 & 90,01 & 40,77 & 37,21 & 50,07 & 52,80 & 0,45 & 0,41 & 0,55 & 0,59 & 9,15 & 9,99 & 1,494 & 1,54 & 1,43 & 1,46 \\
\hline 14 & & 91,17 & 90,93 & 41,25 & 35,13 & 49,92 & 55,79 & 0,45 & 0,39 & 0,55 & 0,61 & 8,83 & 9,07 & 1,489 & 1,58 & 1,43 & 1,50 \\
\hline 15 & & 91,36 & 91,76 & 39,45 & 36,28 & 51,91 & 55,48 & 0,43 & 0,40 & 0,57 & 0,60 & 8,64 & 8,24 & 1,517 & 1,57 & 1,45 & 1,50 \\
\hline 16 & & 92,60 & 92,08 & 38,66 & 31,56 & 53,94 & 60,52 & & 0,34 & 0,58 & 0,66 & 7,40 & 7,92 & 1,537 & 5 & 1,48 & 1,57 \\
\hline 17 & & 93,33 & 92,16 & 40,98 & 35,94 & 52,35 & 56,22 & 0,44 & 0,39 & 0,56 & 0,61 & 6,67 & 7,84 & 1,507 & 1,58 & 1,46 & 1,51 \\
\hline 18 & & 93,34 & 92,32 & 48,24 & 45,45 & 45,09 & 46,87 & 0,52 & 0,49 & 0,48 & 0,51 & 6,66 & 7,68 & 1,408 & 1,44 & 1,37 & 1,39 \\
\hline 19 & & 94,27 & 92,76 & 41,41 & 34,49 & 52,86 & 58,27 & 0,44 & 0,37 & 0,56 & 0,63 & 5,73 & 7,24 & 1,507 & 1,60 & 1,46 & 1,54 \\
\hline 20 & & 94,42 & 93,68 & 42,01 & 37,01 & 52,42 & 56,67 & 0,44 & 0,40 & 0,56 & 0,60 & 5,58 & 6,32 & 1,499 & 1,57 & 1,46 & 1,52 \\
\hline 21 & & 14,32 & 17,29 & 8,62 & 8,66 & 5,70 & 8,64 & 0,60 & 0,50 & 0,40 & 0,50 & 85,68 & 82,71 & 1,314 & 1,43 & 1,04 & 1,05 \\
\hline 22 & & 20,40 & 22,86 & 11,01 & 9,73 & 9,39 & 13,13 & 0,54 & 0,43 & 0,46 & 0,57 & 79,60 & 77,14 & 1,382 & 1,53 & 1,06 & 1,09 \\
\hline 23 & & 22,50 & 23,66 & 11,71 & 9,98 & 10,79 & 13,68 & & 0,42 & & 0,58 & 77,50 & 76,34 & 1,404 & 1,53 & 1,07 & 1,09 \\
\hline 24 & & 35,91 & 38,41 & 18,51 & 17,43 & 17,40 & 20 & & & & & 64,09 & & 1,410 & & 1,12 & 14 \\
\hline 25 & & 36,49 & 42,86 & 18,75 & 18,07 & 17,74 & 24,78 & 0,51 & 0,42 & 0,49 & 0,58 & 63,51 & 57,14 & 1,412 & 1,53 & 1,12 & 1,17 \\
\hline 26 & & 57,20 & 47,39 & 26,18 & 19,45 & 31,01 & 27,94 & 0,46 & 0,41 & 0,54 & 0,59 & 42,80 & 52,61 & 1,482 & 1,55 & 1,23 & 1,20 \\
\hline 27 & & 67,24 & 73,28 & 29,27 & 28,26 & 37,97 & 45,01 & 0,44 & 0,39 & 0,56 & 0,61 & 32,76 & 26,72 & 1,512 & 1,58 & 1,30 & 1,37 \\
\hline 28 & & 72,04 & 77,07 & 31,92 & 30,06 & 40,12 & 47,01 & 0,44 & 0,39 & 0,56 & 0,61 & 27,96 & 22,93 & 1,502 & 1,58 & 1,32 & 1,39 \\
\hline 29 & $2 / 1$ & 78,67 & 79,90 & 33,20 & 33,63 & 45,48 & 46,28 & 0,42 & 0,42 & 0,58 & 0,58 & 21,33 & 20,10 & 1,531 & 1,53 & 1,38 & 1,38 \\
\hline 30 & & 80,10 & 82,07 & 39,24 & 34,25 & 40,86 & 47,82 & 0,49 & 0,42 & 0,51 & 0,58 & 19,90 & 17,93 & 1,441 & 1,54 & 1,32 & 1,40 \\
\hline 31 & & 82,79 & 83,26 & 32,84 & 32,84 & 49,95 & 50,41 & 0,40 & 0,39 & 0,60 & 0,61 & 17,21 & 16,74 & 1,567 & 1,57 & 1,43 & 1,43 \\
\hline 32 & & 88,65 & 87,06 & 41,53 & 36,25 & 47,13 & 50,81 & 0,47 & 0,42 & 0,53 & 0,58 & 11,35 & 12,94 & 1,468 & 1,54 & 1,39 & 1,44 \\
\hline 33 & & 89,66 & 90,38 & 38,65 & 32,11 & 51,01 & & & & & 0,64 & 10,34 & & 1,518 & 1,63 & 1,44 & 1,54 \\
\hline 34 & & 90,73 & 90,69 & 35 , & 33 & 55 , & & 0,39 & 0 & 0,61 & 0,63 & 9,27 & 1 & 1,572 & 0 & 1,49 & 1,52 \\
\hline 35 & & 91,61 & 91,28 & 44,37 & 35,73 & 47,24 & 55,56 & 0,48 & 0,39 & 0,52 & 0,61 & 8,39 & 8,72 & 1,448 & 1,58 & 1,40 & 1,50 \\
\hline 36 & & 93,03 & 92,99 & 46,22 & 35,71 & 46,81 & 57,28 & 0,50 & 0,38 & 0,50 & 0,62 & 6,97 & 7,01 & 1,432 & 1,59 & 1,39 & 1,52 \\
\hline 37 & & 93,36 & 93,78 & 46,16 & 37,63 & 47,20 & 56,15 & 0,49 & 0,40 & 0,51 & 0,60 & 6,64 & 6,22 & 1,435 & 1,56 & 1,40 & 1,51 \\
\hline 39 & & 14,87 & 17,23 & 7,67 & 8,27 & 7,21 & 8,96 & 0,52 & 0,48 & 0,48 & 0,52 & 85,13 & 82,77 & 1,410 & 1,45 & 1,05 & 1,06 \\
\hline 40 & & 16.90 & 21.84 & 8.45 & 10.43 & 8.44 & 11.41 & 0.50 & 0.48 & 0.50 & 0.52 & 83.10 & 78.16 & 1.428 & 1.46 & 1.05 & 1.07 \\
\hline 41 & & 17,65 & 22,23 & 9.78 & 10,76 & 7,87 & 11,47 & 0,55 & 0,48 & 0,45 & 0,52 & 82,35 & 77,77 & 1,365 & 1,45 & 1,05 & 1,07 \\
\hline 42 & & 19.56 & 23.70 & 10.83 & 11.23 & & 12.47 & 0.55 & & 0.45 & 0.53 & 80.44 & 76.30 & 1.366 & 1.46 & 1.06 & 1.08 \\
\hline 43 & & 25,99 & 28,92 & 15,47 & 12,87 & 10.53 & 16,06 & 0,60 & 0,44 & 0,40 & 0,56 & 74,01 & 71,08 & 1,321 & 1,50 & 1,07 & 1,11 \\
\hline 44 & & 30.01 & 30.43 & 16.09 & 14.45 & 13.91 & 15.98 & 0.54 & 0.47 & 0.46 & 0.53 & 69.99 & 69.57 & 1.385 & 1.46 & 1.09 & 1.11 \\
\hline 45 & & 30,25 & 35,15 & 15,54 & 15,97 & 14,72 & 19,18 & 0,51 & 0,45 & 0,49 & 0,55 & 69.75 & 64,85 & 1,412 & 1.49 & 1,10 & 1,13 \\
\hline 46 & & 38.15 & 41.90 & 19.95 & 18.15 & 18.21 & 23.75 & 0.52 & 0.43 & 0.48 & 0.57 & 61.85 & 58.10 & 1.401 & 1.52 & 1.12 & 1.17 \\
\hline 47 & & 38,64 & 46,30 & 17,95 & 17,67 & 20,69 & 28,63 & 0,46 & 0,38 & 0,54 & 0,62 & 61,36 & 53,70 & 1,473 & 1,59 & 1,14 & 1,21 \\
\hline 48 & $3 / 1$ & 49.79 & 59.23 & 24.65 & 20.22 & 25.14 & 39.01 & 0.50 & 0.34 & 0.50 & 0.66 & 50.21 & 40.77 & 1.435 & 1.65 & 1.18 & 1.31 \\
\hline 49 & & 49,85 & 61,62 & 21,12 & 26,59 & 28,73 & 35,02 & 0,42 & 0,43 & 0,58 & 0.57 & 50,15 & 38,38 & 1,528 & 1,52 & 1,21 & 1,27 \\
\hline 50 & & 56.76 & 65.47 & 39.77 & 42.17 & 16.99 & 23.30 & 0.70 & 0.64 & 0.30 & 0.36 & 43.24 & 34.53 & 1.219 & 1.27 & 1.11 & 1.16 \\
\hline 51 & & 68,16 & 76,41 & 27,39 & 26,42 & 40,77 & 49,99 & 0,40 & 0,35 & 0.60 & 0,65 & 31,84 & 23,59 & 1,560 & 1,65 & 1,32 & 1,43 \\
\hline 52 & & 67.59 & 79.28 & 24.94 & 29.89 & 42.65 & 49.39 & 0.37 & 0.38 & 0.63 & 0.62 & 32.41 & 20.72 & 1.609 & 1.60 & 1.34 & 1.42 \\
\hline 53 & & 76,44 & 81,26 & 41,17 & 43,19 & 35,28 & 38,07 & 0,54 & 0,53 & 0,46 & 0,47 & 23,56 & 18,74 & 1,383 & 1,39 & 1,27 & 1,30 \\
\hline 54 & & 83,69 & 88,15 & 33,73 & 44,19 & 49,96 & 43,95 & 0,40 & 0,50 & 0,60 & 0,50 & 16,31 & 11,85 & 1,558 & 1,43 & 1,43 & 1,36 \\
\hline 55 & & 87,51 & 88,68 & 38,83 & 30,96 & 48,68 & 57,72 & 0,44 & 0,35 & 0,56 & 0,65 & 12,49 & 11,32 & 1,501 & 1,64 & 1,41 & 1,53 \\
\hline 56 & & 89,34 & 90,06 & 41,65 & 33,07 & 47,70 & 56,99 & 0,47 & 0,37 & 0,53 & 0,63 & 10,66 & 9,94 & 1,471 & 1,61 & 1,40 & 1,52 \\
\hline 57 & & 92.33 & 91.50 & 43.00 & 45.02 & 49.33 & 46.48 & 0.47 & 0.49 & 0.53 & 0.51 & 7.67 & 8.50 & 1.472 & 1.44 & 1.42 & 1.39 \\
\hline
\end{tabular}

Nota: $(*)$ - Lodo sem cal; $(* *)$ - Lodo com cal. 
APÊNDICE 5 - Resultados de ovos de helmintos totais, viáveis e inviáveis - Etapa 2

\begin{tabular}{|c|c|c|c|c|c|c|c|c|c|c|c|}
\hline \multicolumn{4}{|c|}{$1^{\text {a }}$ CICLO } & \multicolumn{4}{|c|}{$2^{\mathrm{a}}$ CICLO } & \multicolumn{4}{|c|}{$3^{\mathrm{a}}$ CICLO } \\
\hline \multicolumn{4}{|c|}{ (n $\mathbf{n}^{\mathrm{a}}$ ovos/gMS) } & \multicolumn{4}{|c|}{ (n ${ }^{\mathrm{a}}$ ovos/gMS) } & \multicolumn{4}{|c|}{ (n ${ }^{\mathrm{a}}$ ovos/gMS) } \\
\hline \multicolumn{4}{|c|}{$12 / 12 / 07$} & \multicolumn{4}{|c|}{$12 / 03 / 08$} & \multicolumn{4}{|c|}{$4 / 06 / 08$} \\
\hline Amostras & Totais & Viáveis & Inviáveis & Amostras & Totais & Viáveis & Inviáveis & Amostras & Totais & Viáveis & Inviáveis \\
\hline L1 & \multirow{2}{*}{0,930} & \multirow{2}{*}{0,257} & \multirow{2}{*}{0,673} & $\mathbf{L 1}$ & \multirow{2}{*}{0,743} & \multirow{2}{*}{0,206} & \multirow{2}{*}{0,537} & \multirow{2}{*}{ L1/L2 } & \multirow{2}{*}{0,726} & \multirow{2}{*}{0,293} & \multirow{2}{*}{0,433} \\
\hline L2 & & & & $\mathbf{L} 2$ & & & & & & & \\
\hline LC1 & \multirow{2}{*}{1,074} & \multirow{2}{*}{0,312} & \multirow{2}{*}{0,762} & LC1 & \multirow{2}{*}{0,641} & \multirow{2}{*}{0,171} & \multirow{2}{*}{0,470} & \multirow{2}{*}{ LC1/LC2 } & \multirow{2}{*}{0,773} & & \\
\hline LC2 & & & & LC2 & & & & & & & 0,512 \\
\hline & 26/ & 2/07 & & & $26 / 0$ & 3/08 & & & $18 / C$ & 6/08 & \\
\hline Amostras & Totais & Viáveis & Inviáveis & Amostras & Totais & Viáveis & Inviáveis & Amostras & Totais & Viáveis & Inviáveis \\
\hline L1 & 0,725 & 0,308 & 0,417 & $\mathbf{L 1}$ & 0,710 & 0,227 & 0,483 & $\mathbf{L 1}$ & 0,681 & 0,301 & 0,380 \\
\hline L2 & 0,617 & 0,233 & 0,384 & $\mathbf{L} 2$ & 0,722 & 0,201 & 0,521 & $\mathbf{L} 2$ & 0,592 & 0,279 & 0,313 \\
\hline LC1 & 0,790 & 0,270 & 0,520 & LC1 & 0,605 & 0,216 & 0,389 & LC1 & 0,760 & 0,227 & 0,533 \\
\hline LC2 & 0,681 & 0,188 & 0,493 & LC2 & 0,534 & 0,135 & 0,399 & LC2 & 0,667 & 0,260 & 0,407 \\
\hline & & 1/08 & & & & $1 / 08$ & & & & $/ 08$ & \\
\hline Amostras & Totais & Viáveis & Iniviáveis & Amostras & Totais & Viáveis & Inviáveis & Amostras & Totais & Viáveis & Inviáveis \\
\hline L1 & 0,476 & 0,274 & 0,202 & L1 & 0,639 & 0,188 & 0,451 & L1 & 0,452 & 0,238 & 0,214 \\
\hline $\mathbf{L} 2$ & 0,570 & 0,259 & 0,311 & $\mathbf{L} 2$ & 0,600 & 0,127 & 0,473 & L2 & 0,366 & 0,103 & 0,263 \\
\hline LC1 & 0,630 & 0,156 & 0,474 & LC1 & 0,623 & 0,222 & 0,401 & LC1 & 0,369 & 0,177 & 0,192 \\
\hline LC2 & 0,414 & 0,112 & 0,302 & LC2 & 0,460 & 0,184 & 0,276 & LC2 & 0,380 & 0,211 & 0,169 \\
\hline & & $1 / 08$ & & & & $/ 08$ & & & $16 / C$ & 7/08 & \\
\hline Amostras & Totais & Viáveis & Inviáveis & Amostras & Totais & Viáveis & Inviáveis & Amostras & Totais & Viáveis & Inviáveis \\
\hline L1 & 0,393 & 0,152 & 0,241 & L1 & 0,439 & 0,150 & 0,289 & L1 & 0,293 & 0,095 & 0,198 \\
\hline L2 & 0,352 & 0,185 & 0,167 & L2 & 0,446 & 0,089 & 0,357 & $\mathbf{L} 2$ & 0,336 & 0,116 & 0,220 \\
\hline LC1 & 0,526 & 0,199 & 0,327 & LC1 & 0,423 & 0,051 & 0,372 & LC1 & 0,298 & 0,123 & 0,175 \\
\hline LC2 & 0,258 & 0,063 & 0,195 & LC2 & 0,361 & 0,178 & 0,183 & LC2 & 0,272 & 0,089 & 0,183 \\
\hline & & $2 / 08$ & & & $21 / 0$ & $5 / 08$ & & & $13 / 6$ & 8/08 & \\
\hline Amostras & Totais & Viáveis & Inviáveis & Amostras & Totais & Viáveis & Inviáveis & Amostras & Totais & Viáveis & Inviáveis \\
\hline L1 & 0,345 & 0,157 & 0,188 & L1 & 0,461 & 0,133 & 0,328 & L1 & 0,293 & 0,110 & 0,183 \\
\hline L2 & 0,337 & 0,135 & 0,202 & $\mathbf{L} 2$ & 0,423 & 0,109 & 0,314 & $\mathbf{L} 2$ & 0,362 & 0,123 & 0,239 \\
\hline LC1 & 0,303 & 0,160 & 0,143 & LC1 & 0,391 & 0,093 & 0,298 & LC1 & 0,281 & 0,112 & 0,169 \\
\hline LC2 & 0,210 & 0,098 & 0,112 & LC2 & 0,409 & 0,112 & 0,297 & LC2 & 0,304 & 0,103 & 0,201 \\
\hline
\end{tabular}


APÊNDICE 6 - Resultados referentes ao monitoramento de vírus do lodo não encaminhado ao digestor aeróbio, das células L1, L2, LC1 e LC2 durante os Ciclos $1 / 2,2 / 2$ e $3 / 2$

\section{Vírus em amostras de lodo que não foi submetido à digestão}

Padrão Conama (<0,25 UFF/gST)

\begin{tabular}{|c|c|c|c|c|c|c|c|c|c|c|c|c|c|c|c|c|c|c|c|c|c|c|}
\hline \multirow{3}{*}{ 을 } & \multirow{3}{*}{$\begin{array}{l}\text { Data } \\
\text { Coleta }\end{array}$} & \multirow{3}{*}{$\begin{array}{l}\text { Tempo } \\
\text { (dia) }\end{array}$} & \multicolumn{5}{|c|}{ L1 (Lodo sem cal) } & \multicolumn{5}{|c|}{ L2 (Lodo sem cal) } & \multicolumn{5}{|c|}{ LC1 (Lodo com cal) } & \multicolumn{5}{|c|}{ LC2 (Lodo com cal) } \\
\hline & & & \multirow[b]{2}{*}{$\mathbf{H A V}^{(\mathrm{a})}$} & \multicolumn{2}{|c|}{ Adeno $^{(b)}$} & \multirow[b]{2}{*}{$\begin{array}{l}\text { Rota }^{(c)} \\
\text { (UFF/gST) }\end{array}$} & \multirow{2}{*}{$\frac{\overparen{\varrho}}{\stackrel{0}{0}}$} & \multirow[b]{2}{*}{$\mathbf{H A V}^{(\mathbf{a})}$} & \multicolumn{2}{|c|}{ Adeno $^{(\mathbf{b})}$} & \multirow[b]{2}{*}{$\begin{array}{l}\text { Rota }^{(c)} \\
\text { (UFF/gST) }\end{array}$} & \multirow{2}{*}{ 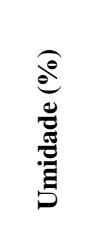 } & \multirow[b]{2}{*}{ HAV $^{(\mathbf{a})}$} & \multicolumn{2}{|c|}{ Adeno $^{(b)}$} & \multirow[b]{2}{*}{$\begin{array}{l}\text { Rota }^{(c)} \\
\text { (UFF/gST) }\end{array}$} & \multirow{2}{*}{ 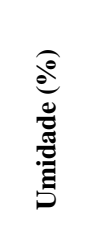 } & \multirow[b]{2}{*}{$\mathbf{H A V}^{(\mathrm{a})}$} & \multicolumn{2}{|c|}{ Adeno $^{(b)}$} & \multirow[b]{2}{*}{$\begin{array}{l}\text { Rota }^{(c)} \\
\text { (UFF/gST) }\end{array}$} & \multirow{2}{*}{ 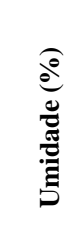 } \\
\hline & & & & 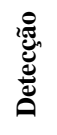 & $\mathrm{CC}$ & & & & 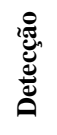 & $\mathrm{CC}$ & & & & 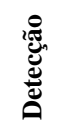 & CC & & & & 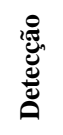 & CC & & \\
\hline \multirow{3}{*}{$1 / 2$} & $12 / 12 / 07$ & $0^{(\mathrm{d})}$ & $\mathrm{P}$ & $\mathrm{N}$ & $\mathrm{P}$ & 1,60 & 89,12 & $\mathrm{P}$ & $\mathrm{N}$ & $\mathrm{P}$ & 1,60 & 89,12 & $\mathrm{~N}$ & $P$ & $\mathrm{P}$ & 1,20 & 84,41 & $\mathrm{~N}$ & $\mathrm{P}$ & $\mathrm{P}$ & 1,20 & 84,41 \\
\hline & $16 / 01 / 08$ & 35 & $\mathrm{~N}$ & $\mathrm{~N}$ & $\mathrm{P}$ & 0,38 & 26,79 & $\mathrm{~N}$ & $\mathrm{P}$ & $P$ & $0^{(\mathrm{e})}$ & 20,93 & $\mathrm{~N}$ & $\mathrm{P}$ & $\mathrm{P}$ & $0^{(\mathrm{e})}$ & 20,32 & $\mathrm{~N}$ & $\mathrm{~N}$ & $\mathrm{P}$ & $0^{(\mathrm{e})}$ & 21,67 \\
\hline & $20 / 02 / 08$ & 70 & $\mathrm{~N}$ & $\mathrm{P}$ & $\mathrm{S}$ & 2,00 & 5,93 & $\mathrm{~N}$ & $\mathrm{P}$ & $\mathrm{S}$ & 2,80 & 6,29 & $\mathrm{~N}$ & $\mathrm{~N}$ & $\mathrm{~S}$ & 2,80 & 5,76 & $\mathrm{~N}$ & $\mathrm{P}$ & $\mathrm{S}$ & 0,38 & 6,16 \\
\hline \multirow{3}{*}{$2 / 2$} & $12 / 03 / 08$ & $0^{(\mathrm{d})}$ & $\mathrm{N}$ & $\mathrm{P}$ & $\mathrm{S}$ & 0,40 & 85,21 & $\mathrm{~N}$ & $\mathrm{P}$ & $\mathrm{S}$ & 0,40 & 85,21 & $\mathrm{~N}$ & $\mathrm{~N}$ & $\mathrm{~S}$ & 1,20 & 82,28 & $\mathrm{~N}$ & $\mathrm{~N}$ & $\mathrm{~S}$ & 1,20 & 82,28 \\
\hline & $16 / 04 / 08$ & 35 & $\mathrm{~N}$ & $\mathrm{P}$ & $\mathrm{P}$ & 1,20 & 29,07 & $\mathrm{~N}$ & $\mathrm{~N}$ & $\mathrm{P}$ & 1,60 & 41,62 & $\mathrm{~N}$ & $\mathrm{~N}$ & $\mathrm{P}$ & 7,20 & 18,03 & $\mathrm{~N}$ & $\mathrm{~N}$ & $\mathrm{~S}$ & 1,98 & 36,80 \\
\hline & $21 / 05 / 08$ & 70 & $\mathrm{~N}$ & $\mathrm{~N}$ & S & $0^{(\mathrm{e})}$ & 8,10 & $\mathrm{~N}$ & $\mathrm{P}$ & $\mathrm{S}$ & 1,60 & 18,75 & $\mathrm{~N}$ & $\mathrm{P}$ & $\mathrm{S}$ & 0,80 & 10,08 & $\mathrm{~N}$ & $\mathrm{P}$ & $\mathrm{P}$ & $0^{(\mathrm{e})}$ & 14,49 \\
\hline \multirow{3}{*}{$3 / 2$} & $04 / 06 / 08$ & $0^{(\mathrm{d})}$ & $\mathrm{N}$ & $\mathrm{P}$ & $\mathrm{S}$ & 1,20 & 89,27 & $\mathrm{~N}$ & $\mathrm{P}$ & $S$ & 1,20 & 89,27 & $\mathrm{~N}$ & $P$ & $\mathrm{~S}$ & 0,78 & 87,92 & $\mathrm{~N}$ & $\mathrm{P}$ & $\mathrm{S}$ & 0,78 & 87,92 \\
\hline & $16 / 07 / 08$ & 42 & $\mathrm{~N}$ & $\mathrm{P}$ & $\mathrm{S}$ & 0,40 & 25,82 & $\mathrm{P}$ & $\mathrm{P}$ & S & 0,40 & 60,20 & $\mathrm{~N}$ & $\mathrm{P}$ & $\mathrm{S}$ & $0^{(\mathrm{e})}$ & 20,65 & $\mathrm{~N}$ & $\mathrm{~N}$ & $\mathrm{~S}$ & ND & 53,42 \\
\hline & $13 / 08 / 08$ & 70 & $\mathrm{~N}$ & $\mathrm{P}$ & $\mathrm{S}$ & 1,18 & 12,29 & $\mathrm{~N}$ & $\mathrm{P}$ & S & 0,40 & 27,96 & $\mathrm{~N}$ & $P$ & $\mathrm{~S}$ & 2,00 & 11,05 & $\mathrm{~N}$ & $\mathrm{P}$ & $\mathrm{S}$ & 3,20 & 21,90 \\
\hline
\end{tabular}

Nota: P - Positivo; N - Negativo; S - culturas com efeito citopático sugestivo da presença de adenovírus e/ou grupo de enterovirus na primeira passagem.

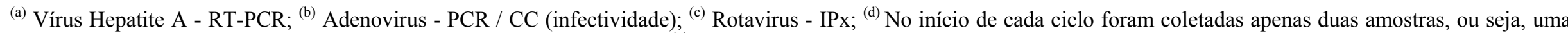
referente ao lodo sem cal (L1 e L2) e outra ao lodo com cal (LC1 e LC2); ${ }^{(e)}$ valor inferior a 0,3 UFF/gST, sendo esse o limite de detecção do metodologia utilizada. 


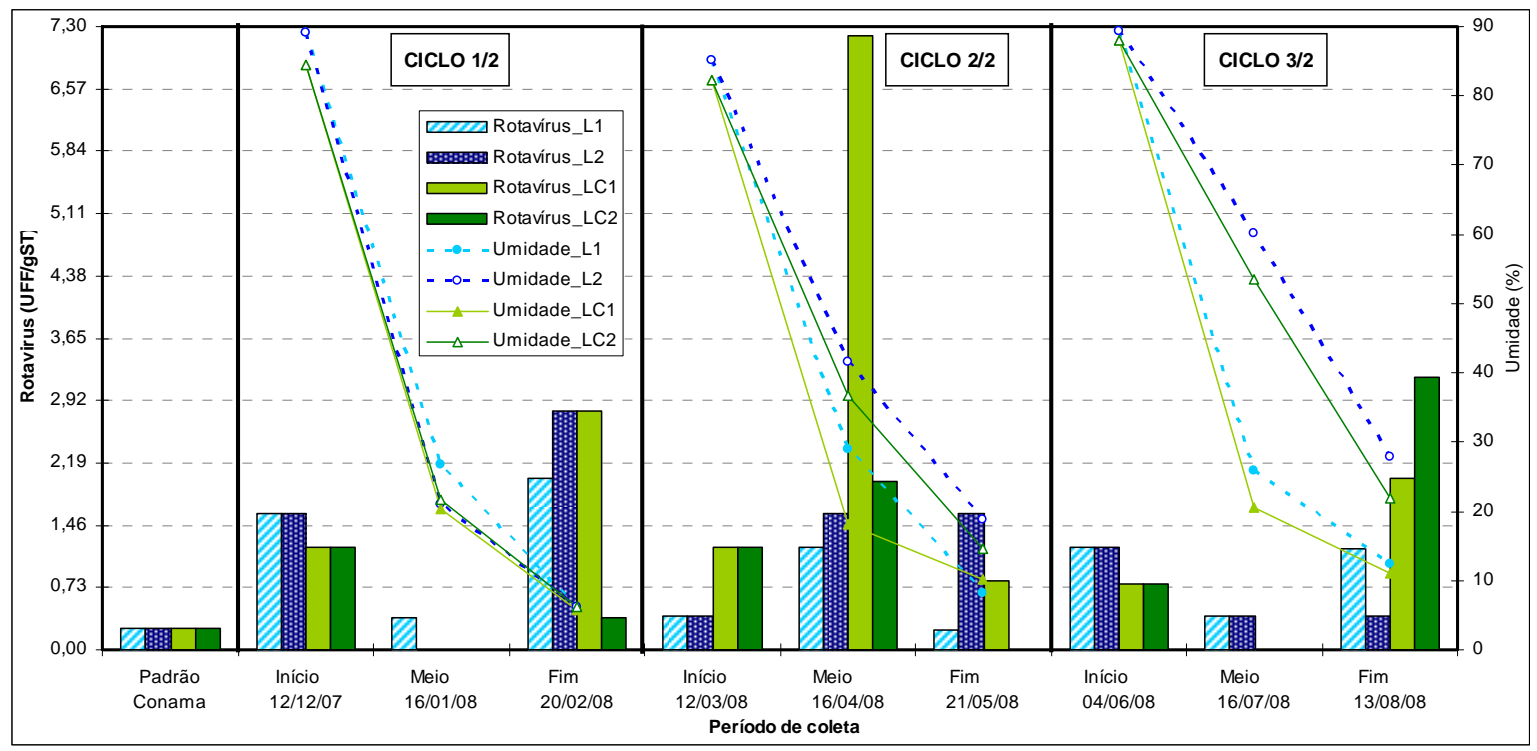

Comportamento de rotavírus durante o desenvolvimento dos Ciclos 1/2, 2/2 e 3/2 do lodo não submetido à digestão sem a adição de cal (L1 e L2) e com a adição de cal (LC1 e LC2) - Etapa 2

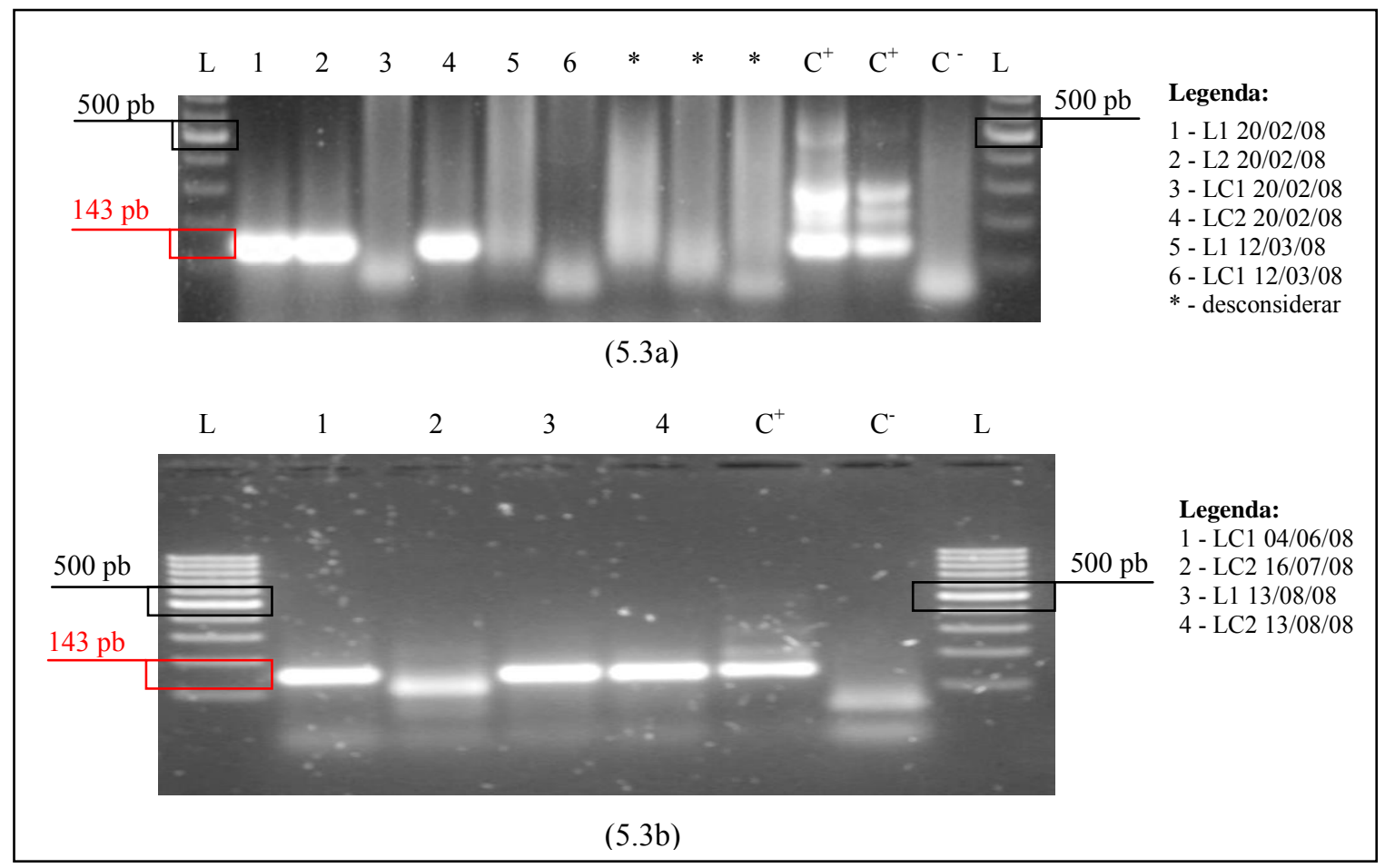

Resultados da reação de amplificação gênica de adenovírus presentes em amostras de lodo de esgoto não submetido à digestão - Etapa 2.

Nota: Eletroforese em gel de agarose 1,5\% corado com solução de brometo de etídeo $(5 \mathrm{mg} / \mathrm{mL})$. Marcador de peso molecular: DNA ladder de 100pb (L). Controles: positivo $(\mathrm{C}+)$ e negativo $\left(\mathrm{C}^{-}\right)$das reações. Amostras de lodo: canaletas 1 a 6 (5.3a) e canaletas 1 a $4(5.3 b)$. 


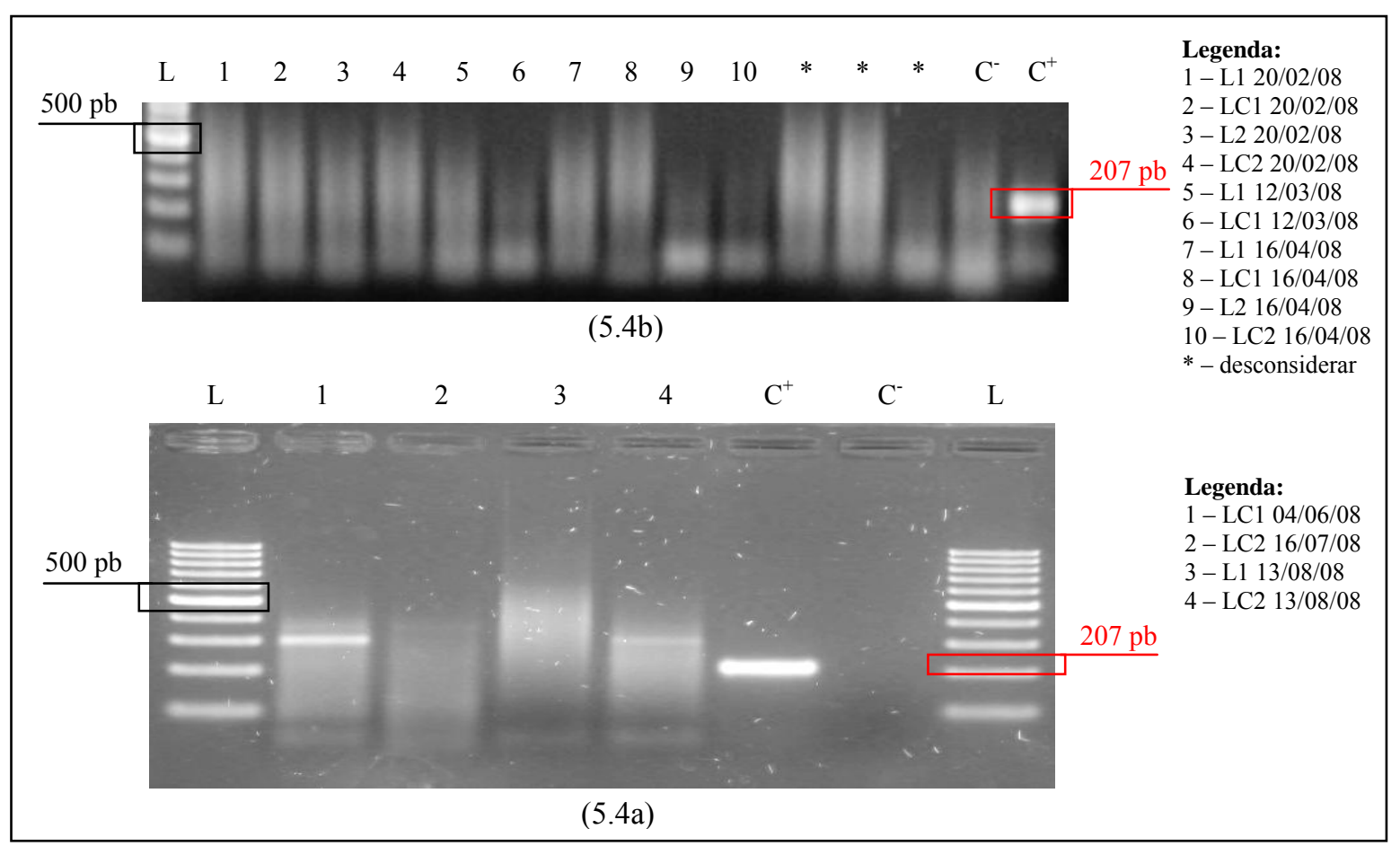

Resultados da reação de amplificação gênica de vírus da hepatite A presentes em amostras de lodo de esgoto não submetido à digestão - Etapa 2

Nota: Eletroforese em gel de agarose 1,5\% corado com solução de brometo de etídeo $(5 \mathrm{mg} / \mathrm{mL})$. Marcador de peso molecular: RNA ladder de 100pb (L). Controles: positivo $(\mathrm{C}+)$ e negativo $\left(\mathrm{C}^{-}\right)$das reações. Amostras de lodo: canaletas 1 a 6 (5.3a) e canaletas 1 a 4 (5.3b). 
APÊNDICE 7 - Parâmetros de interesse agronômico - Etapa 2

\begin{tabular}{|c|c|c|c|c|c|c|c|c|}
\hline \multicolumn{9}{|c|}{ CICLO 1/2 (12/12/2007 a 20/02/2008) } \\
\hline \multirow{3}{*}{ Parâmetro } & \multicolumn{9}{|c|}{ Lodo sem cal } & \multicolumn{4}{c|}{ Lodo com cal } \\
\cline { 2 - 11 } & \multicolumn{2}{|c|}{ L1 (\%) } & \multicolumn{2}{c|}{ L2 (\%) } & \multicolumn{2}{c|}{ LC1 (\%) } & \multicolumn{2}{c|}{ LC2 (\%) } \\
\cline { 2 - 11 } & Início & Final & Início & Final & Início & Final & Início & Final \\
\hline Matéria Orgânica & 67 & 58 & 67 & 67 & 62 & 57 & 62 & 56 \\
\hline Carbono orgânico & 38,86 & 33,64 & 38,86 & 38,86 & 35,96 & 33,06 & 35,96 & 32,48 \\
\hline $\mathrm{N}$ & 4,50 & 4,00 & 4,50 & 4,40 & 4,00 & 3,00 & 4,00 & 2,90 \\
\hline $\mathrm{P}$ & 1,40 & 1,47 & 1,40 & 1,26 & 1,22 & 1,09 & 1,22 & 1,3 \\
\hline $\mathrm{K}$ & 0,86 & 0,56 & 0,86 & 0,63 & 0,71 & 0,60 & 0,71 & 0,58 \\
\hline $\mathrm{Ca}$ & 1,48 & 1,23 & 1,48 & 0,99 & 7,08 & 5,34 & 7,08 & 5,64 \\
\hline $\mathrm{Mg}$ & 0,39 & 0,54 & 0,39 & 0,38 & 0,28 & 0,30 & 0,28 & 0,3 \\
\hline $\mathrm{S}$ & 0,41 & 0,62 & 0,41 & 0,5 & 1,16 & 1,26 & 1,16 & 1,35 \\
\hline Relação C/N & $9 / 1$ & $9 / 1$ & $8 / 1$ & $9 / 1$ & $9 / 1$ & $11 / 01$ & $9 / 1$ & $11 / 01$ \\
\hline
\end{tabular}

\begin{tabular}{|c|c|c|c|c|c|c|c|c|}
\hline \multicolumn{9}{|c|}{ LICLO 2/2 (12/03/2008 a 21/05/2008) } \\
\hline \multirow{3}{*}{ Parâmetro } & \multicolumn{4}{|c|}{ Lodo sem cal } & \multicolumn{4}{c|}{ Lodo com cal } \\
\cline { 2 - 10 } & \multicolumn{2}{|c|}{ L1 (\%) } & \multicolumn{2}{c|}{ L2 (\%) } & \multicolumn{2}{c|}{ LC1 (\%) } & \multicolumn{2}{c|}{ LC2 (\%) } \\
\cline { 2 - 10 } & Início & Final & Início & Final & Início & Final & Início & Final \\
\hline Matéria Orgânica & 65 & 68 & 65 & 63 & 57 & 75 & 57 & 53 \\
\hline Carbono orgânico & 37,70 & 39,44 & 37,70 & 36,54 & 33,06 & 43,50 & 33,06 & 30,74 \\
\hline $\mathrm{N}$ & 4,60 & 4,20 & 4,60 & 4,00 & 3,50 & 2,50 & 3,50 & 2,70 \\
\hline $\mathrm{P}$ & 1,83 & 2,14 & 1,83 & 2,14 & 1,49 & 1,83 & 1,49 & 1,79 \\
\hline $\mathrm{K}$ & 0,68 & 0,67 & 0,68 & 0,84 & 0,43 & 0,78 & 0,43 & 0,63 \\
\hline $\mathrm{Ca}$ & 1,97 & 2,06 & 1,97 & 2,14 & 9,76 & 10,75 & 9,76 & 10,88 \\
\hline $\mathrm{Mg}$ & 0,45 & 0,47 & 0,45 & 0,47 & 0,37 & 0,37 & 0,37 & 0,39 \\
\hline $\mathrm{S}$ & 0,40 & 0,51 & 0,40 & 0,57 & 0,70 & 0,73 & 0,70 & 0,74 \\
\hline Relação C/N & $8 / 1$ & $9 / 1$ & $8 / 1$ & $9 / 1$ & $9 / 1$ & $17 / 1$ & $9 / 1$ & $11 / 1$ \\
\hline
\end{tabular}

\begin{tabular}{|c|c|c|c|c|c|c|c|c|}
\hline \multicolumn{9}{|c|}{ CICLO 3/2 (04/06/2008 a 13/08/2008) } \\
\hline \multirow{3}{*}{ Parâmetro } & \multicolumn{4}{|c|}{ Lodo sem cal } & \multicolumn{4}{|c|}{ Lodo com cal } \\
\hline & \multicolumn{2}{|c|}{ L1 (\%) } & \multicolumn{2}{|c|}{ L2 (\%) } & \multicolumn{2}{|c|}{ LC1 (\%) } & \multicolumn{2}{|c|}{ LC2 (\%) } \\
\hline & Início & Final & Início & Final & Início & Final & Início & Fina \\
\hline Matéria Orgânica & 67 & 67 & 67 & 64 & 61 & 55 & 61 & 55 \\
\hline Carbono orgânico & 39 & 39 & 39 & 37 & 35 & 32 & 35 & 32 \\
\hline $\mathrm{N}$ & 4,80 & 5,20 & 4,80 & 4,40 & 4,00 & 2,40 & 4,00 & 2,40 \\
\hline$P$ & 1,46 & 1,09 & 1,46 & 1,48 & 0,42 & 1,19 & 0,42 & 1,20 \\
\hline $\mathrm{K}$ & 0,53 & 0,72 & 0,53 & 0,71 & 0,14 & 0,55 & 0,14 & 0,70 \\
\hline $\mathrm{Ca}$ & 1,47 & 1,50 & 1,47 & 1,63 & 8,75 & 8,30 & 8,75 & 11,06 \\
\hline $\mathrm{Mg}$ & 0,44 & 0,40 & 0,44 & 0,50 & 0,29 & 0,30 & 0,29 & 0,44 \\
\hline $\mathrm{S}$ & 0,29 & 0,16 & 0,29 & 0,48 & 0,27 & 0,57 & 0,27 & 0,77 \\
\hline Relação C/N & $8 / 1$ & $7 / 1$ & $8 / 1$ & $8 / 1$ & $9 / 1$ & $13 / 1$ & $9 / 1$ & $13 / 1$ \\
\hline
\end{tabular}


APÊNDICE 8 - Íons Metálicos - Etapa 2

\begin{tabular}{|c|c|c|c|c|c|c|c|c|c|}
\hline \multicolumn{10}{|c|}{ CICLO 1/2 (12/12/2007 a 20/02/2008) } \\
\hline \multirow{3}{*}{ Parâmetro } & \multirow{3}{*}{ Padrão (1) } & \multicolumn{4}{|c|}{ Lodo sem cal } & \multicolumn{4}{|c|}{ Lodo com cal } \\
\hline & & \multicolumn{2}{|c|}{$\begin{array}{c}\text { L1 } \\
\text { (mg/kg base seca) }\end{array}$} & \multicolumn{2}{|c|}{$\begin{array}{c}\text { L2 } \\
\text { (mg/kg base seca) }\end{array}$} & \multicolumn{2}{|c|}{$\begin{array}{c}\mathrm{LC1} \\
\text { (mg/kg base seca) }\end{array}$} & \multicolumn{2}{|c|}{$\begin{array}{c}\text { LC2 } \\
\text { (mg/kg base seca) } \\
\end{array}$} \\
\hline & & Início & Final & Início & Final & Início & Final & Início & Final \\
\hline Arsênio & 41 & 6 & 9 & 6 & 12 & 10 & 17 & 10 & 14 \\
\hline Bário & 1300 & 170 & 238 & 170 & 208 & 201 & 214 & 201 & 198 \\
\hline Cádmio & 39 & 2,8 & 3,1 & 2,8 & 1,7 & 3,3 & 2,3 & 3,3 & 2,7 \\
\hline Chumbo & 300 & 13 & 21 & 13 & 29 & 17 & 33 & 17 & 27 \\
\hline Cobre & 1500 & 463 & 435 & 463 & 4,2 & 430 & 501 & 430 & 449 \\
\hline Cromio & 1000 & 200 & 247 & 200 & 261 & 241 & 314 & 241 & 298 \\
\hline Mercurio & 17 & 0,12 & 0,09 & 0,12 & 0,13 & 0,08 & 0,16 & 0,08 & 0,04 \\
\hline Molibidênio & 50 & 26 & 31 & 26 & 35 & 22 & 25 & 22 & 28 \\
\hline Níquel & 420 & 19 & 23 & 19 & 30 & 21 & 24 & 21 & 25 \\
\hline Selênio & 100 & 0,7 & 0,6 & 0,7 & 0,9 & 1,1 & 1,2 & 1,1 & 0,8 \\
\hline Zinco & 2800 & 541 & 680 & 541 & 625 & 572 & 590 & 572 & 710 \\
\hline
\end{tabular}

Nota: (1) - mg/kg base seca - Resolução n ${ }^{0} 375 / 2006$ do Conama (BRASIL, 2006c).

\begin{tabular}{|c|c|c|c|c|c|c|c|c|c|}
\hline \multicolumn{10}{|c|}{ CICLO 2/2 (12/03/2008 a 21/05/2008) } \\
\hline \multirow{3}{*}{ Parâmetro } & \multirow{3}{*}{ Padrão (1) } & \multicolumn{4}{|c|}{ Lodo sem cal } & \multicolumn{4}{|c|}{ Lodo com cal } \\
\hline & & \multicolumn{2}{|c|}{$\begin{array}{c}\mathrm{L1} \\
\text { (mg/kg base seca) } \\
\end{array}$} & \multicolumn{2}{|c|}{$\begin{array}{c}\text { L2 } \\
\text { (mg/kg base seca) } \\
\end{array}$} & \multicolumn{2}{|c|}{$\begin{array}{c}\text { LC1 } \\
\text { (mg/kg base seca) } \\
\end{array}$} & \multicolumn{2}{|c|}{$\begin{array}{c}\text { LC2 } \\
\text { (mg/kg base seca) } \\
\end{array}$} \\
\hline & & Início & Final & Início & Final & Início & Final & Início & Final \\
\hline Arsênio & 41 & 11 & 19 & 11 & 15 & 16 & 15 & 16 & 10 \\
\hline Bário & 1300 & 135 & 119 & 135 & 182 & 219 & 175 & 219 & 157 \\
\hline Cádmio & 39 & 2,6 & 2,9 & 2,6 & 3,8 & 2,0 & 3,0 & 2,0 & 2,2 \\
\hline Chumbo & 300 & 9 & 12 & 9 & 21 & 12 & 26 & 12 & 19 \\
\hline Cobre & 1500 & 317 & 295 & 317 & 360 & 324 & 315 & 324 & 308 \\
\hline Cromio & 1000 & 370 & 358 & 370 & 400 & 320 & 290 & 320 & 347 \\
\hline Mercurio & 17 & 0,08 & 0,08 & 0,08 & 0,21 & 0,16 & 0,05 & 0,16 & 0,09 \\
\hline Molibidênio & 50 & 27 & 25 & 27 & 33 & 32 & 28 & 32 & 35 \\
\hline Níquel & 420 & 45 & 58 & 45 & 55 & 52 & 47 & 52 & 53 \\
\hline Selênio & 100 & 1,2 & 1,6 & 1,2 & 1,9 & 1,2 & 1,6 & 1,2 & 2,7 \\
\hline Zinco & 2800 & 378 & 460 & 378 & 572 & 433 & 602 & 433 & 555 \\
\hline
\end{tabular}

Nota: (1) - mg/kg base seca - Resolução n $n^{0}$ 375/2006 do Conama (BRASIL, 2006c).

\begin{tabular}{|c|c|c|c|c|c|c|c|c|c|}
\hline \multicolumn{10}{|c|}{ CICLO 3/2 (04/06/2008 a 13/08/2008) } \\
\hline \multirow{3}{*}{ Parâmetro } & \multirow{3}{*}{ Padrão (1) } & \multicolumn{4}{|c|}{ Lodo sem cal } & \multicolumn{4}{|c|}{ Lodo com cal } \\
\hline & & \multicolumn{2}{|c|}{$\begin{array}{c}\text { L1 } \\
\text { (mg/kg base seca) }\end{array}$} & \multicolumn{2}{|c|}{$\begin{array}{c}\text { L2 } \\
\text { (mg/kg base seca) }\end{array}$} & \multicolumn{2}{|c|}{$\begin{array}{c}\text { LC1 } \\
\text { (mg/kg base seca) }\end{array}$} & \multicolumn{2}{|c|}{$\begin{array}{c}\text { LC2 } \\
\text { (mg/kg base seca) }\end{array}$} \\
\hline & & Início & Final & Início & Final & Início & Final & Início & Final \\
\hline Arsênio & 41 & 7 & 12 & 7 & 15 & 8 & 9 & 8 & 16 \\
\hline Bário & 1300 & 138 & 221 & 138 & 209 & 195 & 222 & 195 & 235 \\
\hline Cádmio & 39 & 1,7 & 2,1 & 1,7 & 2,8 & 2,1 & 4,1 & 2,1 & 3,4 \\
\hline Chumbo & 300 & 21 & 19 & 21 & 16 & 11 & 15 & 11 & 22 \\
\hline Cobre & 1500 & 220 & 233 & 220 & 207 & 241 & 259 & 241 & 240 \\
\hline Cromio & 1000 & 217 & 255 & 217 & 251 & 202 & 290 & 202 & 330 \\
\hline Mercurio & 17 & 0,05 & 0,1 & 0,05 & 0,07 & 0,08 & 0,05 & 0,08 & 0,17 \\
\hline Molibidênio & 50 & 11 & 17 & 11 & 14 & 23 & 21 & 23 & 19 \\
\hline Níquel & 420 & 27 & 41 & 27 & 38 & 32 & 35 & 32 & 45 \\
\hline Selênio & 100 & 1,8 & 1,5 & 1,8 & 2,2 & 1,0 & 2,0 & 1,0 & 1,3 \\
\hline Zinco & 2800 & 608 & 572 & 608 & 703 & 590 & 545 & 590 & 612 \\
\hline
\end{tabular}

Nota: (1) - mg/kg base seca - Resolução n ${ }^{\circ}$ 375/2006 do Conama (BRASIL, 2006c). 
APÊNDICE 9 - Valores de densidade para o lodo sem adição de cal (L1 e L2) durante a Etapa 2

\begin{tabular}{|c|c|c|c|c|c|c|c|c|c|c|c|c|c|c|c|c|c|}
\hline \multirow{2}{*}{$\mathbf{N}$} & \multirow{2}{*}{$\begin{array}{l}\text { Ciclo/ } \\
\text { Etapa }\end{array}$} & \multicolumn{2}{|c|}{ ST (\%) } & \multicolumn{2}{|c|}{ SV (\%) } & \multicolumn{2}{|c|}{ SF (\%) } & \multicolumn{2}{|c|}{ SV/ST } & \multicolumn{2}{|c|}{ SF/ST } & \multicolumn{2}{|c|}{$\begin{array}{c}\text { Umidade } \\
(\%)\end{array}$} & \multicolumn{2}{|c|}{$\begin{array}{l}\text { Densidade } \\
\text { sólidos }\end{array}$} & \multicolumn{2}{|c|}{$\begin{array}{l}\text { Densidade } \\
\text { lodo }\end{array}$} \\
\hline & & $\begin{array}{c}\mathbf{L 1} \\
\mathbf{L 2}^{(*)}\end{array}$ & $\begin{array}{l}\text { LC1 } \\
\text { LC2 } \\
(* *)\end{array}$ & $\begin{array}{l}\text { L1 } \\
\text { L2 }\end{array}$ & $\begin{array}{l}\text { LC1 } \\
\text { LC2 }\end{array}$ & $\begin{array}{l}\text { L1 } \\
\text { L2 }\end{array}$ & $\begin{array}{l}\text { LC1 } \\
\text { LC2 }\end{array}$ & $\begin{array}{l}\text { L1 } \\
\text { L2 }\end{array}$ & $\begin{array}{l}\text { LC1 } \\
\text { LC2 }\end{array}$ & $\begin{array}{l}\text { L1 } \\
\text { L2 }\end{array}$ & $\begin{array}{l}\text { LC1 } \\
\text { LC2 }\end{array}$ & $\begin{array}{l}\text { L1 } \\
\text { L2 }\end{array}$ & $\begin{array}{l}\text { LC1 } \\
\text { LC2 }\end{array}$ & $\begin{array}{l}\text { L1 } \\
\text { L2 }\end{array}$ & $\begin{array}{l}\text { LC1 } \\
\text { LC2 }\end{array}$ & $\begin{array}{l}\text { L1 } \\
\text { L2 }\end{array}$ & $\begin{array}{l}\text { LC1 } \\
\text { LC2 }\end{array}$ \\
\hline 1 & \multirow{19}{*}{$1 / 2$} & 10,88 & 15,60 & 8,57 & 9,48 & 2,31 & 6,11 & 0,79 & 0,61 & 0,21 & 0,39 & 89,12 & 84,41 & 1,15 & 1,31 & 1,01 & 1,04 \\
\hline 2 & & 19,66 & 21,15 & 12,68 & 11,50 & 6,98 & 9,65 & 0,64 & 0,54 & 0,36 & 0,46 & 80,34 & 78,85 & 1,27 & 1,38 & 1,04 & 1,06 \\
\hline 3 & & 22,36 & 23,19 & 12,35 & 12,39 & 10,01 & 10,80 & 0,55 & 0,53 & 0,45 & 0,47 & 77,64 & 76,81 & 1,37 & 1,39 & 1,06 & 1,07 \\
\hline 4 & & 41,03 & 37,92 & 22,81 & 21,33 & 18,22 & 16,59 & 0,56 & 0,56 & 0,44 & 0,44 & 58,97 & 62,08 & 1,36 & 1,36 & 1,12 & 1,11 \\
\hline 5 & & 46,45 & 48,17 & 23,71 & 23,92 & 22,74 & 24,25 & 0,51 & 0,50 & 0,49 & 0,50 & 53,55 & 51,83 & 1,42 & 1,43 & 1,16 & 1,17 \\
\hline 6 & & 60,90 & 62,23 & 26,46 & 26,31 & 34,45 & 35,93 & 0,43 & 0,42 & 0,57 & 0,58 & 39,10 & 37,77 & 1,51 & 1,53 & 1,26 & 1,27 \\
\hline 7 & & 63,66 & 62,80 & 33,46 & 25,62 & 30,20 & 37,18 & 0,53 & 0,41 & 0,47 & 0,59 & 36,34 & 37,20 & 1,40 & 1,55 & 1,22 & 1,29 \\
\hline 8 & & 73,21 & 78,17 & 29,81 & 41,08 & 43,40 & 37,09 & 0,41 & 0,53 & 0,59 & 0,47 & 26,79 & 21,83 & 1,55 & 1,40 & 1,35 & 1,29 \\
\hline 9 & & 75,49 & 78,33 & 42,61 & 31,21 & 32,88 & 47,12 & 0,56 & 0,40 & 0,44 & 0,60 & 24,51 & 21,67 & 1,35 & 1,56 & 1,25 & 1,39 \\
\hline 10 & & 79,07 & 79,62 & 39,19 & 38,02 & 39,88 & 41,60 & 0,50 & 0,48 & 0,50 & 0,52 & 20,93 & 20,38 & 1,43 & 1,46 & 1,31 & 1,33 \\
\hline 11 & & 81,17 & 79,68 & 41,73 & 30,39 & 39,43 & 49,29 & 0,51 & 0,38 & 0,49 & 0,62 & 18,83 & 20,32 & 1,41 & 1,59 & 1,31 & 1,42 \\
\hline 12 & & 83,57 & 86,13 & 32,04 & 31,29 & 51,53 & 54,85 & 0,38 & 0,36 & 0,62 & 0,64 & 16,43 & 13,87 & 1,59 & 1,62 & 1,45 & 1,49 \\
\hline 13 & & 87,09 & 87,36 & 41,37 & 32,87 & 45,73 & 54,49 & 0,47 & 0,38 & 0,53 & 0,62 & 12,91 & 12,64 & 1,46 & 1,60 & 1,38 & 1,49 \\
\hline 14 & & 87,86 & 88,20 & 49,84 & 40,19 & 38,02 & 48,01 & 0,57 & 0,46 & 0,43 & 0,54 & 12,14 & 11,80 & 1,35 & 1,48 & 1,30 & 1,40 \\
\hline 15 & & 87,95 & 90,46 & 43,67 & 33,02 & 44,28 & 57,44 & 0,50 & 0,36 & 0,50 & 0,64 & 12,05 & 9,54 & 1,43 & 1,62 & 1,36 & 1,53 \\
\hline 16 & & 88,63 & 90,50 & 35,43 & 30,92 & 53,20 & 59,58 & 0,40 & 0,34 & 0,60 & 0,66 & 11,37 & 9,50 & 1,56 & 1,65 & 1,47 & 1,56 \\
\hline 17 & & 89,08 & 90,69 & 39,36 & 36,73 & 49,72 & 53,95 & 0,44 & 0,41 & 0,56 & 0,59 & 10,92 & 9,31 & 1,50 & 1,56 & 1,43 & 1,48 \\
\hline 18 & & 93,71 & 93,84 & 46,78 & 36,96 & 46,93 & 56,88 & 0,50 & 0,39 & 0,50 & 0,61 & 6,29 & 6,16 & 1,43 & 1,57 & 1,39 & 1,52 \\
\hline 19 & & 94,07 & 94,24 & 43,29 & 37,14 & 50,78 & 57,10 & 0,46 & 0,39 & 0,54 & 0,61 & 5,93 & 5,76 & 1,48 & 1,57 & 1,44 & 1,52 \\
\hline 20 & \multirow{19}{*}{$2 / 2$} & 14,79 & 17,72 & 9,55 & 9,23 & 5,24 & 8,49 & 0,65 & 0,52 & 0,35 & 0,48 & 85,21 & 82,28 & 1,27 & 1,40 & 1,03 & 1,05 \\
\hline 21 & & 16,78 & 23,78 & 8,68 & 10,76 & 8,10 & 13,02 & 0,52 & 0,45 & 0,48 & 0,55 & 83,22 & 76,22 & 1,41 & 1,49 & 1,05 & 1,08 \\
\hline 22 & & 23,14 & 24,98 & 11,46 & 11,09 & 11,68 & 13,89 & 0,50 & 0,44 & 0,50 & 0,56 & 76,86 & 75,02 & 1,43 & 1,50 & 1,08 & 1,09 \\
\hline 23 & & 28,25 & 32,92 & 17,25 & 15,89 & 10,99 & 17,03 & 0,61 & 0,48 & 0,39 & 0,52 & 71,75 & 67,08 & 1,30 & 1,45 & 1,07 & 1,11 \\
\hline 24 & & 29,70 & 34,72 & 14,29 & 17,73 & 15,41 & 16,99 & 0,48 & 0,51 & 0,52 & 0,49 & 70,30 & 65,28 & 1,45 & 1,42 & 1,10 & 1,11 \\
\hline 25 & & 33,80 & 41,81 & 15,86 & 14,99 & 17,95 & 26,82 & 0,47 & 0,36 & 0,53 & 0,64 & 66,20 & 58,19 & 1,47 & 1,63 & 1,12 & 1,19 \\
\hline 26 & & 40,96 & 47,70 & 18,67 & 17,93 & 22,29 & 29,77 & 0,46 & 0,38 & 0,54 & 0,62 & 59,04 & 52,30 & 1,48 & 1,60 & 1,15 & 1,22 \\
\hline 27 & & 43,84 & 48,12 & 19,72 & 18,04 & 24,12 & 30,08 & 0,45 & 0,37 & 0,55 & 0,63 & 56,16 & 51,88 & 1,49 & 1,60 & 1,17 & 1,22 \\
\hline 28 & & 56,71 & 62,20 & 24,43 & 24,86 & 32,28 & 37,34 & 0,43 & 0,40 & 0,57 & 0,60 & 43,29 & 37,80 & 1,52 & 1,56 & 1,24 & 1,29 \\
\hline 29 & & 58,38 & 63,20 & 25,63 & 23,22 & 32,75 & 39,98 & 0,44 & 0,37 & 0,56 & 0,63 & 41,62 & 36,80 & 1,51 & 1,61 & 1,24 & 1,32 \\
\hline 30 & & 66,77 & 73,57 & 25,45 & 23,58 & 41,33 & 49,99 & 0,38 & 0,32 & 0,62 & 0,68 & 33,23 & 26,43 & 1,59 & 1,69 & 1,33 & 1,43 \\
\hline 31 & & 70,93 & 77,48 & 30,39 & 25,91 & 40,53 & 51,57 & 0,43 & 0,33 & 0,57 & 0,67 & 29,07 & 22,53 & 1,52 & 1,66 & 1,32 & 1,45 \\
\hline 32 & & 72,10 & 79,23 & 29,40 & 27,65 & 42,71 & 51,58 & 0,41 & 0,35 & 0,59 & 0,65 & 27,90 & 20,77 & 1,55 & 1,64 & 1,34 & 1,45 \\
\hline 33 & & 74,55 & 81,97 & 31,21 & 30,41 & 43,34 & 51,56 & 0,42 & 0,37 & 0,58 & 0,63 & 25,45 & 18,03 & 1,54 & 1,61 & 1,35 & 1,45 \\
\hline 34 & & 81,25 & 83,88 & 33,73 & 28,40 & 47,52 & 55,48 & 0,42 & 0,34 & 0,58 & 0,66 & 18,75 & 16,12 & 1,54 & 1,66 & 1,40 & 1,50 \\
\hline 35 & & 87,06 & 85,06 & 37,53 & 28,53 & 49,53 & 56,53 & 0,43 & 0,34 & 0,57 & 0,66 & 12,94 & 14,94 & 1,52 & 1,66 & 1,42 & 1,51 \\
\hline 36 & & 89,38 & 85,51 & 38,09 & 29,82 & 51,29 & 55,69 & 0,43 & 0,35 & 0,57 & 0,65 & 10,62 & 14,49 & 1,53 & 1,64 & 1,44 & 1,50 \\
\hline 37 & & 90,18 & 89,92 & 38,46 & 31,54 & 51,72 & 58,38 & 0,43 & 0,35 & 0,57 & 0,65 & 9,82 & 10,08 & 1,52 & 1,64 & 1,45 & 1,54 \\
\hline 38 & & 91,90 & 90,36 & 38,18 & 31,36 & 53,73 & 59,00 & 0,42 & 0,35 & 0,58 & 0,65 & 8,10 & 9,64 & 1,54 & 1,64 & 1,48 & 1,55 \\
\hline 39 & & 10,73 & 12,08 & 8,56 & 8,03 & 2,18 & 4,05 & 0,80 & 0,66 & 0,20 & 0,34 & 89,27 & 87,92 & 1,14 & 1,25 & 1,01 & 1,02 \\
\hline 40 & & 12,34 & 13,85 & 7,62 & 6,19 & 4,72 & 7,66 & 0,62 & 0,45 & 0,38 & 0,55 & 87,66 & 86,15 & 1,30 & 1,50 & 1,03 & $\begin{array}{l}1,02 \\
1,05\end{array}$ \\
\hline 41 & & 14,72 & 14,48 & 9,22 & 6,89 & 5,50 & 7,59 & 0,63 & 0,48 & 0,37 & 0,52 & 85,28 & 85,52 & 1,29 & 1,46 & 1,03 & 1,05 \\
\hline 42 & & 18,54 & 21,80 & 10,44 & 10,24 & 8,10 & 11,56 & 0,56 & 0,47 & 0,44 & 0,53 & 81,46 & 78,20 & 1,36 & 1,47 & 1,05 & 1,07 \\
\hline 43 & & 19,54 & 26,34 & 11,99 & 13,56 & 7,55 & 12,78 & 0,61 & 0,51 & 0,39 & 0,49 & 80,46 & 73,66 & 1,30 & 1,41 & 1,05 & 1,08 \\
\hline 44 & & 22,75 & 28,61 & 12,71 & 13,30 & 10,05 & 15,31 & 0,56 & 0,46 & 0,44 & 0,54 & 77,25 & 71,39 & 1,36 & 1,47 & 1,06 & 1,10 \\
\hline 45 & & 27,66 & 31,35 & 14,30 & 14,86 & 13,36 & 16,49 & 0,52 & 0,47 & 0,48 & 0,53 & 72,34 & 68,65 & 1,41 & 1,46 & 1,09 & 1,11 \\
\hline 46 & & 30,27 & 32,58 & 16,00 & 13,64 & 14,27 & 18,94 & 0,53 & 0,42 & 0,47 & 0,58 & 69,73 & 67,42 & 1,39 & 1,54 & 1,09 & 1,13 \\
\hline 47 & $3 / 2$ & 31,98 & 36,27 & 17,20 & 15,12 & 14,78 & 21,15 & 0,54 & 0,42 & 0,46 & 0,58 & 68,02 & 63,73 & 1,38 & 1,54 & 1,10 & 1,15 \\
\hline 48 & & 37,29 & 49,91 & 18,81 & 19,56 & 18,47 & 30,34 & 0,50 & 0,39 & 0,50 & 0,61 & 62,71 & 50,09 & 1,42 & 1,57 & 1,12 & 1,22 \\
\hline 49 & & 46,97 & 56,07 & 23,64 & 23,25 & 23,33 & 32,82 & 0,50 & 0,41 & 0,50 & 0,59 & 53,03 & 43,93 & 1,42 & 1,54 & 1,16 & $\begin{array}{l}1,25 \\
1,25\end{array}$ \\
\hline 50 & & 56,06 & 64,66 & 28,20 & 23,26 & 27,86 & 41,40 & 0,50 & 0,36 & 0,50 & 0,64 & 43,94 & 35,34 & 1,42 & 1,62 & 1,20 & 1,33 \\
\hline 51 & & 59,60 & 72,03 & 27,61 & 25,22 & 31,99 & 46,80 & 0,46 & 0,35 & 0,54 & 0,65 & 40,40 & 27,97 & 1,47 & 1,64 & 1,24 & 1,39 \\
\hline 52 & & 72,04 & 78,10 & 32,95 & 25,79 & 39,09 & 52,31 & 0,46 & 0,33 & 0,54 & 0,67 & 27,96 & 21,90 & 1,48 & 1,67 & 1,31 & 1,46 \\
\hline 53 & & 78,79 & 85,05 & 36,17 & 30,01 & 42,63 & 55,03 & 0,46 & 0,35 & 0,54 & 0,65 & 21,21 & 14,95 & 1,48 & 1,63 & 1,34 & 1,49 \\
\hline 54 & & 83,62 & 86,95 & 36,87 & 29,01 & 46,75 & 57,94 & 0,44 & 0,33 & 0,56 & 0,67 & 16,38 & 13,05 & 1,50 & 1,67 & 1,39 & 1,53 \\
\hline 55 & & 87,71 & 88,95 & 33,09 & 30,63 & 54,62 & 58,33 & 0,38 & 0,34 & 0,62 & 0,66 & 12,29 & 11,05 & 1,60 & 1,65 & 1,49 & 1,54 \\
\hline
\end{tabular}

Nota: $(*)$ - Lodo sem cal; $(* *)$ - Lodo com cal. 
APÊNDICE 10 - Umidade - Fatores tipo de lodo e cal: Resultados de p-valores para os testes a posteriori de Tukey

\begin{tabular}{|c|c|c|c|c|c|c|c|c|c|c|}
\hline Tempo & UMI_7 & UMI_14 & UMI_21 & UMI_28 & UMI_35 & UMI_42 & UMI_49 & UMI_56 & UMI_63 & UMI_70 \\
\hline UMI_0 & 0,2289 & 0,0000 & 0,0000 & 0,0000 & 0,0000 & 0,0000 & 0,0000 & 0,0000 & 0,0000 & 0,0000 \\
\hline UMI_7 & & 0,0000 & 0,0000 & 0,0000 & 0,0000 & 0,0000 & 0,0000 & 0,0000 & 0,0000 & 0,0000 \\
\hline UMI_14 & & & 0,0000 & 0,0000 & 0,0000 & 0,0000 & 0,0000 & 0,0000 & 0,0000 & 0,0000 \\
\hline UMI_21 & & & & 0,0000 & 0,0000 & 0,0000 & 0,0000 & 0,0000 & 0,0000 & 0,0000 \\
\hline UMI_28 & & & & & 0,3585 & 0,0000 & 0,0000 & 0,0000 & 0,0000 & 0,0000 \\
\hline UMI_35 & & & & & & 0,0067 & 0,0001 & 0,0000 & 0,0000 & 0,0000 \\
\hline UMI_42 & & & & & & & 0,9967 & 0,3020 & 0,1031 & 0,0530 \\
\hline UMI_49 & & & & & & & & 0,9093 & 0,0875 & 0,0502 \\
\hline UMI_56 & & & & & & & & & 0,9222 & 0,0725 \\
\hline UMI_63 & & & & & & & & & & 0,8833 \\
\hline
\end{tabular}


APÊNDICE 11 - Umidade - Fator disposição/revolvimento: Resultados de p-valores para os testes a posteriori de Tukey

\begin{tabular}{|c|c|c|c|c|c|c|c|c|c|c|c|c|}
\hline \multirow{2}{*}{$\begin{array}{c}\text { Modo de } \\
\text { revolvimento e } \\
\text { disposição }\end{array}$} & \multirow{2}{*}{ Tempo } & \multicolumn{11}{|c|}{$10 \mathrm{~cm}$ e $\mathrm{m} / 3 \mathrm{x}+1 \mathrm{x}$} \\
\hline & & UMI_0 & UMI_7 & UMI_14 & UMI_21 & UMI_28 & UMI_35 & UMI_42 & UMI_49 & UMI_56 & UMI_63 & UMI_70 \\
\hline \multirow{11}{*}{$10 \mathrm{~cm} \mathrm{e} \mathrm{m} / 3 \mathrm{x}+1 \mathrm{x}$} & UMI_0 & & 0,3482 & 0,0000 & 0,0000 & 0,0000 & 0,0000 & 0,0000 & 0,0000 & 0,0000 & 0,0000 & 0,0000 \\
\hline & UMI_7 & & & 0,0000 & 0,0000 & 0,0000 & 0,0000 & 0,0000 & 0,0000 & 0,0000 & 0,0000 & 0,0000 \\
\hline & UMI_14 & & & & 0,0000 & 0,0000 & 0,0000 & 0,0000 & 0,0000 & 0,0000 & 0,0000 & 0,0000 \\
\hline & UMI_21 & & & & & 0,0001 & 0,0000 & 0,0000 & 0,0000 & 0,0000 & 0,0000 & 0,0000 \\
\hline & UMI_28 & & & & & & 1,0000 & 0,0022 & 0,0966 & 0,0011 & 0,0001 & 0,0000 \\
\hline & UMI_35 & & & & & & & 0,0055 & 0,1796 & 0,0029 & 0,0004 & 0,0000 \\
\hline & UMI_42 & & & & & & & & 1,0000 & 1,0000 & 1,0000 & 0,9996 \\
\hline & UMI_49 & & & & & & & & & 1,0000 & 1,0000 & 0,7379 \\
\hline & UMI_56 & & & & & & & & & & 1,0000 & 1,0000 \\
\hline & UMI_63 & & & & & & & & & & & 1,0000 \\
\hline & UMI_70 & & & & & & & & & & & \\
\hline \multirow{11}{*}{$10 \mathrm{~cm} \mathrm{e} \mathrm{m} / 3 \mathrm{x}$} & UMI_0 & 1,0000 & 0,9999 & 0,0002 & 0,0002 & 0,0002 & 0,0002 & 0,0002 & 0,0002 & 0,0002 & 0,0002 & 0,0002 \\
\hline & UMI_7 & 1,0000 & 1,0000 & 0,0002 & 0,0002 & 0,0002 & 0,0002 & 0,0002 & 0,0002 & 0,0002 & 0,0002 & 0,0002 \\
\hline & UMI_14 & 0,0271 & 0,8471 & 1,0000 & 0,0002 & 0,0002 & 0,0002 & 0,0002 & 0,0002 & 0,0002 & 0,0002 & 0,0002 \\
\hline & UMI_21 & 0,0002 & 0,0037 & 1,0000 & 0,9976 & 0,0002 & 0,0002 & 0,0002 & 0,0002 & 0,0002 & 0,0002 & 0,0002 \\
\hline & UMI_28 & 0,0002 & 0,0002 & 0,7220 & 1,0000 & 0,9999 & 0,1344 & 0,0002 & 0,0005 & 0,0002 & 0,0002 & 0,0002 \\
\hline & UMI_35 & 0,0002 & 0,0002 & 0,1034 & 1,0000 & 0,8549 & 1,0000 & 0,0024 & 0,0130 & 0,0019 & 0,0009 & 0,0002 \\
\hline & UMI_42 & 0,0002 & 0,0002 & 0,0012 & 0,9941 & 1,0000 & 1,0000 & 0,9999 & 0,4735 & 0,1448 & 0,0792 & 0,0111 \\
\hline & UMI_49 & 0,0002 & 0,0002 & 0,0002 & 0,7568 & 1,0000 & 1,0000 & 0,6380 & 1,0000 & 0,5786 & 0,4043 & 0,0944 \\
\hline & UMI_56 & 0,0002 & 0,0002 & 0,0002 & 0,2294 & 1,0000 & 1,0000 & 0,9848 & 0,9999 & 1,0000 & 0,9123 & 0,4832 \\
\hline & UMI_63 & 0,0002 & 0,0002 & 0,0002 & 0,0675 & 1,0000 & 1,0000 & 0,9999 & 1,0000 & 0,9997 & 1,0000 & 0,8340 \\
\hline & UMI_70 & 0,0002 & 0,0002 & 0,0002 & 0,0078 & 0,9996 & 0,9999 & 1,0000 & 1,0000 & 1,0000 & 1,0000 & 1,0000 \\
\hline \multirow{11}{*}{$10 \mathrm{~cm} / 3 \mathrm{x}$} & UMI_0 & 1,0000 & 0,9673 & 0,0002 & 0,0002 & 0,0002 & 0,0002 & 0,0002 & 0,0002 & 0,0002 & & 0,0002 \\
\hline & UMI_7 & 1,0000 & 1,0000 & 0,0002 & 0,0002 & 0,0002 & 0,0002 & 0,0002 & 0,0002 & 0,0002 & 0,0002 & 0,0002 \\
\hline & UMI_14 & 0,0365 & 0,9881 & 0,9708 & 0,0002 & 0,0002 & 0,0002 & 0,0002 & 0,0002 & 0,0002 & 0,0002 & 0,0002 \\
\hline & UMI_21 & 0,0002 & 0,0002 & 1,0000 & 0,9949 & 0,0002 & 0,0002 & 0,0002 & 0,0002 & 0,0002 & 0,0002 & 0,0002 \\
\hline & UMI_28 & 0,0002 & 0,0002 & 0,0566 & 1,0000 & 0,9998 & 0,0924 & 0,0002 & 0,0002 & 0,0002 & 0,0002 & 0,0002 \\
\hline & UMI_35 & 0,0002 & 0,0002 & 0,0002 & 0,6167 & 1,0000 & 1,0000 & 0,0810 & 0,3410 & 0,0624 & 0,0270 & 0,0020 \\
\hline & UMI_42 & 0,0002 & 0,0002 & 0,0002 & 0,0159 & 1,0000 & 1,0000 & 1,0000 & 0,9996 & 0,9026 & 0,7417 & 0,2005 \\
\hline & UMI_49 & 0,0002 & 0,0002 & 0,0002 & 0,0002 & 0,9563 & 0,9807 & 1,0000 & 1,0000 & 1,0000 & 1,0000 & 0,9855 \\
\hline & UMI_56 & 0,0002 & 0,0002 & 0,0002 & 0,0002 & 0,7590 & 0,8416 & 1,0000 & 1,0000 & 1,0000 & 1,0000 & 0,9998 \\
\hline & UMI_63 & 0,0002 & 0,0002 & 0,0002 & 0,0002 & 0,4732 & 0,5756 & 1,0000 & 1,0000 & 1,0000 & 1,0000 & 1,0000 \\
\hline & UMI_70 & 0,0002 & 0,0002 & 0,0002 & 0,0002 & 0,1847 & 0,2490 & 1,0000 & 1,0000 & 1,0000 & 1,0000 & 1,0000 \\
\hline \multirow{11}{*}{$20 \mathrm{~cm} / 3 \mathrm{x}$} & UMI_0 & 1,0000 & 0,9872 & 0,0002 & 0,0002 & 0,0002 & 0,0002 & 0,0002 & 0,0002 & 0,0002 & 0,0002 & 0,0002 \\
\hline & UMI_7 & 1,0000 & 1,0000 & 0,0002 & 0,0002 & 0,0002 & 0,0002 & 0,0002 & 0,0002 & 0,0002 & 0,0002 & 0,0002 \\
\hline & UMI_14 & 1,0000 & 1,0000 & 0,8366 & 0,0002 & 0,0002 & 0,0002 & 0,0002 & 0,0002 & 0,0002 & 0,0002 & 0,0002 \\
\hline & UMI_21 & 0,6751 & 1,0000 & 0,0041 & 0,4138 & 0,0002 & 0,0002 & 0,0002 & 0,0002 & 0,0002 & 0,0002 & 0,0002 \\
\hline & UMI_28 & 0,1049 & 0,9874 & 0,0836 & 0,0002 & 0,1179 & 0,0002 & 0,0002 & 0,0002 & 0,0002 & 0,0002 & 0,0002 \\
\hline & UMI_35 & 0,0069 & 0,5488 & 0,5573 & 0,0002 & 0,0002 & 0,2053 & 0,0002 & 0,0002 & 0,0002 & 0,0002 & 0,0002 \\
\hline & UMI_42 & 0,0002 & 0,0021 & 1,0000 & 0,0403 & 0,0002 & 0,0002 & 0,1692 & 0,0002 & 0,0002 & 0,0002 & 0,0002 \\
\hline & UMI_49 & 0,0002 & 0,0003 & 1,0000 & 0,2443 & 0,0002 & 0,0002 & 0,0002 & 0,3614 & 0,0002 & 0,0002 & 0,0002 \\
\hline & UMI_56 & 0,0002 & 0,0002 & 0,9998 & 0,9995 & 0,0075 & 0,0053 & 0,0002 & 0,0002 & 0,6215 & 0,0002 & 0,0002 \\
\hline & UMI_63 & 0,0002 & 0,0002 & 0,0245 & 1,0000 & 0,9908 & 0,9798 & 0,0130 & 0,0596 & 0,0101 & 0,9881 & 0,0006 \\
\hline & UMI_70 & 0,0002 & 0,0002 & 0,0002 & 0,7016 & 1,0000 & 1,0000 & 0,6966 & 0,9538 & 0,6388 & 0,4610 & 0,9998 \\
\hline
\end{tabular}




\begin{tabular}{|c|c|c|c|c|c|c|c|c|c|c|c|c|}
\hline \multirow{2}{*}{$\begin{array}{c}\text { Modo de } \\
\text { revolvimento e } \\
\text { disposição }\end{array}$} & \multirow{2}{*}{ Tempo } & \multicolumn{11}{|c|}{$10 \mathrm{~cm} \mathrm{e} \mathrm{m} \mathrm{/} 3 x$} \\
\hline & & UMI_0 & UMI_7 & UMI_14 & UMI_21 & UMI_28 & UMI_35 & UMI_42 & UMI_49 & UMI_56 & UMI_63 & UMI_70 \\
\hline \multirow{11}{*}{$10 \mathrm{~cm} \mathrm{e} \mathrm{m} / 3 \mathrm{x}+1 \mathrm{x}$} & UMI_0 & 1,0000 & 1,0000 & 0,0271 & 0,0002 & 0,0002 & 0,0002 & 0,0002 & 0,0002 & 0,0002 & 0,0002 & 0,0002 \\
\hline & UMI_7 & 0,9999 & 1,0000 & 0,8471 & 0,0037 & 0,0002 & 0,0002 & 0,0002 & 0,0002 & 0,0002 & 0,0002 & 0,0002 \\
\hline & UMI_14 & 0,0002 & 0,0002 & 1,0000 & 1,0000 & 0,7220 & 0,1034 & 0,0012 & 0,0002 & 0,0002 & 0,0002 & 0,0002 \\
\hline & UMI_21 & 0,0002 & 0,0002 & 0,0002 & 0,9976 & 1,0000 & 1,0000 & 0,9941 & 0,7568 & 0,2294 & 0,0675 & 0,0078 \\
\hline & UMI_28 & 0,0002 & 0,0002 & 0,0002 & 0,0002 & 0,9999 & 0,8549 & 1,0000 & 1,0000 & 1,0000 & 1,0000 & 0,9996 \\
\hline & UMI_35 & 0,0002 & 0,0002 & 0,0002 & 0,0002 & 0,1344 & 1,0000 & 1,0000 & 1,0000 & 1,0000 & 1,0000 & 0,9999 \\
\hline & UMI_42 & 0,0002 & 0,0002 & 0,0002 & 0,0002 & 0,0002 & 0,0024 & 0,9999 & 0,6380 & 0,9848 & 0,9999 & 1,0000 \\
\hline & UMI_49 & 0,0002 & 0,0002 & 0,0002 & 0,0002 & 0,0005 & 0,0130 & 0,4735 & 1,0000 & 0,9999 & 1,0000 & 1,0000 \\
\hline & UMI_56 & 0,0002 & 0,0002 & 0,0002 & 0,0002 & 0,0002 & 0,0019 & 0,1448 & 0,5786 & 1,0000 & 0,9997 & 1,0000 \\
\hline & UMI_63 & 0,0002 & 0,0002 & 0,0002 & 0,0002 & 0,0002 & 0,0009 & 0,0792 & 0,4043 & 0,9123 & 1,0000 & 1,0000 \\
\hline & UMI_70 & 0,0002 & 0,0002 & 0,0002 & 0,0002 & 0,0002 & 0,0002 & 0,0111 & 0,0944 & 0,4832 & 0,8340 & 1,0000 \\
\hline \multirow{11}{*}{$10 \mathrm{~cm} \mathrm{e} \mathrm{m} / 3 \mathrm{x}$} & UMI_0 & & 1,0000 & 0,0001 & 0,0000 & 0,0000 & 0,0000 & 0,0000 & 0,0000 & 0,0000 & 0,0000 & 0,0000 \\
\hline & UMI_7 & & & 0,0557 & 0,0000 & 0,0000 & 0,0000 & 0,0000 & 0,0000 & 0,0000 & 0,0000 & 0,0000 \\
\hline & UMI_14 & & & & 0,4523 & 0,0000 & 0,0000 & 0,0000 & 0,0000 & 0,0000 & 0,0000 & 0,0000 \\
\hline & UMI_21 & & & & & 0,0007 & 0,0000 & 0,0000 & 0,0000 & 0,0000 & 0,0000 & 0,0000 \\
\hline & UMI_28 & & & & & & 1,0000 & 0,3061 & 0,0129 & 0,0001 & 0,0000 & 0,0000 \\
\hline & UMI_35 & & & & & & & 0,9991 & 0,6682 & 0,0545 & 0,0039 & 0,0001 \\
\hline & UMI_42 & & & & & & & & 1,0000 & 0,9978 & 0,8373 & 0,1458 \\
\hline & UMI_49 & & & & & & & & & 1,0000 & 1,0000 & 0,8500 \\
\hline & UMI_56 & & & & & & & & & & 1,0000 & 1,0000 \\
\hline & UMI_63 & & & & & & & & & & & 1,0000 \\
\hline & UMI_70 & & & & & & & & & & & \\
\hline \multirow{11}{*}{$10 \mathrm{~cm} / 3 \mathrm{x}$} & UMI_0 & 1,0000 & 1,0000 & 0,0245 & 0,0002 & 0,0002 & 0,0002 & 0,0002 & 0,0002 & 0,0002 & 0,0002 & 0,0002 \\
\hline & UMI_7 & 1,0000 & 1,0000 & 0,4604 & 0,0006 & 0,0002 & 0,0002 & 0,0002 & 0,0002 & 0,0002 & 0,0002 & 0,0002 \\
\hline & UMI_14 & 0,3866 & 0,9813 & 1,0000 & 0,3482 & 0,0002 & 0,0002 & 0,0002 & 0,0002 & 0,0002 & 0,0002 & 0,0002 \\
\hline & UMI_21 & 0,0002 & 0,0002 & 0,5293 & 1,0000 & 0,4280 & 0,0345 & 0,0004 & 0,0002 & 0,0002 & 0,0002 & 0,0002 \\
\hline & UMI_28 & 0,0002 & 0,0002 & 0,0002 & 0,0257 & 1,0000 & 1,0000 & 0,9928 & 0,7408 & 0,2180 & 0,0632 & 0,0072 \\
\hline & UMI_35 & 0,0002 & 0,0002 & 0,0002 & 0,0002 & 0,5776 & 1,0000 & 1,0000 & 1,0000 & 1,0000 & 0,9998 & 0,9305 \\
\hline & UMI_42 & 0,0002 & 0,0002 & 0,0002 & 0,0002 & 0,0326 & 0,4146 & 1,0000 & 1,0000 & 1,0000 & 1,0000 & 1,0000 \\
\hline & UMI_49 & 0,0002 & 0,0002 & 0,0002 & 0,0002 & 0,0008 & 0,0225 & 0,6076 & 1,0000 & 1,0000 & 1,0000 & 1,0000 \\
\hline & UMI_56 & 0,0002 & 0,0002 & 0,0002 & 0,0002 & 0,0003 & 0,0074 & 0,3519 & 0,8580 & 1,0000 & 1,0000 & 1,0000 \\
\hline & UMI_63 & 0,0002 & 0,0002 & 0,0002 & 0,0002 & 0,0002 & 0,0026 & 0,1825 & 0,6528 & 0,9868 & 1,0000 & 1,0000 \\
\hline & UMI_70 & 0,0002 & 0,0002 & 0,0002 & 0,0002 & 0,0002 & 0,0007 & 0,0670 & 0,3625 & 0,8866 & 0,9939 & 1,0000 \\
\hline \multirow{11}{*}{$20 \mathrm{~cm} / 3 \mathrm{x}$} & UMI_0 & 1,0000 & 1,0000 & 0,0680 & 0,0002 & 0,0002 & 0,0002 & 0,0002 & 0,0002 & 0,0002 & 0,0002 & 0,0002 \\
\hline & UMI_7 & 1,0000 & 1,0000 & 0,2210 & 0,0005 & 0,0002 & 0,0002 & 0,0002 & 0,0002 & 0,0002 & 0,0002 & 0,0002 \\
\hline & UMI_14 & 1,0000 & 1,0000 & 1,0000 & 0,0103 & 0,0002 & 0,0002 & 0,0002 & 0,0002 & 0,0002 & 0,0002 & 0,0002 \\
\hline & UMI_21 & 0,9587 & 1,0000 & 1,0000 & 1,0000 & 0,0002 & 0,0002 & 0,0002 & 0,0002 & 0,0002 & 0,0002 & 0,0002 \\
\hline & UMI_28 & 0,4550 & 0,9745 & 1,0000 & 0,8692 & 0,9260 & 0,0002 & 0,0002 & 0,0002 & 0,0002 & 0,0002 & 0,0002 \\
\hline & UMI_35 & 0,0806 & 0,5622 & 1,0000 & 0,9996 & 0,0036 & 0,9107 & 0,0002 & 0,0002 & 0,0002 & 0,0002 & 0,0002 \\
\hline & UMI_42 & 0,0003 & 0,0056 & 0,9619 & 1,0000 & 0,4588 & 0,0586 & 0,9674 & 0,0002 & 0,0002 & 0,0002 & 0,0002 \\
\hline & UMI_49 & 0,0002 & 0,0008 & 0,6474 & 1,0000 & 0,8770 & 0,2635 & 0,0085 & 0,9661 & 0,0002 & 0,0002 & 0,0002 \\
\hline & UMI_56 & 0,0002 & 0,0002 & 0,0226 & 0,9464 & 1,0000 & 0,9964 & 0,4172 & 0,1074 & 0,9961 & 0,0039 & 0,0006 \\
\hline & UMI_63 & 0,0002 & 0,0002 & 0,0002 & 0,0097 & 1,0000 & 1,0000 & 1,0000 & 1,0000 & 0,9776 & 1,0000 & 0,3912 \\
\hline & UMI_70 & 0,0002 & 0,0002 & 0,0002 & 0,0002 & 0,6044 & 0,9928 & 1,0000 & 1,0000 & 1,0000 & 1,0000 & 1,0000 \\
\hline
\end{tabular}




\begin{tabular}{|c|c|c|c|c|c|c|c|c|c|c|c|c|}
\hline \multirow{2}{*}{$\begin{array}{c}\text { Modo de } \\
\text { revolvimento e } \\
\text { disposição }\end{array}$} & \multirow{2}{*}{ Tempo } & \multicolumn{11}{|c|}{$10 \mathrm{~cm} / 3 \mathrm{x}$} \\
\hline & & UMI_0 & UMI_7 & UMI_14 & UMI_21 & UMI_28 & UMI_35 & UMI_42 & UMI_49 & UMI_56 & UMI_63 & UMI_70 \\
\hline \multirow{11}{*}{$10 \mathrm{~cm} \mathrm{e} \mathrm{m} / 3 \mathrm{x}+1 \mathrm{x}$} & UMI_0 & 1,0000 & 1,0000 & 0,0365 & 0,0002 & 0,0002 & 0,0002 & 0,0002 & 0,0002 & 0,0002 & 0,0002 & 0,0002 \\
\hline & UMI_7 & 0,9673 & 1,0000 & 0,9881 & 0,0002 & 0,0002 & 0,0002 & 0,0002 & 0,0002 & 0,0002 & 0,0002 & 0,0002 \\
\hline & UMI_14 & 0,0002 & 0,0002 & 0,9708 & 1,0000 & 0,0566 & 0,0002 & 0,0002 & 0,0002 & 0,0002 & 0,0002 & 0,0002 \\
\hline & UMI_21 & 0,0002 & 0,0002 & 0,0002 & 0,9949 & 1,0000 & 0,6167 & 0,0159 & 0,0002 & 0,0002 & 0,0002 & 0,0002 \\
\hline & UMI_28 & 0,0002 & 0,0002 & 0,0002 & 0,0002 & 0,9998 & 1,0000 & 1,0000 & 0,9563 & 0,7590 & 0,4732 & 0,1847 \\
\hline & UMI_35 & 0,0002 & 0,0002 & 0,0002 & 0,0002 & 0,0924 & 1,0000 & 1,0000 & 0,9807 & 0,8416 & 0,5756 & 0,2490 \\
\hline & UMI_42 & 0,0002 & 0,0002 & 0,0002 & 0,0002 & 0,0002 & 0,0810 & 1,0000 & 1,0000 & 1,0000 & 1,0000 & 1,0000 \\
\hline & UMI_49 & 0,0002 & 0,0002 & 0,0002 & 0,0002 & 0,0002 & 0,3410 & 0,9996 & 1,0000 & 1,0000 & 1,0000 & 1,0000 \\
\hline & UMI_56 & 0,0002 & 0,0002 & 0,0002 & 0,0002 & 0,0002 & 0,0624 & 0,9026 & 1,0000 & 1,0000 & 1,0000 & 1,0000 \\
\hline & UMI_63 & 0,0002 & 0,0002 & 0,0002 & 0,0002 & 0,0002 & 0,0270 & 0,7417 & 1,0000 & 1,0000 & 1,0000 & 1,0000 \\
\hline & UMI_70 & 0,0002 & 0,0002 & 0,0002 & 0,0002 & 0,0002 & 0,0020 & 0,2005 & 0,9855 & 0,9998 & 1,0000 & 1,0000 \\
\hline \multirow{11}{*}{$10 \mathrm{~cm} \mathrm{e} \mathrm{m} / 3 \mathrm{x}$} & UMI_0 & 1,0000 & 1,0000 & 0,3866 & 0,0002 & 0,0002 & 0,0002 & 0,0002 & 0,0002 & 0,0002 & 0,0002 & 0,0002 \\
\hline & UMI_7 & 1,0000 & 1,0000 & 0,9813 & 0,0002 & 0,0002 & 0,0002 & 0,0002 & 0,0002 & 0,0002 & 0,0002 & 0,0002 \\
\hline & UMI_14 & 0,0245 & 0,4604 & 1,0000 & 0,5293 & 0,0002 & 0,0002 & 0,0002 & 0,0002 & 0,0002 & 0,0002 & 0,0002 \\
\hline & UMI_21 & 0,0002 & 0,0006 & 0,3482 & 1,0000 & 0,0257 & 0,0002 & 0,0002 & 0,0002 & 0,0002 & 0,0002 & 0,0002 \\
\hline & UMI_28 & 0,0002 & 0,0002 & 0,0002 & 0,4280 & 1,0000 & 0,5776 & 0,0326 & 0,0008 & 0,0003 & 0,0002 & 0,0002 \\
\hline & UMI_35 & 0,0002 & 0,0002 & 0,0002 & 0,0345 & 1,0000 & 1,0000 & 0,4146 & 0,0225 & 0,0074 & 0,0026 & 0,0007 \\
\hline & UMI_42 & 0,0002 & 0,0002 & 0,0002 & 0,0004 & 0,9928 & 1,0000 & 1,0000 & 0,6076 & 0,3519 & 0,1825 & 0,0670 \\
\hline & UMI_49 & 0,0002 & 0,0002 & 0,0002 & 0,0002 & 0,7408 & 1,0000 & 1,0000 & 1,0000 & 0,8580 & 0,6528 & 0,3625 \\
\hline & UMI_56 & 0,0002 & 0,0002 & 0,0002 & 0,0002 & 0,2180 & 1,0000 & 1,0000 & 1,0000 & 1,0000 & 0,9868 & 0,8866 \\
\hline & UMI_63 & 0,0002 & 0,0002 & 0,0002 & 0,0002 & 0,0632 & 0,9998 & 1,0000 & 1,0000 & 1,0000 & 1,0000 & 0,9939 \\
\hline & UMI_70 & 0,0002 & 0,0002 & 0,0002 & 0,0002 & 0,0072 & 0,9305 & 1,0000 & 1,0000 & 1,0000 & 1,0000 & 1,0000 \\
\hline \multirow{11}{*}{$10 \mathrm{~cm} / 3 \mathrm{x}$} & UMI_0 & & 0,9753 & 0,0000 & 0,0000 & 0,0000 & 0,0000 & 0,0000 & 0,0000 & 0,0000 & 0,0000 & 0,0000 \\
\hline & UMI_7 & & & 0,0247 & 0,0000 & 0,0000 & 0,0000 & 0,0000 & 0,0000 & 0,0000 & 0,0000 & 0,0000 \\
\hline & UMI_14 & & & & 0,0000 & 0,0000 & 0,0000 & 0,0000 & 0,0000 & 0,0000 & 0,0000 & 0,0000 \\
\hline & UMI_21 & & & & & 0,0000 & 0,0000 & 0,0000 & 0,0000 & 0,0000 & 0,0000 & 0,0000 \\
\hline & UMI_28 & & & & & & 0,0077 & 0,0000 & 0,0000 & 0,0000 & 0,0000 & 0,0000 \\
\hline & UMI_35 & & & & & & & 0,9505 & 0,0031 & 0,0001 & 0,0000 & 0,0000 \\
\hline & UMI_42 & & & & & & & & 0,9849 & 0,6698 & 0,2074 & 0,0170 \\
\hline & UMI_49 & & & & & & & & & 1,0000 & 1,0000 & 0,9977 \\
\hline & UMI_56 & & & & & & & & & & 1,0000 & 1,0000 \\
\hline & UMI_63 & & & & & & & & & & & 1,0000 \\
\hline & UMI_70 & & & & & & & & & & & \\
\hline \multirow{11}{*}{$20 \mathrm{~cm} / 3 \mathrm{x}$} & UMI_0 & 1,0000 & 1,0000 & 0,1316 & 0,0002 & 0,0002 & 0,0002 & 0,0002 & 0,0002 & 0,0002 & 0,0002 & 0,0002 \\
\hline & UMI_7 & 1,0000 & 1,0000 & 0,4173 & 0,0002 & 0,0002 & 0,0002 & 0,0002 & 0,0002 & 0,0002 & 0,0002 & 0,0002 \\
\hline & UMI_14 & 1,0000 & 1,0000 & 1,0000 & 0,0002 & 0,0002 & 0,0002 & 0,0002 & 0,0002 & 0,0002 & 0,0002 & 0,0002 \\
\hline & UMI_21 & 0,6503 & 0,9998 & 1,0000 & 0,9959 & 0,0002 & 0,0002 & 0,0002 & 0,0002 & 0,0002 & 0,0002 & 0,0002 \\
\hline & UMI_28 & 0,0962 & 0,8084 & 1,0000 & 0,2193 & 0,6521 & 0,0002 & 0,0002 & 0,0002 & 0,0002 & 0,0002 & 0,0002 \\
\hline & UMI_35 & 0,0062 & 0,1997 & 1,0000 & 0,8330 & 0,0002 & 0,3280 & 0,0002 & 0,0002 & 0,0002 & 0,0002 & 0,0002 \\
\hline & UMI_42 & 0,0002 & 0,0004 & 0,2461 & 1,0000 & 0,0432 & 0,0002 & 0,5049 & 0,0002 & 0,0002 & 0,0002 & 0,0002 \\
\hline & UMI_49 & 0,0002 & 0,0002 & 0,0407 & 1,0000 & 0,2567 & 0,0003 & 0,0002 & 0,3983 & 0,0002 & 0,0002 & 0,0002 \\
\hline & UMI_56 & 0,0002 & 0,0002 & 0,0003 & 0,9891 & 0,9996 & 0,0546 & 0,0010 & 0,0002 & 0,7199 & 0,0002 & 0,0002 \\
\hline & UMI_63 & 0,0002 & 0,0002 & 0,0002 & 0,0070 & 1,0000 & 1,0000 & 0,7859 & 0,0963 & 0,0362 & 0,9955 & 0,0038 \\
\hline & UMI_70 & 0,0002 & 0,0002 & 0,0002 & 0,0002 & 0,6845 & 1,0000 & 1,0000 & 0,9844 & 0,8955 & 0,7108 & 1,0000 \\
\hline
\end{tabular}




\begin{tabular}{|c|c|c|c|c|c|c|c|c|c|c|c|c|}
\hline \multirow{2}{*}{$\begin{array}{c}\text { Modo de } \\
\text { revolvimento e } \\
\text { disposição }\end{array}$} & \multirow{2}{*}{ Tempo } & \multicolumn{11}{|c|}{$20 \mathrm{~cm} / 3 x$} \\
\hline & & UMI_0 & UMI_7 & UMI_14 & UMI_21 & UMI_28 & UMI_35 & UMI_42 & UMI_49 & UMI_56 & UMI_63 & UMI_70 \\
\hline \multirow{11}{*}{$10 \mathrm{~cm} \mathrm{e} \mathrm{m} ; 3 \mathrm{x}+1 \mathrm{x}$} & UMI_0 & 1,0000 & 1,0000 & 1,0000 & 0,6751 & 0,1049 & 0,0069 & 0,0002 & 0,0002 & 0,0002 & 0,0002 & 0,0002 \\
\hline & UMI_7 & 0,9872 & 1,0000 & 1,0000 & 1,0000 & 0,9874 & 0,5488 & 0,0021 & 0,0003 & 0,0002 & 0,0002 & 0,0002 \\
\hline & UMI_14 & 0,0002 & 0,0002 & 0,8366 & 0,0041 & 0,0836 & 0,5573 & 1,0000 & 1,0000 & 0,9998 & 0,0245 & 0,0002 \\
\hline & UMI_21 & 0,0002 & 0,0002 & 0,0002 & 0,4138 & 0,0002 & 0,0002 & 0,0403 & 0,2443 & 0,9995 & 1,0000 & 0,7016 \\
\hline & UMI_28 & 0,0002 & 0,0002 & 0,0002 & 0,0002 & 0,1179 & 0,0002 & 0,0002 & 0,0002 & 0,0075 & 0,9908 & 1,0000 \\
\hline & UMI_35 & 0,0002 & 0,0002 & 0,0002 & 0,0002 & 0,0002 & 0,2053 & 0,0002 & 0,0002 & 0,0053 & 0,9798 & 1,0000 \\
\hline & UMI_42 & 0,0002 & 0,0002 & 0,0002 & 0,0002 & 0,0002 & 0,0002 & 0,1692 & 0,0002 & 0,0002 & 0,0130 & 0,6966 \\
\hline & UMI_49 & 0,0002 & 0,0002 & 0,0002 & 0,0002 & 0,0002 & 0,0002 & 0,0002 & 0,3614 & 0,0002 & 0,0596 & 0,9538 \\
\hline & UMI_56 & 0,0002 & 0,0002 & 0,0002 & 0,0002 & 0,0002 & 0,0002 & 0,0002 & 0,0002 & 0,6215 & 0,0101 & 0,6388 \\
\hline & UMI_63 & 0,0002 & 0,0002 & 0,0002 & 0,0002 & 0,0002 & 0,0002 & 0,0002 & 0,0002 & 0,0002 & 0,9881 & 0,4610 \\
\hline & UMI_70 & 0,0002 & 0,0002 & 0,0002 & 0,0002 & 0,0002 & 0,0002 & 0,0002 & 0,0002 & 0,0002 & 0,0006 & 0,9998 \\
\hline \multirow{11}{*}{$10 \mathrm{~cm} \mathrm{e} \mathrm{m} / 3 \mathrm{x}$} & UMI_0 & 1,0000 & 1,0000 & 1,0000 & 0,9587 & 0,4550 & 0,0806 & 0,0003 & 0,0002 & 0,0002 & 0,0002 & 0,0002 \\
\hline & UMI_7 & 1,0000 & 1,0000 & 1,0000 & 1,0000 & 0,9745 & 0,5622 & 0,0056 & 0,0008 & 0,0002 & 0,0002 & 0,0002 \\
\hline & UMI_14 & 0,0680 & 0,2210 & 1,0000 & 1,0000 & 1,0000 & 1,0000 & 0,9619 & 0,6474 & 0,0226 & 0,0002 & 0,0002 \\
\hline & UMI_21 & 0,0002 & 0,0005 & 0,0103 & 1,0000 & 0,8692 & 0,9996 & 1,0000 & 1,0000 & 0,9464 & 0,0097 & 0,0002 \\
\hline & UMI_28 & 0,0002 & 0,0002 & 0,0002 & 0,0002 & 0,9260 & 0,0036 & 0,4588 & 0,8770 & 1,0000 & 1,0000 & 0,6044 \\
\hline & UMI_35 & 0,0002 & 0,0002 & 0,0002 & 0,0002 & 0,0002 & 0,9107 & 0,0586 & 0,2635 & 0,9964 & 1,0000 & 0,9928 \\
\hline & UMI_42 & 0,0002 & 0,0002 & 0,0002 & 0,0002 & 0,0002 & 0,0002 & 0,9674 & 0,0085 & 0,4172 & 1,0000 & 1,0000 \\
\hline & UMI_49 & 0,0002 & 0,0002 & 0,0002 & 0,0002 & 0,0002 & 0,0002 & 0,0002 & 0,9661 & 0,1074 & 1,0000 & 1,0000 \\
\hline & UMI_56 & 0,0002 & 0,0002 & 0,0002 & 0,0002 & 0,0002 & 0,0002 & 0,0002 & 0,0002 & 0,9961 & 0,9776 & 1,0000 \\
\hline & UMI_63 & 0,0002 & 0,0002 & 0,0002 & 0,0002 & 0,0002 & 0,0002 & 0,0002 & 0,0002 & 0,0039 & 1,0000 & 1,0000 \\
\hline & UMI_70 & 0,0002 & 0,0002 & 0,0002 & 0,0002 & 0,0002 & 0,0002 & 0,0002 & 0,0002 & 0,0006 & 0,3912 & 1,0000 \\
\hline \multirow{11}{*}{$10 \mathrm{~cm} / 3 \mathrm{x}$} & UMI_0 & 1,0000 & 1,0000 & 1,0000 & 0,6503 & 0,0962 & 0,0062 & 0,0002 & 0,0002 & 0,0002 & 0,0002 & 0,0002 \\
\hline & UMI_7 & 1,0000 & 1,0000 & 1,0000 & 0,9998 & 0,8084 & 0,1997 & 0,0004 & 0,0002 & 0,0002 & 0,0002 & 0,0002 \\
\hline & UMI_14 & 0,1316 & 0,4173 & 1,0000 & 1,0000 & 1,0000 & 1,0000 & 0,2461 & 0,0407 & 0,0003 & 0,0002 & 0,0002 \\
\hline & UMI_21 & 0,0002 & 0,0002 & 0,0002 & 0,9959 & 0,2193 & 0,8330 & 1,0000 & 1,0000 & 0,9891 & 0,0070 & 0,0002 \\
\hline & UMI_28 & 0,0002 & 0,0002 & 0,0002 & 0,0002 & 0,6521 & 0,0002 & 0,0432 & 0,2567 & 0,9996 & 1,0000 & 0,6845 \\
\hline & UMI_35 & 0,0002 & 0,0002 & 0,0002 & 0,0002 & 0,0002 & 0,3280 & 0,0002 & 0,0003 & 0,0546 & 1,0000 & 1,0000 \\
\hline & UMI_42 & 0,0002 & 0,0002 & 0,0002 & 0,0002 & 0,0002 & 0,0002 & 0,5049 & 0,0002 & 0,0010 & 0,7859 & 1,0000 \\
\hline & UMI_49 & 0,0002 & 0,0002 & 0,0002 & 0,0002 & 0,0002 & 0,0002 & 0,0002 & 0,3983 & 0,0002 & 0,0963 & 0,9844 \\
\hline & UMI_56 & 0,0002 & 0,0002 & 0,0002 & 0,0002 & 0,0002 & 0,0002 & 0,0002 & 0,0002 & 0,7199 & 0,0362 & 0,8955 \\
\hline & UMI_63 & 0,0002 & 0,0002 & 0,0002 & 0,0002 & 0,0002 & 0,0002 & 0,0002 & 0,0002 & 0,0002 & 0,9955 & 0,7108 \\
\hline & UMI_70 & 0,0002 & 0,0002 & 0,0002 & 0,0002 & 0,0002 & 0,0002 & 0,0002 & 0,0002 & 0,0002 & 0,0038 & 1,0000 \\
\hline \multirow{11}{*}{$20 \mathrm{~cm} / 3 \mathrm{x}$} & UMI_0 & & 1,0000 & 0,9898 & 0,0316 & 0,0001 & 0,0000 & 0,0000 & 0,0000 & 0,0000 & 0,0000 & 0,0000 \\
\hline & UMI_7 & & & 1,0000 & 0,2994 & 0,0028 & 0,0000 & 0,0000 & 0,0000 & 0,0000 & 0,0000 & 0,0000 \\
\hline & UMI_14 & & & & 0,9993 & 0,3933 & 0,0074 & 0,0000 & 0,0000 & 0,0000 & 0,0000 & 0,0000 \\
\hline & UMI_21 & & & & & 1,0000 & 0,9041 & 0,0001 & 0,0000 & 0,0000 & 0,0000 & 0,0000 \\
\hline & UMI_28 & & & & & & 1,0000 & 0,0384 & 0,0007 & 0,0000 & 0,0000 & 0,0000 \\
\hline & UMI_35 & & & & & & & 0,7437 & 0,0989 & 0,0000 & 0,0000 & 0,0000 \\
\hline & UMI_42 & & & & & & & & 1,0000 & 0,3725 & 0,0000 & 0,0000 \\
\hline & UMI_49 & & & & & & & & & 0,9752 & 0,0000 & 0,0000 \\
\hline & UMI_56 & & & & & & & & & & 0,1719 & 0,0000 \\
\hline & UMI_63 & & & & & & & & & & & 0,9716 \\
\hline & UMI_70 & & & & & & & & & & & \\
\hline
\end{tabular}


APÊNDICE 12 - SV/ST - Fator tipo de lodo: Resultados de p-valores para os testes a posteriori de Tukey

\begin{tabular}{|c|c|c|c|c|c|c|c|c|c|c|c|c|}
\hline \multirow{2}{*}{ Lodo } & \multirow{2}{*}{ Tempo } & \multicolumn{11}{|c|}{ Digerido } \\
\hline & & SVST_0 & SVST_7 & SVST_14 & SVST_21 & SVST_28 & SVST_35 & SVST_42 & SVST_49 & SVST_56 & SVST_63 & SVST_70 \\
\hline \multirow{11}{*}{ Digerido } & SVST_0 & & 0,134562 & 0,199330 & 0,000016 & 0,000015 & 0,000015 & 0,000015 & 0,000015 & 0,000015 & 0,000015 & 0,000015 \\
\hline & SVST_7 & & & 1,000000 & 0,592212 & 0,365383 & 0,000015 & 0,000015 & 0,000015 & 0,000015 & 0,000015 & 0,000015 \\
\hline & SVST_14 & & & & 0,472784 & 0,266646 & 0,000015 & 0,000015 & 0,000015 & 0,000015 & 0,000015 & 0,000015 \\
\hline & SVST_21 & & & & & 1,000000 & 0,025037 & 0,071666 & 0,000015 & 0,000016 & 0,000015 & 0,000017 \\
\hline & SVST_28 & & & & & & 0,067326 & 0,166090 & 0,000017 & 0,000019 & 0,000015 & 0,000028 \\
\hline & SVST_35 & & & & & & & 1,000000 & 0,822893 & 0,895290 & 0,360855 & 0,953758 \\
\hline & SVST_42 & & & & & & & & 0,599541 & 0,709163 & 0,177408 & 0,825763 \\
\hline & SVST_49 & & & & & & & & & 1,000000 & 1,000000 & 1,000000 \\
\hline & SVST_56 & & & & & & & & & & 1,000000 & 1,000000 \\
\hline & SVST_63 & & & & & & & & & & & 0,999999 \\
\hline & SVST 70 & & & & & & & & & & & \\
\hline
\end{tabular}

\begin{tabular}{|c|c|c|c|c|c|c|c|c|c|c|c|c|}
\hline \multirow{2}{*}{ Lodo } & \multirow{2}{*}{ Tempo } & \multicolumn{11}{|c|}{ Lodo não encaminhado ao digestor (Sem digerir) } \\
\hline & & SVST_0 & SVST_7 & SVST_14 & SVST_21 & SVST_28 & SVST_35 & SVST_42 & SVST_49 & SVST_56 & SVST_63 & SVST_70 \\
\hline \multirow{11}{*}{ Digerido } & SVST_0 & 0,897158 & 1,000000 & 0,999937 & 0,017100 & 0,070692 & 0,001051 & 0,001376 & 0,000184 & 0,000182 & 0,000181 & 0,000180 \\
\hline & SVST_7 & 0,000180 & 1,000000 & 1,000000 & 0,670528 & 0,940875 & 0,129475 & 0,161746 & 0,002455 & 0,001728 & 0,001168 & 0,000354 \\
\hline & SVST_14 & 0,000180 & 0,999987 & 1,000000 & 0,614413 & 0,915614 & 0,107532 & 0,135377 & 0,001945 & 0,001379 & 0,000938 & 0,000312 \\
\hline & SVST_21 & 0,000180 & 0,648278 & 0,861406 & 1,000000 & 1,000000 & 0,896855 & 0,932079 & 0,107461 & 0,080173 & 0,056216 & 0,013941 \\
\hline & SVST_28 & 0,000180 & 0,537529 & 0,776177 & 0,999998 & 1,000000 & 0,947944 & 0,969214 & 0,153541 & 0,116645 & 0,083258 & 0,021707 \\
\hline & SVST_35 & 0,000180 & 0,006895 & 0,018961 & 0,999964 & 0,989242 & 1,000000 & 1,000000 & 0,997105 & 0,992064 & 0,979055 & 0,804551 \\
\hline & SVST_42 & 0,000180 & 0,011237 & 0,030158 & 0,999998 & 0,997226 & 1,000000 & 1,000000 & 0,988890 & 0,975452 & 0,947350 & 0,699766 \\
\hline & SVST_49 & 0,000180 & 0,000317 & 0,000629 & 0,773676 & 0,412331 & 0,999291 & 0,998008 & 1,000000 & 1,000000 & 1,000000 & 0,999984 \\
\hline & SVST_56 & 0,000180 & 0,000357 & 0,000769 & 0,817827 & 0,463058 & 0,999708 & 0,999082 & 1,000000 & 1,000000 & 1,000000 & 0,999948 \\
\hline & SVST_63 & 0,000180 & 0,000219 & 0,000326 & 0,547614 & 0,226908 & 0,986735 & 0,974887 & 1,000000 & 1,000000 & 1,000000 & 1,000000 \\
\hline & SVST_70 & 0,000180 & 0,000424 & 0,000991 & 0,865737 & 0,528377 & 0,999916 & 0,999685 & 1,000000 & 1,000000 & 1,000000 & 1,000000 \\
\hline \multirow{11}{*}{$\begin{array}{c}\text { Sem } \\
\text { digerir }\end{array}$} & SVST_0 & & 0,000015 & 0,000015 & 0,000015 & 0,000015 & 0,000015 & 0,000015 & 0,000015 & 0,000015 & 0,000015 & 0,000015 \\
\hline & SVST_7 & & & 1,000000 & 0,000015 & 0,000029 & 0,000015 & 0,000015 & 0,000015 & 0,000015 & 0,000015 & 0,000015 \\
\hline & SVST_14 & & & & 0,000017 & 0,000501 & 0,000015 & 0,000015 & 0,000015 & 0,000015 & 0,000015 & 0,000015 \\
\hline & SVST_21 & & & & & 0,999996 & 0,974757 & 0,993038 & 0,001382 & 0,000500 & 0,000166 & 0,000015 \\
\hline & SVST_28 & & & & & & 0,401545 & 0,547119 & 0,000023 & 0,000017 & 0,000015 & 0,000015 \\
\hline & SVST_35 & & & & & & & 1,000000 & 0,472372 & 0,307401 & 0,164217 & 0,006426 \\
\hline & SVST_42 & & & & & & & & 0,334376 & 0,200007 & 0,097588 & 0,002936 \\
\hline & SVST_49 & & & & & & & & & 1,000000 & 1,000000 & 0,998443 \\
\hline & SVST_56 & & & & & & & & & & 1,000000 & 0,999880 \\
\hline & SVST_63 & & & & & & & & & & & 0,999998 \\
\hline & SVST_70 & & & & & & & & & & & \\
\hline
\end{tabular}


APÊNDICE 13 - SV/ST - Fator cal: Resultados de p-valores para os testes a posteriori de Tukey

\begin{tabular}{|c|c|c|c|c|c|c|c|c|c|c|c|}
\hline Tempo & SVST_0 & SVST_7 & SVST_14 & SVST_21 & SVST_28 & SVST_35 & SVST_42 & SVST_49 & SVST_56 & SVST_63 & SVST_70 \\
\hline SVST_0 & & 0,000015 & 0,000015 & 0,000015 & 0,000015 & 0,000015 & 0,000015 & 0,000015 & 0,000015 & 0,000015 & 0,000015 \\
\hline SVST_7 & & & 1,000000 & 0,000020 & 0,000063 & 0,000015 & 0,000015 & 0,000015 & 0,000015 & 0,000015 & 0,000015 \\
\hline SVST_14 & & & & 0,000042 & 0,000232 & 0,000015 & 0,000015 & 0,000015 & 0,000015 & 0,000015 & 0,000015 \\
\hline SVST_21 & & & & & 0,999999 & 0,035139 & 0,085653 & 0,000015 & 0,000015 & 0,000015 & 0,000015 \\
\hline SVST_28 & & & & & & 0,008308 & 0,023894 & 0,000015 & 0,000015 & 0,000015 & 0,000015 \\
\hline SVST_35 & & & & & & & 1,000000 & 0,112362 & 0,098155 & 0,014365 & 0,013885 \\
\hline SVST_42 & & & & & & & & 0,048106 & 0,041122 & 0,004734 & 0,004560 \\
\hline SVST_49 & & & & & & & & & 1,000000 & 0,999886 & 0,999870 \\
\hline SVST_56 & & & & & & & & & & 0,999945 & 0,999937 \\
\hline SVST_63 & & & & & & & & & & & 1,000000 \\
\hline SVST_70 & & & & & & & & & & & \\
\hline
\end{tabular}

APÊNDICE 14 - SV/ST - Fator disposição/revolvimento: Resultados de p-valores para os testes a posteriori de Tukey

\begin{tabular}{|c|c|c|c|c|c|c|c|c|c|c|c|}
\hline Tempo & SVST_0 & SVST_7 & SVST_14 & SVST_21 & SVST_28 & SVST_35 & SVST_42 & SVST_49 & SVST_56 & SVST_63 & SVST_70 \\
\hline SVST_0 & & 0,000015 & 0,000015 & 0,000015 & 0,000015 & 0,000015 & 0,000015 & 0,000015 & 0,000015 & 0,000015 & 0,000015 \\
\hline SVST_7 & & & 1,000000 & 0,000019 & 0,000059 & 0,000015 & 0,000015 & 0,000015 & 0,000015 & 0,000015 & 0,000015 \\
\hline SVST_14 & & & & 0,000039 & 0,000213 & 0,000015 & 0,000015 & 0,000015 & 0,000015 & 0,000015 & 0,000015 \\
\hline SVST_21 & & & & & 0,999999 & 0,033598 & 0,082665 & 0,000015 & 0,000015 & 0,000015 & 0,000015 \\
\hline SVST_28 & & & & & & 0,007833 & 0,022759 & 0,000015 & 0,000015 & 0,000015 & 0,000015 \\
\hline SVST_35 & & & & & & & 1,000000 & 0,108768 & 0,094873 & 0,013615 & 0,013155 \\
\hline SVST_42 & & & & & & & & 0,046144 & 0,039381 & 0,004441 & 0,004276 \\
\hline SVST_49 & & & & & & & & & 1,000000 & 0,999881 & 0,999865 \\
\hline SVST_56 & & & & & & & & & & 0,999943 & 0,999934 \\
\hline SVST_63 & & & & & & & & & & & 1,000000 \\
\hline SVST_70 & & & & & & & & & & & \\
\hline
\end{tabular}


APÊNDICE 15 - pH - Fator tipo de lodo: Resultados de p-valores para os testes a posteriori de Tukey

\begin{tabular}{|c|c|c|c|c|c|c|c|c|c|c|c|}
\hline TEMPO & pH_0 & pH_7 & pH_14 & pH_21 & pH_28 & pH_35 & pH_42 & pH_49 & pH_56 & pH_63 & pH_70 \\
\hline pH_0 & & 0,7521 & 0,0000 & 0,0000 & 0,0000 & 0,0000 & 0,0000 & 0,0000 & 0,0000 & 0,0000 & 0,0000 \\
\hline pH_7 & & & 0,0000 & 0,0000 & 0,0000 & 0,0000 & 0,0000 & 0,0000 & 0,0000 & 0,0000 & 0,0000 \\
\hline pH_14 & & & & 1,0000 & 0,9323 & 0,9921 & 0,7997 & 0,8557 & 0,2912 & 0,1260 & 0,0861 \\
\hline pH_21 & & & & & 0,9967 & 1,0000 & 0,9726 & 0,9855 & 0,6253 & 0,3657 & 0,2792 \\
\hline pH_28 & & & & & & 1,0000 & 1,0000 & 1,0000 & 0,9933 & 0,9415 & 0,8947 \\
\hline pH_35 & & & & & & & 0,9998 & 1,0000 & 0,9383 & 0,7757 & 0,6836 \\
\hline pH_42 & & & & & & & & 1,0000 & 0,9996 & 0,9895 & 0,9745 \\
\hline ph_49 & & & & & & & & & 0,9988 & 0,9792 & 0,9552 \\
\hline ph_56 & & & & & & & & & & 1,0000 & 1,0000 \\
\hline ph_63 & & & & & & & & & & & 1,0000 \\
\hline ph_70 & & & & & & & & & & & \\
\hline
\end{tabular}


APÊNDICE $16-\mathrm{pH}$ - Fator cal: Resultados de p-valores para os testes a posteriori de Tukey

\begin{tabular}{|c|c|c|c|c|c|c|c|c|c|c|c|c|}
\hline \multirow{2}{*}{ Cal } & \multirow{2}{*}{ Tempo } & \multicolumn{11}{|c|}{ Sem cal } \\
\hline & & pH_0 & pH_7 & pH_14 & pH_21 & pH_28 & pH_35 & pH_42 & pH_49 & pH_56 & pH_63 & pH_70 \\
\hline \multirow{11}{*}{ Sem cal } & pH_0 & & 1,0000 & 0,8773 & 0,9461 & 0,0898 & 0,1447 & 0,1019 & 0,0531 & 0,0004 & 0,0003 & 0,0000 \\
\hline & pH_7 & & & 1,0000 & 1,0000 & 0,7266 & 0,8349 & 0,7568 & 0,5985 & 0,0262 & 0,0236 & 0,0016 \\
\hline & pH_14 & & & & 1,0000 & 0,9997 & 1,0000 & 0,9998 & 0,9984 & 0,4848 & 0,4617 & 0,0973 \\
\hline & pH_21 & & & & & 0,9981 & 0,9997 & 0,9988 & 0,9921 & 0,3461 & 0,3260 & 0,0547 \\
\hline & pH_28 & & & & & & 1,0000 & 1,0000 & 1,0000 & 0,9990 & 0,9986 & 0,8897 \\
\hline & pH_35 & & & & & & & 1,0000 & 1,0000 & 0,9952 & 0,9939 & 0,7998 \\
\hline & pH_42 & & & & & & & & 1,0000 & 0,9984 & 0,9979 & 0,8696 \\
\hline & pH_49 & & & & & & & & & 0,9998 & 0,9998 & 0,9485 \\
\hline & pH_56 & & & & & & & & & & 1,0000 & 1,0000 \\
\hline & pH_63 & & & & & & & & & & & 1,0000 \\
\hline & pH_70 & & & & & & & & & & & \\
\hline \multirow{12}{*}{ Com cal } & pH_0 & 0,0002 & 0,0002 & 0,0002 & 0,0002 & 0,0002 & 0,0002 & 0,0002 & 0,0002 & 0,0002 & 0,0002 & 0,0002 \\
\hline & pH_7 & 0,0002 & 0,0002 & 0,0002 & 0,0002 & 0,0002 & 0,0002 & 0,0002 & 0,0002 & 0,0002 & 0,0002 & 0,0002 \\
\hline & pH_14 & 0,0002 & 0,0002 & 0,0489 & 0,0002 & 0,0002 & 0,0002 & 0,0002 & 0,0002 & 0,0002 & 0,0002 & 0,0002 \\
\hline & pH_21 & 0,0002 & 0,0002 & 0,0002 & 0,1170 & 0,0002 & 0,0002 & 0,0002 & 0,0002 & 0,0002 & 0,0002 & 0,0002 \\
\hline & pH_28 & 0,0002 & 0,0002 & 0,0002 & 0,0002 & 0,0886 & 0,0002 & 0,0002 & 0,0002 & 0,0002 & 0,0002 & 0,0002 \\
\hline & pH_35 & 0,0002 & 0,0002 & 0,0002 & 0,0002 & 0,0002 & 0,0633 & 0,0002 & 0,0002 & 0,0002 & 0,0002 & 0,0002 \\
\hline & pH_42 & 0,0002 & 0,0002 & 0,0002 & 0,0002 & 0,0002 & 0,0002 & 0,1384 & 0,0002 & 0,0002 & 0,0002 & 0,0002 \\
\hline & pH_49 & 0,0002 & 0,0002 & 0,0002 & 0,0002 & 0,0002 & 0,0002 & 0,0002 & 0,0965 & 0,0002 & 0,0002 & 0,0002 \\
\hline & pH_56 & 0,0002 & 0,0002 & 0,0002 & 0,0002 & 0,0002 & 0,0002 & 0,0002 & 0,0002 & 0,0803 & 0,0002 & 0,0002 \\
\hline & pH_63 & 0,0003 & 0,0002 & 0,0002 & 0,0002 & 0,0002 & 0,0002 & 0,0002 & 0,0002 & 0,0002 & 0,1268 & 0,0002 \\
\hline & pH_70 & 0,0002 & 0,0002 & 0,0002 & 0,0002 & 0,0002 & 0,0002 & 0,0002 & 0,0002 & 0,0002 & 0,0002 & 0,0750 \\
\hline & & \multicolumn{11}{|c|}{ Com cal } \\
\hline \multirow{11}{*}{ Com cal } & pH_0 & & 0,0580 & 0,0000 & 0,0000 & 0,0000 & 0,0000 & 0,0000 & 0,0000 & 0,0000 & 0,0000 & 0,0000 \\
\hline & pH_7 & & & 0,0000 & 0,0000 & 0,0000 & 0,0000 & 0,0000 & 0,0000 & 0,0000 & 0,0000 & 0,0000 \\
\hline & pH_14 & & & & 0,9990 & 0,7490 & 0,9952 & 0,1857 & 0,4973 & 0,0539 & 0,0017 & 0,0066 \\
\hline & pH_21 & & & & & 1,0000 & 1,0000 & 0,9825 & 0,9998 & 0,8546 & 0,2318 & 0,4407 \\
\hline & pH_28 & & & & & & 1,0000 & 1,0000 & 1,0000 & 0,9999 & 0,8857 & 0,9760 \\
\hline & pH_35 & & & & & & & 0,9951 & 1,0000 & 0,9283 & 0,3383 & 0,5768 \\
\hline & pH_42 & & & & & & & & 1,0000 & 1,0000 & 0,9996 & 1,0000 \\
\hline & pH_49 & & & & & & & & & 1,0000 & 0,9779 & 0,9980 \\
\hline & pH_56 & & & & & & & & & & 1,0000 & 1,0000 \\
\hline & pH_63 & & & & & & & & & & & 1,0000 \\
\hline & pH_70 & & & & & & & & & & & \\
\hline
\end{tabular}


APÊNDICE 17 - pH - Fator disposição/revolvimento: Resultados de p-valores para os testes a posteriori de Tukey

\begin{tabular}{|c|c|c|c|c|c|c|c|c|c|c|c|}
\hline TEMPO & pH_0 & pH_7 & pH_14 & pH_21 & pH_28 & pH_35 & pH_42 & pH_49 & pH_56 & pH_63 & pH_70 \\
\hline pH_0 & & 0,766841 & 0,000015 & 0,000015 & 0,000015 & 0,000015 & 0,000015 & 0,000015 & 0,000015 & 0,000015 & 0,000015 \\
\hline pH_7 & & & 0,000015 & 0,000015 & 0,000015 & 0,000015 & 0,000015 & 0,000015 & 0,000015 & 0,000015 & 0,000015 \\
\hline pH_14 & & & & 0,999994 & 0,937676 & 0,992911 & 0,812448 & 0,865670 & 0,310207 & 0,138469 & 0,095849 \\
\hline pH_21 & & & & & 0,997015 & 0,999963 & 0,975010 & 0,986879 & 0,643880 & 0,385955 & 0,297973 \\
\hline pH_28 & & & & & & 0,999999 & 1,000000 & 1,000000 & 0,993933 & 0,946236 & 0,902442 \\
\hline pH_35 & & & & & & & 0,999861 & 0,999971 & 0,943247 & 0,789453 & 0,700632 \\
\hline pH_42 & & & & & & & & 1,000000 & 0,999664 & 0,990507 & 0,976754 \\
\hline pH_49 & & & & & & & & & 0,998924 & 0,981122 & 0,958960 \\
\hline pH_56 & & & & & & & & & & 1,000000 & 0,999991 \\
\hline pH_63 & & & & & & & & & & & 1,000000 \\
\hline pH_70 & & & & & & & & & & & \\
\hline
\end{tabular}

APÊNDICE 18 - CTt - Fator tipo de lodo: Resultados de p-valores para os testes a posteriori de Tukey

\begin{tabular}{c|cccccc}
\hline Tempo & CTt_0 & CTt_14 & CTt_28 & CTt_42 & CTt_56 & CTt_70 \\
\cline { 2 - 6 } CTt_0 & & 0,919234 & 0,105542 & 0,002324 & 0,001510 & 0,003240 \\
CTt_14 & & 0,006989 & 0,000176 & 0,000155 & 0,000204 \\
CTt_28 & & & 0,763358 & 0,684127 & 0,818987 \\
CTt_42 & & & & 0,999995 & 0,9999998 \\
CTt_56 & & & & & 0,999906 \\
CTt_70 & & & & & \\
\hline
\end{tabular}

APÊNDICE 19 - CTt - Fator cal: Resultados de p-valores para os testes a posteriori de Tukey

\begin{tabular}{|c|c|c|c|c|c|c|c|c|c|c|c|c|c|}
\hline \multirow{2}{*}{ Cal } & \multirow{2}{*}{ Tempo } & \multicolumn{6}{|c|}{ Sem cal } & \multicolumn{6}{|c|}{ Com cal } \\
\hline & & CTt_o & CTt_14 & CTt_28 & CTt_42 & CTt_56 & CTt_70 & CTt_o & CTt_14 & CTt_28 & CTt_42 & CTt_56 & CTt_70 \\
\hline \multirow{6}{*}{$\begin{array}{c}\text { Sem } \\
\text { cal }\end{array}$} & CTt_ 0 & & 0,291024 & 0,000120 & 0,000119 & 0,000119 & 0,000119 & 0,000192 & 0,000428 & 0,000119 & 0,000119 & 0,000119 & 0,000119 \\
\hline & CTt_14 & & & 0,001885 & 0,000132 & 0,000132 & 0,000183 & 0,000121 & 0,725604 & 0,001588 & 0,000133 & 0,000124 & 0,000124 \\
\hline & CTt_28 & & & & 0,973056 & 0,973056 & 0,999378 & 0,966829 & 0,404718 & 1,000000 & 0,997849 & 0,988008 & 0,988008 \\
\hline & CTt_42 & & & & & 1,000000 & 0,999998 & 1,000000 & 0,013545 & 0,938764 & 1,000000 & 1,000000 & 1,000000 \\
\hline & CTt_56 & & & & & & 0,999998 & 1,000000 & 0,013545 & 0,938764 & 1,000000 & 1,000000 & 1,000000 \\
\hline & CTt_70 & & & & & & & 0,999998 & 0,057594 & 0,997210 & 1,000000 & 1,000000 & 1,000000 \\
\hline \multirow{6}{*}{$\begin{array}{c}\text { Com } \\
\text { cal }\end{array}$} & CTt_0 & & & & & & & & 0,005251 & 0,896549 & 1,000000 & 1,000000 & 1,000000 \\
\hline & CTt_14 & & & & & & & & & 0,364119 & 0,019978 & 0,009562 & 0,009562 \\
\hline & CTt_28 & & & & & & & & & & 0,987659 & 0,952772 & 0,952772 \\
\hline & CTt_42 & & & & & & & & & & & 1,000000 & 1,000000 \\
\hline & CTt_56 & & & & & & & & & & & & 1,000000 \\
\hline & CTt_70 & & & & & & & & & & & & \\
\hline
\end{tabular}


APÊNDICE 20 - CTt - Fator disposição/revolvimento: Resultados de p-valores para os testes a posteriori de Tukey

\begin{tabular}{|c|c|c|c|c|c|c|c|c|c|c|c|c|c|}
\hline \multirow{2}{*}{ Disp_Rev } & \multirow{2}{*}{ Tempo } & \multicolumn{6}{|c|}{$10 \mathrm{~cm}$ e $\mathrm{m} / 3 \mathrm{x}+1 \mathrm{x}$} & \multicolumn{6}{|c|}{$10 \mathrm{~cm} \mathrm{e} \mathrm{m} \mathrm{/} 3 x$} \\
\hline & & CTt_0 & CTt_14 & CTt_28 & CTt_42 & CTt_56 & CTt_70 & CTt_o & CTt_14 & CTt_28 & CTt_42 & CTt_56 & CTt_70 \\
\hline $10 \mathrm{~cm} \mathrm{e} \mathrm{m} / 3 \mathrm{x}+1 \mathrm{x}$ & CTt_0 & & 0,866029 & 0,067762 & 0,014650 & 0,014650 & 0,047264 & 1,000000 & 1,000000 & 0,975253 & 0,639826 & 0,639826 & 0,639826 \\
\hline $10 \mathrm{~cm}$ e $\mathrm{m} / 3 \mathrm{x}+1 \mathrm{x}$ & CTt_14 & & & 0,000208 & 0,000184 & 0,000184 & 0,000196 & 0,980450 & 0,981786 & 0,238730 & 0,037094 & 0,037094 & 0,037094 \\
\hline $10 \mathrm{~cm} \mathrm{e} m / 3 x+1 x$ & CTt_28 & & & & 1,000000 & 1,000000 & 1,000000 & 0,982470 & 0,993391 & 1,000000 & 1,000000 & 1,000000 & 1,000000 \\
\hline $10 \mathrm{~cm} \mathrm{e} m / 3 \mathrm{x}+1 \mathrm{x}$ & CTt_42 & & & & & 1,000000 & 1,000000 & 0,909149 & 0,951589 & 1,000000 & 1,000000 & 1,000000 & 1,000000 \\
\hline $10 \mathrm{~cm} \mathrm{e} \mathrm{m} / 3 \mathrm{x}+1 \mathrm{x}$ & CTt_56 & & & & & & 1,000000 & 0,909149 & 0,951589 & 1,000000 & 1,000000 & 1,000000 & 1,000000 \\
\hline $10 \mathrm{~cm} \mathrm{e} m / 3 x+1 x$ & CTt_ 70 & & & & & & & 0,971619 & 0,988185 & 1,000000 & 1,000000 & 1,000000 & 1,000000 \\
\hline $10 \mathrm{~cm} \mathrm{e} \mathrm{m} / 3 \mathrm{x}$ & CTt_0 & & & & & & & & 1,000000 & 0,999975 & 0,986854 & 0,986854 & 0,986854 \\
\hline $10 \mathrm{~cm} \mathrm{e} \mathrm{m} / 3 \mathrm{x}$ & CTt_14 & & & & & & & & & 0,999996 & 0,994302 & 0,994302 & 0,994302 \\
\hline $10 \mathrm{~cm} \mathrm{e} \mathrm{m} / 3 \mathrm{x}$ & CTt_28 & & & & & & & & & & 1,000000 & 1,000000 & 1,000000 \\
\hline $10 \mathrm{~cm} \mathrm{e} \mathrm{m} / 3 \mathrm{x}$ & CTt_42 & & & & & & & & & & & 1,000000 & 1,000000 \\
\hline $10 \mathrm{~cm}$ e $\mathrm{m} / 3 \mathrm{x}$ & CTt_56 & & & & & & & & & & & & 1,000000 \\
\hline $10 \mathrm{~cm} \mathrm{e} \mathrm{m} / 3 \mathrm{x}$ & CTt_70 & & & & & & & & & & & & \\
\hline
\end{tabular}

\begin{tabular}{|c|c|c|c|c|c|c|c|c|c|c|c|c|c|}
\hline \multirow{2}{*}{ Disp_Rev } & \multirow{2}{*}{ Tempo } & \multicolumn{6}{|c|}{$10 \mathrm{~cm} / 3 \mathrm{x}$} & \multicolumn{6}{|c|}{$20 \mathrm{~cm} / 3 x$} \\
\hline & & CTt_0 & CTt_14 & CTt_28 & CTt_42 & CTt_56 & CTt_70 & CTt_0 & CTt_14 & CTt_28 & CTt_42 & CTt_56 & CTt_70 \\
\hline $10 \mathrm{~cm}$ e $m / 3 x+1 x$ & CTt_0 & 0,995025 & 0,914214 & 0,741565 & 0,317003 & 0,095741 & 0,095741 & 0,971243 & 0,735020 & 0,999937 & 0,336732 & 0,563406 & 0,563406 \\
\hline $10 \mathrm{~cm}$ e $m / 3 x+1 x$ & CTt_14 & 0,095792 & 0,270734 & 0,011756 & 0,001520 & 0,000345 & 0,000345 & 0,087403 & 0,255199 & 0,499559 & 0,004543 & 0,013436 & 0,013436 \\
\hline $10 \mathrm{~cm} \mathrm{e} \mathrm{m} / 3 \mathrm{x}+1 \mathrm{x}$ & CTt_28 & 0,999230 & 0,999996 & 1,000000 & 1,000000 & 1,000000 & 1,000000 & 1,000000 & 1,000000 & 0,999482 & 1,000000 & 1,000000 & 1,000000 \\
\hline $10 \mathrm{~cm}$ e $\mathrm{m} / 3 \mathrm{x}+1 \mathrm{x}$ & CTt_42 & 0,973604 & 0,998510 & 0,999974 & 1,000000 & 1,000000 & 1,000000 & 0,999999 & 1,000000 & 0,980852 & 1,000000 & 1,000000 & 1,000000 \\
\hline $10 \mathrm{~cm}$ e $m / 3 x+1 x$ & CTt_56 & 0,973604 & 0,998510 & 0,999974 & 1,000000 & 1,000000 & 1,000000 & 0,999999 & 1,000000 & 0,980852 & 1,000000 & 1,000000 & 1,000000 \\
\hline $10 \mathrm{~cm}$ e $\mathrm{m} / 3 \mathrm{x}+1 \mathrm{x}$ & CTt_70 & 0,997700 & 0,999973 & 1,000000 & 1,000000 & 1,000000 & 1,000000 & 1,000000 & 1,000000 & 0,997717 & 1,000000 & 1,000000 & 1,000000 \\
\hline $10 \mathrm{~cm} \mathrm{e} \mathrm{m} / 3 \mathrm{x}$ & CTt_0 & 1,000000 & 0,999998 & 0,999930 & 0,994322 & 0,945765 & 0,945765 & 0,999988 & 0,999302 & 1,000000 & 0,977944 & 0,996130 & 0,996130 \\
\hline $10 \mathrm{~cm} \mathrm{e} \mathrm{m} / 3 \mathrm{x}$ & CTt_14 & 1,000000 & 1,000000 & 0,999990 & 0,998183 & 0,972930 & 0,972930 & 0,999998 & 0,999890 & 1,000000 & 0,990023 & 0,998733 & 0,998733 \\
\hline $10 \mathrm{~cm} \mathrm{e} \mathrm{m} / 3 \mathrm{x}$ & CTt_28 & 1,000000 & 1,000000 & 1,000000 & 1,000000 & 1,000000 & 1,000000 & 1,000000 & 1,000000 & 1,000000 & 1,000000 & 1,000000 & 1,000000 \\
\hline $10 \mathrm{~cm} \mathrm{e} \mathrm{m} / 3 \mathrm{x}$ & CTt_42 & 0,999862 & 0,999997 & 1,000000 & 1,000000 & 1,000000 & 1,000000 & 1,000000 & 1,000000 & 0,999667 & 1,000000 & 1,000000 & 1,000000 \\
\hline $10 \mathrm{~cm} \mathrm{e} \mathrm{m} / 3 \mathrm{x}$ & CTt_56 & 0,999862 & 0,999997 & 1,000000 & 1,000000 & 1,000000 & 1,000000 & 1,000000 & 1,000000 & 0,999667 & 1,000000 & 1,000000 & 1,000000 \\
\hline $10 \mathrm{~cm}$ e $\mathrm{m} / 3 \mathrm{x}$ & CTt_70 & 0,999862 & 0,999997 & 1,000000 & 1,000000 & 1,000000 & 1,000000 & 1,000000 & 1,000000 & 0,999667 & 1,000000 & 1,000000 & 1,000000 \\
\hline $10 \mathrm{~cm} / 3 \mathrm{x}$ & CTt_0 & & 1,000000 & 1,000000 & 0,999882 & 0,986262 & 0,986262 & 1,000000 & 0,999999 & 1,000000 & 0,998890 & 0,999974 & 0,999974 \\
\hline $10 \mathrm{~cm} / 3 \mathrm{x}$ & CTt_14 & & & 1,000000 & 1,000000 & 0,999350 & 0,999350 & 1,000000 & 1,000000 & 1,000000 & 0,999970 & 1,000000 & 1,000000 \\
\hline $10 \mathrm{~cm} / 3 \mathrm{x}$ & CTt_28 & & & & 1,000000 & 0,999990 & 0,999990 & 1,000000 & 1,000000 & 1,000000 & 1,000000 & 1,000000 & 1,000000 \\
\hline $10 \mathrm{~cm} / 3 \mathrm{x}$ & CTt_42 & & & & & 1,000000 & 1,000000 & 1,000000 & 1,000000 & 0,999876 & 1,000000 & 1,000000 & 1,000000 \\
\hline $10 \mathrm{~cm} / 3 \mathrm{x}$ & CTt_56 & & & & & & 1,000000 & 1,000000 & 1,000000 & 0,992211 & 1,000000 & 1,000000 & 1,000000 \\
\hline $10 \mathrm{~cm} / 3 \mathrm{x}$ & CTt_70 & & & & & & & 1,000000 & 1,000000 & 0,992211 & 1,000000 & 1,000000 & 1,000000 \\
\hline $20 \mathrm{~cm} / 3 \mathrm{x}$ & CTt_ 0 & & & & & & & & 1,000000 & 1,000000 & 1,000000 & 1,000000 & 1,000000 \\
\hline $20 \mathrm{~cm} / 3 \mathrm{x}$ & CTt_14 & & & & & & & & & 0,999991 & 1,000000 & 1,000000 & 1,000000 \\
\hline $20 \mathrm{~cm} / 3 \mathrm{x}$ & CTt_28 & & & & & & & & & & 0,996652 & 0,999825 & 0,999825 \\
\hline $20 \mathrm{~cm} / 3 \mathrm{x}$ & CTt_42 & & & & & & & & & & & 1,000000 & 1,000000 \\
\hline $20 \mathrm{~cm} / 3 \mathrm{x}$ & CTt_56 & & & & & & & & & & & & 1,000000 \\
\hline $20 \mathrm{~cm} / 3 \mathrm{x}$ & CTt_70 & & & & & & & & & & & & \\
\hline
\end{tabular}


APÊNDICE 21 - OVH - Fator tipo de lodo: Resultados de p-valores para os testes a posteriori de Tukey

\begin{tabular}{c|cccccc}
\hline Tempo & OVH_0 & OVH_14 & OVH_28 & OVH_42 & OVH_56 & OVH_70 \\
\cline { 2 - 6 } OVH_0 & & 0,036811 & 0,000120 & 0,000120 & 0,000120 & 0,000120 \\
OVH_14 & & 0,001224 & 0,000120 & 0,000120 & 0,000120 \\
OVH_28 & & & 0,175099 & 0,019583 & 0,009235 \\
OVH_42 & & & & 0,954620 & 0,876913 \\
OVH_56 & & & & & 0,999887 \\
OVH_70 & & & & & & \\
\hline
\end{tabular}

APÊNDICE 22 - OVH - Fator cal: Resultados de p-valores para os testes a posteriori de Tukey

\begin{tabular}{c|cccccc}
\hline Tempo & OVH_0 & OVH_14 & OVH_28 & OVH_42 & OVH_56 & OVH_70 \\
\cline { 2 - 7 } OVH_0 & & 0,046627 & 0,000120 & 0,000120 & 0,000120 & 0,000120 \\
OVH_14 & & 0,001827 & 0,000120 & 0,000120 & 0,000120 \\
OVH_28 & & & 0,201237 & 0,025700 & 0,012605 \\
OVH_42 & & & & 0,959884 & 0,889686 \\
OVH_56 & & & & & 0,999902 \\
OVH_70 & & & & & & \\
\hline
\end{tabular}

APÊNDICE 23 - OVH - Fator disposição/revolvimento: Resultados de p-valores para os testes a posteriori de Tukey

\begin{tabular}{c|cccccc}
\hline TEMPO & OVH_0 & OVH_14 & OVH_28 & OVH_42 & OVH_56 & OVH_70 \\
\hline OVH_0 & & 0,040568 & 0,000121 & 0,000121 & 0,000121 & 0,000121 \\
OVH_14 & & 0,001471 & 0,000121 & 0,000121 & 0,000121 \\
OVH_28 & & & 0,184688 & 0,021967 & 0,010576 \\
OVH_42 & & & & 0,956398 & 0,881282 \\
OVH_56 & & & & & & 0,999892 \\
OVH_70 & & & & & & \\
\hline
\end{tabular}




\section{ANEXO -}

ANEXO 1 - Planta baixa e pespectiva da estufa agrícola dimensionada para a ETE Aeroporto.

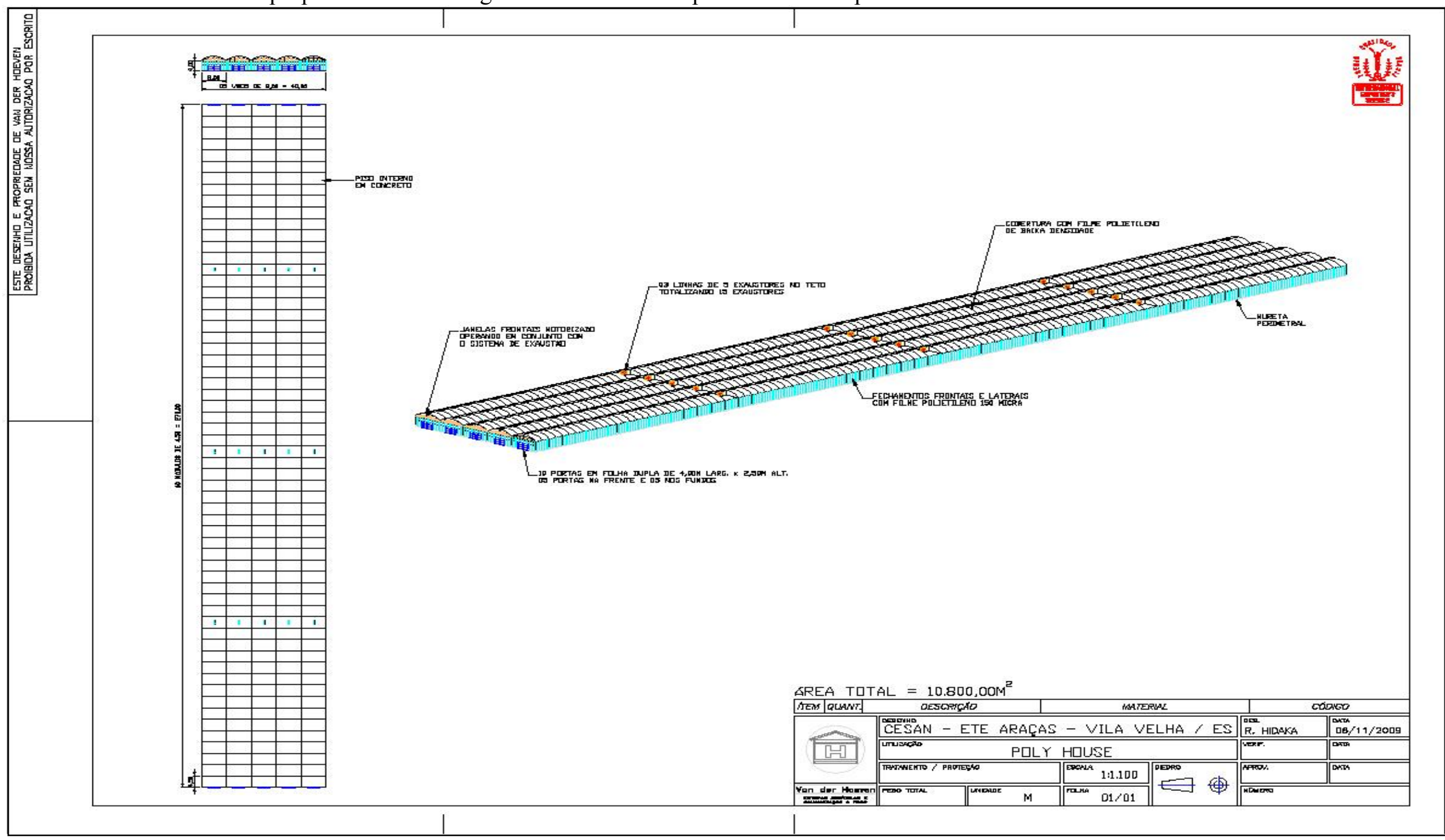


ANEXO 2 - Orçamento das estufas detalhado, emitido pela empresa contactada.

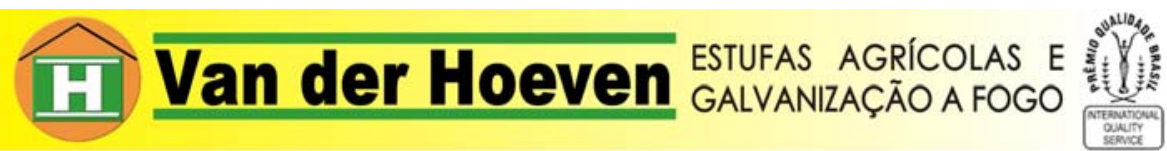

Artur Nogueira/SP, 06 de novembro de 2009.

Cliente : CESAN - CIA. ESPI RITO SANTENSE DE SANEAMENTO

\section{CESAN}

Endereço: Avenida Governador Bley, 186 - Edifício BEMGE, $3^{0}$ Andar - Centro

Cidade: Vitória

Estado: ES

Fone: (27) 2127-5353 / 2157-5000

Cep 29.010-150

Home-Page : http://www.cesan.com.br

Contato: $\quad$ Eng $^{a}$. Márcia Regina Pereira Lima

IFES - Instituto Federal do ES

Saneamento Ambiental

Fone (27) 3322-2029

Cel. (27) 8827-2920

e-mail marcialima@ifes.edu.br

\section{Ref.: Cobertura para de Secagem de Lodo}

\section{Proposta : 532/ 09 Estufas Agrícolas}

Prezada Márcia,

Agradecemos pela oportunidade que nos foi concedida de participarmos no processo de implantação de seu projeto.

Abaixo apresentamos e submetemos à apreciação de Vossa Senhoria a proposta comercial acompanhada das condições comerciais previstas para fornecimento e instalação de Estufas, tipo Agrícola, dentro dos padrões de construção adotados em Estufas para Cobertura de Leitos e Pátios de Secagem/Compostagem de Lodo que já atendemos em outras Estações de Tratamento. 
A - ESPECI FI CAÇÕES TÉCNI CAS:

\section{A-01. Modelo :}

Poly House (vãos livres de 8,00 m e cobertura em Arcos).

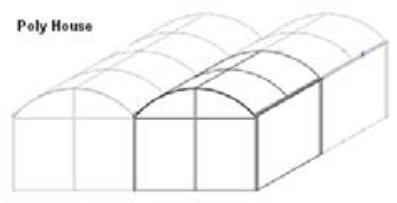

\section{A-02. Dimensões}

\begin{tabular}{|c|c|c|c|c|c|}
\hline \multicolumn{6}{|c|}{ ETE ARAÇAS - VILHA VELHA/ES } \\
\hline Item & Qtd. & Tipo & Medida (m) & Total & Unid. \\
\hline Largura & 05 & Vãos & 8,00 & 40,00 & $\mathrm{~m}$ \\
\hline Comprimento & 60 & Módulos & 4,50 & 270,00 & $\mathrm{~m}$ \\
\hline Altura livre & & & & 4,00 & $\mathrm{~m}$ \\
\hline Total unitário & & & & $10.800,00$ & $\mathrm{~m}^{2}$ \\
\hline Total da ETE & & 03 unida & & $32.400,00$ & $\mathrm{~m}^{2}$ \\
\hline
\end{tabular}

\begin{tabular}{|c|c|c|c|c|c|}
\hline \multicolumn{6}{|c|}{ ETE AEROPORTO - GUARARAPES/ES } \\
\hline Item & Qtd. & Tipo & Medida (m) & Total & Unid. \\
\hline Largura & 05 & Vãos & 8,00 & 40,00 & $\mathrm{~m}$ \\
\hline Comprimento & 10 & Módulos & 4,50 & 45,00 & $\mathrm{~m}$ \\
\hline Altura livre & & & & 4,00 & $\mathrm{~m}$ \\
\hline Total unitário & & & & $2.880,00$ & $\mathrm{~m}^{2}$ \\
\hline Total da ETE & & 03 unida & & $8.640,00$ & $\mathrm{~m}^{2}$ \\
\hline
\end{tabular}

\begin{tabular}{|c|c|c|c|c|c|}
\hline \multicolumn{6}{|c|}{ ETE BANDEIRANTES - CARIACICA/ES } \\
\hline Item & Qtd. & Tipo & Medida (m) & Total & Unid. \\
\hline Largura & 05 & Vãos & 8,00 & 40,00 & $\mathrm{~m}$ \\
\hline Comprimento & 30 & Módulos & 4,50 & 135,00 & $\mathrm{~m}$ \\
\hline Altura livre & & & & 4,00 & $\mathrm{~m}$ \\
\hline Total unitário & & & & $5.940,00$ & $\mathrm{~m}^{2}$ \\
\hline Total da ETE & & 03 unida & & $17.820,00$ & $\mathrm{~m}^{2}$ \\
\hline
\end{tabular}

\begin{tabular}{|c|c|c|c|c|c|}
\hline \multicolumn{6}{|c|}{ ETE MULEMBÁ - VITÓRIA/ES } \\
\hline Item & Qtd. & Tipo & Medida (m) & Total & Unid. \\
\hline Largura & 05 & Vãos & 8,00 & 40,00 & $\mathrm{~m}$ \\
\hline Comprimento & 29 & Módulos & 4,50 & 130,50 & $\mathrm{~m}$ \\
\hline Altura livre & & & & 4,00 & $\mathrm{~m}$ \\
\hline Total unitário & & & & $5.760,00$ & $\mathrm{~m}^{2}$ \\
\hline Total da ETE & & 03 unida & & $17.280,00$ & $\mathrm{~m}^{2}$ \\
\hline
\end{tabular}

\section{A-03. Estrutura Metálica :}

03.1-Aco: a estrutura é composta por perfis de aço-carbono, galvanizados a fogo em banho de zinco fundente conforme a norma NBR 6323 da ABNT. Os principais componentes são:

\section{- Colunas verticais de chumbamento}

Perfil "Ue" 25x60x90 com espessura de 2,00mm, com espaçamento a cada 8,00m e 4,50m

- Travamentos interno entre colunas (no sentido transversal)

Treliças Poly House, formadas por Perfil " $\mathrm{U}$ " 60x20mmcom espessura de 2,00mm e treliçamento diagonal em aço trefilado Ø $8,00 \mathrm{~mm}$

- Apoio da Cobertura

Arcos formados por Tubos Oblongos $40 \times 77 \mathrm{~mm}$ e espaçados a cada $2,25 \mathrm{~m}$

- Travamentos dos Arcos

03 linhas longitudinais, formados por tubos industriais $\varnothing 31,75 \mathrm{~mm}$

- Mão francesa de sustentação frontal

Tubos Industriais quadrados $\varnothing 40 \times 40 \mathrm{~mm}$

- Contraventamentos " $X$ " verticais 
Tirantes em aço trefilado $\varnothing 8,0 \mathrm{~mm}$ tracionados por esticadores forjado $\varnothing 3 / 8$ ", instalados no segundo e penúltimo módulos de todas as linhas de colunas + um travamento a cada $50,00 \mathrm{~m}$

- Suportes de calhas, suportes dos arcos e demais peças.

Chapa dobrada

- Funis $\varnothing 150 \mathrm{~mm}$ para a captação das águas pluviais

Acompanham os tubos de PVC, com captações intermediárias a cada 50,00m

03.2-Alumínio: Serão utilizados os seguintes perfis de alumínio extrusado (Ligas 6063/6261) (Temperas T6/T5):

- Calhas para o escoamento das águas pluvias e fixação do filme da cobertura

Tipo "U" com $180 \mathrm{~mm}$ de largura x $90 \mathrm{~mm}$ de altura, instaladas no sentido longitudinal em todas as linhas de colunas.

- Arremates nas Travessas Frontais

Perfil Base dupla (duas canaletas).

- Fixação dos filmes nas calhas e Frontais

Perfil Lock de encaixe na Base dupla

\title{
A-04. Fundações :
}

Para cada coluna será escavado um buraco de aproximadamente $30 \mathrm{~cm}$ de diâmetro e $90 \mathrm{~cm}$ de profundidade. Estes buracos receberão concreto para fixação das colunas.

\section{A-05. Cobertura:}

A cobertura das Estufas serão feitas com filme de polietileno de baixa densidade com transparência de $\mathbf{9 0 \%}$, espessura 150 micra, com tratamento contra raios ultravioleta, com fixação nas calhas e frontais com perfis lock de alumínio.

\section{A-06. Mureta Perimetral :}

Para dar acabamento nos fechamentos verticais, será construída uma mureta perimetral em concreto, com aproximadamente $0,35 \mathrm{~m}$ de altura.

\section{A-07. Fechamentos Fixos:}

As duas frontais e as laterais das Estufas terão fechamentos fixos com filme de polietileno, espessura de 150 micra fixados nas travessas frontais, colunas dos vértices e mureta perimetral com perfis de alumínio.

\section{A-08. Portas:}

Serão instaladas 10 (dez) portas em folha dupla, sendo 05 na frente e a outras 05 nos fundos, com dimensões unitárias de 4,00m de largura x 2,50m de altura.

As portas serão do tipo de correr, construída com perfis de alumínio e vedadas com filme de polietileno transparente, espessura de 150 micra, com tratamento contra raios ultravioleta.

\section{A-09. Piso I nterno:}

Internamente às Estufas será feito piso com lastro de concreto desempenado com espessura de 5,0cm e grelha central para escoamento d'água.

\section{A-10. Sistema Automático de Exaustão:}

\begin{abstract}
A-10.1 - EXAUSTORES NO TETO:
No teto da Estufa, será instalado sistema de exaustão que funcionará em conjunto com as janelas frontais, composto exaustores dotados de venezianas automáticas com sistema de hélices auto-limpantes. $O$ compartimento quadrado do exaustor e o venturi são feitos de chapa de aço galvanizado e reforçado. A hélice de seis pás é balanceada estática e dinamicamente para um menor nível de ruído e uma menor vibração. A hélice é acionada através de um sistema de correia e polias apoiada em um sistema de rolamento de esferas protegido contra água.
\end{abstract}

Estão previstos:

- ETE ARACAS - 03 linhas - total de 15 exaustores.

- ETE GUARARAPES - 01 linha - total de 05 exaustores.

- ETE BANDEI RANTES - 02 linhas - total de 10 exaustores.

- ETE MULEMBÁ - 02 linhas - total de 10 exaustores.

\section{A-10.2 - SISTEMAS DE JANELAS FRONTAIS:}

Nas duas frontais superiores da Estufa está prevista a instalação de Janelas Articuláveis (sistema de abertura interno). As janelas serão construídas com perfis de alumínio e fechamentos com filme de polietileno transparente, espessura 150 mícrons, com mecanismo de abertura através de hastes cremalheira de alumínio e com acionamento Motorizado feito através de conjunto motorredutor elétrico trifásico 220/380 V, interligados a 
um painel de comando com botoeiras de abrir e fechar no término de cada operação e com controle de abertura e fechamento através de fim de curso.

Obs.: $O$ sistema operara em conjunto com o sistema de exaustão.

\section{A-11. Sistema de Revolvimento e Movimentação do Lodo :}

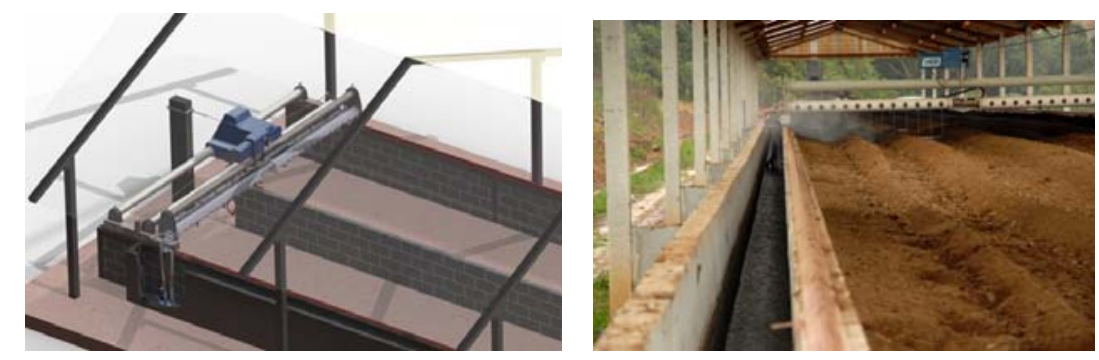

Equipamento para Revolvimento/Secagem de Lodo fabricado em aço carbono com tratamento de superfície especial e pintura epóxi. O acionamento das pás agitadoras é efetuado por moto redutor de engrenagens e as movimentações, longitudinal e transversal, são feitas diretamente entre moto redutores e cabos de aço.

Possui sensores de posicionamento para os sentidos longitudinal e transversal, e painel elétrico dotado de CLP para operação em modo automático, gerenciando o funcionamento total do equipamento

\section{A-12. Mão de Obra :}

Os serviços serão executados por técnicos especializados da Van der Hoeven, todos registrados, que trabalham de acordo com o plano de risco elaborado pelo nosso técnico de segurança do trabalho.

\section{B - PROPOSTA COMERCI AL:}

\section{B-01. Preço (R\$):}

Os valores correspondem aos materiais e montagem, incluindo todas as despesas transporte dos materiais, com viagens, hospedagem e alimentação, epi's da equipe de montagem:

\begin{tabular}{|c|c|}
\hline Componentes do Orçamento & Valores em R\$ \\
\hline \multicolumn{2}{|l|}{ ETE ARAÇAS - VILHA VELHA - 03 UNIDADES - TOTAL DE $32.400,00 \mathrm{~m}^{2}$} \\
\hline - Estrutura Metálica & $1.318 .444,00$ \\
\hline - Fundações + mureta & $46.562,00$ \\
\hline - Perfis de fechamentos + portas & $75.524,00$ \\
\hline - Sistema de Exaustão $=$ exaustores + janelas & $234.510,00$ \\
\hline - Filme para a cobertura e fechamentos & $124.282,00$ \\
\hline Total Estrutura Básica & $1.799 .322,00$ \\
\hline \multicolumn{2}{|l|}{ Opcionais } \\
\hline - Piso de concreto com esp. $5,0 \mathrm{~cm}$ (materiais e mão de obra) & $952.962,00$ \\
\hline - Revolvedor do Lodo - 05 equipamentos por Estufa & $825.000,00$ \\
\hline Total Geral da Proposta & $3.577 .284,00$ \\
\hline
\end{tabular}

\begin{tabular}{|c|c|}
\hline Componentes do Orçamento & Valores em R\$ \\
\hline \multicolumn{2}{|l|}{ ETE AEROPORTO - GUARARAPES - 03 UNIDADES - TOTAL DE $8.640,00 \mathrm{~m}^{2}$} \\
\hline - Estrutura Metálica & $252.292,00$ \\
\hline - Fundações + mureta & $17.049,00$ \\
\hline - Perfis de fechamentos + portas & $42.900,00$ \\
\hline - Sistema de Exaustão = exaustores + janelas & $101.375,00$ \\
\hline - Filme para a cobertura e fechamentos & $24.304,00$ \\
\hline Total Estrutura Básica & $437.920,00$ \\
\hline \multicolumn{2}{|l|}{ Opcionais } \\
\hline - Piso de concreto com esp. $5,0 \mathrm{~cm}$ (materiais e mão de obra) & $175.928,00$ \\
\hline - Revolvedor do Lodo - 05 equipamentos por Estufa & $705.000,00$ \\
\hline Total Geral da Proposta & $1.318 .848,00$ \\
\hline
\end{tabular}




\begin{tabular}{|c|c|}
\hline Componentes do Orçamento & Valores em R\$ \\
\hline \multicolumn{2}{|l|}{ ETE BANDEIRANTES - CARIACICA - 03 UNIDADES - TOTAL DE $17.820,00 \mathrm{~m}^{2}$} \\
\hline - Estrutura Metálica & $673.420,00$ \\
\hline - Fundações + mureta & $39.359,00$ \\
\hline - Perfis de fechamentos + portas & $56.122,00$ \\
\hline - Sistema de Exaustão $=$ exaustores + janelas & $169.164,00$ \\
\hline - Filme para a cobertura e fechamentos & $58.520,00$ \\
\hline Total Estrutura Básica & 996.585,00 \\
\hline \multicolumn{2}{|l|}{ Opcionais } \\
\hline - Piso de concreto com esp. 5,0 cm (materiais e mão de obra) & $472.034,00$ \\
\hline - Revolvedor do Lodo - 05 equipamentos por Estufa & $750.000,00$ \\
\hline Total Geral da Proposta & $2.218 .619,00$ \\
\hline
\end{tabular}

\begin{tabular}{|c|c|}
\hline Componentes do Orçamento & Valores em R\$ \\
\hline \multicolumn{2}{|l|}{ ETE MULEMBÁ - VITÓRIA - 03 UNIDADES - TOTAL DE $17.280,00 \mathrm{~m}^{2}$} \\
\hline - Estrutura Metálica & $644.277,00$ \\
\hline - Fundações + mureta & $38.632,00$ \\
\hline - Perfis de fechamentos + portas & $55.725,00$ \\
\hline - Sistema de Exaustão $=$ exaustores + janelas & $169.164,00$ \\
\hline - Filme para a cobertura e fechamentos & $58.423,00$ \\
\hline Total Estrutura Básica & $966.221,00$ \\
\hline \multicolumn{2}{|l|}{ Opcionais } \\
\hline - Piso de concreto com esp. $5,0 \mathrm{~cm}$ (materiais e mão de obra) & $460.779,00$ \\
\hline - Revolvedor do Lodo - 05 equipamentos por Estufa & $750.000,00$ \\
\hline Total Geral da Proposta & $2.177 .000,00$ \\
\hline
\end{tabular}

Obs.: A Van der Hoeven se reserva o direito de cobrar eventuais diferenças ocorridas quando da implantação do projeto devido a variações verificadas no campo como: distorções da planta topográfica ou informações incorretas fornecidas pelo comprador. Os materiais a serem fornecidos são exclusivamente aqueles constantes na proposta comercial

\section{B-02. Forma de Pagamento e Prazo de entrega:}

- Conforme cronograma físico e financeiro a ser estabelecido entre as partes.

\section{B-03. Garantias:}

Lurídicas: A Van der Hoeven apresenta para seus clientes, todos os documentos que comprovam sua total regularidade com os pagamentos de tributos municipais, estaduais e federais, e obrigações trabalhistas.

\section{*** ATENÇÃO $* * *$}

Para sua própria segurança no processo de compra, solicitamos consultar a regularidade de seu fornecedor no site www.comprasnet.gov.br para conferir através do cadastro no SICAF, a veracidade das certidões abaixo:

(CNPJ Van der Hoeven: 43.989.292/0001-40)

Prova de Regularidade Seguridade Social - C.N.D - INSS

Prova de Regularidade de Situação - C.R.S - FGTS

Prova de Regularidade: Fazenda Federal, Divida Ativa da União, Estadual e Municipal.

\section{Garantias Técnicas:}

Os produtos e serviços "Van der Hoeven" têm 01 (um) ano de garantia contra defeitos de fabricação e de instalação; têm 05 (cinco) anos de garantia para os serviços de galvanização a fogo, e têm 06 (seis) meses de garantia para os materiais e componentes elétricos, exceto se forem danificados por descargas atmosféricas ou falta de fase. Danos causados por má operação ou conservação pelo usuário e por terceiros, ou da ação agressiva de agentes da natureza (ex. raios, vendavais, tempestades, granizos, ciclones) não serão cobertos pelas garantias.
}

\section{B-04. I mpostos :}

Inclusos nos preços, exceto os devidos no Estado do destinatário.

\section{B-05. Validade deste orçamento :}

Garantimos materiais, serviços e valores descritos neste orçamento por até 15 (quinze) dias da data de sua emissão. 


\section{B-06. I tens de Responsabilidade do Cliente :}

$\checkmark \quad$ Escolher, compactar, nivelar o terreno para instalação das Estufas, se necessário.

$\checkmark$ Deixar a área livre de qualquer obstáculo para realização dos serviços de montagem.

$\checkmark \quad$ Efetuar o levantamento topográfico do solo e subsolo, se necessário.

$\checkmark \quad$ Autorização da obra junto aos órgãos públicos competentes quando necessário.

$\checkmark \quad$ Fornecer energia elétrica e água para os serviços de montagem.

$\checkmark$ Executar captação de águas pluviais a partir da base das colunas.

$\checkmark$ Providenciar local seguro e próximo à obra para guardar os materiais.

$\checkmark$ Executar serviços de construção civil, se necessários, exceto os especificados acima.

$\checkmark \quad$ Executar quaisquer outros serviços não descritos na parte técnica acima.

$\checkmark$ Fornecer a alimentação elétrica até o quadro de comando.

Nossa proposta não prevê a instalação de andaimes, linhas de vida, munks, pantográfica ou qualquer outro equipamento adicional para segurança do trabalho. Nossos funcionários são todos registrados na empresa, possuem todos os documentos e exames médicos pertinentes ao trabalho que exercem e possuem treinamento e todos os equipamentos de segurança individual necessários. No caso desse trabalho, se houver qualquer necessidade de equipamentos adicionais ou EPI's especiais (diferentes dos quais possuímos), os mesmos deverão ser providenciados pelo cliente ou então descritos/definidos antecipadamente para serem orçados e adicionados à nossa proposta, se for o caso.

\section{B-08. Obras de Referência:}

- Companhia de Saneamento de Jundiaí - CSJ, em J undiaí-SP: 25.600,00 m² implantados.

Contato : Antônio Carlos dos Santos, fone (19) 4599-2922

- Sabesp, ETE Lavapés em São J osé dos Campos-SP: $7.884,80 \mathrm{~m}^{2}$ implantados.

Contato : Fernando Carvalho Oliveira, fone (19) 9608-5589

- Semae, ETe Rio Preto em São José do Rio Preto-SP: 9.679,80 $\mathrm{m}^{2}$ implantados, sob a responsabilidade da Araguaia Engenharia.

Contato : Eng. Bruno Barrozo Legramandi, fone (17) 8132-5605

\section{Diferenciais importantes Van der Hoeven:}

- Estufa Agrícola com medidas especiais fora do padrão de mercado desenvolvida especialmente pela VAN DER HOEVEN para processos de secagem/compostagem de lodo, leitos de secagem.

- Toda a documentação necessária para participação em licitações públicas.

- Obras do mesmo porte ou maior com as mesmas características e para a mesma finalidade.

- Garantias técnicas, emissão e recolhimento de ART.

Certos de estarmos apresentando uma solução que atenda as sua necessidades, nos colocamos à sua disposição para esclarecer eventuais dúvidas, onde objetivamos sermos contemplados com a sua preferência.

Cordialmente

I van Seghetto

Consultor Comercial

e-mail ivan.seghetto_vdh@terra.com.br cel. (19) 9100-0116

Van der Hoeven Ind. Com. Estufas Agrícolas Ltda.

Rodovia SP 107, km 41 - Caixa Postal 81 - CEP 13.160-000 - Artur Nogueira - SP.

website: http://www.vdh.com.br

fone (19) 3877-2281 